\title{
A Moeda da Arte \\ A DINÂMICA DOS CAMPOS ARTÍSTICO E ECONÔMICO NO PATROCÍNIO DO CCBB
}

Tese apresentada à Faculdade de Filosofia, Letras e Ciências Humanas da Universidade de São Paulo para obtenção do título de Doutor em Sociologia.

Orientadora: Profa. Dra. Maria Helena Oliva Augusto

São Paulo

2008 
Catálogo na Publicação

Serviço de Documentação

Faculdade de Filosofia, Letras e Ciências Humanas

Souza, Eduardo Fragoaz.

A Moeda da Arte: a dinâmica do campo artístico e econômico no patrocínio do CCBB / Eduardo Fragoaz de Souza; orientadora Maria Helena Oliva Augusto. - São Paulo, 2008.

Capa e Diagramação Gráfica: Edson Fragoaz

Tese (Doutorado - Programa de Pós-Graduação em Sociologia) - Faculdade de Filosofia, Letras e Ciências Humanas da Universidade de São Paulo.

1. Patrocínio Artístico. 2. Marketing Cultural. 3. Sociologia da Cultura. I. Título 
4

Antônio Araúio 


\section{Agradecimentos}

Algum sociólogo da Cultura algum dia ainda fará pesquisa acerca dos agradecimentos constantes nos trabalhos acadêmicos. As suas conclusões apontarão certamente o quanto revelam das relações das quais os pesquisadores são tributários. Ele terá mais dificuldade, contudo, em delimitar os múltiplos laços afetivos que dão sustentação a esses débitos acadêmicos. Espero que, com os agradecimentos a seguir, eu possa, mais que delimitar as interdependências sociais que certamente influenciaram intelectualmente esse trabalho, dar conta do quão importante afetivamente foram as pessoas citadas, para que eu pudesse empreender essa "aventura sociológica".

Primeiramente, agradeço profundamente a minha orientadora, Profa. Dra. Maria Helena Oliva Augusto, pela parceria construída desde a graduação e pelo respeito, estímulo, confiança e compreensão sempre demonstrados.

Agradeço igualmente aos professores José Carlos Durand e Sérgio Miceli pelas contribuições prestadas no Exame de Qualificação.

Sou imensamente grato aos funcionários do CCBB São Paulo pelo apoio, companheirismo e pela coragem de se permitirem tornar objeto de investigação, em especial a Camila R. V. Lundberg, Carlos Rogério Campos, Luis Fernando Spaziani, Marcelo M. Mendonça, Marcos Mantoan, Omar B. Lopes, Sueli Yamauti e Wagner M. Vasconcelos.

Agradeço também:

- aos colegas da Diretoria de Marketing do Banco do Brasil: Giselle F. Vieira, Lourivaldo P. de Lima Júnior, Marco Estevão de M. Vieira e Maria Elizabete A. de Assis, pela forma carinhosa com que me concederam entrevistas importantes para o desenvolvimento do trabalho. Aos dois últimos agradeço também pelo compartilhamento de seus trabalhos acadêmicos, cujas pesquisas auxiliaram na construção do meu objeto de investigação;

- aos colegas do CCBB Brasília: Luis Cesar F. Rossato, Maria Luzineide M. Soares e Marco Antônio C. Marra, pelas entrevistas concedidas;

- aos meus amigos que assumiram parte de minhas atribuições bancárias em meus afastamentos para aulas e pesquisas, em especial a Arvid $S$. Hammarstrom, Carlos A. Depaule, Cristiane C. Santinho, Elizangela C. Lopes, 
Fernando F. Campos, Henrique A. Almirates Jr., João E. Silvestre, Patricia M. Kondo, Patrícia T. Rossi, Pedro A. C. Dias, Raphael A. A. Martins, Ricardo M. Neves e Walter Andrade Jr.;

- aos produtores teatrais Germano Bahia e Sérgio Scamilla e a Sônia Sobral pela amizade e pelas entrevistas concedidas;

- ao amigo e companheiro de travessia no Programa de Pós-Graduação, Guilherme G. F. Xavier Sobrinho, pelas leituras parciais e finais desse trabalho e pelas sugestões efetuadas;

- a Archibald Araújo Silva pela ajuda no tratamento estatístico dos dados;

- ao amigo Paulo Carvalho, pela generosa acolhida na temporada brasiliense da pesquisa e pela interlocução sempre intelectualmente estimulante;

- a Leandro Rezende, pelo "ombro" amigo sempre pronto ao apoio generoso e a Luiz Fernando B. Ferreira que, apesar da distância, esteve igualmente presente;

- a Lya Paes de Barros por, ao me ajudar na compreensão de questões subjetivas, me proporcionar que fizesse vôos intelectuais mais arriscados, que, em última instância, reelaboram, em outro nível, essas mesmas questões;

- ao meu colega de docência na Universidade São Caetano do Sul, Liraucio Girardi Jr. pela leitura do último capítulo desta tese e aos meus alunos nessa universidade por manterem sempre acessa em mim a paixão pela Sociologia;

- a meu irmão, Edson Fragoaz, pela diagramação gráfica, pela foto da capa e, principalmente, pela amizade e pela parceria de toda a vida.

Por último, mas talvez essa seja a gratidão mais significativa, agradeço a minha mãe pelo exemplo, estímulo e pelo apoio sempre presentes. 
O certo é que seria inútil buscar o fiador ou a garantia última dessa moeda fiduciária que é o poder de consagração fora da rede das relações de troca através da qual ela se produz e circula a uma só vez, isto é, em uma espécie de Banco Central que seria a caução última de todos os autos de crédito. (...) A institucionalização da anomia que resultou da constituição de um campo de instituições colocadas em situação de concorrência pela legitimidade artística, fez desaparecer a própria possibilidade de um julgamento em última instância e condenou os artistas à luta sem fim por um poder de consagração que já não pode ser adquirido senão na e pela própria luta. (Bourdieu, 2005:259-60) 


\section{RESUMO}

A pesquisa teve como objetivo compreender as motivações que sustentam o patrocínio artístico do Banco do Brasil, a partir da análise dos critérios utilizados na seleção dos projetos e na estruturação da programação do Centro Cultural Banco do Brasil (CCBB) São Paulo, nas áreas de artes cênicas e artes plásticas, nos anos de 2005 e 2006. Identificou-se que o CCBB situa-se na intersecção dos campos econômico e artístico que, não obstante obedecerem a normatividades muitas vezes antagônicas, estabelecem, na ação de patrocínio, dinâmica de interdependência, que também é permeada por conflitos. Para o mantenedor, as ações de patrocínio se justificam por quatro razões fundamentais: a busca pela melhoria de sua "imagem" diante de seus públicos de interesse, a necessidade de se afirmar como empresa "socialmente responsável", a utilização do patrocínio como instrumento de "marketing de relacionamento" e a obtenção de benefícios tributários. Essas justificativas se ancoram em universo valorativo próprio do campo econômico, calcado em racionalidade que se sustenta pela busca constante de lucratividade e conquista de mercados. Por outro lado, na qualidade de instituição cultural, o CCBB seleciona os projetos a serem patrocinados e estrutura a sua programação, a partir de juízos próprios do campo artístico (inovação, relevância conceitual e temática, grau de consagração de obras e artistas, dentre outros). Se houvesse a preponderância dos julgamentos econômicos na seleção das obras, a arte patrocinada perderia a sua moeda de troca, já que seu capital simbólico decorre justamente da negação de qualquer constrição externa ao campo artístico. Analisando a programação do CCBB nas áreas pesquisadas, identificamos que o resultado das escolhas é coerente com o principal eixo curatorial da instituição que é a diversidade. Apesar do destaque dado a nomes consagrados, artistas menos conhecidos também são contemplados, ainda que em menor número e com espaços reduzidos. Nas artes cênicas, a preocupação central é com a presença de atores renomados, sendo que sua programação não se qualifica nem como "teatro comercial", nem como "teatro experimental". Nas artes plásticas, aparece também uma posição dúbia, já que ao tempo em que promove a arte contemporânea, correndo certa dose de riscos em suas escolhas, privilegia, por outro lado, formas de patrocínio menos arriscadas, como as mostras museológicas e coletivas (essas abrangendo outras manifestações que não apenas as contemporâneas). A exposição nos meios de comunicação de massa e a quantidade de público nos eventos patrocinados são os principais fatores considerados na qualificação do patrocínio como "bem sucedido". Isso revela características eminentemente narcísicas que envolvem as ações de patrocínio, nas quais a repercussão na mídia garante a amplificação da "imagem benevolente" e pretensamente desinteressada da empresa, mesmo junto aos públicos não fruidores das artes patrocinadas. A preocupação com a percepção desse público foi decisiva na opção da empresa em retirar uma obra iconoclasta da exposição Erotica, no momento em que a instituição foi confrontada por segmentos da população que julgaram que seus símbolos religiosos haviam sido vilipendiados.

Palavras-chave: patrocínio artístico empresarial, marketing cultural, imagem das empresas, jornalismo cultural, política cultural, Centro Cultural Banco do Brasil 


\begin{abstract}
This study aims to explore the reasons behind Banco do Brasil's sponsorship of the arts. To this end, an analysis of the criteria used both for selecting theater and visual arts projects and designing Banco do Brasil's Cultural Center (CCBB) program of cultural activities between 2005 and 2006 was carried out. It was found out that the CCBB lies at the interface between the economic and artistic fields, which, albeit governed by conflicting normativities, become interdependent when it comes to sponsoring, but not without dispute. Justification for the bank's sponsorship activities is fourfold: as an attempt to improve its "image" with the bank's various stakeholders; the need to become publicly known as a "socially responsible" company; the use of sponsorship as a tool of "relationship marketing"; and the possibility of earning tax benefits. These reasons stem from a set of values that are typically from the economic field. The rationality behind them is an ongoing search for profit and the conquest of new markets. As a cultural institution, however, the CCBB uses artistic criteria such as innovation, conceptual and thematic relevance, and the reputation of art works and artists to select artistic projects for sponsorship and to design its own program of cultural activities. If economic criteria prevailed, the sponsored art, whose symbolic capital stems precisely from the denial of any external restraint to the artistic field, would lose its role as a medium-ofexchange. By analyzing CCBB's theater and visual arts programs, the choices that were made were found to be consistent with its main curatorial policy, namely, that of promoting diversity. Although highly renowned artists prevail, minor artists are also present but in smaller numbers, and taking less space. As for theater projects, the CCBB's main concern is to ensure that widely acclaimed actors are included in its theatrical program, which can be neither regarded as purely commercial nor experimental theater. In the visual arts, the institution's position is also ambivalent. Although it promotes contemporary art, which includes a fair amount of risk-taking, sponsorship of less risky pieces, such as museum collections (including art from other historical periods) and group shows, prevail. Media exposure and the number of viewers attending sponsored events are perceived as the main indicators of a "successful" event. Sponsoring therefore can be seen as highly narcissistic: media repercussion ensures that the company's supposedly unbiased "benefactor image" is widely spread, even among those who do not attend the sponsored events. Concern about the perception of the latter group was critical when the company chose to withdraw an iconoclastic piece from a show called Erotica. The institution had been challenged by members of the public who believed their religious symbols had been profaned.
\end{abstract}

Key words: corporate sponsorship of the arts, corporate image, cultural policy, cultural journalism, Centro Cultural Banco do Brasil. 


\section{RESUMÉ}

Cette recherche a eu comme objectif comprendre les motivations qui soutiennent les actions de sponsoring d'art de la banque Banco do Brasil, à partir de l'analyse des critères utilisés dans la sélection des projets et dans la structuralisation de la programmation du Centro Cultural Banco do Brasil (CCBB) São Paulo, dans les domaines des arts scéniques et des arts plastiques des années 2005 et 2006. On a identifié que le CCBB est placé dans l'intersection des champs économique et artistique qui, malgré le fait d'obéir à des normes maintes fois antagoniques, établissent, dans l'action de sponsorisation, une dynamique d'interdépendence, ce qui est marqué aussi par des conflits. Considérant le parranaige de la banque, les actions de sponsorisation se justifient par quatre raisons fondamentales: la recherche pour l'amélioration de son «image» face à ses publics d'intérêt, le besoin de s'affirmer comme entreprise "socialement responsable», l'utilisation de la sponsorisation comme outil de «marketing relationnel» et l'obtention des avantages fiscaux. Ces justificatives sont ancrées à un ensemble de valeurs propre au champ économique, basé sur une rationalité qui se soutient par la recherche constante de rentabilité et la conquête de marchés. D'autre part, en tant qu'institution culturelle, le CCBB sélectionne les projets à être sponsorisés et structure sa programmation à partir de jugements propres au champ artistique (innovation, importance conceptuelle et thématique, dégré de notoriété d'oeuvres et d'artistes, entre autres). S'il y avait une prépondérence des jugements économiques dans la sélection des oeuvres, l'art sponsorisé perdrait sa monnaie d'échange, car son capital symbolique vient justement de la négation de toute contrainte externe au champ artistique. A partir de l'analyse de la programmation du CCBB dans les domaines recherchés, on identifie que le résultat des choix est cohérent avec le principal axe d'action des commissaires de l'instituition, celui de la diversité. Malgré la notoriété donnée à des artistes célèbres, ceux moins renomés sont aussi contemplés, même si en nombre plus petit et avec des espaces réduits. Dans les arts scéniques, le souci principal est avec la présence d'acteurs renomés, étant donné que leur programmation ne se qualifie ni comme du «théâtre commercial», ni comme du «théâtre expérimental». Dans les arts plastiques, une position douteuse apparaît aussi, puisque si d'une part on promouvoit l'art contemporain, avec certains risques dans ses choix, on privilegie, d'autre part, les formes de sponsorisation moins risquées, comme les expositions muséologiques et collectives (comprenant d'autres manifestations, pas seulement les contemporaines). La couverture médiatique et la quantité de public présente dans les événements sponsorisés constituent les principaux facteurs pris en compte lors de la qualification de la sponsorisation comme étant «bien réussie». Cela dévoile les caractéristiques éminemment narcissiques qui engagent les actions de sponsorisation, dans lesquelles la repercussion dans les médias garantit l'amplification de «l'image bénévole» et soi- disant désintéressée de l'entreprise, même auprès des publics qui ne jouissent pas des arts sponsorisés. Le souci avec la perception de ce public a été décisif pour l'entreprise quand elle a décidé de retirer une oeuvre iconoclaste de l'exposition Erotica, dû au fait d'avoir été confrontée par une partie de la population qui jugeait que ses symboles réligieux avaient été vilipendiés.

Mots-clés: sponsoring d'art, parrainage des entreprises, marketing culturel, image des entreprises, journalisme culturel, politique culturelle, Centro Cultural Banco do Brasil. 


\section{SUMÁRIO}

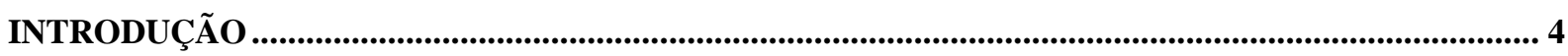

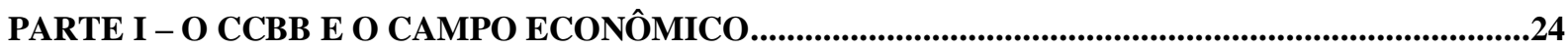

O CCBB, O SEU MANTENEDOR E O CAMPO ECONÔMICO.............................................................25

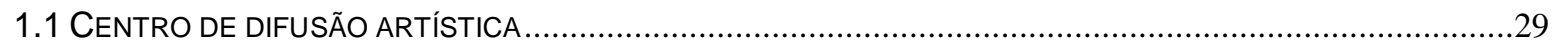

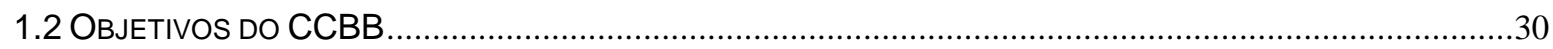

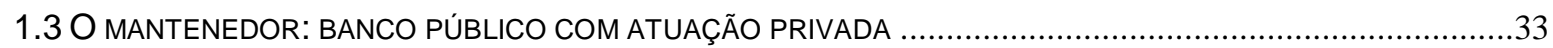

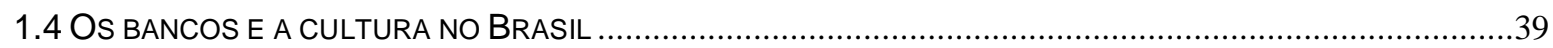

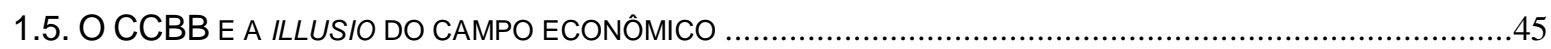

AS RAZÕES DO MARKETING CULTURAL DO BANCO DO BRASIL ............................................49

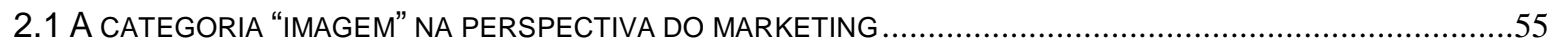

2.2 "NEM PARECE BANCO" - O PATROCÍNIO ARTÍSTICO E A IMAGEM DAS INSTITUIÇÕES FINANCEIRAS............61

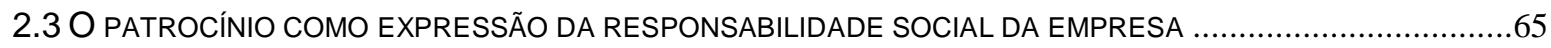

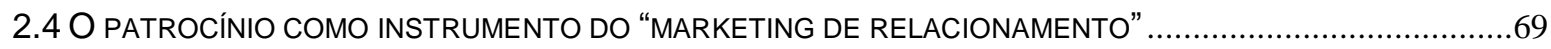

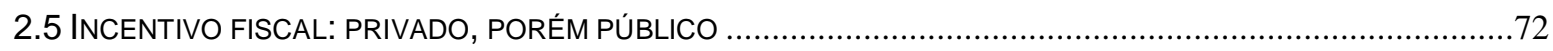

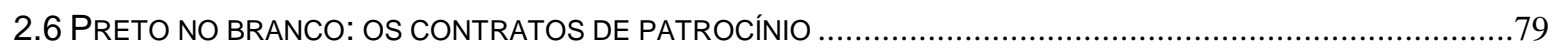

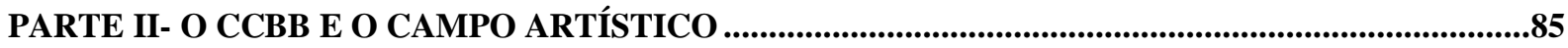

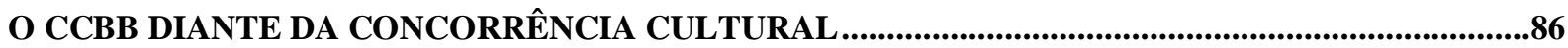

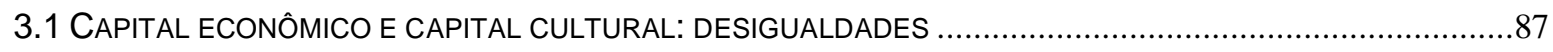

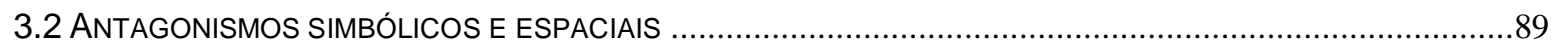

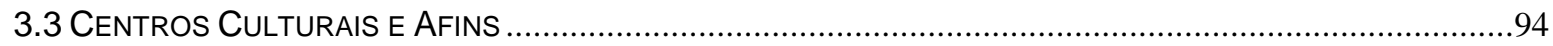

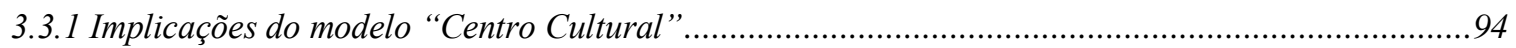

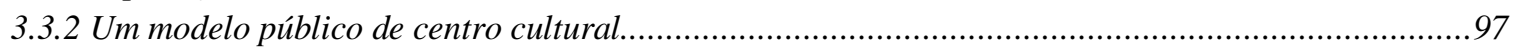

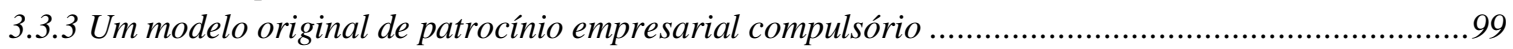

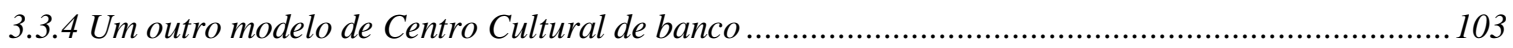

3.4 CONSIDERAÇÕES SOBRE O CAMPO DAS ARTES CÊNICAS EM SÃO PAULO …...........................................105

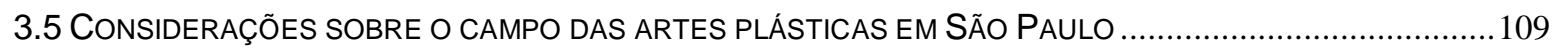

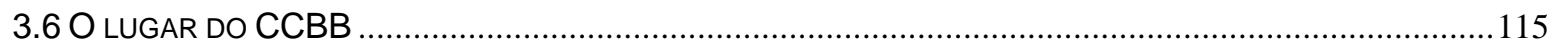

CRITÉRIOS DE ESCOLHA - RÉGUAS DE COMPARAÇÃO NO PROCESSO DE SELEÇÃO DOS

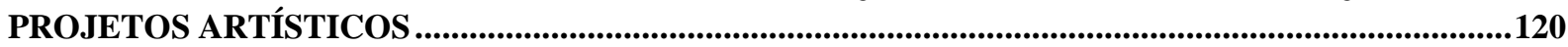

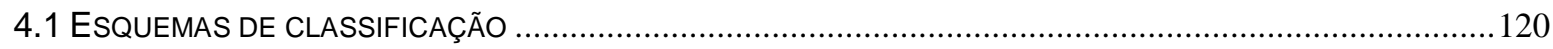

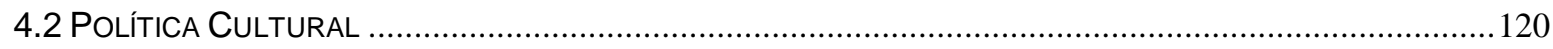

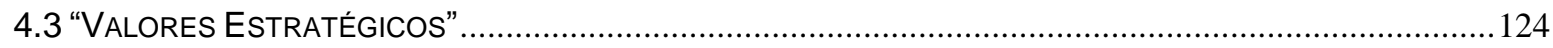

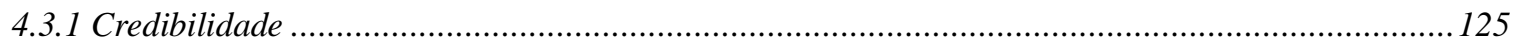

4.3.2 Regularidade

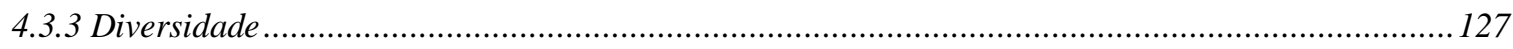

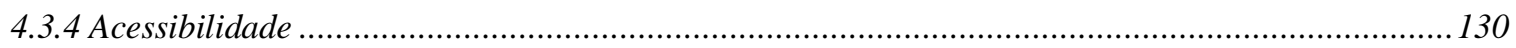

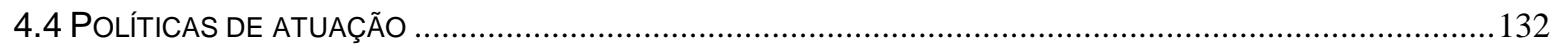

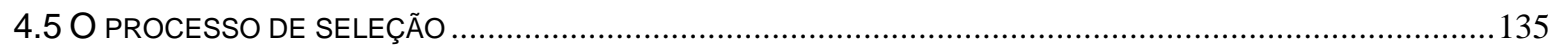

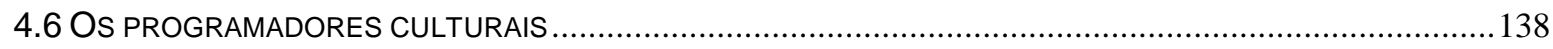

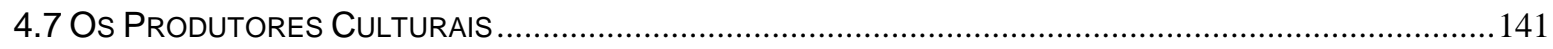

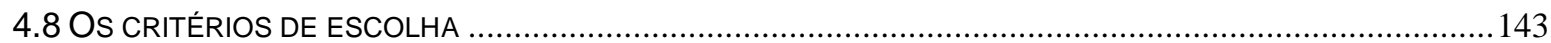

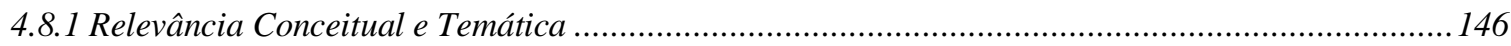




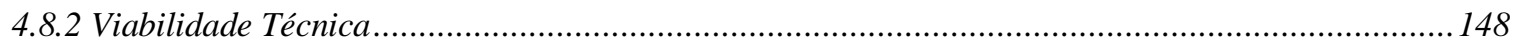

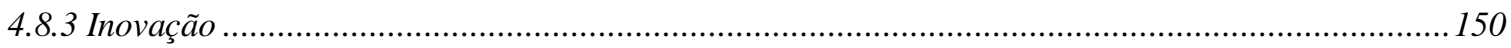

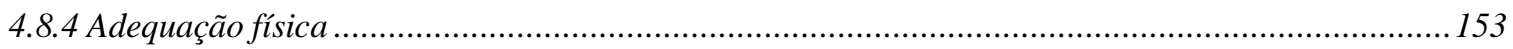

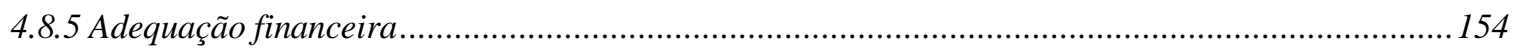

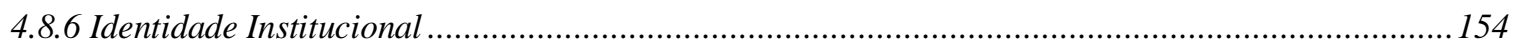

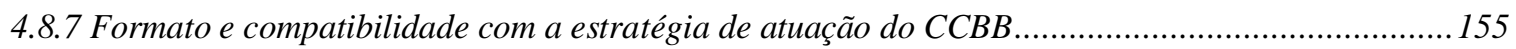

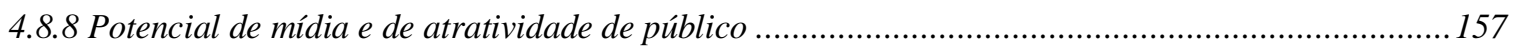

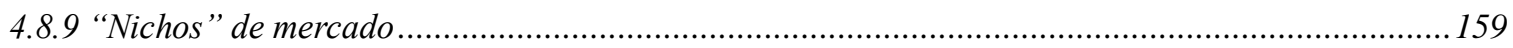

4.9. O ARTÍSTICO E O ECONÔMICO: INTERDEPENDÊNCIAS E CONFLITOS ....................................................160

A PROGRAMAÇÃO DO CCBB - EQUACIONANDO CONSAGRAÇÃO E INOVAÇÃO .......................164

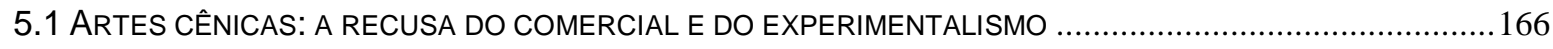

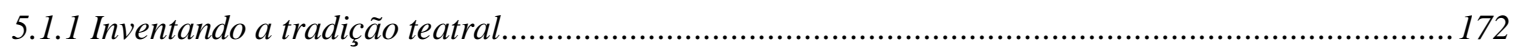

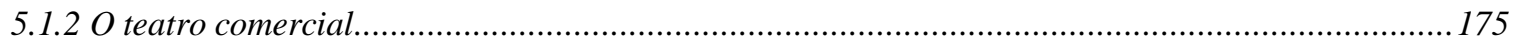

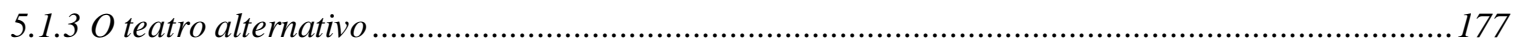

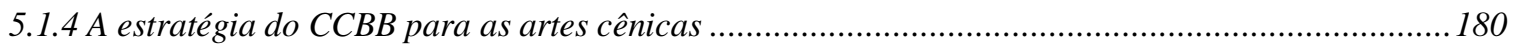

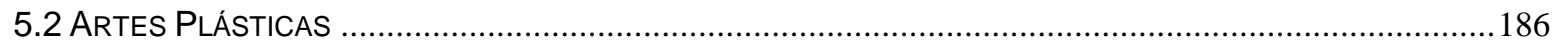

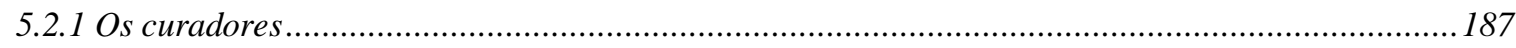

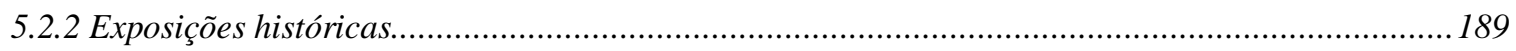

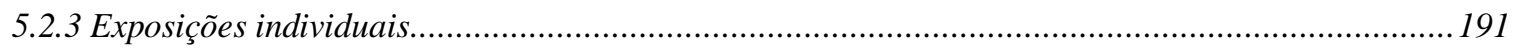

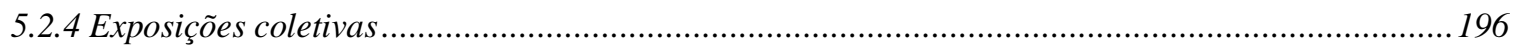

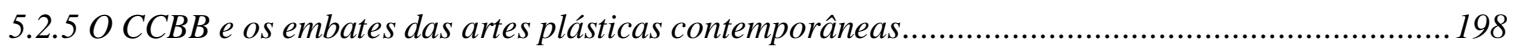

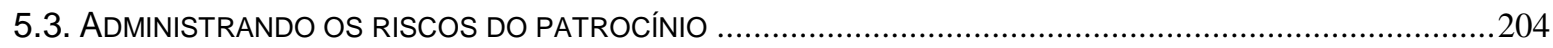

PARTE III- O CCBB E OUTROS CAMPOS DA VIDA SOCIAL ...............................................................209

EROTICA: A REAFIRMAÇÃO DA RACIONALIDADE ECONÔMICA NO PATROCÍNIO.................210

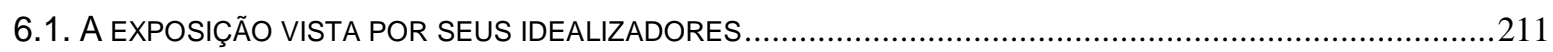

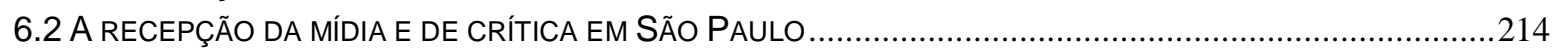

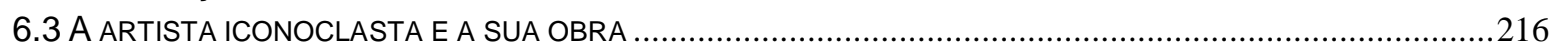

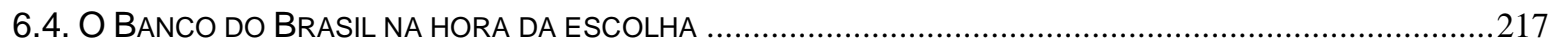

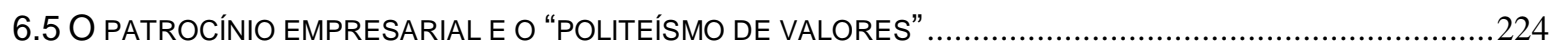

AVALIANDO A EFICÁCIA DO PATROCÍNIO: MÍDIA, PÚBLICO E CRÍTICA .................................231

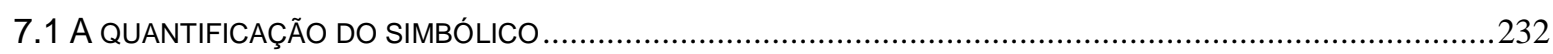

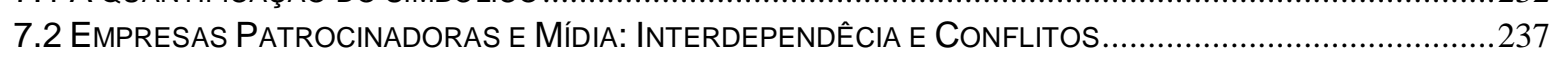

7.3 JORNALISMO CULTURAL: COMO TRANSFORMAR ARTE EM NOTÍCIA ......................................................24

7.4 O PAPEL DO ASSESSOR DE IMPRENSA NA FABRICAÇÃO DA PAUTA CULTURAL …..................................246

7.5 A POUCA EXPRESSIVIDADE DA CRÍTICA DE ARTE NA AVALIAÇÃO DO PATROCÍNIO.................................250

7.6 O PATROCÍNIO MIDIÁTICO COMO PROPULSOR DA REPUTAÇÃO, IMAGEM E PRESTÍGIO DA EMPRESA .......260

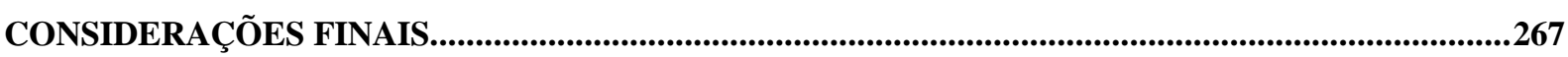

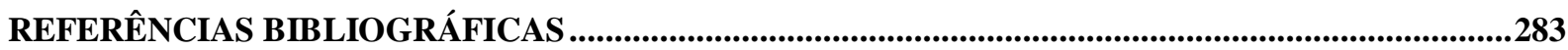

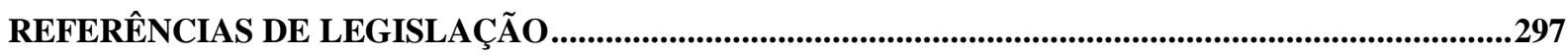

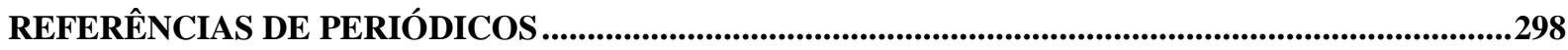

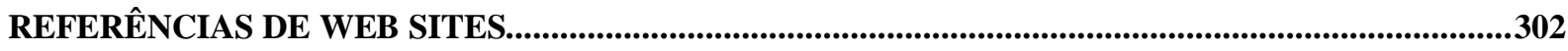




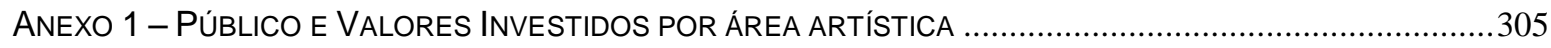

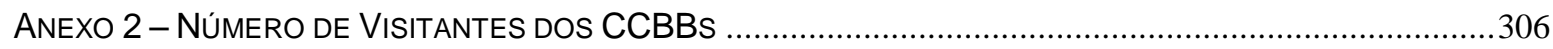

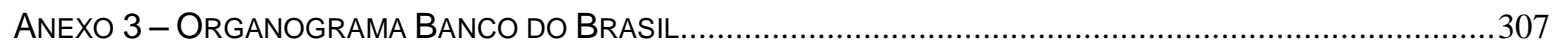

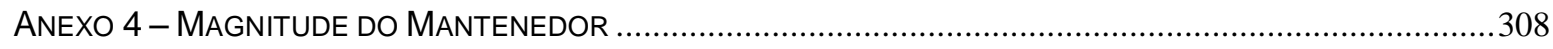

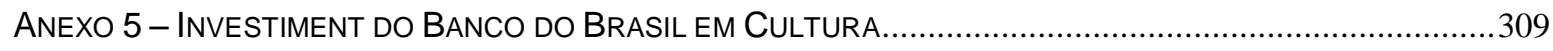

ANEXO 6 - COMPARATIVO DOS INVESTIMENTOS CULTURAIS DAS EMPRESAS .............................................311

ANEXO 7 - INSTITUTOS E FUNDAÇÕES CULTURAIS VINCULADOS A INSTITUIÇÕES FINANCEIRAS ..................312

ANEXO 8 - INVESTIMENTOS EM CULTURA POR SEGMENTO DA ECONOMIA - 101 MAIORES GRUPOS

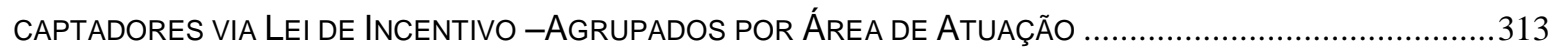

ANEXO 9 - RECURSOS CAPTADOS VIA LEI DE INCENTIVO POR SEGMENTO DA ECONOMIA ........................314

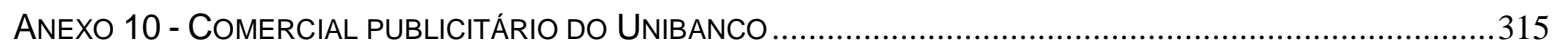

ANEXO 11 - TEATROS NA CIDADE DE SÂO PAULO (LOCALIZAÇÃO, CAPACIDADE E PREÇO) ……..................317

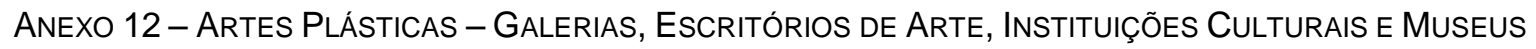

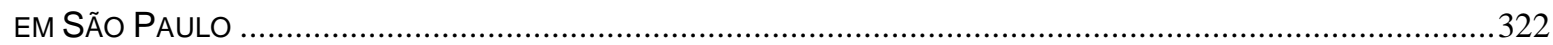

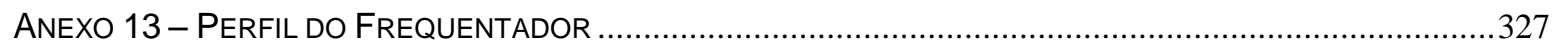

Anexo 14 - Grau de Transparência na SeleÇão dos Projetos Culturais ...................................329

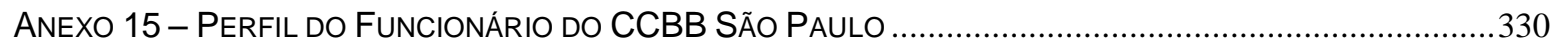

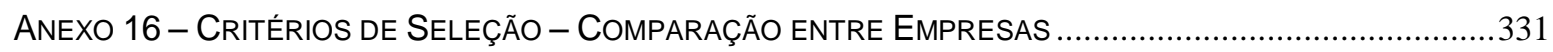

Anexo 17 - Artes Cênicas - Qtde. de Semestre em Cartaz, Período e Dias da Semana ...............333

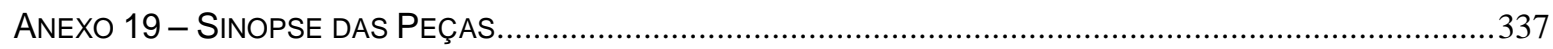

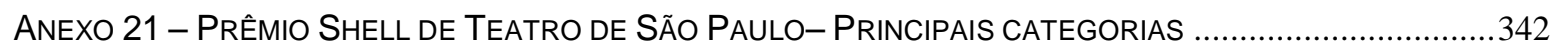

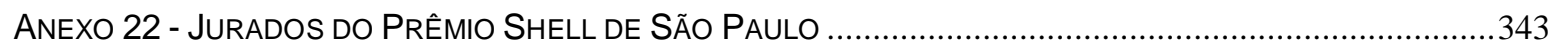

ANEXO 23 - SINOPSE DAS EXPOSIÇÕES DE ARTES PLÁSTICAS ................................................................... 344

Anexo 24 - Artes Plásticas: Ficha TÉCnica, localização no Prédio, Valores Patrocinados,

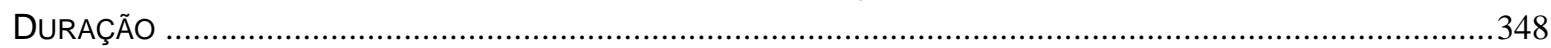

ANEXO 25 - ARTES PLÁSTICAS - AgRUPAMENTO POR MODALIIDADE DE EXPOSIÇÃO (R\$) ........................350

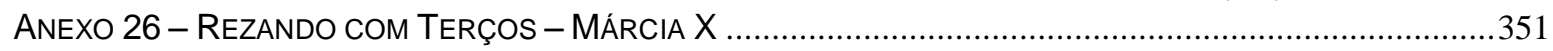

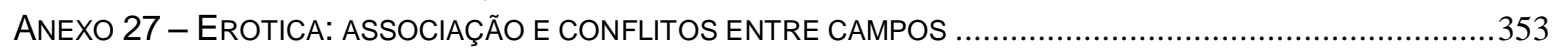

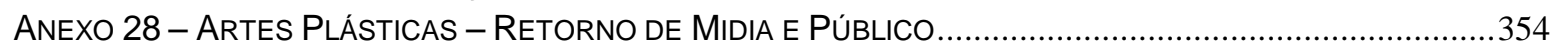

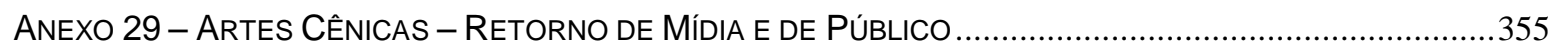

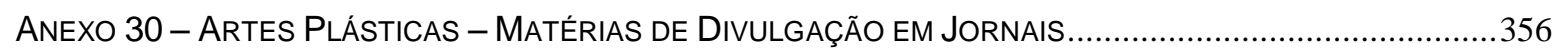

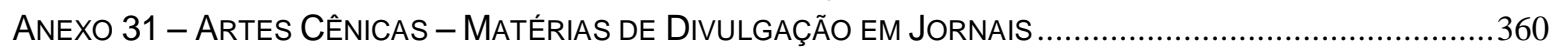

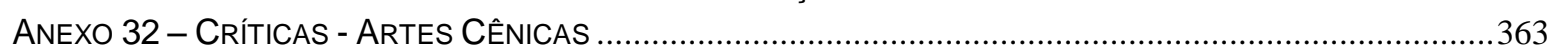

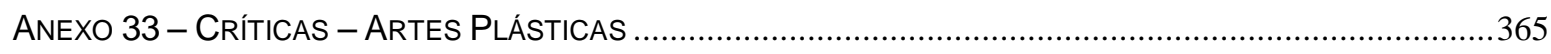

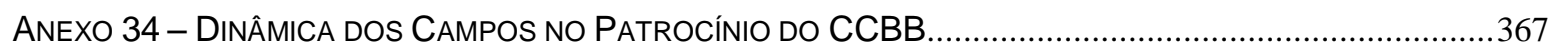




\section{INTRODUÇÃO}

A pesquisa, cujos resultados são explicitados nesta tese, teve como objetivo desvendar as motivações que sustentam as ações de patrocínio artístico do Banco do Brasil (BB), e as implicações delas decorrentes, a partir da análise dos critérios utilizados na seleção dos projetos e estruturação da programação do Centro Cultural Banco do Brasil (CCBB), em São Paulo, nas áreas de artes cênicas e artes plásticas, nos anos de 2005 e 2006.

$\mathrm{Na}$ encruzilhada de dois universos sociais, regidos por normas, valores e lógicas bastante distintos, o processo de seleção dos projetos artísticos encaminhados para patrocínio e a programação dele resultante envolve a conjugação de juízos artísticos - próprios do mercado de bens simbólicos - e juízos mercadológicos, próprios de uma visão instrumental que vê, na arte, um veículo de comunicação institucional da empresa, com a finalidade de melhorar sua imagem perante os consumidores.

A arte - assim como outras formas de simbolização, entre elas a religião e o pensamento científico e intelectual - sempre manteve relações conflituosas e dinâmicas com as instâncias econômicas e materiais da vida social. Mesmo antes da instauração das formas capitalistas de racionalização econômica, a relação dos artistas com os grupos sociais que dispunham de mecanismos capazes de lhes assegurar a sobrevivência engendrou formas recíprocas de trocas, interesses, subordinações, dependências e conflitos.

As conclusões da pesquisa realizada se inserem em uma abordagem mais ampla que busca descortinar o sentido, na configuração atual do capitalismo, da relação social estabelecida entre os atores sociais produtores de bens simbólicos e aqueles que detêm o poder econômico.

O apoio financeiro às manifestações artísticas assumiu formas diferenciadas ao longo da História. Esse suporte econômico remete às origens do termo mecenato, surgido na Roma Antiga, que designa o apoio concedido por um indivíduo, pertencente às elites econômicas e/ou políticas, a um produtor cultural. $\mathrm{O}$ mecenato não pressupõe necessariamente a aquisição da obra de arte, mas significa, sobretudo, o suporte financeiro necessário à sua realização.

Contemporaneamente, os mecenas são substituídos gradualmente por patrocinadores, entidades públicas ou privadas que apóiam o produtor cultural, mas 
exigem a veiculação do nome do financiador acoplado ao produto artístico financiado. O mecenato também não era isento de interesses, já que, muitas vezes, o apoio ao artista decorria de motivações religiosas ou políticas, e normalmente tinha por motivação aumentar o prestígio social do mecenas.

No capitalismo, o apoio financeiro assume, às vezes de forma explícita, outras vezes velada, o retorno esperado do investimento. Ao contrário do mecenato, no qual o mecenas e/ou sua família são os agentes da subvenção da atividade artística, a característica principal das formas atuais de patrocínio é o fato de que é uma empresa a financiadora da atividade cultural.

Uma nova especialidade, o Marketing ${ }^{1}$ Cultural, começa a se constituir nas últimas décadas para explorar os critérios de concessão e acompanhamento dos recursos aplicados na área artística. Ainda não consolidado totalmente como saber acadêmico, mas certamente legitimado como estratégia empresarial, o Marketing Cultural fundamenta-se em uma ação de comunicação corporativa, que tem por finalidade fixar ou projetar o nome da empresa entre os seus potenciais consumidores. O surgimento dessa nova forma de atuação deve-se, dentre outros motivos, à saturação da publicidade convencional que levou as organizações a diversificarem suas estratégias de comunicação com seus públicos.

O uso "contaminado" do termo Marketing Cultural pelo campo econômico faz com que pareça mais adequado utilizar a noção de "patrocínio empresarial" ao se analisar a complexa relação entre o criador cultural e a empresa que lhe garante o suporte material para sua empreitada.

O suporte econômico empresarial se justifica em função da proeminência e valorização da arte nas sociedades contemporâneas, sendo uma manifestação cultural que possui conotação positiva em diversos meios sociais ${ }^{2}$. Acreditam os profissionais de marketing que haveria uma espécie de "contágio simbólico": o produto artístico emprestaria seu prestígio à empresa patrocinadora. Valores como beleza, sofisticação, ousadia e criatividade, próprios da atividade artística, Ihe seriam

\footnotetext{
${ }^{1}$ Em inglês, market significa mercado e o sufixo ing indica ação. Num esforço de tradução, marketing pode ser tomado como "mercadização" (ato de "mercadizar") ou como mercadologia. Contudo, por ser uma palavra cuja tradução literal pode ocasionar a perda de seu significado, optamos por manter a palavra em inglês, tendo em vista o uso corrente na língua portuguesa. É interessante notar, contudo, que nos países de língua inglesa, não se utiliza a expressão "cultural marketing", preferindo-se o termo "sponsorship" (patrocínio).

2 Abbing (2002:46) aponta diversos sinais do status elevado da arte nas sociedades contemporâneas: os rendimentos de alguns artistas são extremamente altos; os preços das obras de arte consagradas são também bastante caros; doações e subsídios formam a grande parte das receitas em artes; muitas pessoas desejam se tornar artistas mesmo apesar das expectativas de baixas recompensas financeiras; mesmo
} 
transferidos. Entretanto, a princípio em função da dificuldade de mensuração da eficácia desse "contágio simbólico", o Marketing Cultural se torna, muitas vezes, um investimento arriscado, em que as garantias de retorno são de difícil comprovação. A racionalidade instrumental e econômica, própria do universo empresarial, mantém diálogo conflituoso com a esfera cultural, na qual os nexos raramente se traduzem em equações matemáticas, o que inibe, possivelmente, que maior número de empresas tenha ações de patrocínio.

No Brasil, a área de Marketing Cultural teve um desenvolvimento mais incisivo, a partir da década de 1990, em função principalmente de uma redefinição da política do Estado na área cultural. A grande tônica da administração cultural, a partir de então, é uma enviesada idéia de "parceria público-privada", na qual os Governos Federal, Estaduais e Municipais estimulam o patrocínio cultural, mediante leis de incentivo fiscal. Essas leis são objeto de intenso debate público, em que se apresentam posições divergentes. De um lado, há quem valorize essa legislação de fomento, por ela diversificar as fontes de apoio, aumentando as possibilidades de viabilização dos projetos. De outro lado, faz-se crítica à privatização da gestão das políticas culturais no país, pela transferência da responsabilidade pela escolha da arte a ser fomentada às empresas.

O crescimento do subsídio empresarial às artes, nas últimas duas décadas, em função dessas leis, modifica o campo de forças e a competição no interior do campo artístico. No Brasil, grande parte do patrocínio corporativo é efetuada por empresas vinculadas ao governo. Petrobrás, Banco do Brasil, Eletrobrás e BNDES são grandes investidores em cultura. Muito embora esses recursos sejam públicos, a mudança de sua origem implica modificações na dinâmica dos patrocínios.

Quando procedentes de instâncias exclusivamente governamentais (como Ministério da Cultura e Secretarias da Cultura), a disputa pelos recursos era movida principalmente por interesses que vão da valorização do político que viabiliza a produção artística ao formulador da política pública, muitas vezes preocupado com a democratização da criação e do consumo cultural. Quando submetidos aos ditames das áreas de marketing das empresas, ainda que vinculadas ao governo, obedecem a outra lógica, que é a da racionalidade burocrática e empresarial.

jovens e mal sucedidos artistas têm status especial; governo, realezas e corporações importantes consomem artes etc.. (Abbing, 2002:46-7) 
A maior parte dos países do mundo tem pouca tradição no subsídio empresarial às artes, sendo que normalmente o Estado assume de forma preponderante esse papel. Os EUA são a exceção a essa regra, já que lá as contribuições de empresas e de indivíduos superam largamente o apoio estatal às artes.

O maior apoio estatal para as artes na Europa Ocidental pode ser explicado menos em função da ausência de incentivos fiscais na legislação tributária desses países do que como decorrência de processos históricos e culturais, que remontam ao subsídio monárquico e nobiliárquico à música, ao teatro e à pintura. A existência de orquestras, companhias teatrais, óperas, e pintores oficiais na maioria dos reinos europeus criou raízes que sustentam o posicionamento do contribuinte, para quem, se o governo já investe em cultura, isso significa que os próprios cidadãos já o fazem por intermédio dos impostos recolhidos, não sendo pertinentes outras contribuições voluntárias (Schuster, 1985).

No Brasil, o apoio empresarial ainda é bastante incipiente e o governamental também possui patamares muito reduzidos. O patrocínio que será analisado é o empresarial, mas de uma empresa do Governo. Esse fato insere alguns componentes adicionais à análise, muito embora, como será visto, a motivação principal que dá sustentação ao patrocínio artístico realizado pelo Banco do Brasil seja uma preocupação mercadológica, da mesma natureza das que levam empresas privadas adotarem ações de patrocínio. Isso é coerente com a tentativa da instituição financeira de consolidar-se como "banco de mercado".

A grande crítica que os atores sociais campo artístico tem com relação ao subsídio empresarial às artes é que essa origem do recurso pode corromper as predisposições que configuram autonomia àquele campo, já que as criações podem começar a orientar-se pelos atributos que tornem o bem simbólico atrativo para as empresas, o que prejudicaria criações mais experimentais e controvertidas. Assim, pondera um diretor teatral:

Assim como já acontece nos campos de futebol, cada vez mais os patrocinadores estão invadindo tudo. Invadem a camisa, a beirada do campo. Não basta o patrocínio na beirada do campo, tem que ficar aquela coisa imensa que, enquanto você vai assistindo, vai se treinando para não enxergar. E aí eu fiquei pensando se, no futuro, a gente também não vai montar assim: Romeu Shell e Julieta Petrobrás. Porque talvez seja a única forma de conseguir grana 
numa boa. Nessa moda de permuta o que conta é vender. (Fauzi Arap. "Mesa I". In Garcia, 2002:34)

Algumas perguntas percorrem a análise efetuada neste estudo: os recursos empresariais utilizados na criação artística efetivamente comprometem a autonomia dessa criação? Quais são as alianças estabelecidas entre os profissionais de marketing e os artistas? A que interesses tais alianças atendem e a que fração do campo artístico beneficia? A busca da visibilidade pela empresa diante de seus consumidores por meio do patrocínio empresarial reafirma as estruturas de dominação no interior do campo artístico, já que a arte patrocinada reforça o poder dos segmentos dominantes desse campo?

A perspectiva teórica de Pierre Bourdieu (1999, 2003, 2004, 2005) é a que nos proporciona melhor instrumental de análise para a problematização acima elaborada. Não obstante sua obra ter como preocupação uma teoria muito mais abrangente - ficando, portanto, o tema do patrocínio empresarial em posição subalterna, expressa apenas em referências pontuais, sem desenvolvimento mais aprofundado -, ela oferece referencial teórico que permite melhor apropriação do objeto de pesquisa construído. A obra do autor em que o assunto se encontra um pouco mais explorado talvez seja a menos teórica de sua vasta produção. Trata-se de Livre-troca (Bourdieu, 1995), publicada na França, em 1994, que consiste na transcrição de diálogos realizados com o artista plástico Hans Haacke, em 1991. A oralidade que predomina na publicação não é muito propícia ao aprofundamento teórico. De maneira recorrente, o tema do patrocínio empresarial tende a ser colocado de maneira mais enfática por Haacke, sendo que Bourdieu responde a algumas provocações, concordando com o teor crítico que o artista alemão quanto à forma como as empresas vêm se inserindo no universo artístico. A não ser nas esparsas referências à sistemática da empresa francesa Cartier apoiar as artes, Bourdieu se coloca mais à vontade quando explora as ameaças à autonomia do campo intelectual francês, do que quando explora o patrocínio empresarial. É possível que Ihe faltasse sustentação empírica, na medida em que a França é o país europeu no qual a intervenção do Estado na esfera cultural se dê da forma mais intensa, sendo ainda reduzido o patrocínio empresarial.

As discussões reunidas em seu livro As Regras da Arte, não obstante realizarem uma única menção ao patrocínio empresarial, são bastante úteis para esta pesquisa, na medida em que o autor, em sua análise do campo literário, 
desvenda as relações dos artistas com seus editores e também com as demais instâncias mediadoras, como os críticos e a imprensa.

Entretanto mais importante, contudo, para a análise empreendida será a teoria bourdiana dos campos, considerando-se que o objeto da pesquisa se constitui pela articulação de dois universos simbólicos distintos e com lógicas sociais que se estruturam de forma diferenciada. Bourdieu define seu conceito de campo da seguinte forma:

uma rede ou uma configuração de relações objetivas entre posições. Essas posições são definidas objetivamente em sua existência e nas determinações que elas impõem aos seus ocupantes, agentes ou instituições, por sua situação atual e potencial na estrutura da distribuição das diferentes espécies de poder (ou de capital) cuja posse comanda o acesso aos lucros específicos que estão em jogo no campo e, ao mesmo tempo, por suas relações objetivas com as outras posições (dominação, subordinação, homologia etc.). Nas sociedades altamente diferenciadas, o cosmo social é constituído do conjunto destes microcosmos sociais relativamente autônomos, espaços de relações objetivas que são o lugar de uma lógica e de uma necessidade específicas e irredutíveis às que regem os outros campos. Por exemplo, o campo artístico, o campo religioso ou o campo econômico obedecem a lógicas diferentes." (Bourdieu e Wacquant, 1992:72)

Campo seria, portanto, um espaço social multidimensional, no qual os indivíduos ocupam posições diferenciadas de acordo como o capital ${ }^{3}$ (simbólico $^{4}$, econômico, entre outros) de que dispõem. Cada campo se caracteriza por se estruturar mediante uma lógica própria, que lhe garante certa autonomia. A noção de campo comporta, desta forma, tanto o universo valorativo e simbólico, como as relações de força e de dominação, ou seja, relações de poder, por meio das quais as frações dominantes lutam pela manutenção de seus privilégios em meio a conflitos

\footnotetext{
${ }^{3}$ Apesar da noção de "capital" ser central na sociologia marxista, no sentido, grosso modo, de posse de recursos materiais e humanos, Bourdieu não a conecta diretamente à obra de Marx. Para ele, o conceito de capital é entendido como o instrumento por intermédio do qual operam os processos no interior do campo. Outra característica importante da noção de capital é a sua escassez, o que permite que assuma a função de arbitrar as diferenciações sociais. (Grenfell e Hardy, 2007: 30)

${ }^{4}$ Abordaremos a noção de capital simbólico designando o "crédito (no sentido, ao mesmo tempo, de crença e de confiança concedida antecipadamente) posto à disposição de um agente pela adesão de outros agentes, que Ihe reconhecem esta ou aquela propriedade valorizante (...). Existir socialmente é, essencialmente, ser percebido, isto é, fazer com que sejam reconhecidas tão positivamente quanto possível as suas propriedades distintivas" (Bonnewitz, 2003: 103) Bourdieu usa muitas vezes o termo de uma forma mais abrangente. Para ele, como tudo o que ocorre no interior de um campo determinado tem elevado grau de arbitrariedade, a compreensão da dinâmica do campo só é possível simbolicamente, já que o valor que as coisas, as pessoas e as ações adquirem é imputado pela lógica do campo. O "capital simbólico" seria essa valoração dos constituintes do campo.
} 
com as frações dominadas, ansiosas pela aquisição de maior capital. Campo é um espaço arbitrário, reconhecido por aqueles que estão no jogo e que, portanto, compartilham de uma crença. Mesmo o compartilhamento não configurando unanimidade, as lutas se travam sobre um fundo consensual, que pressupõe a adesão às regras básicas. A posição de dominância implica orientar as regras do jogo ou ser, nas palavras de Bourdieu, o "nomoteta".

A diferenciação e a afirmação da autonomia dos campos é uma forma de distribuição de status e privilégios, já que cada um deles se estruturam em hierarquias que seguem legalidade própria que correspondem a formas específicas de distribuição de poder e de dinâmicas de dominação. Contudo, é possível identificar propriedades comuns a esses campos, ou, nas palavras de Bourdieu, existem "homologias estruturais e funcionais entre todos os campos". Esses pontos em comum entre os campos são freqüentemente interpretados weberianamente com conceitos retirados da eco nomia (como capital, concorrência, monopólio, oferta, procura, lucro):

\begin{abstract}
A teoria geral da economia dos campos permite descrever e definir a forma específica de que se revestem, em cada campo, os mecanismos e os conceitos mais gerais (capital, investimento, ganho), evitando assim todas as espécies de reducionismo, a começar pelo economismo, que nada mais conhece além do interesse material e a busca da maximização do lucro monetário. Compreender a gênese social de um campo, e aprender aquilo que faz a necessidade específica da crença que o sustenta, do jogo de linguagem que nele se joga, das coisas materiais e simbólicas em jogo que nele se geram, é explicar, tornar necessário, subtrair ao absurdo do arbitrário e do não-motivado os atos dos produtores e as obras por eles produzidas e não, como geralmente se julga, reduzir ou destruir. (Bourdieu, 2007:69)
\end{abstract}

As homologias identificadas nos campos dizem respeito à existência de uma relação de subordinação, diferenciando dominantes e dominados, na luta pela preservação dos capitais e privilégios que asseguram a dominação e as formas de reprodução social.

A matriz weberiana da noção de campo remete à concepção de que a existência humana pode ser pensada a partir da presença de esferas distintas ${ }^{5}$ da

5 Há quem veja na configuração atual do capitalismo uma negação da autonomia das esferas sociais: "a dinâmica do capitalismo globalizado anulou a autonomia das esferas. Além disso, na minha tradição teórica, a economia política é a anatomia da sociedade. Se quisermos fazer uma ciência social 'à la americana', sem 
vida social: a saber, a religião, a economia, a política, a arte, o direito etc. Os processos de racionalização e autonomização dessas esferas são centrais na teoria weberiana. Nas "sociedades tradicionais", aquelas esferas estavam imbricadas de tal maneira que não fazia sentido pensar em uma segmentação da vida social. A crescente racionalização do mundo ocidental teria introduzido novos elementos na ordem social:

O desenvolvimento do intelectualismo e da racionalização da vida modifica essa situação. Nessas condições, a arte torna-se um cosmo de valores independentes, percebidos de forma cada vez mais consciente, que existem por si mesmos. A arte assume a função de uma salvação neste mundo, não importa como isto possa ser interpretado. Proporciona uma salvação das rotinas da vida cotidiana, e especialmente das crescentes pressões do racionalismo teórico e prático." (Weber, 1988:256)

O processo de autonomização do campo artístico em relação aos demais campos sociais foi progressivo. Bourdieu (2004) afirma que este se intensificou com a Revolução Industrial, estando também relacionado com a generalização do ensino elementar que permitiu a novas classes o acesso a bens culturais. Essa autonomia atingiu seu ápice quando o produtor cultural deixou de relacionar-se (ao menos exclusivamente) com seu mecenas ou seu patrão, e passou a dirigir-se a um mercado impessoal, constituído por um público numeroso de compradores anônimos de ingressos de teatro, de concertos, de livros ou de quadros. Na visão de Bourdieu, esse processo concedeu ao artista uma liberdade apenas "formal", considerando que representa uma

submissão às leis do mercado de bens simbólicos, vale dizer, a uma demanda que, feita sempre com atraso em relação à oferta, surge através dos índices de venda e das pressões explícitas ou difusas, dos detentores dos instrumentos de difusão, editores, diretores de teatro, marchands de quadros. (Bourdieu, 2004:104)

A ampliação do público consumidor ou das platéias é um dos pilares da autonomização do campo artístico, uma vez que sem ela seria impossível a desvinculação do artista do seu patrocinador. Portanto, essa autonomia relaciona-se diretamente com a transição de uma forma, digamos, protetora de patrocínio privado

determinações entre as diversas esferas, poderemos até ver virtude numa 'sociedade civil' que institui 'segurança' nos morros do Rio e nas imensas Heliópolis - veja o sarcasmo da denominação grega de São Paulo." (Oliveira, 2004). 
e público para o mercado "livre" e auto-regulado, obrigando os artistas a travarem luta sem precedentes por sua existência material.

A Sociologia da Cultura, e mais especificamente a Sociologia da Arte, tem se preocupado com a investigação do objeto artístico em si ou com a recepção da obra de arte. Serão objeto de preocupação, neste estudo, essencialmente as motivações que dão sustentação às ações de uma instituição cultural, bem como as decisões tomadas no sentido de equilibrar interesses do campo artístico e empresarial.

Muitas vezes, a obra de arte mostrou-se como objeto empírico privilegiado de investigação, a partir do qual se reconstituíam os nexos sociais que propiciavam uma interpretação para a própria obra e para os grupos que a designavam como digna de ser considerada um bem destinado à apreciação estética. Muitos estudos centram-se nas relações que se estabelecem entre autor => obra => público e não destacam a importância dos intermediários que viabilizam essa relação nas sociedades contemporâneas.

No estudo da grade de programação do CCBB, a análise será feita a partir da identificação de sua situação no interior do campo artístico, a fim de delimitar quais componentes (inovação, reputação, competência técnica etc.) são valorizados nas escolhas efetuadas.

$\mathrm{Na}$ Brasil, as instituições financiadoras, sejam públicas ou privadas, são decisivas para que a produção artística ocorra. São elas que fazem a mediação tanto do processo de produção, quanto de recepção da obra. A competição que se estabelece no interior do campo artístico pelos recursos econômicos - sempre escassos e insuficientes - que viabilizam a produção das obras, reverbera uma outra luta também constante no interior do campo, que remete aos processos de legitimação e a busca incessante por prestígio dentro e fora da esfera artística. Se, outrora, a busca por financiamento governamental pelos artistas os obrigava a estabelecer relações com as esferas de poder político, a proliferação da prática do marketing cultural empresarial, impôs uma nova dinâmica de relações sociais ao campo artístico. Um estudo que vise a analisar este campo não deve, contudo, centrar-se apenas na relação artista e patrocinador empresarial, desconsiderando uma série de outros intervenientes do processo de produção, circulação e consumo dos bens simbólicos, tais como o público, a obra artística, os órgãos governamentais, os meios de comunicação de massa, os críticos, os curadores, os produtores, os jornalistas, os assessores de imprensa, entre outros. Uma análise 
dessa natureza, mais ampliada, não significa abandonar a obra, mas enfatizar o olhar e as perspectivas que os atores do campo artístico - e também os que lhe são exteriores, mas interessados em sua eficácia simbólica - dirigem a ela.

Poucas pesquisas têm se dedicado ao processo de produção e circulação de bens simbólicos e artísticos em suas interações com os diversos atores sociais em jogo no campo artístico. O que nos interessou foi investigar como o fazer artístico, seus processos artesanais de produção e o próprio conteúdo do produto construído estabelecem relações conflituosas com os trâmites burocratizados e racionalizados das empresas. Essa parece ser uma tarefa imprescindível para a compreensão da dinâmica do campo artístico, tal como ele se configura no Brasil. A produção do conhecimento em Sociologia assume constantemente a função de desvelar determinadas ações as quais, ou não são conhecidas pelos atores que as praticam, ou Ihes aparecem de forma contraditória e obtusa. Seu princípio epistemológico por excelência é o da busca da objetividade na construção do saber. Rompendo com a herança fundadora do positivismo, a possibilidade de neutralidade das interpretações sociológicas tem sido constantemente colocada à prova, sem que, com isso, seja abandonada a necessidade do distanciamento que se impõe na relação sujeito-objeto do conhecimento. Esse distanciamento é ao mesmo tempo crítico e indagante, na medida em que coloca questões que os atores investigados não colocariam, ao tentar estabelecer nexos causais entre elementos desconectados na prática cotidiana. No entanto, a própria formulação do objeto da investigação traz em si um universo valorativo que o sociólogo precisa também colocar em questão, sob pena de contaminar seu conhecimento com pré-julgamentos que colocarão seu discurso a serviço de uma "sociologia espontânea", pouco distinta das demais noções elaboradas por outros atores sociais. Mesmo que valores subjacentes à formulação da pergunta estejam presentes no curso da investigação, devem ser explicitados, sob pena de comprometerem o pressuposto básico da busca da objetividade.

Nesta pesquisa, portanto, o valor presente na construção do problema investigativo é o da própria autonomia da esfera artística, constituída enquanto espaço contraposto a uma sociedade que se constrói como mercado. A pergunta que percorre toda a investigação é de se a arte pode ser agente de emancipação, no cenário de extrema desigualdade e barbárie social como o brasileiro? Ou, ao contrário, considerando a inserção cada vez maior de agentes empresariais no 
fomento à criação, se o objeto artístico se encontra domesticado pelo peso, ainda que escamoteado, dos princípios do marketing corporativo?

A busca da objetividade nas ciências sociais é preceito fundamental a garantir que a investigação e as conclusões delas decorrentes não sejam contaminadas pelos juízos do sujeito da pesquisa. No entanto, a própria escolha do objeto e o "recorte" feito da realidade não estão imunes às condicionantes sociais nas quais o pesquisador está inserido. Assim, apesar das precauções tomadas para garantir a objetividade que o estudo requer, é fundamental explicitar também os vínculos que o pesquisador mantém com a instituição objeto de investigação e sua influência na escolha do problema a ser pesquisado. Embora não faça parte dos quadros do CCBB, o pesquisador é funcionário do Banco do Brasil há 21 anos, em área diferenciada, não tendo qualquer contato com o CCBB em suas atividades profissionais. Atualmente, faz parte do quadro de uma agência bancária voltada ao atendimento a médias e grandes empresas. Certamente, a longa vivência como funcionário da empresa permitiu compreender mais facilmente as relações do CCBB com seu mantenedor, bem como delimitar o papel da instituição cultural no contexto geral do conglomerado Banco do Brasil.

A proximidade com o objeto de análise não significou, contudo, abertura irrestrita a todas as informações. O vínculo com o Banco do Brasil obriga o CCBB a todas as restrições legais e mercadológicas relativas à confidencialidade de dados $\mathrm{e}$ informações. Seus funcionários sempre foram receptivos, generosos e compreenderam, desde o início, a importância da pesquisa. Não se furtaram a externalizar suas opiniões e os conhecimentos que detinham em entrevistas formais, bate-papos informais e e-mails. Como recurso ético, houve o comprometimento da manutenção do anonimato dos funcionários, ainda que muitos não achassem necessário, para evitar qualquer tipo de preocupação em torno das relações com superiores, artistas ou pares.

A maior parte dos dados foi franqueada sem qualquer restrição, desde que os documentos não fossem retirados do ambiente do CCBB. Outros, contudo, eram mostrados, com a solicitação de que não houvesse qualquer tipo de registro ou apontamento a respeito. Essas restrições, entretanto, em nada prejudicaram o levantamento de informações as quais permitiram obter os elementos necessários para responder às questões que havia levantado. 
A receptividade com que o pesquisador era recebido era permeada por certa desconfiança, jamais explicitada, quanto a eventuais conclusões "negativas" que a pesquisa poderia evidenciar. Isso se explica pelo fato de o CCBB ser uma instituição vinculada à área de marketing, cuja preocupação com a imagem é o leitmotiv em torno do qual giram as ações cotidianas de toda a equipe. Além disso, nas entrevistas, a defesa das escolhas e diretrizes efetuadas pela instituição superou largamente as raras críticas que eram feitas ao CCBB. Isso pode ser decorrente do orgulho dos entrevistados em trabalhar na instituição, e da responsabilidade e comprometimento com as escolhas por ela efetuadas. Contudo, a parcimônia em criticar, supõe-se, deva-se também ao fato de o pesquisador ser externo à instituição e não haver, em conseqüência, controle do uso que poderia fazer das informações colhidas que, se utilizadas, teriam caráter eminentemente público, de certa forma, legitimado pelo meio acadêmico.

A escolha das artes cênicas e plásticas como elementos privilegiados de investigação reside no caráter ainda artesanal de sua produção e de sua resistência aos processos de massificação, o que as torna, principalmente as artes cênicas, mais dependentes de formas de financiamento de fontes exteriores ${ }^{6}$ ao campo artístico. Os produtores culturais dessas artes parecem preocupar-se com a afirmação de sua obra identificada com a "arte pura", avessa ao que se considera a industrialização promovida pelo cinema, literatura, música e televisão, dentre outros:

A economia anti-econômica da arte pura que, baseada no reconhecimento indispensável dos valores de desinteresse e na denegação da 'economia' (do 'comercial') e do lucro 'econômico' (a curto prazo), privilegia a produção e suas exigências específicas, oriundas de uma história autônoma; essa produção que não pode reconhecer outra demanda que não a que ela própria pode produzir, mas apenas a longo prazo, está orientada para a acumulação de capital simbólico, como capital 'econômico' denegado, reconhecido, portanto legítimo, verdadeiro crédito, capaz de assegurar, sob certas condições e a longo prazo, lucros 'econômicos.' (Bourdieu, 2005:163)

Assim, procura-se entender como essas artes, que se afirmam pela negação do econômico, se aliam a uma empresa que se constitui pela atividade econômica. As artes cênicas talvez sejam dos ramos artísticos, o que mantém seu lado mais

\footnotetext{
${ }^{6}$ Como veremos, o CCBB é ao mesmo tempo parte integrante e elemento externo ao campo artístico. É integrante na medida em que se configura como instituição cultural, mas é externo na medida em que não tem existência separada do Banco do Brasil, seu mantenedor.
} 
artesanal ao longo do tempo, já que sempre pressupõe a relação pessoal atorespectador, mesmo com a incorporação de novas tecnologias. Da mesma forma, muito embora exista um mercado de artes plásticas, com galerias e leilões, ele ainda mantém caráter bastante restrito, não se configurando uma produção industrial, como acontece no meio literário e musical, e depende diretamente das instituições culturais como instâncias de consagração. Ambas as manifestações artísticas direcionam-se, via de regra, a um público dotado de elevado capital cultural, exigindo, portanto, o domínio de códigos do campo artístico apropriados para sua fruição.

A pesquisa ficou centrada nos espetáculos teatrais e nas exposições de artes plásticas patrocinados pelo CCBB São Paulo, nos anos de 2005 e 2006. A escolha desse período se justifica por dois motivos: em primeiro lugar, a necessidade de delimitar o tempo abrangido, considerando o elevado número de processos submetidos à apreciação do CCBB. Em segundo, o período escolhido se caracteriza pela passagem de dois diretores de marketing pela instituição, com perfis bastante diferenciados: Henrique Pizzolato, possuindo vínculo político estreito com o Governo Federal, e Paulo Cafarelli, técnico de carreira do BB.

Foram três as fontes de dados da pesquisa:

a) entrevistas com os atores sociais envolvidos. Foram entrevistados 15 funcionários do BB e do CCBB de diferentes níveis hierárquicos (1 executivo, quatro do nível diretivo-gerencial, cinco gerentes de nível intermediário e cinco analistas, esses de nível operacional). Foram entrevistados também dois Produtores Culturais ${ }^{7}$. A participação em um curso de Jornalismo Cultural, promovido pela Revista Cult e pela Faculdade Cásper Líbero, com palestras de jornalistas, críticos de arte e editores, muito contribui para a redação do último capítulo desta tese.

b) documentos do CCBB, incluindo pareceres e relatórios acerca dos projetos artísticos inscritos (aprovado ou não) nos anos de 2005 e 2006, em São Paulo; pareceres da assessoria jurídica, relatórios de avaliação das atividades, entre outros. Assim, foram analisadas 200 fichas com as

\footnotetext{
${ }^{7}$ Grafou-se com maiúsculas a fim de se efetuar a distinção da denominação genérica, mais usualmente utilizada nesta tese, designando o produtor efetivo dos bens simbólicos, normalmente como sinônimo de artista. $\mathrm{O}$ Produtor Cultural, como veremos adiante, é aquele encarregado de ser o elo de ligação entre o artista e as instituições patrocinadoras, bem como cuidar dos aspectos mais materiais e concretos que viabilizam a execução da obra artística.
} 
atribuições e julgamentos feitos pelo CCBB aos projetos inscritos, que resultaram na seleção das obras patrocinadas (essa quantidade foi distribuída em número proporcional aos projetos inscritos nas duas artes nos anos sob análise). Estudamos também as "notas técnicas" (10 de artes plásticas e 9 de artes cênicas) que eram elaboradas pelo CCBB para subsidiar a decisão da Diretoria de Marketing pela aprovação ou não do projeto. Essas notas seguiam modelo padronizado, que compreendiam dentre outros aspectos informações sobre os proponentes (dados curriculares e análise da reputação do artista), as razões da escolha, a regularidade fisco-tributária do proponente, e o orçamento. Foram analisados os cadernos de planejamento resultantes do processo de seleção dos projetos dos dois anos sob análise, assim com os relatórios anuais de avaliação das atividades. Esses documentos, por serem considerados sigilosos pelo Banco do Brasil, não puderam receber citação nesta tese.

c) trajetória e repercussão dos projetos aprovados, mediante análise da mídia impressa (principalmente Revista Bravo!, jornais Folha de S. Paulo e O Estado de São Paulo). A pesquisa da repercussão dos projetos na mídia justifica-se por seu peso decisivo dentro do campo artístico. Foram estudadas as notícias coletadas pelos proponentes e pela assessoria de imprensa do CCBB de todos projetos patrocinados (nas áreas e anos sob análise), reunidas em cadernos denominados "clippings de imprensa".

No levantamento bibliográfico efetuado, foram localizadas poucas pesquisas sociológicas brasileiras sobre marketing cultural ou patrocínio empresarial. Há muitas publicações, dissertações e teses sobre o assunto (Ajzenberg, 2005; Alonso, 1992; Cordeiro, 2002; Correia, 2002; Fé, 1997; Fischer, 1998; Mandaji, 2003; Pugnaloni, 2004; Tavares, 2003), na área de Comunicações, Administração de Empresas, Relações Públicas e Marketing, possuindo, portanto, uma perspectiva diferente da que orientou esta pesquisa. Em linhas gerais, esses trabalhos procuram legitimar uma área ainda em fase de consolidação e muitas vezes possuem caráter mais prescritivo do que interpretativo.

O CCBB já foi objeto de alguns trabalhos acadêmicos (Lemos,1994; Prazeres,1996; Vieira,2006; Assis,2007), porém nenhum deles abordou as condicionantes e conseqüências das escolhas artísticas da instituição, temática 
central desta pesquisa, que aborda o CCBB como agente intermediário no processo de produção do objeto artístico. Embora não sejam os protagonistas do campo artístico, são considerados elementos importantes para o funcionamento e a dinâmica desse campo, não só porque detêm poder econômico, mas, principalmente, porque são instâncias legitimadoras e instituídas como atribuidoras de prestígio e status aos ocupantes do campo. Ao patrocinarem a produção e a circulação do objeto artístico, criam as condições necessárias para que esse campo se reproduza e mantenha sua eficácia social.

A presente pesquisa mostra-se relevante em função do reconhecimento de que, no Brasil, patrocínio empresarial com fins mercadológicos é um fenômeno recente e em expansão. O interesse das empresas na produção artística e o retraimento ${ }^{8}$ do Estado no fomento às atividades culturais instauram um novo dinamismo nas relações entre os atores sociais pertencentes ao campo artístico. Trata-se do que Eco (1989:25) denomina de temática "quente", não só pela contemporaneidade da questão social abordada, mas também porque tem sido alvo de inúmeros debates, gerando demandas para a revisão da lei de incentivos pelo Governo Federal.

Resistir à tentação e à demanda do objeto de pesquisa e dos demais intervenientes acerca de um posicionamento do pesquisador, se favorável ou não às formas hodiernas de patrocínio cultural, foi também condição para a desejada busca de objetividade na investigação. O papel do sociólogo não é o de alimentar as lutas e disputas existentes no meio social, mas o de compreender seus fundamentos, 0 que "permite ao pesquisador se movimentar entre as diferentes posições, envolvendo-se no jogo, sem para isso jogar mais com um jogador que com outro, de maneira a restituir as regras do jogo, como tentaria fazer um etnólogo exterior a esse mundo" (Heinich, 1998a:15)

Analisar o financiamento empresarial à atividade artística nos propicia acesso às modificações havidas nas duas esferas envolvidas nessa inter-relação. De um

\footnotetext{
${ }^{8}$ Retraimento talvez não seja a palavra mais adequada já que a presença do Estado na esfera artística sempre foi muito incipiente, principalmente, se compararmos com países, como a França, por exemplo, onde essa atuação é mais marcante. Entretanto, assim como se deu em outras esferas da vida social, o Estado brasileiro nunca esteve completamente ausente do campo artístico, seja na qualidade de normatizador ou de fomentador da produção cultural. O momento inicial dessa presença estatal no segmento elitizado ou erudito da vida cultural pode ser localizado na vinda de Dom João VI e na implantação da Biblioteca Nacional. Se, por um lado, o financiamento público à produção artística sempre foi considerado insuficiente pelos atores sociais desse campo, por outro, pode-se verificar uma atuação estatal clara, ao menos na dimensão regulamentadora, se assim caracterizarmos o ordenamento jurídico. Já na Constituição de 1824, garante-se a
} 
lado, as empresas, inseridas em um mercado altamente competitivo, para construir uma imagem institucional favorável a qual, por conseqüência, incremente suas vendas, parecem necessitar de ferramentas mais diversificadas do que a mera ação publicitária. De outro lado, artistas, alheios ao chamado mercado de arte - ainda incipiente e que possui os mesmos mecanismos excludentes de qualquer mercado e abandonados por uma ação estatal sempre insuficiente - que adquiriu sinais evidentes de esgotamento com o advento de governos marcadamente neoliberais -, vêem no patrocínio empresarial a possibilidade de continuar produzindo suas obras.

A presente trajetória analítica passou, especialmente, pelo exame dos juízos que determinados atores sociais, inseridos no mercado financeiro, constroem sobre o objeto artístico e sobre sua eficácia simbólica, não somente no interior do próprio campo, mas também no campo econômico. A discussão acerca das relações entre os campos artístico e econômico é mais freqüente na literatura sociológica quando a obra é objeto de comercialização, como acontece com o mercado de artes plásticas, de forma não massificada, ou no caso do mercado editorial ou fonográfico, de forma industrializada. Nesta pesquisa, a tensão entre essas esferas mostrou-se sempre presente, ainda que a obra não se apresente como mercadoria, ao menos de forma explícita. A produção cultural fomentada pelo BB não visa a obter ganho financeiro direto com a venda de obras. O lucro almejado é eminentemente simbólico. Assim, a fricção entre esses campos ocorre de forma muito mais dissimulada e implícita do que a que acontece no mercado das artes. De qualquer maneira, a hostilidade e a animosidade entre os campos mostram-se presentes. Se é verdade que o BB não almeja lucro com o patrocínio, não é menos verdade que esse patrocínio também seja pensado em termos monetários, não somente no que se refere aos benefícios fiscais, mas também em termos do retorno "financeiro" obtido com a mídia "espontânea".

O CCBB tem uma função essencialmente mediadora em dois níveis. No primeiro, internamente ao campo econômico, ocupa posição subalterna na estrutura hierárquica dentro do BB e precisa legitimar-se constantemente junto à Diretoria de Marketing e ao Conselho Diretor da empresa. Não constituindo a "área-fim" da empresa, e sendo uma central de custo, com ganhos totalmente intangíveis, sua existência é constantemente colocada à prova. Em um segundo nível, faz mediação 
no interior do campo artístico de duas formas: concorrendo e competindo com as demais instituições culturais por prestígio, público, espaço na mídia e reputação, e mediando a relação do público com o artista, isto é, a produção e o consumo.

Além das instituições culturais, outros atores sociais, vinculados ou não a elas, assumem a função de intermediários no campo artístico: produtores, marchands, curadores, críticos, gestores culturais, programadores culturais, funcionários públicos vinculados a Secretarias e Ministério da Cultura, jornalistas culturais, entre outros. Mais do que "atravessadores" da relação mais central do campo (artista-obra-público), esses intermediários viabilizam a criação e dão sustentabilidade a todos os mecanismos de consagração, divulgação e apoio econômico que mantêm a aura em torno dos objetos simbólicos criados e, portanto, a autonomia do campo. Hoje a eficácia simbólica da arte é impensável sem esses intermediários.

Considera-se que o incremento do apoio financeiro dado pelas empresas às artes se insere em contexto social de avanço do neoliberalismo e do enfraquecimento do Estado como órgão fomentador de atividades consideradas não essenciais. $O$ avanço sem precedente ocorrido nas últimas décadas na "corporatização" das instituições artísticas envolve a criação de institutos e fundações com o nome e a ingerência direta dos patrocinadores, como é o caso do CCBB, e repercute em diversos outros setores como o aumento do preço dos ingressos, seções de museus com "merchandising", aumento do espaço e recursos destinados a restaurantes, cafés e lojas e a integração dessas instituições com eventos não-artísticos e comerciais. No entanto, como ocorre ao objeto de análise deste estudo, o Estado continua com forte presença, seja como fomentador indireto, via patrocínio por empresa estatal, sejar garantindo o aporte de recursos via lei de incentivo fiscal, ainda que aqui delegue papel importante a agentes privados.

A busca da causalidade nas escolhas do CCBB envolve, além dos critérios artísticos, valores relacionados ao campo econômico, mais especificamente relacionados à área de marketing, e também princípios - do que vem sendo chamado recentemente - de "responsabilidade social". Esses últimos muitas vezes se colocam em conflito com valores próprios ao campo artístico, que reivindica autonomia e não se sujeita a critérios externos. As regras do patrocínio governamental, público, parecem ser mais aderentes aos anseios dos artistas, 
enquanto a sujeição aos critérios dos executivos de marketing das empresas surge como um "mal necessário", haja vista a escassez de recursos disponível.

Esta tese se estrutura em três partes. Na primeira delas, o foco da interpretação é análise das justificativas mercadológicas para o patrocínio, procurando detectar as múltiplas relações da instituição cultural com os campos econômico e empresarial. No caso específico sob análise, as relações com o campo governamental também ganham destaque, não só em função do caráter central das leis de incentivo no patrocínio empresarial, mas também em decorrência do vínculo do mantenedor com a União.

Na segunda parte, a discussão foca a inserção do CCBB no campo artístico, procurando delimitar as implicações das motivações mercadológicas na atuação propriamente cultural que desenvolve.

$\mathrm{Na}$ última parte, a preocupação é a relação do CCBB com elementos exteriores ao campo artístico e econômico.

A trajetória da interpretação do objeto construído tem início, portanto, com uma análise da inserção (e suas consequências) do CCBB no Banco do Brasil. No primeiro capítulo, procura-se caracterizá-lo como instituição de divulgação cultural, bem como interpretar os objetivos a que se propõe. Serão também abordadas suas características de instituição mantenedora, especialmente a dicotomia que marca sua face contemporânea, em que procura aliar o seu vínculo com o Governo Federal a uma atuação comercial e empresarial focada na competição no mercado e na obtenção de margens crescentes de lucro. Por fim, procura-se traçar um panorama das instituições culturais vinculadas a bancos para buscar explicações para a inserção das instituições financeiras no campo artístico.

No segundo capítulo, buscar-se-ão as razões que levaram o BB a ter uma atuação na área de marketing cultural, esclarecendo como é tratada a categoria “imagem”, cuja melhoria se almeja por intermédio do patrocínio. Busca-se explicar também como o investimento em cultura é utilizado para afirmar o mantenedor como empresa "socialmente responsável". Analisa-se ainda a utilização do CCBB como ferramenta de relacionamento interpessoal com os clientes. Finaliza-se com discussão acerca do papel do incentivo fiscal no patrocínio artístico do BB.

No terceiro capítulo, discute-se a inserção do CCBB no panorama cultural paulistano. Problematiza-se a noção de Centro Cultural, como forma paradigmática de consumo cultural contemporâneo, reunindo formas artísticas diversas em um 
único espaço. Discorre-se brevemente sobre a distribuição espacial dos equipamentos culturais na cidade e as implicações da escolha pelo centro da cidade, pelo CCBB.

A análise dos competidores inicia-se com as instituições que se assemelham no formato de reunir, em um único espaço, modalidades artísticas diferenciadas, a saber, o Centro Cultural São Paulo (CCSP), o Serviço Social do Comércio (SESC) e - Itaú Cultural, os quais se diferenciam em função de suas políticas e de suas formas de financiamento. Prossegue um breve mapeamento do campo cultural de São Paulo nas artes cênicas e plásticas, para se delimitar o lugar do CCBB no conflito com outras instituições patrocinadoras de cultura.

No quarto capítulo, faz-se uma análise do processo de seleção dos projetos e os critérios utilizados na definição da programação. O CCBB, também por estar vinculado ao Governo Federal, faz processo de seleção pública para escolher as obras que serão objetos de patrocínio. Os critérios são explicitados e divulgados antes do início de cada processo seletivo, que ocorre anualmente. Nesse capítulo, discute-se o que é definido como sua política cultural, bem como os valores que the dão sustentação. Analisa-se também sua forma de atuação e como ocorre o processo de seleção dos projetos artísticos que lhe são enviados. Também é feita minuciosa investigação sobre cada um dos critérios explícitos e implícitos nas escolhas.

No quinto capítulo, é analisada a programação do CCBB, nos anos de 2005 e 2006, nas áreas de artes cênicas e plásticas. A interpretação de como é estruturada essa programação utiliza conceitos diferentes para cada uma das artes em estudo. No caso das artes cênicas, investiga-se como a programação do CCBB se estabelece em relação ao que se denomina teatro comercial e teatro experimental. No caso das artes plásticas, a agenda é analisada à luz do conceito de "arte contemporânea" e do grau de adesão a essa noção das escolhas artísticas do CCBB. O roteiro dos espetáculos e exposições revela a existência de tensão, discutida nesse capítulo, entre o investimento em artistas consagrados e aqueles que são considerados como "talentos em ascensão".

No sexto capítulo, discute-se um episódio ocorrido no CCBB Rio de Janeiro, envolvendo a exposição Erotica - os sentidos da arte. Aqui se utiliza um atalho para discutir algo que não envolve diretamente o CCBB São Paulo, mas revela muito da tensão entre o Banco do Brasil e seus centros culturais. Naquela exposição, o 
patrocinador, em função da instauração de um conflito entre religiosos e artistas, se viu obrigado a escolher um dos lados. Optou pelos religiosos, mas justificou sua escolha em função de critérios "corporativos". Aqui, afirmou-se a preponderância da preocupação com a racionalidade econômica em detrimento da defesa dos valores artísticos que a instituição proclamava.

No último capítulo, analisam-se os dois critérios que, apesar de aparecerem timidamente no processo de escolha dos projetos, são fundamentais na definição da programação: a atratividade de público e de mídia. "Centimetragem" na mídia impressa e audiência são os fatores fundamentais na definição do patrocínio bemsucedido. Isso define como interlocutores privilegiados da instituição, de um lado, os jornalistas culturais e críticos e, de outro, os consumidores de cultura.

Não ser banco comercial, mas parte de uma instituição financeira; ser instituição cultural, parte de um banco comercial são dilemas que estão na própria identidade do CCBB e evidenciam a articulação e conflitos de valores cardinais da vida contemporânea: o peso da racionalidade econômica convive, mesmo de forma conflituosa, com maneiras altamente autonomizadas de simbolização. 


\section{PARTE I - O CCBB E O CAMPO ECONÔMICO}




\section{Capítulo 1}

\section{O CCBB, O SEU MANTENEDOR E O CAMPO ECONÔMICO}

O Centro Cultural Banco do Brasil (CCBB) São Paulo é uma instituição mantida pelo Banco do Brasil que promove atividades nas seguintes áreas:

- Artes Cênicas - teatro e dança;

- Cinema e Vídeo - mostras e festivais;

- Exposições - pinturas, esculturas, fotografias, gravuras, instalações multimídia e outros;

- "Idéias" - palestras, seminários e conferências;

- Música - popular, erudita, instrumental;

- Programa Educativo - oficinas, cursos e visitas orientadas.

A decisão da criação do primeiro Centro Cultural Banco do Brasil, no Rio de Janeiro, deu-se em reunião da diretoria do Banco, realizada em 18 de junho de 1987 e coordenada pelo então presidente da instituição, Camillo Calazans de Magalhães.

A prática do patrocínio artístico pelo Banco do Brasil realizava-se de forma esporádica e esparsa anteriormente à criação do CCBBs. Os pedidos de apoio eram então recepcionados pelas agências, analisados e deferidos pelas superintendências $^{9}$ do Banco. Alguns projetos mais vultosos eram aprovados no âmbito da Diretoria de Marketing, que concentrava suas ações em campanhas publicitárias e de relacionamento. A Fundação Banco do Brasil e as empresas subsidiárias (BB DTVM, Brasilcap, Ourocard, Brasilveículos etc.), vinculadas ao Banco do Brasil e integrantes do conglomerado, também patrocinavam espetáculos, shows e filmes.

A opção pelo Centro Cultural que veio substituir os patrocínios pontuais de espetáculos e projetos, inseriu-se na tendência de as empresas de batizarem com

\footnotetext{
${ }^{9}$ Unidade tática que jurisdiciona a rede de agências.
} 
seus nomes determinados institutos ou equipamentos culturais ${ }^{10}$, como estratégia de relação com o público, à medida que exige a menção do nome do patrocinador pelos veículos de comunicação. Esta passa a ser uma informação essencial para o público, indicando o local em que determinado evento se realiza. Se o nome do patrocinador de eventos específicos aparece em tamanho e espaço reduzidos em cartazes, prospectos e programas de espetáculos - e raramente é mencionado em matérias de divulgação na grande imprensa -, dar o nome da empresa a uma instituição cultural garante a visibilidade que as organizações desejam. Além disso, ela deixa de ser somente um balcão de atendimento de projetos e distribuição de recursos e passa a atuar na concepção e execução de produtos culturais, tendo assim maior inserção no campo artístico.

Das áreas patrocinadas pelo CCBB São Paulo, a de artes plásticas é a que recebe maior público e é uma das que possui maior dotação orçamentária (Anexo 1). Nos anos de 2005 e 2006, recebeu público médio de 847.000 pessoas (Anexo 2), o que corresponde a uma média diária de 3.100 visitantes. $O$ orçamento médio do CCBB nesses anos foi de aproximadamente $R \$ 8.300 .000,00$, considerados apenas os valores gastos com os projetos patrocinados, sem incluir despesas administrativas e demais custos.

Em 12 de outubro de 1989, o BB inaugurou seu primeiro Centro Cultural no Rio de Janeiro, com $1.430 \mathrm{~m}^{2}$, para exposições, cinema com 110 lugares, sala de vídeo para 53 pessoas, três salas para espetáculo teatral, com 175, 158 e 140 lugares, um auditório para 90 pessoas, biblioteca, além de salas para exposição permanente sobre a história do Banco do Brasil e do acervo numismático. O imóvel conta com uma área total de $17.000 \mathrm{~m}^{2}$ e se localiza na Rua Primeiro de Março, no centro da cidade. O prédio, construído em 1906, em estilos neoclássico e art nouveau, pertence ao BB desde a década de 20 e abrigou a sede da empresa até 1960, quando foi transferida para Brasília. O Centro Cultural incorporou as atividades culturais já desenvolvidas pelo BB, como o Arquivo Histórico, o Museu Numismático e a Biblioteca, esta, até então, de uso exclusivo dos funcionários.

Inicialmente, a atuação do Centro Cultural esteve intimamente relacionada à Fundação Banco do Brasil, que já patrocinava alguns projetos artísticos e de provinham os recursos necessários aos patrocínios.

${ }^{10}$ Além do CCBB, há inúmeros outros exemplos na cidade de São Paulo: Itaú Cultural, Espaço Unibanco, Teatro Folha, Teatro Vivo, Teatro Cosipa Cultura, Teatro Abril, Teatro Copa Airlines, Teatro Gazeta, Teatro Alfa, 
Em 12 de outubro de 2000, o BB inaugurou seu Centro Cultural em Brasília, com dois espaços para exposições que totalizam $1.180 \mathrm{~m}^{2}$, além de um teatro com capacidade para 309 lugares e uma praça de eventos com área de $1.500 \mathrm{~m}^{2}$. Ocupa parte do edifício projetado por Oscar Niemeyer, em 1986, antes integralmente utilizado pela área de recursos humanos do Banco.

Os CCBBs são parte integrante do Banco do Brasil (BB) e não se caracterizam como figura jurídica autônoma. Vinculam-se à Diretoria de Marketing da empresa ${ }^{11}$ (Anexo 3), que se reporta ao presidente da instituição, o de São Paulo foi criado em 2001, após os do Rio de Janeiro e de Brasília.

O CCBB São Paulo foi inaugurado em 21 de abril de 2001. Ocupa prédio na rua Álvares Penteado, construído em 1901 e adquirido pelo BB, em 1923, quando abrigou a primeira agência do BB na cidade. A construção de quatro andares (mais subsolo e mezanino) foi tombada pelo Conselho de Defesa do Patrimônio Arqueológico e Turístico de São Paulo (Condephaat) e pelo Departamento do Patrimônio Histórico/Conselho Municipal de Preservação do Patrimônio Histórico, Cultural e Ambiental da Cidade de São Paulo (DPH/Conpresp). Dos seus $4.183 \mathrm{~m}^{2}$-espaço bem inferior ao do CCBB Rio de Janeiro --, $496 \mathrm{~m}^{2}$ são utilizados para exposição, distribuídos no térreo, segundo e terceiro andar, além do subsolo; um cinema para 69 pessoas, um auditório com 45 lugares, um teatro para 125 pessoas, além de pequeno espaço expositivo no primeiro andar. É administrado por equipe de dezessete funcionários, sendo um gerente geral, três gerentes de núcleos e treze funcionários de nível operacional, além de aproximadamente uma centena de funcionários terceirizados (portaria, informações, segurança, limpeza, monitoria de eventos e técnicos). Hoje, nada mais lembra a agência bancária de outrora, a não ser o cofre ${ }^{12}$ de dimensões avantajadas, mantido no subsolo.

Citibank Hall, Credicard Hall, HSBC Brasil, dentre outros.

${ }^{11}$ Faremos referência ao Banco do Brasil ora como empresa, ora como organização, ora como instituição não porque sejam termos substituíveis, mas porque todos eles se aplicam ao Banco do Brasil. O seu caráter organizacional está presente em sua orientação em direção a um objetivo e a coordenação das atividades no interior de uma estrutura deliberada (Bagla, 2003). O seu caráter empresarial é evidente na sua dinâmica hierarquizada, racional e burocrática, além da busca incessante por lucratividade (Bernoux, 1999). O seu caráter institucional se ancora na sua longevidade, importância política e econômica na história do país e presença marcante no imaginário coletivo.

12 "Um elemento fundamental desse edifício é o cofre. Aquele espaço foi substantivo para as funções que eram ali exercidas no passado e hoje, requalificados os usos dessa construção que por vários anos foi a antiga sede do Banco do Brasil em São Paulo, aquele compartimento assume um caráter simbólico de interesse. Se antes ele guardava o tesouro do Banco, hoje ele evoca o poder que as instituições bancárias assumiram na sociedade capitalista...." (Chiarelli, 2005) 
No que se refere à interação com a cidade, o CCBB Rio de Janeiro possui centralidade e importância maior que os demais, recebendo, inclusive, parcela maior de recursos. Isso se deve a alguns fatores. O primeiro deles se refere ao porte, com área e espaços bastante superiores aos demais. Além disso, trata-se do CCBB mais antigo, tendo consolidado sua atuação cultural no cenário da cidade. Por fim, tendo em vista o fato de a configuração das atividades culturais do Rio de Janeiro apresentar dinâmica diferenciada das de São Paulo, isso pode garantir a ele maior projeção e inserção no panorama cultural daquela cidade.

Paralelamente aos Centros Culturais, desde 1999 o Banco do Brasil patrocina o Circuito Cultural, hoje denominado CCBB Itinerante. Este teve como precursor o Brasil Musical, existente no período 1993-1998, que tinha como característica a itinerância de shows de música instrumental brasileira, e contemplava variadas manifestações artísticas: exposições, música, artes cênicas e programas educativos. Teve início em quatro cidades em 1999 e chegou a atingir dezenove cidades. Em 2002, foi adotado um formato constituído por um complexo de tendas instalado em único local para a realização de todas as atividades da programação, o que, na visão dos organizadores, propiciou grande visibilidade à marca BB, já que atingia área de aproximadamente $4.800 \mathrm{~m}^{2}$. Em 2006, o Circuito de Música e Teatro esteve em cinco cidades e o Circuito de Palestras em outras oito cidades.

A opção por prédios históricos em São Paulo e no Rio de Janeiro e pela moderna arquitetura de Niemeyer em Brasília procura inscrever a ambientação artística no espaço físico. A imponência dos edifícios faz com que o próprio prédio configure opção de fruição artística, o que tem sido explorado com visitas orientadas, que procuram abordar aspectos da arquitetura e da história dos locais.

O investimento nos Centros Culturais tem sido considerado pela empresa uma estratégia bem-sucedida e mais um deles se encontra em fase de instalação em Belo Horizonte. Houve também um projeto, não levado a cabo, de instalação de um Centro Cultural em Recife. 


\subsection{Centro de difusão artística}

O CCBB pode ser classificado como uma instituição de divulgação cultural. Não possui companhia artística estável própria (companhias de teatro, de música ou de dança), tampouco um acervo de artes plásticas. Para realizar suas atividades, necessita contratar profissionais que farão seu processo de criação; ou, para ser mais exato, na maior parte das vezes o que contrata são eventos, que consistem em agrupar obras já existentes ${ }^{13}$. Não há residência artística para criação dos quadros de artes plásticas. Não é patrocinada a produção de filmes, a criação de músicas ou de livros. As mostras de cinema são realizadas pelo agrupamento de filmes já prontos. Os espetáculos de música, eventualmente podem ter músicas inéditas, mas não decorrem de uma encomenda específica do patrocinador. A exceção está na área de artes cênicas, que não abre espaço para espetáculos que já tenham estreado em outros teatros. Porém, identificamos apenas um caso em que o texto não estava pronto na contratação do espetáculo, sendo que ao menos a dramaturgia era de conhecimento prévio dos patrocinadores. Contudo, poder-se-ia argumentar, com razão, que a dramaturgia, na cena contemporânea, não daria elementos suficientes para qualquer conhecimento prévio do espetáculo, o que nos faz acreditar que ela se configura como a área de maior risco para o patrocinador.

Essa característica central do CCBB condiciona de maneira decisiva as formas como se darão as relações com os artistas, com os públicos e com o mantenedor. Em primeiro lugar, a contratação de obras já prontas dá maior segurança ao patrocinador, que pode ter uma noção prévia do que será veiculado/exposto em suas instalações. É claro que essa segurança está longe de ser absoluta, pois há um trabalho de criação no agrupamento da(s) obra(s) já existentes. Assim, uma exposição com obras famosas e de relevância não assegura por si só o sucesso do empreendimento, pois sempre existirá a criação do curador, que propõe um recorte determinado em sua seleção e uma forma específica de classificação dessas obras. O mesmo se aplicaria ao cinema e à música. A criação não se restringe somente à confecção do objeto simbólico, mas também à sua re-

\footnotetext{
${ }^{13}$ No caso das artes plásticas, em caráter de exceção, algumas obras destinadas ao cofre e ao saguão de entrada são criadas especificamente para esses locais.
} 
apropriação por outros integrantes do campo artístico, anteriormente considerados como meros intermediários.

Uma segunda conseqüência importante da ausência de um corpo residente de criadores é a necessidade de estabelecer relações freqüentes e de curta duração com diversos componentes do campo artístico. Um vínculo permanente com artistas contraria a lógica da subcontratação dos serviços, na área financeira e no mercado econômico de maneira geral, que exclui dos seus quadros todas atividades sem vínculo imediato com o interesse principal. No caso dos artistas - e essa é a terceira conseqüência -, eles são colocados em uma posição de prestadores de serviços que serão comprados pelo patrocinador. O lugar de comprador, ocupado pela instituição cultural na relação de patrocínio, dá-lhe amplas possibilidades de "manobras" e barganhas, tendo em vista a oferta abundante e a escassez de compradores de produtos artísticos no mercado.

A delimitação das atividades passíveis de patrocínio exclui determinadas áreas artísticas que se vinculam à indústria cultural, tais como a publicação de livros (muito embora sejam patrocinados os catálogos das exposições) e a produção de filmes (forte área de atuação da Petrobrás) e discos. Isso afasta a política cultural do BB no que vem sendo chamado de "marketing de entretenimento", naquilo que envolve formas massificadas de difusão e, algumas vezes, outras consideradas menos nobres de produção simbólica.

\subsection{Objetivos do CCBB}

O site do Banco do Brasil (www.bb.com.br) insere o Centro Cultural em sua política de marketing cultural, indicando os seus objetivos almejados para criá-lo e mantê-lo:

- "Promover a instituição como apoiadora da cultura, comprometida com os anseios da sociedade."

A presença do vocabulário e dos conceitos-chaves da área de marketing é marcante no texto, do mesmo modo que no discurso e na prática dos profissionais entrevistados. Assim, termos como "promoção", "agregar valor", "fidelização" e "mercados" ressaltam como a linguagem, própria da ciência administrativa, está impregnada no universo conceitual e simbólico do CCBB. É interessante notar que o 
verbo empregado nesse primeiro objetivo não indica a busca por "ser" um organismo de apoio à cultura, mas "promover a instituição [BB] como apoiadora da cultura".

O objetivo de promover a empresa é inerente à atuação clássica das áreas de marketing das empresas, na divulgação e valorização dos produtos comercializados junto aos públicos consumidores. A promoção preocupa-se com a forma como os produtos comercializados serão percebidos pelos clientes. Também se associa a outro conceito central na área de marketing cultural que é a visibilidade. Almeja-se, portanto, que a instituição BB seja vista como empresa que apóia a cultura, pois esse seria um "anseio da sociedade" (conceito aqui empregado sem precisão).

- "Reforçar o conceito de empresa cidadã e o compromisso com as comunidades e com o país".

Novamente fica claro que o objetivo não é o de ser uma "empresa cidadã", mediante as ações de patrocínio, que não seria suficiente para isso; outrossim, a de que a percepção que os públicos possam ter da empresa a associem com uma organização ciosa dos direitos das pessoas a quem atinge. Portanto, como no objetivo anterior, reforça-se a idéia de apresentar o compromisso da empresa com algo que transcende a sua atividade precípua, vinculando-a à coletividade que está embutida nos conceitos de comunidade e de país. Dessa forma, procura-se afirmar que seus objetivos não respondem apenas às demandas mercadológicas (de lucro, conquista de clientes e mercado), senão que vincula-se a valores superiores aos interesses privados.

- "Agregar valor à marca BB, por meio de transferência de atributos relacionados à cultura".

"Agregar valor" é outro chavão dos profissionais de marketing e denota justamente o esforço de contribuir para a comercialização dos produtos. A área de marketing não atua diretamente na definição nem na produção dos produtos e serviços que são comercializados, tendo, portanto, um caráter de assessoramento no processo produtivo bancário. No entanto, pretende contribuir adicionando atributos que extrapolem a materialidade e as funções objetivas do que é adquirido. Trata-se, portanto, de alguma forma, de "mistificar" o produto, através de artifícios que seduzam o cliente, mobilizando-o para a compra, não apenas descrevendo suas características e funcionalidades, mas informando, geralmente de forma subliminar, os benefícios (imaginários), que os objetos alvos da promoção podem proporcionar a 
quem os adquirir. Os profissionais de marketing acreditam ${ }^{14}$ que, ao associar seu nome a uma atividade artística, a empresa compartilha a aura que envolve a criação simbólica e os valores que estão presentes nas manifestações artísticas, entre os quais, inovação, criatividade, ousadia, intuição, emoção.

O mecanismo é sutil e tende a ser subliminar. A informação do patrocínio fazse presente na percepção do público potencial e contribui para que a imagem da instituição seja diferenciada. Isto - associado a outros fatores tais como localização das agências, tarifas cobradas, qualidade de atendimento, prestígio da marca pode, em algum momento, garantir a conquista de novos clientes e a manutenção dos existentes.

Informações coletadas durante a investigação de campo, através de entrevistas, corroboram o que foi afirmado anteriormente. Questionados sobre como - CCBB pode contribuir na prospecção de clientes, os funcionários entrevistados esclareceram que não se trata de uma adesão imediata que se dá a partir de determinado consumo cultural, isto é, dificilmente um espectador encantado com a peça que assistiu no CCBB irá se tornar cliente do BB. O objetivo é de longo prazo e consiste na sedimentação de uma imagem positiva da empresa, que se consolida com o patrocínio.

Os dois últimos objetivos a que o CCBB se propõe são:

- "Contribuir no processo de prospecção e fidelização dos segmentos de clientes priorizados em todos os mercados atendidos pelo Banco"; e

- "Ser instrumento na consolidação da estratégia do Banco junto a mercados priorizados". ${ }^{15}$

A intenção mercadológica a que se propõe a instituição cultural fica clara. Contudo, esses objetivos são os mais difíceis de atingir, levando-se em conta que, nos últimos anos, os profissionais do CCBB tenham sido muito cobrados pela direção da empresa em relação a esse assunto.

\footnotetext{
${ }^{14}$ Optei por tratar essa "contaminação simbólica" como crença. Contudo, considerando pesquisa não exaustiva efetuada na bibliografia de marketing cultural e também as respostas negativas ao pedido, feito aos diversos entrevistados, de comprovação empírica dessa "contaminação", não é possível afirmar que essa transferência de atributos efetivamente ocorra. A princípio, considerava pouco provável que uma instituição tão racionalizada e economicamente orientada pudesse ancorar decisões que envolvem valores tão expressivos em dados não comprováveis. Porém, essa crença encontra-se de tal forma disseminada que ela é, para os atores sociais envolvidos, um fato, além de alimentar considerável número de publicações especializadas.

${ }^{15}$ Conforme consulta realizada ao site da instituição em 22/07/08.
} 
A prospecção de clientes no segmento bancário é pauta permanente da competitividade do mercado financeiro, embora seus fundamentos sejam de extrema complexidade. A escolha do banco pelo consumidor é baseada em uma multiplicidade de fatores, cujos pesos são de difícil delimitação. Uma das estratégias adotadas é a compra da folha de pagamentos das grandes empresas, remunerando o empregador pela transferência ou a manutenção das contas de seus empregados em determinada instituição.

Os objetivos mercadológicos envolvem o treinamento dos gerentes de contas para estimulá-los a utilizar a instituição como forma de atrair novos clientes ou intensificar o relacionamento com os já existentes, convidando-os para os vernissages, seja distribuindo entradas para os espetáculos. O objetivo desejado e

buscado é, portanto, a transferência de características do campo cultural ao processo de compra de produtos da área financeira.

Ficou claro, nas entrevistas realizadas durante o trabalho de campo, que os profissionais do CCBB e da Diretoria de Marketing do BB entendem que os valores a serem "cedidos" pelo patrocínio envolvem noções como as de criatividade, empreendedorismo, ousadia, beleza e inovação as quais, de alguma forma, tendem a ser consideradas antagônicas às do universo financeiro.

\subsection{0 mantenedor: banco público com atuação privada}

Reconstituir o percurso biográfico do ator social investigado, mapeando suas relações com outros agentes do campo é procedimento importante em pesquisas sociológicas de inspiração "bourdieusiana". Não se pretende, contudo, ser exaustivo nessa recuperação histórica, pois interessa, sobretudo, a história recente da instituição, quando o BB começa a sua inserção no campo artístico.

O Banco do Brasil foi fundado em 1808 por Dom João VI, já como sociedade anônima, mas levou nove anos para obter a subscrição das 1.200 ações iniciais. Em virtude de saques efetuados pela Coroa Portuguesa, além da má gestão financeira, foi liquidado em 1833. Em 1851, o Barão de Mauá recriou-o, com uma nova oferta pública de ações. Em 1905, após autorização do Congresso Nacional, o Governo passou a deter $50 \%$ do capital da instituição financeira, mantendo, contudo, sua 
característica de sociedade anônima, com ações transacionadas em Bolsa de Valores.

Em 1937, foi criada a Carteira de Crédito Agrícola e Industrial, propiciando ao Banco atuação mais incisiva no fomento à atividade produtiva, custeando a agricultura e auxiliando a estruturação industrial do país.

Ao longo de sua história, o BB mesclou sua atuação comercial com a função de Tesouro Nacional, responsável pela emissão de moeda e controle dos meios de pagamento da economia brasileira. A preparação para a segregação dessa função iniciou-se em 1945 com a criação da Superintendência da Moeda e do Crédito (Sumoc), apartando as funções de controle monetário e fiscalização dos bancos comerciais. Em 1964, a Sumoc foi extinta e criou-se o Banco Central do Brasil e o Conselho Monetário Nacional, mas o BB ainda manteve algumas funções de autoridade monetária nacional, só perdidas na década de 80.

Em 1985, foi criada a Fundação Banco do Brasil com ações nas áreas educacional, esportiva e de assistência a comunidades urbanas e rurais. Em 1986, extinguiu-se a Conta Movimento mantida pelo Banco Central, que assegurava suprimento automático de recursos para as operações financeiras do BB. Em contrapartida, foi lhe autorizada a atuação em todos os mercados já ocupados pelas demais instituições financeiras. A partir de então, suas características tornaram-se marcadamente comerciais, com a criação de diversas empresas (BB DTVM, BB Financeira, BB Corretora de Seguros, BB Administradora de Cartões de Crédito, BB Leasing), transformando-se em um conglomerado financeiro, com uma vasta gama de "produtos" 16.

Em 1995, foi lançado o Plano de Demissão Voluntária, para reduzir seu quadro de pessoal, o qual, em um ano, proporcionou o desligamento de 13.388 funcionários. No ano seguinte, em grave crise financeira, o banco registrou prejuízo de $R \$ 7,6$ bilhões, o que obrigou o Tesouro Nacional para manter a instituição operacional a fazer um aporte de capital de $\mathrm{R} \$ 8$ bilhões. O prejuízo acumulado, entre 1995 e 1998, foi de $\mathrm{R} \$ 20,8$ bilhões $^{17}$. A partir de então, com investimento maciço em tecnologia, tem apresentado lucros crescentes: já em 1997, seu lucro foi de $\mathrm{R} \$ 573,8$ milhões, atingindo patamares de $\mathrm{R} \$ 2,4$ bilhões, em 2003, $\mathrm{R} \$ 3$ bilhões,

\footnotetext{
${ }^{16}$ Embora seja denominação usual no meio bancário a utilização da nomenclatura produtos não é precisa, pois os bancos não vendem nenhum produto tangível, apenas prestam serviços.

${ }^{17}$ Conforme Cruz, Ney Hayashi. "Bancos Federais ganhamR\$ 24,4 bi sob Lula", Folha de S. Paulo, 28/02/2007, Economia, B1.
} 
em 2004, $R \$ 4,154$ bilhões, em 2005, $R \$$ 6,043 bilhões, em 2006 e $R \$ 5,058$ bilhões em 2007.

Alguns números explicitam a magnitude da empresa BB (Anexo 4). Com 81,5 mil funcionários, 8,9 mil contratados e 9,9 mil estagiários, possui a maior rede própria de atendimento bancário do país. São mais de 15 mil pontos, distribuídos em mais de três mil municípios. Entre os bancos brasileiros possui a maior rede de atendimento no exterior, estando presente em 23 países.

Além do banco múltiplo, o conglomerado reúne 15 empresas controladas e uma entidade fechada de previdência complementar, possui uma base de clientes na ordem de 24,3 milhões (Banco do Brasil, 2008). Sua posição no campo econômico é essencialmente relacional, isto é, é sempre referida sua distância em relação aos demais concorrentes, muito mais do que de qualquer outro fator de ordem interna (volume histórico de negócios, grau de eficiência). Dessa forma, os números citados só fazem sentido, quando comparados com os dos demais bancos concorrentes.

A busca pela liderança em todos os mercados em que atua é a força motriz que move a instituição, em um contexto no qual as empresas menores são "canibalizadas" pela concorrência. Nessa situação, quanto maior for a instituição, mais segurança de retorno ela terá.

Os bancos esforçam-se por afirmar os pontos em que lideram, também pelo fato de que os números, cada vez em ordem de grandeza mais elevada, dificultam a apreensão da sua correta magnitude pelo público. No caso do BB, é afirmada sua liderança em Ativos ( $\mathrm{R} \$ 357,8$ bilhões), Administração de Recursos de Terceiros ( $\mathrm{R} \$$ 220,1 bilhões) e Carteira de Crédito ( $R \$ 160,7$ bilhões), dentre outros (idem, ibidem). Da mesma forma, seus principais concorrentes, Bradesco e Itaú, também afirmam sua liderança em tantas outras áreas do mercado.

O caráter híbrido do BB, que mescla as esferas públicas e privadas, é algo digno de análise. Desde sua criação, intimamente ligado ao Governo Federal, gerindo os principais aspectos macro-econômicos do país, e tendo ação decisiva no desenvolvimento dos principais agentes produtivos, sejam eles rurais ou urbanos, sempre foi, por um lado, um dos principais instrumentos do Estado para ditar os rumos econômicos do país. Por outro lado, é a empresa mais antiga com ações negociadas em Bolsa de Valores, com mais de 100 anos, o que atesta o interesse de agentes privados em participar da empresa. 
O caráter comercial do BB intensificou-se a partir de 1986, o que garantiu não apenas a sustentabilidade da empresa, mas também preciosa fonte de receitas ao Governo Federal, em função dos elevados lucros obtidos nos últimos exercícios, tendo em vista os dividendos que as ações proporcionam. Em 2005, a título de remuneração pelas ações de posse do Tesouro Nacional, $R \$ 1,1$ bilhão foram destinados ao acionista majoritário.

Em 2001, o BB iniciou sua política de segmentação do atendimento e relacionamento com clientes, remodelando sua estrutura organizacional em três pilares: Varejo (pessoas físicas e micro e pequenas empresas), Atacado (médias, grandes e empresas corporates) e Governo (poderes Executivo, Legislativo e Judiciário, nos três níveis). Essa forma de relacionamento vinculou-se a uma política de marketing denominada "Identidade com o cliente" - que orientou diversas escolhas do CCBB - e se associou a outra política de posicionamento ${ }^{18}$ da empresa no mercado: "Banco completo ${ }^{19}$, especializado em segmento de mercado"

Em 2005, o investimento em marketing do $B B$ foi da ordem de $R \$ 180$ milhões, sendo que $R \$ 100$ milhões direcionados para o esportivo e cultural ${ }^{20}$. O investimento em cultura foi de $R \$ 31$ milhões em 2006, contra $R \$ 44$ milhões no ano anterior. Como veremos adiante, em torno de $20 \%$ desses recursos são próprios e o restante é deduzido do imposto de renda, através do uso da lei federal de incentivo. Em 2007, o valor destinado à cultura, elevou-se um pouco: $R \$ 32,6$ milhões. Comparados ao Resultado Operacional e à Receita Líquida da empresa, os valores investidos em cultura pelo BB estão em declínio, ou seja, a elevação dos resultados que vem obtendo nos últimos anos não está sendo acompanhada de mais investimentos em cultura. (Anexo 5)

Em termos comparativos, o Banco do Brasil está em volume absoluto muito atrás do maior investidor empresarial do país, que é a Petrobrás e, em 2007, investiu em cultura valores inferiores aos seus principais concorrentes, Bradesco e Itaú.

Tomada como parâmetro a relação entre os recursos investidos e o resultado operacional da empresa, o BB fica atrás somente do Bradesco. Porém, ponderados os investimentos em relação à receita líquida, o BB fica atrás não só dos seus

\footnotetext{
${ }^{18}$ Posicionamento é um dos conceitos-chave de marketing e envolve a percepção dos consumidores sobre uma empresa ou produto na sua relação com os demais concorrentes.

${ }^{19}$ O Bradesco, em 2006, passou a adotar estratégia de marketing semelhante com o "slogan" "Bradescompleto".

20 Garçon, Juliana. Território de Gigantes. Folha de S. Paulo, São Paulo, 24/10/2006. Folha Top of Mind, 78-86.
} 
concorrentes e da Petrobrás, como também do grupo Usiminas e da Votorantim (Anexo 6).

A Petrobrás investe valores muito superiores aos das demais empresas em patrocínio artístico. Em relação ao orçamento da Secretaria Municipal de Cultura de São Paulo, maior cidade do país, o valor destinado pela Petrobrás ao patrocínio cultural é $41 \%$ superior. Por mais que o fomento às atividades artísticas pelas empresas possa ser analisado como benéfico (e, certamente, sem esse recursos, muitas áreas artísticas estariam hoje com suas atividades praticamente paralisadas), causa estranheza que uma empresa petrolífera invista mais em cultura do que o maior município do país. Isso evidencia o poder econômico das corporações ante ao modelo econômico privatista do Estado na contemporaneidade, que acarreta o deslocamento da arena política e das formas de reivindicação dos patrocínios: deixa de ser a esfera institucionalizada e pública dos órgãos do Estado e passa a ser o departamento de marketing das empresas.

O mesmo raciocínio poderia ser aplicado ao BB. Entretanto, o mais perverso no modelo de patrocínio adotado no Brasil, é que a maior parte dos recursos investidos pelas empresas, nessa área, públicos ou privados, são recursos públicos, já que deduzidos do Imposto de Renda pelos mecanismos da Lei de Incentivo Fiscal (Lei Rouanet).

O vínculo do BB com o Governo Federal induziu-o a uma atuação empresarial não exclusivamente financeira, centrada somente na obtenção do lucro. Seu papel como agente de desenvolvimento econômico-social centrou-se durante muitos anos no crédito agrícola, mercado em que as demais instituições atuavam de maneira mais tímida, em função dos riscos envolvidos e do baixo retorno.

A preocupação em atuar como agente no desenvolvimento social e econômico é ressaltada constantemente, estando inclusive na missão ${ }^{21}$ da empresa, e constitui-se um contraponto com a ênfase dada nas últimas décadas na construção de um banco de mercado.

\footnotetext{
${ }^{21}$ As empresas costumam fazer declarações corporativas de caráter genérico e duradouro em que procuram mostrar aos acionistas e demais públicos interessados o motivo da existência da organização e o alcance das suas ações. Dá-se a isso o nome de missão. É interessante notar o cunho religioso da palavra, de onde provém a designação missionário, denotando o caráter vocacional que deseja expressar. A redação atual da missão do Banco do Brasil é: "Ser a solução em serviços e intermediação financeira, atender às expectativas de clientes e acionistas, fortalecer o compromisso entre os funcionários e a Empresa e contribuir para o desenvolvimento do País." (grifo nosso)
} 
Essa dimensão esteve um pouco enfraquecida durante os governos de Fernando Henrique Cardoso, haja vista a preocupação de manter sua competitividade no mercado, considerando que as ações e estratégias estavam mais voltadas para atuação comercial da empresa. Cogitou-se que esse movimento levaria à sua privatização. Ainda que timidamente, a partir do governo Lula, o BB voltou parte de seus esforços para buscar maior engajamento em questões sociais, mesmo mantendo clara preponderância de ações comerciais, voltadas para a lucratividade da empresa, em sua atuação. Assim, a partir de 1994, foi criada uma Diretoria exclusiva para tratar de ações relacionadas à "Responsabilidade Socioambiental" do Banco.

Segundo Assis (2007:170), o gasto total da empresa com marketing cultural não ultrapassou $10 \%$ do recurso disponibilizado pela Diretoria de Marketing, em 2005. Trata-se, portanto, de uma forma menos valorizada da empresa se comunicar e se promover diante dos seus interlocutores. No Banco do Brasil, a publicidade e o marketing esportivo angariam recursos superiores aos destinados ao patrocínio artístico.

Interessante notar que o espaço do CCBB não é utilizado de forma explícita como espaço de propaganda mercadológica do Banco do Brasil. Não há cartazes de divulgação de produtos ou serviços, folders não são distribuídos, não é possível abrir uma conta, nem há possibilidade de contato direto do público com funcionários da empresa. Há terminais de auto-atendimento, mas estão em lugares muito discretos. É como se a afirmação do patrocinador, que está no nome da instituição e nos logotipos constantes nos cartazes e programas, necessariamente precisasse ser sutil e sucinta para que 0 artístico se afirmasse em sua plenitude. $O$ nome da empresa precisa estar presente, mas em posição coadjuvante, de forma quase subliminar. A informação acintosa do patrocinador poderia deixar demasiadamente explícito o interesse mercadológico que dá sustentação ao patrocínio.

Se as ações do BB não são meramente publicitárias e demonstram a intenção da empresa de ter ação pública pautada em determinados princípios éticos, essa mesma organização possui diversos comportamentos condenáveis quando avaliados por esses mesmos princípios. Tais comportamentos não têm o mesmo grau de divulgação dos primeiros, mas possuem elevado potencial de danos aos públicos envolvidos com a empresa. 
O vínculo com o Governo Federal é usado freqüentemente para diferenciar o Banco do Brasil dos seus concorrentes, sendo que diversas campanhas publicitárias reforçam a idéia de se tratar de um "banco dos brasileiros". A campanha publicitária realizada no primeiro semestre de 2007 , de forte impacto, trocou a fachada de algumas agências substituindo "Banco do Brasil" por "Banco do João", "Banco da Maria", "Banco da Carla", utilizando nomes próprios tipicamente brasileiros. Contudo, esse vínculo com o Governo também é causa de diversos escândalos de corrupção e desvios de verbas. Desde o "Escândalo da Mandioca", no final da década de 70, até os recentes casos de corrupção no governo petista, envolvendo o empresário Marcos Valério Fernandes de Souza, são vários os exemplos de corrupção que sempre marcaram a história da empresa, cujos dirigentes são nomeados pelo Executivo Federal.

\subsection{Os bancos e a cultura no Brasil}

A relação entre bancos e instituições culturais não é exclusividade brasileira. Diversos bancos no exterior também criaram seus centros culturais e patrocinam atividades artísticas. Outros preferiram constituir suas coleções privadas de obras de artes plásticas, eventualmente fazendo exposições (cf. Lisbonne e Zürcher, 2007 e Wu, 2006). De maneira não exaustiva, o Anexo 7 mostra os principais institutos culturais vinculados a instituições financeiras, atestando tratar-se de fenômeno de proporções mundiais.

As instituições financeiras são o segmento da economia brasileira que mais investe em manifestações artísticas. Considerando os 101 grupos econômicos que mais investiram em cultura em 2007, utilizando recursos das leis federais de incentivo, 21 grupos eram da área financeira (Anexo 8). Em termos monetários, os Bancos investiram $R \$ 200,2$ milhões (Anexo 9) o que corresponde a $21 \%$ do total concedido pelo governo federal como isenção fiscal. Verificada a lista dos maiores tomadores de recursos federais, via leis de incentivo (ou seja, aquelas empresas que deduzem do seu imposto de renda a pagar valores dados ao patrocínio artístico), nota-se que dos vinte maiores grupos, sete são da área financeira ${ }^{22}$.

\footnotetext{
${ }^{22}$ Na seguinte ordem: Bradesco ( $R \$ 50.016$ mil), Itaú ( $\left.R \$ 46.739 \mathrm{mil}\right)$, Banco do Brasil ( $R \$ 25.483$ mil), BNDES ( $R \$ 12.646$ mil), Unibanco ( $R \$ 12.252$ mil), Banco Credit Suisse ( $R \$ 11.025$ mil) e ABN AMRO Real ( $R \$$ $9.927 \mathrm{mil})$.
} 
No Brasil, o primeiro Centro Cultural vinculado a uma instituição financeira foi o Instituto Cultural Itaú (atualmente denominado Itaú Cultural), criado em 1987, sediado em São Paulo. Em 1990, foi criado o Instituto Moreira Salles (IMS), vinculado ao Unibanco, com forte atuação nas áreas de fotografia e exibição de filmes, nos Espaços Unibanco de Cinema. O Banco do Brasil decidiu criar seu Centro Cultural no ano em que o Itaú iniciou as atividades de seu Instituto.

É sabida a extrema competição existente no mercado financeiro, sendo que soluções de tecnologia, de atendimento e de produtos e serviços lançados por determinado banco, normalmente são seguidas por outras semelhantes pelos concorrentes. Podemos supor que o mesmo tenha ocorrido com o patrocínio artístico. Dos cinco principais bancos do país ${ }^{23}$ (Fundação Getúlio Vargas, junho de 2007), dois optaram pela manutenção de patrocínios artísticos pontuais e não constituiram seus centros culturais: Bradesco e ABN AMRO Real. O perfil de patrocínio artístico do primeiro concentra-se nos espetáculos com fórmulas já consagradas em outros países, como foi o caso do Cirque du Soleil e de musicais "ao estilo Broadway", patrocinados na cidade de São Paulo, além do investimento em manifestações folclóricas e celebrações regionais. $O A B N$ limita seu patrocínio à preservação do patrimônio histórico e a algumas exposições, principalmente àquelas que se vinculam a artistas ou a personagens holandesas, pelo fato de sua sede localizar-se naquele país.

Com atuação centrada quase exclusivamente na divulgação da cultura nacional, o IMS não costuma destinar verbas à criação artística. Em São Paulo, Belo Horizonte, Rio de Janeiro e Poços de Caldas, possui alguns espaços, mais amplos e diversificados, aos quais denomina Centros Culturais. Além deles, também possui as chamadas Galerias IMS, em São Paulo, Rio de Janeiro, Porto Alegre e Curitiba, e espaços de cinema em sete cidades. Possui vasto acervo de fotografias, música e artes plásticas, além de uma biblioteca especializada na área de artes e literatura.

O Instituto Moreira Salles, em São Paulo, foi inaugurado em 1996, destacando-se pela documentação e pelos acervos fotográfico e iconográfico. As exposições fotográficas são muito freqüentes e destinam-se a um público bastante familiarizado com essa linguagem artística. Predominam as imagens históricas e as

\footnotetext{
${ }^{23}$ Cfe. Fundação Getúlio Vargas. "Conglomerados Financeiros”. Conjuntura Econômica, junho de 2007.
} 
que possuem relevância documental e artística. Localizado em bairro nobre da cidade, seu prédio não possui espaço muito avantajado. O horário de funcionamento é mais restrito: abre regularmente de terça a domingo, somente no período da tarde, o que limita seu público a um nicho bastante específico. Publica semestralmente os Cadernos de Literatura Brasileira, cada título dedicado a um autor nacional, e os Cadernos de Fotografia Brasileira, com periodicidade anual, além de outros livros e catálogos.

Por essas características, e apesar de ambos terem um elemento comum importante, o de ser mantido por uma instituição financeira, o Instituto Moreira Salles não se configura como um concorrente do CCBB, uma vez que os projetos que este patrocina têm alcance mais ampliado em termos do público a ser atingido.

A criação de um instituto garante certa sistematização e continuidade do patrocínio, bem como uma ação mais autoral por parte da instituição patrocinadora. Esta, deixa de ser mera dispensadora de recursos, geridos por intermédio de um balcão de financiamento que normalmente orienta a seleção dos pedidos aprovados, segundo afinidades, relacionamentos ou gosto pessoal daquele(s) que autorizará(ão) o dispêndio da verba. Institutos culturais ligados a bancos possuem programas de caráter permanente, além de forte atuação educacional, o que os configura como um tipo diferenciado de mecenato e os identifica como instituições culturais que interferem no desenvolvimento do campo artístico.

A concentração do capital, a partir da incorporação de bancos menores, incrementou a lucratividade dos bancos, atingindo patamares bastante elevados. A intermediação financeira tornou-se muito lucrativa principalmente em função da política de juros elevados adotada pelo Governo Federal. Associado a isso, ampliouse enormemente a quantidade de "produtos" oferecidos. Basta observar que, na década de 80 , conta corrente e poupança concentravam quase a totalidade de opções de aplicação financeira. Hoje, as possibilidades são inumeráveis e "customizadas" de acordo com o perfil do cliente. Poucos bancos ${ }^{24}$ detêm a maior

\footnotetext{
${ }^{24}$ Em 1964, havia 336 bancos no Brasil; em 2003, esse número se reduziu para 164 e, em 2006 para 104 (Sucursal Brasília. Concentração avança no setor bancário. Folha de S. Paulo, São Paulo, 26/05/2007, Dinheiro, B3.). Em 1996, os dez maiores bancos detinham 70\% do total de ativos. Em 2006, o índice foi a 82,2\% (Barros, Guilherme. Basiléia 2 aumenta concentração. Folha de S. Paulo, São Paulo, 12/08/2007, Dinheiro, B2). Estudo da FEBRABAN mostra que países como Argentina, México e Chile vivenciaram o mesmo processo, sendo que esses países possuem uma concentração ainda maior que a brasileira (Troster, Roberto Luis. "Concentração Bancária", consultado em 02 de agosto de 2007 http://www.febraban.org.br/Arquivo/Servicos/Imprensa/Conc0404.pdf).
} 
parte do mercado e possuem lucratividade astronômica, sem paralelos em outros setores da economia.

No Brasil, o processo de fusão de bancos iniciou-se com os governos de Fernando Collor de Mello e Fernando Henrique Cardoso, concentrando o capital em uma área que já primava pela concentração de riqueza. A concentração de capitais nas mãos dos banqueiros é tão grande que segundo a revista Fortune ${ }^{25}$, ao apontar as quinhentas maiores empresas em atuação no mundo, segundo seu faturamento anual, apenas o Brasil, em um total de 31 países que aparecem nesse ranking, apresenta três bancos (Banco do Brasil, Itaú e Bradesco) entre as quatro maiores empresas do país (a outra é a Petrobrás) ${ }^{26}$.

A competição, no sistema financeiro brasileiro, é imperfeita e limitada, o que permite aos bancos impor pesadas tarifas por seus serviços, especialmente aos pequenos clientes. Conseguem também praticar taxas de juros acima das sancionadas por $1 \mathrm{ei}^{27}$ nos empréstimos que fazem às empresas e pessoas físicas. Isso tudo contribui para que se construa imagem dessas instituições que a qualificam de mesquinhas e usurárias.

Há um conflito de interesses elementar na relação instituição financeiracliente. O leitmotiv da atuação empresarial financeira é a obtenção incessante de lucro, sempre considerado insuficiente e passível de incremento, estimulado por mercado que é extremamente competitivo. Os interesses dos consumidores bancários giram em torno do maior rendimento possível para suas aplicações e os menores juros possíveis em seus empréstimos. São interesses antagônicos e

${ }^{25}$ Conforme consulta efetuado ao site www.observatoriosocial.org.br/portal/index em 25/10/2008.

${ }^{26}$ Conforme estudos do SERASA e do INEPAD (Folha de S. Paulo. Reportagem Local. Bancos ganham bem mais que empresas. Folha de S. Paulo, São Paulo, 01/04/2007, Dinheiro, B4) a receita bruta dos 50 maiores bancos do país aumentou $41 \%$ entre 2004 e 2006, contra 6,4\% das empresas do setor produtivo. Esses estudos revelam que a causa do aumento das receitas reside nos elevados spreads auferidos pelos bancos. Esses spreads são tanto mais elevados quanto menor é o poder de barganha do consumidor, o que institui um mecanismo, no mínimo socialmente injusto de maior cobrança de juros daqueles que menos recursos possuem. Procuram atingir público não-bancarizado, em sua maioria sem possibilidade de comprovação de renda, muitas vezes, por terem seus ganhos provenientes da economia informal. A justificativa dada pelos bancos para taxas maiores reside no maior risco de inadimplência. No entanto, não há dúvidas de que o spread elevadíssimo compensa, com folga, os não pagamentos dos empréstimos. O sistema financeiro brasileiro se estrutura em esquema altamente perverso, que contribui para a concentração de renda, na medida em que presta atendimento a taxas menores e com tarifas reduzidas a quem tem poder aquisitivo e cobra juros elevados e tarifas pesadas daqueles que possuem menor recursos. As tentativas de estruturação de bancos populares, iniciadas na primeira gestão do governo Lula, com ênfase no micro-crédito, ainda não mostraram seus resultados. Isso considerando que o total de crédito concedido pelas instituições financeiras em toda a economia é muito baixo na comparação com outros países, equivale a aproximadamente $32 \%$ do PIB.

${ }^{27}$ A Constituição Federal Brasileira (Brasil, 1989), ao tratar do Sistema Financeiro Nacional, no parágrafo $3^{\circ}$ do artigo 192, determina que as taxas de juros reais não poderão ser superiores a doze por cento ao ano, patamar bastante inferior ao praticado no mercado financeiro hoje, principalmente para as pessoas físicas. 
conflitantes que se mostram desproporcionais quando se considera o poder financeiro dos bancos diante dos consumidores. Para tornar essa relação possível, os bancos utilizam-se de vasta estratégia discursiva e simbólica, para "fidelizar" clientes e manter sua base de contas. Há grande esforço dos bancos para tentar reduzir a distância e a aversão dos clientes, uma vez que consumidor e fornecedor dos serviços, nesse caso, encontram-se em pólos opostos da relação mercadológica.

Os bancos diversificaram sua área de atuação inserindo-se fortemente na área de prestação de serviços, auferindo grande parte de suas receitas não somente com o spread da intermediação financeira, mas, sobretudo, com as tarifas cobradas pelos serviços prestados. Seguridade, previdência complementar, títulos de capitalização, planos de assistência médica, cartões de crédito, vales alimentação, pagamento de salários, arrecadação de tributos são "produtos" agora comercializados nas agências bancárias.

A demanda por serviços bancários abrange públicos com possibilidades financeiras diversas, desde trabalhadores com baixa remuneração, cujas necessidades se limitam à retirada de benefícios e pequenos pagamentos até grandes fortunas, que exigem consultoria financeira. Para prestar atendimento de acordo com as necessidades dos clientes e para melhor receber aqueles que dão maior retorno aos bancos, as instituições financeiras começaram a criar espaços diferenciados, recrutando funcionários com qualificações diferenciadas, de acordo com o perfil do cliente a ser atendido.

A insatisfação com o atendimento prestado pelos bancos, especialmente para aqueles que não dispõem de recursos para ter um espaço e um gerente disponível para atendê-los, costuma ser grande. Muitas são as razões para esse descontentamento: filas, falta de cortesia no atendimento, tarifas e juros elevados, dificuldade para ingressar na agência, em função das portas giratórias e burocracia, entre outras.

Mais um aspecto importante a ser observado quanto ao papel das instituições financeiras nas sociedades contemporâneas reside no peso econômico e político que detêm. Segundo Souza ${ }^{28}$, o lucro dos bancos, no Brasil, subiu mais de $1.000 \%$ em dez anos. No mesmo período verificou-se queda na concessão do crédito,

\footnotetext{
${ }^{28}$ Souza, Leonardo. Lucros dos Bancos sobem mais. Folha de S. Paulo, São Paulo, 21/06/2004, Dinheiro, B4.
} 
elevação em seis vezes nas receitas decorrentes de cobrança de tarifas e acréscimo no número de reclamações junto ao Banco Central. Beneficiados durante anos com o cenário de elevados índices inflacionários, em que recursos captados praticamente sem remuneração eram aplicados com taxas de retorno altamente lucrativas, quando a inflação foi reduzida, os bancos redirecionaram seus esforços para a cobrança de tarifas sobre os serviços prestados. Contudo, como essa redução foi obtida graças à manutenção de taxas de juros elevadas, os bancos também obtêm grandes ganhos com a compra de títulos públicos federais.

A própria desproporcionalidade da relação do cliente com seu banco, evidencia o desfavorecimento do consumidor, na medida em que não há negociação possível diante de conglomerado financeiro detentor de imenso poder econômico. A concentração de capitais, decorrentes de inúmeros processos de fusões e privatizações, ampliou a magnitude dos bancos, cuja elevada lucratividade reforça a idéia de exploração. Bancos de grande porte foram incorporados por concorrentes, como o Nacional e o Econômico. Grandes bancos estaduais, como o Banespa e o Banerj, também foram privatizados. Assim, os grandes bancos souberam substituir os ganhos que anteriormente obtinham com a escalada inflacionária por outras fontes de receitas em um cenário de maior estabilidade econômica.

Interessante notar que, não obstante o impacto dos lucros obtidos pelos bancos na opinião pública, raramente é associado ao que se denomina usura ou extorsão. Atualmente, usura designa cobrança de juros ilegais, também chamado de agiotagem. A usura tipificada como crime - já que existe no ordenamento jurídico brasileiro uma lei específica sobre o tema - está em franco declínio em um contexto no qual o próprio Governo paga juros elevadíssimos sobre os títulos que emite e tem nos bancos seus principais compradores.

Alguns bancos efetivamente se aproveitam comercialmente do mercado das artes, não buscando lucros simbólicos, objetivo maior do patrocínio, mas interferindo na lógica financeira inerente a certos segmentos artísticos. A proximidade com as manifestações artísticas, movidas por interesses de retorno de imagem, permitiu, em alguns casos, que a arte fosse utilizada como um produto a mais a ser oferecido aos clientes. Esse é o caso do grupo financeiro holandês ING que oferece assessoria aos seus clientes desejosos de iniciar ou ampliar suas coleções de obras de arte, envolvendo política de compras, questões legais e tributárias, contato com conservadores e restauradores, entre outras. A arte, neste caso, não é apenas 
instrumento para melhoria da imagem, mas também opção de investimento financeiro.

No Brasil, o sistema financeiro vivenciou momentos de profunda alteração nas últimas décadas. A inserção de novas tecnologias e a diversificação da economia talvez sejam os principais motores dessas mudanças. Diversas foram as transformações mais recentes no sistema financeiro nacional: a concentração do capital, mediante inúmeros processos de aquisição de bancos menores pelos maiores, a ampliação da área de atuação das instituições financeiras por meio da diversificação dos "produtos" e serviços oferecidos, a privatização dos bancos públicos, a segmentação do atendimento e a entrada de bancos estrangeiros no mercado.

Talvez a resposta mais acertada para a pergunta: "por que bancos investem tanto em cultura seja a mais simples possível?" Porque podem e porque precisam. Como sua lucratividade não tem equivalentes em outros segmentos da economia, possuem capital suficiente para investir no que quiserem, principalmente quando esse investimento não significa necessariamente desembolso de recurso, em função das leis de incentivo. Em segundo lugar, porque eles precisam, na medida em que sua imagem perante os consumidores, considerando-se os motivos supracitados, é bastante prejudicada.

\subsection{O CCBB e a illusio do campo econômico}

Por sua vinculação direta com o mantenedor, o CCBB insere-se no campo econômico, apesar de configurar-se preponderantemente para o público que comparece a seus eventos como agente do campo artístico, do qual, obviamente, também é integrante. Essa inserção no campo econômico o coloca como elemento dominado de um campo de forças no qual se estabelece múltiplas relações de poder, e resultam em formas específicas de mando e obediência. Por configurar-se internamente como órgão regional, apesar de seu vínculo com a direção da empresa, da qual emanam as diretrizes e normas da instituição, fica-lhe reservado o papel mais de executor do que de formulador das políticas. Trata-se, portanto, de papel subordinado, em uma instituição extremamente permeada pela hierarquia e 
pela burocracia, por meio das quais se assegura a subserviência aos ditames estabelecidos por aqueles que ocupam os cargos de maior prestígio e poder.

A posição do CCBB no interior da instituição bancária responde à necessidade de que suas ações sirvam de instrumento para as políticas de marketing do mantenedor. A preocupação central da área de marketing é a conquista e retenção de clientes, por meio de estratégias de persuasão, que envolvem vasta gama de intervenções no espaço público, em publicidade, promoções, marketing esportivo ou marketing cultural.

Também é preciso ressaltar o papel da área de marketing no campo de forças que constituem a instituição mantenedora. Por um lado, a vinculação direta com a presidência da empresa denota importância, reservando-Ihe um papel de destaque, mormente por tratar-se de uma empresa de serviços que atua predominantemente no segmento de varejo, em que as ações de marketing assumem necessariamente, um papel decisivo. Por outro, não possui o mesmo peso das áreas encarregadas de gerir produtos e clientes, obviamente as responsáveis pelas receitas auferidas pela empresa, tendo também papel politicamente inferior a outras áreas de assessoramento, como a área tecnológica, cuja atuação é central.

Em uma empresa da dimensão do BB, há lutas, confrontos e alianças constantes entre os funcionários e, mesmo com políticos, pelo vínculo com o Governo Federal, a fim de se garantir acesso aos postos com maior prestígio e remuneração mais alta. Isso é tanto mais intenso quanto mais elevada a posição na hierarquia da empresa. Um bom indicador desse campo de forças é a análise da estrutura organizacional da empresa.

A Diretoria Executiva da empresa é composta pelo presidente (nomeado pelo presidente da República), nove vice-presidentes (eleitos pelo Conselho de Administração, mediante indicação do presidente do BB) e por 26 diretores (privativo de funcionários da ativa do BB). A diretoria de marketing disputa prestígio, poder e reconhecimento com as outras 25 que possuem o mesmo nível hierárquico. Essa disputa segue parâmetros que buscam atender a objetivos estratégicos da empresa no mercado, o que faz com que alguns segmentos tenham mais prestígio do que outros em função de determinados interesses mercadológicos, mas também relações de apadrinhamento e dependências decorrentes de filiação a um ou outro grupo que esteja ou não em posição de mando. O fato de essa relação de forças alterar-se periodicamente devido a um fator externo de elevado grau de 
imprevisibilidade, as eleições presidenciais, reforça a necessidade de que se estabeleçam redes interpessoais de proteção, a fim de manter as posições de prestígio e os cargos com mais poder.

A bem-sucedida estratégia de consolidar a empresa como banco comercial voltado para o mercado, em detrimento de sua atuação mais vinculada ao Governo Federal, resultou no predomínio, na cultura organizacional, de uma ideologia que tem na lucratividade e na competição com os demais bancos a força motriz que justifica uma série de medidas e ações da empresa. Dessa forma, os benefícios indiretos, intangíveis e de difícil comprovação colocam o CCBB em uma posição de vulnerabilidade frente a essa lógica dominante.

Não obstante sua posição subalterna no jogo de poder da empresa, não se identifica muita interferência direta do corpo diretivo da empresa naquilo que é a razão de ser do CCBB, qual seja, a sua programação artística. Isso denota sua relativa autonomia do $\mathrm{CCBB}$, o que não o isenta de pressões, no fundo de caráter mercadológico, como a necessidade de que os patrocínios tenham intensa divulgação na mídia.

O campo econômico no qual o BB, e por decorrência o CCBB, se inserem é movido por uma crença coletiva (illusio) no jogo que é jogado pelos atores sociais que o constituem. Assim define Bourdieu essa noção:

As lutas pelo monopólio da definição do modo de produção cultural contribuem para reproduzir continuamente a crença no jogo, o interesse pelo jogo e pelas apostas, a illusio, a qual são também o produto. Cada campo produz sua forma específica de illusio, no sentido de investimento no jogo que tira os agentes da indiferença e os inclina e dispõe a operar as distinções pertinentes do ponto de vista da lógica do campo, a distinguir o que é importante ('o que me importa', interest, por oposição 'ao que me é igual', in-diferente). Mas é igualmente verdade que certa forma de adesão ao jogo, de crença no jogo e no valor das apostas, que fazem com que o jogo valha a pena ser jogado, está no princípio do funcionamento do jogo, e que a colusão dos agentes na illusio está no fundamento da concorrência que os opõe e que constitui o próprio jogo. Em suma, a illusio é a condição do funcionamento de um jogo no qual ela é também, pelo menos parcialmente, o produto. (Bourdieu, 2005, pág. 258).

Essa illusio, que dá plausibilidade para as diversas ações em curso no interior do campo econômico, se ancora em três valores centrais:

a) todo o lucro é insuficiente; 
b) mesmo a liderança do mercado (que se subdivide em inúmeras categorias: ativos, quantidade de liderança, cartões de crédito etc.) não é condição suficiente para arrefecer a agressividade da atuação comercial, já que a ameaça da concorrência está sempre presente, e mesmo empresas líderes de mercado podem perecer;

c) todas as ações da empresa devem de alguma forma contribuir para que os objetivos anteriores sejam atendidos.

Assim, o CCBB, como integrante do campo econômico, deve jogar esse jogo, contribuindo para a manutenção da illusio e submetendo-se a essas regras básicas, cujo não-compartilhamento significaria a exclusão do campo. Por outro lado, como integrante do campo artístico deve obediência a normatividade que se ancora em universo valorativo diverso. 


\section{Capítulo 2}

\section{As Razões do Marketing Cultural do Banco do BRASIL}

A primeira questão que se coloca ao investigador diante de uma instituição como o CCBB é por que uma instituição financeira investe em cultura? Quais são as motivações e interesses que a fazem incursionar em terreno tão distinto de sua atividade precípua? O que impulsiona a inserção no campo artístico e que resultados espera dela? Ou ainda, de que maneira profissionais com atividades burocratizadas e racionalizadas dialogam com atributos simbólicos tão distanciados de sua prática, já que imersos em normatividade tão distinta? O que o BB espera como retorno dos investimentos que faz em cultura? O patrocínio artístico insere-se na lógica própria do universo empresarial, na qual predomina o cálculo econômico racional? Ou tratase da busca de capital simbólico sem que isso tenha necessariamente a ver com retornos financeiros à empresa?

Este capítulo procurará descortinar as motivações do Banco do Brasil ao incursionar pelo campo artístico. O seu objetivo é, então, o de analisar a inserção do CCBB no campo econômico, o que implica delimitar as relações que se estabelecem com seu mantenedor, bem como investigar como o BB dá plausibilidade e justifica sua inserção no campo cultural. Ora, se a configuração do banco é essencialmente de mercado, voltado para a lucratividade, é importante investigar se esses interesses econômicos possuem efetivamente caráter "nocivo", ferindo a autonomia da criação artística.

A análise terá como subsídios os objetivos da instituição enunciados no capítulo precedente, as entrevistas realizadas com seus funcionários e os dados explicitados nos contratos firmados com os artistas patrocinados.

Nas entrevistas realizadas com funcionários do BB e do CCBB a primeira questão supracitada (por que uma instituição financeira investe em cultura?) tinha como resposta invariavelmente (em ordem de freqüência de resposta) uma justificativa para o patrocínio empresarial:

a) obter ganhos de imagem, em função da visibilidade que o patrocínio artístico proporciona; 
b) afirmar-se como empresa socialmente responsável, preocupada em proporcionar ganhos aos públicos que têm interesse na empresa, e não somente em obter lucros para o acionista;

c) fazer com que o patrocínio crie oportunidades de relacionamento interpessoal com os clientes (marketing de relacionamento), em ambiente distinto daquele destinados aos negócios.

Uma resposta raramente explicitada, mas certamente com um papel importante no patrocínio do BB, reside na existência de incentivos fiscais proporcionados pelas instâncias governamentais.

Essas motivações não possuem o mesmo peso, sendo que a primeira é muito mais importante do que as demais. As justificativas dadas pelos atores sociais para explicar as ações desenvolvidas também tiveram peso diferenciado ao longo desses anos de patrocínio artístico. Tal diferenciação fica patente quando analisados os documentos que deram subsídio às decisões de criação dos CCBBs.

Quando o primeiro CCBB foi criado, no Rio de Janeiro, o discurso predominante era quase épico e eivado de carga emocional, sua criação aparecendo como uma missão da empresa com elevada conotação altruísta. A questão mercadológica quase não é mencionada. Naquele momento (1987), a segunda das três justificativas mencionadas acima parecia ter mais plausibilidade, ainda que não se falasse de responsabilidade social de maneira elaborada, nos moldes posteriormente incorporados pela teoria administrativa. A terceira justificativa nem mesmo era citada:

O endereço da rua $1^{\circ}$ de Março, 66 [sede do CCBB], no Rio de Janeiro, para os que servem ao Banco do Brasil ou àqueles que simplesmente admiram a instituição, seguindo de perto ou à distância sua honrosa e profícua trajetória, evoca um passado de grandeza. Foi dali que, durante 56 anos, a direção do Banco do Brasil contribuiu com seu trabalho e a experiência acumulada por gerações na condução das finanças do País. Quantos programas de disseminação de desenvolvimento econômico nasceram naquelas salas austeras e que enormes repercussões eles tiveram no impulso do progresso brasileiro. (...) O resgate dessa mística assumiria a forma de uma homenagem do Banco do Brasil à cidade que o viu nascer e prosperar, restaurando o prédio da rua $1^{\circ}$ de Março e fazendo dele um centro de cultura devotado a apoiar e difundir o saber e as artes, ao mesmo tempo que voltaria a abrigar o Gabinete da Presidência no Rio de Janeiro. A iniciativa se torna ainda mais 
oportuna na medida em que ocorreria num momento de intensa modernização e ampliação da face comercial do Banco, ao tempo em que enfatizaria sua fidelidade a seus princípios tradicionais. Com isso, mostraríamos à sociedade brasileira e ao funcionalismo da Casa que ela muda mas preserva sempre o mesmo caráter." (Banco do Brasil, 1987 apud Vieira, 2006, grifo nosso)

Percebe-se que a única menção a um aspecto econômico ou mercadológico, no texto é logo sucedida por uma ponderação que a ameniza, isto é, é feita referência ao iniciado processo de "ampliação da face comercial do Banco", para relativizá-lo com uma forte defesa da tradição, a qual remete justamente ao Banco de Governo, mais preocupado com o desenvolvimento do país do que com a lucratividade de seus negócios. Ao mesmo tempo que a ênfase na frase final está não na mudança mas na continuidade do "caráter da empresa".

Os documentos que dão sustentação à criação do CCBB Brasília e do CCBB São Paulo já são predominantemente permeados pelo discurso mercadológico do marketing cultural, no qual fica explícito o desejo de retorno com ganhos de imagem. O mantenedor não é o mesmo da criação do primeiro CCBB quando estava em curso um processo de transição, mas já tem como certa a primazia do banco comercial como estratégia de sustentabilidade da empresa:

Tem-se como inquestionável que a criação do Centro Cultural Banco do Brasil - São Paulo beneficiaria o patrimônio do Banco e sua imagem, além de servir como instrumento extremamente útil na alavancagem de novos negócios. As possibilidades negociais no maior centro financeiro do País, evidentemente estratégico para o Banco, são bastante amplas. (...) Inúmeras pesquisas indicam que as empresas que investem em projetos culturais são vistas pelo público como detentoras de perfil confiável e moderno, socialmente ativas e com visão estratégica. O patrocínio é uma tendência mundial, em virtude da perda de eficácia e aumento dos custos da mídia tradicional e da exigência, por parte do consumidor, de compromissos das empresas com a comunidade. (...) A mídia, a classe artística, os intelectuais e os formadores de opinião, em geral, certamente hão de conceder o devido, destaque à iniciativa, promovendo a imagem do Banco do Brasil como parceiro do País e da sociedade. (Banco do Brasil, 28/05/1999 apud Vieira, 2006, grifo nosso)

É possível correlacionar o perfil inicial do CCBB Rio de Janeiro, que se caracterizava por uma programação mais arrojada, com menor preocupação com o 
retorno de imagem, com a tônica posterior, como será visto das escolhas artísticas efetuadas.

A diferença de motivação na criação dos institutos culturais de mesma natureza explica-se em grande parte pela remodelagem de atuação da empresa, em função das novas diretrizes que conduziram o Banco nos governos Collor, Itamar Franco e FHC. A ênfase dada à afirmação da competitividade do Banco no mercado econômico, com lucratividade semelhante à das demais instituições financeiras, não permitiria que a empresa atuasse com custos altos, que a impedissem de obter retorno compatível com os dos seus concorrentes.

As falas dos entrevistados mostram a aderência do BB à percepção de outras empresas pesquisadas pelo Centro de Estudos Históricos e Culturais (CEHC), da Fundação João Pinheiro (1999). A preocupação com a imagem da empresa é a principal justificativa dada pelos empresários para investir em cultura. Um 65,4\% delas fazem-no por acreditar ser esse um meio de ganho de imagem institucional, enquanto $27,64 \%$ acreditam que o marketing cultural agrega valor à marca da empresa (que se correlaciona intimamente à melhoria de imagem - percentual que poderia, portanto, ser agrupado à primeira resposta), 23,6\% o fazem para reforçar as políticas de cunho social da empresa, e $21 \%$, em razão de incentivos fiscais (Fundação João Pinheiro, 1999).

A preocupação com o investimento de recursos excedentes privados no subsídio à produção artística só começou a aparecer no século XX. Surgiu sob a forma de benevolência ou caridade, ou a partir de uma incipiente preocupação com a imagem corporativa, muitas vezes nomeadas como mecenato ou filantropia. Nos EUA, país onde reside a mais intensa tradição de apoio privado às artes, famílias abastadas, vinculadas ao capital industrial e freqüentadoras do circuito cultural europeu, foram decisivas na implementação de aparelhos de conservação e produção artística. As primeiras coleções dos museus americanos foram provenientes de doações das famílias milionárias, como Rockefeller, Vanderbilt e Carnegie (Reis, 2003).

Após a Segunda Guerra Mundial, no ambiente empresarial, modificou-se a noção de patrocínio ${ }^{29}$ para um conceito mais elaborado, o de marketing cultural.

\footnotetext{
${ }^{29}$ Teixeira Coelho considera o patrocínio como uma forma de patronato e seria "próprio de uma época em que as obras de arte e de cultura surgem no mercado como objeto de negócio. Caracteriza-se pela oferta de um apoio inicial a artistas iniciando carreira, em troca, muitas vezes, da propriedade das obras assim produzidas (ou de parte delas). [...] Uma versão deste modo é a do patrocínio comercial, que visa à produção de obras
} 
O surgimento desse conceito correlaciona-se com as transformações do capitalismo, principalmente no que se refere à multiplicação de produtos ofertados, o acirramento da concorrência entre as empresas e a diversificação dos canais de acesso aos produtos. Muitos livros de marketing costumam estabelecer três fases do relacionamento das empresas com seus mercados: a primeira, orientada para a produção e para o produto, quando o importante era o consumidor encontrar o produto, e com baixo custo; a segunda, orientada para vendas, cuja preocupação era a distribuição e o anúncio do produto; e a terceira, orientada para o mercado ("a era do marketing"), cuja ênfase está nas necessidades dos clientes.

A definição mais recorrente de marketing é a elaborada pela American Marketing Association:

uma função organizacional e um conjunto de processos de criação, comunicação e transferência de valores aos clientes e para o gerenciamento da relação com os consumidores, que irão beneficiar a organização e seus públicos ("stakeholders"). (www.marketingpower.com, "Dictionary of Marketing Terms")

A abrangência dessa definição permite a constituição de conceitos derivados, como é o caso do marketing cultural, mas também de marketing político, marketing social, marketing esportivo e de marketing pessoal, todos de uso corrente hoje. Por trás dessas subdivisões reside a lógica da persuasão dos públicos diante de uma imagem que, acredita-se, pode ser manipulada em prol de benefícios econômicos, políticos ou profissionais.

O uso dos conceitos foi disseminado nas universidades norte-americanas e logo absorvido pelo meio empresarial, sendo hoje adotado como prática gerencial e ensinado nos cursos superiores de administração de empresas. Diversas organizações possuem departamentos ou diretorias de marketing, que têm, como cerne de suas atividades, a elaboração de estratégias que visem a atender as necessidades dos clientes, conquistando-os e tornando constante 0 seu relacionamento com as empresas.

Dentre as ações de marketing, a mais glamourosa é a relacionada à promoção dos produtos e serviços desenvolvidos pela empresa, envolvendo

das quais se espera futuramente um retorno econômico (trata-se de um investimento, portanto) ou alguma forma de propaganda institucional. [...] O patronato confunde-se com o mecenato sendo este uma versão terminológica atualizada daquele." (Coelho,2004:291). O Decreto 1494/91, em seu artigo $3^{\circ}$, inciso IX, letra "a", define patrocínio como a "transferência gratuita de recursos, em caráter definitivo, à pessoa física ou 
fundamentalmente as atividades de publicidade e propaganda, cuja natureza é também considerada, assim como as artes, como altamente criativa. Contudo, a área de marketing também se responsabiliza pela definição dos canais de distribuição e pontos de venda dos produtos, pelo estabelecimento dos preços, considerando a concorrência e o status proporcionado por eles. Também interfere nas decisões sobre os produtos ou serviços prestados pelas empresas, identificando oportunidades de lançamento, além de sua adequação às necessidades dos clientes.

A essência dessas atividades, além da percepção das tendências e dos comportamentos de consumo, está na capacidade de persuasão e de convencimento dos públicos a que a empresa atende. Seu caráter ideológico e fetichista muitas vezes é explicitado:

A meta do marketing é tornar a venda supérflua, é conhecer e entender tão bem o consumidor que o produto ou o serviço se adapte a ele e se venda sozinho. (Drucker, 1981)

As ações de marketing envolvem duas estratégias centrais correlacionadas, nomeadas pelos teóricos da área como "diferenciação" e "posicionamento". A primeira, diz respeito ao ato de uma empresa estabelecer simbólica e concretamente um conjunto de diferenças significativas (do ponto de vista do cliente), para distinguir sua oferta quando comparada às dos concorrentes; a segunda é o desenvolvimento de uma oferta e de uma imagem que levem a empresa a ocupar lugar diferenciado e valorizado na mente dos consumidores-alvos.

Podemos entender o marketing como uma esfera decisiva na circulação das mercadorias, permitindo retorno mais rápido dos capitais investidos, além de diminuir a imponderabilidade do consumo (Arruda, 1985:186) ${ }^{30}$. Ocupa centralidade ainda maior na configuração atual do capitalismo, quando a concorrência atinge escala internacional, e a abundância de estímulos publicitários tornou mais difícil o processo de persuasão dos consumidores.

Mais do que vinculado à venda de determinado produto, o marketing cultural insere-se nas estratégias de comunicação empresarial das corporações. É na

jurídica de natureza cultural, proponentes com ou sem fins lucrativos, de numerário para realização de projetos culturais com finalidade promocional e institucional ou publicidade.

${ }^{30}$ É interessante notar que nesse trabalho, datado de 1978, sobre a publicidade no Brasil são reduzidíssimas as menções ao termo marketing, o que indica o quão recente são a prática e reflexão acerca desse tema (cf. Arruda, 1986). 
"venda da empresa" e de sua marca que reside a eficácia simbólica do marketing cultural. Vincula-se, portanto, com outra categoria denominada de "marketing institucional". A escolha de consumo envolve não só as vantagens do produto, o seu preço, o status agregado, a comodidade de acesso para sua aquisição, mas cada vez mais o imaginário que envolve a empresa que o fabricou.

\subsection{A categoria "imagem" na perspectiva do marketing}

Imagem e prestígio, de maneira geral, são questões-chaves para as empresas, e constituem, sobretudo, preocupação significativa para os bancos. Prestígio, imagem, reputação, aparência, honra, status, renome são questões determinantes das relações sociais em diversas sociedades.

A princípio, pode parecer estranho que as empresas, locais por excelência de realização da lógica capitalista, com sua racionalidade econômica burocratizada, tenham colocado como questão central atributos simbólicos tão pouco aparentados à previsibilidade calculista da dinâmica de lucros que as movem. Contudo, é inegável, ao menos naquilo que se refere às empresas de varejo que se relacionam com o chamado "grande público", que isso seja pauta permanente nas decisões administrativas e mercadológicas. A área de marketing tem assento cativo nos conselhos diretores das grandes organizações, em grande medida pela relevância que 0 assunto adquiriu no capitalismo pós-industrial. Nesse sentido, afirma Harvey (1992, pág. 238):

A competição no mercado de construção de imagens passa a ser um aspecto vital da concorrência entre as empresas. O sucesso é tão claramente lucrativo que o investimento na construção da imagem (patrocínio das artes, exposições de artes, produções televisivas etc.) se torna tão importante quanto o investimento em novas fábricas $\mathrm{e}$ maquinário. A imagem serve para estabelecer uma identidade no mercado, o que se aplica também ao mercado de trabalho. A aquisição de uma imagem (por meio da compra de um sistema de signos como roupas de griffe e o carro da moda) se torna um elemento singularmente importante na auto-apresentação nos mercados de trabalho e, por extensão, passa a ser parte integrante da busca de identidade individual, auto-realização e significado da vida. 
A questão da imagem adquire centralidade ainda maior com os bancos, já que um dos aspectos decisivos na escolha da instituição financeira pelos clientes é a confiança que ela inspira. O aplicador de recursos quer ter a segurança de que, quando necessitar, as retiradas serão possíveis. Não é à toa que as instituições financeiras investem pesadamente em publicidade. Em um mercado no qual a comparação de preço é muito dificíl (pacotes de tarifas com características diferentes, taxas de empréstimos que variam de acordo com o grau de relacionamento do cliente com a instituição financeira, serviços com nomenclaturas diferentes), em que os "produtos" são basicamente os mesmos e o número de agências das instituições é equivalente, a imagem que a cada uma delas consegue construir é decisiva para conquistar e manter clientes.

A categoria "imagem" utilizada pelos profissionais de marketing necessita ser problematizada e não pode ser aceita pacificamente sem delimitação precisa de seus significados. Na bibliografia sobre marketing, não foi localizado um conceito "consagrado", assim entendido aquele que possui certa freqüência de referências. Dois trabalhos que tratam especificamente desse assunto definem essa categoria a partir da justaposição ou confronto de enunciados de alguns teóricos:

Imagem é a "soma de crenças, atitudes e impressões (verdadeiras ou falsas, reais ou imaginárias) que uma pessoa ou grupo de pessoas tem de um objeto (companhia, produto, marca, lugar ou pessoa)" [Barich, Howard e Kotler, Philip. A framework for marketing image management. Sloan Management Review, v. 32, n. 2, p.9410, Winter, 1991.] e que essas crenças, atitudes e impressões resultam de contatos diretos ou indiretos com os aspectos emocionais e simbólicos (personalidade) e com aspectos físicos, tangíveis (identidade visual) e funcionais (benefícios racionais) do objeto. [Senupta, Subroto. Brand positioning. New Delhi: McGrawHill,1990.] (apud Fé, 1997)

A imagem de uma empresa representa um fenômeno intangível, por vezes, muito pouco estável, e geralmente construído a partir de um processo de acumulação de inputs que, em si mesmos, não seriam determinantes no momento de adotar uma decisão de compra ou de orientar uma escolha, mas que, em conjunto, podem chegar a ser decisivos. Essa idéia de globalidade e a sua natureza intangível são talvez os dois atributos definitivos da imagem que, com maior coincidência, se encontram entre os distintos autores que se dedicaram ao seu estudo. Assim, Chaves [Chaves, N. La Imagem Corporativa. Teoría y Metodología de la Indentificación Institucional. Gustavo Gili, 1988] define-a como um discurso imaginário; para Valls [Valls, J.F. La Imagen de Marca de los Países. McGraw-Hill, 1992.] é 
uma representação do emissor; Heude [Heude, R.P. L'image de marque. Eyrolles, 1989] e Colin [Collin. Marketing Communication. Heinemann, 1986] como uma "overall impression". (apud Villafañe, 1998).

Um termo bastante utilizado, em Sociologia, que, apesar de aparentado ao de “imagem", possui maior amplitude conceitual é o de "representação social”. Uma vez constituídas, as representações tornam-se realidades parcialmente autônomas, com vida própria, isto é, mesmo mantendo íntimas relações com seus respectivos substratos, as representações individuais e coletivas são, até certo ponto, independentes (Durkheim, 1970).

Durkheim acredita que os julgamentos individuais sejam, a cada instante, mutilados e deformados por 'julgamentos inconscientes'. Apenas vemos aquilo que nossos preconceitos permitem. Os modos de agir individuais, o sentir e o pensar socialmente são, pois, resultados provocados pelos 'meios próprios da consciência coletiva' em sua ação sobre os indivíduos. É conhecida, contudo, a crítica à perspectiva durkheimiana no que se refere à ênfase constante no aspecto "reprodutivista" do social, na homogeneidade do coletivo, e falta de dinamismo e conflituosidade do plano simbólico da vida social. Dessa forma, a categoria "imagem" dos profissionais de marketing e a categoria "representação social" da perspectiva sociológica têm em comum o fato de serem entendidas como perspectivas simbólicas socialmente elaboradas e partilhadas, as quais transcendem a mera opinião, já que residem em nível mais profundo de sedimentação social. Além disso, ambos os vieses referem-se às atribuições de valores imputadas a determinados referentes, qualificando-os a partir desses juízos.

As representações sociais também se materializam em práticas e, também nisso, sociólogos e profissionais de marketing estão de acordo. Para os administradores de empresas, a imagem só é algo relevante porque interfere e influi diretamente nas ações de consumo e nas escolhas de compra.

O que diferencia a perspectiva sociológica da compreensão dos profissionais de marketing são certas nuances que o caráter eminentemente instrumental da área empresarial e administrativa não apreende. O primeiro aspecto reside na generalização com que normalmente esse conceito é usado, sem especificar quem é o sujeito dessa representação. Quando os administradores e profissionais das empresas se referem à imagem que elas possuem, fazem-no geralmente tomando a 
sociedade (ou os consumidores), vista de forma coesa e homogênea, como sujeito sem levar em conta que as representações são produto de grupos/classes/coletividades específicos, os quais podem entrar em conflito com representações diversas de outros agrupamentos em um mesmo espaço social.

Os profissionais de marketing utilizam a categoria imagem, muitas vezes como sinônimo de reputação, status ou honra, normalmente, dissociada de qualquer prática da instituição que pudesse ancorar tais atributos. A separação torna a imagem plenamente manipulável, nos termos de Baudrillard (1991), para quem, na contemporaneidade, o puro simulacro venceu e matou a "realidade" que deveria representar e libertou-se definitivamente do mecanismo da representação, que não possui mais original, nem referência.

É curioso notar que a preocupação com a imagem é algo que extrapola o imediatismo e a racionalidade baseada em cálculos predominantes no mundo econômico-empresarial. Há expectativa de uma recompensa com o investimento em cultura, mas trata-se de algo muito difuso, não quantificável e de longo prazo.

Pesquisa do Instituto Ethos demonstra que somente $6 \%$ dos entrevistados apontaram a promoção de eventos culturais como atitude que estimularia maior volume de compra ou a recomendação para amigos (Reis, 2003:29), sendo inferior a todos os demais itens mencionados (como contratar portadores de deficiência ou adotar práticas de combate à poluição). Isso parece significar que o patrocínio artístico não representa benefício direto em termos de incremento de consumo ou de adesão de novos clientes. Os funcionários do BB entrevistados pareciam estar bem cientes disso.

Entretanto, existe a crença de que o marketing cultural teria uma atuação decisiva na consolidação da imagem institucional da empresa. Haveria o que designamos por "contaminação simbólica" entre os universos artístico e mercadológico. Ao associar a marca de sua empresa a uma atividade artística, o empresário estaria agregando à imagem institucional de sua empresa toda "aura" que as manifestações culturais possuem na sociedade. Há um capital simbólico de reconhecimento público acumulado que poderia, em longo prazo, ser convertido em capital econômico nos balanços da empresa.

$\mathrm{Na}$ área econômica e empresarial, a marca tem sido considerada um dos principais patrimônios de certas organizações. Alguns estudos (Pomaro, 2004; Miranda, 2006) vêm sendo efetuados no intuito de mensurar o valor econômico- 
financeiro desse bem intangível que, em alguns casos, é incluído contabilmente nos ativos das empresas. Trata-se de estudos que, em essência, quantificam o que em princípio não pode ser reduzido a uma equação matemática, a saber - prestígio, reputação, carisma. Quase a totalidade das empresas lembradas espontaneamente pelos consumidores possui ações de patrocínio, reforçando a hipótese de que elas possam ter influência no processo de lembrança espontânea da marca (Crescitelli et al, 2005) ${ }^{31}$.

No capitalismo pós-industrial, a marca tem tal peso que muitas das maiores corporações deixaram de preocupar-se com a fabricação de seus produtos, e em suas sedes, as estratégias centrais passaram a ser o desenvolvimento da imagem e da marca, levando-se em conta que, aos produtos comprados de outras empresas normalmente instaladas em países periféricos, onde o custo da mão-de-obra é reduzido -, é agregada a marca dessas corporações, o que será decisivo para a venda:

Um seleto grupo de corporações vem tentando se libertar do mundo corpóreo dos produtos, passando fabricantes e produtos a existir em outro plano. Todo mundo pode fabricar um produto, raciocinam eles. Essa tarefa ignóbil, portanto, pode e deve ser delegada a terceiros cuja única preocupação é atender às encomendas a tempo e dentro do orçamento (e o ideal é que fiquem no Terceiro Mundo, onde a mão-de-obra é quase de graça, as leis são frouxas e isenções fiscais são obtidas a rodo). As matrizes, enquanto isso, estão livres para se concentrar em seu verdadeiro negócio - criar uma mitologia corporativa poderosa o bastante para infundir significado a esses toscos objetos apenas assinalando-os com seu nome. (Klein, 2006: 46, grifo nosso)

Dessa maneira, o universo corporativo se assemelha, em um certo sentido e cada vez mais, ao universo artístico, uma vez que os empresários estão tão preocupados em produzir bens quanto em produzir significados, mitologias, criar identidades, construir reputação, visando a induzir o consumo.

Se as marcas também são eivadas de mitologias que lhes são próprias, em alguns casos, o patrocínio também pode ser vantajoso para os artistas, não só no

\footnotetext{
${ }^{31}$ Esse estudo, contudo, contempla diversas ações de patrocínios - artístico, esportivo, social - e não permite conclusões abrangentes, pois a imagem da empresa se constitui a partir de uma multiplicidade de fatores, sendo impossível isolar a variável patrocínio das demais.
} 
sentido econômico, mas em termos de reputação, na medida em que eles podem ser contaminados pelo universo valorativo que a marca patrocinadora carrega ${ }^{32}$.

As estratégias de marketing podem ser agrupadas em um grande plano de branding ou gestão de marcas, envolvendo desde pesquisas de mercado até publicidade, patrocínios, gerenciamento do logotipo e das cores institucionais. Considerado um dos principais ativos das grandes corporações, a marca é um atributo normalmente visto como o principal bem intangível das empresas e contribui decisivamente para o seu sucesso financeiro, pelo poder que exerce sobre o comportamento dos consumidores e a dificuldade de diferenciação dos concorrentes pelos bens e serviços produzidos. Para exemplificar tome-se o caso da Coca-cola: a empresa possui ativos da ordem de US\$ 2 bilhões; entretanto, sua marca, a mais valiosa do mundo, vale $R \$ 48$ bilhões (Sarkovas, 2001). Segundo estudo da consultoria inglesa Brand Finance, o BB é a quarta marca mais valiosa do país, com valor de $\mathrm{R} \$ 5,8$ bilhões, inferior apenas à da Petrobrás, Bradesco e Ambev (Pugliese Jr, 2007).

A julgar pelas pesquisas realizadas pela Folha de S. Paulo, intitulada Top of Mind, a marca BB tem posição consolidada no imaginário social. Desde a primeira edição da pesquisa, em 1992, o BB é o mais lembrado, quando o entrevistado é questionado a responder sobre a primeira marca que lhe vem à cabeça quando se fala em instituição bancária. Não só a marca é lembrada, como também a logomarca é facilmente identificada com a empresa, o que permitiu ao BB prescindir da assinatura institucional em suas publicidades e comunicados. A utilização do ícone é suficiente para remeter à empresa.

O fato de carregar o nome do país em sua razão social criaria uma forte identificação das pessoas, independentemente de serem ou não clientes. Supõe-se que a empresa seja percebida como símbolo nacional, o que geraria grande carga afetiva no relacionamento com os públicos, e daria legitimidade à sua atuação comercial. Segundo o Banco do Brasil,

para esse resultado [a liderança na pesquisa Top of Mind], contribuem a maior base de clientes, a maior capilaridade no Sistema Financeiro Nacional, a atuação em todos os segmentos da

\footnotetext{
${ }^{32}$ Klein (2006, pág. 89) cita o exemplo do cantor e compositor Rufus Wainwright cujo aparecimento em uma propaganda da Gap estimulou as vendas de seus discos, por ele ter se tornado o "cara da propaganda da Gap". O papel da Nike na transformação do jogador de basquete Michael Jordan em um pop-star também foi decisivo. A situação de dominação em um campo da vida social também propicia ganhos em outro campo, fazendo com que ambos os lados da "parceria" se beneficiem.
} 
economia, os investimentos em esporte e cultura e as ações sociais. (Banco do Brasil, 2008)

\section{2 "NEM PARECE BANCO" - O PATROCÍNIO ARTístico E A IMAGEM DAS INSTITUIÇÕES FINANCEIRAS}

Interessante notar que as campanhas publicitárias dos bancos têm muitos pontos em comum, o principal residindo no fato de que raramente elas acontecem em agências bancárias. É constante mostrarem pessoas, jovens, crianças, idosos, exibindo felicidade em situações cotidianas.

A campanha lançada pelo Unibanco, no final de 2006, tinha como chamada o bordão: "Nem parece banco" (Anexo 10). Veiculada no cinema e na televisão, mostrava a entrega de caixas em uma agência bancária. Cada caixa continha dizeres evidenciando as principais causas da insatisfação dos clientes com os bancos: burocracia, filas, mau atendimento, em contraposição ao banco da campanha publicitária, em que não havia esses "dificultadores" e, de maneira contraditória, em nada se assemelharia a um banco.

Outro comercial afirma: "Às vezes, tudo o que você quer não é pagar menos tarifa, e tudo o que seu banco faz é cobrar mais ainda? O Unibanco inventou o revolucionário programa tarifa zero. Quanto melhor (sic) você usa os serviços, menos tarifa você paga. Até chegar a zero. Não é tudo o que você queria? Unibanco. Nem parece banco." Entenda-se por "quanto melhor você usa os serviços" o volume de aplicação financeira, e/ou empréstimos tomados, e/ou baixo uso dos canais presenciais de atendimento.

Interessante também observar que se procura construir uma imagem positiva a partir da negação da atividade bancária, associada a incontáveis atributos negativos. Os comerciais evidenciam o desprestígio dos bancos em nossa sociedade e o esforço que precisam fazer para adquirir legitimidade como prestadores de serviços dignos de confiança, e não como aproveitadores ou usurpadores da boa-fé pública.

Para reverter essa imagem, teóricos da área de marketing de serviços (cf. Kotler \& Bloom, 2002 e Las Casas, 2007) enunciam características que evidenciam suas dificuldades, quando comparadas a outras modalidades de marketing:

a) o fato de os serviços serem intangíveis, impalpáveis, ao contrário do que normalmente ocorre na área de comércio, isso faz com que os 
bancos, por exemplo, tenham preocupação constante com "folders" e informativos impressos para dar alguma dimensão material ao serviço;

b) nos serviços, a produção e o consumo ocorrem simultaneamente: são fases inseparáveis. Produtor e vendedor confundem-se na mesma pessoa, daí a preocupação dos bancos com a capacitação dos funcionários;

c) os serviços não podem ser estocados, têm alta perecibilidade e apresentam demanda flutuante. No caso dos bancos, por exemplo, os dias considerados de "pico" normalmente caracterizam-se por filas e mau atendimento, o que ocorre em geral no início de cada mês, não sendo possível "estocar" os "produtos" para o dia posterior;

d) por serem indissociáveis da pessoa que presta o atendimento, são variáveis e de difícil padronização. O mesmo funcionário pode prestar excelente serviço a um cliente e deixar a desejar no atendimento a um outro, no momento seguinte.

Segundo Herranz, Dávila e Fernándes (1998), os serviços bancários têm algumas peculiaridades que tornam as estratégias mercadológicas ainda mais específicas:

a) há uma dupla relação entre clientes e bancos. Por um lado, captam recursos e, por outro, emprestam recursos, em alguns casos, aos mesmos clientes. Em outras palavras, o cliente é fornecedor e consumidor;

b) há uma elevada regulamentação por parte de instituições governamentais, normalmente os Bancos Centrais, a fim de proteger os clientes, zelar pela sua segurança e pela solvência e eficácia do sistema financeiro;

c) em decorrência dessa regulamentação, os bancos possuem muitas limitações na estruturação de seus serviços e "produtos", fazendo com que estes sejam, no fundo, os mesmos, independentemente da instituição financeira que os comercializa. Além disso, não há proteção com relação à inovação, diverso do que acontece com as patentes na área industrial;

d) as relações entre bancos e clientes são mais estáveis do que em outros serviços, mesmo considerando que uma parcela considerável da população seja "multibancarizada". 
Os profissionais de marketing trabalham com os múltiplos fatores que envolvem a construção da imagem da empresa. A decisão de escolha por uma instituição bancária se dá a partir da percepção pelo consumidor de uma vasta gama de elementos, dentre os quais: credibilidade, qualidade do atendimento, custos, proximidade, status, rapidez do atendimento, aparência da agência bancária, automatização, identidade visual, rede de dependências. Na literatura de marketing, os patrocínios culturais e esportivos e as ações sociais dos bancos parecem ser considerados elementos acessórios ou complementares na constituição do que concebem como imagem da empresa, sem a mesma centralidade do que os anteriormente citados.

As instituições financeiras, assim como outros segmentos econômicos, necessitam de visibilidade e de presença marcante no imaginário dos seus clientes e potenciais consumidores. A estratégia de criar Centros Culturais com nomes de bancos justifica-se pela constatação de que patrocínios eventuais são insuficientes para a consolidação da imagem da empresa.

Os mecanismos para a manutenção da presença constante do logotipo das empresas no espaço público envolvem formas diversificadas de atuação, entre as quais o patrocínio cultural. A proibição dos anúncios em outdoors na cidade de São Paulo certamente teve grande impacto nesse desejo de visibilidade, levando a diversificação de estratégias. Por exemplo, o Bradesco tem contratado pessoas, devidamente uniformizadas, para que fiquem circulando pelas calçadas das grandes avenidas e parques da cidade, em pequenos veículos motorizados de duas rodas, sem qualquer abordagem mais incisiva, como distribuição de panfletos. Basta, para essa estratégia, que sua presença seja notada pelos transeuntes. Da mesma forma, porteiros podem ser pagos para manterem caixas vazias com o logotipo de alguma empresa, na entrada dos edifícios, como se estivessem à espera de algum morador para serem removidas, apenas para serem vistas ${ }^{33}$. Portanto, assim como o patrocínio cultural, as estratégias para obtenção de visibilidade são cada vez mais sutis e parecem ser tanto mais eficazes quanto menos demonstrem sua intenção de persuasão.

\footnotetext{
${ }^{33}$ Klein (2006, pág. 33) menciona outras artimanhas utilizadas pelas empresas na visibilidade frente aos seus consumidores como tiras de perfume colocadas no verso de envelopes de ingressos de concertos, ligações interurbanas "gratuitas" interrompidas por anúncios, adesivos publicitários em frutas promovendo programas televisivos, propaganda de filmes projetada em fachadas de edifícios ou calçadas etc.
} 
Mais do que uma experiência, muitas estratégias de marca procuram associar as empresas a um determinado "estilo de vida". A Nike não quer vender tênis, mas melhorar a vida das pessoas por intermédio da prática de esportes; a IBM não vende computadores ou softwares, mas "soluções para os negócios". É preciso toda uma estratégia discursiva, a fim de que as marcas deixem de relacionar-se com produtos e passem a interagir com um conjunto de valores e com uma reputação.

A idéia de interferir na percepção e no olhar que o outro tem das empresas revela o caráter manipulador das ações de marketing cultural. Ora, o julgamento que fazemos das pessoas, instituições e coisas é influenciado pelos múltiplos estímulos e ações que elas nos dirigem, avaliados de acordo com nosso universo valorativo. A própria intenção premeditada de um determinado agente de aparecer perante os demais de uma certa forma, pode revelar o quanto ele efetivamente não é da maneira como gostaria de ser visto. Em outras palavras, se fosse daquela forma, não precisaria preocupar-se em querer ser visto assim, já que a percepção desejada seria decorrente de suas ações. Contudo, a obtenção de capital simbólico não decorre exclusivamente das práticas sociais, mas também do jogo de relações estabelecido com outros atores sociais (incluindo estratégias discursivas que podem ser contraditórias com aquelas práticas).

O direcionamento do olhar do outro e a tentativa de que sua avaliação se construa da maneira que mais interessa à instituição patrocinadora de eventos revela a instrumentalização das ações de marketing para o proveito mercadológico da empresa. $O$ fato de a motivação do patrocínio ser fartamente anunciada pelas empresas revela que há uma tentativa bem sucedida de naturalizar a lógica capitalista de indução ao consumo, fazendo com que o ato manipulador não seja percebido como moralmente incorreto. Resulta também da constatação de que o universo valorativo e simbólico, determinante na construção da imagem que o consumidor formará da empresa, é um campo de lutas em que agentes com motivações contrárias (imprensa, governos, juízes, sindicatos, órgãos de defesa do consumidor, sociólogos, intelectuais, artistas) também tenham interesses em manipular a percepção das pessoas, para que sejam construídas imagens negativas das empresas.

A preocupação com a imagem também é, portanto, estratégia defensiva em um universo que se configura como palco de uma guerra simbólica, no qual a afirmação dos meus interesses é feita pela negação dos atributos positivos dos 
meus opositores. É como se o ator quisesse manipular o sentido atribuído pelo outro à sua ação social, de maneira a obter benefícios simbólicos. Não se trata apenas de uma estratégia discursiva, mas caracteriza uma ação efetiva, cujos fins parecem não residir nela mesma, mas nos lucros simbólicos que proporciona.

\subsection{O PATROCÍNIO COMO EXPRESSÃO DA RESPONSABILIDADE SOCIAL DA EMPRESA}

Não obstante serem o cerne do capitalismo excludente que marca as sociedades de mercado, nas últimas décadas as empresas têm assumido discurso (e há que se dizer: também algumas práticas) que enfatiza a assim chamada, responsabilidade sócio-ambiental da organização. Partem da premissa de que a organização não tem como função única atender aos interesses de seus donos ou acionistas, mas deve corresponder às expectativas de diversos públicos ("stakeholders"): clientes, fornecedores, concorrentes, governo, meio ambiente, funcionários, entre outros. A defesa dos códigos de proteção ao consumidor, a lisura tributária, o respeito ao meio ambiente e a ausência de reclamações trabalhistas são indícios da chamada cidadania corporativa. O pressuposto básico é que o interesse econômico dos negócios não pode estar acima de determinados princípios éticos e não pode ser utilizado como justificativa para ações que provoquem danos às pessoas ou à natureza. Os defensores dessa perspectiva argumentam que é possível superar o antagonismo normalmente estabelecido entre interesses privados empresariais e interesses públicos. Essa postura valoriza as interações das organizações com o meio, desvinculando sua imagem do mero interesse econômico, ao demonstrar que se procura pautar suas ações por princípios e valores éticos. $O$ investimento no campo artístico, mediante patrocínios, é uma forma de a empresa reforçar seu compromisso com a responsabilidade social.

O discurso empresarial da responsabilidade sócio-ambiental foi incorporado facilmente pelos profissionais de marketing, se sua origem não estiver aí localizada. No caso do BB, a Diretoria de Marketing, à qual os CCBBs estão vinculados, surgiu antes da Diretoria de Responsabilidade Sócio-Ambiental, que se estruturou somente durante o Governo Lula, sob a gestão de um vice-presidente muito vinculado ao Partido dos Trabalhadores e ao movimento sindical. 
A criação de uma estrutura administrativa voltada para a atuação na chamada área social pode ter significados contraditórios. Se, por um lado, representa o reconhecimento da importância desse segmento, e dá condições em termos de recursos (humanos, tecnológicos e orçamentários) para que ele possa encadear suas ações, por outro, pode significar também certa "guetização" dessas ações. Se, antes da década de 90, não havia qualquer dúvida de que o BB fosse um banco fortemente comprometido com objetivos os quais extrapolavam o mero retorno financeiro, a partir de então, essas questões passam a ser responsabilidade exclusiva de uma Diretoria, enquanto as demais podem preocupar-se com as questões eminentemente comerciais e econômicas, sabendo que uma parte da organização está voltada para os "aspectos morais".

Na maior parte das empresas e - também no BB -, os interesses financeiros acabam tendo peso maior na decisão do que aspectos relacionados à responsabilidade social, fazendo com que a lucratividade dos negócios, ao garantir de maneira mais imediata sua sustentabilidade, acabe canalizando a maior parte dos esforços e da energia da organização. O corpo executivo das empresas tem urgência em tornar claros os seus resultados em curto prazo, até para assegurar futuras promoções. Esse objetivo é mais rapidamente adquirido na área de negócios, enquanto as ações de responsabilidade social podem até render resultados financeiros, mas certamente necessitará de muito mais tempo. A divulgação exaustiva de suas ações "sociais" é feita com bastante ênfase pelos profissionais de marketing, os quais acreditam ser esse procedimento desejável para diminuir os impactos negativos causados à imagem do banco pelos juros altos e mau atendimento, por exemplo.

Deve-se ressaltar, contudo, a existência de ações efetivas, as quais demonstram que a adesão a princípios éticos não é mera retórica da empresa. $A$ atuação junto a comunidades carentes pela Fundação Banco do Brasil; a necessidade de licenciamento ambiental para financiamento de atividades que possam causar danos ao meio ambiente; a vedação na concessão de créditos a empresas que submetem trabalhadores a situações análogas ao trabalho escravo, dentre outras ações, demonstram preocupação com essas questões.

Baxandall (1991) aponta o exemplo do negociante florentino Giovanni Rucellai, que empregava vários pintores e justificava sua intensa atuação como 
mecenas, dentre outros motivos, em função da virtude e do prazer de bem gastar seu dinheiro, que seria superior ao de simplesmente ganhá-lo:

Para uma pessoa visivelmente rica, em especial alguém como Rucellai, que enriqueceu por meio da cobrança de juros - na realidade com agiotagem -, gastar seu dinheiro financiando igrejas e obras de arte para embelezar o patrimônio público era, por sua vez, um prazer e uma virtude necessária, uma justa indenização à sociedade, algo entre uma doação caridosa e o pagamento de taxa ou de impostos à Igreja. (Baxandall, 1991: pág. 13)

É provável que tanto no Renascimento italiano quanto no capitalismo pósindustrial do século XXI, haja uma tentativa de compensação dos malefícios causados pela exploração econômica através do fomento à atividade artística.

A análise das justificativas que amparam as escolhas dos projetos patrocinados pelo CCBB permite-nos compreender como o conceito de responsabilidade social é operacionalizado pelos funcionários. A defesa do patrocínio do espetáculo Elevador Panorâmico, por exemplo, que fugia totalmente à regra predominante de beneficiar nomes consagrados do teatro, salientava que a oportunidade oferecida a novos talentos estimulava o ineditismo e reforçaria o papel da empresa como socialmente responsável. Outras vezes, a temática sugerida pelo artista na obra a ser beneficiada era o que endossava o mote da empresa responsável, como, por exemplo, a questão do idoso no Brasil, abordada na peça Um homem indignado.

A "responsabilidade social" também aparece na cessão de parte dos ingressos para estudantes das escolas públicas e no transporte gratuito deles para ver exposições com o acompanhamento do setor educativo do CCBB. Além disso, $20 \%$ do valor arrecadado pela bilheteria é destinado ao programa "Arca das Letras" 34 do Governo Federal.

A arte-educação é considerada a área que mais contribui para afirmar a "responsabilidade social" do BB, já que permite a democratização do acesso à cultura junto aos segmentos que ainda não possuem capital simbólico para fruição das obras expostas.

\footnotetext{
${ }^{34}$ Trata-se de programa do Ministério do Desenvolvimento Agrário de implantação de bibliotecas em assentamentos, comunidades de agricultura familiar e remanescentes de quilombolas.
} 
As chamadas "exposições históricas" (Por ti América, Antes - Histórias da Pré-História) também receberam justificativas relacionadas à "responsabilidade social”, já que visariam “à preservação do patrimônio artístico brasileiro".

É importante ressaltar que a justificativa da responsabilidade social e do ganho de imagem analisada anteriormente mantém aspectos contraditórios. Se o ganho de imagem visa, ainda que no longo prazo, a maior propensão ao consumo, ele se ancora em interesses privados e mercadológicos. Ora, os princípios de responsabilidade social das empresas sustentam-se justamente na extrapolação dos interesses empresariais em direção a motivações públicas. Não seria contraditório se a empresa se afirmasse primeiramente intencionada a ter uma atuação com interesses públicos, e como conseqüência, obtivesse um ganho de imagem. No entanto, não é dessa maneira que a problemática se propõe: a empresa quer ter um ganho de imagem, e, para isso, procura ter atuação voltada a interesses públicos. É sutil, mas se trata de diferença fundamental.

A atuação "socialmente responsável" das empresas também é fruto de uma série de pressões e constrangimentos sociais que as compele a investir em ações sociais, culturais e esportivas. O próprio BB solicita os balanços sociais das empresas de grande porte que atende, os quais entram como elemento, ainda que secundário, na análise de concessão de crédito. Portanto, se a atuação desinteressada produz recompensas positivas para o doador, há o risco da nãodoação gerar sanções negativas. O investimento em cultura pode ser explicado não apenas como ação afirmativa, mas também como ação defensiva. Empresas se sentiriam coagidas ou obrigadas a patrocinar. Por exemplo:

Por que na Holanda todos os maiores bancos apóiam arte e mantêm coleções substanciais de arte moderna e contemporânea? Não colecionar arte enfraquece a posição de um banco? $\mathrm{O}$ comportamento de um banco pode ser explicado em termos do medo de aparecer contrário ou particularmente desinteressado em cultura. [...] Custos certamente aumentariam como conseqüência de uma identidade não cultivada. Acreditando que é muito mais provável que convenções relacionadas a noções simples de bom ou mau são internalizadas, 0 que basicamente compele administradores a promover arte como necessidade (Abbing, 2002:193)

O casamento entre o desejo de melhoria da imagem da empresa e a vontade de aparecer como agente "responsável socialmente" é o combustível das ações de patrocínio: 
Primeiro: ao patrocinar cultura eu estou associando minha imagem a obras já consagradas, que têm respaldo popular, que as pessoas reconhecem. Sabendo escolher projetos que sejam bem-feitos, sérios e de renome, estou associando minha imagem a eles. Não há por que esconder isso. Se estou patrocinando uma ópera ou uma orquestra sinfônica, de certa forma a minha imagem está sendo vinculada a alguma coisa séria. Ao mesmo tempo, estou cumprindo essa função cidadã, proporcionando ao público bons espetáculos, fazendo a minha parte, dando minha contribuição. (Alonso,1992:84)

\subsection{O PATROCÍNIO COMO INSTRUMENTO DO “MARKETING DE RELACIONAMENTO"}

As ações de patrocínio também são consideradas pelos profissionais bancários como simultaneamente de comunicação e de relações públicas. São vistas como complementares às ações de publicidade e propaganda. Os defensores do marketing cultural argumentam que o patrocínio possui vantagens em relação à propaganda, uma vez que a persuasão ocorre de forma menos explícita e mais subliminar:

propõe um novo rosto da empresa e uma relação diferente com um público que não é considerado apenas na sua dimensão de cliente ou comprador, mas também como amante da arte, do desporto ou da cultura. [...] O diálogo entre a empresa e a coletividade fixa-se sobre um registro distinto do registro dos negócios. (Weil, 1990).

O patrocínio se configura também como instrumento de relações públicas uma vez que, ao evento patrocinado, se agregam ações de comunicação (vernissages, coquetéis de lançamento, estréias de espetáculos) as quais permitem contato com os clientes em ambiente distinto dos negócios, possibilitando diálogo, em princípio, mais descompromissado e aberto.

"Relacionamento" é a palavra-chave mais ouvida pelos profissionais de vendas da área bancária, desde que a disseminação de tecnologias e a padronização dos produtos se tornaram irreversíveis, em meados da década de 90 . Não tendo mais como se diferenciar dos concorrentes pelos produtos oferecidos, nem pela maneira de distribuí-los, a ênfase nas estratégias de conquista e retenção de clientes utiliza a intermediação dos funcionários, que se relacionam com os correntistas e usuários.

Como a remuneração da mão-de-obra representa parte considerável das despesas de uma instituição financeira e o crescimento do montante a ele destinado 
pode comprometer o resultado, os bancos passaram a segmentar o seu público, de forma a se relacionar com ele de acordo com necessidades supostas (em princípio, um trabalhador de baixa renda teria menos necessidade de consultoria financeira do que o possuidor de grande soma de recursos) e, principalmente, com suas possibilidades de oferecer retornos financeiros. Foram criados espaços diferenciados pautados por essa segmentação, os quais ampliam a sofisticação e qualidade do atendimento proporcionalmente à renda do cliente.

Os ingressos para as peças e os vernissages que ocorrem no CCBB normalmente são distribuídos aos clientes pelos gerentes das contas, que os acompanham nos eventos. É nesse momento que o bancário consegue ter relação mais próxima com seu cliente, em ambiente menos burocratizado e com menos pressa do que o de uma agência bancária. Ao mesmo tempo, muitas vezes essa aproximação maior é propiciada pela desvinculação dos interesses comerciais que regem a relação cliente-funcionário, permitindo conversas de natureza mais "pessoal", vinculadas aos gostos e às preferências.

A palavra vernissage vem do francês, do verbo "vernir", que significa aplicar ou revestir de verniz uma determinada superfície. Adquiriu o sentido de inauguração de exposição, notadamente de pinturas, pelo fato de, habitualmente nesse dia, os artistas poderem terminar de envernizar suas pinturas no local da exposição, antes da abertura ao público (Robert, 2000). Interessante observar que a palavra verniz, tanto em francês quanto em português, pode ser entendida como algo que possui, ao mesmo tempo, aspecto sedutor e superficial - não altera substancialmente a superfície na qual é aplicado, mas dá-lhe um aspecto mais brilhante e atraente.

Do mesmo modo funciona a relação bancário-cliente, que é também "envernizada" nos coquetéis de abertura de exposições, propiciando, segundo relatos, resultados satisfatórios nos negócios e na "fidelização" do cliente. Deve ser esse o motivo pelo qual o CCBB, em conjunto com a Diretoria de Gestão de Pessoas do Banco, tenha estruturado treinamento interno (Oficina CCBB) em que os gerentes das contas são capacitados a utilizar suas estruturas e eventos, como instrumento de "relacionamento" com os clientes. Bancários, via de regra, possuem maior dificuldade com determinadas apreciações estéticas, conectados que são, por dever de ofício, a aspectos bastante pragmáticos da vida material. O treinamento, contudo, com duração de oito horas, no entanto, não parece ser suficiente para 
suprir essa lacuna ${ }^{35}$ e permitir maior familiaridade desses profissionais com os bens disseminados pelo CCBB.

Por trás de gestos corteses e despretensiosos, como o convite para um vernissage, há interesses precisos de relacionamento, de cunho empresarial e mercadológico, muito embora o bancário também possa estar genuinamente interessado nas obras expostas e nas opiniões de seus clientes.

Se as intervenções na área de marketing, sejam elas publicitárias ou de outra natureza, utilizam, sobretudo, técnicas discursivas, aquela vinculada à cultura visa propiciar uma experiência positiva com a marca. Exige que o consumidor assuma posição ativa, já que pressupõe deslocamento e certa abertura cognitiva para atividade pouco pragmática, cujos fins exigem compartilhamento da crença subjacente à fruição artística.

Trata-se, portanto, de estratégia mais sofisticada, que busca envolver 0 consumidor e valorizar a imagem da empresa, e que pressupõe certa dose de risco, pois a relação com o objeto patrocinado nem sempre é positiva.

Em um mercado de marcas padronizadas, o fator de diferenciação mais eficiente entre marcas é a emoção que cada produto oferece e gera no consumidor. (...) Os projetos culturais apresentam maleabilidade ímpar para romper barreiras. Ao patrocinar apresentações folclóricas, editar exposições e catálogo de fotos ou associar seus valores aos da música clássica ou contemporânea, as empresas transpõem fronteiras de resistências, porque não lidam com a dimensão racional do consumidor e sim com sua experimentação e vivência de uma sintonia emocional. (Reis, 2003: pág. 26).

Espera-se que o sentimento positivo vivenciado no contato do público com a arte seja transferido para a imagem da empresa que patrocinou o evento. Com isso, está presente a tentativa de estabelecer um vínculo emocional da empresa patrocinadora com quem usufrui a arte.

\footnotetext{
35،A conquista dessa espécie nova e única de capital [cultural] se realiza em grande medida pela mediação de uma socialização em famílias cultas e instruídas, capazes de transmitir aos herdeiros certos recursos, meios e facilidades de acesso, em especial o investimento para que adquiram habilidades que requerem maior dispêndio de tempo e disposições especialíssimas de ânimo, como, por exemplo, o aprendizado de línguas estrangeiras, a intimidade com repertórios da cultura erudita (música clássica, artes plásticas, literatura, etc.) e o treinamento dissimulado para converter qualquer acontecimento de sociabilidade ou situação de consumo em uma prova de discernimento, juízo e criatividade, em suma, um capital apto para enlaçar o conceito de tradição com modalidades novas." (Miceli, 2002).
} 


\subsection{INCENTIVO FISCAL: PRIVADO, PORÉM PÚBLICO}

Nas entrevistas, o incentivo fiscal não foi mencionado como razão para o patrocínio artístico. Porém, a aprovação do projeto pelo Ministério da Cultura tornouse pré-requisito de sua inscrição na seleção anual da programação. $O$ fato de haver incentivos fiscais também é fator que corrobora a decisão interna de desembolso dos recursos. A aprovação de despesas, sem que se configurem como investimentos com retornos calculados, é cada vez mais difícil nas empresas, haja vista a necessidade de lucros crescentes em função da intensa competição. Com o incentivo fiscal, a decisão do desembolso dos recursos para o fomento artístico se respalda na futura dedução dos impostos. Trata-se, portanto, de mecanismo que contribui para que o BB mantenha suas ações de marketing cultural.

A ausência de menção ao incentivo fiscal pelos funcionários do BB revela a necessidade de configurar $\circ$ patrocínio como doação, dádiva, atitude desinteressada, ainda que no fundo não o seja, já que, em última instância, os recursos não são da empresa, mas do Governo. A empresa é, no máximo, quem irá operacionalizar a doação, mas os recursos são públicos. Ora, a própria afirmação de que os recursos não são da empresa contradiz as razões acima arroladas de melhoria de imagem e de responsabilidade social.

O BB não exigia a aprovação prévia pelo Ministério da Cultura (configurando o enquadramento necessário para o benefício tributário) dos projetos a serem patrocinados, em função da impossibilidade de isenção fiscal, já que a empresa tinha créditos em haver com a Receita Federal. Nos últimos anos, essa aprovação tornou-se obrigatória, muito embora nem todo patrocínio cultural seja posteriormente utilizado para isenção fiscal. Em alguns casos, o desembolso dos valores é efetuado com recursos próprios.

Em 2007, dos $R \$ 32$ milhões (Banco do Brasil, 2008) investidos em cultura, $\mathrm{R} \$ 25$ milhões (Revista Marketing Cultural, 2008) foram deduzidos do imposto de renda a pagar, o que significa que $21 \%$ dos investimentos foram com recursos próprios.

A produção cultural brasileira sempre contou muito mais com os recursos públicos do que com os privados para fomento a suas atividades. Diante da demanda, contudo, as verbas destinadas à cultura sempre tenham sido insuficientes. A criação de estruturas governamentais (Instituto do Patrimônio Histórico e Artístico 
Nacional, Biblioteca Nacional, Empresa Brasileira de Filmes, Funarte) para implementação de políticas junto a determinadas áreas é evidência da inserção do Estado no campo artístico, cuja atuação inicial fora essencialmente patrimonialista.

O modelo patrimonialista só perdeu fôlego quando a lógica privatizante tornou-se preponderante em alguns governos, o que engendrou a retirada do caráter público da gestão dos recursos, embora se mantivesse a participação do Estado. Dessa forma, "a patrimonialização da cultura pelo Estado foi substituída pela ‘culturalização' da estratégia mercadológica das empresas.” (Dória, 2003:18)

Não obstante as décadas de atuação governamental no campo artístico, sua inserção ainda carece de política cultural ampliada, caracterizando-se, sobretudo, pela utilização de recursos públicos na produção de eventos, sem que se criem mecanismos para a sustentabilidade econômica do campo, se é que isso seja possível, ou ao menos que se delineie um projeto de longo prazo, visando objetivos cruciais, tais como a formação de público, a profissionalização dos artistas e demais intervenientes, a valorização da diversidade e o desenvolvimento e alargamento das fronteiras do campo cultural.

A complexa relação do Estado Brasileiro com os agentes empresariais envolve a tributação de diversas etapas da produção industrial e da prestação de serviços. Visando objetivos estratégicos, algumas vezes a incidência de impostos é flexibilizada. Via de regra, a sistemática de incentivos fiscais é uma forma de o Governo estimular a presença de recursos privados em segmentos considerados estratégicos, os quais, sem esse incentivo, não teriam condições de se viabilizar financeiramente pela simples atuação dos agentes econômicos envolvidos. A desoneração tributária seria uma forma de impulsionar atividades econômicas cujas dinâmicas de mercado não permitem a sobrevivência e rentabilidade dos produtores. $^{36}$

O volume de impostos que a Receita Federal abriu mão de arrecadar em 2008 ultrapassará a marca de $\mathrm{R} \$ 76$ bilhões. A área cultural responde por pouco mais de $1 \%$ desse valor. Trata-se, portanto, de valor irrisório diante dos incentivos

\footnotetext{
${ }^{36} \mathrm{O}$ Tribunal de Contas da União cobra maior controle do executivo sobre os resultados desses incentivos. "A renúncia fiscal para o setor cultural é uma das que mais têm chamado a atenção de auditores do TCU, sobretudo pelo atraso na análise das prestações de contas. De acordo com o levantamento mais atualizado feito pelo tribunal, o Ministério da Cultura mantinha quase 4.000 processos pendentes de análise. Esses processos consumiram $R \$ 3,6$ bilhões em benefícios fiscais. A área cultural terá neste ano mais de $R \$ 1$ bilhão em incentivos, o que corresponde a pouco mais de $1 \%$ dos impostos que a Receita deixará de recolher" (Salomon, Marta. Governo eleva renúncia fiscal em 44\%. Folha de São Paulo, São Paulo, 07/07/08, Dinheiro, B1)
} 
que o Estado concede a outras áreas da economia. Contudo, no referente à cultura, a cobrança do Estado com relação à correta aplicação desses recursos parece darse de forma mais intensa do que ocorre a outros setores da economia também beneficiados por leis de incentivo.

Pela lógica liberal, o mecanismo de isenção fiscal é uma política econômica que se insere em segmentos que precisam de apoio governamental para se tornarem economicamente sustentáveis. Porém, essa sistemática ainda não se mostrou eficiente para solidificar a chamada economia da cultura, o que permitiria que o governo se encarregasse mais intensamente das atividades sem interesses comerciais. O cinema, por exemplo, talvez a atividade artística mais passível de se inserir em uma lógica industrial de retornos financeiros, carece de grande intervenção governamental.

A maior parte dos recursos governamentais federais destinados à cultura são concedidos por intermédio de incentivo fiscal. Considerados os recursos gastos, em 2007, pelo Ministério da Cultura somente em "ações finalísticas" (desconsiderando, portanto, os gastos com "ações-meio": pessoal e encargos sociais) tem-se o montante de $\mathrm{R} \$ 561,6$ milhões, bem inferior ao valor tornado disponível pela Lei de Incentivo à Cultura $\left(\mathrm{R} \$ 960\right.$ milhões) ${ }^{37}$. Isso significa que, ao menos em termos quantitativos, a esfera empresarial possui maior ingerência no campo artístico do que o campo governamental federal ${ }^{38}$. Esse dado é atenuado quando se constata que grande parte dos investidores em cultura é constituída por empresas vinculadas ao Governo. Considerando as captações efetuadas pelos 101 maiores grupos investidores (correspondem a $82 \%$ do total captado pela via da Lei de Incentivo), verifica-se que $36 \%$ desses recursos ( $R \$ 282$ milhões) foram utilizados por empresas ligadas ao Governo ${ }^{39}$. Somente a Petrobrás respondeu por $19 \%$ do total captado desse modo ( $\mathrm{R} \$ 180,2$ milhões), devendo ser ressaltado que, das estatais, é a que a mais se alinha ao Ministério da Cultura. Isso não significa que esteja ocorrendo esvaziamento dos recursos do Ministério da Cultura para as empresas, tendo em vista que se têm ampliado os recursos orçamentários destinados pelo

\footnotetext{
${ }^{37}$ Fonte: Ministério da Cultura (site www.minc.gov.br, consultado em 12/09/08)

${ }^{38}$ Deve-se considerar, contudo, outras duas variáveis. Primeiramente, os gastos públicos concentram-se na esfera municipal $(49,1 \%$, contra apenas $18,1 \%$ na esfera federal e $32,8 \%$ na estadual) (Silva, 2002). A outra variável é que os níveis estaduais também possuem leis de incentivo, embora não existam esses dados consolidados.

39 Fonte: Revista Marketing Cultural On-Line (site www.revistamarketingcultural.com.br, consutado em 25/10/2008)
} 
Tesouro ao Ministério da Cultura $^{40}$. A centralidade da utilização das empresas públicas para gerirem recursos destinados à cultura foi atitude premeditada, sendo que elas se configurariam, nas palavras do ex-presidente da República, Fernando Henrique Cardoso, como um "braço do Ministério da Cultura" (Cardoso, 1998: 125.)

Tem havido, portanto, uma abertura para que parte da gestão de recursos públicos destinada à política cultural seja efetuada por agentes empresariais. Esse fenômeno poderia ser chamado genericamente de privatização. Contudo, essa denominação normalmente é aplicada quando o Estado transfere para a iniciativa privada a exploração comercial de determinada atividade econômica, o que não ocorre exatamente com o financiamento à cultura. Primeiramente, porque a presença estatal continua existindo, aplicando seus recursos, ainda que insuficientes diante da demanda, por meio de políticas públicas que ele próprio elabora. Ademais, a exploração econômica que se faz via patrocínio pelas empresas não visa obter lucratividade a partir da comercialização de produtos ou serviços. Almeja-se, outrossim, um benefício simbólico e não monetário. Não obstante a intenção dos legisladores ao propor a Lei de Incentivos Fiscais - de envolver outros segmentos da chamada sociedade civil na gestão da cultura -, o Estado continua tendo papel central, haja vista que os recursos são eminentemente públicos.

Independentemente do nome atribuído ao fenômeno, trata-se de gestão privada de recursos públicos, em virtude da qual o Estado se abstém da gestão de parte dos recursos arrecadados com os impostos pagos pelos contribuintes e delega aos profissionais de marketing das empresas, que se utilizam dos incentivos fiscais. O patrocínio como forma de melhoria de imagem institucional das empresas configura, certamente, como apropriação privada de um recurso, que é público.

A contestação desse mecanismo é grande, principalmente por aqueles que possuem maior dificuldade de estabelecer alianças com a lógica de mercado do patrocínio empresarial. Isto tem gerado sua articulação coletiva para exigir mudanças na legislação, reivindicação acolhida pelo Governo Lula, mas ainda não implementada.

\footnotetext{
${ }^{40}$ Os valores do orçamento realizado pelo Ministério da Cultura são $\mathrm{R} \$ 398.709$ mil, $\mathrm{R} \$ 542.635$ mil, $\mathrm{R} \$ 661.165$ mil e $R \$ 823.887$ mil, respectivamente em 2004, 2005, 2006 e 2007 (dados disponíveis no site do Ministério da Cultura, www.ming.gov.br, conforme consulta realizada em 12/09/2008).
} 
A principal crítica que se faz ao uso da Lei de Incentivos ${ }^{41}$ é que ela financia prioritariamente as produções artísticas que se poderiam viabilizar sem necessidade de apoio governamental, e exclui aquelas que mais necessitam dela. Dessa forma, contribui para a manutenção das estruturas de dominação do campo artístico, dando mais capital econômico e simbólico àqueles que se localizam na fração dominante do campo, e mantendo em posição inferiorizada aqueles que não dispõem de recursos para viabilizar suas produções. Isso ocorre porque as empresas, visando obter maior visibilidade às suas marcas, normalmente apóiam empreendimentos com artistas consagrados e fórmulas que possuem maior apelo popular:

Várias foram as conseqüências desse laissez-faire cultural. A primeira foi substituir o artista, o criador de cultura, por empresários culturais na apropriação dos recursos públicos. [...] A segunda conseqüência foi a própria subordinação dos empresários culturais, que substituíram os artistas, ao gosto médio dos dirigentes das corporações, abandonando [...] a cultura de matriz experimental, a arte de vanguarda e contestadora. O conservadorismo que se impôs como gosto dominante, favorecendo a cultura blockbuster, trouxe para o mercado brasileiro uma tendência mundial, uma onda conservadora." (Dória, 2003:65)

As escolhas artísticas, visando atender objetivos mercadológicos empresariais, recairiam sobre o gosto de uma população economicamente favorecida, que já consome cultura e que não precisaria ter ingressos subsidiados. Trata-se, portanto, de mecanismo estatal que, em vez, de estimular o acesso à produção artística pelas camadas que se encontram dela excluídas, corrobora para aumentar a desigualdade do consumo cultural.

A alteração na lei ${ }^{42,}$ permitindo que $100 \%$ (anteriormente havia a necessidade da empresa investir recursos próprios) dos valores destinados aos projetos artísticos fossem deduzidos dos impostos a pagar pelas empresas, atendeu a lobby de representantes dos artistas, ansiosos por mais recursos para suas produções; também se relaciona à dificuldade do Ministério da Cultura para elevar sua disponibilidade orçamentária, num país em que as exigências de outras áreas sociais (saúde, educação, previdência) têm maior plausibilidade. O incentivo fiscal atende também a uma necessidade econômica governamental de gerar superávit

\footnotetext{
${ }^{41}$ A Lei Federal de Incentivos à Cultura (Lei 8.313), também conhecida como Lei Rouanet, instituída em 1991, substituiu a Lei Sarney, promulgada em 1986 e revogada em 1990.

${ }^{42}$ Lei $9.874 / 99$ que alterou o artigo 18 da Lei $8.313 / 91$ permitindo $100 \%$ de dedução.
} 
primário, já que não se trata de despesa, mas de recurso que deixa de ingressar nos cofres públicos.

Outra crítica freqüente a essa forma de financiamento à atividade artística reside nos ganhos econômicos empresariais que muitas atividades patrocinadas proporcionam a capitalistas que não precisam investir qualquer recurso para obter retorno, ou seja, manifestações artísticas economicamente viáveis utilizam recursos públicos e lucram com eles. O caso mais notório é o da empresa mexicana CIE (Companhia Interamericana de Entretenimento), especializada em grandes produções teatrais, normalmente musicais. As principais contestações à utilização do incentivo fiscal por essa empresa devem-se aos altos preços cobrados pelos ingressos, o que garante elevada rentabilidade financeira ao investidor e impede o acesso da maior parte da população ao usufruto do bem financiado com recursos públicos. Além disso, trata-se de fórmula cultural considerada como mero entretenimento, já que até por exigências contratuais reproduz a fórmula bemsucedida dos musicais norte-americanos. Essa empresa foi a responsável pela captação de $R \$ 8$ milhões (dos $R$ \$ 9,4 milhões autorizados pelo Minc) de recursos incentivados por intermédio do Bradesco e da Visa no patrocínio do Cirque du Soleil, cujos ingressos foram vendidos a preços elevados (de $R \$ 50$ a $R \$ 370$ mil) em sua primeira passagem pelo Brasil,. Além disso, configura-se como uma empresa internacional de entretenimento ${ }^{43}$.

O principal problema é que, em nome de não haver ingerência estatal nas escolhas, não há julgamento da relevância artística do projeto na qualificação efetuada pelo Ministério da Cultura. Predomina, portanto, a lógica liberal na visão da qual não deve haver "aparelhamento político da cultura" (conforme argumentava o editorial Aperfeiçoar a Lei Rouanet. Folha de S. Paulo, São Paulo, 06/04/08, Opinião, A2) pelo Estado, que relega o patrocínio artístico às escolhas mercadológicas dos departamentos de marketing das empresas.

Critica-se ainda a concentração elevada dos recursos subsidiados na Região Sudeste $^{44}$ e nos grandes centros, deixando sem apoio as regiões do país com menor interesse mercadológico para as empresas. Dessa forma, a lei reforça as

\footnotetext{
${ }^{43}$ Arantes, Silvana. O circo do incentivo. Folha de S. Paulo, São Paulo, 26/04/2006, Ilustrada, E1.

${ }^{44} 64 \%$ dos projetos submetidos ao Ministério da Cultura em 2003 foram provenientes da região Sudeste (Silva, 2005) e $80 \%$ dos recursos captados foram naquela região (Ministério da Cultura, 2008), o que denota que a pouca utilização de recursos incentivados nas regiões Norte, Centro-Oeste e Nordeste também decorre da baixa demanda dos produtores culturais.
} 
distorções do mercado, concentrando a oferta cultural viabilizada por recursos públicos nas regiões com maior desenvolvimento econômico, onde se localizam as sedes das principais empresas e a maior parte dos produtores e consumidores culturais.

Segundo o próprio Governo, a lei de incentivo tem sido utilizada na produção de peças teatrais, para temporadas cada vez mais curtas e com número de sessões mais reduzido, o que denota maior preocupação pelo benefício da isenção fiscal do que por proporcionar espetáculo de forma acessível ao público (Frateschi, Celso e Ferreira, Juca. Incentivo ao Teatro?. Folha de S. Paulo, São Paulo, 27/03/08, Opinião, A3)

Os opositores também contestam a utilização da Lei de incentivo pelas empresas que mantêm institutos culturais, como o CCBB, assim como o número reduzido de proponentes que efetivamente captam recursos por meio dela.

As próprias instituições culturais do Estado, em todos os níveis (Funarte, Pinacoteca, Osesp, TV Cultura $^{45}$ ), utilizam-se das leis de incentivo para captar recursos junto às empresas. Obviamente, fica muito difícil para produtores independentes competirem com as próprias organizações estatais de renome na busca desse apoio.

A utilização de incentivos fiscais por órgãos públicos denota como é bizarra a forma de financiamento às artes no Brasil e a pouca expressividade política da área cultural no campo governamental, o que resulta no reduzido orçamento do Ministério e das Secretarias de Cultura. Para financiar seus próprios projetos, o Estado, mesmo utilizando os seus próprios recursos, necessita da intervenção de agentes empresariais, que nada desembolsam, mas têm lucros simbólicos com a ação.

Trata-se de tema polêmico, objeto de inúmeros debates entre posições divergentes. A interpretação acerca dele pode ser feita pelo posicionamento político que diz respeito ao papel do Estado na regulação da produção cultural, o qual contrapõe duas posturas extremas do debate e várias gradações entre elas (Durand, 2000:95). De um lado, em uma perspectiva neoliberal, a defesa do incentivo fiscal, que permitiria a presença de outros agentes sociais no patrocínio artístico, além de

\footnotetext{
${ }^{45}$ A Fundação Padre Anchieta captou $R \$ 11,8$ milhões, a Osesp captou $R \$ 8,6$ milhões e a Pinacoteca do Estado, $\mathrm{R} \$ 8,5$ milhões, sendo que foram a $3^{\underline{a}}, 7^{\underline{a}}$ e $8^{\underline{a}}$ maiores captadoras do país. O governo federal acusa o governo estadual de usar uma brecha da lei para financiar suas estruturas permanentes, que, em princípio, deveriam ser financiadas pelo Estado. (Arantes, Silvana. Minc revida artilharia de São Paulo. In Folha de S. Paulo, São Paulo,16/06/08, Ilustrada, E4).
} 
reduzir a tributação. De outro, mais à esquerda do debate político, aqueles que defendem maior presença do Estado, contrários à submissão dos interesses artísticos aos ditames das estratégias de comunicação e de marketing das empresas.

Outra forma de leitura desse debate relaciona-se à manutenção ou não de privilégios e formas de obtenção do capital econômico. Aqueles que não conseguem acesso às empresas ficam alijados de uma parcela importante dos recursos e, também por isso, se manifestam contrariamente à Lei de incentivo. Por outro lado, os que normalmente possuem os atrativos (que envolvem, dentre outros fatores, a consagração no campo artístico) se posicionam favoravelmente aos incentivos dados às empresas patrocinadoras.

É inegável que as leis de incentivo propiciaram mais recursos para o fomento à atividade artística. Tal fato despertou o interesse de outros segmentos interessados em obter também recursos para financiar suas atividades, como as igrejas e o esporte, gerando preocupação no campo artístico. A ampliação das demandas existentes elevaria o número de competidores por esses recursos.

O que é perverso nesse modelo é que o investimento em cultura aparece como um gesto de benevolência, uma atitude desinteressada, quando ele é motivado principalmente por questões tributárias e fiscais. Conforme diz Bourdieu, "os cidadãos contribuem para pagar sua própria mistificação". (Bourdieu \& Haacke, 1995: 27)

Apesar de toda a controvérsia e debates polarizados, algo parece consensual: o Estado não deveria investir em projetos culturais que o mercado pudesse financiar e nem relegar à iniciativa privada - já que não é de interesse dela -, o financiamento de alguns projetos e manifestações artísticas que seriam de sua responsabilidade.

\subsection{Preto no branco: os Contratos de PATRocínio}

As razões do marketing cultural do BB são objetivadas nos contratos estabelecidos com os artistas patrocinados. Juridicamente, um contrato existe para que as vontades das partes sejam estabelecidas, visando resguardar os interesses em jogo em um negócio ou acordo, e prevendo penalidades caso haja descumprimento do acordado. 
Para a análise aqui estabelecida trata-se de documento importante, pois demonstra os pontos no relacionamento instituição-artista que merecem maior cuidado e que, portanto, têm maior relevância, à medida que permitiriam o acesso às esferas judiciais no caso de desvio do estabelecido. Há que se destacar, contudo, que esse contrato revela preponderantemente os interesses da instituição na ação do patrocínio não resguardando muitos direitos para os produtores e artistas, denominados nos instrumentos jurídicos como "contratados".

O contrato firmado pelo CCBB segue um modelo padrão e não há discussão com os outros interessados no patrocínio acerca da pertinência das cláusulas que ele contém. Tendo em vista a relação assimétrica, em termos econômicos, políticos e sociais, que existem entre o $\mathrm{BB}$, o contratante, e os contratados, não resta muita escolha para os artistas e seus representantes senão assinar o instrumento tal qual Ihes é fornecido ou desistir do patrocínio. Das 25 cláusulas que compõem o contrato, dezessete constituem obrigações ou penalidades a serem observadas pelos "contratados". O "contratante" possui duas obrigações: ceder o espaço e efetuar o pagamento do patrocínio, que é condicionado ao cumprimento de muitos requisitos.

Os artistas não são contratados diretamente pelo Centro Cultural. Eles são representados por pessoas jurídicas que firmam o contrato com a instituição e se obrigam, em nome dos artistas, às condições estabelecidas. Os sócios-proprietários dessas empresas normalmente são Produtores, profissionais com quem o CCBB mantêm contato mais estreito. Esses Produtores respondem pelo cumprimento do cronograma, pela consecução da planilha de despesas previamente aprovada, pela aprovação do projeto junto ao Ministério da Cultura, além das devidas prestações de contas, feitas posteriormente. Os artistas recebem seus cachês dos Produtores. Visando menor incidência tributária, os artistas também, muitas vezes, possuem suas próprias empresas, para quem os cachês são repassados. Vê-se, desse modo, que o campo artístico também se encontra muito estruturado em termos empresariais, afastando-se bastante do ideal romântico do artista distanciado das questões econômicas e jurídicas.

Da parte do contratante, quem assina o contrato é o Banco do Brasil, representado pelo gerente do CCBB. A prática de os artistas fazerem-se representar por empresas é padrão nos patrocínios empresariais. Assim, querendo ou não, os artistas entraram definitivamente no mundo dos negócios. 
Antes de firmar o contrato, a Assessoria Jurídica do BB atesta, a cada evento patrocinado, se a contratação do "serviço artístico" pode ser dispensada de licitação pública, enquadrando o evento em uma ressalva prevista na própria lei de licitações.

Como em todo contrato, são estabelecidas as obrigações de cada um dos signatários. De parte do contratado, a principal responsabilidade assumida é a realização do evento artístico, na forma em que foi aprovado, cujas especificações são descritas, de forma minuciosa, em documento anexo ao contrato. De parte do CCBB, a principal obrigação é o pagamento do serviço prestado. Um dos parágrafos do contrato padrão resume a sua principal preocupação:

É vedada, durante a execução do objeto contratado qualquer alusão, citação ou ato que traga prejuízo à imagem institucional do contratante [Banco do Brasil] e do Centro Cultural Banco do Brasil São Paulo.

Os pagamentos são feitos pelo BB de forma parcelada, sendo que a primeira parcela habitualmente se dá com a apresentação do cronograma de realização, a planilha de orçamento, a relação da equipe técnica e as declarações firmadas pelos artistas relativos à cessão de uso de imagem e direitos autorais. A segunda parcela é vinculada à prestação de contas da parcela anterior e à aprovação pelo CCBB das peças gráficas (folder, cartazes, convites), que devem seguir rigidamente o padrão do BB, com a utilização das cores e das letras patenteadas pela empresa. Outras parcelas intermediárias são instituídas de acordo com a natureza de cada projeto. A última é paga após a entrega do prédio (no caso das exposições) nas condições que foram encontradas no início do evento, vinculando-se também à apresentação do "clipping" de imprensa, com a valoração do espaço na mídia. As parcelas são pagas mediante entrega de recibos de mecenato, que propiciam a utilização da lei de incentivo fiscal.

O profissional ou empresa que fará o trabalho de assessoria de imprensa, apesar de contratado pelos artistas, é escolhido pelo CCBB, a partir de uma lista tríplice fornecida pelo contratante.

A equipe técnica que realizará o projeto também consta de documento anexo ao contrato. Em uma das claúsulas, o contrato padrão estabelece:

No caso dos artistas, curadores, palestrantes ou outros profissionais reconhecidos, consagrados, ou de notória especialização, nos termos da lei, é vedada a substituição sem anuência prévia do Centro Cultural Banco do Brasil - São Paulo. Qualquer substituição 
deverá ser submetida ao Contratante, para concordância, no prazo mínimo de 60 dias antes do início do evento.

Essa cláusula é importante juridicamente, pois a dispensa da licitação se ampara na existência da equipe de criadores de profissionais com notória especialização e consagração, o que inviabilizaria a abertura de processo de concorrência pública.

O contrato também estabelece uma série de obrigações relacionadas à divulgação e relacionamento com os públicos e demais intervenientes:

- confecção de catálogos, folderes, cartazes, programas, convites, apostilas, cartazetes, postais publicitários e banners em quantidades pré-estabelecidas;

- submissão para aprovação do CCBB de qualquer contato, declaração ou pronunciamento prestado pela assessoria de imprensa contratada pela produtora;

- citação do nome do BB como patrocinador do projeto, e o CCBB como realizador em todas as entrevistas que forem concedidas por qualquer envolvido na criação ou produção do evento;

- não divulgação do nome de qualquer outra empresa;

- providenciamento da aplicação da logomarca do CCBB como realizador e registro dos dizeres "Banco do Brasil apresenta e patrocina" em todo o material gráfico promocional;

- entrega de arquivo com "mailing" de convidados;

- priorização da difusão da logomarca e do nome do Banco do Brasil, e do CCBB em toda a ação de divulgação do objeto contratado.

O contratado se obriga a manter o nome do patrocinador nas peças publicitárias até um ano após o término do evento do CCBB, ou seja, se a peça ou exposição tiver continuidade em outros espaços, o que tem se mostrado comum, o BB continua aparecendo como patrocinador ainda que não tenha desembolsado novos recursos.

Apesar da distância no tempo e na configuração das sociedades envolvidas, é interessante traçar um paralelo com o já citado estudo de Baxandall (1991), acerca da relação dos pintores renascentistas com seus mecenas. Obviamente, não havia a 
figura hodierna do patrocinador. Em seu lugar estava o mecenas, que era ao mesmo tempo cliente. Naquela época também se estabelecia um contrato, cujo objetivo principal era assegurar que as minuciosas especificações artísticas estabelecidas pelo mecenas-cliente fossem cumpridas. A arte era realizada sob encomenda e o mecenas tinha um papel ativo na relação com o artista. Um dos contratos daquela época rezava:

[o pintor] deve pintar o dito painel inteiramente com sua própria mão, segundo o modelo desenhado em papel, com as figuras e da forma indicada no modelo, em todos os detalhes segundo o que eu, Fra Bernardo [o mecenas], julgo o melhor; não se desviando da maneira e da composição do dito desenho; e deve pintá-lo às suas próprias custas com cores de boa qualidade e com ouro em pó nos ornamentos como se deve, e todas as despesas incorridas no mesmo painel, e o azul deve ser ultramarino [...] deve acabar e entregar o dito painel dentro de trinta meses [prazo impensável hoje!] a contar de hoje. (apud Baxandall,1991: 18)

A interferência do mecenas na especificação da obra era total, tanto na definição dos objetos e pessoas que seriam representados, abarcando dimensões e cores utilizadas, quanto na definição das paisagens que eventualmente os rodeavam. Os aspectos especificamente artísticos das pinturas ocupavam a maior parte dos contratos.

Nos contratos firmados pelo CCBB, os aspectos especificamente artísticos resumem-se a um parágrafo de uma cláusula, que remete a um anexo, no qual está a "discriminação das atividades do evento". Esse reduzido texto é uma síntese da peça ou da exposição, tal qual já constava na proposta efetuada pelo próprio artista. Não se nota qualquer interferência do patrocinador na concepção artística do projeto, o que seria hoje uma ofensa a ele.

Assim como no patrocínio empresarial, na Renascença, a obra patrocinada também tinha como uma de suas finalidades a celebração e promoção do mecenas. Porém, não havia qualquer cláusula nos contratos de outrora a esse respeito. Nos contratos firmados pelo CCBB, ocorre o oposto. A maioria das cláusulas versa sobre as formas de promoção do evento artístico, procurando assegurar a presença do patrocinador em todos os registros possíveis de divulgação do evento patrocinado. $O$ mecenas deixou de ter qualquer ingerência na obra patrocinada para assumir controle total na sua divulgação, visando à promoção de sua imagem no grau mais elevado possível. 
Contratando os artistas como prestadores de serviços, o patrocínio empresarial retiraria, caso isso fosse explicitado, a aura romântica que envolve a percepção social do artista, reduzindo-o a um trabalhador especializado, que produz um tipo de mercadoria marginal. As razões que ancoram os patrocínios artísticos se inserem na normatividade, racionalidade e valores próprios do campo econômico, que dá identidade para a empresa e a coloca como ator legitimado no universo social, o qual preza também pela não interferência na atividade criadora do artista. 
PARTE II- O CCBB e o CAMpo Artístico 


\section{Capítulo 3}

\section{O CCBB DIANTE DA CONCORRÊNCIA CULTURAL}

A atuação do CCBB na vida social e cultural paulistana também é influenciada pela competição existente entre as instituições produtoras de cultura da cidade. $O$ objetivo deste capítulo é delinear a inserção do Centro Cultural no embate com seus concorrentes.

O conflito entre as instituições culturais objetiva a conquista, acima de tudo, de capital simbólico. As instituições aspiram a patrocinar peças que sejam grandes sucessos de crítica e de público. Desejam viabilizar exposições que sejam importantes na história das artes plásticas e tenham reconhecimento dos especialistas. A disputa entre as instituições é concomitante à disputa dos artistas, que buscam instituições com recursos e espaços de consagração para viabilizar seus trabalhos. Esses interesses, ora conflitantes, ora convergentes, formam uma complexa rede de interações, subordinações e dependências cujas configurações pretendemos explicitar.

A concorrência no campo artístico, apesar de não ser tão explícita como no campo econômico, está presente de forma intensa. Para o público consumidor, ela se manifesta de forma velada, e em alguns casos, é sutil também para os integrantes do campo artístico. Essa concorrência se mascara muitas vezes na forma do reiterado e controverso discurso sobre a carência de aparelhos culturais, dada a elevada demanda do público. Por esse discurso, não haveria que falar em concorrência elevada, já que a oferta seria menor do que a demanda. Acredita-se, contudo, que interesses concorrenciais são obscurecidos por uma percepção de harmonia e cooperação no campo artístico devido à necessidade de manter a illusio que cimenta as relações entre os atores sociais, já que predomina a crença de que a arte é a livre manifestação do espírito criador do artista e que as instituições são entes capazes de detectar os talentos, consagrando-os.

A crença na imanência da obra de arte é contrária à constatação de que existem interesses localizados, sobretudo, na inter-relação entre os atores sociais e, portanto, na competição por capital simbólico e econômico. Esse quadro não é diferente quando se pensa nas ações do CCBB. 
A definição da programação do CCBB depende do debate interno com os diversos níveis decisórios do Banco do Brasil (BB), do diálogo intenso com os artistas e produtores culturais, e de forma mais velada, com as outras instituições culturais, procurando conquistar espaços e criar marcos distintivos com relação às demais organizações.

Sem a intenção de fazer análise conclusiva sobre o modus operandi de cada instituição abordada, pretende-se principalmente verificar a maneira preponderante como se relacionam com seus públicos e como o CCBB se posiciona diante delas.

\subsection{CAPITAL ECONÔMICO E CAPITAL CULTURAL: DESIGUALDADES}

A imagem de São Paulo como capital cultural do país é amplamente disseminada. Constantemente, reforça-se o caráter da amplitude de oferta cultural que a cidade proporciona: teatros, cinemas, casas de shows, museus, galerias de arte, centros culturais. Bares, restaurantes e shoppings, complementam as opções de lazer daqueles que possuem capital econômico favorável para essas alternativas.

Informações relativas aos equipamentos culturais no Brasil, além de escassas, não permitem comparações seguras, em função da multiplicidade de formas e metodologias de coleta. Contudo, considerando-se a população de São Paulo - 10.670.760 habitantes (ano de referência: 2004, cf. www.seade.gov.br) e a renda $-9,4 \%$ do PIB nacional, em 2003 (cf. www.seade.gov.br) - que a cidade concentra, é bem provável que supere as demais cidades brasileiras em termos de oferta cultural. Mais difícil é avaliar se essa oferta é suficiente, adequada, ampla ou compatível com o tamanho da cidade e com os anseios da população $0^{46}$.

A existência do equipamento cultural não é condição suficiente para o seu uso. Certamente, os modos artísticos analisados no presente estudo são principalmente usufruídos por segmentos mais favorecidos da população no aspecto sócio-econômico. Importa lembrar também a heterogeneidade de opções de consumo, englobando uma extensa série de produtos da indústria cultural, para os quais, considerando alguns dados demográficos brasileiros, tais como expectativa

\footnotetext{
${ }^{46}$ Os anexos 11 e 12 relacionam os teatros e espaços destinados à exposição de artes plásticas existentes na cidade.
} 
de vida e aumento do poder aquisitivo de determinadas camadas, apontam para um cenário que vislumbra perspectivas otimistas de incremento.

A escassez de dados sobre o consumo cultural dos paulistanos tem sido amenizada apenas por pesquisa realizada em $1999^{47}$, na qual é constatado que a fruição artística não está entre as principais atividades exercidas no tempo livre da população. Dos indivíduos consultados naquela oportunidade, 69\% declararam preferir shopping centers e 56\%, restaurantes. As atividades culturais aparecem a partir do terceiro lugar de preferência: a leitura, com 47\%; o cinema, com 43\%; o teatro, com 17\%; e os museus e galerias, com 15\%.

Percebe-se que os modos artísticos analisados nesta pesquisa estão longe de ser as opções culturais preferidas pela maior parte da população. O uso da televisão certamente concentra as preferências de lazer, delimitando o tempo livre ao espaço doméstico, acompanhado das condições de trânsito da cidade, o medo da violência urbana e as condições financeiras de grande parcela da população para quem mesmo o módico valor da passagem de ônibus já constitui uma limitação de deslocamento para espaços de atividades culturais.

Pesquisa mais recente realizada pelo Datafolha ${ }^{48}$, aponta outros hábitos de consumo dos paulistanos não mencionados na pesquisa supracitada, e reforça o menor destaque dado ao teatro e às artes plásticas nas escolhas: $26 \%$ dos entrevistados dizem freqüentar museus e exposições, e, o teatro, somente $16 \%$. Quando questionados a respeito das atividades preferidas, essas escolhas (artes cênicas e plásticas) reduziram-se ambas a 1\%. Estas opções de consumo cultural situam-se bem atrás de outras como a música, o cinema ou a leitura de livros.

Se $84 \%$ dos paulistanos não freqüentam teatro, a intensidade dessa opção cultural varia, contudo, de acordo com a escolaridade. É possível observar que nas salas de espetáculos têm-se, então, um menor fluxo de pessoas que cursaram apenas o ensino fundamental; $94 \%$ destas pessoas não freqüentam espetáculos contra os indivíduos com ensino superior, dos quais $64 \%$ não freqüentam teatros.

O mesmo fenômeno se observa quando a variável é a renda. Quando questionados sobre quais as peças vistas no último ano, a minoria que freqüenta teatros optou preferencialmente por peças comerciais e por musicais: $6 \%$ dos

\footnotetext{
${ }^{47}$ Realizada pela Secretaria de Estado da Cultura, no ano de 1999 e publicada no jornal O Estado de São Paulo em 16 de julho de 2000.

${ }^{48}$ Arantes, Silvana. Bem na Fita. Folha de S. Paulo, São Paulo, 08/06/08, llustrada, E1-E4.
} 
entrevistados mencionaram O Fantasma da Ópera; $5 \%$, a comédia que ficou mais de uma década em cartaz intitulada Trair e Coçar é Só Começar, e 4\%, o musical Miss Saigon. As peças mencionadas, além de forte apelo comercial, inclusive com anúncios na mídia impressa e televisiva, apresentam valores de ingresso altos, acessíveis a poucas pessoas, as quais muitas vezes utilizam a freqüência a esses espetáculos como capital simbólico, e indicador de status social; ou, ainda, peças de humor fácil, aclamadas pelo público menos exigente. Esses dados evidenciam que a demanda não é tão abundante como muitas vezes se divulga, e que a freqüência às atividades artísticas analisadas está concentrada na elite com maior capital econômico.

Com relação à distribuição dos equipamentos culturais, nota-se acentuada irregularidade. Existe evidente desequilíbrio entre a disponibilidade quantitativa e a densidade populacional da região na qual se inserem. Os extremos das zonas leste e sul, regiões densamente povoadas, mas de população com baixo poder aquisitivo, são praticamente desprovidos de tais equipamentos. Os teatros, galerias e museus concentram-se nas regiões em que vivem os que possuem maior poder aquisitivo. Os teatros (66\%) estão concentrados nos distritos da Bela Vista, Consolação, Liberdade, República, Santa Cecília, Itaim Bibi e Perdizes, enquanto, 51 dos 96 distritos do município não possuem nenhum teatro. Também os museus, (61\%) estão concentrados nos distritos da Sé, Bela Vista, Bom Retiro, Vila Mariana, Butantã, Morumbi e Jardim Paulista ${ }^{49}$, sendo inexpressiva a sua presença nos demais bairros da cidade. Sendo assim, a localização desses equipamentos acompanhou o processo de segregação econômica e espacial da cidade, havendo maior concentração de salas de espetáculos nas regiões onde habitam os segmentos com maior nível de escolaridade e renda.

\subsection{ANTAGONISMOS SIMBÓLICOS E ESPACIAIS}

O CCBB localiza-se no chamado centro velho de São Paulo, justamente no triângulo histórico formado pelas ruas São Bento, Direita e Quinze de Novembro. 
Trata-se de região de grande importância histórica, onde está situada a maior parte dos edifícios considerados patrimônios, muitos deles tombados.

É importante refletir sobre os motivos que levaram à escolha desse espaço para a instalação do CCBB. Em primeiro lugar - e crê-se que esse tenha sido o fator decisivo - essa eleição ocorreu em virtude das configurações estéticas do prédio, que já pertencia ao BB. O edifício em questão tinha características arquitetônicas julgadas adequadas para instalação de um Centro Cultural, não em função de seu porte - de proporções reduzidas -, mas, principalmente, devido a sua arquitetura.

Localizado na esquina das ruas Álvares Penteado e Quitanda, o prédio foi inaugurado em 1927, época da consolidação de São Paulo como centro financeiro do país, em função do grande fluxo de recursos da economia cafeeira. Essa região começou então a firmar-se como distrito financeiro. O edifício Hipólito Pujol oferecia, então, à elite paulista enriquecida pela produtividade cafeeira, um desejado símbolo de refinamento e ostentação.

A obra arquitetônica em estilos neoclássico e art nouveau impressiona pela grande área constituída, por janelas emolduradas e por pilastras monumentais, entre outros atributos. O prédio possui cinco andares, arrematados por uma mansarda e por uma cúpula no torreão da esquina. A característica mais marcante é o vão que atravessa todos os andares, iluminado por uma clarabóia no quarto andar. Seu estilo, fortemente influenciado pela arquitetura européia, impressiona em um cenário no qual, de maneira geral, os imóveis não possuem refinamento semelhante.

A ornamentação do prédio é, ao mesmo tempo, sóbria e luxuosa. Arandelas, balcões de ferro, mármores, pisos em mosaico, molduras em gesso, afrescos e guichês em madeira de lei dão ar de sofisticação e requinte ao local. No subsolo, encontra-se o enorme cofre, importado da França, utilizado como espaço de exposições, e para a apresentação de peças teatrais.

Além dos motivos supracitados para a escolha do edifício Hipólito Pujol, devese levar em conta que a direção do BB dificilmente aprovaria os custos decorrentes da construção de um prédio específico para o CCBB, pelo acirramento da concorrência entre instituições financeiras àquela época, e em um contexto de esforços concentrados no sentido de rentabilizar e estimular o crescimento da

49 Fonte: Fundação Seade. "Equipamentos culturais, por tipo, segundo subprefeituras e distritos". Dados de 2002. Disponível em www.seade.gov.br, consultado em 13/03/07. 
empresa. A reforma de imóvel próprio, apesar de muito custosa, acarretou despesas menores.

Experiência bem-sucedida do Rio de Janeiro emergiu como modelo a ser seguido, uma vez que também lá o empreendimento estava localizado no centro da cidade, e igualmente, em imóvel do início do século XX. Ademais, a adesão do BB ao esforço, já existente naquele momento, no sentido de revitalização do centro da cidade,$^{50}$ poderia gerar ganho substancial de capital simbólico para a empresa. O BB possuía patamares inferiores de participação no mercado financeiro, comparados os dados da instituição em São Paulo em relação a outras capitais. Qualquer investimento gerador de projeção de sua imagem era bem-vindo, em um momento de diagnóstico de posição secundária, incômoda aos seus dirigentes.

Algumas iniciativas realizadas na década de 90 provocaram melhoria urbanística e arquitetônica no entorno do CCBB, como a reurbanização da Praça do Patriarca, do Vale do Anhangabaú, do Largo São Bento e do Viaduto Santa Ifigênia, sem, contudo, alterar a configuração geral do espaço, que continua degradado.

O processo de revitalização das áreas urbanas degradadas tem ocorrido em diversas metrópoles, como Londres, Nova York, Barcelona e Buenos Aires. Em muitos desses lugares ocorreu um processo denominado gentrificação, que consiste na expulsão de antigos ocupantes, normalmente de classes pauperizadas, em função da valorização imobiliária provocada pelo "enobrecimento" do espaço urbano.

A região que se convencionou denominar centro é composta pelos distritos da Sé e da República e caracteriza-se, sobretudo, por pela baixa densidade demográfica. Isto é agravado ao se considerar que a população vem sofrendo redução: em 1980, eram 93.964 habitantes e, em 1999, eram 60.263 (IBGE, http://www.vivaocentro.org.br/bancodados/centrosp/estatisticas.htm; www.sead.org.br, dados de 2006). Os habitantes dessa região com renda acima de dez salários mínimos ${ }^{51}$ constituem $19,65 \%{ }^{52}$, percentual abaixo da média da cidade (com $23 \%$ da população nessa faixa de rendimento), e bem abaixo dos distritos nobres da cidade (Moema, Jardim Paulista, Alto de Pinheiros, Morumbi, Itaim Bibi,

\footnotetext{
${ }^{50} \mathrm{O}$ processo de dotar o centro da cidade de maior dinamismo ganhou força com a constituição da Associação Viva o Centro, fundada em 1991, sob a coordenação de Henrique Meirelles, na época, presidente do Banco de Boston, que também instalara sua sede no local.

51 Dados da Fundação SEADE, relativos ao ano de 2000, referem-se a pessoas responsáveis pelos domicílios particulares permanentes. (www.seade.gov.br, consultado em 27/08/2007)

${ }^{52} \mathrm{O}$ distrito República é limítrofe de bairros nobres da cidade como o de Higienópolis.
} 
Pinheiros e Perdizes), onde os habitantes com essa faixa de rendimento estão em torno de $67 \%$.

Em termos de violência urbana, os indicadores da região central também são desfavoráveis: a taxa de homicídios é de 51 por 100 mil habitantes, enquanto a média da cidade é de 24 por 100 mil habitantes e os bairros nobres citados acima apresentam a taxa de 9 por 100 mil habitantes ${ }^{53}$.

A região central possui número razoável de teatros, concentrados no distrito da República. Recentemente, em torno da Praça Roosevelt, foram inaugurados seis espaços de arte, a maior parte sedes de grupos teatrais. O distrito da Sé tem um número razoável de museus ${ }^{54}$, os quais, entretanto, não são os mais expressivos em termos de programação e atratividade de público da cidade. Os teatros existentes na Sé, além do CCBB, são o Teatro Municipal e o do Centro Cultural da Caixa, cuja atuação ainda é incipiente.

O CCBB está situado em região de "calçadão" para ser utilizado exclusivamente por pedestres. Recentemente, a Prefeitura de São Paulo permitiu o trânsito de veículos na região, mas não é permitido estacionar e não existem estacionamentos muito próximos com horários estendidos de funcionamento. Apesar de o site do BB enfatizar a facilidade de acesso ao CCBB, uma vez que "além das várias linhas de ônibus que passam pelo local, o prédio fica próximo das estações de metrô Sé e São Bento", há que se considerar que a maior parte do público (Anexo $13)^{55}$ que o freqüenta, normalmente, em seus momentos de consumo cultural, se locomove em seus próprios veículos. Além disso, a região fica bastante deserta no período noturno e os índices de criminalidade verificados também inibem consideravelmente a presença de público. Tudo isso coloca o CCBB em posição de fragilidade relativamente a outros equipamentos culturais da região central, como a Sala São Paulo, a Pinacoteca do Estado e o Teatro Municipal, todos com opções de estacionamento. Se, na década de 50, "[...] a cidade era imensa, mas o centro, onde a vida mundana se desenrolava, era um quadrilátero reduzido, onde todos os lugares poderiam ser alcançados a pé", para uma boêmia intelectualizada que fazia

53 Fonte: Fundação Seade. "Crimes contra a pessoa por distrito". Dados de 2005. Disponível em www.seade.gov.br, consultado em 10/03/2007.

${ }^{54}$ Os seguintes museus localizam-se no distrito da Sé: Museu da Cidade de São Paulo/Solar da Marquesa, Museu da Faculdade de Direito da USP, Museu do Tribunal de Justiça e o Museu Banespa.

55 Os dados referentes ao perfil do público que visita o CCBB são coletados, ao que parece sem uma metodologia muito rigorosa, mas nos possibilita uma percepção da caracterização desse freqüentador. Tratase, preponderantemente, de público pertencente às camadas com maior renda e maior escolaridade. 
dos bares do centro da cidade espaço de sociabilidade (Arruda, 2001:64), hoje, andar à noite no centro é prática quase exclusiva daqueles que fazem da rua a sua morada, desprovidos que são de melhores opções habitacionais.

Vieira (2004) estabelece uma diferenciação existente entre o que a Associação Viva o Centro e os órgãos públicos - na gestão de Marta Suplicy -, vislumbravam como projetos de mudança para a região central. A primeira, falava em requalificação urbana, o que consiste em apropriação cultural do espaço do Centro, mediante

usos ligados ao consumo cultural do lugar (o centro, patrimônio de toda a cidade). Tal consumo está estruturado pela oferta de uma série de equipamentos culturais, instalados em edifícios ligados ao patrimônio da cidade, geralmente tombados pelas instâncias do patrimônio histórico nacional (o que permite custear as reformas através de leis culturais de incentivo, sobretudo federais, como a lei Rouanet), os quais são reformados para abrigar usos ligados à fruição da história e da cultura da cidade ou ao de consumo de lugares, na medida em que encarnam cultura e história. O centro de São Paulo que nasce daí é o centro da cidade estruturado para promover esse consumo de seus lugares de patrimônio, o que pressupõe a presença de certos grupos que detenham capital (também simbólico) para isso. (Vieira, 2004: 98)

Já o discurso do poder público municipal falava em reconstrução urbana no sentido de garantir o direito à cidade àqueles que fazem uso cotidiano dela, ou seja, pelas chamadas classes populares, que fazem também um certo uso do centro considerado ilegítimo (comércio ambulante, invasão de prédios abandonados para fins de moradia). Tal discurso difundia a idéia de que o direito à moradia e ao trabalho garantiria a esses cidadãos ao menos a interlocução com as autoridades estabelecidas. (Vieira, 2004: 99-100) Dessa forma, as práticas culturais preservadas referiam-se não só ao patrimônio histórico, mas também às manifestações culturais populares, entendidas aqui no sentido antropológico do termo, tais como as tendas de adivinhos e artistas de ruas.

Pesquisa realizada pelo CCBB demonstra que somente $16 \%$ dos freqüentadores da instituição habitam a região central da cidade, sendo que a maior parte dos usuários provém da região Sul (33\%). Isso mobiliza algumas ações do CCBB no sentido de atrair a população do entorno, que vão desde a colocação de mesas de sua cafeteria no calçadão, até a instalação de obras de arte no espaço externo, como o que ocorreu com a mostra Cubo, no aniversário de cinco anos do 
Centro Cultural. No entanto, tem sido muito reduzido o efeito dessas ações para o aumento do diálogo do CCBB com os seus vizinhos, provavelmente devido à pouca atratividade que a programação desperta nessas pessoas, que não dispõem de capital cultural suficiente para usufruí-las. O próprio caráter monumental e altamente sofisticado do edifício é fator de forte inibição para ingresso, no prédio, de grande parte dos "habitantes do centro", ainda que a programação pudesse ser atraente a eles. O CCBB, de certa forma, portanto, amedronta o centro.

Em contrapartida, aqueles que poderiam ser atraídos por sua programação e atividades do CCBB têm dificuldade para inseri-lo em seus hábitos de lazer e consumo cultural, em função do medo provocado pelo centro, do temor da violência, do predominante aspecto desértico da região no período noturno e nos finais de semana. Dão eles preferência a outros locais, em função da comodidade e da segurança que estacionamentos proporcionam - de maneira cada vez mais insuficiente - quando comparados às ruas centrais da cidade. Desta forma, o centro amedronta o público em potencial do CCBB.

\subsection{Centros Culturais e Afins}

\subsubsection{Implicações do modelo "Centro Cultural”"}

A noção de Centro Cultural caracteriza-se pela conjunção, num único lugar, de áreas artísticas diversas: teatro, artes plásticas, dança, cinema, música, fotografia. O que diferencia os Centros Culturais de instituições correlatas, como museus, bibliotecas, cinemas, teatros ou galerias de arte é, portanto, sua multifuncionalidade.

Sua origem remonta ao ano de 1959, quando o governo francês criou as Maison des Arts et de la Culture ${ }^{56}$, cuja missão era "[...] tornar acessíveis as obras capitais da humanidade, e em primeiro lugar da França, ao maior número possível de franceses; assegurar a mais vasta audiência para o patrimônio cultural; favorecer a criação das obras de arte e do espírito que o enriqueçam" (Coelho, 1986).

\footnotetext{
${ }^{56}$ Segundo Silva (1995:16), os centros de cultura franceses "foram criados mais como uma opção de lazer, do que voltados para estimular a reflexão e o espírito críticos". Tendo como referência, o trabalho de Dumazedier (2004), a origem dos centros culturais na França teria como força impulsionadora a tentativa de criar mais uma opção de lazer para os operários franceses.
} 
Percebe-se, nessa missão, a idéia da arte como bem escasso e restrito a um público seleto, cabendo à instituição cultural a tarefa de disseminação e ampliação da audiência. Essa proposição para os Centros Culturais apresentava uma contradição que, de alguma forma, persiste até hoje. Por um lado, concebe-se a arte como um produto coletivo ("obras capitais da humanidade" e "patrimônio cultural"), isto é, algo que foi constituído ao longo de gerações por indivíduos ou grupos de artistas e, graças à sua representatividade e genialidade, se apresenta como um objeto cultural que deve ser preservado, já que não diz respeito somente a quem o produziu, mas a toda uma coletividade. Por outro lado, pressupõe o caráter restrito de seu uso, daí a necessidade de garantir sua "acessibilidade" ao "maior número possível" de pessoas e a uma "vasta audiência". A definição do que compõe esse patrimônio digno de preservação é fruto de uma concepção de arte proveniente do discurso competente das academias de arte, museus, curadores, marchands, críticos, enfim, de uma elite que normalmente dialoga com seus pares, coloca-se a missão de ampliar e envolver as camadas sociais consideradas excluídas do usufruto desse bem coletivo, mas pouco realizam nesse sentido.

A noção de Centro Cultural traz em si, essencialmente, um duplo objetivo: o fomento da criação artística e o incentivo ao uso ou ao consumo das obras produzidas. Instituições essencialmente urbanas e contemporâneas, permitem o encontro do público com a obra artística, podendo ser vistos também como espaços de lazer, ou locais de convivência, de intercâmbio ou de encontro. A reunião em um único lugar de diversas atividades que tradicionalmente se realizam em locais públicos distintos nem sempre se configura tentativa de romper as barreiras entre as modalidades artísticas, mediante projetos que inter-relacionam teatro com artes plásticas ou cinema e música, por exemplo. A segmentação ainda é muito forte nos Centros Culturais, não havendo, normalmente, um eixo curatorial que integre as artes. Na programação dos CCBBs, como veremos, em muitos momentos, há preocupação de interligação entre as diversas manifestações, embora essa não seja a tônica preponderante. A análise dos projetos é efetuada por funcionários especializados em determinada área artística, sem que haja muita preocupação em articulação das diversas áreas em eventos conjuntos.

O modelo da instituição artística estruturada como Centro Cultural já estava relativamente consagrado quando da criação do CCBB. A própria cidade de São Paulo já tinha seu Centro Cultural, vinculado à prefeitura e havia diversos modelos 
internacionais. O Centre National D'Art et de Culture Georges Pompidou, por exemplo, foi inaugurado no coração de Paris, em 1977, ocupando um prédio com uma arquitetura que se tornou emblemática no final do século XX. Ao contrário do CCBB, o Georges Pompidou possui acervo próprio, que constitui uma das mais importantes coleções de arte do século XX, além de cinema, restaurante, biblioteca, um instituto de pesquisas musicais, livraria, entre outros. Baudrillard (1991) critica a criação do Beaubourg, considerando-o um monumento aos jogos de simulação de massa, em que o modelo é o de fusão cultural e dissuasão política. É considerado um hipermercado da cultura, onde se concretiza a hiper-realidade da mercadoria. Em sua perspectiva, "as massas são a catástrofe do Beaubourg".

Em 1982, Londres também inaugurou o seu Centro Cultural: o Barbican Centre. Vinculado à Prefeitura de Londres, é o terceiro maior patrocinador de cultura na Grã-Bretanha (http://www.barbican.org.uk/about-barbican).

Nos EUA, o modelo mais próximo ao dos Centros Culturais é o Lincoln Center for the Perfoming Arts, localizado em Nova lorque. Engloba doze organizações culturais na área de artes performáticas (orquestra sinfônica, ópera, teatro, música de câmara, cinema e dança), além de um instituto voltado para o ensino de artes. Diferencia-se dos demais por não englobar artes plásticas, um dos principais modos artísticos das duas outras instituições citadas. A idéia de reunir em um único local diversas modalidades artísticas revela a intenção de abranger público maior em quantidade e mais diversificado em termos de interesses.

Os Centros Culturais se configuram, mais do que museus ou salas de cinema, como espaços de lazer, em que a presença do público independe, muitas vezes, de motivação para ver uma atividade específica, podendo configurar-se, inclusive, como alternativa para a ida ao shopping center, ao parque temático ou a algum centro de ciência.

No Brasil, os funcionários do CCBB ressentem-se e lamentam freqüentemente o espaço físico reduzido de que dispõem, mas certamente ninguém imagina transformá-lo em um espaço exclusivo de exposição ou em um local com diversas salas de cinema. Preferem, portanto, manter diversos espaços pequenos a um de proporções maiores.

Iremos analisar a seguir alguns modelos de Centro Cultural existentes na cidade, com perfis bem distintos: um centro cultural público, um centro cultural 
subsidiado por empresas, mas com elevada autonomia, e um centro cultural vinculado a banco.

\subsubsection{Um modelo público de centro cultural}

Inaugurado, em 1982, o Centro Cultural São Paulo (CCSP) foi o primeiro da cidade, declaradamente inspirado no parisiense Centro Nacional de Arte e de Cultura Georges Pompidou. Possui programação diversificada, oferecendo teatro, dança, espetáculos de música, cinema, vídeo, biblioteca, discoteca, oficinas e cursos. Ocupa área de $46.500 \mathrm{~m}^{2}$ e está localizado em região de fácil acesso. Vinculado à Prefeitura da cidade, oferece entradas gratuitas ou a preços reduzidos. Em 2003, recebeu 650 mil usuários (http://www.centrocultural.sp.gov.br/ccsp_oquee.asp). Ao contrário do CCBB, cuja fachada austera pode ser fator inibidor do público, a arquitetura do CCSP - sem barreiras, jardim de $700 \mathrm{~m}^{2}$, além de diversos ambientes vazados e envidraçados estabelece conexão direta com a rua, tornando o acesso totalmente franqueado. Possui orçamento cujo montante, em 2007, foi de $R \$ 8,4$ milhões (http://sempla.prefeitura.sp.gov.br/orc orc 2007.php), incluindo material de consumo, obrigações tributárias, equipamentos, entre outros.

$\mathrm{Na}$ área de artes cênicas e plásticas, via de regra o apoio consiste na cessão do espaço, sem nenhum custo para os artistas. No caso do teatro, a remuneração normalmente se resume à bilheteria, bastante reduzida, em função dos ingressos populares.

A programação de teatro é bastante diversificada. Possui duas salas, uma das quais com capacidade bem superior ao do CCBB, 324 lugares, além de, em algumas peças, utilizar também o porão. Alterna os dias de apresentação das peças, sendo que algumas se apresentam no final e outras durante a semana. Normalmente, são produções de orçamentos limitados e, muitas, de artistas em fase inicial da carreira. Ao contrário do CCBB, raramente suas peças reúnem artistas consagrados. Consegue, contudo, atrair público considerável, marcadamente o mais jovem, haja vista sua política de ingressos populares. 
No que se refere às artes plásticas, suas exposições têm menos repercussão do que as realizadas pelo CCBB. Normalmente, privilegia jovens artistas em início de carreira. Mantém processo público de seleção de artistas, que se realiza por meio de edital ${ }^{57}$. Para a programação em artes plásticas de 2008, estava previsto cachê de $R \$ 1.500,00$ para o artista, além de quatro prêmios de $R \$ 3.900,00$.

Apesar dos recursos reduzidos, o CCSP assume certo "papel democrático", ao estabelecer como diretriz o privilégio do

debate sobre a produção artística contemporânea, propondo um mapeamento da jovem produção artística, com o objetivo de abrir espaço a artistas em início de carreira para a inserção no circuito de artes plásticas e possibilitar 0 acesso do público a obras representativas das principais linhas artísticas contemporâneas. (http://www.centrocultural.sp.gov.br)

O edital de seleção é bastante vago no que se refere aos critérios a serem utilizados na escolha dos projetos, que se dá a partir da análise do curriculum vitae do candidato, da análise de documentação fotográfica de obras recentes do artista e de eventuais publicações sobre exposições anteriores ou catálogos.

A biblioteca é uma das âncoras de atividades culturais do CCSP, e se configura como espaço de convivência, notadamente para jovens estudantes, que constituem a maior parcela de seu público (Oliveira, 1995). Assim como no Beaubourg, essa biblioteca tem características de espaço acadêmico, sendo livre o acesso às obras, sem que seja necessário recorrer à intermediação de qualquer funcionário.

Durante a gestão de Marilena Chauí na Secretaria Municipal de Cultura (1989-1992), o CCSP teve atuação destacada na área teatral, tendo realizado montagens com diretores renomados como Gabriel Vilela, José Celso Martinez Correa, Marcio Aurélio, Ulisses Cruz e Bia Lessa.

Vítima das vicissitudes dos órgãos públicos brasileiros, o CCSP sofre com problemas de falta de verbas e estrutura para realização de suas atividades. Sua inauguração, inúmeras vezes adiada, efetuou-se de forma precipitada, por interesses eleitorais. Diversas vezes, suas salas tiveram de ser interditadas pela ocorrência de vazamentos, goteiras e outros problemas estruturais. Em suma, tem papel acanhado diante do seu potencial e do porte da cidade, apesar de cumprir

57 Fonte: Centro Cultural São Paulo. "Programa de Exposições 2008 CCSP”. Disponível em 
função social importante nas artes, dando espaço a jovens artistas em início de carreira, sem recursos ou notoriedade para ter seus trabalhos divulgados em outros espaços, inclusive no CCBB.

\subsubsection{Um modelo original de patrocínio empresarial compulsório}

É inegável a preponderância e o peso do Serviço Social do Comércio (SESC) no cenário teatral paulistano. Com grande quantidade de teatros bem equipados, com ampla capacidade de público e localizados em diversos pontos da cidade, além de contar com recursos abundantes, o SESC consolidou-se como instituição com forte presença entre os consumidores culturais.

O SESC foi criado, em 1946, pelo Decreto-Lei número 9.853

com a finalidade de planejar e executar medidas que contribuam para o bem-estar e melhoria do padrão de vida dos empregados no comércio e serviços e seus familiares e, bem assim, para 0 aperfeiçoamento moral e cívico da coletividade.

É uma instituição de caráter privado, sem fins lucrativos e de âmbito nacional.

Sua missão permanente é a de inserir e integrar pessoas e grupos de diferentes idades e estratos sociais ao universo cultural, entendido de forma ampla, isto é, relacionado às expressões da arte, expressão corporal e esportiva, turismo, educação ambiental e outras.(http://www.sescsp.org.br/sesc/sos/index.cfm? forget=14\&inslog=16, consultado em 24/11/07).

Inicialmente voltado mais para a assistência médica e odontológica, o SESC passou a promover atividades recreativas e esportivas e, mais recentemente, atividades culturais.

Os números do SESC são grandiosos e colocam o CCBB em posição de razoável inferioridade. Está presente em todo país e possui trinta e uma unidades somente no Estado de São Paulo. O seu orçamento anual é em torno de $\mathrm{R} \$ 400$ milhões. Possui 27 espaços para apresentações, incluindo teatros e auditórios. Em 2007, foram realizados em seus espaços 5.333 espetáculos teatrais e 640 exposições. 
Em 1982, foi criado o Centro de Pesquisa Teatral, na unidade do Sesc Consolação (unidade que abriga o Teatro Anchieta, palco de inúmeras montagens célebres do teatro paulistano), o qual, sob a coordenação de Antunes Filho, realiza encenações destacadas no meio cultural. No final da década de 80 , obteve grande destaque a transformação, por Lina Bo Bardi, de uma antiga fábrica no bairro da Pompéia, em um dos mais importantes centros culturais naquele momento (Cenni, 1991).

Como o CCSP e o CCBB, o SESC mantém política de ingressos a preços populares. No entanto, seus serviços e instalações são de qualidade bem superior às do CCSP. Instalações grandiosas, grande número de funcionários, atendimento informatizado, empregados capacitados são características de suas unidades. Possui 14 unidades espalhadas na capital, além do Cinesesc, atingindo também localidades onde predomina a população de baixa renda, como Itaquera e Interlagos.

O SESC São Paulo também possui um canal de televisão e um corpo de 3.500 funcionários, que atendem 1,2 milhão de associados, e a população em geral. Fomenta a cultura nacional pelo patrocínio de atividades artísticas e também propicia a vinda de artistas e intelectuais estrangeiros para o Brasil. Produtores do porte de Kazuo Ohno, Cesárea Évora, Trisha Brown, a Companhia de Dança Angelin Prejolcaj, Jerzy Grotowski, Massimo Canevacci, La Fura Dels Baus, Vanessa Redgrave (SESC,1997:121) e, mais recentemente, o Thêátre du Soleil vieram ao Brasil graças ao patrocínio do SESC. Este também é um ponto no qual o CCBB não se destaca, muito embora haja algum intercâmbio internacional nas mostras de artes plásticas, cinema e, eventualmente, na música e na dança.

A programação do SESC São Paulo é bastante diversificada, até em função do grande número de eventos que acolhe. Mantém, contudo, a preocupação de apresentar espetáculos que experimentam novas linguagens, na área de teatro, da música ou das artes plásticas. O SESC Belenzinho, onde hoje se localiza a sede administrativa da organização, notabilizou-se nos anos 90 pela radicalidade de suas propostas teatrais ${ }^{58}$. Possuía diversos espaços que apresentavam amplas

\footnotetext{
58 Só para citar algumas produções, podemos listar Woyzeck, com Matheus Nachtergaele; A Paixão Segundo G.H., monólogo dirigido por Enrique Diaz, a partir de livro homônimo de Clarice Lispector interpretado por Mariana Lima; Bispo, elogiado trabalho do ator baiano João Miguel; e A Poltrona Escura, com Cacá Carvalho.
} 
possibilidades de estruturação física, o que facilitava a experimentação artística. Esse caráter de busca da inovação está explícito em documentos da organização:

É necessário que os objetos assim reconhecidos pelo SESC sejam aqueles capazes de enriquecer intelectualmente os indivíduos, leválos a desenvolver uma percepção mais acurada, propiciar-lhes uma nova compreensão das relações sociais, uma releitura de seu estarno-mundo, permitir-Ihes transcender suas condições de origem e formação, dotando-os, por conseguinte, de uma consciência mais universal. Em outras palavras, significa privilegiar produtos artísticoculturais que contribuam para construir um novo olhar-o-mundo, e que se instrumentalizam em uma ação transformadora dos indivíduos e da sociedade, excluindo-se, portanto, da ação programática da Entidade, aqueles produtos culturais que tendem à sua reificação, por se formarem a partir de conteúdos e formas reiterativas de padrões culturais já gravados na memória de seus receptores. [...] Nesse sentido, a definição da programação no campo da cultura deverá considerar que a sua realização, além de responder às necessidades imediatas dos consumidores culturais, deverá provocar uma alteração na qualidade do agir e pensar dos mesmos, dotandoos de uma compreensão mais adequada do significado dos produtos artístico-culturais e permitindo assim que o gostar ou não gostar seja conseqüência de um efetivo compreender (SESC, 2004).

Essa opção de política cultural não se dissocia da preocupação com o lazer, digamos, mais inconseqüente, como é afirmado em outra parte do mesmo documento:

O SESC também procura atender às necessidades de lazer cultural de sua clientela e da população em geral, sensível para o fato de que, além do pensamento e da reflexão, as necessidades de integração social, liberação de emoções, entretenimento e diversão são fundamentais para o desenvolvimento do ser humano. Assim, o SESC procura respeitar o desejo de simples divertimento, mas sem que isso seja apenas a ocupação de tempo livre com prática consumista, reiterativa e evasiva. Ao contrário, o usufruir do lazer cultural contribui também, para uma alteração na qualidade do agir e pensar, enriquecendo e tornando mais complexos os níveis de exigência. (SESC, 2004)

Para muitos, o SESC acaba sendo modelo de eficiência na gestão da cultura, servindo de base para argumentações em prol da privatização dos serviços da área artística:

Caso essa verba fosse destinada ao ministério ou a uma secretaria de cultura, o impacto seria equivalente? Os funcionários trabalhariam com o mesmo empenho e atenderiam o público com a mesma 
cortesia? As instalações seriam cuidadas com tanto esmero? Ou parte substancial dos recursos seria malbaratada nos meandros da burocracia, desperdiçada em ações fúteis, desviada ou imobilizada por interferências de políticos e seus apaniguados? Que o modelo colocado em prática pelo Sesc sirva de exemplo para outras instituições interessadas em retribuir à sociedade uma fração do bem que usufruem ${ }^{59}$.

Algumas ponderações precisam ser efetuadas com relação a tal posicionamento recorrente, para termos visão mais completa do que o "modelo SESC", sui generis no panorama internacional, constitui para o universo cultural brasileiro. A primeira, relaciona-se ao fato de que essa instituição só existe em função de ação do Estado. Criado em 1946, por decreto-lei federal, tem caráter claramente assistencialista e apaziguador dos conflitos sociais, como diz o próprio texto do decreto:

- Serviço Social, do Comércio muito poderá contribuir para o fortalecimento da solidariedade entre as classes, o bem estar da coletividade comerciária e, bem assim, para a defesa dos valores espirituais que se fundam as tradições da nossa civilização. (http://www6.senado.gov.br/legislacao/ListaTextolntegral.action?id=7 $\underline{8724)}$

Além de não ter sido iniciativa exclusiva do empresariado, trata-se de remuneração compulsória, de $2 \%$ sobre o valor total da folha de pagamento, que é recolhido ao INSS juntamente com as demais contribuições previdenciárias, e depois redirecionado pelo Governo Federal. Caso os empregadores não façam tal recolhimento, serão incluídos no CADIN - Cadastro de Devedores da União, o que comprometerá sua imagem no sistema financeiro e criará obstáculos para obtenção de financiamentos e empréstimos. Assim, não se trata propriamente de uma "retribuição" voluntária dos empresários à sociedade. Caso os empresários não fossem obrigados a contribuir, certamente o SESC não teria os recursos de que dispõe.

A valorização da programação do SESC pelos demais membros do campo artístico pode ser atestada pelo recebimento do Prêmio Bravo! Prime de Cultura em 2007, cuja justificativa recebeu a seguinte redação:

\footnotetext{
${ }^{59}$ Dráuzio Varella. Tributo ao SESC. Folha de S. Paulo, São Paulo, 29/09/2007, Ilustrada, E15.
} 
Com várias unidades espalhadas pela cidade, o SESC se destaca por possuir uma programação intensa e diversificada, estimulando 0 intercâmbio dos produtores e oferecendo cultura de qualidade e preços acessíveis.

(http://bravonline.abril.com.br/premiobravo/retrospectiva.shtml, consultado em 21/09/08).

\subsubsection{Um outro modelo de Centro Cultural de banco}

Das instituições culturais paulistanas, o Itaú Cultural possui dois pontos importantes de convergência com o CCBB. O primeiro é ter um banco como patrocinador e o segundo a diversificação dos projetos que patrocina. Possui localização mais privilegiada. Por estar na Avenida Paulista, tem acesso facilitado seja por transporte coletivo, seja por veículos privados, além de atender a população que habita ou trabalha na redondeza, de maior poder aquisitivo e com mais familiaridade com a produção artística apoiada.

A área de artes plásticas mantém a mesma regularidade que as exposições do CCBB, com alternância das mostras e mantendo continuidade de eventos ao longo do ano. No caso das artes cênicas, ao contrário do CCBB, e apesar de o teatro possuir platéia maior, não mantém programação regular. Só muito raramente sedia espetáculos teatrais. Vem mantendo o programa "Próximo Ato", que consiste de encontros promovidos com teóricos, professores e, recentemente, também com grupos teatrais.

As exposições destacam-se pelo uso de tecnologia, atributo por meio do qual - Banco patrocinador também procura diferenciar-se dos concorrentes. Seus comerciais publicitários associam sua logomarca ao símbolo da arroba (“@”), amplamente utilizada na comunicação eletrônica. Assim, a exposição Emoção Art.ficial teve cinco edições, contemplando trabalhos que propõem a linguagem eletrônica como forma de criação artística.

Iniciou suas atividades em 1989, com grande ênfase na documentação. Busca-se o mapeamento da produção artística, mediante pesquisas de grande abrangência, o que resulta em publicações, dicionários e catálogos eletrônicos que se tornam referências nas áreas abordadas. Em seu site está definido que se trata de "[...] um instituto voltado para a pesquisa e a produção de conteúdo e para o 
mapeamento, o incentivo e a difusão de manifestações artísticointelectuais"(http://www.itaucultural.org.br/index.cfm?cd_pagina=2676, consultado em 07/10/07).

Um dos objetivos centrais das atividades desenvolvidas no Itaú Cultural é a geração de conhecimentos sobre as artes brasileiras. Dessa forma, além de incentivar a produção cultural, demonstra forte preocupação com a pesquisa e com a catalogação, o que resultou em grande número de publicações (366), em seus primeiros 20 anos de existência. A sistematização do conhecimento produzido normalmente utiliza as novas tecnologias de comunicação, como as enciclopédias nas áreas de artes visuais, teatro, arte e tecnologia e super 8. No CCBB, em contrapartida, a produção de conhecimentos atinge temáticas as mais diversas, não se restringindo ao universo artístico, através de ações culturais dentro da área denominada "Idéias".

A política de fomento do Itaú Cultural, consolidada em programas denominados Rumos, privilegia a produção artística nacional e, apesar de ter instalações somente em São Paulo, tem ampla rede de instituições parceiras em diversas cidades, o que lhe assegura a presença em muitas outras cidades. Outra diferença em relação ao CCBB a realçar é sua iniciativa de organizar cursos, workshops, seminários, colóquios e fóruns, o que amplia a ação educativa da instituição, que não se limita - como ocorre no CCBB - àquela que focaliza as exposições de artes plásticas em cartaz e as palestras da área de "Idéias".

Assim como no CCBB, a diversidade parece ser também ali a palavra-chave. O primeiro objetivo enunciado por Olavo Setúbal, idealizador e fundador do Instituto, foi o de valorizar a diversidade das experiências culturais. Essa diversidade, contudo, tem limitações. O seu Código de Conduta estabelece como os compromissos maiores da instituição: "[...] traçar a linha de demarcação entre o que é ou não adequado promover em termos de manifestações artísticas, ao avaliar com prudência o risco que a imagem do Itaú Cultural pode vir a sofrer." (www.itaucultural.org.br)

Ao contrário do CCBB, que cobra pela entrada em alguns eventos, no Itaú Cultural, todas as atividades são gratuitas. Em 2006, o público que esteve na sede da instituição atingiu o número de 60.302 visitantes. Nesse ano, foram despendidos, $\mathrm{R} \$ 28$ milhões ( $\mathrm{R} \$ 21$ milhões incentivados pela Lei Rouanet) nas atividades que patrocinou, as quais abarcaram eventos em todo o país. Sua equipe é 8 vezes maior 
do que a do CCBB, o que denota maior autonomia em relação à instituição mantenedora.

Sua atuação teve início com um grande acervo de obras de arte (Itaú Cultural, 1998), muitas vezes expostos nas agências bancárias, denominadas Itaugalerias. Esse acervo constitui hoje uma das maiores coleções institucionais do país, voltado essencialmente para a arte brasileira, notadamente a moderna e a contemporânea.

Da mesma forma que o CCBB Rio, o Itaú Cultural possui acervo numismático. Ele inovou ao oferecer ao público imagens digitalizadas de obras de arte em sua inauguração, numa época em que esse grau de informatização praticamente inexistia em outras instituições brasileiras.

Ao contrário do CCBB, em que a maior parte dos projetos patrocinados é concebida por artistas que os submetem a processo de seleção e também ao Ministério da Cultura (Minc) para viabilizar o uso do incentivo fiscal, no Itaú Cultural, é o próprio Instituto que submete sua programação ao Minc, o qual lhe autoriza a dedução fiscal. Isso dá um caráter mais autoral para a instituição.

Considerando que este estudo tem como um de seus objetos de análise a produção de artes cênicas em São Paulo, o próximo item discorrerá sobre o tema.

\subsection{Considerações SOBRE O CAMPO dAS ARTES CÊNICAS EM SÃo PAULO}

Em 20 de setembro de 2008, o guia semanal de um dos principais jornais da cidade contabilizava 87 peças em cartaz em São Paulo ${ }^{60}$. Se levarmos em conta a baixa preferência pelo teatro entre as opções culturais do paulistano, conforme apontam as pesquisas anteriormente citadas, associada a essa oferta, -- que não é muita, considerando o tamanho da população paulistana, mas é considerável, dado o público que a consome -, constataremos que a competição por esse público, consagração, espaços de divulgação e patrocínio é bastante grande.

Além dos teatros do SESC, dos teatros do CCSP e dos demais teatros distritais da prefeitura citados anteriormente, a cidade possui também vasta gama de salas privadas. Pode-se subdividi-las, em dois grandes grupos - utilizando-se do

60 "Buenos Aires, cidade com população bastante menor, possuía 265 peças em cartaz no mesmo dia (Neves, Lucas. "Portenhos em cena". In Folha de S. Paulo, São Paulo, 22/09/08, Ilustrada, E1). 
mesmo aparato conceitual a ser mais bem detalhado no quinto capítulo -, teatros comerciais e teatros alternativos.

Teatros renomados, dentre os quais pode-se citar: Renaissance, Maria Della Costa, Ruth Escobar, Teatro Abril, Teatro Folha, Teatro Shopping Frei Caneca, Crowne Plaza, Teatro Gazeta, Teatro Vivo e o Cultura Artística, destruído há poucos meses por um incêndio, possuem programação com predominância de espetáculos comerciais. Os mesmos recebem, em alguns casos, artistas conhecidos do grande público, muitos dos quais com atuações em redes de televisão. Em outros casos, apresentam fórmulas que se mostram bem aceitas pela audiência de maior poder aquisitivo, mas com pouco capital cultural, como é o caso das comédias de costumes ou os musicais.

Em contraposição, as salas do CCSP, alguns teatros do SESC, o Viga Espaço Cênico, e os espaços de grupos teatrais (a exemplo do Espaço Parlapatões, as salas do Teatro Fábrica, o Teatro Oficina, as salas do Espaço dos Satyros ${ }^{61}$, o Galpão do Folias, o Núcleo Bartolomeu de Depoimentos e o Teatro da Companhia do Feijão) abrigam peças consideradas "alternativas".

Os espaços utilizados pelo teatro experimental (alternativo) normalmente possuem maior mobilidade e polivalência, rompendo com o esquema rígido do palco italiano. Alguns grupos teatrais ocupam espaços públicos para suas apresentações não se limitando aos prédios destinados a esse fim. Dessa forma, é cada vez mais freqüente a utilização de espaços não-convencionais como fábricas, transportes coletivos, praças públicas, hospitais, igrejas, presídios, barcos, dentre outros.

É fato que a Lei de Fomento à Cultura da Prefeitura de São Paulo, cujos objetivos são: "apoiar a manutenção e criação de projetos de trabalho continuado de pesquisa, produção teatral visando ao desenvolvimento do teatro, e o melhor acesso da população ao mesmo" (www.prefeitura.sp.gov.br), possibilitou incremento considerável no número de espaços e espetáculos teatrais da cidade, com verba nunca inferior a $R \$ 6$ milhões/ano. São aprovados até trinta projetos por ano, sendo que o valor máximo por projeto é de $R \$ 400$ mil. Esse apoio governamental beneficia, sobretudo, grupos de teatro qualificados como alternativos e que apresentem trabalhos continuados, radicalmente diferenciado dos projetos patrocinados, por exemplo, pelo CCBB que contemplam arranjos de artistas

${ }^{61}$ O Espaço dos Satyros concorreu com o SESC e com o Museu da Língua Portuguesa para o prêmio Bravo! Prime de Melhor Instituição Cultural em 2007, do qual o SESC saiu vencedor. 
especificamente formados para tal evento, sem continuidade posterior. A Lei de Fomento $^{62}$ contribuiu bastante para que muitos grupos alternativos pudessem constituir seus espaços de ensaio e exibição. Alguns grupos se instalaram na praça Roosevelt (como o Satyros e o Parlapatões), o que permitiu um certo revigoramento da região.

Paulo Arantes vê no surgimento de coletivos teatrais na década de 90 um fenômeno de proporções maiores:

Ao lado da explosão do hip-hop, com o qual tem muito a ver malgrado as diferenças de escala e classe, não sou por certo o único a reconhecer no atual renascimento do teatro de grupo o fato cultural público mais significativo hoje em São Paulo. Fala-se em mais de 500 coletivos, por assim dizer, dando combate no front cultural que se abriu com a ofensiva privatizante. Não são só os números que impressionam, mas também a qualidade das encenações, cuja contundência surpreende, ainda mais quando associada a uma ocupação inédita de espaços os mais inesperados da cidade, gerando pelo menos o desenho de uma mistura social que ninguém planejou, simplesmente está acontecendo como efeito colateral das segregações e hierarquias que o novo estado do mundo vai multiplicando. [...] Um encontro de grupos teatrais independentes pode perfeitamente ser catalisado pelo departamento de responsabilidade cultural de um banco [referência ao programa Próximo Ato do Itaú Cultural, cujas últimas edições têm se dedicado a discutir as problemáticas que envolvem os coletivos de teatro], por exemplo. Ninguém estranha mais essa anomalia, contabilizada como um fato da vida. O desencontro que está nos ocupando é parte desse conjunto de incongruências. [...] A fábrica, fracionada pelas cadeias produtivas globais, saiu de cena, e com ela a consciência de classe de uma multidão de indivíduos entregues ao deus-dará de uma exploração para a qual ainda não se tem nome. A engrenagem infernal dessa ciranda da viração me parece estar na origem de uma resposta coletiva como o teatro de grupo, bem como na raiz do silêncio político da universidade. Pensando na deambulação perene desses novos condenados da terra, também me parece claro que o novo chão de fábrica seja o próprio território conflagrado da cidade, daí a relação orgânica do teatro de grupo com o espaço urbano,

62 A lei 13.279 de 08/01/02 instituiu o Programa Municipal de Fomento ao Teatro para a Cidade de São Paulo, "com o objetivo de apoiar a manutenção e criação de projetos de trabalho continuado pesquisa e produção teatral visando o desenvolvimento do teatro e o melhor acesso da população ao mesmo." A lei estabelece recurso mínimo anual para o Programa de $\mathrm{R} \$ 6$ milhões (mas, em 2007 e 2008 esses valores ultrapassaram $\mathrm{R} \$ 9$ milhões). Os projetos escolhidos por comissão julgadora composto por sete membros, sendo quatro, nomeados pela Secretaria Municipal de Cultura e três membros eleitos pelos próprios proponentes dos projetos a partir de lista elaborada por entidades representativas do meio teatral (leia-se Cooperativa Paulista de Teatro- CPT - , Associação dos Produtores Teatrais de São Paulo - APTESP - e Associação Paulista dos Críticos de Arte - APCA). Nas doze primeiras edições do Programa forma inscritos 1.218 núcleos e selecionados 182 projetos de 91 núcleos artísticos da cidade (www.decsp.org, consultado em23/09/08). 
vivido agora em regime de urgência. Por isso, uma outra cena de rua é novamente a célula geradora de um leque expressivo das poéticas que animam esse vasto front cultural, que vem a ser o teatro de grupo. $^{63}$

A importância social que o autor atribui à consolidação de uma forma coletivizada de fazer teatral é ainda mais digna de nota por caminhar na contramão das formas contemporâneas de organização do trabalho. Enquanto estas se configuram cada vez mais por formas provisórias, instáveis e superficiais (Sennet, 1999) que sempre marcaram o fazer artístico (Menger, 2002) - dando cada vez menor espaço ao trabalho estável e duradouro -, a disseminação dos coletivos teatrais na cidade é, sem dúvida, fato que revela algo novo no campo artístico. Trata-se de uma forma de resistência (apontando a correção da idéia de front utilizada por Paulo Arantes) da fração com menos capital econômico, que se tornou possível graças a uma articulação política acolhida pelo Governo Municipal, o qual propiciou o incentivo financeiro para que esses grupos pudessem se manter e produzir suas peças, alijados que são dos mecanismos de patrocínio empresarial.

O "teatro de grupo" é costumeiramente alijado do acesso ao patrocínio empresarial, por não reunir os atributos normalmente requeridos pelas empresas. Essa denominação "teatro de grupo" é também estratégia discursiva que visa a legitimar certo contingente de profissionais como merecedores de receberem subvenções públicas. Tal caracterização adquire tonalidades políticas nos movimentos Arte contra a Barbárie e Redemoinho, que reúnem grupos para reivindicar apoio dos governos e protestar contra as manipulações comerciais da arte.

Outra forma de manifestação artística, a dança ocupa espaço menor do que o teatro no campo artístico paulistano. Sua presença menor decorre ainda da quantidade menor de profissionais e grupos envolvidos com essa arte. Ao contrário do teatro, que não possui grupos governamentais estáveis, a dança conta com duas companhias mantidas pelo Estado: o Balé da Cidade de São Paulo (vinculado ao Teatro Municipal de São Paulo) e a recém-criada São Paulo Companhia de Dança ${ }^{64}$

\footnotetext{
${ }^{63}$ Arantes, Paulo. Entrevista a Beth Néspoli. "Paulo Arantes: um pensador na cena paulistana" O Estado de São Paulo, São Paulo, 16/07/07, Caderno 2, D3

${ }^{64}$ Apesar de vinculada à Secretaria de Estado da Cultura, a Companhia será gerida por uma Organização Social (OS), nos moldes do que ocorre com a Orquestra Sinfônica do Estado e com a Pinacoteca, sendo assim, seus funcionários serão contratados pelo regime da CLT e não serão funcionários públicos. A crítica de dança, Helena Katz, criticou a desproporcionalidade de recursos destinados à nova companhia, $R \$ 13$ milhões, em relação aos $R \$ 1,4$ milhão destinados às companhias já existentes (Helena Katz em "São Paulo ganha sua companhia oficial de dança”. In $O$ Estado de São Paulo, São Paulo, 28/01/08, Caderno 2, D5).
} 
(mantida pelo Estado de São Paulo). Entre as companhias não mantidas diretamente pelo Estado, o Ballet Stagium e o Grupo de Dança Cisne Negro são dois exemplos de companhias com maior longevidade, sendo que o primeiro foi fundado em 1971 e o segundo, em 1978.

Algumas mostras procuram dar conta da produção recente das companhias, como os programas Dança em Pauta do CCBB, o Rumos Dança do Itaú Cultural ou - Panorama Sesi de Dança. A destinação de verba orçamentária para o subsídio a grupos de dança, a partir de 2006, através de lei de fomento nos moldes da existente para o teatro, e a destinação do Teatro Itália para ser um teatro governamental específico para espetáculos de dança, têm apontado um cenário mais favorável a essa manifestação artística.

\subsection{ConsideraÇões SOBRE O CAMPo dAS ARTES PLÁsticAs EM SÃo PAULO}

A produção das artes plásticas possui um sistema de circulação de obras estruturado por diversos mediadores. As galerias e escritórios de artes (estes normalmente com acervos fechados ao público, voltados mais para colecionadores) têm papel preponderante nesse sistema, na medida em que os mediadores, representam dos artistas junto aos colecionadores e demais compradores, comercializam suas obras.

Fenômeno recente na cidade de São Paulo é a multiplicação das galerias ${ }^{65}$, o que indica o aquecimento do setor de venda de obras de arte. Além da venda, as galerias também "recebem e doam prestígio" aos artistas que representam ${ }^{66}$. Tratase então, de uma relação de reciprocidade, na qual a galeria valoriza o artista e é valorizada por ele. Dessa forma, das dezenas de galerias existentes, algumas estão em destaque na atualidade, tais como a Galeria Vermelho, a Fortes Villaça, a Galeria de Arte Rachel Arnaud, muito em função dos artistas que representam.

Os museus inserem-se nesse sistema, na distribuição de prestígio aos artistas que são convidados pelos curadores para compor as suas coleções. Ressalta-se

\footnotetext{
65 Dubra, Pedro Ivo. Entre Novas Paredes - Nem tão cubos, nem tão brancos. Folha de S. Paulo, São Paulo, 02 a 08/03/2007, Guia da Folha, 70-76. Margarido, Orlando. "Com que quadro eu vou?" Veja SP, São Paulo, 16/05/2007. Arte. 22-40. Marti, Silas. "Galerias de arte miram o mercado internacional". Folha de S. Paulo, São Paulo, 19/08/2007, Negócios, 2-3.

66 Para uma análise sobre o "mercado de arte", que envolve marchands, colecionadores, galeristas e leiloeiros veja Durand (1989), Moulin (1997) e Moulin (2007).
} 
também o papel decisivo que as bienais e feiras de arte possuem no campo das artes plásticas.

O circuito das artes plásticas envolve centros culturais e instituições com finalidades múltiplas (como, por exemplo, o SESC, o Itaú Cultural, dentre outros), museus, galerias e escritórios de arte. Os dois últimos têm caráter mercadológico explícito, pois são espaços nos quais obras são adquiridas, ao contrário dos primeiros, cuja função reside na circulação, exposição e consagração dos artistas.

Os museus diferenciam-se dos Centros Culturais e das demais instituições artísticas por possuírem acervo próprio. Todavia, as exposições temporárias, compostas por obras emprestadas de outras instituições, têm cada vez mais destaque na atratividade que exercem sobre o público.

As exposições temporárias normalmente contam com patrocinador específico, que se beneficia também do marketing de relacionamento proporcionado pela abertura da mostra. Os curadores e artistas normalmente transitam por essas instituições, esferas de projeção e consagração dos artistas, e seus currículos se engrandecem quando convidados para expor, ainda que em uma mostra coletiva.

Considerados apenas os museus, os centros culturais e demais instituições artísticas, a quantidade de competidores é bastante expressiva, e, de certa forma, o CCBB disputa com todos não só pelos artistas mais prestigiados, mas também pelo público e pela divulgação na mídia. Não serão abordados, nesse momento, todos esses concorrentes, senão os mais expressivos iniciando-se pelo mais renomado deles.

Museu-símbolo da cidade, cartão postal de destaque nacional e ponto de visita obrigatório dos turistas, o Museu de Arte de São Paulo Assis Chateaubriand ${ }^{67}$, MASP, tem sua trajetória intimamente relacionada com a tentativa de, dotar o país de um museu nos moldes de muitos já existentes na Europa e EUA embora tardiamente.

O museu se destaca, sobretudo, por seu acervo e pelas exposições temporárias que realiza. Uma das primeiras instituições brasileiras a abrir espaço

\footnotetext{
67 Inaugurado em 1947, por Assis Chateaubriand e Pietro Maria Bardi, ofereceu à cidade uma coleção de obras que, mesmo distanciada dos renomados museus europeus pelo número inferior de peças, mantém representatividade pela relevância do acervo. Sua atual sede, concebida por Lina Bo Bardi para a Avenida Paulista, tem como característica marcante o imenso vão livre no térreo. A estrutura do museu, inaugurado em 1968, é suportada por quatros pilares laterais. Mesmo sendo entidade cultural privada, sem fins lucrativos, o MASP recebe subsídios da prefeitura de São Paulo.
} 
para a arte moderna, faz atualmente exposições temporárias que alternam as produções de artes plásticas modernas e contemporâneas, sempre com artistas conhecidos e consagrados. As exposições temporárias normalmente são realizadas graças a patrocínios.

Atravessando grave crise financeira, decorrente principalmente de dívidas tributárias, o museu chegou a sofrer cortes de energia em razão da inadimplência. Seu público diminuiu consideravelmente nos últimos anos. Uma interpretação possível é a não ocorrência de exposições de magnitude, em virtude da carência de receitas para produzi-las.

$\mathrm{Na}$ década de 90, o MASP realizou exposições "blockbusters" com nomes consagrados da pintura, como Monet, na mostra Monet - O Mestre do Impressionismo, realizada em 1997, para comemorar seu cinqüentenário, contando com um público considerável em termos de Brasil, de 700.000 pessoas. Recentemente, em função da crise financeira, o Masp deixou de realizar as megaexposições internacionais, que outrora atraiu muito público.

O faturamento anual do museu, de aproximadamente $R \$ 6$ milhões, proveniente de patrocínios, bilheteria e subsídios da Prefeitura, parece não ser montante capaz de bancar exposições suficientemente atrativas ${ }^{68}$. Algumas de suas mostras se constituíram em tentativas de popularizar as exposições que mantém; como exemplos, mencionam-se Pelé: a arte do Rei, que frustrou as expectativas, atraindo apenas 60 mil visitantes, e a exposição sobre Darwin, realizada em 2007.

O MASP mantém esquema de patrocínio, diretamente vinculado às suas origens históricas, que se aproxima muito do mecenato tradicional, isto é, uma elite econômica "esclarecida", ávida por prestígio, doadora de obras para o acervo da instituição e diretamente vinculada ao empresariado, o qual sempre deu sustentação às exposições.

Os patronos do museu reúne grupo de pessoas provenientes da elite tradicional da cidade, que assistiu impotente ao processo de diminuição das contribuições, relacionada à mudança de interesse dos antigos patrocinadores. Estes, passaram a almejar retornos mais significativos, orientados por ações mais efetivadas em suas próprias instituições culturais.

\footnotetext{
${ }^{68}$ Difícil saber ao certo o número de visitantes do museu. A Revista Bravo! (maio de 2006) aponta média de 180 mil visitantes ao ano, enquanto carta de seu presidente a um jornal (Neves, Julio. Folha de São Paulo, São Paulo, 05/07/06, Opinião, A3), fala em um número médio de 258 mil visitantes (no período de 2001-2004) e de 364 mil pessoas em 2005.
} 
O MASP passou a significar uma modernidade provinciana, ultrapassada por formas mais sofisticadas de obtenção de prestígio por meio do fomento das artes. Concebido como museu privado, não conseguiu angariar sócios suficientemente benevolentes, contribuintes regulares e em número razoável, como costumam ser as fundações que amparam os museus norte-americanos. A crise do MASP ${ }^{69}$ parece decorrer essencialmente do fato de que agentes privados deixaram de ter lucros simbólicos com a instituição.

Se o MASP tem mostrado uma trajetória de declínio, a Pinacoteca do Estado tem caminhado no sentido oposto. Com um acervo de destaque da arte brasileira, do século XIX à arte contemporânea, a Pinacoteca ampliou seu público consideravelmente após a reforma realizada no período de 1993 a 1998. A partir de 1992, sob a direção de Emanuel Araújo, realizou exposições que atraíram multidões de pessoas às suas instalações, como as de Rodin - esta reuniu 150 mil pessoas - e a de Miró. Teve seus espaços expositivos ampliados com a criação da Estação Pinacoteca, no antigo prédio do Departamento de Ordem Política e Social (DOPS), e do Pavilhão das Artes. Instituição centenária, manteve-se à margem dos movimentos de renovação artística do século $\mathrm{XX}$, seguindo grande parte de sua história com a preocupação de formar acervo consistente de arte acadêmica, rumo diferente dos museus criados na capital paulista, na década de 40 (o MASP e o MAM).

A reforma do edifício gerou grande mudança na relação com o público, fazendo com que o museu se destacasse em relação aos demais, em razão da fragilidade e da ausência de recursos predominantes nos demais museus públicos da cidade.

A exposição de obras de Rodin, em 1995, obteve sucesso expressivo de público, com mais de 120 mil visitantes, provocando filas e longas esperas. A mostra De Picasso a Barceló atraiu em torno de 200 mil visitantes, em 2001. A estratégia de

\footnotetext{
${ }^{69}$ Uma das soluções defendidas pelo Conselho de Sócios foi a ocupação do prédio ao lado do museu, onde se construiria edifício bastante alto, com restaurante giratório no último andar, ostentando anúncio publicitário do patrocinador, uma empresa de telefonia, a Vivo. A compra do prédio, doado ao Museu pela empresa, tinha por objetivo denominar o novo edifício com a alcunha "MASP Vivo". Essa solução causou enorme repercussão, grande parte dela contrária à proposta, e acabou sendo vetada pelo Conpresp (Conselho Municipal de Preservação do Patrimônio Histórico, Cultural e Ambiental), órgão da prefeitura responsável pelo patrimônio histórico, uma vez que, segundo sua análise, a nova construção interferiria no MASP a ponto de descaracterizar o museu.
} 
investir em artistas consagrados da pintura moderna, e de conhecimento do grande público, foi bem sucedida, atraindo contingente considerável de visitantes ao museu.

Outro museu de grande importância é o Museu de Arte Moderna. O nome engana, pois se trata mais precisamente de museu de arte contemporânea, com acervo e organização de exposições temporárias de artistas que produziram, sobretudo, após a segunda guerra mundial. O museu é uma sociedade civil de interesse público, sem fins lucrativos. Atualmente é presidido por Milú Villela, também presidente do Instituto Itaú Cultural (o Banco Itaú é um dos principais mantenedores do museu). Tem também programa educativo com diversos cursos regulares, nas áreas de artes plásticas, teatro, fotografia, história da arte e figurino. Assim, como o MASP, o prédio do MAM também foi concebido por Lina Bo Bardi, sob a marquise de autoria de Oscar Niemeyer.

Fundado em 1948, pelo empresário Francisco Matarazzo, o MAM tem como missão: "colecionar, estudar, incentivar e difundir a arte moderna e contemporânea brasileira, tornando-a acessível ao maior número de pessoas possível." (site www.mam.org.br $^{70} \mathrm{O}$ núcleo inicial do acervo era a coleção particular de Ciccilo Matarazzo e da esposa Yolanda Penteado, com obras de Anita Malfatti, Di Cavalcanti, Volpi, Miró, Picasso e Chagall. Em 2005, o acervo reunia 4.108 obras. O museu teve papel decisivo na circulação e divulgação de artistas internacionais, já que organizou as seis primeiras bienais de arte e também contribuiu para movimentos importantes da arte brasileira, como o Concretismo.

Em 1963, Matarazzo decidiu criar a Fundação Bienal de São Paulo e doou o acervo do MAM para o Museu de Arte Contemporânea da Universidade de São Paulo. Somente em 1968 - depois de ter ocupado o prédio dos Diários Associados, o Museu da Aeronáutica e o Pavilhão Armando Arruda Pereira, onde hoje está a

\footnotetext{
${ }^{70}$ Possui em sua equipe nomes de destaque no cenário de artes plásticas. Tem como diretores César Giobbi, ex-jornalista do jornal O Estado de S. Paulo, Eduardo Brandão, proprietário da Galeria Vermelho e professor universitário, Tadeu Chiarelli, curador e professor universitário. O curador do museu é Felipe Chaimovich, cargo já ocupado por Tadeu Chiarelli e Ivo Mesquita. Entre os conselheiros, possui nomes conhecidos da elite econômica e da elite cultural paulistana: Benjamin Steinbruch (presidente da Companhia Siderúrgica Nacional, cuja família tem o controle também do grupo têxtil Vicunha), Chella Safra (esposa do banqueiro Moise Safra), Danilo Miranda (diretor superintendente do SESC São Paulo), José Ermírio de Moraes Neto (sobrinho do empresário Antônio Ermírio de Moraes do grupo Votorantim), Gilberto Chateaubriand (colecionador, vice-presidente do MAM Rio e membro dos conselhos do MoMa de Nova York e da Fundação Cartier de Paris), José Midlin (bibliófilo e ex-presidente do MASP), Lily Marinho (esposa de Roberto Marinho das Organizações Globo) e Pedro Piva (ex-senador, proprietário do Grupo Klabin). Tem um conselho consultivo de artes plásticas composto por Annateresa Fabris (professora universitária), Lisete Lagnado (curadora da $27^{a}$ Bienal Internacional de São Paulo) e Luis Camillo Osório (crítico de arte), que "fica responsável pelo aconselhamento e sugestões de obras a serem adquiridas ou doadas ao museu e para a escolha de mostras e projetos culturais a serem apresentados nos espaços do MAM" (www.mam.org.br).
} 
Fundação Bienal, além das sedes provisórias no Conjunto Nacional e no Edifício Itália - o MAM passou a ocupar o seu atual espaço.

O público visitante do MAM foi de 201.974, em 2005, e 237.125 pessoas, em 2006 (www.mam.org.br). Os recursos para produção de exposições são captados por intermédio do corpo de sócios, que, em 2003, era constituído por 1.139 pessoas físicas e 118 pessoas jurídicas. Dentre os principais doadores, encontram-se três bancos: o Bradesco, o ABN Real e o Itaú (daí o vínculo da presidente da instituição), além da Mastecard e da Camargo Corrêa, todos considerados mantenedores. As demais empresas e órgãos públicos relacionados com o MAM classificam-se como parceiros, hierarquizados da seguinte forma: seniores plus, seniores, plenos, masters, apoiadores culturais e parceiros institucionais, classificados de acordo com o volume das doações efetuadas. Os sócios da categoria "pessoas físicas" também têm benefícios - descontos nos ingressos e cursos, na loja e restaurante - que variam de acordo com o valor da doação. O museu tem ainda a prática de alugar seus espaços para eventos empresariais.

Outro instituto inaugurado recentemente, em 2001, que se configura como um jogador importante na arena das artes plásticas é o Instituto Tomie Othake. Conta com $7.500 \mathrm{~m}^{2}$ para exposições que se dedicam, assim como o MAM, à arte contemporânea produzida nos últimos cinqüenta anos. Localiza-se em complexo empresarial, em Pinheiros, concebido pelo arquiteto Rui Othake. O Instituto funciona no imóvel em regime de comodato, tendo sido cedido pelo Grupo Aché, cujos dirigentes mantêm "[...] vínculo muito próximo e afetivo com a família Ohtake, há mais de 30 anos" (www.institutotomieothake.org.br). Prevê-se ainda a criação de espaços para teatro, performance, música, dança e cinema no Instituto, o que o transformará de espaço de exposições em um Centro Cultural. Oferece também cursos, seminários e simpósios. Em seu site, o Instituto propõe o que denomina uma nova concepção de parceria:

O Instituto, como qualquer iniciativa voltada à promoção e ao estímulo da cultura, procura parceria de terceiros no que se refere à complementação de recursos para a realização de sua programação. Por princípio, o Instituto é o parceiro de empresas que buscam, publicitária e institucionalmente, construir e solidificar uma marca, para a qual o Instituto Tomie Ohtake tem ótimas condições de agregar valor. A marca parceira associará sua imagem a um local onde as pessoas que o freqüentam se sentem em um espaço diferenciado, pela qualidade das exposições, pelas montagens, 
pelas produções cênicas, pelo caráter pedagógico, pelo aprendizado cultural e cívico, pela arquitetura, pelo respeito ao público." (http://www.institutotomieohtake.org.br/instituto/parcerias/teparcerias. $\underline{\mathrm{htm}})$

Em seu site também são listadas algumas empresas parceiras, como o Instituto Goethe, a Petrobrás, os Correios, o próprio Centro Cultural Banco do Brasil e a Aliança do Brasil, empresa também vinculada ao Banco do Brasil. Tem como diretor geral Ricardo Othake, filho de Tomie Othake, que já foi Secretário de Estado da Cultura de São Paulo, além de diretor do Centro Cultural São Paulo, do MIS e da Cinemateca Brasileira.

\subsection{O LUGAR DO CCBB}

Se levarmos em conta a população da cidade e compararmos São Paulo com outras metrópoles do mesmo porte, o número de museus e teatros que possui é reduzido ${ }^{71}$. Entretanto, também é necessário considerar que o número de instituições culturais disponíveis na cidade não é tão inexpressivo, permitindo a circulação de obras de produtores culturais diversos, tanto nacionais como internacionais.

A situação do CCBB é desigual quando comparada à do MASP, do MAM e da Pinacoteca, em função de dois fatores básicos: o primeiro, é a ausência de acervo, o que, acredita-se, garantiria por si só público visitante, muito embora as exposições temporárias sejam os "grandes chamarizes de audiência"; o segundo, é a vida mais longa daquelas instituições, mais conhecidas tanto pelos habitantes da cidade quanto por aqueles que as visitam, já que são citadas com destaque nos guias turísticos.

Arruda (2001) nos mostra que a criação das primeiras instituições de arte em São Paulo, principalmente o MASP e o MAM, esteve relacionada com o que acontecia nos países centrais, já que os mecenas que os idealizaram eram estrangeiros ou descendiam deles, e também porque tinham como modelo de

\footnotetext{
${ }^{71}$ Além de pouco numerosos, os museus não têm o porte do Metropolitan ou do Moma de Nova York, do Louvre e do Georges Pompidou de Paris, do Museu do Prado e do Reina Sophia de Madrid, do Macba de Barcelona, das National Gallery, Tate Gallery ou Tate Modern de Londres ou da Neue Nationalgalerie de Berlim. Também não atraem tantos turistas como eles.
} 
inspiração seus pares europeus e norte-americanos. Na década de 50 , o surgimento daqueles museus se vinculou ao "aparecimento de renovado mecenato cultural, nutrido nos quadros de um empresariado vigoroso, frequentemente de origem migrante, comprometido com a dinâmica das transformações" (Arruda, 2001). Por sua vez, as instituições que começaram a surgir no final do século $X X$ têm cunho fortemente impessoal e são inseridas em uma lógica corporativa que visa, sobretudo, à manutenção e à conquista de mercados, muito mais do que a manifestação de cunho idealista ou desejo de distinguir traços ou status pessoais.

Se, na metade do século passado, a fração mais moderna da burguesia industrial se investia do papel de mecenas, agora, o capital financeiro passa a ter peso maior no fomento à produção artística. A efervescência cultural dos anos 50 apontava para o surgimento de uma cultura cosmopolita, que tinha - na proposta artística de Niemeyer para o Parque do Ibirapuera, por exemplo - a busca de um projeto arquitetônico moderno, que seria a imagem do progresso urbano. A escolha do prédio de Hipólito Pujol para a instalação do CCBB revela, em comparação ao ideário dos anos 50, certo reacionarismo, já que, no lugar de se lançar como vanguarda arquitetônica, como faziam as investidas culturais da burguesia da década de 50, remonta ao período oligárquico e rural da economia cafeeira em sua constante busca mimética dos padrões europeus de gosto. O Banco do Brasil reforça a solidez centenária e a tradição que o caracterizam, ao escolher aquele imóvel para instalar seu Centro Cultural, contrapondo-se às configurações arquitetônicas mais contemporâneas e ousadas de seus concorrentes Itaú Cultural, Instituto Tomie Othake, Centro Cultural São Paulo, MASP e MAM. No entanto, essa escolha joga ao mesmo tempo com a contemporaneidade, na medida em que 0 artista convidado para a exposição inaugural subverte o espaço pré-moderno do imóvel, permitindo ao público fruir de ambos os prazeres: as características arquitetônicas do prédio e a radicalidade da exposição.

Tendo investido muitos milhões na reforma do edifício, e tendo o projeto de instalação da instituição na cidade demorado alguns anos para se concretizar, corajosamente, o primeiro artista convidado pelo CCBB expôs obra que, em tudo, procurava subverter a riqueza arquitetônica, de estilos neoclássico e art nouveau, do edifício. Transcendendo os seus espaços de exposição, a instalação Resgate, do artista plástico Tunga, consistia de inúmeros lençóis remendados um no outro, que desciam desde a clarabóia até o térreo, percorrendo todo o imenso vão central do 
edifício. A peça usou 4 toneladas de ferro esculpido, 100 quilos de batom, 8.000 lençóis, sopa e 2.000 pratos. Juntamente com a instalação houve performance com duração de oito horas, com a presença de 130 atores coordenados por Lia Rodrigues. A obra fazia referência às "terezas", cordas construídas para fuga de prisioneiros, a partir de lençóis. Os atores distribuíam sopa para o público, vestidos de mendigos, invertendo a lógica assistencialista da classe média de alimentar os desabrigados durante o inverno. Esses lençóis, espalhados pelo grande vão central do edifício, impediam que sua "beleza" fosse revelada e poderiam também sugerir a representação de um enfretamento simbólico dos habituais freqüentadores do centro da cidade (pobres, pessoas em situação de rua) ao espaço elitizado da instituição que abrigava a obra.

A escolha do centro da cidade reforça as ambigüidades de nossa modernidade inconclusa, ao expor as desigualdades culturais e simbólicas que dificultam a fruição plena das obras expostas, tanto pelos habitantes da região central degradada e pauperizada, quanto dos privilegiados dos bairros nobres. A violência e o medo dela decorrente restringem o acesso da elite ao bairro central transfigurado em terreno ermo e ameaçador. A violência simbólica das obras produzidas pela elite limita o acesso da população do centro, que não se reconhece nos bens expostos, desprovidas das disposições culturais necessárias para sua fruição.

A área de cultura e entretenimento vem se profissionalizando e se burocratizando no Brasil por intermédio de empreendimentos empresariais dignos de nota. O mencionado exemplo da empresa Corporación Interamericana de Entretenimiento (CIE) (http://207.36.181.42/show_subcat.cfm?SubCatID=9) que é proprietária no Brasil de diversas casas de espetáculos e tem sido responsável pela produção de musicais (Fantasma da Ópera) e exposições "blockbusters" (Leonardo da Vinci - A Exibição de um Gênio e Corpo Humano: Real e Fascinante), denota a comercialização do campo artístico. A concorrência por público e espaço na mídia é acirrada, sendo que os "jogadores" do "mercado de arte" são cada vez mais profissionalizados e os patrocinadores parecem dispostos a investir recursos, visando muitas vezes não só o lucro simbólico (como ocorre no caso do mecenato empresarial), mas também lucro financeiro.

Nas entrevistas realizadas com os funcionários do CCBB, sobressaiu como principal dificuldade na atuação do Centro Cultural o tamanho do prédio. A dimensão 
reduzida limitaria as possibilidades de expor um número maior de obras, sendo que, mostras itinerantes provenientes de outros CCBBs, freqüentemente precisavam de ser repensadas em função da necessária exclusão de algumas peças. Outra limitação, as montagens das peças teatrais sempre necessitam de elencos reduzidos e cenários modestos, já que o palco não comporta grandes produções.

Certamente, o tamanho do espaço influencia a forma de atuação da instituição, principalmente, quando se deseja obter ganhos de imagem para o financiador, já que maior visibilidade e mais público implicam, supostamente, que mais bem-sucedida ela será.

Pode-se considerar que instituições culturais menores, como pequenos museus, pequenas editoras, pequenas gravadoras costumam se dedicar a fatias específicas de mercado, haja vista não conseguirem competir com as grandes instituições por mais público. No entanto, o CCBB, apesar de considerado pequeno em função do vínculo com um grande financiador, não se preocupa com a definição de uma maneira específica de atuar, mas dar conta da pluralidade e da diversidade das manifestações artísticas. Derivado de instituição centenária que porta o nome do país, o CCBB tem conseguido destaque no competitivo cenário cultural paulistano.

Mais jovem do que instituições como a Pinacoteca do Estado, o MASP ou o MAM, e com localização menos privilegiada do que o CCSP, o Instituto Tomie Othake e o Instituto Itaú Cultural, o CCBB São Paulo não possui a mesma centralidade do CCBB Rio no panorama cultural da cidade de São Paulo. Na área de artes cênicas, também não possui a mesma representatividade de um gigante como - SESC. Ocupa, portanto, espaço ainda não consolidado e constantemente ameaçado pelas demais instituições, precisando ainda asseverar cada escolha cultural de patrocínio. Entretanto, a julgar pelos prêmios recebidos, tem obtido sucesso em suas escolhas. No ano seguinte a sua criação, em 2001, o CCBB recebeu seus primeiros prêmios da Associação Paulista dos Críticos de Arte (APCA), na categoria fotografia, pela exposição $O$ esplendor dos contrários de Arthur Omar e também no quesito "instituição cultural", na categoria artes plásticas. Nessa categoria, voltou a ganhar prêmio, em 2003, no quesito "exposição nacional", pela mostra Claraluz de Regina Silveira. Em 2004, novamente ganhou prêmio na área de artes visuais pela exposição de Nuno Ramos, Morte das Casas, também no quesito "exposição nacional". Também no mesmo ano, ganhou prêmio no quesito "exposição 
internacional" pela mostra Arte da África. Em 2005, voltou a ganhar prêmio na categoria "exposição nacional" pela mostra de Farnese de Andrade.

$\mathrm{Na}$ área de artes cênicas, três peças patrocinadas pelo CCBB receberam premiações mais destacadas:

- Pólvora e Poesia - prêmio Shell de melhor ator, autor e diretor, em 2001;

- A Casa dos Budas Ditosos - prêmio Shell de melhor atriz para Fernanda Torres, em 2004;

- Longa Jornada de um dia noite adentro - "Grande Prêmio da Crítica" da APCA pela interpretação de Cleide Yáconis, em 2003.

Talvez o prêmio mais importante recebido tenha sido o Prêmio Bravo! Prime de Cultura, curiosamente patrocinado pelo Bradesco, na categoria Melhor Programação Cultural de 2006, vencendo dois grandes competidores: o SESC, que acabou ganhando no ano seguinte, e a Pinacoteca do Estado. Nessa categoria, votavam todos os jurados que premiam as demais categorias (melhor espetáculo de teatro, melhor livro, melhor disco de música popular e erudita, melhor filme nacional, melhor espetáculo de dança e melhor exposição de artes plásticas).

Mesmo sem a mesma importância de outras instituições culturais nas áreas priorizadas nesta pesquisa - artes cênicas e artes plásticas -, o CCBB tem obtido bastante prestígio, o que lhe garante papel intermediário no campo artístico, e em vias de ascensão, considerando que possui o amparo de um corpo de especialistas daquele campo e o respaldo simbólico da instituição que o mantém. Dizer que seu papel é intermediário no interior do campo artístico acarreta duas implicações. A primeira, é lhe negar o papel de hegemonia, de centro capaz de ditar tendências e influenciar os rumos das manifestações artísticas patrocinadas. A segunda é, também, negar-lhe papel subalterno, reservado às instituições sem autoria e sem expressividade e relevância no campo das artes. Ressalta-se, contudo, para relativizar esse posicionamento, a fluidez cada vez mais evidente dessas posições de preeminência e subordinação no campo artístico. 


\section{Capítulo 4}

\section{Critérios de escolha - RÉGuAs de comparação no PROCESSO DE SELEÇÃO DOS PROJETOS ARTÍSTICOS}

\subsection{ESQUEMAS DE CLASSIFICAÇÃO}

A análise do processo de seleção dos projetos artísticos pelo CCBB tem como substrato falas obtidas mediante registros documentais ou entrevistas. Procurar-se-á estabelecer como são construídos - pelos atores sociais que definem a programação da instituição - os esquemas classificatórios que permitem hierarquizar os projetos, excluindo aqueles considerados inadequados e elegendo os que se beneficiarão do patrocínio. Essas falas serão cotejadas com aspectos observados na prática desses atores e na percepção de outros elementos do campo artístico sobre as escolhas efetuadas. A análise será complementada com a do capítulo subseqüente, voltado para os resultados finais do processo, que resulta na programação do CCBB.

Não obstante trabalharmos com critérios declarados em documentos públicos, além dos presentes em justificativas internas e os explicitados (e implícitos) nas falas dos atores sociais envolvidos, certamente outros fatores, de aferição mais difícil, estão presentes nessas escolhas, como contatos informais por meio de redes de relacionamentos interpessoais, afinidades e interesses, amizades.

\subsection{Política Cultural}

O termo política cultural remete às diretrizes e intervenções que determinados atores sociais, normalmente dotados de poder político ou financeiro, fazem no campo artístico, no intuito de fomentar e apoiar a produção ou a disseminação de obras e/ou espetáculos. Essa noção é usada, sobretudo, na gestão pública dos recursos, mas começou a ser utilizada também por empresas, como acontece com o BB. 
Na tradição francesa, o termo é indissociável da política estatal: "a política cultural é um objeto composto que revela tanto a história das idéias e das representações sociais quanto uma história do Estado (ou de outras instâncias públicas)." (Urfalino, 2004: 14)

Teixeira Coelho define o conceito da seguinte forma:

A política cultural é entendida habitualmente como programa de intervenções realizadas pelo Estado, instituições civis, entidades privadas ou grupos comunitários com o objetivo de satisfazer às necessidades culturais da população e promover o desenvolvimento de suas representações simbólicas. Sob este entendimento imediato, a política cultural apresenta-se assim como o conjunto de iniciativas tomadas por esses agentes, visando promover a produção, a distribuição e o uso da cultura, a preservação e divulgação do patrimônio histórico e o ordenamento burocrático por elas responsável. (Coelho, 2004)

De maneira não muito diferente, Brunner define o termo política cultural como:

Formas de intervenção que tendem a operar sobre o nível organizacional da cultura: preparação e carreira dos agentes, distribuição e organização dos meios, renovação dos meios, formas institucionais da produção e circulação de bens simbólicos. (Brunner, 1992: 211)

Esse autor classifica as políticas culturais, segundo seus objetivos principais, em: políticas que visem à construção institucional; políticas de caráter restritivo de censura a determinadas manifestações; políticas de determinação de pautas de financiamentos para as atividades culturais; e políticas de ampliação de acessos ao mercado de bens culturais (Brunner, 1992: 217-219).

O último modelo, predominante nas políticas culturais públicas e privadas cujo norte tem sido o de difusão e democratização do acesso aos bens artísticos, tem sido objeto de muita discussão. A política cultural do CCBB, como foi visto anteriormente, não se limita somente à difusão de bens culturais; ela também fomenta a criação artística, como ocorre na área de artes cênicas, com a montagem de novos espetáculos.

$\mathrm{Na}$ área de artes plásticas, não obstante a quase totalidade das obras já estarem prontas quando o projeto de exposição é submetido à apreciação, é também possível pensar a escolha curatorial como uma criação artística, na medida em que há inventividade na seleção das obras, no "conceito da exposição", na 
maneira como estarão dispostas, nos textos que orientarão o público. Por outro lado, a ênfase interna aos dados quantitativos de público e mídia evidencia grande preocupação com a recepção dessas obras e na amplitude da difusão que essa recepção atingirá. Tendo em vista o número reduzido de projetos aprovados em relação aos inscritos ${ }^{72}$, a clareza da política cultural no processo de seleção é decisiva para que as escolhas se constituam a partir de critérios que permitam algum grau de transparência.

A crítica feita ao modelo de ampliação de acessos é a de que ele privilegia determinadas manifestações culturais, valorizadas por núcleo restrito de pessoas que possuem poder para classificar e legitimar determinados bens, os quais devem ser levados a pessoas de diferentes capitais culturais, com um propósito quase messiânico de formação educacional, excluindo dessa política todas as manifestações culturais das frações dominadas, cuja produção não se enquadre nos cânones da "alta cultura". Coelho considera a política das instituições que privilegiam a realização de tais eventos como o oposto de política cultural, na medida em que aquela possui caráter "imediatista (ação que se encerra em si mesma, sem deixar resíduos) e, eventualmente, oportunista (serve ocasionalmente para promover políticos, partidos, beneficiar artistas, etc.)" (2004:301). No entanto, ele também reconhece o alcance multiplicador dos eventos culturais, o qual pode ser tão ou mais importante do que os efeitos de determinadas políticas culturais. Assim, conclui Coelho:

Mostras internacionais de cinema ou vídeo, por exemplo, podem ter mais significação cultural - como estimuladora e multiplicadora da ação de agentes e produtores culturais - do que várias oficinas de cinema e vídeo. São no mínimo complementos indispensáveis destas atividades regulares. (idem).

Essa visão, que classifica as ações culturais como políticas culturais ou políticas de eventos, é corroborada em documento do IPEA, que as menciona como "ações complementares e que se apóiam estrategicamente" (Silva, 2007:19). Dessa forma, depreende-se que uma política de eventos, que, no limite, atestaria a ausência de política cultural, se caracteriza por fomentar projetos isolados, desarticulados, fragmentados e sem continuidade, enquanto a política cultural seria caracterizada pela sistematização e pela continuidade, criando "condições que

\footnotetext{
72 Para a programação de 2005 foram selecionados 12\% dos projetos; para 2006, 7\%; para 2007, 4\%.
} 
permitam o desenvolvimento das práticas culturais e favoreçam a melhoria da qualidade de vida e do acesso ao repertório de bens culturais" (Silva, 2007:20).

Duas grandes linhas dizem respeito às ênfases políticas e aos valores alocados na gestão da política cultural. A primeira é a ênfase no Estado como poder civilizador da sociedade e em decorrência a importância de instituições culturais permanentes capazes de contar a história social e cultural da Nação. A outra política de eventos refere-se ao momento conjuntural dos governos $e$ às suas necessidades de legitimação. A oposição entre uma política de eventos e uma política de serviços culturais permanentes não é absoluta. Uma pode e deve se apoiar na outra. Entretanto, se o objetivo é a universalização de direitos culturais, a gestão pública de cultura não pode prescindir de instituições consolidadas, com recursos técnicos e humanos capacitados, com critérios e orientações claras, com recursos financeiros suficientes para retirar do mercado o poder de imposição de seus produtos e valores. A intervenção pública no setor cultural tem de contar com recursos institucionais relevantes, do contrário resume-se à promoção de eventos e à cristalização de valores fugazes, quando não da simples mercantilização da cultura. (Silva, 2007: p. 75/76).

Silva distingue a política cultural da política de eventos, quanto aos seus objetivos: enquanto a primeira buscaria a legitimação e a universalização dos direitos culturais, a segunda visaria à legitimação e promoção dos governos. Quanto ao planejamento, a primeira seria de longo prazo e a segunda, de curto. $\mathrm{O}$ autor enquadra toda a produção cultural fomentada pela via das leis de incentivo como estando sob o auspício de uma política de eventos, à qual também denomina de "quase-políticas". Caracteriza também a política do Governo Federal para a cultura, no período 2002-2006, como política de eventos, sem a sistematização que se esperaria de uma política cultural:

Entre os problemas mais sérios enfrentados pelo governo federal para a implantação de uma política referida a um conceito amplo de cultura, com abrangência nacional e sistêmica, estão os limites muito precisos relacionados às capacidades institucionais e financeiras. Esses limites induzem a atuação do governo federal ao atendimento de projetos prioritários decididos ano a ano ou ao atendimento da livre camada, variável conforme a ocasião e a mobilização do dia. Tais características dão à política cultural um caráter fragmentário e muitas vezes sem continuidade no tempo, o que a define como uma política de eventos e do espetáculo, caracterizada por um emaranhado de ações pontuais, ou por ações emergenciais, sobretudo nas áreas do patrimônio edificado. (Silva, 2007:141) 
Utilizando esse modelo de análise, pode-se afirmar que a atuação cultural dos CCBBs está mais próxima de uma política de eventos do que de uma política cultural. Isso decorre em grande parte da principal diretriz que sustenta o que é definido como sua "política cultural": a diversidade da programação. Os eventos patrocinados procuram atender a públicos distintos e, por isso, têm características e objetivos diferenciados, o que dificulta sua sistematização e concatenação. Há outras ações, contudo, que se configurariam como decorrentes de uma política cultural, como a atuação do programa educativo, que mantém constância e manutenção de linha pedagógica desde o início da existência dos CCBBs. Outrossim, há programas que, no relativo ao CCBB São Paulo, mantêm certa continuidade, como é o caso dos projetos Dramaturgias e Dança em Pauta (ainda que esse último, apesar de repetir-se todos os anos, tenha característica muito próxima à de festival, aproximando-se, portanto, de um evento).

Algumas vezes há a preocupação de atingir certa interdisciplinaridade dos projetos, como ocorreu com a exposição Arte de Cuba, que se associou à programação musical daquele país. Essa característica de diálogo entre as áreas artísticas era bem marcante na programação inicial do CCBB Rio de Janeiro (Ferreira, 1997). A continuidade e a regularidade da programação podem ser vistas como decorrentes de política cultural, ainda que não haja sistematização quanto ao conteúdo mesmo das abordagens artísticas. A política cultural do CCBB ficará mais clara com a discussão de seus "valores estratégicos".

\section{3 "VAlORES EstratÉGicos"}

Em seu site na internet, o Banco do Brasil torna pública a política cultural que implementa, ancorada em quatro "valores estratégicos" que serão discutidos detalhadamente:

- Credibilidade: atender com eficiência, pontualidade, segurança, conforto, limpeza.

- Regularidade: oferecer eventos regulares, de terça a domingo.

- Diversidade: manter programação diversificada, destinada a vários públicos.

- Acessibilidade: proporcionar acesso à cultura em três níveis: intelectual, financeiro e físico. (www.bb.com.br) 
Não foi localizado documento que explicite claramente a política cultural do CCBB. No site da internet, a página cujo "link" é denominado "Política Cultural" traz o seguinte texto que é acompanhado dos "valores" acima: "O Banco do Brasil tem como valor corporativo o compromisso com o desenvolvimento da sociedade brasileira e o apoio à cultura". Esses "valores" podem dar algumas pistas do que seja a política cultural do CCBB, mas não são suficientes para uma análise aprofundada, razão pela qual o estudo da programação escolhida, a ser efetuado no próximo capítulo, complementará o que se configura aqui, muito em função da análise das falas dos atores envolvidos.

\subsubsection{Credibilidade}

É curioso que a credibilidade seja colocada como pressuposto da política cultural. Seria de esperar que ela decorresse de uma política cultural bem formulada e bem aplicada, não que fosse princípio norteador de políticas. Uma determinada instituição tem credibilidade em função do seu trabalho e de suas escolhas, não porque a deseje ter ou julgue esse atributo importante. Entender a credibilidade como objetivo e não como conseqüência é fruto de raciocínio extremamente eivado por pressupostos de marketing, nos quais a aparência e a percepção das pessoas têm mais importância do que os atributos que eventualmente um produto ou serviço possa ter.

Pela descrição do que é entendido pela empresa por 'credibilidade' ("atender com eficiência, pontualidade, segurança, conforto e limpeza"), depreende-se que ela se relaciona, sobretudo, com o entendimento da cultura como serviço, que deve ser prestado com qualidade, da mesma forma que o serviço bancário também precisa ser eficaz para agradar aos clientes.

A importação da terminologia do universo mercadológico e empresarial, envolvendo as noções de "eficiência", "pontualidade" e "segurança", reforça o destaque dado, sobretudo, à relação da instituição com o usuário do serviço cultural, em detrimento de escolhas e diretrizes relacionadas com a natureza dos trabalhos a serem patrocinados, os quais, em princípio, deveriam ter mais centralidade na definição da política cultural. A relação com o usuário da instituição, que deveria ser conseqüência das escolhas artísticas efetuadas, parece ter maior relevância do que 
qualquer princípio estético que possa orientar o perfil de atuação do CCBB. É como se o "atendimento" garantisse em grande parte a adesão do público, independentemente da qualidade artística do que é produzido e apresentado.

A noção de credibilidade poderia (ou deveria) decorrer da relevância artística dos objetos fomentados ou da aderência das obras aos cânones e princípios consagrados pela crítica especializada ou, ainda, pelo pioneirismo e inventividade da produção simbólica patrocinada. A credibilidade não advém do produto que recebeu seu patrocínio - a obra de arte -, mas da maneira como essa obra é "administrada", "gerenciada" e ofertada ao público. Dessa maneira, o CCBB omite-se no pantanoso e incerto debate sobre a arte contemporânea, em suas mais diversas modalidades. Não toma o partido dessa ou daquela perspectiva teórica ou estética e concentra seus esforços na prestação de serviços.

Se a obra artística dá prestígio à instituição que a fomenta, o contrário também ocorre. A credibilidade de uma instituição também ajuda na promoção do artista. Apresentar sua obra no CCBB é algo valorizado nos currículos dos artistas. Isso denota a credibilidade da instituição no campo artístico, em função do status proporcionado àqueles a quem patrocina. Segundo relato de funcionário, no caso de cessão de obras de museus e instituições do exterior para exposições no país, considerando que, muitas vezes, o CCBB é desconhecido, o que acaba dando credibilidade e conforto ao remetente da obra é o peso da marca "Banco do Brasil", de maior conhecimento em outros países.

O princípio da credibilidade pressupõe corresponder à expectativa do público sobre o que é mostrado pela instituição: deve ser bom, adequado, pertinente. Mais do que isso, devido à instabilidade dos critérios definidores do que seja uma obra de arte, é a credibilidade da instituição, que, por exemplo, convida o público a pensar, em relação à escolha de uma obra para um espaço de exibição: "Bem talvez... talvez, essa seja uma peça de arte".

Credibilidade, prestígio e reputação são termos que se assemelham, apesar de não possuírem exatamente o mesmo significado. São atributos muitíssimo valorizados pelos profissionais de marketing financeiro, haja vista a influência que possuem nas escolhas efetuadas pelo consumidor bancário. Busca-se que o público creia na instituição cultural, confie nela, a legitime, reconhecendo-a digna de respeito e admiração. Enfim, é buscada a crença do público; crença na capacidade que a 
instituição artística deve ter de contribuir com a construção da aura que envolve a obra de arte e em sua eficácia simbólica.

\subsubsection{Regularidade}

Regularidade é característica importante no panorama cultural paulistano, pois a programação de muitos dos equipamentos culturais paulistas é não-contínua. A regularidade da programação e a multiplicidade de horários podem tornar o Centro Cultural um espaço de lazer em sentido amplo, uma vez que parte do público pode visitá-lo sem o objetivo específico de aderir a um ou outro produto cultural, por saber que encontrará alguma atividade, ainda que desconheça de antemão a programação existente.

Grande parte dos equipamentos culturais da cidade não mantém regularidade de programação, em função, principalmente, da ausência de recursos. Sem constância de eventos, não se estruturam vínculos entre a instituição e seus públicos e também não se atende a preceito básico das estratégias de marketing, pelo qual a abundância de exposição da marca é o que garante a retenção, na memória do consumidor, da empresa como opção de compra.

O CCBB está aberto ao público de terça a domingo, das 10 às 20 horas, para as exposições de artes plásticas. Oferece espetáculos teatrais, com pequenos intervalos entre uma peça e outra. As sessões acontecem de quinta a domingo ${ }^{73}$. Shows de música, ocorrem normalmente às terças e quartas, à noite, e também no horário do almoço; sessões de cinema têm horários variados. A regularidade contribui para que o CCBB estabeleça como instituição cultural na cidade e rompe com a prática mais freqüente de patrocínio empresarial, que consiste no fomento a produções episódicas e eventuais.

\subsubsection{Diversidade}

Diversidade talvez seja o eixo curatorial que defina, na perspectiva dos funcionários da instituição, a programação do CCBB. Foi recorrentemente citada, e sempre com ênfase, em praticamente todas as entrevistas. Essa política é coerente

\footnotetext{
${ }^{73} \mathrm{Em}$ alguns momentos, o CCBB apresentou peças também às terças e quartas- feiras.
} 
com o perfil da empresa patrocinadora. $\mathrm{O} B \mathrm{~B}$, como foi visto no primeiro capítulo, é essencialmente um banco de varejo, e atende públicos diferenciados. Possui políticas e estratégias mercadológicas tanto para a população que é cliente do banco e possui baixa renda - pensionistas, aposentados, servidores públicos, trabalhadores com baixa qualificação -, como para detentores de grandes fortunas. Além do segmento de pessoas físicas, atua nos segmentos Governo e pessoa jurídica (de micro-empresas a grandes corporações). Não é, portanto, instituição que se preocupe com um nicho específico de mercado; antes, seus consumidores potenciais englobam a maior parte da população.

Percebe-se o esforço para contemplar públicos diversos na programação, já que, certamente, não há homogeneidade nos espetáculos e exposições patrocinadas. Contudo, como veremos no próximo capítulo, há, sim, predomínio de determinadas "linhas de programação". Se o objetivo é contemplar gostos e preferências distintas, e, com isso, atrair público o mais diversificado possível, certamente as camadas populares não são as mais contempladas na programação. Entretanto, a diversidade é quase um dogma no CCBB, sendo muito recorrente a afirmação, como aparece na justificativa que embasou a decisão de patrocinar a peça Um Homem Indignado, que ao destacar o fato de que se estava optando, naquele espetáculo especificamente, por um nome consagrado (Walmor Chagas), ressaltava-se que o CCBB SP também patrocinava "trabalhos populares", "artistas iniciantes", e tanto "abordagens convencionais" quanto "experimentais", "tudo para que se possa atingir todos os segmentos da sociedade."

A diversidade, como pressuposto, remete à noção de que a instituição é para todos, não devendo beneficiar apenas determinados grupos. Esse é hoje valor muito em voga na área cultural. Não é por acaso que a mais importante manifestação da ONU sobre o assunto é a "Declaração Universal sobre a Diversidade Cultural", aprovado pela UNESCO em 2001. Os dois primeiros artigos dessa Declaração estabelecem o seguinte:

A cultura adquire formas diversas através do tempo e do espaço. Essa diversidade se manifesta na originalidade e na pluralidade de identidades que caracterizam os grupos e as sociedades que compõem a humanidade. Fonte de intercâmbios, de inovação e de criatividade, a diversidade cultural é, para o gênero humano, tão necessária como a diversidade biológica para a natureza. Nesse sentido, constitui o patrimônio comum da humanidade e deve ser reconhecida e consolidada em beneficio das gerações presentes e futuras. Em nossas sociedades cada vez mais diversificadas, torna- 
se indispensável garantir uma interação harmoniosa entre pessoas e grupos com identidades culturais a um só tempo plurais, variadas e dinâmicas, assim como sua vontade de conviver. As políticas que favoreçam a inclusão e a participação de todos os cidadãos garantem a coesão social, a vitalidade da sociedade civil e a paz. Definido desta maneira, o pluralismo cultural constitui a resposta política à realidade da diversidade cultural. Inseparável de um contexto democrático, o pluralismo cultural é propício aos intercâmbios culturais e ao desenvolvimento das capacidades criadoras que alimentam a vida pública. (www.unesco.org.br/publicacoes/copy_of_pdf/decunivdiversidadecu Itural.doc)

O termo cultura aparece no texto da Declaração em seu sentido mais amplo, nos moldes utilizados pela Antropologia, como teias de significados, valores, crenças e normas construídas por determinados grupos, não se limitando ao sentido estrito que normalmente adquire quando associado às manifestações artísticas. De qualquer forma, há, tanto na Declaração, quanto na política cultural do CCBB, uma intenção apaziguadora e conciliadora embutida na idéia de diversidade cultural. O pluralismo remete à idéia democrática de oportunidades para todos, sem privilégio a determinado grupo ou perspectiva artística. A não hierarquização das manifestações culturais, contudo, admite a inclusão de formas mais ampliadas em um vasto guarda-chuva, que, no limite, deve admitir a todos sem restrições e, portanto, acaba negando a própria noção de política cultural, que requer o estabelecimento de distinções e preferências. Para uma instituição que tem a própria imagem e a de seu financiador como preocupação central, essa é uma saída diplomática, já que atende a todos e evita conflitos com qualquer grupo.

A defesa da diversidade cultural, no âmbito das relações internacionais, insere-se em debate que recusa o imperialismo norte-americano, tendo em vista 0 poder de inserção da indústria fonográfica e cinematográfica daquele país em todos os continentes, deixando pouco espaço para manifestações locais ou regionais. A luta pela diversidade configura-se como luta política, principalmente por estar vinculada, no caso brasileiro, à defesa de grupos distintos, como os povos indígenas e quilombolas, e de suas diversas manifestações.

Deslocando o foco para eventuais conflitos que ocorram no interior do campo artístico brasileiro, área de interesse principal do CCBB, poder-se-ia supor que a atuação da instituição caminharia no sentido de recusar grupos ou manifestações que fossem hegemônicos ou dominantes no campo, dando espaço para as 
manifestações alternativas ou "subalternas", pois elas teriam condições de assegurar, a diversidade e a pluralidade de expressão. Poder-se-ia supor que a diversidade, como política cultural, englobaria a promoção de manifestações artísticas de grupos marginalizados, sem acesso aos mecanismos convencionais de difusão das obras, ou, ainda, de manifestações culturais não legitimadas pelas instâncias instituídas de reconhecimento, como a crítica especializada ou o pensamento acadêmico. Poder-se-ia supor, ainda, que a diversidade, como "valor estratégico", implicaria a inclusão de obras e artistas que não estivessem inseridos nos mecanismos mercadológicos de difusão. Sendo verdade que essas manifestações "contraculturais" encontram espaço no CCBB, não é menos verdade que não são elas as predominantes.

\subsubsection{Acessibilidade}

"Proporcionar acesso à cultura em três níveis: físico, intelectual e financeiro." Assim como ocorre com a categoria "diversidade", aqui é manifesta a preocupação que demonstra um esforço de inclusão. Proporcionar contato com os bens simbólicos ao maior número possível de interessados é a raiz da política cultural de inúmeras instituições artísticas. Cercada por muitas ofertas massificadas de consumo cultural e vista como bem escasso, a arte é investida da illusio que lhe proporciona um traço de distinção e, dessa forma, alçada a lugar de destaque nas opções de lazer da "elite cultivada". Entretanto, ainda está distante de ser fruída pela imensa parcela da população que, muito em função de ser desprovida de capital cultural que the permita a apropriação simbólica dos bens expostos, não vê espaço acolhedor, nas instituições culturais. A intenção democratizante, presente na noção de acessibilidade, normalmente desconsidera as predisposições sociais necessárias (lingüísticas, econômicas, educacionais e outras) para um contato efetivo e gratificante com os produtos da "alta cultura".

A acessibilidade física relaciona-se tanto ao acesso dos portadores de deficiência física, quanto à facilidade para chegar ao CCBB, derivada da existência de vias públicas e transportes coletivos adequados. Acerca desse último aspecto, já foi analisada anteriormente a limitação que o CCBB representa para as classes abastadas, por estar no centro da cidade e em região de calçadão. No que se refere 
aos cadeirantes, o acesso é facilitado por rampas de acesso, elevadores e banheiros adaptados.

Quanto à acessibilidade financeira, as atrações nas áreas das artes plásticas e música são gratuitas. O teatro possui ingressos com preços reduzidos. Certamente não há objetivo de lucro nessa cobrança. Questionados sobre a razão da cobrança, os funcionários alegam que os ingressos gratuitos costumam gerar muita desistência, ficando, por vezes, lugares ociosos em demasia. A compra gera maior comprometimento com a presença, segundo eles.

Há aqui tentativa, que não se concretiza, de abarcar as camadas menos favorecidas economicamente. A desigualdade social na cidade é tão grande que expulsou as camadas mais empobrecidas para os extremos norte, sul e leste do município, sendo que o acesso à região central, embora parcialmente facilitado pela estrutura - ainda que ineficiente - de transporte coletivo, apresenta custo de locomoção bastante dispendioso para grande parcela da população, cujos rendimentos são insuficientes para atender às necessidades elementares de sobrevivência.

Acessibilidade intelectual é um termo bastante controverso. Pelas entrevistas realizadas, depreende-se que os funcionários a entendem remetendo-a à "missão" do CCBB de permitir maior diálogo do público com o universo artístico mediante programa educativo consistente. Como nos ensina Bourdieu, a fruição dos bens artísticos depende da existência de capital cultural, cuja posse se dá prioritariamente por meio de processos educativos, normalmente no âmbito do sistema de ensino escolar, mas também da classe social de origem daqueles que os buscam:

Para explicar como se aumenta com o capital escolar a propensão ou, ao menos, a pretensão de apreciar uma obra 'independentemente de seu conteúdo', como dizem frequentemente os sujeitos mais ambiciosos culturalmente, e, mais geralmente, a propensão a esses investimentos 'gratuitos' e 'desinteressados' que demandam as obras legítimas, não é suficiente invocar o fato de que a aprendizagem escolar fornece os instrumentos lingüísticos e as referências que permitem exprimir: o que se afirma, de fato, nesta relação, é a dependência da disposição estética em relação às condições materiais de existência, passadas e presentes, que são condição tanto de sua constituição quanto de sua concretização, ao mesmo tempo em que da acumulação de um capital cultural (sancionado ou não escolarmente) que só pode ser adquirido ao preço de uma espécie de recuo da necessidade econômica. (Bourdieu, 2003:56) 
A apropriação de obras artísticas da chamada alta cultura constitui um trabalho de deciframento que demanda disposições simbólicas e cognitivas adquiridas ao longo do tempo. A ausência dessas predisposições não é facilmente superada pelas visitas guiadas dos programas educativos nas instituições culturais, normalmente conduzidos por estudantes universitários dos cursos de artes. Porém, trata-se possivelmente de uma tentativa de ampliar o repertório de certos segmentos da população, sem cair na tentação "populista" de fornecer produtos simbólicos que atendam a demandas pré-estabelecidas.

\subsection{Políticas de ATUAÇÃo}

O CCBB divulga, também em seu site na Internet, o que denomina de política de atuação, e estabelece duas diretrizes e duas interdições. A primeira diretriz afirma que os "eventos culturais" serão realizados nas instalações do CCBB e enumera as áreas artísticas objetos de patrocínio (cênicas, plásticas, música, audiovisual, "idéias" e programa educativo). As áreas patrocinadas, embora suficientemente abrangentes, não incluem, contudo, algumas formas de expressão artística, como a literatura, o circo, a ópera, a performance. São excluídas também diversas manifestações que recusam 0 abrigo de instituições artísticas e procuram estabelecer diálogo mais efetivo com o espaço urbano, por meio da ocupação de espaços "alternativos", as quais, entretanto, necessitam de patrocínio para sua realização.

A intervenção em locais não especificamente destinados à exibição artística retira a sacralidade e a autoridade que o espaço institucional dá a obra. Entretanto, permite que o espaço utilizado seja re-significado e também faça parte da criação da criação, dialogando com a obra de forma inusitada e diferente daquela propiciada pelos museus, centros culturais, salas de teatro ou de concerto.

A política de limitar o patrocínio a obras exibidas no espaço do CCBB é justificada, se for considerada a preocupação com a contaminação simbólica almejada pelas ações de marketing cultural, uma vez que o nome do patrocinador fica mais evidente para o público. Não obstante, alguns eventos foram concebidos para terem apresentação fora do espaço do Centro Cultural. A mostra Cubo, com 
audiovisuais, realizada no calçadão do Centro, no aniversário de cinco anos do CCBB, e a obra de Anish Kapoor, embaixo do Viaduto do Chá, são exemplos de suspensão dessa política. Também tem havido patrocínio para exposição de parte do acervo de artes plásticas do BB nas estações do metrô.

O uso da expressão "eventos culturais" não é casual. A noção de evento, como foi dito acima, remete à transitoriedade dos bens artísticos patrocinados e sua constante alteração. A necessidade de fatos novos, para atrair público e mídia, e a ausência de um acervo consistente na área de artes plásticas não permitem a permanência contínua da mesma atividade cultural nos espaços do CCBB, por mais bem-sucedida que ela seja. Contudo, alguns projetos têm sido patrocinados por anos, como os ciclos Dança em Pauta e Dramaturgias, garantindo a continuidade das propostas e maior interação com os públicos neles interessados.

A definição das áreas de atuação em artes cênicas, plásticas, audiovisual, música, idéias e programa educativo delimita o escopo de patrocínio do CCBB. O último - programa educativo - é considerado área de atuação específica, não obstante ocorrer em função das demais. Trata-se de atividade bastante valorizada pelos funcionários, por seu caráter "social", já que a prioridade é atender alunos das escolas públicas da cidade, em visitas monitoradas às exposições de artes plásticas, área com a qual o programa educativo dialoga mais amiúde. O audiovisual é citado pelos funcionários como o âmbito mais bem sucedido do CCBB São Paulo. Questionados sobre o porquê dessa interpretação, os entrevistados apresentaram resposta imediata: é o que tem maior recepção de mídia e público constante, ainda que seu espaço de exibição seja reduzido.

A programação audiovisual aproxima-se bastante da dos cineclubes, com mostras que privilegiam ora temas específicos, ora determinados diretores ou atores. As mostras têm duração reduzida quando comparadas aos períodos das exposições e à duração das temporadas de teatro; dessa forma, constantemente apresentam "fatos novos", o que lhes garante espaço constante na mídia.

A segunda diretriz da política de atuação estabelece que o CCBB "realiza anualmente processo de inscrição de projetos". Efetivamente, isso acontece seguindo um ritual que não varia muito de ano para ano. A abertura das inscrições, muitas vezes, é precedida de publicidade paga nos principais jornais. Pelo levantamento realizado, foi possível perceber que a maior parte dos projetos selecionados foi inscrita no site específico da internet, seguindo o trâmite 
estabelecido. Outros, em menor número, foram enquadrados na categoria "prospecção", o que significa que a iniciativa para o patrocínio partiu do CCBB. Isso tende a ocorrer em alguns casos, seja porque o projeto previamente selecionado se mostrou inviável na época da sua execução, seja pela não cessão dos direitos autorais ou pela indisponibilidade de algum ator-chave, no caso das peças, ou, ainda, pela impossibilidade de empréstimo de obras, no caso das artes plásticas. Em outras situações, os funcionários do CCBB convidam determinados artistas para que inscrevam o seu projeto.

A primeira interdição constante das políticas de atuação estabelece que a produção de CDs, livros ou filmes não seja patrocinada isoladamente. Ela evidencia a recusa de inserção em área de predomínio da indústria cultural, com suas características massificadas de produção e recepção. A palavra "isoladamente" é importante, pois o CCBB tem por praxe produzir catálogos das exposições que patrocina, considerados forma significativa de registro histórico. Da mesma forma, torna tangível o produto cultural, permitindo que ele faça parte das relações públicas do Banco, ao ser oferecido de brinde aos clientes. Esses catálogos também são colocados à venda nas lojas dos CCBBs.

O último elemento da política de atuação estabelece as restrições legais e morais ao patrocínio:

Não associamos nossa marca às atividades consideradas ilegais ou proibidas; às atividades que evidenciem preconceito ou discriminação de qualquer espécie; às atividades ligadas a jogos de azar ou especulativos, salvo se regulamentados em legislação específica; às atividades com má reputação ou falta de integridade; às atividades que causem impacto negativo à saúde, ao meio ambiente e às atividades de caráter político-partidário. (www.bb.com.br)

A propósito desse aspecto, o caráter institucional do patrocínio implica o estabelecimento de limites ao tipo de arte fomentada. Se, por um lado, a autonomia do campo artístico se afirma justamente por estar acima, ou à margem, das convenções sociais, posição que assegura ao artista a liberdade de expressão e crítica que integra a magia de sua construção simbólica, as instituições culturais, por outro lado, acabam estabelecendo restrições a esse desejado poder de não sujeição a determinadas regras. Esse talvez seja o cerne dos conflitos entre os artistas e as instituições que os abrigam. 
As instituições, necessariamente, estruturam-se em torno de regras que disciplinam seus procedimentos internos; ao mesmo tempo, zelam por sua adaptação ao entorno, já que sua sobrevivência depende das relações que mantêm com outros órgãos e atores sociais. Precisam sujeitar-se a certas regras de convívio com governos, imprensa, sindicatos, representações consulares e empresas, que não possuem a mesma fugacidade dos projetos que patrocinam, a fim de garantir sua continuidade, Por mais progressistas que sejam, as instituições de arte normalmente têm muitos compromissos e acordos tácitos a honrar com elementos exteriores ao campo artístico. Entretanto, na prática, é muito pouco exeqüível tentar excluir do patrocínio - mantendo certa imparcialidade e distanciamento valorativo "atividades com má reputação ou falta de integridade". Quem define o que seja uma forma de expressão artística de má reputação? Com quais bases referenciais é possível dizer que uma obra não possui integridade? Diversas daquelas hoje consideradas obras-primas foram, em seu tempo, repudiadas por não terem boa reputação. Há, portanto, o risco de a instituição cair em moralismos completamente avessos à autonomia da criação artística. Esse tema será retomado no Capítulo 6, ao discutirmos o debate em torno da exposição Erotica.

\subsection{O PROCESSO DE SELEÇÃO}

O processo de seleção dos projetos artísticos, levado a efeito pelo CCBB, destoa das práticas de patrocínio da maior parte das empresas, por resultar na definição da programação de uma instituição cultural, distanciando-se, portanto, da chamada prática de "balcão", em que os artistas, com seu projeto embaixo do braço, procuram o diretor de marketing e tentam vendê-lo a uma empresa.

A Revista Marketing Cultural (www.marketingcultural.com.br) analisou os critérios de escolha das cem maiores empresas que captaram recursos facultados por leis de incentivo do Governo Federal. A análise teve como subsídio as informações presentes nos sites dessas empresas, na internet.

A princípio, essa parece uma fonte de pouco valor, porém é o local atualmente mais "publicizado", buscado pelos produtores culturais, para a tomada de informações acerca dos critérios que norteiam os procedimentos de seleção dessas empresas. Com base nesse material, as empresas foram classificadas em quatros 
categorias, de acordo com o grau de transparência dos critérios adotados. Não foi julgado nem o mérito nem a adequação dos critérios, mas se eles estavam ou não disponíveis para a consulta ${ }^{74}$.

Pode-se observar que a maior parte das empresas (50\%) não divulga seus critérios e outras (24\%) o fazem de maneira precária. Apenas uma minoria (16\%) possui graus de transparência classificados como excelentes ou bons.

A falta de transparência pode ser forte indício da ausência de critérios minimamente ancorados em categorias artísticas, mas isso não ocorre em todos os casos. Por exemplo, o Itaú Cultural foi classificado como instituição com grau de transparência inexistente, o que não parece corresponder à ausência de uma linha curatorial. Nesse caso, a não divulgação dos critérios não decorre de ausência de critérios artísticos em suas escolhas. O BB foi considerado com grau excelente de transparência, juntamente com a Petrobrás, a Usiminas e o grupo Votorantim.

As inscrições para a seleção do CCBB são feitas no site da instituição, com o preenchimento de extenso formulário eletrônico, muito antes do período em que efetivamente será realizada. Normalmente, no mês de março, são inscritos os projetos artísticos que poderão ser viabilizados no ano seguinte. Portanto, muitas inscrições ocorrem sem a expectativa de que os projetos serão efetivados no formato proposto. Nas artes cênicas, por exemplo, é praticamente impossível acordar um projeto com todos os intervenientes (diretor, atores, assistente de direção, cenógrafos, figurinistas etc.) com uma antecedência que pode chegar a 21 meses.

Terminada a fase de inscrição, os projetos são estudados por analistas que compõem o quadro do CCBB. Para subsidiar as escolhas, eles recebem orientações da Diretoria de Marketing, acerca das estratégias mercadológicas do BB para o ano, e a contribuição possível do Centro Cultural para que sejam atingidas as metas comerciais da empresa. Em outra estratégia, o CCBB tem realizado o denominado Painel de Tendências, para o qual são convidados artistas, produtores culturais, teóricos e curadores das diversas áreas patrocinadas, a fim de traçar um panorama de suas necessidades e perspectivas naquele ano.

Após uma pré-seleção de cada analista, os projetos são discutidos com o gerente de programação, que, posteriormente, os submete à chefia do Centro Cultural e ao gerente de planejamento do CCBB. Os gerentes dos CCBBs levam

\footnotetext{
${ }^{74}$ Esses dados foram compilados e são apresentados no Anexo $14 .$.
} 
suas propostas de programação para uma discussão conjunta, visto que os projetos podem ser inscritos para um único ou para mais de um Centro Cultural. É comum haver itinerância dos projetos patrocinados, pois isso diminui consideravelmente os custos do patrocínio.

No caso das artes plásticas, de acordo com a Lei 9.874, para haver dedução de $100 \%$ do valor investido no imposto de renda a pagar, é necessário que a exposição circule. Nesse caso, há certa disputa na definição de qual Centro Cultural será sede da estréia ou inauguração, pois, dependendo do porte do evento, a abertura poderá atrair toda a mídia nacional, havendo menos repercussão nas passagens posteriores.

Definidos os valores possíveis para cada projeto, conforme definição do orçamento para o ano pelo BB, a programação é, então, submetida à aprovação do Comitê da Diretoria de Marketing, passando depois pelos crivos da Secretaria de Comunicação da Presidência da República, do Ministério da Cultura, do Comitê de Comunicação e do Conselho Diretor do Banco do Brasil, âmbitos nos quais não tem havido maiores questionamentos.

Antes da divulgação pela imprensa dos projetos selecionados, o CCBB ainda negocia com os produtores a respeito de valores e eventuais adequações nas propostas. Normalmente, as importâncias aprovadas são inferiores ao montante solicitado, o que implica a necessidade de adequações no orçamento pelos proponentes.

À época do desembolso dos recursos, o CCBB redige documento submetido à Diretoria de Marketing, que, finalmente, aprova o crédito ao projeto aprovado, já constante da grade de programação daquele ano. Simultaneamente, a Assessoria Jurídica analisa o contrato que será assinado entre o BB e o Produtor Cultural e tece considerações acerca da inexigibilidade da licitação pública para a escolha do projeto a ser patrocinado.

Antes de depositar o recurso ao produtor, o CCBB divulga, no Diário Oficial da União, a dispensa da licitação pública e o valor a ser desembolsado. Os projetos também precisam ser aprovados individualmente pelo Ministério da Cultura, dentro dos parâmetros da Lei Rouanet, para que o BB possa ter o valor do patrocínio deduzido do imposto de renda.

Nos últimos quatro anos, o Banco do Brasil tem tido, em média, 2.626 projetos inscritos e patrocinado em torno de 226 deles por ano. 
O fato de os projetos serem defendidos por seus propositores por meio de relatório escrito, em modelo pré-determinado, torna determinante para a escolha o arrazoado que sustenta a idéia ou proposta artística. Essa habilidade, bastante comum aos proponentes da área denominada "Idéias", não é necessariamente desenvolvida pelos proponentes de outras áreas, que, em sua prática de trabalho, muitas vezes privilegiam outras linguagens.

Uma proposta interessante mal elaborada textualmente tem grandes chances de não ser aprovada. A instituição valoriza, com esse modelo, os artistas que tenham condições de sistematizar seu pensamento e de fundamentar suas propostas, fazendo uma defesa consistente das idéias que desejam implementar artisticamente.

$\mathrm{Na}$ análise dos projetos rejeitados, foram constatadas propostas de profissionais de renome tão mal redigidas, que não tornavam minimamente claras suas intenções. Essa dificuldade pode ser decorrente do processo de formação desses profissionais, talvez muito centrado em aspectos práticos e técnicos, em detrimento de visão mais ampliada que envolva o desenvolvimento da expressão lingüística e possibilite formas mais elaboradas de raciocínio.

O domínio da palavra faz-se presente no campo artístico tanto nessa fase pré-obra, quanto, se for pensado o papel do crítico e dos demais especialistas do campo, na de intermediação da obra com o seu público. O poder da palavra investe o locutor de uma competência superior que interfere na avaliação das competências técnicas da obra sob análise. Argumentos persuasivos podem tornar convincentes um olhar, um ato ou uma obra, cuja proposta, na ausência do suporte discursivo, fica sem sustentação.

\subsection{OS PROGRAMADORES CULTURAIS}

Os programadores culturais são funcionários do BB que ingressaram na carreira como escriturários e, mediante processo seletivo, obtiveram promoções e foram "comissionados". Os que possuem nível de execução ocupam o cargo de analista, nomenclatura genérica atribuída a grande número de funções comissionadas, em órgãos regionais, como é o CCBB, e nas diretorias do Banco do Brasil. 
Atualmente, dez analistas, quatro gerentes (um dos quais gerencia a equipe dos programadores culturais), dois escriturários e uma assistente, totalizando dezessete funcionários, compõem o quadro do CCBB. Os analistas assumem o papel de programadores somente em um período muito específico, o da seleção dos projetos. No restante do ano, trabalham na viabilização dos projetos selecionados anteriormente e atuam junto aos seus Produtores. Cada analista julga os projetos de uma determinada área, normalmente aquela que conhece melhor e com a qual tem mais afinidade. Os "programadores" das artes cênicas e plásticas do CCBB São Paulo atuaram anteriormente nas áreas sob sua responsabilidade, o primeiro como ator e o segundo como pintor.

A faixa etária média dos funcionários do CCBB São Paulo é relativamente elevada: 40,83 anos (Anexo 15); em média, estão lá há 5 anos, grande parte deles desde que foi inaugurado e também têm longa trajetória como funcionários do BB: em média 18 anos. Quanto à formação, apenas uma funcionária possui somente o ensino médio; os demais cursaram o ensino superior ou a pós-graduação - quatro possuem pós-graduação lato sensu, todos nas áreas de marketing ou administração de eventos.

Quanto à área de formação, somente dois deles possuem graduação em área que pode ser considerada específica do campo artístico: um possui graduação em artes cênicas e outra, licenciatura em artes plásticas. No entanto, outros dez possuem curso superior em áreas que podem ser consideradas afins à de gestão cultural - as de Marketing, Comunicação, Publicidade e Relações Públicas, Letras e Desenho Industrial. Ressalte-se que ainda há poucos cursos na área de gestão cultural no país e que apenas algumas universidades oferecem especialização nessa área, em nível de pós-graduação.

Diante desses dados, pode-se concluir que, apesar de demonstrarem possuir conhecimentos e afinidades com ele, os funcionários do CCBB não podem ser considerados especialistas ou autoridades no campo artístico, ao contrário do que diagnosticou Claudia Madeira (2002) estudando algumas instituições culturais de Lisboa.

A nossa análise destaca que, no caso dos programadores integrados em instituições, a formação acadêmica serviu como 'reforço' da posição de entrada no mundo da arte. Existe uma articulação cumulativa entre os campos acadêmico e artístico (os programadores são paralelamente professores universitários). 
Estamos perante um forte fator de intermutabilidade através de uma diversificação conexa ou periférica. A posição elevada num campo serviu de catalisador para o convite para a posição elevada no mundo artístico. (Madeira, C, 2002:33)

Os programadores do CCBB não possuem vínculos com a academia e não são teóricos ou críticos do campo artístico. Dessa forma, seu recrutamento não derivou de ocuparem posição de destaque nas artes; entretanto, talvez pelo fato de, no universo dos funcionários do $\mathrm{BB}$, predominarem formações acadêmicas em Administração de Empresas, Direito e Economia, foram selecionados para o CCBB os analistas que mais afinidade possuíam com as artes. Entretanto, na medida em que não mantêm posições de prestígio no campo artístico ou não são vistos como originários dele, de alguma forma, acabam colocando o CCBB como instituição exógena ao universo artístico.

Algumas instituições, como a Petrobrás, convidam nomes de destaque nas diversas áreas artísticas para comporem o júri que selecionará os projetos a serem patrocinados, divulgando-os juntamente com a identificação dos escolhidos. A empresa coordena e participa de todo o processo e geralmente ratifica a decisão tomada. Também a Caixa Econômica Federal convida especialistas para essa atividade. Ambas as empresas são assessoradas por consultorias terceirizadas que colaboram com o processo seletivo.

No CCBB, esse processo é inteiramente conduzido por funcionários do Banco. Os artistas e "representantes" de cada área são ouvidos em momento anterior ao da seleção, no denominado Painel de Tendências, mas a decisão sobre o que (e quem) patrocinar é tomada por membros do CCBB e da Diretoria de Marketing. Questionados a respeito da baixa participação de artistas na seleção dos projetos, os funcionários do CCBB alegaram que, como as opções jamais são consensuais e não é viável uma sistemática eletiva, as escolhas recairiam sobre a tendência ou preferência do(s) selecionador(es), não sendo obtida a diversidade preconizada pela política cultural da instituição.

O recrutamento dos profissionais que trabalham no Centro Cultural algumas vezes ocorre por processo seletivo interno, para o qual se pode habilitar qualquer funcionário do BB, seguindo os esquemas tradicionais de seleção, os quais envolvem análise de currículos, entrevistas e dinâmicas de grupos. Outras vezes - 
que parecem ser mais freqüentes -, as escolhas vinculam-se a relacionamentos interpessoais e a processos seletivos mais limitados.

Apesar de exercerem papel decisivo na triagem e na proposição inicial do programa, os analistas têm papel subalterno no processo. A escolha é influenciada pela correlação de forças existente na empresa, sendo que, embora ocorra interferência dos níveis gerenciais superiores externos ao CCBB, ela é bastante limitada.

\subsection{Os Produtores Culturais}

Não obstante não sejam avaliados no momento da seleção dos projetos, os Produtores Culturais são os profissionais com quem o CCBB tem maior interface, intermediando a relação com os artistas. Tamanha é a sua importância que o CCBB São Paulo preparou um manual com orientações práticas para esse profissional. Havendo um Produtor Cultural eficiente, é facilitado o trabalho mais burocrático que os funcionários precisam desempenhar, o que assegura certa tranqüilidade na hora de viabilizar o projeto.

Denominam-se Produtores Culturais, aqueles profissionais que trabalham para os artistas, a fim de viabilizar a produção da obra em termos não-artísticos. No caso das artes cênicas, sua função primeira, está relacionada aos técnicos dos espetáculos (cenógrafos, iluminadores, figurinistas), provendo-os dos insumos necessários -- matérias-primas - necessários ao suporte tangível da obra. No caso das artes plásticas, trabalham junto aos montadores da exposição, provendo os materiais necessários para a montagem, mas também se envolvem com outras questões, tais como aspectos administrativos e comerciais para a cessão das obras, transporte e seguros, entre outros. Nas artes cênicas, muitas vezes administram financeiramente os recursos do espetáculo. Responsabilizam-se pela gerência da bilheteria (não no caso do CCBB, já que ali essa incumbência cabe ao patrocinador), pelo pagamento do cachê aos artistas, pelo pagamento aos fornecedores e pelo recolhimento dos impostos.

Após a criação das leis de incentivo, novas atribuições foram agregadas às acima citadas. Os Produtores Culturais a passaram a responsabilizar-se, muitas vezes, pela captação dos recursos junto às empresas, pela submissão dos projetos 
às instâncias governamentais que permitirão a isenção fiscal ao patrocinador propiciada pelo projeto, e também pelas prestações de contas decorrentes do uso de recursos incentivados.

Tais responsabilidades levaram ao surgimento de diversos cursos visando a capacitar esses profissionais, os quais, para a prestação de contas, precisam entender minimamente da legislação de incentivo e de técnicas contábeis de controle dos recursos.

Os artistas com menos recursos econômicos acumulam a função de Produtores Culturais, impossibilitados que estão de remunerar esse profissional. Porém, mesmo quando é possível contratá-lo, a criação artística não consegue eximir-se da intromissão das preocupações desses agentes no momento da confecção da obra, o que provoca a internalização de valores empresariais, contábeis e legais em terreno que sempre fora hostil a essas questões "profanas":

Antes, o acesso às verbas sempre escassas (isto é, ofertadas em quantia menor do que a demanda) dependia de uma combinação de critérios objetivos - como concursos e licitações - e patrimonialistas - como 'direitos de procedência' baseados na tradição ou na articulação política de lobbies poderosos. No contexto inaugurado pela Lei Rouanet, os criadores culturais e produtores tradicionais foram levados a se travestirem de 'empresários', pois o objetivo de 'produzir cultura' foi substituído pelo de 'captar' recursos no mundo empresarial. O treinamento e capacitação em técnicas gerenciais tornaram-se mais importantes do que a habilitação artística. (...) Se antes o artista ou artesão mais se aproximava do modelo de um funcionário público contratado por empreitadas, agora o profissional cultural mais se assemelha ao consultor de grandes corporações: ele leva até os diretores de marketing - ou diretores corporativos - as 'oportunidades de negócio' que vislumbra pela combinação de renúncia fiscal, administração da produção cultural e fortalecimento da imagem pública do cliente num mercado que, agora, valoriza ações de cunho social e cultural como diferenciais competitivos. (Dória, 2003:18-19)

Muitas vezes, o trabalho do Produtor é bastante conveniente para o artista, pois exerce funções semelhantes às do editor, do marchand, ou à do denominado "empresário", que trabalham para os grandes nomes da literatura, das artes plásticas e da música, antes existentes somente em terrenos nos quais havia efetivamente um mercado de arte. 
O Produtor age como anteparo, permitindo que o artista mantenha a aura de desinteresse em relação às questões econômicas, transferindo o encargo para esse profissional, já que o envolvimento com os aspectos financeiros the poderia ser desmoralizante. Nos casos das artes cênicas ou plásticas, contudo, o Produtor não tem o mesmo poder e conhecimento simbólico dos profissionais citados acima (editores, marchands, por exemplo) no que diz respeito a descobrir e investir em talentos ainda desconhecidos do mercado. Trata-se mais de uma especialização necessária para atender a uma demanda de novas competências, que não interessava aos artistas desenvolver, decorrente do grau maior de complexidade presente no campo artístico, na medida em que aumentam a participação das empresas no fomento à produção, e os controles exigidos pelos Governos para propiciar os incentivos fiscais.

No entanto, os Produtores são, eventualmente, também apontados não só como intermediários, mas como atravessadores que se beneficiam de modo indevido de recursos que deveriam ser utilizados diretamente no fomento artístico:

Os maiores lucros, contudo, ficam com os intermediários. De um lado, as empresas de comunicação, cujos anúncios pagos, constituem gigantesca fonte de renda, em média $30 \%$ dos orçamentos. De outro, a casta dos 'captadores de recursos', gente que embolsou de $10 \%$ a $20 \%$ do bilhão do ano passado apenas por ter acesso ao cafezinho das diretorias de empresas. (Carvalho, Sérgio de e Rodrigues, Marco Antônio. O negócio da cultura. Folha de S. Paulo, São Paulo, 16/04/08, Opinião, A3).

\subsection{OS CRITÉRIOS DE ESCOLHA}

Ao apresentar a razão das escolhas feitas para a programação do CCBB, não se pretende estabelecer discussão acerca de uma "estética do gosto", já que os atores sociais responsáveis pela seleção jamais identificam esse elemento como um dos considerados, muito embora também esteja presente na definição das propostas. Se o juízo estético se apresenta normalmente vinculado à esfera da subjetividade, esse fato fica obnubilado no processo de seleção, devido à complexa rede de categorias componentes do mecanismo de regulação e normatização dos valores presentes nas preferências.

A relatividade e a diversidade dos juízos estéticos ancoram-se em acordos intersubjetivos com certo grau de solidez e estabilidade (sem os quais seriam 
fenômenos de difícil apreensão). Entretanto, a maneira como, na contemporaneidade, as obras de arte são hierarquizadas e classificadas parece muito mais confusa do que foi outrora. Para a maior parte dos seus apreciadores, o campo artístico aparece como carente de coerência e organização. Mesmo sendo verdade que as diferenças e as hierarquias de valor continuam existindo, elas são controversas. "A instabilidade e a fragilidade do juízo estético são tão fortes como sua pretensão de ser categórico" (Michaud, 2002:45)

Estamos utilizando a expressão "julgamento estético" para fazer referência às avaliações relativas ao valor artístico de um objeto. O corpo de especialistas e conhecedores, a saber, críticos, intelectuais e os próprios produtores culturais, continua sendo referência na distinção e classificação das obras, porém o saber produzido é pleno de relativizações, baseado em consensos provisórios, quando não inexistentes. Ao contrário da arte renascentista ou da arte acadêmica do século XVIII europeu, para as quais os referenciais que distinguiam a boa obra daquela de qualidade inferior eram amplamente validados por todos os integrantes do campo artístico, hoje, parece que as instâncias de consagração possuem maior dificuldade de tornar hegemônicos os seus esquemas de classificação, em função da diversidade mesma das obras produzidas, as quais possibilitam apreciações sob prismas muito variados.

A triagem efetuada pelos analistas do CCBB tem como roteiro uma ficha de avaliação com critérios que permitem identificar o grau de aderência das propostas às expectativas de patrocínio do BB. A maior parte desses critérios é de prévio conhecimento dos proponentes, pois também está disponível no site da instituição. Essas fichas sofreram alteração de conteúdo nos dois anos em que o CCBB foi objeto desta análise, sendo aperfeiçoados os critérios utilizados.

Em 2006, a ficha utilizada para a seleção dos projetos foi dividida em duas fases, a primeira sendo eliminatória ("capacidade técnica”, "inovação", "compatibilidade com a estratégia de atuação do CCBB" e "adequação ao espaço físico"), com peso maior no cômputo final. Ela continha um número maior de critérios e teve a incorporação de aspectos ausentes em 2005, entre eles "Compatibilidade com a estratégia de atuação do CCBB", "Identidade Institucional", "Potencial de Mídia" e "Potencial de Público". A ficha do ano anterior não possuía essa divisão entre primeira e segunda fases, além de possuir um número menor de critérios. No 
quadro a seguir, é relacionada a nomenclatura utilizada nas fichas de análise dos projetos selecionados para a programação dos anos de 2005 e 2006:

\begin{tabular}{|c|c|}
\hline \begin{tabular}{|lr} 
Critérios & \\
utilizados & para \\
seleção & da \\
programação & de \\
2005 & \\
\end{tabular} & Critérios utilizados para a seleção da programação de 2006 \\
\hline Temática & Relevância Cultural e Temática $-2^{\mathrm{a}}$ Fase \\
\hline Nomes envolvidos & Capacidade Técnica de Realização (ficha técnica) - 1ª Fase \\
\hline Formato & $\begin{array}{l}\text { Inovação (originalidade + ineditismo) }-1^{\underline{a}} \text { Fase } \\
\text { Adequação ao espaço físico do CCBB }-1^{\underline{a}} \text { Fase }\end{array}$ \\
\hline Produção & Capacidade Técnica de Realização (ficha técnica) - $1^{\text {a }}$ Fase \\
\hline Orçamento & Compatibilidade orçamentária $-2^{2}$ Fase \\
\hline $\begin{array}{ll}\text { Sem } & \text { critério } \\
\text { equivalente } & \end{array}$ & $\begin{array}{l}\text { Compatibilidade com a estratégia de atuação do CCBB - } 1^{\mathrm{a}} \\
\text { Fase }\end{array}$ \\
\hline $\begin{array}{ll}\text { Sem } & \text { critério } \\
\text { equivalente } & \end{array}$ & $\begin{array}{l}\text { Identidade Institucional (conforme Planejamento Estratégico } \\
2006 \text { CCBB SP) }-2^{2} \text { Fase }\end{array}$ \\
\hline $\begin{array}{ll}\text { Sem } & \text { critério } \\
\text { equivalente } & \end{array}$ & Potencial de Mídia - 2ª Fase \\
\hline \begin{tabular}{|ll} 
Sem & critério \\
equivalente &
\end{tabular} & Atratividade de Público- $2^{\mathrm{a}}$ Fase \\
\hline
\end{tabular}

Pela análise dos documentos, é possível inferir que, muitas vezes, as fichas de avaliação foram preenchidas de forma burocrática, sem que efetivamente fossem utilizadas de forma detida como instrumento de classificação dos projetos.

O prazo para a classificação é restrito e muito grande o número de projetos em análise; além disso, o analista que examina as propostas é o mesmo que cuida da produção e da efetivação das aprovadas no ano anterior, o que, certamente, acaba sendo priorizado. Apesar disso, muitas fichas estudadas parecem ter sido preenchidas com cuidado, havendo a precaução, por parte do analista, de justificar as razões do seu (in) deferimento. Nas entrevistas, também foi possível comprovar 
que os critérios supracitados acabaram sendo os decisivos para a definição da programação, ainda que de maneira incipiente e sem a devida sistematização.

Os critérios utilizados pelo CCBB mantêm certa coerência com os utilizados por outras instituições em que ocorrem processos públicos para a escolha de projetos artísticos a patrocinar. No Anexo 16, podem ser vistos os critérios utilizados pela Caixa Econômica Federal e pela Petrobrás em seus procedimentos de seleção. É possível identificar critérios recorrentes nos vários processos existentes, tais como relevância, qualidade artística, ineditismo, capacidade técnica de realização e viabilidade financeira.

As escolhas do CCBB estão vinculadas à pretensão de universalidade, imparcialidade e isenção no julgamento. No entanto, o campo artístico constitui um espaço de luta, no qual os atores nele inseridos tomam determinadas posições reveladas justamente pelos esquemas classificatórios, que assumem o papel de armas de combate:

A maior parte das noções que os artistas e os críticos empregam para se definir ou para definir seus adversários são armas e apostas de lutas, e muitas das categorias que os historiadores da arte aplicam para pensar seu objeto não são mais que esquemas classificatórios oriundos dessas lutas e mais ou menos habilmente mascarados ou transfigurados. Inicialmente concebidos, a maior parte do tempo, como insultos ou condenações (mas nossas categorias não vêm do grego kategorein, acusar publicamente?), esses conceitos de combate tornam-se pouco a pouco categoremas técnicos a que, graças à amnésia da gênese, as dissecações da crítica e as dissertações ou as teses acadêmicas conferem um ar de eternidade. (Bourdieu, 2005:332)

Assim, a presente análise parte do pressuposto de que esses critérios, ao contrário da universalidade que almejam, são construídos a partir de uma tomada de posição diante das lutas que se travam no interior do campo artístico, revelando, portanto, interesses determinados. Procura-se transcender a incondicionalidade que essas categorias almejam para revelar as condições sociais que lhes deram origem.

\subsubsection{Relevância Conceitual e Temática}

O site do Banco do Brasil na Internet (www.bb.com.br) tenta explicar o significado do critério de relevância conceitual e temática: "Concepção e argumentação que evidenciem importância histórica, cultural e artística." O propósito 
é, então, o de patrocinar eventos cuja importância não se resuma à área artística, mas também envolva relevância histórica e cultural. Não só a idéia artística ("concepção") deve ser interessante, mas também sua justificativa ("argumentação"). O tema abrangido precisa ter sua importância, assim como o conceito que dá sustentação ao projeto. A pergunta que então emerge se refere à forma como ocorre a aferição dessas características.

Sem dúvida, existe um conjunto de saberes instituídos e "discursos competentes" os quais avaliam e hierarquizam os objetos artísticos, classificando-os de acordo com sua importância e relevância. Para dar conta dessa questão, disciplinas como a Estética, a História da Arte, a Teoria da Arte, a Crítica da Arte foram institucionalizadas no meio universitário. É possível, atualmente, levar em conta a Crítica Genética e as pesquisas que se voltam mais ao processo do que ao resultado, mas ainda predominam as teorias sobre o objeto pronto e concluído.

Selecionando os projetos que serão patrocinados, o trabalho das instituições culturais centra-se, sobretudo, na idéia que será desenvolvida, portanto, num "vir-aser". Ademais, os saberes produzidos por essas "ciências" não são verdades absolutas e não têm possibilidade de indicar, de modo claro e preciso, o que é ou não relevante. Muitas vezes, só a posteriori é possível averiguar o acerto (ou não) da decisão tomada. A propósito, a história está repleta de exemplos de obras renegadas por longos períodos que depois obtiveram consagração. Há, sim, críticos e teóricos que acabam criando tendências, quando valorizam determinado trabalho ou artista, pelo prestígio que gozam junto aos demais atores sociais do campo, dando parâmetros para aquilo que deva ser considerado adequado ou pertinente num determinado momento.

Os instrumentos utilizados para avaliar a relevância artística de uma idéia são múltiplos. O modelo hegemônico remete aos juízos dos especialistas, ancorados em saberes intelectualizados, que definem o que é digno de exposição, conservação e admiração coletiva. Como se trata de saber limitado a grupo reduzido, esses julgamentos freqüentemente se confrontam com a capacidade de avaliação cultural dos usuários de museus e instituições culturais, cujas obras podem propiciar ou não a satisfação estética que eles procuram. Se bem que essa procura normalmente já é constituída, ou ao menos influenciada, pelo saber autorizado dos especialistas.

É clássica a interpretação de Bourdieu acerca de como o capital cultural é determinante da (im)possibilidade do diálogo do apreciador com o objeto artístico. "A 
obra de arte só adquire sentido e só tem interesse para quem é dotado do código segundo a qual ela é codificada" (Bourdieu, 2008: 10). Como a apreensão desses códigos ou, na expressão de Bourdieu, dessa "competência cultural" só é possível pelo intenso processo de socialização e educação dos sentidos, os gostos e julgamentos estéticos funcionam como marcadores de distinção da classe social à qual se vinculam. Esses códigos, contudo, não são explicitados definitivamente e de maneira unívoca: "Tudo parece indicar que, mesmo entre os profissionais da atribuição, os critérios que definem as propriedades estilísticas das obrastestemunho nas quais se apóiam todos os julgamentos permanecem, quase sempre, no estado implícito." (Bourdieu, 2008: 12)

O objeto artístico é reverenciado como "sagrado", o que afirma a superioridade dos que se sabem satisfazer com os "prazeres sublimados, requintados, desinteressados, gratuitos, distintos" (Bourdieu, 2008: 14) que a arte proporciona, fazendo com que ela assuma uma função social de legitimação das diferenças sociais. Dessa forma, a relevância buscada pelo CCBB nos projetos a serem patrocinados procura valorizar a obra dotada de características que a constituam como um signo de distinção, não acessível àqueles desprovidos de capital cultural.

\subsubsection{Viabilidade Técnica}

Por viabilidade técnica, o CCBB entende a "demonstração de capacidade de realização ou envolvimento de profissionais com notória especialização." Não basta ter uma idéia e demonstrar que ela é relevante, é preciso comprovar a capacidade de realizá-la, de tornar concreto e palpável aquilo que é apenas um plano e uma intenção.

A demonstração da competência para a realização do projeto proposto é sustentada pelas evidências demonstradas pelo proponente, de ter posse do conhecimento necessário para concretizar o projeto, normalmente baseadas em diplomas e certificações obtidos no sistema formal de ensino. Embora no meio artístico isso seja menos importante do que em outras áreas do saber - pela relevância atribuída ao talento e ao dom no fazer artístico, considerados qualidades inatas -, ainda assim os certificados têm seu valor e adquirem maior peso quando emitidos por instituições internacionais de renome. 
Outra forma de demonstrar a competência do fazer artístico é a apresentação de trabalhos anteriores, de qualidade. Acima de qualquer diploma, nada propicia mais prestígio do que uma obra bem-sucedida, assim entendida aquela que foi agraciada pela crítica, respaldada por instituição cultural de prestígio ou cujo preço de venda tenha atingido patamares elevados (no caso das artes plásticas). Exposições em museus ou galerias prestigiadas, presença em bienais consagradas, peças com críticas favoráveis veiculadas em jornais de grande circulação, realização de espetáculos em festivais de peso são eventos que "engrandecem" currículos e são elementos consistentes para a conclusão de existência de "viabilidade técnica", por parte do patrocinador, que the daria conforto para apoiar um dado projeto.

Caso o proponente não consiga demonstrar sua capacidade técnica, o CCBB ainda the faculta uma alternativa - o "envolvimento de profissionais com notória especialização" no projeto. Notoriedade, prestígio, fama, status são termos correlatos e configuram a principal moeda do campo artístico. Muitas vezes, ela é resultado justamente da capacidade técnica do proponente. A grande crítica que alguns artistas de teatro costumam fazer à televisão é sua capacidade de "fabricar famosos", sem que eles demonstrem qualquer habilidade especial ou competência técnica em algum métier. Assim, artistas do meio teatral vêem com restrição o grande número de modelos presentes em novelas ou a notoriedade atingida por envolvidos em "reality shows".

Esse critério limita a possibilidade de aprovação de projetos de artistas em início de carreira, os quais terão maior dificuldade de comprovar sua competência técnica ou de valer-se de "profissionais com notória especialização". Se, na análise, esse critério preponderar sobre os outros, há o risco de o CCBB acabar consagrando somente os já consagrados, o que seria grosso modo um "patrocínio fácil". Percebe-se, contudo, nos documentos analisados, a preocupação com o auxílio a "novos talentos" - vários projetos foram agrupados nessa categoria e, como será visto no próximo capítulo, mesmo com espaço reduzido, esses artistas também têm lugar na programação do Centro Cultural.

A propósito, seleção de projetos sem licitação pública, em termos jurídicos, só é possível em função justamente da notoriedade dos beneficiados com o patrocínio. Pelo fato de o CCBB ser empresa controlada pelo Governo Federal, todas as contratações por ele feitas de serviços de terceiros devem submeter-se a processos de licitação, obedecendo aos parâmetros da Lei 8.666. No entanto, essa mesma Lei 
apresenta a ressalva, no inciso terceiro do artigo vigésimo-quinto, de que não é necessária a licitação quando "houver inviabilidade de competição, em especial para a contratação de profissional de qualquer setor artístico, diretamente ou através de empresário exclusivo, desde que consagrado pela crítica especializada ou pela opinião pública." (grifo nosso)

Os legisladores, a fim de evitar favorecimentos ilícitos ou desvios de verbas públicas, certamente não atentaram para a natureza restritiva do artigo, que, de certa forma, inviabiliza a contratação de jovens artistas se não houver processo licitatório. Por tratar-se de temática controversa, antes de assinar contratos com os produtores, o CCBB submete-os à assessoria jurídica do Banco, que emite parecer acerca da inexigibilidade do processo aludido.

Talvez esse seja o critério mais determinante nas escolhas, pois é o que dá mais garantias, ainda que sempre insuficientes, de que a obra patrocinada terá a qualidade desejada. Considerando que a arte contemporânea rompeu definitivamente com as categorias estáveis e consensuais de avaliação do objeto artístico, a reputação torna-se, muitas vezes, o critério predominante. No entanto, esse fato dá poder ainda mais acentuado para as estruturas de consagração, a saber, críticos, júris de premiação, instituições culturais etc..

\subsubsection{Inovação}

Esse é um critério estético por excelência na contemporaneidade. A afirmação da singularidade do criador e da obra de arte é o que lhe define a autonomia e constitui propriamente o campo artístico como campo diferenciado da vida social. Originalidade, inventividade, ousadia são nele valores extremamente importantes.

É complexa a relação que, no momento atual, a obra artística precisa estabelecer com a tradição e com a inovação:

Assim se define a posição ambígua do artista. Se sua produção não está impregnada de uma característica pessoal muito forte, marcada (o que implica uma posição individualista, e por conseqüência fortemente anti-social e, portanto, subversiva), ela não tem validade. Se, entretanto, esse temperamento individualista é incitado a ponto de recusar toda comunicação com o público, se esse temperamento individualista se exaspera até não mais desejar que a obra produzida seja colocada sob os olhos de alguém, ou mesmo até fazê-la intencionalmente tão secreta, tão cifrada, que ela se dissimula diante 
de todo olhar, sua característica de subversão, portanto, desaparece; ela se torna como uma detonação que, produzida no vazio, não emite mais nenhum som. $O$ artista se acha solicitado por duas aspirações contraditórias, virar as costas ao público e encontrar-se com ele. (Dubuffet, 1986).

Algumas rejeições de projetos no processo de seleção são justificadas pelos analistas como sendo relativas àquelas propostas artísticas que possuem similares "no mercado". Temas que foram objeto de exposições anteriores na cidade também não têm avaliação positiva. Por exemplo, o projeto Vestido de Artista, uma exposição de Arte e Moda foi considerado inadequado por sua similaridade com a exposição Do Espartilho ao Silicone, realizado pelo Instituto Cultural Itaú. O projeto O ouro da América, que propunha a exposição de peças de ouro para, por seu intermédio, explicar o passado colonial do continente, foi rejeitado, apesar de ser considerado interessante, pelo fato de, anteriormente, ter havido exposições que retratavam objetos de arte latino-americanos (Por ti América). Projetos que tinham por foco a arte africana ou a temática racial foram rejeitados pelo mesmo motivo, como Filhos do silêncio: a imagem do negro; nele, o analista registrou a seguinte justificativa: "tema já muito explorado pelo museu Afro Brasil - desgaste da temática". Também propostas já apresentadas ou submetidas a outros museus e espaços expositivos são, com freqüência, rejeitadas no processo seletivo.

A necessidade de novidade relaciona-se diretamente com a demanda das instituições culturais, as quais buscam alimentar a mídia com pautas que também atraiam o público consumidor de jornais e revistas, garantindo a visibilidade desejada.

A inventividade relaciona-se intimamente com a aura que ronda a criação artística e que the dá prestígio praticamente inigualável entre as produções humanas. A obra de arte possui a capacidade de, a partir da imaginação de quem a produziu, divertir e tocar a quem dela usufrui. Normalmente, a criação artística choca, questiona e instiga mediante processos metafóricos que muitas vezes envolvem o deslocamento do sentido e a quebra de regras e normas sociais. Isso é bastante contraditório com o espaço bancário, do qual o CCBB herda determinadas características, em que predomina o ambiente do controle, da obediência às regras, da previsibilidade do comportamento e da interação social.

O critério de inovação revela certa ingenuidade, na medida em que remete à idéia romântica de liberdade absoluta do gênio criador, como se toda criação 
(artística, científica, religiosa etc.) não fosse resultante do espaço dos possíveis que se configuram em dado momento histórico. Qualquer campo social apresenta um universo finito de liberdade de ação. Portanto, as inovações precisam existir em estado potencial no espectro dos possíveis já realizados, como lacunas, brechas que esperam o preenchimento. Além disso, "é preciso que tenham possibilidade de ser recebidas, isto é, aceitas e reconhecidas como 'razoáveis', pelo menos por um pequeno número de pessoas, aquelas mesmas que sem dúvida teriam podido concebê-las." (Bourdieu, 2005: 266)

Se esse critério tivesse peso considerável nas escolhas, certamente haveria uma programação efetuada principalmente por artistas em início de carreira, o que, como veremos no próximo capítulo, não ocorre. Com menos capital simbólico acumulado, os jovens, premidos pela necessidade de diferenciar-se, correm mais riscos em suas escolhas, têm menos a perder e procuram afirmar-se em contraposição à tradição. Buscam a valorização pelo desenvolvimento que suas produções almejam:

A iniciativa da mudança cabe quase por definição aos recémchegados, ou seja, aos mais jovens, que são também os mais desprovidos de capital específico e, que, em um universo onde existir é diferir, isto é, ocupar uma posição distinta e distintiva, existem apenas na medida em que, sem ter necessidade de o querer, chegam a afirmar sua identidade, ou seja, sua diferença, a fazê-la conhecida e reconhecida ("fazer um nome"), impondo modos de pensamento e de expressão novos, em ruptura com os modos de pensamento em vigor, portanto, destinados a desconcertar por sua "obscuridade" e sua "gratuidade". (Bourdieu, 2005:270-271)

$\mathrm{Na}$ arte contemporânea, notadamente nas artes plásticas, a comparação necessária para definição da qualidade de uma obra - com as normas e com as regras básicas do fazer artístico tem peso reduzido diante do imperativo da originalidade e de seu corolário que é a inovação, o que torna o trabalho do selecionador em uma instituição cultural bastante complexo:

A convenção de originalidade reduz o espaço de possíveis especificando qual deve ser a condição necessária para preencher para obter o status de obra de arte contemporânea, mas esta condição está longe de ser suficiente. Subsiste assim uma forte incerteza quanto aos critérios ulteriores de decisão sobre as inovações importantes dignas de entrar na história da arte. É por isso 
que as redes de legitimação, construídas sobre o modo adocrático ${ }^{75}$ são construídas para tratar a complexidade e a instabilidade do meio e oferecer sua resposta ao problema da determinação da qualidade. As instâncias de legitimação do mundo da arte são constituídas por especialistas, o que o inscreve definitivamente na configuração adocrática na qual são os especialistas que detêm 0 poder. (Moureau, 1995:321)

\subsubsection{Adequação física}

Para muitas propostas artísticas, o espaço do CCBB é reduzido. Tanto o espaço expositivo quanto o teatro onde se realizam os espetáculos de artes cênicas e de música trazem limitações à criação artística. Essa é a principal queixa dos funcionários e, na visão deles, associada à localização, o principal limitador para o engrandecimento da presença do CCBB.

Um número considerável de projetos é recusado por não considerar essas limitações. Assim, uma exposição com cerca de cinqüenta cartazes e outras cinqüenta publicações do "designer" Pierre Mendell foi considerada excessiva para o espaço físico do CCBB São Paulo, apesar de considerada conceitualmente boa, segundo registros do analista. Da mesma forma, foi rejeitado projeto que previa a grafitagem das paredes do CCBB, pelo fato de o prédio ser tombado. Muitas exposições provindas da filial carioca são realizadas em São Paulo com número bastante inferior de objetos, em função do espaço reduzido, o que normalmente acarreta comentários negativos nas reportagens de divulgação.

Alguns artistas utilizam-se das constrições espaciais para elaborar propostas artísticas que as subvertam em prol de certa ousadia conceitual, como ocorreu na já mencionada exposição inaugural do Tunga.

Existiram tentativas de aumentar as instalações do Centro Cultural paulista, que envolveram as idéias de saída do atual espaço e de estabelecimento de outra sede. Entretanto, sair do centro da cidade poderia acarretar problemas de imagem ao BB, uma vez que a opção pela instalação do CCBB na região central se articulava com o processo em curso de revitalização do centro. Apesar do interesse dos funcionários de São Paulo, provavelmente pelos altos custos envolvidos, o projeto de ampliação não conseguiu apoio da direção do Banco,.

\footnotetext{
${ }^{75} \mathrm{O}$ conceito de adocracia, usado na área de Administração de Empresas (Toffler, 1982), provém do latim ad hoc e significa "para isso", "para esse fim". Remete a um estilo organizacional mais flexível, favorecendo
} 


\subsubsection{Adequação financeira}

Esse critério procura observar a compatibilidade dos projetos com "a disponibilidade orçamentária e os preços praticados no mercado" (www.bb.com.br).

Se a criatividade e o impulso libertário da produção artística são vistos como ilimitados e, a princípio, sem restrições de qualquer natureza, eles sempre se deparam com barreiras orçamentárias que restringem o potencial imaginativo dos criadores. Assim, obras grandiosas, mesmo bem fundamentadas, não foram aprovadas por sua inadequação ao orçamento disponível. Como a política cultural se ancora na regularidade da programação, a concentração de recursos em um projeto pode inviabilizar a produção de outros.

Via de regra, os projetos aprovados não recebem os valores propostos por seus produtores. A contraproposta do CCBB, normalmente, apresenta valor inferior ao solicitado pelo proponente. No que se refere à remuneração de artistas e técnicos, o Centro trabalha com tabela elaborada pela Articultura, empresa da área de produção cultural, que indica os preços médios praticados no mercado artístico, procurando evitar qualquer superfaturamento.

Considerando os projetos selecionados para artes cênicas e plásticas, em 2005 e 2006, os valores desembolsados pelo CCBB foram, em média, 30\% inferiores aos solicitados.

\subsubsection{Identidade Institucional}

No site da instituição, a explicação desse critério diz respeito à:

- Afinidade com princípios e valores éticos, de transparência, respeito e compromisso com a comunidade e o País.

Trata-se de assertiva apregoada como princípio fundamental pela organização Banco do Brasil que, em alguns momentos, soa contraditório com a atuação financeira da empresa. Em outros, entretanto, como foi visto anteriormente, 
ela dá a plausibilidade pública para a empresa. De qualquer modo, o critério parece não ter muito sentido quando transposto para um projeto artístico. Habitualmente, a arte afirma-se por sua autonomia em relação à ética e à moral. O que seria uma arte "transparente"? O que seria uma arte "compromissada com a comunidade"? Que comunidade ${ }^{76}$ ? É possível falar em uma "comunidade paulistana"?

No começo do primeiro Governo Lula, no Ministério da Cultura e na Secretaria de Comunicação de Governo, teve início ampla discussão sobre a chamada "contrapartida social da arte". Houve manifestações públicas de repúdio, principalmente por parte de cineastas, quando alguns editais de empresas estatais exigiam contrapartida social para o patrocínio. Eles entendiam que a arte já é em si uma contrapartida social e qualquer outra exigência era "dirigismo cultural". No entanto, muitas leis de incentivo em nível estadual e municipal exigem contrapartida social, normalmente efetivada por meio de cursos, oficinas e estágios, com crianças, adolescentes e adultos provenientes das camadas pobres da população. O CCBB não exige nenhum tipo de contrapartida nesse sentido.

O critério evidencia um tom patriótico e altruísta que coaduna com o aspecto economicamente desinteressado esperado das manifestações artísticas patrocinadas.

\subsubsection{Formato e compatibilidade com a estratégia de atuação do CCBB}

Esses critérios não estavam presentes no site do Banco, mas constavam da ficha de avaliação dos projetos, preenchida pelos analistas. ${ }^{77}$.

Das entrevistas, depreendeu-se que por "estratégia de atuação do CCBB" os analistas entendiam algumas linhas gerais de planejamento, abrangendo as várias áreas de interesse, estabelecidas a partir da discussão com a "classe artística" no chamado "Painel de Tendências". Trata-se de reunião em que expoentes das áreas artísticas são convidados a sugerir o que deveria ser patrocinado no ano seguinte, em termos de linguagem e proposta artística. As estratégias do CCBB surgem da discussão que ali se desenvolve. Questionados sobre se essas estratégias eram

\footnotetext{
${ }^{76}$ O clássico conceito de Tönnies (2002) de comunidade contrapõe essa noção à de sociedade, sendo que a primeira se caracterizaria, grosso modo, pela identidade substancial das vontades de seus membros e a segunda pela estrita individualidade dos interesses.

77 O primeiro, "Formato", em 2005, e o segundo, “Estratégia de atuação", em 2006.
} 
registradas em algum documento, os funcionários entrevistados responderam negativamente.

As observações que fundamentam a análise dos projetos rejeitados por não atenderem ao critério de compatibilidade com a estratégia de atuação permitem perceber como os analistas o entendem. Foram rejeitados alguns musicais por não se coadunarem com a estratégia de atuação do CCBB. Projetos ousados de profissionais desconhecidos também foram descartados por não se enquadrarem nessa categoria. Projetos que não se realizem dentro das instalações do CCBB também não são considerados inseridos em sua estratégia de atuação. Formatos diferentes de espetáculo teatral também são desclassificados em função da incompatibilidade com a estratégia de atuação do CCBB. Assim, o projeto Bertolt Brecht - Oito experimentos com as peças de aprendizagem, no qual diversas companhias apresentariam trechos de peças, seguidas por "apreciações críticas" de intelectuais, foi considerado inadequado, por não seguir a sistemática usual de peça teatral.

Os manuais de marketing estabelecem os seguintes procedimentos básicos para o estabelecimento dos planos de patrocínio de empresa:

[O processo de seleção de projetos culturais] deriva da estratégia de marketing da empresa, que é traçada considerando-se seu posicionamento atual e o que seria desejado no futuro, contempla os fatores internos, detectando as oportunidades e ameaças oferecidas à marca. (Reis, 2003: 67)

Percebeu-se, contudo, pelas entrevistas e pela análise dos documentos, que essa fundamentação teórica do marketing cultural não estava plenamente incorporada pelos funcionários do CCBB. Dessa forma, a vinculação com as estratégias da empresa era feita de maneira não muito espontânea. Em alguns momentos, pareceu clara a instrumentalização do patrocínio em prol de objetivos mais estratégicos, como, por exemplo, quando foi citado um evento de música eletrônica que tinha como objetivo mercadológico contribuir para o rejuvenescimento da base de clientes.

Apesar da afirmação de que a estratégia de atuação do CCBB derivava das estratégias constantes do Plano Diretor da empresa, decorrente de um planejamento de longo prazo, isso não se concretizava nas justificativas que embasavam a fundamentação de cada patrocínio aprovado. Muito embora haja planejamento 
formal estabelecido pelo conglomerado para a atuação da área de marketing, seu reflexo nas escolhas de patrocínio não se manifesta de maneira muito intensa, o que certamente dá maior liberdade para as escolhas artísticas efetuadas.

\subsubsection{Potencial de mídia e de atratividade de público}

Esses critérios também não constam do site do CCBB; foram incluídos na ficha de análise dos projetos de 2006, mas receberam poucas observações por parte dos analistas. $\mathrm{Na}$ escolha dos projetos, esses aspectos são levados em consideração, como é possível verificar na justificativa do patrocínio da peça As Turca: "O gênero comédia geralmente é bastante atraente para o grande público, o que faz pressupor não só a manutenção do público costumeiro como também a ampliação do número de espectadores".

Aqui aparecem os critérios que poderiam ser classificados mais claramente como mercadológicos, apesar de igualmente valorizados no campo artístico. Esses dois itens, potencial de mídia e atratividade de público, constavam até recentemente do Acordo de Trabalho $^{78}$ dos CCBBs, o que denota a sua importância para a empresa. Eles revelam o peso da visibilidade no patrocínio empresarial.

A presença do público é fator fundamental, pois o seu contato com as obras de arte patrocinadas pode provocar a "contaminação simbólica" desejada pela empresa, mediante a qual os atributos próprios do meio artístico são incorporados à imagem que os freqüentadores possuem do Banco. A arte normalmente provoca sentimentos, emociona, instiga a reflexão e se associa a atributos muito valorizados como criatividade, ousadia, erudição, sofisticação, beleza. O patrocinador que viabiliza sensações, impressões e emoções marcantes para o público tem, acreditase, a gratidão e o reconhecimento daqueles que usufruem de momentos ímpares de deleite. Além disso, por ter acesso a produtos simbólicos que carregam elevado grau de sofisticação e erudição, o público, ainda que muitas vezes não os compreenda, ou dialogue de maneira incompleta com as obras, sente-se valorizado e

\footnotetext{
${ }^{78}$ Acordo de Trabalho é um instrumento de gestão de todas as dependências do Banco do Brasil. Por meio dele é possível avaliar o desempenho das agências, dos órgãos regionais e da direção da empresa. Interfere na forma de mensurar a avaliação de cada funcionário, repercutindo, inclusive, na Participação nos Lucros e Resultados (PLR). Os órgãos estratégicos da empresa definem os quesitos pelos quais o desempenho de cada unidade será avaliado e estabelecem metas quantitativas para cada um. A variação percentual em torno da meta estabelecida gera uma nota para cada fator de avaliação. Esses quesitos possuem pesos diferenciados e sua soma gera um placar que varia de 0 a 600 . As unidades da empresa que atingem placar acima de 400 têm a PLR integral de seus funcionários assegurada.
} 
"enriquecido" por compartilhar de algo que é "para poucos", pois necessita de capital simbólico para ser usufruído. Também é suposto que a erudição proporcionada pela produção artística seja incorporada à imagem da empresa, a partir desse contato com o público.

Sem a presença de público mais ampliado, o patrocínio empresarial perde sentido, pois resiste à idéia de hermetismo da produção artística, não admitindo que ela seja algo somente para pares ou restritas aos membros do campo artístico. Em contrapartida, a popularização ou vulgarização do objeto simbólico também é algo indesejado, pois implica perda de prestígio que a produção artística precisa conter para provocar a "contaminação simbólica" almejada. As exposições ou peças consideradas "blockbuster" podem ser vistas com ressalvas por críticos, curadores, especialistas e outros membros de "grupos estratégicos" (Cf. Weber, 2003) do campo artístico, que validam e legitimam a produção simbólica como digna de apreciação. Sem a illusio ou a aura, a produção simbólica recebe o rótulo de entretenimento ou produto massificado, perdendo a atratividade para o público mais dotado de capital cultural.

O reconhecimento do trabalho pelos que o vêem ou assistem não está ligado exclusivamente a critérios mercadológicos, já que a quase totalidade dos artistas almeja ter sua obra apreciada e aprovada. Raros são os projetos artísticos cujo fim não seja a apresentação pública. Aliás, tem-se tornado freqüente o contato com o público, antes mesmo da conclusão da obra, tanto no teatro, em ensaios abertos ou apresentação do work in progress, como nas artes plásticas ${ }^{79}$.

A presença de público é habitualmente considerada dos principais fatores de sucesso de uma investida artística. A ela associam-se as avaliações da critica, de especialistas, dos pares e a repercussão na mídia. O motivo de a mídia ser valorizada pelo CCBB é que ela amplifica a "contaminação simbólica" mencionada anteriormente. Além disso, dá visibilidade mesmo àqueles que não freqüentam instituições culturais, mas valorizam o fato de a produção artística estar sendo viabilizada por uma empresa. A centralidade da mídia no patrocínio empresarial será explorada detalhadamente no Capítulo 7.

79 Exemplo disso foi a mostra que ocorreu no Centro de Arte José de Azeredo Perdigão, da Fundação Calouste Gulbenkian de Lisboa, em julho de 2007, que transformou seu espaço expositivo em um imenso ateliê, onde os artistas executavam seu trabalho na frente do público. 
O critério de atratividade pressupõe que o selecionador terá a capacidade de avaliar o gosto do público ou, pelo menos, do que o atrairá para o espaço do CCBB, tarefa bastante complexa.

\subsection{9 "Nichos" de mercado}

As grandes instituições financeiras têm se esforçado para afirmarem-se como bancos completos, isto é, aqueles que podem atender qualquer tipo de cliente, mas se especializam em certos segmentos do mercado. Assim, têm construído canais diferenciados de atendimento, de acordo com o tipo de cliente. O CCBB procura distribuir seus convites tentando abranger esses públicos, notadamente aqueles com faixa de renda mais elevada.

Algumas escolhas são justificadas por atingirem determinados segmentos em relação aos quais o interesse da empresa tem caráter estratégico, normalmente por serem ainda pouco explorados e indicarem oportunidades de negócios. Para exemplificar: um dos pontos que preocupam a direção da empresa é o fato de sua base de clientes ser composta por pessoas cujo perfil etário, em média, é mais elevado do que o dos concorrentes, o que, em longo prazo, poderia comprometer sua preservação. Esse critério demonstra claramente a presença de objetivo mercadológico na escolha do projeto artístico. Na esteira dessa preocupação, o "nicho" juvenil foi alvo de projeto financiado na área de música eletrônica, conforme citado acima. Também esse foi um dos motivos para que a exposição Henfil do Brasil fosse aprovada com a justificativa de que geraria interesse em público jovem, que se identifica com a linguagem dos quadrinhos e isso contribuiria para o rejuvenescimento da base de clientes do Banco.

As características demográficas, de classe social, de padrões de consumo, de pretensões de status são ferramentas normalmente utilizadas pelos profissionais de marketing para definirem as estratégias de atuação sobre determinados segmentos de consumidores. O meio artístico também delimita seus apreciadores de acordo com o grau de abrangência da obra e sua capacidade de interessar ou dialogar com públicos ampliados ou reduzidos. Espetáculos teatrais musicais ou vinculados a comédias de costumes têm público maior do que peças alternativas e experimentais. Exposições de nomes consagrados da pintura universal são mais atraentes do que instalações de arte contemporânea de artistas iniciantes. 


\subsection{O ARTÍSTICO E O ECONÔMICO: INTERDEPENDÊNCIAS E CONFLITOS}

A afirmação da autonomia da esfera artística é um valor muito caro tanto para aqueles que têm a arte como profissão quanto para aqueles que a apreciam. A recusa de qualquer determinação ou constrangimento é o que permite pensar o artístico como domínio da liberdade e da expressão genuína daquele que é visto como portador de talento e habilidades especiais. Bourdieu (2005), ao tempo em que confirma o processo histórico que possibilitou a constituição da arte como campo autônomo, liberto das determinações do Estado, da nobreza ou da religião, também reforça a relatividade dessa autonomia. A esfera material, econômica, racional, sob a dominação do capital, influencia e interfere nos diversos domínios que constituem a vida social contemporânea. A empresa capitalista, em especial as instituições financeiras, é portadora por excelência dessa racionalidade. Sua competição pelo lucro e pela conquista de mercados e clientes torna supérfluo e anacrônico tudo o que foge do esquema matemático que garante a longevidade da organização e patamares ascendentes de rentabilidade.

O processo de escolha de projetos artísticos a serem patrocinados por uma instituição bancária revela o conflito existente entre esferas distintas da vida social, ao tempo em que procura estabelecer interdependências e benefícios mútuos que permitam a sua viabilização. É perceptível a preocupação com a neutralidade e a imparcialidade das categorias de seleção criadas, coerentes com uma instituição pública, vinculada ao Governo Federal. Contudo, esses critérios não são estranhos à sociedade em que são postos em uso, que é de classes, e marcada pela extrema desigualdade na distribuição de riquezas, de poder e de capital cultural. Nesse sentido, ensina-nos Bourdieu que os sistemas de classificação

são menos instrumentos de conhecimento do que instrumentos de poder subordinados a funções sociais e orientados, mais ou menos abertamente, para a satisfação dos interesses de um grupo. (Bourdieu, 2008: 556).

A distinção do grupo social beneficiado por esses esquemas classificatórios não é algo que se revele de maneira evidente na análise das falas dos representantes da instituição. Tudo indica que a classificação atende a interesses da área de marketing do BB, os quais são subordinados a critérios mercadológicos de ampliação de consumidores e de padrões de consumo, concentrados nas classes 
favorecidas economicamente. O atendimento a seus padrões de gosto e de consumo é o primeiro objetivo desses esquemas, porém isso ocorre de maneira bastante velada, mediante enunciações como "diversidade" ou "acessibilidade". Certamente, se fossem explicitados, seria revelada a exclusão da maior parte da população, o que seria contraditório com o caráter público do empreendimento.

Interessante observar que as categorias criadas para classificar, hierarquizar e justificar as escolhas efetuadas aparecem com ênfases distintas de acordo com o interlocutor a quem o documento se destina. As que poderiam ser vistas como mais próximas do universo artístico ("inovação", "diversidade", "relevância conceitual e temática", "viabilidade técnica") são tornadas públicas no site da instituição, permitindo ao CCBB afirmar-se como pertencente ao campo artístico, compartilhando seus valores e princípios. Em outros documentos internos, nos quais se torna porta-voz dos artistas, procurando viabilizar o dispêndio de recursos e, ao mesmo tempo, legitimar-se como departamento que também contribui para a eficácia e rentabilidade da instituição patrocinadora, vale-se de outra gama de categorias, mais intimamente relacionadas ao universo empresarial e econômico ("identidade institucional", "compatibilidade com as estratégias de atuação do CCBB", "relacionamento", "nichos de mercado", "adequação financeira").

A avaliação dos projetos não é feita por quem possua o poder de definir os aspectos estéticos valorizados no campo artístico. Esses aspectos são estabelecidos por experts que, por portarem elevado capital cultural, estão em posição de domínio e ascendência no campo e são capazes de ditar regras e valores seguidos pelos artistas, e que influenciam seus comportamentos e criações. Nesse grupo estão incluídos críticos de arte, intelectuais, teóricos, pesquisadores e curadores que possuem autoridade suficiente no campo para distinguir o que é uma boa arte.

Os funcionários do CCBB selecionadores dos projetos não fazem parte desse grupo, muito embora, sigam preceitos e valores ditados pelos experts, no momento de hierarquizar e excluir aqueles a serem beneficiados com patrocínio.

$O$ poder dos experts na definição dos valores artísticos é negado com radicalidade por eles próprios e pelos artistas - o reconhecimento desse poder envolveria a negação do valor intrínseco do objeto artístico, o que poderia desestruturar completamente a aceitação do aspecto "sagrado" da arte e de seu poder imanente. Contudo, uma das contribuições possíveis da Sociologia da Arte 
sobre o tema vincula-se à afirmação de que o valor estético não é um valor independente, mas um valor social, sujeito aos conflitos e determinações que decorrem da posição, do prestígio e do poder que os diversos atores sociais possuem no interior do campo artístico.

A não explicitação dos interesses monetários que fundamentam o patrocínio empresarial acaba por preservar valores caros aos artistas patrocinados, além de camuflar o aspecto utilitário e menos benevolente do marketing cultural. A aparência de doação incondicional, de Banco preocupado com a cultura, mascara os aspectos econômicos que norteiam o patrocínio, além de manter e corroborar o aspecto sagrado do objeto artístico acima de qualquer interesse mercadológico.

A análise das falas dos analistas entrevistados evidencia maior comprometimento com os valores artísticos do que com as estratégias mercadológicas do patrocinador. Apesar de cientes das expectativas dos dirigentes acerca de seu trabalho, eles se vêem, sobretudo, como integrantes de uma instituição cultural. Ao compartilhar valores caros ao universo artístico, procuram revestir aspectos estéticos com roupagem mercadológica, a fim de justificar internamente o investimento em marketing. O retorno a ser obtido com o patrocínio é pouco mensurável, a priori, quando comparado aos outros negócios realizados pelas instituições financeiras. Por isso, foram notadas divergências entre os que ocupam posições superiores na hierarquia da organização, distanciados da "magia" que o objeto artístico oferece aos inseridos no campo, e os funcionários do CCBB. Dessa forma, nas entrevistas com os funcionários e mesmo nos documentos analisados, as justificativas estéticas ganham mais consistência do que as justificativas mercadológicas, mas perdem intensidade nas conversas com representantes da Diretoria de Marketing, à qual os CCBBs estão vinculados. Aos olhos dos executivos menos suscetíveis à illusio artística, a ausência de mecanismos confiáveis que permitam medir monetariamente o retorno do patrocínio torna frágil qualquer tentativa de justificar o investimento. Afinal, na área de marketing, a instrumentação e a metodologia do saber não permitem dar à sua fala a plausibilidade matemática que predomina na gestão dos negócios empresariais. Dessa forma, o CCBB precisa de esforço constante paralegitimar-se perante a própria Diretoria de Marketing e as demais áreas da empresa. Isso ocorre mediante a divulgação sistemática, junto aos veículos internos de comunicação, das ações de patrocínio que trouxeram ganhos negociais às demais áreas da empresa. 
Tanto para artistas quanto para patrocinadores, é vantajoso negar a existência de qualquer interesse econômico no patrocínio artístico. Para os primeiros, porque isso reafirma a autonomia do campo artístico e sua aura de sacralidade, acima de qualquer relação mercantil, além do comprometimento incondicional do artista com sua expressão - seu desinteresse pela esfera mundana que o dinheiro representa e seu auto-sacrifício para externar sua inventividade. Para os segundos, é ocultada a "lucratividade" que o patrocínio acarreta, porque é mais vantajoso reafirmar a imagem de generosidade, de justiça social, de compromisso e respeito para com valores não-monetários, seguindo os princípios de "responsabilidade social". Para ambos, portanto, a afirmação do caráter "sagrado" e desinteressado da arte contribui para o prestígio das obras patrocinadas, em relação às quais o interesse mercadológicos subjacente precisa ser ocultado, a fim de não desvalorizar a aura sobre a qual se estrutura o campo artístico.

O aspecto monetário da relação que o patrocinador possui com a arte só é afirmado internamente para justificar o dispêndio dos recursos, compensado pelos ganhos de imagem (somente possível pela negação do interesse econômico) e dos benefícios fiscais. Externamente, contudo, as transações monetárias entre artistas e patrocinadores precisam ter a aparência de doação desinteressada. Mais do que esferas hostis, é possível diagnosticar certa interdependência entre esses campos da vida social, mesmo que, muitas vezes, a afirmação do contrário seja a condição para que a relação se torne possível. 


\section{Capítulo 5}

\section{A ProgramaÇÃo do CCBB - EQUACIONANDO CONSAGRAÇÃO E INOVAÇÃO}

Pretende-se neste capítulo abarcar de maneira mais detida as obras de arte patrocinadas ${ }^{80}$. Não se almeja, contudo, obviamente, fazer delas análise estética ou artística, tarefa a que se dedicam com mais propriedade os teóricos e críticos de arte. O que se objetiva é verificar como as obras patrocinadas pelo CCBB se inserem no campo artístico e como são percebidas pelos demais atores desse campo, para isso considerando os seus critérios de avaliação e consagração. Não se pretende avaliar se a programação é de qualidade ou não, se ela contribui ou não para o desenvolvimento do campo artístico, mas contrastar sua estrutura com os critérios estabelecidos pelos próprios atores daquele campo, nas artes analisadas.

Não é que o sociólogo deva se desinteressar pela qualidade artística "em si": é que em se interessando por ela, ele não faz especificamente o trabalho de sociólogo, já que ele faz o que as outras categorias de atores são capazes de fazer, enquanto que não faz aquilo que só ele pode fazer: saber compreender os princípios de classificação. Qualificar os objetos não é proibido ao sociólogo, nem mesmo inútil: é somente pouco produtivo, porque pouco específico de sua competência. (Heinich, 1998a:13)

O aspecto abnegado que o artista procura imputar ao seu trabalho, negando qualquer subordinação a aspectos externos a sua vontade de expressão e a sua inventividade, faz com que o patrocínio empresarial seja visto com desconfiança. Entretanto, tendo em vista a escassez de recursos públicos para o fomento da atividade artística, ele acaba sendo, contraditoriamente, desejado. Os interesses empresariais por ganho de imagem, propiciado por ações de marketing cultural, provocam escolhas que remetem à necessidade de que a obra atinja o maior público possível, e tenha repercussão positiva nos órgãos de imprensa. Isso propicia a incorporação de novas regras ao campo artístico, regras essas vistas com ressalvas, já que o "artista genuíno" deveria, na lógica do campo, estar mais interessado em sua expressão simbólica do que em atingir esse ou aquele público, ou obter repercussão na mídia. Esses aspectos seriam vistos como conseqüência do talento

\footnotetext{
${ }^{80}$ A estruturação da programação ao longo do período sob análise, bem como a distribuição das exposições pelos espaços do CCBB, pode ser verificada nos anexos 17 (Artes Cênicas) e 18 (Artes Plásticas).
} 
ou habilidade do artista. Portanto, questiona-se: a arte patrocinada pelo CCBB busca o espetacular? O facilmente digerível? Seria essa arte voltada para atender gosto mais hegemônico, a fim de atingir mais público? O CCBB é uma instituição que contribui para a inovação no campo artístico ou segue receitas de sucesso, com fórmulas conhecidas e de "menor risco"? Artistas consagrados, por terem público cativo, são patrocinados em maior número do que "talentos ascendentes"? Essas e outras questões serão discutidas neste capítulo.

As categorias utilizadas para analisar a programação (no caso das artes cênicas, teatro comercial e teatro experimental; e, no caso das artes plásticas, a contemporaneidade ou não da arte) procuram situar a arte patrocinada pelo CCBB na luta "pelo monopólio da imposição das categorias de percepção e de apreciação legítimas" (Bourdieu, 2005:181). Procura-se delimitar as forças em luta nos campos artísticos analisados, sua disputa por legitimidade, público e patrocínio, cuja conflituosidade

engendra-se no combate entre aqueles que marcaram época e que lutam para perdurar e aqueles que não podem marcar época por sua vez sem expulsar para o passado aqueles que têm interesse em deter o tempo, em eternizar o estado presente; entre os dominantes que pactuam com a continuidade, a identidade, a reprodução, e os dominados, os recém-chegados, que têm interesse na descontinuidade, na ruptura, na diferença, na revolução. Marcar época é, inseparavelmente, fazer existir uma nova posição para além das posições estabelecidas, na dianteira dessas posições, na vanguarda, e, introduzindo a diferença, produzir o tempo. (Bourdieu, 2005:181)

A análise ocorrerá simultaneamente em dois níveis distintos e a partir das relações entre eles, que, supõe-se, mantêm certa homologia (Bourdieu, 2005:264). O primeiro nível diz respeito às relações entre as posições objetivas dos produtores culturais (daí recorrer-se muitas vezes a aspectos biográficos e curriculares). $\mathrm{O}$ segundo diz respeito às tomadas de posição no espaço das obras artísticas. 


\subsection{ARTES CÊNICAS: A RECUSA DO COMERCIAL E DO EXPERIMENTALISMO}

Nos anos de 2005 e 2006, o CCBB patrocinou os seguintes espetáculos teatrais ${ }^{81}$ :

- As Turca

- Cinema Éden

- Madame de Sade

- Molly Sweeney - Um rastro de luz

- Outono e Inverno

- Peça de Elevador

- Rita Formiga

- Um homem indignado

Além dessas peças teatrais, o CCBB também patrocinou dois projetos, que vêm sendo realizados anualmente: o Dramaturgias e o Dança em Pauta. O primeiro consiste de leituras dramáticas, seguidas de discussão com o público de textos inéditos da dramaturgia nacional; o segundo é constituído por apresentações de diversos espetáculos de dança, em um período de quatro semanas. No Dança em Pauta cada espetáculo se apresenta de uma a três vezes, assumindo formato semelhante a um festival, e contando, inclusive, com companhias estrangeiras. São projetos que mantêm certa continuidade na proposta e regularidade, o que os diferencia das demais ações de patrocínio caracterizadas por serem pontuais.

No que se refere à dramaturgia ${ }^{82}$ das peças patrocinadas, observou-se, nas peças analisadas que:

$>$ há equilíbrio em relação à procedência dos dramaturgos, sendo que metade é constituída de autores estrangeiros, e metade de brasileiros;

$>$ os textos de autores nacionais são inéditos, tendo estreado no palco do CCBB (Um Homem Indignado, As Turca, Peça de Elevador e Rita Formiga), todos os dramaturgos estão vivos e em atividade;

$>$ os autores dos textos nacionais não são consagrados como dramaturgos, à exceção de Domingos de Oliveira, cujo nome, contudo, se destacou mais no

81 O Anexo 20 traz a ficha técnica resumida dos espetáculos, além dos valores de patrocínio, quantidade de apresentações e horários e dias dos espetáculos. 
cinema $^{83}$ (Rita Formiga). Dois dos autores podem ser considerados iniciantes: Andréa Bassit ${ }^{84}$ (As Turca) e Cássio Pires ${ }^{85}$ (Peça de Elevador) e dois são mais renomados, em função de suas atuações em diferentes áreas artísticas: o ator Walmor Chagas ${ }^{86}$ (Um Homem Indignado) e o cineasta Domingos de Oliveira;

$>$ os demais textos existiam previamente à montagem do espetáculo, com exceção da Peça de Elevador, cujo texto foi escrito em "processo colaborativo" ${ }^{87}$ entre atores e diretor;

$>$ os textos de autores estrangeiros são consagrados e tiveram diversas montagens em muitos países:

- Molly Sweeney, o menos clássico, foi escrito por Brian Friel ${ }^{88}$ em 1994, sendo ele autor de renome na Irlanda, e tendo suas peças obtido sucesso em Londres e Nova York. Já havia sido montada anteriormente em São Paulo, em 2000, com Miriam Mehler no papel principal.

- Cinema Éden foi a primeira montagem da peça no Brasil do texto adaptado, em 1977, por Marguerite Duras, de romance de sua autoria.

- Madame de Sade foi escrito pelo célebre dramaturgo japonês Yukio Mishima, em 1965.

- Finalmente, Lars Noren, autor de Outono e Inverno, é considerado um dos mais proeminentes dramaturgos suecos contemporâneos;

$>$ considerando a temática sugerida pelos textos, predomina o que se pode chamar de "drama familiar", haja vista que personagens em conflitos

${ }^{82}$ Para uma descrição sucinta das peças veja sinopse no Anexo 19.

${ }^{83}$ Domingos de Oliveira nasceu em 1936, no Rio de Janeiro, se destacou como diretor de cinema, tendo atuado também como ator em diversos deles. Em 1980, recebe o Prêmio Mambembe de melhor autor com Assunto de Família, com direção de Paulo José, a montagem tem no elenco Fernanda Montenegro e Fernando Torres. Em 1983, Dirige Marília Pêra em Adorável Júlia, de Maugham e Marc-Gilbert Sauvajon. (Enciclopédia Itaú Cultural - Teatro, www.ttaucultural.org.br, consultada em 20/11/2007)

${ }^{84} \mathrm{Em}$ sua carreira conjuga a atuação como atriz e o trabalho como dramaturga, tendo atuado em algumas peças que escreveu: "Filhos do Brasil", "As Favoritas do Rádio" (ambas como co-dramaturga). Atuou e assinou textos de teatro infantil e infanto-juvenil como "Operilda e os Fantasmas da Ópera", "Operilda e o QuebraNozes" e "Quem Canta Seus Males Espanta", além de assinar o texto de "Mozart Criança".

${ }^{85}$ Cássio Pires havia atuado como diretor de companhias de pouco destaque (Cia Ensaio Aberto e Ninguém Atemporal) e escreveu outros textos como dramaturgo, sem grande repercussão.

${ }^{86}$ Ator de grande destaque no teatro brasileiro, tendo feitos muitos trabalhos também no cinema e na televisão. Trata-se de único trabalho de dramaturgo do ator. Foi casado com a atriz Cacilda Becker.

${ }^{87}$ Processo de criação por meio do qual os diferentes intervenientes (dramaturgo, atores e diretor) trabalham conjuntamente na concepção e estruturação do texto e do espetáculo, mantendo as suas respectivas funções criativas (cf. Silva, 2008)

${ }^{88}$ Autor irlandês cuja peça Dancing at Lughnasa (o título em português foi Dança das Paixões) foi adaptada para o cinema, tendo Meryl Streep como protagonista. 
familiares estão presentes na maioria das peças patrocinadas. Em Cinema Éden, tem-se a relação de uma mãe displicente com seus dois filhos. Em As Turca, três irmãs vivenciam a decadência financeira em uma família de ascendência árabe. Em Outono e Inverno, o mote da dramaturgia é o conflito de dois pais idosos com suas duas filhas "quarentonas", em seu jantar mensal. Madame de Sade explora a relação da religiosa marquesa com a "imoralidade" de seu marido. Em Molly Sweeney, também está presente, de maneira central, a relação da portadora de deficiência visual com seu marido.

Considerando-se a reputação dos autores estrangeiros, o CCBB arriscou mais quando optou por autores brasileiros. Abdicou de nomes conhecidos do grande público, como Nelson Rodrigues, Plínio Marcos, Naum Alves de Souza, Maria Adelaide Amaral, Ariano Suassuna ou Leilah Assumpção, e também dos novos nomes consagrados nas últimas décadas - com viés mais "alternativo" -, como Bosco Brasil, Luis Alberto de Abreu, Newton Moreno ou Mário Bortoloto, assim como dramaturgos considerados mais "populares", como Miguel Falabella, Jandira Martini ou Mauro Rasi ${ }^{89}$. Esse risco corrido com dramaturgos não tão experientes pode ter acarretado dramaturgias menos consistentes, a julgar pela crítica (ou ausência dela) de alguns espetáculos.

Em relação a diretores, também predominam nomes consagrados. Eduardo Tolentino $^{90}$, Roberto Lage ${ }^{91}$, Domingos de Oliveira, Emílio di Biasi ${ }^{92}$, Djalma Limongi

${ }^{89}$ Veja a sutil crítica de um dramaturgo: "E aí entramos nos anos 1980-90, e temos casos como os de Miguel Falabella e Mauro Rasi, para começar falando de quem tem grande repercussão, grande capacidade de comunicação com esse público. De certa forma, Falabella e Rasi estão fazendo uma dramaturgia que também não tem outra pretensão senão entreter, ou retratar de outra forma a sua própria realidade e a realidade de sua gente. Só que, ao contrário de Abílio Pereira de Almeida, que estava na verdade dizendo: "olha, eu faço parte de uma burguesia que sabe pegar no talher", os dois fazem questão de dizer: "olha, a gente não sabe pegar no talher". E é muito interessante que eles façam sucesso exatamente no momento em que essa classe média perde a vergonha de ser brega, em que as rádios são tomadas pela deturpação pop da música sertaneja, pela utilização, em forma mercadológica, do mau gosto. Em resumo: no momento em que essa elite perde a vergonha de ter mau gosto, de ser deseducada, encontra nas peças de Falabella e de Rasi o prazer de ver esse mau gosto, essa falta de educação elevada à condição de arte, ou pelo menos se pretendendo arte. Em nenhum momento quero dizer que os dois não têm talento; pelo contrário, eles têm uma grande capacidade de fabulação e um excelente diálogo, a serviço de uma realidade específica que é essa que estou desenhando." (Labaki, Aimar. In Garcia, 2002: 52/53)

90 Nasceu em 1954 e é um dos fundadores do grupo Tapa e dirigiu, dentre outros, Viúva, porém honesta, Navalha na Carne, A Serpente, Major Bárbara e A importância de ser fiel (Enciclopédia Itaú Cultural Teatro)

${ }^{91}$ Nasceu em 1947 e "alterna trabalhos em grupos experimentais e produções comerciais". Em 2003, já havia dirigido também no CCBB, o espetáculo Orgia, de Pier Paolo Pasolini (Enciclopédia Itaú Cultural Teatro)

92 Nasceu em 1939 e é um dos fundadores do grupo Decisão. Além de dirigir atuou em diversos espetáculos. Codirigiu diversas novelas na Rede Globo de Televisão. Ganhou prêmio Shell de melhor ator por sua interpretação em Um passeio no bosque e o prêmio de melhor diretor da Apetesp por ppp@wlmshkspr.gr, dirigindo a companhia Parlapatões, Patifes \& Paspalhões (Enciclopédia Itaú Cultural - Teatro) 
Batista $^{93}$ e Celso Nunes ${ }^{94}$ são reconhecidamente experientes (o mais novo possui 25 anos de carreira), tendo em seus currículos a direção de inúmeros espetáculos anteriores. Somente Regina Galdino ${ }^{95}$ e Marcelo Lazzaratto ${ }^{96}$ são de outra geração, apesar de longe de serem iniciantes.

Embora consagrados, esses diretores não têm a mesma reputação, se observados os critérios da crítica, da chamada Santíssima Trindade ${ }^{97}$ do teatro brasileiro, composta por Antunes Filho, Gerald Thomas e José Celso Martinez Correia, aclamados pela crítica, que acolheu positivamente suas pesquisas de linguagem cênica.

Os diretores patrocinados não possuem a mesma radicalidade estética, apesar de serem igualmente bem aceitos pela crítica. Curioso é o fato de dois diretores de cinema, Domingos de Oliveira e Djalma Limongi Batista, assinarem a encenação de espetáculos, já que esse trânsito entre as duas áreas, apesar de comum para os atores, é raríssimo entre diretores.

Os atores, igualmente, em sua maior parte, são personagens de destaque no meio teatral. Walmor Chagas, Cleide Yáconis, Sérgio Britto, Suely Franco e Júlia Lemmertz são intérpretes com longa e bem-sucedida carreira artística, e, certamente, são âncoras nos espetáculos patrocinados pelo CCBB.

A política de contratar atores renomados para os espetáculos é intencional, conforme entrevistas realizadas com os funcionários do CCBB. Contudo, há também intérpretes menos experientes no elenco de espetáculos com participação de grandes nomes. Os espetáculos Madame de Sade, Rita Formiga e As Turca, muito embora não haja nomes da grandeza dos anteriormente citados, contam, no seu elenco, com nomes conhecidos do grande público como Bárbara Paz (pela participação em programa de reality show na televisão), Guta Stresser (em função do programa humorístico A Grande Família da Rede Globo de Televisão), Andrea Bassit e Claudia Mello (por suas participações em programas de televisão). Constitui

\footnotetext{
${ }^{93}$ Dedica-se, sobretudo, à direção no cinema, responsável pelos filmes Asa Branca, um sonho brasileiro e Brasa adormecida, dentre outros; nasceu em 1950.

${ }^{94}$ Nasceu em 1941 e tiveram sua direção os espetáculos O Interrogatório, em 1970, e Victor, ou as crianças do poder, em 1974, premiado com o Prêmio da APCA. Dirigiu também a peça premiada As Lágrimas Amargas de Petra von Kant, com Fernanda Montenegro e Juliana Carneiro da Cunha.

${ }^{95}$ Nasceu em 1964 e dirigiu, entre outros, Intimidade Indecente e Memórias Póstumas de Brás Cubas

${ }^{96}$ Nasceu em 1968. Foi diretor da Cia Razões Inversas e atualmente dirige a Cia Elevador Panorâmico. É professor de interpretação na Unicamp e na Teatro-Escola Célia Helena. Dirigiu o monólogo Loucura, que foi bem recebido pela crítica e $A$ Entrevista, que rendeu a indicação de melhor atriz para Lígia Cortez no prêmio Shell.

97 Sá, Nelson de. http://cacilda.folha.blog.uol.com.br/arch2007-03-25_2007-03-31.html. consultado em 25/10/2008
} 
exceção o espetáculo Peça de Elevador, cujo elenco é composto de jovens atores de teatro, provenientes em sua maior parte do Teatro-Escola Célia Helena.

A escolha curatorial de trabalhar com grandes nomes do teatro está relacionada à facilidade com que essa referências enaltecedoras são "compradas" pela mídia, que reverbera a reputação dos atores. Isso é facilmente comprovado pela abundância de citações das "celebridades" nas manchetes da mídia impressa:

- "Cleyde Yáconis investiga a memória de Duras" "A "A memória de Marguerite Duras encontra a força de Cleyde Yáconis"99 e "A mãe coragem de Cleyde Yáconis"100

- "Walmor Chagas critica poder da imagem"101 e "O aniversário do indignado Walmor Chagas"102

- "Guta Stresser estrela peça de Domingos de Oliveira"103

Mais do que qualquer outra referência ao espetáculo, o nome do artista conhecido se sobrepõe, na divulgação da obra. Interessante que a figura do Produtor raramente é lembrada nos textos jornalísticos de divulgação. No entanto, quando se trata de alguém de renome, isso se torna chamariz, como aconteceu com o espetáculo As Turca:

"Engraçadíssima produção de Irene Ravache, com um elenco de comediantes exemplares onde se destaca o talento de Claudia Mello na direção inspirada de Regina Galdino"104

Em grande parte pela relevância atribuída pela mídia, os critérios de seleção de produções artísticas pelo CCBB, também levam em conta a experiência e o reconhecimento público dos envolvidos nas produções patrocinadas.

A diversidade defendida na política cultural, apesar de realmente existir, tem suas limitações. Há claramente o predomínio de um modelo de teatro que envolve

\footnotetext{
${ }^{98}$ Stivalleti, Thiago. Cleyde Yáconis investiga a memória de Duras. Folha de S. Paulo, São Paulo, 12/01/05, Ilustrada, E5.

99 Stivalleti, Thiago. A memória de Marguerite Duras encontra a força de Cleyde Yáconis, Folha de S. Paulo, São Paulo, 23/01/05, llustrada, E6..

${ }^{100}$ Brasil, Ubiratan. A mãe coragem de Cleyde Yáconis, O Estado de S. Paulo, São Paulo, 12/01/05, Caderno 2, D1.

101 Santos, Valmir. Walmor Chagas critica poder da imagem. Folha de S. Paulo, São Paulo, 16/03 /05, llustrada, E10.

102 Brasil, Ubiratan. O aniversário do indignado Walmor Chagas. O Estado de S. Paulo, São Paulo, 18/03/05, Caderno 2, D6.

103 Dubra, Pedro Ivo. Guta Stresser estrela peça de Domingos de Oliveira. Folha de S. Paulo, São Paulo, 15/09/06, Guia da Folha, 32.

${ }^{104}$ Abreu, Silvio de. Ilustrada Escolhe. Folha de S. Paulo, São Paulo, 08/01/06, llustrada, E7.
} 
profissionais consagrados, com carreiras constituídas ou que possuam notoriedade junto ao público (principalmente os atores).

A característica mais marcante das artes cênicas é a sua fugacidade. Não são comuns descobertas ou valorizações a posteriori, como é freqüente nas artes plásticas. O acontecimento ao vivo, cujo consumo ou fruição só é possível naqueles poucos minutos em que ocorre o espetáculo, exige do programador maior abertura para o risco. A escolha do ator de renome é um porto seguro em uma arte em que todos os outros elementos possuem elevado grau de imponderabilidade. A reputação do ator é o elemento exterior à cena que está indissociavelmente presente nas avaliações do público e da crítica em sua recepção e avaliação do espetáculo.

Há exceções? Sim, não se tinha nem a dramaturgia escrita, quando se decidiu patrocinar a Peça de Elevador, de um grupo iniciante (cinco anos à época) e sem nenhum ator consagrado. Essa peça, contudo, tinha apresentações somente às quintas e sextas-feiras, tradicionalmente os dias com menor audiência.

Dos espetáculos analisados, a Peça de Elevador foi o que teve menor percentual de ocupação $(58 \%)$ e também o menor retorno de mídia ${ }^{105}$ ( $R \$$ $273.577,00)$, valor pouco superior ao investido $(R \$ 250.000,00)$.

No documento em que foi aprovado o montante do patrocínio ao espetáculo, já era esperado retorno não tão expressivo, apesar de os números obtidos terem sido ainda inferiores ao planejado. Mesmo estimando números não tão promissores e considerando os aspectos mercadológicos desejados com o Marketing Cultural, o que embasou a aprovação do projeto foi a justificativa da responsabilidade social. O diretor foi considerado um "talento ascendente", associado ao ineditismo da obra, reforçaria o "papel da empresa como socialmente responsável".

A Peça de Elevador é exceção também, porque com ela se configurou o patrocínio a um grupo, e não a artistas isolados que se reúnem com o objetivo precípuo de realizar o projeto de um deles, o submetem ao pedido de patrocínio, e depois angariam colaboradores para sua concretização. Ao contrário dos demais espetáculos patrocinados, cujas temporadas podem até se estender em outros teatros, mas seus núcleos criadores não se mantêm por período muito longo, no caso do grupo Elevador Panorâmico trata-se de um coletivo com trabalho

105 O retorno de mídia é calculado em função do custo que seria desembolsado caso o espaço destinado ao evento patrocinado fosse pago como anúncio publicitário (Capítulo 7). 
continuado. A dinâmica estabelecida no processo de criação de um grupo que mantém certa constância de trabalho ao longo de diversos espetáculos, difere radicalmente daquela instituída por profissionais que se reúnem em torno de um projeto com prazo delimitado para encerrar.

\subsubsection{Inventando a tradição teatral}

O objetivo aqui é traçar um breve panorama de como se constituiu o campo teatral na cidade de São Paulo, aprofundando a interpretação do Capitulo 3, na direção de compreender a competição que se dá pela legitimidade dos "grupos de filiação", formados em função das afinidades de propostas artísticas, e da disputa por público e por consagração.

Como visto anteriormente, as artes cênicas estão longe de ser a opção preferencial de consumo cultural do paulistano ${ }^{106}$. Países como a Rússia e a Inglaterra, cuja tradição teatral remonta ao início da modernidade, têm nos espetáculos teatrais um apelo mais popular.

[No Brasil], a grande maioria do público é composta pela burguesia rica, a classe média e os estudantes. As crianças constituem igualmente, aos sábados e domingos nas matinês, um público estável com o qual os produtores podem contar. A ausência quase total de descentralização das salas e os preços praticados limitam a freqüência dos teatros às camadas menos favorecidas da população, excluindo os habitantes das periferias distantes e das vilas satélites dos grandes centros. (Corvin, 1995)

Ressalta-se também como é recente a "tradição teatral brasileira":

As técnicas modernas da encenação foram introduzidas no Brasil em 1943, por Ziembinski, um polonês. Só nessa data conhecemos a fórmula posta em prática há algumas décadas de subordinar-se o conjunto do espetáculo à visão unitária do diretor. Empregamos pela primeira vez recursos variados de iluminação, cenários ao gosto

\footnotetext{
${ }^{106}$ Apesar do discurso mais freqüente ser o da escassez de oferta cultural, mesmo sendo São Paulo um dos pólos culturais do continente, há quem afirme o oposto. A oferta, em artes cênicas, por exemplo, seria excessiva, haja vista o hábito restrito do paulistano de ir ao teatro: "Na primeira peça que escrevi, tinha uma frase que se revelava profética, já naquele tempo. Escrevi em 1973, era assim: 'Acho que ninguém mais quer ver teatro, todo mundo quer fazer!'. E mais ou menos em cima disso eu digo que, no futuro, as pessoas vão querer receber para assistir. As pessoas vão dizer: 'Ah, no Sesi é de graça, mas vamos na peça do Paulo Autran que está pagando mais" [risos] Ou seja, o espetáculo, para existir, para o público ter saco de sentar e assistir, vão ter de pagar." Fauzi Arap In Garcia (org.), 2002.
} 
estético atual e a liberdade expressiva dos contemporâneos. (Magaldi, 1997).

Não obstante o caráter restrito da produção teatral, ela se organiza em um amplo leque de linguagens artísticas, que se estrutura ao redor de certos parâmetros relativamente consensuais no campo. Toda categorização pressupõe certo reducionismo e as tipologias são bastante controversas na área da teoria teatral, porém, trata-se de instrumento útil para traçar uma cartografia da cena paulistana.

Há que ressaltar também o conflito instaurado no meio teatral, no Brasil e no mundo, com o advento e a popularização da televisão. Presença marcante nos domicílios e com forte ascendência sobre o imaginário social, a televisão tornou-se forma privilegiada de mecanismo publicitário das grandes corporações, recebendo investimento maciço da iniciativa privada. Dessa forma, seus profissionais gozam de melhor remuneração e usufruem da glamourização que o veículo proporciona. Apesar de a linguagem televisiva não se confundir com a das artes cênicas, os profissionais, muitas vezes, transitam por ambos os meios. Dramaturgos e atores têm conciliado trabalhos em televisão e teatro, muitas vezes utilizando o prestígio que obtêm em um veículo para garantir também sucesso no outro. Por exemplo, alguns dos atores patrocinados pelo CCBB possuem carreira consolidada na televisão, como Julia Lemmertz e Walmor Chagas.

A linguagem teatral e a televisiva diferenciam-se fundamentalmente em função dos seus públicos consumidores. Por ser um veículo de comunicação de massa, com custo relativo reduzido para o consumidor, a televisão atinge uma audiência muito superior à do teatro. A televisão se aproximou da linguagem cinematográfica e se distanciou do teatro, quando o aperfeiçoamento tecnológico permitiu a gravação, o playback e a edição, distanciando-se do imediatismo ("aqui e agora") próprio da linguagem teatral. Outras distinções podem ser identificadas entre essas linguagens, tais como as características diversas da recepção, as maneiras de estilização da imagem e as interferências diferenciadas de montagem (cf. Pavis, 1999).

No meio teatral existe uma categorização freqüente, principalmente na fala dos profissionais de teatro, que remete a uma contraposição básica entre o chamado "teatro comercial" e o "teatro experimental" (ou "alternativo" ou de "vanguarda" ou "de 
pesquisa") ${ }^{107}$. Essa categorização, aparentemente, tem-se sobreposto a outras, também em voga no meio, como a que distingue o teatro musical, o teatro popular, o teatro político, o teatro de costumes, o teatro épico e a performance (Pavis, 1999).

A oposição fundamental entre "comercial" e "não comercial" não se limita ao teatro, mas está presente em todas as formas de produção de bens culturais, o que faz com que Bourdieu (2005) a considere um dado estrutural do campo artístico. Ele utiliza essas categorias em sua análise do teatro francês:

A diferença entre "teatro burguês" e "teatro de vanguarda", que funciona como um princípio de divisão que permite classificar praticamente os autores, as obras, os estilos, os temas, manifesta-se tanto nas características sociais do público dos diferentes teatros parisienses [...] quanto nas características, perfeitamente congruentes, dos autores representados [...] e das obras ou das próprias empresas teatrais. Com efeito, é sob todos esses aspectos ao mesmo tempo que o "teatro de pesquisa" opõe-se ao "teatro de bulevar": de um lado, os grandes teatros subvencionados (Odéon, Théatre de l'Est parisiene, Teatro Nacional Popular) e alguns pequenos teatros da margem esquerda (Vieux Colombier, Montparnasse etc.), empresas econômicas e culturalmente arriscadas, que propõem, por preços relativamente reduzidos, espetáculos em ruptura com as convenções (no conteúdo ou na encenação) e destinados a um público jovem e "intelectual" (estudantes, professores etc.); do outro lado, os teatros "burgueses", empresas comerciais ordinárias cuja preocupação com a rentabilidade econômica obriga a estratégias culturais de uma prudência extrema, que não assumem riscos e não fazem seus clientes assumi-los: propõem espetáculos testados ou concebidos segundo receitas seguras e confirmadas, para um público idoso, "burguês" (quadros profissionais, membros das profissões liberais e chefes de empresas), disposto a pagar preços elevados para assistir espetáculos de simples divertimento que obedecem, tanto em seus motivos quanto em sua encenação, aos cânones de uma estética inalterada há um século. (Bourdieu, 2005:186)

107 "Hoje em dia o leigo, o adolescente, o universitário que não faz teatro, que pega o jornal ou entra na Internet para ir ao teatro, vai ter que driblar, em primeiro lugar, das oitenta peças que estão em cartaz, sessenta de muito baixa qualidade. Em segundo lugar, vai ter que escolher entre o 'TBC' que está em cartaz no Auditório Augusta - que o Paulo Autran está fazendo maravilhosamente bem - e experiências formais que em qualquer lugar do mundo estariam em salas desse tamanho (referindo-se ao Teatro Ágora, que possui noventa lugares), mas que aqui botamos em salas para seiscentas pessoas, esperando que algum milagre aconteça”. (Aimar Labaki, in Garcia, 2002: 56/57) 


\subsubsection{O teatro comercial}

O "teatro comercial", também denominado "teatro de boulevard"108 na tradição francófona, como menciona Bourdieu no texto acima, reúne as seguintes características:

a) enquadra-se como teatro de divertimento e entretenimento, cuja fruição não requer muito esforço intelectual. Assume freqüentemente o gênero comédia, ou o vaudeville, ou a comédia de costumes. Nesses casos, o chavão, o chiste, o uso freqüente de palavras de baixo calão garantem o riso fácil e a cumplicidade da platéia;

b) envolve estrutura dramatúrgica em torno de conflitos, sendo freqüente o qüiproquó, cuja resolução é de antemão previsível e de conhecimento do público, mas não dos personagens em cena. Os conflitos, portanto, sempre são resolvidos no desfecho dos espetáculos, sem surpresa.

Ele [o teatro de boulevard] se caracteriza por comédias leves, escritas por autores de sucesso para um público pequeno-burguês ou burguês, de gosto estético e político totalmente tradicional, que jamais são pertubadoras ou originais. (Pavis, 1999: 380);

c) a temática das peças muitas vezes envolve críticas a questões sociais ou aos costumes, como a corrupção política, a infidelidade conjugal, o machismo, a falsidade discursiva de instituições como Igreja ou Exército. No entanto, essas críticas, sempre superficiais, jamais colocam o espectador na postura de cúmplice ou responsável pelos problemas sociais representados;

d) possui estilo de atuação freqüentemente realista, com cenários e figurinos que procuram reforçar, de maneira naturalista, a caracterização dos personagens.

Neste 'naturalismo de salão', tudo deve parecer verdadeiro, e mesmo um pouco mais: a elegância dos móveis, o luxo sutil e negligente dos interiores 'bon chic, bon genre', o conforto burguês de um mundo bastante próximo para que o espectador possa aspirar a ele sem receio, ou encontrar-se aí como que em sua própria casa. $\mathrm{O}$ recorte dessa fatia sociológica impecável é permitir,

\footnotetext{
${ }^{108}$ A expressão remete aos boulevards Saint Martin e Du Temple, onde, no século XIX, era exibida toda sorte de melodramas e comédias burguesas (Pavis, 1999: 380).
} 
simultaneamente, o reconhecimento ideológico e o sonho de ascensão social. (Pavis, 1999:381);

e) normalmente, envolve produção com patrocínio empresarial, obtido por meio de incentivo fiscal, com divulgação efetuada pela grande mídia, mediante publicidade paga;

f) é apresentado em teatros com grande capacidade de público e as temporadas possuem duração variada. Em São Paulo, casos de grande sucesso, como o espetáculo Trair e Coçar é só começar..., com dramaturgia de Marcos Caruso e Jandira Martini, chegaram a ficar mais de dez anos em cartaz. Via de regra, a temporada dura em torno de três meses;

g) envolve habitualmente atores de prestígio, muitos dos quais vinculados à televisão, sendo conhecidos do grande público, que, geralmente, se sente atraído para assistir essas produções, pois almeja contato mais próximo com seus ídolos;

h) outra característica, apontada por Bourdieu (2005:163), que configuraria uma arte comercial, é o fato de ela ajustar-se a uma demanda preexistente e em formas preestabelecidas;

i) por fim, mas não menos importante, há interesse comercial e de retorno financeiro claramente estabelecido, o que se dá a partir dos patrocínios e da bilheteria.

A partir da década de 90, um subgênero do teatro comercial, o musical, conquistou espaço considerável no campo cultural paulistano. Normalmente, sucessos comerciais na Broadway nova-iorquina ou nos teatros londrinos são literalmente importados para grandes teatros paulistanos. Com lotação completa, longas temporadas e ingressos bem acima do preço médio do teatro na cidade de São Paulo, essas montagens seguem com rigor, por obrigação contratual, o modelo do espetáculo norte-americano: figurino, cenário, encenação. Os atores brasileiros também devem seguir as marcas e a atuação do original. Constituiu-se uma empresa, a CIE Brasil, para produzir esse tipo de espetáculo.

Em São Paulo, musicais como O Fantasma da Ópera, Os Miseráveis, Miss Saigon ganharam o apoio de uma classe média que almeja e se identifica com os padrões de consumo norte-americanos, mas, em grande parte, não possui capital financeiro suficiente para assistir in loco as produções originais. Não seria exagerado 
dizer que se trata de uma taylorização do teatro, na medida em que limita consideravelmente as possibilidades de criação de diretores, atores, cenógrafos e iluminadores, em função da restrição derivada da necessidade de seguir um roteiro pré-definido, do qual contratualmente não se pode desviar. No entanto, esse modelo configurou-se como empreitada muito bem-sucedida do ponto de vista comercial contando também com subsídios públicos, pela via das leis de incentivo -, já que esses espetáculos têm lotação garantida e, inclusive, têm ajudado a incrementar o turismo na cidade.

\subsection{3 $O$ teatro alternativo}

Em contraposição, há o que usualmente é chamado de teatro alternativo ou experimental, caracterizado com freqüência pela proposição de novas linguagens cênicas, rompendo ou enfrentando determinados elementos da tradição teatral. Pavis (1999) adota essa contraposição entre teatro comercial x teatro experimental, ao afirmar que o último se

$$
\begin{aligned}
& \text { opõe ao teatro tradicional, comercial e burguês que visa a } \\
& \text { rentabilidade financeira e se baseia em receitas artísticas } \\
& \text { comprovadas, ou mesmo ao teatro de repertório clássico, que só } \\
& \text { mostra peças ou atores já consagrados. Mais que um gênero, ou um } \\
& \text { movimento histórico [o teatro experimental] é uma atitude dos } \\
& \text { artistas perante a tradição, a instituição e a exploração comercial. } \\
& \text { (Pavis, 1999) }
\end{aligned}
$$

Nesse sentido, o teatro experimental se constitui a partir da negação do interesse financeiro da produção e de seu posicionamento de ruptura em relação à tradição.

De hábito, os espetáculos ditos experimentais são criados em processos mais longos do que as peças comerciais e envolvem menos custos em sua produção, em função, principalmente, da ausência de patrocínios. Ocupam salas com configurações alternativas ou espaços ditos não convencionais, fugindo muitas vezes do palco italiano. Esse tipo de teatro envolve tanto profissionais em início de carreira quanto artistas consagrados pela crítica. Encenadores como Antunes Filho (pós-década de 80), José Celso Martinez Correa e Gerald Thomas possuem espetáculos consagrados pela crítica e fazem montagens que estão longe de ser 
consideradas comerciais, pois se caracterizam pela ousadia na criação e inventividade formal.

Certa variação do teatro "alternativo" vem sendo classificada pela literatura especializada como teatro pós-dramático, que se caracteriza pelo rompimento com a linearidade do texto dramatúrgico e a exploração de todas as potencialidades da criação teatral, muito além do que possa sugerir a estrutura textual da peça:

Com a rejeição das formas teatrais tradicionais, desenvolveu-se um novo tipo de autonomia do teatro como prática artística independente. Foi somente a partir dessa ruptura que o teatro abandonou a orientação incontestável na escolha de seus recursos, de acordo com as exigências do drama a ser montado. Essa orientação havia imposto não só um estreitamento, mas também uma certa incontestabilidade dos critérios técnicos, uma lógica e uma normatividade no emprego dos recursos teatrais a serviço do drama. Nesse sentido, a liberdade recém-conquistada foi acompanhada por uma perda, que sem seu aspecto produtivo pode ser descrita como a entrada do teatro na época da experimentação. Desde que o teatro tomou consciência de que os potenciais de expressão artística nele latentes eram passíveis de ser realizados independentemente do texto, foi lançado no difícil e arriscado campo da liberdade de experimentação contínua, assim como as outras formas de arte. (Lehman, 2007: 81)

Nessa perspectiva, a menor centralidade dada ao drama, anteriormente constituído como o eixo sobre o qual os demais elementos da cena teatral deveriam se aliar, implica colocar a ação teatral em segundo plano, dando maior destaque à temporalidade e à espacialidade próprias dos espaços cênicos. A síntese encerrada em estórias que se estruturam em torno de uma narrativa linear ou aristotélica é combatida de forma veemente. Em vez da causalidade e do encadeamento, é proposta uma forma aberta e fragmentada.

Cabe constatar que o teatro pós-dramático não é apenas um novo tipo de texto da encenação (e ainda menos um novo tipo de texto teatral), constituindo-se antes num modo de tratamento dos signos teatrais que resolve desde a base essas duas camadas do teatro por meio da qualidade estruturalmente diversificada do texto da performance. Ele se torna mais presença do que representação, mais experiência partilhada do que comunicada, mais processo do que resultado, mais manifestação do que significação, mais energia do que informação. (Lehman, 2007: 142-3) 
Outra característica freqüentemente presente no teatro pós-dramático é a utilização de elementos extra-estéticos em cena, seja por meio do trabalho de pessoas que não são atores profissionais, seja pela introdução de elementos que fogem ao aspecto meramente ilusório, sugerido e imaginado, próprios da tradição teatral. Quando profissionais (não-atores) fazem cenas explícitas de sexo ${ }^{109}$, quando não se sabe se um ator está sendo realmente tratado com choques elétricos diante do público ${ }^{110}$, quando porteiros desempregados (não-atores) se representam a si próprios em uma peça ${ }^{111}$, o espectador é colocado em situação em que se rompe a divisão rígida entre o real e o ficcional.

Assim, um teatro que não mais é simplesmente algo "a ser assistido", mas situação social, escapa a uma descrição objetiva porque representa para cada um dos participantes uma experiência que não conflui com a experiência dos outros. Ocorre uma virada do ato artístico em direção ao observador, o qual se depara com sua própria presença e ao mesmo tempo se vê forçado a travar uma contenda virtual com o criador do processo teatral: o que se espera dele? (Lehman, 2007: 173)

A utilização de elementos extra-estéticos representa o rompimento do paradigma da representação que caracterizou as artes pré-moderna e moderna e aproxima o teatro experimental da tradição inaugurada por Duchamp nas artes plásticas, quando o objeto que não fora construído artisticamente passa a adquirir essa dimensão, a partir da inclusão do espectador no contexto artístico. "O teatro agora pode passar sem o ilusionismo, sem com isso deixar de ser teatral" (Lehman, 2007: 180)

O teatro experimental chega a limites de questionar as fronteiras com os demais modos artísticos, deixando muitas vezes de ser "teatro" no sentido estrito do termo. A utilização de vídeos, da dança, de instalações próprias das artes plásticas e da performance, rompe com a divisão das artes e questiona a existência de uma especificidade da arte teatral.

\footnotetext{
109 Apolicapse 1,11, do Teatro da Vertigem, direção de Antônio Araujo, dramaturgia de Fernando Bonassi, encenada no presídio do Hipódromo em São Paulo, em 2000.

110 Regurgitofagia de Michel Melamed, apresentada no SESC Belenzinho de janeiro a março de 2005.

111 Torero Portero, direção de Stefan Kaegi, apresentada no SESC Paulista, em outubro de 2005.
} 


\subsubsection{A estratégia do CCBB para as artes cênicas}

A categorização que distingue "teatro comercial" do "teatro experimental" carrega certa fragilidade, pois, entre esses dois extremos, há uma variedade de opções artísticas que reúne elementos de ambos ${ }^{112}$. Além disso, essa classificação não é assumida por todos os profissionais. Raramente, alguém que faz teatro comercial vai denominar sua criação dessa maneira, já que a nomenclatura é bastante pejorativa.

Duas percepções parecem ser bastante difundidas no meio teatral: a primeira, de que a viabilidade econômica do artista é facilitada para aqueles que se dedicam ao teatro comercial; a segunda, referente à resistência do público ao teatro experimental; a recepção dos espetáculos comerciais passa a ser mais bemsucedida no teatro, não porque o público tenha "gosto subdesenvolvido", mas porque iria ao encontro de certo "gosto médio da população".

O elitismo e/ou hermetismo do teatro experimental é visto por aqueles que produzem essa forma de teatro como uma acusação infundada:

O direito à pesquisa e, portanto, ao erro, estimula os criadores a assumirem riscos a propósito da recepção (a ponto, por vezes, de não procurarem chegar a uma representação pública), a modificar incessantemente a encenação, a buscar e a transformar em profundidade o olhar do espectador muitíssimas vezes instalado na rotina: daí a freqüente acusação de elitismo ou hermetismo. (Pavis, 2001: 389)

Outro aspecto importante diz respeito à inserção precária dos profissionais de teatro, principalmente para os que optam pelo teatro alternativo ou para aqueles que não conseguem inserir-se no teatro comercial, que é mais bem remunerado. $O$ glamour envolvendo a profissão atrai jovens que buscam reconhecimento, prestígio e sucesso. No entanto, predominam esquemas de trabalho extremamente precários, sem respeito a direitos trabalhistas, já que se trata, via de regra, de empreitadas temporárias, nas quais o fim de um projeto é normalmente sucedido por uma longa espera de novos trabalhos (cf. Menger, 2002).

\footnotetext{
112 Bourdieu (2005, pág. 187) delimita uma categoria intermediária que denomina de "teatro clássico", constituída de um lugar neutro que encontra público igualmente em todas as regiões do campo do poder e propõe programas neutros ou ecléticos. A programação do CCBB, apesar de também ser intermediária entre o comercial e o experimental, não pode ser enquadrada como "teatro clássico", já que Bourdieu tem como parâmetro especialmente a programação da "Comédie-Française", ancorada em dramaturgos consagrados, de perfil diferenciado do teatro patrocinado pelo CCBB.
} 
No Brasil, não existe um teatro nacional, como ocorre na França (são cinco, entre os quais o Odéon, além dos Centros Dramáticos Nacionais, que são mais ou menos 40, nas grandes cidades) ou na Inglaterra, vinculado ao Estado e com um corpo de funcionários estáveis. Isso acontece nas áreas de música clássica e dança, que possuem corpo de funcionários públicos com estabilidade profissional adquirida mediante concursos públicos. Além disso, a distinção entre o experimental e o comercial é também feita em função dos públicos que os consomem:

É a qualidade social do público (medida principalmente por seu volume) e o lucro simbólico que ele assegura que determinam a hierarquia específica que se estabelece entre as obras e os autores no interior de cada gênero, correspondendo às categorias hierarquizadas que aí se distinguem muito estreitamente à hierarquia social dos públicos: isso se vê bem no caso do teatro, com a oposição entre o teatro clássico, o teatro de bulevar, o vaudeville e $o$ cabaré (Bourdieu, 2005:135).

Certamente, o teatro experimental exige determinado capital cultural. Sua audiência é formada, principalmente, por produtores culturais (no sentido amplo do termo), envolvendo artistas de áreas diversas, intelectuais, estudantes e pessoas familiarizadas com códigos específicos da tradição teatral. Tem recepção mais positiva do corpo de especialistas do campo (intelectuais e críticos). Dessa forma, despossuídos de capital econômico suficiente para arcar com os custos de produção, cientes do reduzido ganho com bilheteria e tendo maiores dificuldades para conseguir subvenções das empresas para seus projetos, são, por outro lado, dotados de maior capital simbólico, em função de seu vínculo com as estruturas de consagração.

Um dos indícios mais evidentes da acolhida do teatro de vanguarda pela crítica e demais membros do corpo de especialistas é a escolha dos vencedores nas principais categorias pelo Prêmio Shell ${ }^{113}$ de Teatro em São Paulo nos últimos anos (Anexo 21). Tomando-se a categoria diretor como exemplo, todos os premiados são provenientes do que se convencionou chamar de "teatro de grupo", no meio teatral: Cibele Forjaz (Companhia Livre de Teatro), Antônio Araújo (Teatro da Vertigem), Rodolfo Garcia Vasquez (Os Satyros), Cristina Paoli Quito (Nova Dança, não

${ }^{113}$ A única peça patrocinada pelo CCBB que recebeu prêmio Shell foi Pólvora e Poesia, que venceu em três categorias importantes: diretor, autor e ator. 
obstante o trabalho premiado não ser com essa companhia), Marco Antônio Rodrigues (Folias D'Arte) e José Celso Martinez Correa (Teatro Oficina).

Esses grupos têm uma forma de trabalho muito diferenciada da do chamado teatro comercial. Neste, por iniciativa de um dos artistas (normalmente o ator/atriz protagonista ou o diretor), convidam-se os demais profissionais que, por um período médio de três meses, "levantam" o espetáculo, que, na perspectiva mais otimista, fica em cartaz também, em média, por um período equivalente. Apresenta, portanto, um ciclo curto de produção, o que facilita sua adequação à demanda detectável naquele momento, e também propicia a realização rápida de lucros.

O "teatro de grupo", não obstante as trocas de componentes, caracteriza-se pela continuidade de um núcleo básico de artistas que dedicam maior tempo a ensaios e também desenvolvem pesquisa por um prazo mais estendido. $O$ "modo de produção" patrocinado pelo CCBB aproxima-se muito mais do primeiro grupo do que do segundo.

Analisados também os atores e atrizes premiados, mesmo aqueles mais conhecidos do grande público em função dos trabalhos em redes de televisão, como Fernanda Torres e Cacá Carvalho, suas trajetórias propriamente teatrais não são marcadas pelo que caracteriza o teatro comercial. O exame do corpo de jurados do Prêmio Shell de Teatro ${ }^{114}$ (Anexo 22) permite verificar a participação preponderante de professores universitários, teóricos, dramaturgos, jornalistas e críticos. Da mesma forma, a análise dos ganhadores do Prêmio Bravo! Prime de Cultura permite a verificação da predominância do teatro experimental. Em 2007, ganhou o espetáculo Gaivota - Tema para um conto curto, da Cia dos Atores. Em 2006, o vencedor foi o espetáculo A Pedra do Reino, dirigido pelo nada comercial Antunes Filho. No ano de 2005, Os Sertões - Luta I, dirigido por José Celso Martinez Correa, ganhou o prêmio. Todos os espetáculos caracterizam-se pela pesquisa e pela ousadia da encenação.

Portanto, se o teatro de grupo compete, ainda que em situação de desigualdade, pelo financiamento de suas produções, não se configura necessariamente como concorrente pela presença do público, já que o teatro experimental tem sua platéia constituída por produtores culturais, e o teatro

\footnotetext{
${ }^{114}$ Prêmio de $\mathrm{R} \$ 8$ mil, além de troféu, concedido anualmente pela empresa petrolífera inglesa aos profissionais de teatro, agrupados em diversas categorias, nas cidades do Rio de Janeiro e São Paulo.
} 
comercial é composto pelo chamado "grande público", seduzido pela atração de uma ou mais celebridades, normalmente televisivas, ou pela comédia de riso fácil.

Configura-se, portanto, quadro em que o teatro comercial, com freqüência encabeçado por atores "televisivos", se alia aos detentores de capital econômico, já que conseguem mais facilmente patrocínio das empresas, além de obter a adesão do grande público, pouco familiarizado com as inovações de linguagem propostas pelo teatro experimental. De outra parte, este teatro tem a adesão do corpo de especialistas que dão legitimidade ao campo, distribuindo capital simbólico e hierarquizando as competências artísticas. A julgar pela forte presença de jornalistas culturais no júri do Prêmio Shell (Beth Néspoli, Valmir Santos), além de críticos que trabalha(ra)m para os grandes jornais (Alberto Guzik, Maria Lúcia Candeias e Kil Abreu), identifica-se uma aliança entre setores da mídia impressa e o teatro experimental. Dessa forma, o patrocinador preocupado com a exposição na mídia e a acolhida do público precisa fazer uma escolha, já que o teatro experimental teria acesso mais facilitado à mídia "espontânea" impressa e às instâncias de consagração enquanto que o teatro comercial obteria a adesão do grande público.

O teatro experimental carrega certa aura de marginalidade por, raramente atrair subvenções de empresas privadas e, muitas vezes, nem das instâncias governamentais. Por esse motivo, carece de recursos para produções mais grandiosas ou elaboradas, muito embora apoios, por exemplo o dado pela Petrobrás a grupos como o Teatro Oficina e Teatro da Vertigem, tenham viabilizado produções grandiosas, vide a saga d'Os Sertões ${ }^{115}$ e o espetáculo $B R-3^{116}$, realizados, respectivamente, por aquelas companhias.

Na discussão pública sobre a reestruturação da Lei de Incentivo à Cultura, a Associação de Produtores Teatrais do Rio de Janeiro, que sempre esteve amparada pela política de incentivos e ciosa da acolhida por segmentos do Governo Federal dos anseios do teatro experimental, propôs um anteprojeto de lei que continha mudanças, demandava a desburocratização e agilidade na concessão dos benefícios, mas não a alterava substancialmente. A rede Redemoinho, representando o "teatro de grupo", propôs, por sua vez, uma Lei Federal de Fomento que seguia os moldes da existente no município de São Paulo.

\footnotetext{
${ }^{115}$ Espetáculo realizado em cinco partes pelo Teatro Oficina, sob direção de José Celso Martinez Correa, de 2002 a 2006.

${ }^{116}$ Espetáculo realizado pelo Teatro da Vertigem, sob a direção de Antônio Araujo, no leito do Rio Tietê, em São Paulo, em 2006, e na Baía de Guanabara, no Rio de Janeiro, em 2007.
} 
A disputa entre esses dois grupos, com posicionamentos contrários em relação à mudança necessária à Lei de Incentivo à Cultura, revela dois princípios distintos de hierarquização. A Associação de Produtores Teatrais defende o princípio da heteronomia, propondo benefícios àqueles que dominam economicamente 0 campo, e têm atrativos a oferecer aos departamentos de marketing das empresas. $O$ outro grupo defende o princípio da autonomia, que utiliza seu fracasso diante dos pedidos de recursos empresariais como um "sinal de eleição" e da posse de elevado capital simbólico, explicitada na denegação do interesse econômico. (Cf. Bourdieu, 2005:246)

A produção teatral do CCBB não é facilmente inserida em uma ou outra extremidade dessa categorização. Não se pode classificá-la facilmente como teatro comercial, também porque não objetiva retorno financeiro com as produções, pois os ingressos são vendidos a preços reduzidos e o número de espectadores é pequeno, em função do tamanho da sala. Além disso, os textos apresentados possuem maior elaboração e refinamento dramatúrgicos e muitos dos atores envolvidos não podem ser facilmente associados ao rótulo "comercial". Também não se pode caracterizá-la como teatro experimental, pois grande parte dos espetáculos realizados pelo CCBB reúne atores consagrados no meio artístico, textos tradicionais de teatro e é encenada de maneira convencional, não havendo proposta de ruptura ou de criação de nova linguagem cênica.

Os espetáculos encenados pelo CCBB afastam-se da vanguarda pósdramática, que ganha espaço, ancorada em instituições, universidades e críticas que dão legitimidade a essa manifestação artística, a qual ainda é de difícil assimilação pelo grande público. Algo mais próximo do que se pode chamar de teatro pósdramático, e que se apresentou ali, foi o espetáculo Desassossego, com Marilena Ansaldi e direção de Márcio Aurélio, no projeto Dança em Pauta. A maioria das peças produzidas, porém, ancora-se fortemente no texto dramatúrgico e na interpretação acertada de nomes consagrados do teatro. Dessa forma, a programação teatral do CCBB filia-se a uma opção mais conservadora e segura de representação artística. Além disso, o tempo destinado à montagem do espetáculo, a partir da definição da equipe de criação e o desembolso pelo CCBB das verbas de preparação é de, em média, dois meses. Esse tempo é o indicador cabal de como restrições organizacionais e financeiras acabam determinando o tipo de produção artística a ser viabilizada. Os espetáculos experimentais demandam tempo superior 
de criação, pois muitas vezes envolvem o desenvolvimento do texto dramatúrgico em sala de ensaio e exigem maior preparo e ensaio de todos os criadores envolvidos. Como se diz no jargão teatral, dois meses é tempo que apenas possibilita "levantar o espetáculo", sem maiores vôos em termos de pesquisa de linguagem ou para o treinamento e preparações técnicas específicas dos atores.

É usual entre os profissionais do teatro utilizarem o termo teatrão", que poderia ser visto como uma categoria intermediária. O Dicionário do Teatro Brasileiro (Guinsburg e cols., 2006), apesar de incluir tal categorização, ressalta as suas limitações analíticas:

Termo que designa uma montagem bem cuidada sob o ponto de vista da produção (cenários, figurinos, iluminação, música incidental etc.), representada por um bom elenco, mas concebida de forma tradicional, sem maior imaginação e despreocupada de uma pesquisa formal criativa. Na verdade, a expressão da palavra envolve, muitas vezes, um significado preconceituoso, senão desrespeitoso, visando estabelecer pesquisas formalistas como padrão estático de avaliação. Uma peça naturalista cuja montagem obedecesse rigorosamente às indicações do autor deveria ser classificada pejorativamente de teatrão? Comparando-se uma produção de alto nível profissional e outra repleta de novidades, mas mal executada, deve-se privilegiar esta em detrimento daquela? Procurar o beneplácito de público mais tradicional sem fazer concessões de qualidade seria prejudicial ao interesse pelo teatro como uma totalidade? São questões que o uso inconseqüente da expressão pode levantar. (idem:281)

A dificuldade de enquadramento da programação teatral do CCBB na tipologia mais recorrente do meio teatral é reveladora de uma tomada de posição apaziguadora, tal qual preconiza a linha curatorial da diversidade cultural. Contudo, as escolhas efetuadas dialogam com as posições dominantes na cena teatral paulistana e com a não aderência, nem ao teatro comercial, nem ao teatro experimental. Isso pode significar, por um lado, o desejo de não abrir mão de um público refratário ao hermetismo das produções experimentais e, por outro, a expectativa de ter reconhecimento pela classe artística e pela crítica especializada, muito pouco simpática ao teatro comercial.

A recusa do "teatro comercial" representa também a recusa de um público mais numeroso, que seria interessante a um banco cativar, mas que acarretaria perdas em termos de legitimidade no campo artístico, já que se trata de um teatro 
com menos apoio do corpo de especialistas e com visibilidade reduzida na imprensa escrita. A escolha feita pelo Bradesco de patrocinar prioritariamente o teatro comercial $^{117}$ revela interesse em atingir um público maior e de maior poder aquisitivo. A recusa do "teatro experimental" pelo CCBB permite, igualmente, que a platéia não se constitua exclusivamente de produtores culturais e de iniciados, dando maior abrangência aos interessados, e possibilitando a viabilização, de forma mais efetiva, de estratégias de marketing de relacionamento.

\subsection{ARtes Plásticas}

O CCBB patrocinou quinze exposições ${ }^{118}$ de artes plásticas, ${ }^{119}$ em 2005 e 2006:

- Alfredo de Oliveira

- Antes - Histórias da Pré-História

- Artes de Cuba

- Desoriente: o Eu Nômade

- Erotica - Os Sentidos da Arte

- Farnese de Andrade - Objetos

- Henfil do Brasil

- Impressões Originais: a Gravura desde o século XV

- Manobras Radicais

- Mary Vieira - O Tempo do Movimento

- Maurino de Araújo

- Polissemiose - Amílcar Packer

- Por Ti America

- Um Indeterminado - Edouard Fraipont

\footnotetext{
${ }_{117}^{117}$ Patrocinou, por exemplo, o Cirque du Soleil e o Bem Amado.

118 Para uma descrição sucinta das exposições, veja sinopse no Anexo 23.

119 Trata-se de exposições que se iniciaram no período de 2005 e 2006 . Excluímos da análise duas mostras que ocuparam pequenos espaços expositivos do CCBB: "Diretores Brasileiros - Ruy Guerra" e "Agnès Varda". A primeira delas vinculou-se mais a ciclos de cinemas e continha fotos, cartazes e documentos do acervo pessoal do cineasta, além de figurinos de filmes e uma vídeo-projeção sobre o cineasta. Tinha, portanto, um caráter muito mais documental, sendo equivocado englobá-la na categoria "artes plásticas". A exposição de Agnès Varda trazia fotografias efetuadas pela cineasta, mas vinculou-se à mostra cinematográfica da obra da artista realizada no mesmo período. Esses trabalhos ocuparam somente o subsolo do prédio, foram selecionados pelo analista responsável pela área de cinema, tiveram duração reduzida e adquiriram caráter complementar aos filmes exibidos.
} 
- Vik Muniz - Divas e Monstros

Para efeito de análise, elas serão agrupadas em três categorias:

a) Exposições históricas (Antes - Histórias da Pré-História / Por Ti America);

b) Exposições individuais (Alfredo de Oliveira / Desoriente / Farnese de Andrade / Henfil do Brasil / Mary Vieira / Maurino de Araújo / Polissemiose / Um Indeterminado / Vik Muniz);

c) Exposições coletivas (Artes de Cuba / Erotica / Manobras Radicais / Impressões Originais).

\subsubsection{Os curadores}

Categoria-chave no contexto das artes plásticas atuais, os curadores têm imenso poder no campo, legitimando e valorizando obras e artistas. Responsáveis pela seleção do que será inserido ou não em uma determinada exposição, acabam sendo decisivos na valorização econômica das obras e dos artistas, auxiliando na construção de currículos, avalizando as carreiras e reputações e valorizando monetariamente as obras.

O CCBB trabalha com curadores renomados (Anexo 24), com larga experiência e prestígio. Para citar os mais conhecidos:

* Denise Mattar, curadora da exposição Mary Vieira, possui carreira consolidada e premiada. Recebeu dois prêmios da Associação Paulista dos Críticos de Arte (APCA), um pela melhor retrospectiva de 2003, dedicada a Samson Flexor, e outro pelo conjunto da obra, com Frans Krajcberg, no CCBB-SP.

* Charles Cosac, curador da exposição de Farnese de Andrade, tem seu nome mais associado à editora da qual é proprietário. Contudo, como sua editora é especializada na publicação de livros de arte, acaba tendo prestígio considerável na área.

* Paulo Sérgio Duarte, curador da exposição Henfil do Brasil, é outro nome de destaque no campo artístico. É professor universitário com diversos livros publicados, e curador de inúmeras exposições. Trabalha também como crítico de arte. Foi diretor do Paço Imperial no Rio de Janeiro e curador da Fundação Iberê Camargo. Foi também curador da $5^{\mathrm{a}}$ Bienal do Mercosul. 
* Júlia Peregrino, co-curadora da exposição Henfil do Brasil, tem também longa carreira na organização de mostras, trabalhou recentemente na curadoria das mostras do Museu da Língua Portuguesa, que apresentaram as obras de Clarice Lispector e Gilberto Freyre.

* Felipe Chaimovich, curador da pequena mostra Um Indeterminado, é curador do Museu de Arte Moderna de São Paulo e crítico de arte do jornal Folha de S. Paulo. Também é professor universitário e realizou inúmeras curadorias em importantes museus e galerias brasileiras.

* Paulo Herkenhoff, curador da exposição Manobras Radicais, é diretor do Museu de Belas Artes do Rio de Janeiro. Exerceu vários cargos de coordenação e a direção de coleções e instituições de arte; entre elas, foi curador da Fundação Eva Klabin Rapaport, consultor da Coleção Cisneros (Caracas) e da IX Documenta de Kassel, em 1991. Entre 1997 e 1999 assumiu a curadoria geral da XXIV Bienal de São Paulo.

* Pieter Thomas Tjabbes, curador da mostra Impressões Originais é formado em Direito e em História da Arte pela Universidade de Leiden, na Holanda, foi diretor técnico do Museu de Arte Moderna de São Paulo em 1990-1991 e diretor do Stedelijk Museum em Schiedam, na Holanda.

Estruturar conceitualmente uma exposição, pesquisar artistas, selecionar as obras, organizar a disposição espacial, negociar com colecionadores e museus, escrever textos explicativos são as tarefas tradicionais dos curadores. O que é novo na contemporaneidade é a dimensão autoral dada a esse trabalho, que, em muitos casos, tem consagração semelhante à dos artistas expostos. A posição dos curadores é decorrente de seu prestígio intelectual e também de seu elevado capital cultural.

O curador tem se investido de responsabilidade pela criação de uma narrativa da exposição, na qual procura dar um sentido que não resida nas obras isoladamente, mas naquilo que as une. Em contexto no qual a arte contemporânea aparece constantemente associada a discursos, os textos explicativos do curador assumem eminente papel didático para os públicos.

Situando-se em linha limítrofe do campo intelectual, o curador parece muitas vezes estar propondo uma tese com a mostra que organiza, já que as exposições se ancoram em uma linha que estrutura as obras, dando-Ihes consistência em sua totalidade. Assim, ao contrário das organizações dos acervos permanentes dos 
museus, normalmente centradas na cronologia ou nos "-ismos" legitimados pela história da arte, as exposições das instituições culturais contemporâneas parecem desejar que o público não se ocupe tão somente das obras de forma individualizada, mas seja capaz de dar um sentido que as transcenda.

Essa racionalidade articuladora que o curador deve propiciar à mostra é mais uma evidência de como o campo das artes plásticas se autonomizou em um grau tão elevado que os seus membros (públicos, artistas, curadores etc.) devem não só ser capazes de apreciar as obras, mas também de relacioná-las, erigindo cada mostra ao patamar de bem simbólico superior.

\subsubsection{Exposições históricas}

A exposição Antes - Histórias da Pré-História consistiu em uma mostra arqueológica e etnográfica com peças pré-históricas brasileiras. As obras arqueológicas foram organizadas por regiões geográficas: o Litoral, o Interior e o Amazonas. A mostra Por Ti America, também composta por peças arqueológicas da América Pré-Colombiana, possuía divisão didática em quatro módulos Mesoamérica, Andes, Circuncaribe e as Terras Baixas da América do Sul - e em cinco temas: cosmovisão, linguagem, vida em sociedade e assentamento, sociedade e religião, política e sociedade. Essas exposições sucederam a mostra Arte da África, também com peças arqueológicas, que foi recorde de público nos CCBBs.

A mostra Por Ti America teve curadoria de Marcia Arcuri, professora do Museu de Arqueologia e Etnologia da USP e contou com 250 peças provenientes de nove museus de seis países latino-americanos. Em Antes, além de Anne-Marie Pessis e Gabriela Martin, a curadoria foi assinada por Niéde Guidon, uma das mais renomadas arqueólogas brasileiras, que teve papel decisivo nos estudos dos sítios arqueológicos encontrados no estado do Piauí.

Nessas exposições, além dos curadores, surgiu a figura do idealizador, às vezes também chamado de coordenador. Em Por Ti America, o designer chileno, radicado no Brasil, Alex Chacon, assumiu essa função; em Antes - Histórias da PréHistória, quem o fez foi Marcello Dantas, documentarista e especialista em utilização de tecnologias acopladas a exposições artísticas. Ambos são também os criadores dos logotipos das exposições e da ambientação das exposições, com forte apelo cenográfico e ampla utilização de recursos multimídia. 
O mote dessas exposições foi muito mais histórico e etnográfico do que artístico. A escolha de determinados utensílios, objetos de uso cotidiano, fósseis, réplicas de animais extintos e múmias não se deu com a intenção de que fossem apreciados esteticamente, muito embora abundassem as obras de caráter eminentemente simbólico. Por retratarem culturas distantes historicamente, a apreensão desses objetos deu-se, sobretudo, com caráter informativo, sendo que a postura esperada do público não se resumia à fruição estética da mostra. As obras foram expostas de maneira a propiciar compreensão das sociedades existentes nos momentos históricos e espaços geográficos abordados. A preocupação por contextualizar as obras no tempo e no espaço deu um tom eminentemente educativo às exposições. Esse objetivo não foi escondido na seleção do projeto, já que se ressaltou a justificativa da "responsabilidade sócio-ambiental" da empresa ao permitir o acesso das escolas às visitas guiadas e, assim, complementar a formação dos estudantes.

O principal objetivo do destaque dado a essas exposições na programação talvez tenha sido o da ampliação de público. Conforme apontam Bourdieu e Darbel (2003), o interesse por objetos históricos, folclóricos ou etnográficos é muito superior nas classes sociais inferiores. Segundo pesquisa realizada pelos dois intelectuais, na França, na década de $60,71 \%$ dos visitantes das classes trabalhadoras preferiam ver tais objetos, dentre os oferecidos pelos museus, enquanto que somente $17 \%$ das classes superiores manifestavam esse desejo. Não há razões para supor que a situação seja diferente no Brasil de hoje.

As exposições supracitadas, em média, receberam orçamento superior ao das demais exposições patrocinadas pelo CCBB e ocuparam grande espaço do prédio $^{120}$. Tiveram presença maciça de público, principalmente em função das visitas de estudantes em grupos. No entanto, dialogavam muito pouco com o campo artístico. É verdade que as obras expostas possuem inegável valor estético, ainda que a presença do público se tenha devido normalmente, como vimos, a outras razões. Não é à toa que os grandes museus do mundo (Musée du Louvre, British Museum e Metropolitan Museum) possuem acervos arqueológicos que constituem "patrimônio da humanidade" e são objetos de estudos de historiadores e críticos de arte. Contudo, pelo fato de o seu interesse histórico sobrepujar o artístico, o que é

${ }^{120}$ A exposição Por Ti America ocupou todos os espaços expositivos do prédio e a exposição Antes deixou de ocupar apenas o primeiro andar. 
ressaltado como caráter educativo para justificar a organização das mostras, raramente é objeto, por exemplo, de crítica em jornais. O anonimato dos autores das obras expostas retira desses objetos a "aura" que ronda os objetos artísticos, já que não permite a individuação das criações.

Afastando-se do debate contemporâneo da arte, a instituição patrocinadora opta por uma escolha menos arriscada. Se a pertinência da exposição das obras de arte contemporânea é constantemente questionada, seja pelo público pouco informado sobre os cânones de sua produção - o que suscita a dúvida freqüente: "mas, isso é arte?" -, seja pelos especialistas, cujas convenções são postas constantemente à prova, no caso de exposições históricas, esses questionamentos não se colocam, já que sua validade e pertinência se apresentam, sobretudo, pelo valor histórico das obras, o que acaba sendo consensual e raramente gera controvérsias.

\subsubsection{Exposições individuais}

As mostras individuais são as que recebem menos recursos e menores espaços expositivos. Foram nove mostras individuais, sendo a maior parte delas (seis) de artistas vivos. A média de idade desses artistas pode ser considerada elevada, 47 anos, o mais velho na faixa dos sessenta e o mais novo na dos trinta anos. Ressalte-se também que a maior parte dos artistas é constituída por brasileiros, ainda que alguns residam ou tenham residido no exterior. Isso é coerente com diversos esforços mercadológicos e publicitários que procuram reforçar o BB como banco dos brasileiros, distinguindo-o de inúmeros bancos com matriz no exterior.

O número de obras expostas é reduzido, quando comparado às exposições históricas: enquanto estas possuem em média duzentas obras, as mostras individuais possuem 45. O espaço a estas destinado, na maior parte dos casos, é o primeiro andar e o subsolo, cujos ambientes são reduzidos. Constituíram exceções as exposições de Mary Vieira e de Farnese de Andrade, ambos mortos, de maior porte, com número superior de obras expostas e mais recursos de patrocínio. Esses 
dois artistas têm em comum ${ }^{121}$ o fato de serem contemporâneos, terem realizado parte de suas carreiras em Minas Gerais e terem sido alunos de Guignard na Escola do Parque de Belo Horizonte. Entretanto, apesar de possuírem carreiras bemsucedidas e obras bastante valorizadas no mercado de arte, ambos são desconhecidos ${ }^{122}$ do grande público.

Mary Vieira é reconhecida pela crítica internacional como uma das principais representantes da arte cinética. A exposição realizada no CCBB foi a primeira mostra individual mais significativa da artista no Brasil ${ }^{123}$, cuja carreira se deu, em grande parte, na Europa. Trata-se de um nome que estava esquecido no panorama da arte brasileira. A mostra de suas obras, composta por esculturas, maquetes, projeções, filmes, serigrafias e fotografias, em algumas situações, permitia interatividade do público.

A exposição foi precedida de pesquisa realizada na Suíça e na Itália pela curadora e teve consultoria do ISISUF (Istituto Internazionale Studi sul Futurismo). Verificou-se, então, que Mary Vieira contribuiu para a hegemonia do concretismo enquanto estilo, no Brasil da década de 50. A premiação de Mary Vieira na Bienal Internacional de São Paulo, de 1953, consolidou o gosto estético "antifigurativista" nos meios intelectuais e na elite brasileira (Madeira, A. 2002). Se, naquele momento, ela teve papel importante na fundação de uma nova tradição na história das artes plásticas, quando da exposição no $\mathrm{CCBB}$, sua obra não apresentava mais aspecto revolucionário, muito embora estivesse longe de ser uma artista de apelo popular.

A mostra de Farnese de Andrade teve obras igualmente escultóricas, se é possível chamar dessa forma suas assemblages. Igualmente, foi expoente da transição do moderno para o contemporâneo na arte brasileira. Se Mary Vieira se filiou de forma mais assumida à tradição neoconcreta, Farnese seguiu pesquisa muito mais individual e "auto-biográfica". Utilizou materiais reciclados, descartados, coletados nas praias e nos aterros, além de armários, oratórios, gamelas, ex-votos, entre outros. Com uma trajetória profissional desenvolvida em sua maior parte no Brasil, teve inúmeras mostras individuais e participou igualmente em um grande

\footnotetext{
${ }^{121}$ Essa origem biográfica comum não foi explorada em nenhum momento pela instituição patrocinadora, em função do caráter episódico das exposições, que não permitem conexões ou diálogos entre as mostras efetuadas.

122 A considerar o título da matéria do Jornal do Brasil de 26/04/05: "Mary Vieira: a artista que o Brasil desconhece" (Maria, 2005). O caráter "experimental" e pouco convencional da obra de Farnese de Andrade nos faz supor, com grande probabilidade de acerto, que também não seja um artista popular.

${ }^{123}$ A artista já havia realizado uma exposição individual, em 1978, na Galeria de Arte Moderna de Brasília, e inúmeras exposições individuais no exterior.
} 
número de mostras coletivas (o que não impediu o curador de afirmar o quanto sua obra é desconhecida ${ }^{124}$ ). Foi também bastante premiado e suas obras fazem parte de importantes coleções e do acervo de diversos museus brasileiros.

A exposição Henfil do Brasil, apesar da menor proporção, curiosamente recebeu recursos equivalentes às duas supracitadas. Ocupou apenas o primeiro andar do prédio do CCBB e recebeu recurso superior à Farnese de Andrade, com número maior de obras expostas.

A mostra de obras de Henfil significa desvio em relação às demais exposições, com artistas vinculados ao que poderíamos chamar de grupo dominante das artes plásticas, os quais seguem os cânones e os critérios de avaliação hegemônicos no campo. Henfil foi um artista mais popular em dois sentidos. Primeiramente, em função de sua linguagem, o cartum, e também em razão dos veículos em que sua obra foi divulgada: jornais e revistas de grande circulação. Assim, como nas mostras históricas, com Henfil, o CCBB retirou-se do campo das artes plásticas, já que uma exposição dessa natureza não suscita apreciação, comentários ou discussão do corpo de especialistas. Segundo uma das curadoras, Julia Peregrino, a "idéia é desmistificar o cartum como arte menor. O cartum é igual a qualquer outra manifestação artística." 125

Possuindo linguagem mais acessível, tom preponderantemente cômico e estrutura narrativa que mescla imagem e escrita, a mostra dialogou facilmente com não iniciados no campo das artes plásticas. A associação direta e imediata estabelecida entre o artista e a oposição ao regime militar, bem como com sua incansável denúncia das mazelas brasileiras, deu um tom crítico e esquerdista a sua obra. A mostra, que adquiriu tom de homenagem à figura histórica que o artista representou, foi iniciativa de seu filho, que contratou curadores de renome para sua montagem e contou com originais de seu acervo pessoal.

Apesar de não se inserir no circuito dominante das artes plásticas, o artista possui lugar de destaque entre os cartunistas brasileiros, seu trabalho sendo objeto de estudo em diversas obras de caráter mais acadêmico (Moraes, 1997; Rego,

\footnotetext{
${ }^{124}$ A obra desenvolvida por Farnese de Andrade não pertenceu, tampouco gerou, um estilo, uma escola ou um movimento. Esse fato não a posiciona acima ou abaixo de seus contemporâneos, mas denuncia sua singularidade, como também a dificuldade em contextualizá-la conforme a historiografia vigente das artes visuais. Tal dificuldade é ainda agravada pelo fato de ela ter permanecido esquecida e desconhecida nas duas últimas décadas. (Cosac, 2005).

${ }_{125}^{125}$ "Exposição do Henfil do Brasil pode ser vista até 15 de janeiro no CCBB" http://www.artepluralweb.com.br/atualizacao/releases/06/janeiro/capobianco_expos_henfil_brasil.htm, consultado em 16/02/08.
} 
1996; Lago, 1999). Sua aparente "marginalidade" em relação às estruturas de consagração do campo é relativa. A mostra ganhou o 18ํㅜ Troféu HQMIX, em 2006, na categoria exposição. Com essa exposição, o CCBB resgatou um nome conhecido do grande público, com prestígio não só pelo seu trabalho artístico, mas, sobretudo, pela importância histórica e política, material que não havia recebido ainda uma mostra exclusiva de destaque.

Vik Muniz foi o artista vivo que ganhou exposição individual de maior investimento. Trata-se também de nome consagrado no campo artístico, com carreira consolidada não só no Brasil, mas principalmente no exterior. Teve diversas exposições individuais em Nova lorque, Tókio, Barcelona, Amsterdam e Roma, dentre outras cidades. Suas obras fazem parte do acervo de grandes museus e instituições culturais de arte contemporânea do mundo. Seus últimos trabalhos, inclusive os expostos no CCBB, têm como substrato fotografias, recriadas pelo artista, a partir da inclusão de elementos - chocolate, pedras preciosas, sucatas, lixo, açúcar, poeira e cabelo - sobrepostos às imagens, algumas vezes decompostas e desfiguradas. Paralelamente a sua consagração artística, o artista é igualmente bem sucedido comercialmente, sendo que suas obras adquirem preços elevados no mercado de artes. Isso o coloca em uma posição ambígua:

Vik Muniz é hoje um dos artistas brasileiros mais reconhecidos no
exterior. Ser "reconhecido", no vigoroso mercado de arte
internacional, significa, sobretudo, vender bem e a preços
fantásticos. Essa é a posição ocupada por Muniz, que vive em Nova
York há mais de duas décadas. Isso o coloca no melhor dos
mundos, e certamente no pior deles: sua arte é vista a partir do
ângulo de compra e venda, e as análises em torno de suas
intenções batem sempre contra esse mesmo muro: a de ser ele um
"artista comercial". Logo, menos artista. (Rezende, Marcelo. "Artista
da Ilusão".
http://bravonline.abril.com.br/indices/artesplasticas/artesplasticasmat
eria 249259.shtml)

Essa exposição foi uma das poucas que recebeu crítica negativa. Em seu artigo, o crítico $^{126}$ condenava a repetição de uma fórmula e o rompimento com o caráter experimental do artista em seu início de carreira. A julgar por essa avaliação, a exposição de Vik Muniz pode ser caracterizada, na linguagem dos próprios funcionários do CCBB, como um patrocínio fácil, ou seja, aquele que atende ao

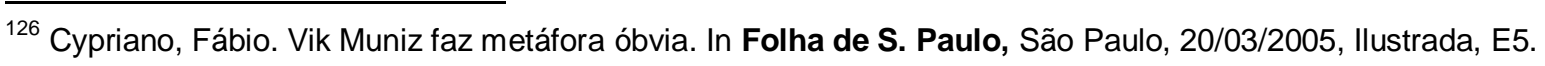


gosto do público, por meio de fórmula conhecida de um artista consagrado, mas que não contribui para a inovação do campo artístico.

O CCBB patrocinou, nos dois anos em análise, outras mostras, de artistas menos consagrados, que tinham a fotografia como forma de linguagem: Desoriente, Um Indeterminado e Polissemiose, de autoria de Leonardo Kossoy, Edouard Fraipont e Amílcar Packer, respectivamente. Eles não são artistas iniciantes, mas estão longe de ter a consagração dos anteriores. Ao contrário das demais, seus nomes não intitulam as exposições.

A primeira mostra não é considerada um patrocínio pelo próprio CCBB, pois houve apenas cessão de espaço, sem desembolso de recursos, configurando um tipo de ação promocional nada freqüente na instituição. Os outros dois são artistas mais jovens, que ainda não tinham tido uma exposição individual de maior destaque em instituição de renome. Tratou-se, portanto, de investimentos mais arriscados do que os precedentes.

Fraipont iniciou um projeto da instituição que consiste em destinar o espaço expositivo do subsolo, onde se localiza o antigo cofre, a novos nomes da arte contemporânea. O caráter experimental do artista foi reforçado em entrevista:

"Se de um lado apresentamos grandes exposições, realizadas por
curadores renomados e com obras consagradas, de outro, e com o
mesmo peso como aponta a nossa seleção, queremos ter um
compromisso com o novo, mostrando ao público a produção atual de
artistas que, como Fraipont, ousam ao manter a experimentação
como princípio de seu projeto artístico", explica Marcos Mantoam,
diretor do CCBB-SP. ${ }^{127}$

Se é verdade que o artista realizou um trabalho experimental, não é menos verdade que a exposição contou com curador de renome - Felipe Chaimovich - e que a galeria (Vermelho) que representa o artista é uma das mais "badaladas" da cidade. Ressalte-se também que se tratou de exposição muito inferior às demais, em três sentidos: espaço reduzido (subsolo), pequeno número de obras (15 fotos) e recursos inferiores $(\mathrm{R} \$ 101.550,00)$. Não teve, portanto, o mesmo peso dado às outras mostras.

Se, com as exposições desses jovens artistas, o CCBB investiu em obras de caráter mais experimental no cenário da arte contemporânea, com a mostra de Maurino de Araújo, a instituição tendeu para o mais tradicional da arte, com obras de 
características barrocas. Com esculturas talhadas em madeira e pintadas, de um artista autodidata, de características quase populares, Maurino de Araújo possui um currículo de destaque, com exposições individuais e internacionais em instituições renomadas.

Outro autodidata patrocinado foi Alfredo de Oliveira, com uma pequena mostra, na qual expôs cinqüenta obras em guache sobre papel, de pequenas dimensões $(22 \mathrm{~cm} \times 22 \mathrm{~cm}$ ), com traçados geométricos e cores fortes. Diferentemente de Maurino de Araujo, mas assim como Amilcar Packer e Edouard Fraipont, trata-se de artista com trabalho ainda não consagrado no campo artístico.

\subsubsection{Exposições coletivas}

A opção de reunir obras de artistas diversos, agrupando-as em torno de uma temática, é recorrente em museus e centros culturais. Nas exposições individuais, a consagração do artista é decisiva para o sucesso da exposição. Nas coletivas, esse fator também está presente, mas é menos preponderante.

Nas exposições coletivas, o trabalho do curador aparece com maior destaque, sendo que os componentes do campo artístico, normalmente, avaliam a exposição por sua coerência, proposta, representatividade das obras, subdivisões e conceito, entre outros aspectos.

As exposições coletivas ganharam mais recursos, no geral, do que as exposições individuais, apesar de estas serem em maior número. Também ocuparam grande parte do edifício, ao contrário das individuais, cujo espaço foi menor. Foram quatro exposições coletivas: uma dedicada a artistas cubanos; outra a mulheres-artistas brasileiras; uma terceira, a obras que se relacionavam com erotismo; e a quarta, a gravuras.

A mostra Artes de Cuba trazia obras do século $\mathrm{XX}$, desde o modernismo cubano até artistas contemporâneos. Era organizada em três linhas temáticas: busca das raízes da cultura cubana, experimentação com a linguagem plástica e compromisso social do artista, seguindo um trajeto bastante cronológico. Reuniu 117 obras de 61 artistas, vindas principalmente do Museo Nacional de Bellas Artes de Cuba, e de coleções particulares. Ania Rodriguez, cubana, curadora da exposição, é uma jovem historiadora da arte. A exposição foi decorrente de um convênio cultural

${ }^{127}$ http://www.vitruvius.com.br/noticia/noticia detalhe.asp?id=146, consultado em 17/02/08. 
celebrado pelo Ministro da Cultura, Gilberto Gil, com seu homólogo cubano, Abel Prieto, quando da visita do presidente Lula a Cuba. Tratou-se, portanto, de uma escolha que não foi decisão do CCBB, mas teve motivação eminentemente política, por conta, acredita-se, da participação do Diretor de Marketing do BB, vinculado ao partido do Presidente da República, na comitiva presidencial (posteriormente afastado por suspeita de envolvimento em esquemas de corrupção).

O mesmo crítico $^{128}$ que apontou problemas na mostra de Vik Muniz, também fez crítica negativa a essa exposição, em função da superficialidade da abordagem, decorrente da abrangência do período histórico contemplado. Outra crítica ${ }^{129}$ caminhou no mesmo sentido, apontando problemas que decorriam do número reduzido de obras por artista.

A mostra Manobras Radicais procurou abranger a participação da mulher na arte brasileira recente, desde os anos 20, reunindo cerca de quarenta artistas de gerações variadas.

O título indica um processo estratégico pelo qual as artistas brasileiras romperam com o rígido sistema da arte, em todo o mundo dominado pelos homens. O termo radical remete à noção de raiz, como fundamento, alicerce ou sustentação, que é a posição muitas vezes ocupada pelas artistas mulheres seja num movimento de vanguarda, seja na discussão da interioridade do ser, ou ainda na consolidação de tradições às quais conferem uma solidez histórica. Por vezes, trata-se de uma audácia estética. Finalmente, 'manobra radical' é associado à vida contemporânea, termo que sai dos esportes para se referir a outros campos (Holanda e Herkenhof, 2006).

Essa mostra apresentou nomes já "clássicos" das artes plásticas brasileiras, conhecidos do grande público, como Anita Malfatti, Lygia Clark e Tarsila do Amaral, nomes contemporâneos já consagrados, como Adriana Varejão, Beatriz Milhazes, Carmela Gross, Claudia Andujar, Iole de Freitas, Leda Catunda, Mira Schendel, Nazareth Pacheco, Rosana Palazian e Rosângela Rennó, e nomes menos conhecidos, como a das paraenses Lise Lobato e Nailana Thielly, esses sem citações na divulgação da exposição realizada pelo CCBB.

O recorte de gênero da mostra não é dos mais originais, mas ganhou a simpatia do público habitué de exposições, normalmente sensível às causas das

${ }_{128}$ Cypriano, Fabio. Tom oficial marca "Arte de Cuba". In Folha de S. Paulo, São Paulo, 27/03/2006, Ilustrada, E6 
"minorias sociológicas". Foi a única mostra coletiva cuja exposição se restringiu ao CCBB São Paulo, ao passo que as demais fizeram itinerância.

A mostra Impressões Originais: a gravura desde o século XVI teve certa ousadia, por escolher linguagem pouco atrativa ao grande público. A reconstituição histórica da gravura, desde suas origens até a pop art, fez um trajeto que incluía xilografura, litografia e serigrafia. Se a linguagem não atraía, os nomes dos artistas, conhecidos do grande público, foram utilizados para divulgar o evento por intermédio dos press releases e da publicidade: Rembrandt, Goya, Toulouse Lautrec, Kandisky, Picasso, Andy Warhol, Matisse e Miró. As obras vieram de museus holandeses e brasileiros.

A mostra Erotica será explorada detalhadamente no próximo capítulo.

\subsubsection{O CCBB e os embates das artes plásticas contemporâneas}

O aparato conceitual utilizado para a compreensão das escolhas do CCBB na área das artes cênicas mostra-se inadequado para as artes plásticas, uma vez que, nesse campo, a dicotomia entre experimental e comercial se coloca a partir de outros critérios classificatórios. Se, nas artes cênicas, o experimental se opõe ao comercial, como se fosse construído em contraposição ao instituído e ao circuito que valoriza os aspectos financeiros das obras, nas artes plásticas não há contradição entre ser experimental, sendo isso quase imperativo para a manutenção da presença no circuito das artes, e ser comercial, já que os mais renomados artistas experimentais são representados por grandes galerias, as quais comercializam suas obras a preços bastante elevados. O prestígio da instituição é estratégia usada por marchands para valorizar coleções -, em alguns casos, eles compram obras a preços baixos, cedem-nas em comodato a museus, e depois as revendem a preços mais altos, por terem sido valorizadas pela exposição na instituição.

Pretende-se, neste caso, portanto, caminho analítico diferente do trilhado na análise das artes cênicas. A forma pela qual a instituição se coloca em relação ao que se convencionou chamar de arte contemporânea dá um bom indício de como ela está situada no campo artístico.

\footnotetext{
${ }^{129}$ Moraes, Angélica. Sem perder a ternura. In Bravo!, São Paulo, fevereiro de 2006, 25.
} 
De início, pode-se afirmar que o CCBB não se define como instituição que priorize as manifestações contemporâneas das artes plásticas, como é o caso do MAC, do MAM, do Instituto Tomie Othake e de diversas galerias. Não há nada em sua política cultural, diretrizes ou valores que afirme compromisso com gênero, estilo ou tendência. Pauta-se, portanto, pela primazia da diversidade.

Inexiste uma definição substancial de arte contemporânea, havendo conceitos contextuais e relacionais. Normalmente, o paradigma contemporâneo é utilizado em oposição ao moderno. Essa noção impõe-se, sobretudo, a partir dos anos 1980, mas seus precursores surgem no período do pós-guerra. Muitas vezes, o termo arte contemporânea confunde-se com o de arte pós-moderna, termo ambíguo, que não se limita ao campo das artes plásticas.

O período abarcado pelo contemporâneo vê suplantar a sucessão de vanguardas, com todos os seus "-ismos", como o Surrealismo, o Expressionismo, o Dadaísmo, o Futurismo, que marcaram o século $X X$, já que a arte contemporânea não pode ser reduzida facilmente a um estilo. Algumas tendências se consolidaram, contudo, passando a criar grupos de filiação dos artistas, como o Minimalismo, o Conceitualismo, a Land Art, a Performance, a Body Art. O que se mostra de forma evidente é a impossibilidade de classificar as artes plásticas no esquema utilizado até os anos 60, que as agrupava em pintura ou escultura.

Não se pretende elaborar uma definição precisa do que o campo artístico nomeia como arte contemporânea, pois resultaria na confrontação de vultosa bibliografia, extrapolando os objetivos deste trabalho. No entanto, vale considerar as três rupturas básicas entre o contemporâneo e o moderno nas artes plásticas, estabelecidas por Sausset (Francblin, Sausset e Leydier, 2003), as quais significam o fim de uma tripla ilusão:

a) a ilusão da eternidade das obras, já que a arte contemporânea, tende a ser efêmera, frágil e se transforma à medida que o tempo passa, muitas vezes, em função dos materiais empregados, perecíveis e que se autodestroem lentamente;

b) a ilusão da ubiqüidade, que garantia à obra moderna sua identidade, independentemente do local onde fosse exposta. O advento da instalação e do site specific fez com que as obras tivessem destino único e se encerrassem no final da mostra e do evento. A associação freqüente 
dessas instalações com performances torna as obras ainda mais conectadas a locais e momentos restritos;

c) a ilusão da evidência, que exige de cada espectador o conhecimento necessário à sua compreensão.

Essa ilusão, diretamente saída da Renascença, repousava também sobre o fato de que a obra de arte tinha um público especializado (cultivado) e uma destinação precisa. Ao contrário, a arte contemporânea repousa o mais frequentemente sobre um efeito que seria da ordem da sensação pura e da "immédiateté" das significações. (Francblin, Sausset e Leydier,2003:10)

Se é possível estar plenamente de acordo com as duas primeiras atribuições, a terceira se mostra amplamente discutível. A reação do público não-familiarizado com a arte contemporânea normalmente resulta na negação da sua qualificação artística. Essas reações são enunciadas com freqüência da seguinte forma: "Meu filho de cinco anos faria igual", "Mas isso é arte?" "Qualquer um poderia fazer isso" "Os artistas não possuem mais uma técnica" "Não tem nada a ver, qualquer coisa serve". Essas assertivas revelam o caráter hermético e impenetrável que a arte contemporânea apresenta ao grande público.

A arte contemporânea modifica também o status do artista.

A palavra artista, antes carregada de uma dupla conotação (intelectual e artesanal), foi substituída pela do "plástico" (plasticien). O artista não possui mais a auréola de um "savoir-faire", mas é manipulador de "coisas". Da mesma forma, ele não realiza mais obras, mas fornece um "trabalho". Ele pode ser um técnico, mas pode também se contentar em ter uma idéia de partida e deixar a uma equipe mais competente profissionalmente o cuidado de realizar a coisa. (Rouge, 2006:39)

No que diz respeito à arte brasileira, Agnaldo Farias prefere não incluir como artistas contemporâneos os que tiveram seu ponto de partida nos anos 50 e 60, como Amilcar de Castro, Tomie Ohtake, Arcângelo lanelli, entre outros, por sua evidente raiz moderna. Considera artistas contemporâneos principalmente os que iniciaram sua trajetória na passagem para os anos 70 :

[...] quando produzir arte significava operar na expansão do objeto artístico, seja pela apropriação de coisas e imagens extraídas do cotidiano, seja por radicalizações cada vez maiores, traduzidas em obras mais complexas do ponto de vista conceitual, mais 
interessadas no plano intelectual dos espectadores do que em suas retinas." (Farias, 2002: pág. 18).

Portanto, a arte contemporânea não difere das suas predecessoras no que concerne à atratividade exercida sobre o público, ainda que não iniciado e com dificuldade de compreendê-la, o que é demonstrado pela permanência dos museus de arte contemporânea existentes em todo o mundo. Da mesma forma que a arte moderna, a capacidade de apreciação da obra de arte contemporânea tornou-se sinal de elevada posição cultural, portanto, símbolo de status e prestígio.

Enquanto se entende a arte de vanguarda como um movimento de estetização do mundo (ou de superação da relação arte-vida) e, simultaneamente, nos termos da crítica, como 'formas autônomas', 'esotéricas', dotadas de 'história interna', e, portanto, independentes de vínculos práticos com a vida, a arte pós-vanguardista pode ser caracterizada pelo abandono dos programas de estetização do real (de retração do estético ao artístico) e, ao mesmo tempo, como uma tentativa de diminuir a distância entre a arte e o público, aproximando-a, ainda nas expressões da crítica, do 'mundo da vida'. Afastada a utopia, esta arte, destituída da força que se quis subversiva das vanguardas, opõe-se ao presente, enquanto chauvinismo, machismo, efeitos da informática, crise da narrativa etc. Da falência das vanguardas como projeto de emancipação, não resultou assim a negação dos poderes de negação da arte; mas resultou uma arte que, mesmo sendo mediada por apropriações, se opõe com suas simbolizações à 'legalidade própria' ou à 'autonomia formal' (atribuídas à arte de vanguarda por artistas e críticos), ou ao seu 'hermetismo' (no lugar-comum do público). (Fabrinni, 2002:195).

Dois precursores da arte contemporânea, constantemente citados (Cauquelin, 2005; Archer, 2001) são Marcel Duchamp (1887-1968) e Andy Warhol (1928-1987). Ambos trazem ao cerne de seu trabalho uma meta-discussão, na medida em que questionam a singularidade da obra, preceito básico de toda arte moderna e prémoderna.

No CCBB, a própria edificação do prédio não favorece a sua constituição como espaço destinado à arte contemporânea ${ }^{130}$. Por tratar-se de imóvel tombado, suas paredes e estrutura arquitetônica são imutáveis, não favorecendo muito as criações gigantescas ou as que subvertem o cubo branco tradicional, muito

\footnotetext{
${ }^{130}$ Os espaços destinados a exposições de arte contemporânea normalmente possuem grande maleabilidade expositiva, constituindo-se de grandes galpões que permitem as mais diversificadas formas de montagem, como, por exemplo, o Palais de Tokyo, em Paris, ou o MACBA, em Barcelona.
} 
adequado para sustentação de quadros, mas inadequado às formas mais contemporâneas das artes plásticas. O que tem sido feito, com criatividade e de maneira recorrente, é a utilização do enorme vão central, como espaço para as obras de maior envergadura, invariavelmente dependuradas sob a clarabóia, perpassando os andares, e, algumas vezes, chegando até o solo.

Em contrapartida, a tão cara diversidade que norteia a política do CCBB talvez seja o que melhor define a arte contemporânea. Diversidade entendida em sentido mais radical, de pluralidade e de recusa à normatização, e de prescrição dos próprios dos "-ismos" do moderno:

A aceitação por artistas e críticos dessa diversidade, resultado do devir de combinatórias, opõe-se, portanto, ao caráter prescritivo e teleológico dos projetos coletivos de vanguarda. O espaço da contemporaneidade se manifesta num tom afirmativo, mas não normativo; é plural e distendido: um espaço inclusivo, de coexistência pacífica, não apenas entre o artístico e o estético, mas ainda no interior do artístico, entre a arte dita "sintático-formal" e a arte dita "semântico-pragmática"; entre a representação figurativa e a abstração, entre a arte construtiva e a arte pulsional. À sucessão de movimentos artísticos, indissociáveis do international up-to-date style das vanguardas, seguiu-se a simultaneidade do radicalmente diverso: a multiplicidade atual, passível de seriações, não pode ser interpretada na continuidade, no sentido da sucessão das vanguardas de ismos (que operaram sismos na arte), mas na transversalidade (na associação de signos heteróclitos de um passado heteróclito). (Fabbrini, 2002:193-4).

Heinich (1998) resume em três movimentos básicos o que caracteriza a arte contemporânea:

Transgressão pelos artistas, rejeição pelo público, integração pelas instituições e, novamente, transgressão um pouco mais provocante, integração pela crítica e pela porção iniciada do público, rejeição ainda mais violenta de um público mais profano, aceleração da assimilação pelos especialistas: com esse "jogo de mãos quentes"131 entre artistas-emissores, espectadores-receptores e especialistasmediadores, se impõe em duas gerações o novo paradgima da arte contemporânea. (Heinich, 1998a)

A caracterização da transgressão como elemento central da arte contemporânea parece bastante adequada, tendo em vista que aquilo que marca

${ }^{131}$ Tradução literal de "partie de main chaude", que consiste de jogo infantil no qual há uma superposição de mãos, sendo a que estava em baixo se coloca por cima e assim sucessivamente. 
essa produção simbólica remete ao alargamento de fronteiras em diversos aspectos: em relação aos conteúdos, às formas, à distância em relação ao mundo ordinário, à materialidade, à autenticidade, à moralidade e, mesmo, à legalidade. Trata-se de ruptura muito mais acentuada do que aquela que ocorreu entre o paradigma moderno e o paradigma clássico, quando o elemento principal foi o rompimento com a figuração, embora mantendo a pintura e a escultura como os principais formatos das artes plásticas.

O ato subversivo do artista só faz sentido, contudo, quando institucionalizado e amparado por uma instância de consagração que dá o estatuto de arte à sua produção. Dessa forma, o valor da proposição artística não reside na obra em si, mas na sua apropriação pelas instâncias de mediação (museus, instituições culturais etc.), que deixam de ser meras intermediárias e se tornam tão produtoras da obra quanto o artista, ainda que a produção artística se construa contra o poder dessas instâncias que a legitimam.

O que torna ainda mais complexa a situação da arte contemporânea é que as instâncias mediadoras, via de regra, e essa é também a posição do CCBB, se recusam a assumir o papel de produtoras do bem simbólico, negando seu lugar na arte contemporânea e procurando localizar a aura artística no valor intrínseco dos objetos destinados à admiração.

Quanto ao público não especializado, sua rejeição é tanto maior quanto mais transgressiva é arte. A transgressão tem o objetivo implícito de surpreender e mesmo de chocar o público, ainda que não seja de bom tom que o público iniciado manifeste seu espanto, pois, assim fazendo, se equipara aos não iniciados.

$\mathrm{Na}$ programação do CCBB, é possível classificar cinco exposições (Mary Vieira, Farnese de Andrade, Vik Muniz, Um Indeterminado, Polissemiose) que se identificam mais claramente com o paradigma contemporâneo, sendo que as exposições coletivas trazem algumas obras que podem ser identificadas como arte contemporânea, associadas a outras que não se enquadram nessa categorização. Já as exposições históricas fogem totalmente desse paradigma.

Dessa forma, o CCBB assume caráter dúbio. Se promove a arte contemporânea, assumindo certa dose de risco em suas escolhas, tendo em vista os consensos ainda não claramente estabelecidos no campo artístico, acaba privilegiando, em termos de espaços para exposição e recursos de patrocínio, formas menos arriscadas de investimento, em particular quando concentra seus 
esforços em mostras museológicas e coletivas, de maior aceitação popular, cuja contestação por parte dos especialistas e grupos dominantes do campo se torna dificultada.

\subsection{Administrando os RIScos do PATROCÍNIO}

O valor mais enfatizado na definição da programação do CCBB, a diversidade, dá uma idéia, e isso é intencional, de que o acesso ao patrocínio é franqueado, amplamente democrático e que todos, independentemente da posição que ocupem, terão oportunidade de subsídio a sua criação, desde que ela o mereça. O processo seletivo pela Internet, a definição prévia dos critérios utilizados na seleção e a divulgação dos valores patrocinados no Diário Oficial da União reforçam o caráter público da competição, o que enfatiza a imagem de lisura e transparência.

No entanto, o CCBB, ao inserir-se no campo artístico, amolda-se a e reforça as regras e convenções próprias desse campo, servindo-se de instrumento de hierarquização, distribuição de prestígio, e reforçando formas de dominação que elegem alguns e excluem a maioria.

Ressalte-se que a preocupação com a diversidade não é mero elemento retórico. Isso se evidencia na programação. Nas artes plásticas, mesclando mostras históricas, individuais e coletivas. Artistas vivos e mortos. Brasileiros e estrangeiros, ainda que com amplo predomínio dos primeiros. Obras pré-históricas, renascentistas, modernas e contemporâneas. Estilos os mais diversos, abrangendo pinturas rupestres (Antes - Histórias da Pré-História), arte Pré-Colombiana (Por Ti América), arte cinética (Mary Vieira - O Tempo do Movimento), escultura barroca (Maurino de Oliveira), desenhos e guache sobre papel em pequenos formatos (Alfredo de Oliveira), vídeoinstalações (Polissemiose), fotografia (Um Indeterminado), cartum (Henfil do Brasil), gravuras (Impressões Originais: a Gravura desde o Século XV) e assemblages (Farnese de Andrade - Objetos).

As temáticas que as mostras envolvem também são amplamente diversificadas: erotismo (Erotica - Os Sentidos da Arte), crítica social (Henfil do Brasi), tempos e movimentos derivados de formas geométricas (Mary Vieira - $O$ tempo do Movimento), melancolia, surrealismo e desejos inconscientes (Farnese de Andrade - Objetos), recriações em torno da cultura popular (Vik Muniz - Divas e 
Monstros), identidade cubana (Artes de Cuba), mitos e rituais do cotidiano indígena pré-colombiano (Por Ti América), religiosidade católica (Maurino de Oliveira), o feminino nas artes contemporâneas (Manobras Radicais), o sentimento de deriva e o equilíbrio (Polissemiose). Enfim, o "conteúdo" suscitado pelos objetos apresentados relaciona-se às mais diversas motivações.

Quando avaliado o destaque que cada obra patrocinada recebe no quadro geral da programação, entretanto, fica evidente que ela obedece a uma hierarquia, determinada pela consagração que o artista possui na esfera artística.

O destaque dado a um evento adquire dois sentidos. Primeiramente, dá-se em função do valor destinado ao patrocínio. Normalmente, quanto mais alto esse valor, mais bem remunerados são os artistas e maior amplitude e liberdade de trabalho podem ter, seja na seleção das obras, seja na ambientação, no caso das artes plásticas, ou no refinamento da produção (cenário, figurino, iluminação), no caso das artes cênicas. Em segundo lugar, no que tange ao espaço dado ao artista, seja no que se refere ao espaço expositivo propriamente dito, no caso das artes plásticas, seja no que se refere aos dias das apresentações, no caso das artes cênicas.

No caso das artes plásticas, os maiores valores e os espaços mais amplos são destinados às mostras históricas ${ }^{132}$, às exposições coletivas, com curadores renomados, e às exposições individuais de artistas consagrados (Mary Vieira, Vik Muniz $^{133}$ e Farnese de Andrade). Artistas menos consagrados ficam com valores de patrocínio mais baixos e espaços expositivos reduzidos (Edouard Fraipont, Amílcar Packer, Maurino de Araújo e Alfredo de Oliveira).

O custo médio de uma exposição histórica $(R \$ 1.081 .660,00)$ patrocinada pelo CCBB é sensivelmente superior ao das mostras individuais ( $R \$ 148.393,00)$ ou coletivas ( $R \$ 371.250,00)$. Não obstante ter havido maior desembolso de recursos para mostras coletivas, com a predominância, no período, da arte contemporânea (Anexo 25), quando se levam em consideração os valores globais desembolsados

${ }^{132}$ O preço varia de acordo com a origem das peças e com a concepção cenográfica da exposição. Muitos museus e colecionadores não emprestam as obras, mas cobram pela "locação". Assim, a exposição mais custosa do período Erotica deve-se ao fato de suas obras serem provenientes de diversos museus que cobraram pelo empréstimo. A exposição Antes teve custo elevado em função das instalações de mídia, projeções e mecanismos interativos presentes em diversas salas.

133 Essa exposição ocupou apenas o $1^{\circ}$ andar do prédio, tinha somente 12 fotografias, mas representou a que teve mais verbas destinadas a um artista vivo. Além disso, a notoriedade do artista foi constantemente enfatizada pela instituição, como atesta o material de divulgação do CCBB ao afirmar que se tratava de "um dos nomes mais aclamados da arte contemporânea internacional". 
pelo BB (já que as mostras históricas invariavelmente circulam pelos três Centros Culturais) e também considerando que, além das duas englobadas no período em análise, o CCBB patrocinou recentemente duas outras grandes mostras de caráter histórico (Arte na África e Lusa), pode-se entender que essa linha curatorial responde a determinados interesses da instituição mantenedora.

A recusa de ser uma instituição artística e de assumir uma posição claramente definida em prol da arte contemporânea é encarada pelos arautos dessa arte como uma inegável posição conservadora:

Por que os especialistas de arte visual contemporânea (vanguarda) têm mais autoridade cultural do que os especialistas de arte visual moderna (tradicional)? Aparentemente, o capital cultural da vanguarda é mais valioso do que o dos tradicionalistas. Os especialistas da vanguarda pertencem à chamada 'nova elite cultural', que desafia a 'elite econômica' tradicionalista. Os tradicionalistas são conectados com a elite econômica que tem mais capital econômico. Então, podemos dizer que os dois grupos diferem na composição do seu capital. [...] A elite cultural tende a preferir a vanguarda, enquanto a elite econômica prefere a arte visual mais tradicional. (Abbing, 2002:69)

O peso maior das mostras históricas na programação do CCBB pode atender ao desejo de aliança com a parcela mais numerosa da população e também, fundamentalmente, ao de atingir público escolar, já que a grande parcela da população, sendo desprovida de grande capital cultural, tem mais dificuldade para interagir com as manifestações contemporâneas das artes plásticas.

No caso das artes cênicas, a variação dos valores de patrocínio em torno da média não é tão expressiva, quando olhados apenas os valores concedidos pelo CCBB São Paulo. Porém, considerando as itinerâncias, pode-se constatar que peças com nomes consagrados - Walmor Chagas, Sérgio Brito, Julia Lemmertz, por exemplo - foram levadas a mais de um CCBB e angariaram valores bem superiores às que se apresentaram somente no CCBB São Paulo. Da mesma forma, peças com nomes menos conhecidos tiveram espaço menor na programação, como aconteceu com a Peça de Elevador e As Turca cujos dias de apresentação se resumiam às quintas e sextas-feiras, dias de menor público nas salas teatrais.

Mesmo quando opta por nomes consagrados, o CCBB procura dar espaço a nomes que não estejam tão em voga no cenário artístico, mas cuja trajetória profissional assegure sua relevância no interior do campo. Explica-se, dessa forma, 
o grande espaço dado a atores septuagenários e octogenários das artes cênicas, como Walmor Chagas, Cleide Yáconis, Sérgio Brito e Marilena Ansaldi.

Nas artes plásticas, o destaque dado a Farnese de Andrade ${ }^{134}$, Mary Vieira e Henfil segue a mesma lógica, por tratar-se de artistas consagrados, mas cujos nomes estavam menos em evidência no campo artístico. É estratégia que evita o risco de patrocinar nomes que não tenham posição consolidada na fração dominante do campo, mas que também não coloca a instituição como legitimadora do já instituído, uma vez que, por se tratar de um "talento esquecido", situa o CCBB também em uma perspectiva autoral, não se limitando a reproduzir o que já é consensual. Não obstante, nas notas manuscritas dos processos de seleção de 2005 e 2006, havia claramente a preocupação de garantir espaço aos chamados "novos talentos". Foi encontrada, inclusive, uma pasta onde eram arquivados os préselecionados dessa categoria, de onde provavelmente foram escolhidos os trabalhos de Amílcar Packer (Polissemiose), Edouard Fraipont (Um Indeterminado), Alfredo de Oliveiro, nas artes plásticas; e da Cia Elevador Panorâmico (Peça de Elevador) e Guta Strasser (Rita Formiga), nas artes cênicas.

Além daqueles espetáculos, o programa regular do CCBB, Dramaturgias, na edição de 2006, teve o seguinte subtítulo: Novos Talentos, em relação ao qual o texto de apresentação do CCBB esclarecia: "Na sua quinta edição, enfoca a produção de artistas novos, que estão no início de sua trajetória, mas que já apresentam trabalhos consistentes, intensos e provocadores."

A preocupação com os não consagrados justificava-se pela fuga do rótulo de instituição que consagra os já consagrados e pela busca de afirmação como centro cultural que se preocupa com a inovação, com o desenvolvimento do campo artístico e com a chamada "responsabilidade sócio-ambiental". Contudo, tendo em vista a pressão mercadológica por público e por repercussão na mídia, e os riscos advindos dessas escolhas, os "novos talentos" acabam tendo espaço reduzido na programação do CCBB.

Patrocínios não ancorados em realizações anteriores dos profissionais, ou que não se vinculem a indícios de competência artística - que se concretizam em critérios de distinção, tais como prêmios e reconhecimento da crítica -, normalmente atraem público menor, já que os critérios de escolha do público passam,

${ }^{134}$ O material de divulgação do CCBB ressalta que a obra do artista "estava adormecida há mais de duas décadas". 
normalmente, pela notoriedade dos artistas envolvidos. Com público reduzido, a legitimidade de uma instituição vinculada a um banco governamental fica comprometida, já que o caráter público dos recursos investidos deveria requerer a apropriação dos resultados por parcela mais significativa da população.

O CCBB insere-se, portanto, em uma das principais dinâmicas conflitivas do campo artístico, dinâmica essa resumida da seguinte forma por Bourdieu, em sua análise do processo de autonomização do campo literário:

As chamadas à ordem, e as sanções, entre as quais a mais terrível é o descrédito, equivalente específico de uma excomunhão ou de uma falência, são o produto automático da concorrência que opõe especialmente os autores consagrados, os mais expostos à sedução dos comprometimentos mundanos e das honras temporais, sempre suspeitos de ser a contrapartida de renúncias ou de renegações, e os recém-chegados, menos sujeitos, por posição, às solicitações externas, e predispostos a contestar as autoridades estabelecidas em nome dos valores (de desinteresse, de pureza etc.) de que elas se valem, ou de que se valeram para impor-se. (Bourdieu, 2005:86)

A percepção e a preocupação dos funcionários do CCBB em relação à programação, para que ela seja "de qualidade", leva a questionar o que eles entendem por isso. Após a análise acima, isso fica bastante claro. Em primeiro lugar, trata-se de uma concepção de programação que foge das manifestações populares e se aproxima das formas elitizadas de arte. Elitizadas, não a ponto de ser limitadas a públicos reduzidos, como seria se focasse a música erudita ou a ópera, e que poderia também gerar uma imagem demais tradicional para um Banco que já tem esse atributo por demais evidenciado. Em segundo, é uma programação que se insere mais no "centro" do que se estabeleceu como "boa arte" do que nas bordas, nas fronteiras em direção à inovação. Investir no estabelecido consensualmente por aqueles que ditam as regras do campo é uma forma de obter legitimidade, fugir de polêmicas (apesar de elas surgirem inevitavelmente, como veremos no capítulo subseqüente), e conseguir público e repercussão na mídia. 


\section{PARTE III- O CCBB E OUtRos CAMPOS DA VIDA SOCIAL}




\section{CAPítulo 6}

\section{EROTICA: A REAFIRMAÇÃO DA RACIONALIDADE ECONÔMICA NO PATROCÍNIO}

“Quem quiser 'visões', que vá ao cinema! [...] Quem quiser 'sermões', que vá ao convento!"135

Pênis. Terços. Artista performática. Curador acadêmico. Banco ameaçado de perder mercado. Juventude religiosa conservadora. Político em busca de eleitores. Jornalistas em busca de notícias. Artistas em defesa da liberdade de expressão. Fiéis em defesa de seus símbolos religiosos. Instituição cultural servindo a múltiplos senhores. Peças de um quebra-cabeça que, não obstante possuirem relevos que possibitam encaixes e, muitas vezes, favorecem acoplamentos, dessa vez, reviraram-se em conflito declarado.

A exposição Erotica - os sentidos da arte teve sua inauguração, no CCBB de São Paulo, no dia 12 de outubro de 2005 e concluiu sua temporada em 8 de janeiro de 2006. Prosseguiu em cartaz, no Rio de Janeiro, de 20 de fevereiro a 30 de abril de 2006. Estava prevista uma terceira inauguração, em Brasília, em 15 de maio, mas a prorrogação foi cancelada em virtude de fatos ocorridos na temporada do Rio de Janeiro, que serão objetos de interpretação neste capítulo.

A pesquisa abre uma ramificação neste momento, para abordar acontecimentos que envolvem o CCBB Rio de Janeiro, o que poderia ser visto como um excurso, já que toda a investigação se concentrou na filial paulista da instituição. No final da análise desse episódio, contudo, espera-se deixar claro que a discussão envolve o Banco do Brasil e torna evidentes aspectos importantes de sua política de patrocínio, o que tornará mais compreensíveis limites e condições que remetem às escolhas e ao processo de definição da programação do CCBB São Paulo.

\footnotetext{
${ }^{135}$ Weber, Max. Apud Pierucci, Antônio Flavio. O desencantamento do Mundo. São Paulo: Editora 34, 2003.
} 


\subsection{A EXPOSIÇÃO VISTA POR SEUS IDEALIZADORES}

A mostra teve curadoria de Tadeu Chiarelli. Professor livre docente do Departamento de Artes Plásticas da Universidade de São Paulo, Chiarelli foi, entre 1996 e 2000, curador-chefe do Museu de Arte Moderna de São Paulo (MAM). Têm várias curadorias em seu currículo, além de diversos trabalhos publicados na área de história, crítica e teoria da arte. Nome consagrado no universo cultural paulistano, trabalhara anteriormente com o CCBB, dando palestras ou escrevendo em catálogos de exposições ${ }^{136}$.

Erotica foi patrocinada pela Aliança do Brasil, uma empresa coligada do Banco do Brasil na área de seguridade. Teve co-patrocínio e foi realizada pelo CCBB. Paralelamente à mostra, houve ciclos de debates com intelectuais, abordando diversos temas como "Erotismo e Poesia Brasileira" e "Sexualidade e Imaginação Erótica", dentre outros. O coordenador dessas conferências foi o médico e psicanalista Reinaldo Mesquita, também consultor da exposição. Houve mostra cinematográfica paralela abordando a mesma temática. A proponente da exposição foi uma pessoa jurídica denominada "Expomus - Exposições, Museus e Projetos Culturais", criada, em 1981, pelas museólogas Maria Ignez Mantovani Franco - que assina a coordenação geral da Erotica - e Sonia Helena Guarita do Amaral.

A exposição, com mais de cem obras, abarcou longo período de tempo, com obras do ano 1.000 a.C. até produções contemporâneas. Contou com artistas anônimos e nomes consagrados, como Picasso, Anita Malfatti, Ismael Nery, Wesley Duke Lee, Rosangela Rennó e Tunga. Contou ainda com alguns jovens artistas, não muito conhecidos, como Pitágoras e Fernanda Preto. Diversas linguagens artísticas foram contempladas: pintura, escultura, fotografia, gravuras, desenhos, vídeos, instalações, além de objetos arqueológicos.

O título da exposição, sem acento, remete à palavra de origem inglesa, substantivo e não à sua homófona portuguesa, acentuada, que é um adjetivo. Teve, nessa acepção, o significado de coletânea, de antologia de imagens eróticas ${ }^{137}$.

\footnotetext{
${ }_{136}^{136}$ Fonte: lattes.cnpq.br, consultado em 08/03/08.

${ }^{137}$ Não se trata de temática propriamente original já que há diversos museus no mundo especializados em obras de arte eróticas, como, por exemplo: Erotic Museum (Amsterdam - Holanda), World Art Erotica Museum of Sexuality (Toronto - Canadá), Montmartre Museum of Erotic Art (Paris - França), Roman Art Museum (Roma - Itália), Museum Erotica (Copenhagem - Dinamarca) The Erotic Museum (Hollywood - Estados Unidos). Muitos museus e instituições não exclusivamente dedicados a essa temática também organizaram
} 
O intuito desta exposição é apresentar objetos e objetos de arte que tragam, na constituição material e imagética de todos eles, componentes eróticos evidentes ou sutis, capazes de, reunidos, constituírem uma erotica específica. (Chiarelli, 2005:8)

A escolha da temática pela instituição patrocinadora deveu-se, segundo o próprio curador, ao

interesse de, com a proposta de Erotica, oferecer ao público uma exposição sobre arte erótica, em que a ênfase recairia essencialmente, e em primeiro lugar, no objeto passível de ser percebido em suas qualidades e especificidades estéticas. (Chiarelli, 2005:8)

Com isso, pretendeu-se afastar qualquer conotação pornográfica, biológica, arqueológica, antropológica ou psicológica da exposição. O curador procurou traçar uma linha de distinção muito tênue entre o significante e o significado dos símbolos, ao reforçar que o objetivo da mostra não era o erotismo, mas a arte. Pareceu, da mesma forma, um pedido de desculpas por abordar temática tão associada a tabus, considerando que esse esclarecimento, colocado de forma introdutória no catálogo da exposição, não faria muito sentido fosse outra a temática da mostra.

A mostra não seguia a fórmula cronológica, mas procurava mesclar objetos de culturas e tempos históricos diferenciados. O curador negou que seu objetivo fosse o de reforçar elementos da natureza humana, como se fosse possível comprovar a existência de uma "essência comum" que unisse artistas e artesões os mais distantes no tempo e no espaço (Chiarelli, 2005:11). O intuito declarado era, porém, contraditório com a própria introdução do catálogo, assinada pelo "Centro Cultural Banco do Brasil", que reforça o caráter universal da sexualidade:

Todos os povos, em todas as épocas e em todas as regiões do planeta, em algum momento de sua história, acabaram por sublimar o impulso sexual, transformando em arte essa pulsão vital que se opõe à morte e à destruição. (Chiarelli, 2005:5).

Segundo o curador, o que permitia a construção de exposição capaz de unir essas obras tão distantes não era a universalidade do desejo, já que as "funções sociais" atribuídas às obras seriam diferentes entre si. 
O que significa que, antes de reivindicar para o conceito ocidental de "objeto de arte" uma universalidade que ele efetivamente não possui, essa curadoria, ao apresentar objetos de origens diferentes num mesmo espaço, atenta para uma característica do ser humano: seu interesse por interpretar ou simbolizar a curiosidade pelos mistérios do sexo e seu desejo sexual - fatores que o diferem dos outros animais (Chiarelli, 2005:11).

Dessa forma, o curador justifica a amplitude temporal das obras expostas substituindo a universalidade do desejo e do impulso sexual pela universalidade da capacidade de simbolização. Afirma também que a concepção geral da mostra se guiou mais "pelo conceito de montagem surrealista do que por qualquer outra estratégia pautada na pura racionalidade" (Chiarelli, 2005:12). Os conceitos surrealistas de automatismo psíquico, culto aos mistérios do banal e do vulgar e a valorização do onírico eram, segundo ele, norteadores da estruturação da exposição.

As obras apresentadas remetem indireta e sutilmente à sexualidade, de formas alegóricas e sugestivas:

Nesse contexto em que o sexo é tratado sem subterfúgios, com uma
sem-cerimônia que pode até constranger alguns, é natural situar as
cerâmicas eróticas pré-colombianas presentes na mostra. De gosto
fundamentalmente popular, demonstram como os preceitos relativos
a determinadas práticas sexuais (a felação, por exemplo) podiam ser
enfrentados com humor e, aparentemente, sem nenhuma espécie de
culpa. (Chiarelli, 2005:15).

Os organizadores demonstraram com isso estar cientes da possibilidade de a mostra ferir suscetibilidades, haja vista o caráter explícito de algumas obras, além dos aspectos morais que, invariavelmente, envolvem a sexualidade. Entretanto, fato curioso é que não foram as obras mais explícitas (fálicas, com penetrações, de conteúdos homo-eróticos) as que causaram mais repercussão.

No discurso dos idealizadores, predominou perspectiva extremamente racionalizada que remete a valores intrínsecos à esfera artística. Tratava-se de uma aproximação cuidadosa da esfera erótica, que procurava não extrapolar as legalidades próprias do campo artístico, recusando qualquer intenção pornográfica, mantendo, portanto, a exposição em universo acadêmico, cuja fundamentação se dava pelos cânones de plausibilidade e pertinência que lhes são próprios. 


\subsection{A ReCEPÇÃo da mídia e de CRítica em SÃo PaUlo}

Em São Paulo, a exposição teve repercussão bastante positiva. Foi capa da Revista Bravo! (Oliva, 2005), um dos maiores destaques possíveis em termos de divulgação de uma mostra. Foi classificada com três estrelas (bom) pela Veja São Paulo $^{138}$, incluída na coluna "Mostras Recomendadas" do jornal O Estado de São Paulo ${ }^{139}$, citada duas vezes por críticos na coluna "llustrada Escolhe" do jornal Folha de S. Paulo ${ }^{140}$, e teve matéria de destaque na revista Bien 'Art ${ }^{141}$. Essas são evidências cabais da grande aceitação encontrada nas instâncias de consagração dos especialistas do campo artístico.

A matéria da Revista Bravo! interpretava, em tom abertamente elogioso, as intenções da curadoria:

Para além das generalizações que inevitavelmente pesam sobre
conceitos tão abrangentes, a mostra é bem-sucedida ao atravessar
temas contemporâneos sem perder de vista o erótico: o corpo como
paisagem (nas obras de Fernanda Preto e Alair Gomes), sua
fragmentação (Hans Bellmer, Pierre Molinier e Cassaro), a
subversão dos padrões de beleza (Pitágoras), o sagrado (Marcia X e
Alfredo Nicolaiewsky), o narcisismo (Duane Michals), a crise da
afetividade (Nan Goldin), a atualização do nu feminino (Eric Fischl,
Thomas Ruff e Jean-Jacques Lebel), a alteridade (Thomas Glassford
e Luiz Zerbini), o belo clássico (Alair Gomes), o auto-retrato (Eliseu
Visconti, Emygdio de Barros e Edgard de Souza), o citacionismo (Vik
Muniz), o neo-surrealismo (Edward Weston) e o embate natureza
versus civilização (Florian Raiss). (Oliva, Fernando. "Arte erótica - O
lugar do desejo". In Bravo!. Outubro de 2005.)

Não houve qualquer tipo de manifestação pública de incômodo diante dos conteúdos das obras expostas em São Paulo e a exposição transcorreu com normalidade. Diante da divulgação e do destaque dados pela imprensa, no CCBB São Paulo, a sensação era de que a mostra havia sido bastante bem sucedida, justificando o elevado investimento feito pelo patrocinador, o mais vultuoso dos dois anos analisados neste trabalho.

\footnotetext{
138 Veja São Paulo, São Paulo, 16/11/2005, Roteiro, 32

139 O Estado de São Paulo. Mostras Recomendadas. O Estado de São Paulo, São Paulo, 11/11/2005, D4.

140 Chaimovich, Felipe. Ilustrada Escolhe - Sexo e desejo através dos tempos, Folha de S. Paulo, São Paulo, 4/12/2005, Ilustrada, E7 e Cypriano, Fábio. Ilustrada Escolhe - Último fim de semana da mostra que traça um panorama da relação entre arte e erotismo. Folha de S. Paulo, São Paulo, 7/1/2006, llustrada, E6.
} 
Seguindo a exposição para o CCBB Rio de Janeiro, não teve, contudo, a mesma recepção. A obra objeto da rejeição por parte do público carioca intitula-se Desenhando com Terços (Anexo 26), que teve a seguinte análise do crítico e curador Adolfo Montejo Navas:

"Aqui um objeto simbólico (religioso) recebe um deslocamento
estético, estabelece um salto de sentido, e não se trata mais da
função e sim da visão. E lembremos que o campo da apropriação de
elementos (quando não da guerra de imagens) sempre atuou em
todos os âmbitos ao longo da história. Assim, a desconstrução
estética está em direção inversa à realidade mimética, mas promove
uma nova equação da tríade imagem/ideologia/vida. Por isso a
dessacralização que existe é fantasmática, evoca uma distância
simbólica. De fato, a obra está mais perto de um "memento mori" do
que de uma orgia profana. ${ }^{142}$

$\mathrm{Na}$ perspectiva valorativa do campo artístico, o sentido imputado à obra reside, portanto, na sua capacidade de subverter o significado religioso do objeto retratado, dessacralizando-o ${ }^{143}$. Na visão do crítico isso não significa profanação, mas a afirmação do terreno, do mundano e da consciência da finitude da vida, na qual a sexualidade emerge como possibilidade de fruição.

Outro crítico caminhou no mesmo sentido, reafirmando que essa obra suscitava negação do ascetismo religioso e afirmação da energia libidinal, rompendo com as lógicas religiosas de desprezo do corpo e das suas sensações, como condição para valorização do espiritual:

Arrancar de um dos símbolos religiosos algo que está ali inscrito (o perigo da carne) e que os imperativos morais da religião preferem ocultar, privilegiando o espírito desencarnado. Com uma manobra quase singela, em meio à grande concentração, rigor e devoção que permeiam essa longa e exaustiva ação, Márcia $X$ coloca em movimento através do ícone fálico uma fonte de energia inesgotável (virilidade), da qual visivelmente se alimenta. (Basbaum, 2003).

A crítica e a mídia impressa, de maneira geral, acompanharam a perspectiva dos idealizadores e artistas da mostra. Viam e reforçavam os significados das obras dentro dos parâmetros artísticos que Ihes davam sustentação. Legitimaram a

\footnotetext{
${ }_{141}^{141}$ Monachesi, Juliana. Onde colocar o desejo. Bien'Art, São Paulo, novembro de 2005, 13-14.

$142 \mathrm{http} / / /$ marciax.uol.com.br/mxText.asp?sMenu=4\&sText=15, consultado em 24/03/08.

${ }^{143} \mathrm{Em}$ uma perspectiva psicanalítica, a aproximação entre sexo e religiosidade não é tão descabida. Freud (1999) compara os rituais religiosos com as obsessões neuróticas, afirmando que, como ambos se caracterizam pela repetição compulsiva (os tiques e manias para os neuróticos e os rituais repetitivos para os religiosos - terços, missas etc.), revelam enorme energia sexual represada.
} 
exposição e deram-Ihe o respaldo que reafirmava a pertinência de sua inserção no debate público.

\subsection{A ARTISTA ICONOCLASTA E A SUA OBRA}

Desenhando com Terços, de 2002, de autoria da artista Márcia X, causou indignação em alguns fiéis católicos. Não foi obra de destaque na mostra. Não recebeu qualquer menção no texto do curador no catálogo. Tampouco foi citada nas matérias de divulgação da imprensa e do próprio CCBB.

Márcia X, nome artístico de Márcia Pinheiro de Oliveira ${ }^{144}$, nasceu em 1959 e faleceu prematuramente no ano da abertura da exposição em São Paulo, em fevereiro de 2005. Não presenciou, portanto, a inclusão de seu trabalho na mostra Erotica. Iniciou sua carreira artística em 1980 e notabilizou-se pelas performances que efetuava. Em 1988, realizou a sua primeira exposição individual, Ícones do Gênero Humano ${ }^{145}$, no Centro Cultural Cândido Mendes, no Rio de Janeiro.

Durante os anos 90, começou a trabalhar com questões ligadas à sexualidade, sendo que uma de suas séries se intitulou Fábrica Fallus. Em 2000, na Casa Petrópolis, realizou a performance Desenhando com Terços, do qual a obra exposta em Erotica é herdeira, utilizando 400 terços para realizar desenhos em formato de pênis, em uma sala de 20 metros quadrados. A obra exposta no CCBB é uma fotografia, de $40 \times 50 \mathrm{~cm}$, de dois desses terços em formato de pênis.

Cocchiarale estabelece distinção entre a atitude performática "pós-moderna" de Márcia X e a de seus antecessores:

Entretanto é indispensável observar que sua iconoclastia diverge daquela das vanguardas históricas do começo do século 20. Voltadas exclusivamente para a radicalização de uma arte em ruptura com a representação mimética clássica, essas vanguardas

\footnotetext{
${ }^{144}$ Ricardo Basbaum explica a mudança de nome que se relaciona com uma performance da artista na qual ela vestia duas camadas de "não-roupas", transparentes, e se despia com o desenrolar da ação. "Acontece que a estilista homônima Márcia Pinheiro não gostou de ver um nome como o seu envolvido em fato tão escandaloso e tratou de enviar nota às colunas sociais, em que dizia: 'Enquanto eu visto as pessoas, esta outra tira a roupa'. Claro: para evitar ter sua imagem associada à da famosa estilista, Márcia então realiza a operação de anexar um " $x$ " ao nome, acoplando-se definitivamente à partícula indicadora de movimentação contínua, sempre atenta a alguma coisa não feita, a mais uma coisa para se fazer." (Basbaum, 2003).

${ }^{145}$ Para essa exposição, a artista distribuiu convites para uma mostra de artes plásticas, que abrangia todos os elementos que constantes desses eventos: galeria de arte, convites, iluminação, coquetel, livro de assinaturas, exceto obras de arte. Quem compareceu foi filmado e fotografado e se tornou objeto da exposição do dia seguinte. A idéia da Bienal de São Paulo de 2009 de ter o vazio como temática tem precedentes.
} 
restringiam sua radicalidade ao campo especializado da investigação plástico-formal, típica da busca pela autonomia da arte. Márcia filiase a uma outra genealogia: a da tradição inaugurada pelo Dadaísmo (1915-16) e por Marcel Duchamp, desdobrada pelo grupo Fluxus (1962), e, no Brasil, por Flávio de Carvalho, Hélio Oiticica, Antonio Manuel, Nelson Leiner e Tunga, dentre outros, cuja ênfase está na atitude e na ação do artista e não somente na produção de objetos. Daí a intensa atividade performática desde o início de sua trajetória." (Cocchiarale, Fernando. "Uma Obra Iconoclasta". In Jornal do Brasil, fevereiro de 2005)

A artista insere-se claramente no paradigma da arte contemporânea, cuja força motriz reside justamente no ato transgressivo. A transgressão é definidora do fazer contemporâneo da arte em diversos sentidos: "transgressão estética das fronteiras entre arte e não-arte; transgressão jurídica da fronteira entre legalidade e ilegalidade; transgressão moral entre o bem e o mal”. (Heinich, 1998a: 329)

O ato transgressor, aliado indissociável da arte na contemporaneidade, pode ser interpretado como forma de afirmação da autonomia do campo artístico, o qual não se submete diante das demais constrições sociais, seguindo apenas a normatividade que rege o próprio campo, ancorada na livre manifestação da criação e do pensamento ${ }^{146}$. Márcia $X$ sublinha o poder expressivo de sua obra que se coloca acima dos tabus, regras e normatividades regentes da vida dos "não-artistas". Nela, a atitude insolente ganha centralidade. Coerente com os preceitos da arte contemporânea, que se afirma como território da prospecção e da afronta, e busca despertar o questionamento do público, para que ele deixe de lado a tradicional postura contemplativa diante das artes plásticas, a obra ancora-se na provocação para adquirir plausibilidade artística.

\subsection{O BANCO DO BRASIL NA HORA DA ESCOLHA}

Diante da reação adversa de parte dos visitantes da exposição, o empresário e ex-deputado estadual Carlos Dias Filho ingressou com denúncia pública, contra o CCBB e o curador da Erotica, na Primeira Delegacia de Polícia do Rio de Janeiro.

\footnotetext{
146 "A persistência das vanguardas em buscar o novo sublinha o desejo dos artistas de manter a experiência estética como fim em si mesmo, longe, como salientou o artista russo Kasimir Malevich em seu Manifesto Suprematista, de 1913, da clássica subserviência à religião ou ao Estado.” (Cf. Farias: 2002, pág. 15)
} 
Alegou atentado contra a fé religiosa, em função de a obra Desenhando com Terços estar exposta. $\mathrm{O}$ autor da denúncia não fora eleito naquele mesmo ano para o cargo de deputado federal pelo Partido Trabalhista Brasileiro (PTB), ao qual concorria, sendo possível que visasse obter maior visibilidade para, com isso, angariar mais votos em uma próxima tentativa.

O repúdio ganhou a adesão do movimento católico conservador Opus Christi 147, que também ingressou com ação nos Ministérios Públicos Estadual e Federal. $O$ Prior do Apostolado Opus Christi, João Carlos Rocha ${ }^{148}$, declarou que a referida obra era de sugestão sodomita, imoral e blasfema ${ }^{149}$. O movimento articulou boicote ao Banco do Brasil e orientou seus seguidores a fecharem suas contas na instituição. Pediu também que fosse retirada da exposição a obra de Alfredo Nicolaiewky, na qual uma figura de São Jorge está ao lado de um homem seminu.

Depoimentos de representante do CCBB e do curador ao delegado responsável pelo caso foram seguidos pelo encaminhamento da denúncia ao Ministério Público, apesar de ele entender, conforme declarou, não ter havido delito necessariamente.

O caso ganhou publicidade quando o jornal sensacionalista Agora fez reportagem sobre a lide. A partir de então, a Central de Atendimento do Banco do Brasil começou a receber, por e-mail e telefone, inúmeras reclamações de católicos.

Diante dessas repercussões, o CCBB sugeriu à Diretoria de Marketing que a obra fosse isolada em uma sala e se colocasse advertência em sua entrada com alerta de que poderia ferir suscetibilidades. Os produtores da exposição foram chamados ao Rio de Janeiro para estudarem proposta de alterar sua disposição espacial.

\footnotetext{
${ }^{147}$ Fundada em 1998, a organização ganhou maior destaque com a subida de Joseph Ratzinger ao papado, já que foi declarada por ele, "apostolado leigo pessoal", o que a desvincula da hierarquia católica, devendo prestar contas somente ao papa de suas ações de caráter doutrinário. Trata-se de grupo de ultra-direita, lembrando o movimento integralista, assim como a Opus Dei, esta de dimensão internacional e mais antiga. Ao que tudo indica, o grupo composto por jovens católicos cariocas, liderados por Luiz Carlos Rocha, mantém vigilância ativa com relação aos símbolos católicos, pois já teve sucesso em outras ações de censura, como as que envolveram as peças teatrais "O Evangelho de Jesus Cristo, segundo Saramago" e "Em nome do Pai", com Rodrigo Galbert.

${ }^{148}$ Tendo sido presidente do PFL Jovem, o ex-seminarista não esconde suas ligações com lideranças da direita brasileira.

${ }^{149}$ O sentimento de injúria não se restringe a católicos. Charges que envolviam o profeta Maomé, publicadas em jornal dinamarquês, levaram muçulmanos a investirem contra embaixadas daquele país e fazerem inúmeros protestos que culminaram com a morte de dezenas de pessoas.
} 
Contudo, o presidente do Banco recebeu telefonema ${ }^{150}$ de bispo de Brasília, em que foi declarada simpatia pelo BB, mas também houve advertência sobre a impossibilidade do controle de manifestações contrárias, feitas pelos padres, nas missas em todo o país. O presidente convocou reunião da Diretoria, na qual foi decidida a retirada da obra da exposição. A notícia foi veiculada como decisão do Banco do Brasil e não do CCBB, como forma de preservar sua imagem junto à classe artística.

Diante dessa decisão, tiveram início manifestações de artistas contrários à medida, que classificaram o ato como censura. Vestindo camisetas com fotos da obra em questão, fizeram passeata do Paço Imperial ao CCBB, onde realizaram enterro simbólico da instituição. Rosangela Rennó, em sinal de protesto e luto, cobriu com pano preto o seu trabalho, uma das obras mais importantes da mostra, e justificou sua decisão em carta à instituição:

A censura perpetrada sobre a obra de Márcia $X$ afeta não somente a imagem e a obra da mesma mas também a todos nós, artistas, na medida em que nos deixa vulneráveis a atos arbitrários de restrição de nossa liberdade de expressão. Atitudes como esta jamais poderiam ser tomadas por uma instituição pública como o CCBB, motivadas por quaisquer interesses ou critérios que não fossem os estéticos, sem um amplo diálogo com a curadoria, a classe artística, os artistas envolvidos ou seus representantes.(Carta de Rosangela Rennó ao CCBB Rio de Janeiro. In http://www.canalcontemporaneo.art.br/brasa/archives/000713.html, consultado em 22/10/08)

Dessa forma, a artista reforçava a autonomia do campo, normatizada por meio da "liberdade de expressão", ao afirmar que a retirada de qualquer obra só seria admissível quando motivada por interesses estéticos, isto é, somente a partir de categorias internas a ele.

Franklin Cassaro também pediu a retirada da "Coleção de Vulvas Metálicas" da exposição. Os artistas lançaram manifesto intitulado "Censura Não - Pelo retorno da obra de Marcia X à exposição Erotica no CCBB”, no qual se lia:

A obra de Márcia $X$, artista consagrada na recente história da arte brasileira, com uma presença ativa nos últimos 20 anos e recém

${ }^{150}$ Essa informação foi prestada por funcionário gabaritado do Banco do Brasil. Matéria da Folha de S. Paulo ratifica esse dado: "A Folha apurou que religiosos da CNBB (Conferência Nacional dos Bispos do Brasil) ligaram para diretores do banco e ameaçaram incluir a questão da obra de Márcia $X$ em seus sermões. Grupos religiosos fizeram ameaças de encerrar contas e promover um boicote ao BB." (Carvalho, Mário Cesar. BB cancela a exposição "Erotica" em Brasília. Folha de S. Paulo, São Paulo, 03/05/06, Cotidiano, C6). 
falecida a [sic] um ano atrás, foi nas últimas semanas vitima de violento ataque por parte de fanáticos religiosos. Em um mundo de 5 bilhões de pessoas, esta seita só tem 1200 membros, sendo 700 no Brasil e 180 no Rio de Janeiro, uma cidade de mais de 6 milhões de habitantes. Como pode esta pequena seita atentar contra o direito da população do Rio de Janeiro de ter livre acesso às obras de arte? O potencial da arte é exatamente deixar ao contemplador da obra a possibilidade da livre interpretação, já que a obra de arte se completa com a interpretação pessoal de cada um, estimulando assim nossa liberdade de pensamento e sentimento - algo que pode chocar alguns, pode alegrar outros, dependendo de sua história cultural e sua personalidade particular. O Centro Cultural Banco do Brasil inacreditavelmente resolveu aderir ao autoritarismo, retirando a obra da exposição, alegando que não queria polêmica e que alguns manifestantes ameaçaram retirar suas contas do banco!!! será que agora a programação do CCBB será desenvolvida para agradar àqueles que possuem aplicações financeiras nesse banco?(...) Com este tipo de atitude, e sendo o Banco do Brasil um órgão federal, presenciamos a possibilidade da implementação no país de uma arte oficial. A partir desta grave mácula na importante história do Centro Cultural Banco do Brasil, com que moral este vai abrir seus próximos editais para projetos culturais? Será que já existe uma censura prévia nos julgamentos do CCBB? Será que o CCBB já é um órgão de arte oficial? (...) A única possibilidade do CCBB se redimir deste lamentável incidente, que macula sua historia, é retornar a obra às suas paredes antes do término da exposição e escrever uma carta à população do Rio de Janeiro, pedindo desculpas pela sua atitude. Censurar obras de arte de reconhecido valor na história da arte brasileira não ajuda a construir um país democrático. (http://www.canalcontemporaneo.art.br/brasa/archives/000708.html, consultado em 22/10/08)

A argumentação dos artistas apóia-se, assim, em três pontos:

* a irrelevância numérica do movimento católico, quando comparada com a população da cidade, partindo, portanto, do pressuposto de que a obra só teria ofendido aos membros da Opus Christi, e não, à totalidade de católicos;

* o fato de a obra permitir múltiplas interpretações, não sendo portadora de mensagem única e, portanto, poder ter sido objeto de fruição para muitos, e não de repúdio;

* a retirada da obra tinha sido um gesto autoritário de censura, que afrontava a liberdade de expressão e estabelecia critérios extra-estéticos nas escolhas artísticas. 
Com essa repercussão, o CCBB sugeriu à direção da empresa que, nos últimos dias da mostra, recolocasse a obra entre os trabalhos expostos, com a advertência sobre o seu conteúdo, o que se equivaleria a um pedido de desculpas aos artistas. No entanto, em nova reunião, a Diretoria da empresa decidiu, por quatro votos a três, pela continuidade da exposição sem a obra e pela suspensão da exposição no Centro Cultural de Brasília.

Em nota divulgada à imprensa, o Banco do Brasil posicionou-se da seguinte forma:

A Diretoria do Banco do Brasil decidiu retirar de exibição a reprodução da obra "Desenhando em terços", de autoria de Márcia $X$, integrante da exposição "Erotica - Os sentidos na arte", em cartaz no CCBB no Rio de Janeiro em virtude das manifestações de repúdio de parcela da sociedade. O Banco do Brasil esclarece que a decisão, tomada após extenso debate interno, considerou questões de imagem e aspectos empresariais, o ambiente onde o BB atua e as críticas recebidas de seus clientes, provenientes de várias cidades brasileiras. (Correspondência enviada pelo Banco do Brasil em resposta aos e-mails recebidos em protesto contra a obra de Marcia $\mathrm{X})$

Diferentemente da decisão tomada pelo $\mathrm{BB}$, em geral, os museus e instituições culturais aliam-se aos artistas nos protestos contra as obras expostas. Em 1999, o Brooklyn Museum, de Nova York, abrigou a exposição Sensation!, que incluía uma obra de Chris Ofili, na qual o manto de Nossa Senhora era pontuado com fezes de elefante. O prefeito de Nova York, talvez preocupado com a fatia irlandesa e italiana de seu eleitorado, ameaçou cortar o subsídio dado ao museu caso a obra não fosse retirada, mas sua demanda não foi aceita. Em Buenos Aires, - Centro Cultural Recoleta também não se dobrou diante dos protestos de católicos contra as obras de Léon Ferrari (uma das quais exibia Nossa Senhora se masturbando diante de Cristo), apesar de ter sido obrigado a fechar a exposição por decisão judicial. A exposição foi reaberta quando a decisão foi cassada. (Carvalho, Mario César. Censura corrompe finalidade de museus. In Folha de S. Paulo, São Paulo, 21/04/2006. Cotidiano, C3).

Na mídia televisiva, outros símbolos da Igreja Católica haviam sido alvos de ataque pelo pastor Sérgio Von Helder, da Igreja Universal do Reino de Deus. Em 1995, durante programa veiculado pela TV Record, o pastor chutou imagem de 
Nossa Senhora Aparecida, no dia do feriado nacional em homenagem a ela. Ao chutar a imagem o pastor afirmava:

Isso aqui não funciona, isso aqui não é santo coisa nenhuma, isso aqui não é Deus coisa nenhuma, será, meu amigo, que Deus o criador do Universo...ele pode ser comparado a um boneco desse tão feio, tão horrível, tão desgraçado? (Matéria veiculado no "Jornal Nacional”, da Rede Globo de Televisão, em 12/10/1995, disponível no site www.youtube.com, consultado em 22/10/2008)

O pastor foi condenado por incitação à discriminação e ao preconceito religioso e também por crime de vilipêndio à imagem religiosa, considerando-se que a legislação brasileira garante a liberdade de crença e institui o Estado laico ${ }^{151}$.

Os critérios de moralidade são complexos e advêm de diversas matrizes valorativas:

Há mais pornografia nas negociações que o ex-diretor de marketing do Banco do Brasil, Henrique Pizzolato152, fez com fundos de pensão do que em pênis cruzados feitos de rosários (Carvalho, Mario César. Censura corrompe finalidade de museus. In Folha de $\mathrm{S}$. Paulo, São Paulo, 21/04/2006. Cotidiano, C3).

A decisão de suspender a exposição no CCBB Brasília foi tomada após três tensas reuniões da Diretoria do Banco e o principal argumento contrário a realização da exposição na capital federal era de que haveria ameaça à marca e aos negócios. Havia o temor de que o boicote dos católicos adquirisse proporções maiores. Dessa forma, O BB retirou-se do debate moral em torno da obra, campo em que se digladiavam artistas e religiosos, e afirmou a primazia do econômico e do empresarial em sua decisão. Tratou-se de decisão coerente com os valores racionais e utilitários da prática administrativa, mas que se chocava com o discurso benevolente de responsabilidade social e defesa das manifestações artísticas.

Nota divulgada à imprensa afirmava:

O Banco do Brasil lamenta esse desfecho, mas o considera um fato isolado, ao tempo em que ratifica sólido apoio à difusão da arte e da cultura, sempre com respeito à pluralidade e à diversidade

\footnotetext{
151 O artigo quinto da Constituição Brasileira estabelece: "é inviolável a liberdade de consciência e de crença, sendo assegurado o livre exercício dos cultos religiosos e garantida, na forma da lei, a proteção aos locais de culto e a suas liturgias".

${ }^{152}$ Pizzolato foi acusado pelo Ministério Público Federal de integrar o braço financeiro do mensalão. Responderá pelos crimes de corrupção passiva e peculato.
} 
Segundo o marido da artista, também artista plástico, Ricardo Ventura, a polêmica em torno da obra serviu para que o trabalho de Marcia $X$ fosse divulgado, sendo que ele já havia recebido contatos de instituições no exterior interessadas em levar o trabalho a outros países. Ele também entrou com ação de indenização contra o BB, em função da censura à obra de sua esposa (Carvalho, Mario Cesar. BB Cancela a exposição "Erotica" em Brasília. Folha de S. Paulo, São Paulo, 03/05/06. Cotidiano, C6).

Editorial da Folha de S. Paulo fez a seguinte avaliação do episódio:

Católicos que tenham se sentido ofendidos com o desenho da autora têm o legítimo direito de protestar e até mesmo de ameaçar fechar suas contas na instituição bancária. Trata-se de manifestação nãoviolenta que faz parte do jogo democrático. O BB, contudo, deveria ter resistido à pressão e mantido-se fiel ao compromisso assumido com o meio artístico quando decidiu patrocinar a mostra. O banco não pode alegar que desconhecia o caráter polêmico de uma exposição dedicada ao erotismo. A liberdade de expressão artística, garantida pelos artigos 5o, IX e 220, da Constituição, é um dos fundamentos do Estado democrático e existe justamente para assegurar que autores possam divulgar idéias ofensivas a parcelas significativas da sociedade. Com efeito, ninguém precisa de autorização legal para dizer o que todos querem ouvir. Nesse episódio, a direção do BB meteu os pés pelas mãos. A um só tempo, mostrou que não tem apreço à liberdade artística, sacrifica princípios elevados ao menor sinal de pressão e, pior, não sabe bem o que financia com seus recursos. (Folha de S. Paulo, São Paulo, 29/04/06. Opinião, A2. grifo nosso).

O Ministro da Cultura, Gilberto Gil, manifestou contrariedade em relação à decisão tomada, afirmando trata-se de ato inconstitucional:

Segundo a Constituição brasileira, é 'livre a expressão da atividade intelectual, artística, científica e de comunicação, independentemente de censura ou licença'. Por isso, não pode haver mais em nosso país nenhum tipo de interdição a obras de arte e a outras formas de expressão. (Carvalho, Mario Cesar. Censura a arte viola a Constituição, afirma Gil. In Folha de S. Paulo, São Paulo, 26/04/2006. Cidades, C8). 


\subsection{O PATROCÍNIO EMPRESARIAL E O “POLITEÍSMO DE VALORES”}

Nesse episódio, o BB viu-se coagido a tomar uma decisão. Premido pela ameaça de fechamento de contas, pela pressão da Igreja Católica e pela parcela da população que, muito embora não veja com simpatia a censura à atividade artística, tampouco é solidária com ataques a símbolos religiosos, a instituição optou pela retirada da obra da exposição. Posteriormente, nova decisão se fazia necessária, já que os artistas, em manifestação amplificada pela mídia, fizeram enterro simbólico do CCBB e exigiram a reinserção da obra. O BB, coerente em sua posição, não só não reintegrou a obra, como suspendeu a seqüência da mostra, que continuaria no CCBB Brasília. A decisão tomada amparou-se, segundo declarações oficiais da instituição, em questões "corporativas" e relacionadas à imagem do Banco. Subentende-se o temor de que o BB perdesse a imagem de mecenas das artes, passando a ser visto como vilipendiador da fé católica.

Claro está que a maior parte daqueles que fruem os bens artísticos patrocinados pelas instituições culturais estabelece distanciamento entre a obra patrocinada e a instituição que a promove. Por mais que esta tenha determinadas responsabilidades pelas escolhas efetuadas, o conteúdo subjacente a cada obra é visto como de autoria de cada artista e não da instituição que a abriga. Entretanto, nesse episódio, o CCBB foi apontado como responsável por dar espaço a obra considerada blasfema por muitos.

O episódio evidencia um conflito valorativo, de grupos sociais que se localizam em pontos distantes no universo cultural, em termos simbólicos. De um lado, um grupo católico bastante conservador, professando certo puritanismo religioso, de outro, uma artista que se afirma pela vanguarda, pela provocação e procura com sua obra gerar questionamentos e inquietações. A disputa, essencialmente, diz respeito ao poder de dar significação a um símbolo. Incomodou aos católicos que um seu símbolo religioso ${ }^{153}$ fosse associado a significados

\footnotetext{
${ }^{153}$ Coincidentemente, recebi pelo correio, no momento da redação deste capítulo, um terço católico. Havia sido enviado pela "Associação Católica Nossa Senhora de Fátima", que desconhecia por completo, não mantendo com ela qualquer relação. Junto com o terço, uma longa carta assinada pelo coordenador da Associação e por um padre. Seu teor exaltava a religiosidade católica: "o Terço é a chave que lhe abre a porta do Céu, e Ihe faz experimentar desde já as alegrias do Paraíso" (...) "se eu the contasse todas as graças alcançadas pelas pessoas que começaram a rezar o Terço, não haveria livro que fosse capaz de contê-las." (...) "Por vezes, são situações em que tudo parece perdido, sob o ponto de vista humano. Rezando o Terço, se obtém a graça de uma intervenção maternal de Nossa Senhora." Junto com o terço e com a carta, foi enviado um boleto bancário.
} 
sexuais. Na medida em que a referência à sexualidade é vista com restrições pelo imaginário cristão, que a associa à função reprodutiva e busca dissociá-la de sua dimensão erótica, a junção promovida pela artista foi vista como um ataque pejorativo à fé católica. É evidente que a artista não era ingênua em sua intenção. Ao contrário, era belicista, questionadora, iconoclasta. Atingidos nessa guerra simbólica, os católicos revoltaram-se não apenas contra a artista, que já havia falecido, mas fundamentalmente contra a instituição que a promoveu. Feridos em seu orgulho, armaram-se com o arsenal que mais atinge uma instituição financeira: a possibilidade de perda de mercado. Ameaçaram encerrar as contas, também empreendendo campanha difamatória contra o Banco do Brasil.

Nesse complexo jogo de xadrez, estavam três forças em disputa: católicos, artistas e instituição patrocinadora. Esta, ponderando os riscos financeiros e de imagem, e considerando que a autonomia artística ainda não era (é) valor consolidado e que, nesse caso, provavelmente a maior parte do público não via muito sentido em associar terços a falos, resolveu aliar-se ao primeiro grupo e renegou aqueles que havia apoiado anteriomente.

Ao reconhecer o poder ofensivo da obra, a Opus Christi validou as intenções transgressoras da artista e atualizou seu poder de contestação. A decisão do BB de retirá-la da mostra e de suspender a exposição de Brasília reforçou o poder da Igreja de interferir no campo artístico, o que tornou também pertinente (na lógica da autonomia das esferas) o potencial crítico da obra da artista.

Quando a obra suscita discussões que transcendem o meramente estético e formal e envolvem questões éticas e morais que extrapolam a normatividade do campo artístico, adentra terreno em que os códigos não são mais garantidos por uma crença comum que cria coesão e identidade, mas, ao contrário, porta elevado grau de imponderabilidade.

O não reconhecimento pelos católicos da qualificação artística da obra de Márcia $X$ evidenciou não um conflito em que esteja presente desacordo quanto à localização de um determinado objeto, numa escala de valores (que varia em grau, mas não em natureza), como é freqüente no interior do campo artístico; tratou-se, antes de conflito em relação ao critério básico de julgamento que permite a inclusão ou não de um objeto como digno de apreciação. Ao defender a liberdade de expressão, os artistas abandonaram o critério estético e aceitaram um confronto ético, no qual os religiosos, por sua vez, lutavam pelo respeito aos símbolos 
religiosos. Desse embate, surgiu um diálogo de surdos, em que não parece existir conciliação possível. Analisando a dinâmica dos campos, desde a criação da obra até a decisão de retirá-la da exposição, verificamos ter havido múltiplas alianças e contraposições em cada fase (Anexo 27).

Weber (1988) também aponta a existência de certa concorrência entre as religiões de salvação e as artes, já que estas propõem também uma espécie de libertação, mas intra-mundana, que aparece para as religiões como manifestação de prazer irresponsável e egoísta. Tais esferas seguem, na modernidade, irreversível processo de racionalização, mas caminham em direções diferenciadas, o que cria uma configuração social em que se manifesta, para utilizar a expressão weberiana, "politeísmo de valores". O declínio das fundamentações religiosas, que davam sustentação à ordem social das sociedades tradicionais, possibilitou o surgimento das esferas diferenciadas da vida.

Essas esferas, em seus processos de racionalização, constroem suas próprias justificativas, que se desvinculam das explicações metafísicas e religiosas. Elas passam por processos de institucionalização, criando legalidades próprias, consolidando-se a partir da constituição de seus quadros profissionais, seus grupos estratégicos de especialistas, encarregados de garantir sua autonomia e também a reprodução e continuidade do campo (Weber, 1988 e 2003)

O "politeísmo de valores" no mundo moderno provoca um permanente estado de tensão na vida social, muitas vezes inconciliável e de luta permanente entre essas esferas:

No mundo moderno radicalmente desencantado, mundo
'desdivinizado pela profecia monoteísta, mundo 'sem Deus e sem
profetas', os melhores valores mundanos vêm se apresentar a nós
como deuses sempre-já guerreiros, 'mortalmente hostis entre si',
leais apenas a si mesmos, obedientes à sua 'legalidade própria'. E,
enquanto tais, guerreiam sem paragem, sem repouso, sem trégua
uns contra os outros e a um só tempo contra 'o Uno', o sentido
objetivo e unificado que um dia expulsou do mundo a magia, e lá se
foi o 'sentido mágico' de cada acontecimento da vida (Pierucci, 2003:
140 )

A tese defendida por Pierucci (2003) sobre o duplo significado do termo weberiano "desencantamento", pela religião e pela ciência, é acompanhada de um "achado" que aponta para a possibilidade de re-encantamento do mundo, na obra do autor alemão, que não reside, entretanto, no domínio religioso, mas justamente na esfera erótica manifesta na obra rechaçada pelo CCBB: 
Aos olhos de Weber, a possibilidade de reencantar parece pois que não está no alardeado 'retorno do sagrado', como andam dizendo, querendo e torcendo, quando não comemorando, tantos sociólogos religiosos da religião que conhecemos. (...) A crer em sua Consideração Intermediária, o lócus da existência humana em que se esgueira uma possibilidade efetiva de encantar novamente 0 mundo não é a esfera religiosa, mas uma outra esfera cultural, ao mesmo tempo não religiosa e não-racional: a esfera erótica, onde reina, segundo Weber, 'a potência mais irracional da vida' - o amor sexual (Pierucci, 2003: 221).

No conflito que envolveu o patrocínio da exposição Erotica evidencia-se a tensão entre quatro esferas distintas da vida social: a econômica ou empresarial, a artística, a religiosa e a erótica, todas materializadas em uma obra, que juntou, em um único significante, dois significados contraditórios: o sagrado e o profano. O lado que se considerou lesado na associação promíscua das outras três esferas recorreu a uma quinta, a jurídica, almejando que a associação das outras três fosse culpabilizada e sofresse penalidades. A associação da esfera artística com a erótica é freqüente, bem como a contraposição dessa última com a religiosa ${ }^{154}$. A novidade nesse caso foi a inserção da racionalidade econômica, representada pela instituição financeira patrocinadora.

A esfera erótica também segue o mesmo padrão de racionalização identificado por Weber nas outras esferas da vida. Se, em muitas configurações sociais pré-modernas, inexistia a tensão entre o religioso e o erótico, a magia tendo estado freqüentemente associada à prática orgiástica, a regulamentação da sexualidade em favor do casamento evidencia o processo de racionalização dessa esfera. Em contrapartida, Weber sublinha a ambivalência da esfera erótica, que mantém sua natureza sensitiva e fortemente emocional, permitindo a emergência do "âmago mais irracional e, portanto, mais real da vida, em contraposição aos mecanismos de racionalização ${ }^{155 ", ~(W e b e r, ~ 1988) . ~}$

O CCBB, cuja associação com o artístico visava ganhos simbólicos em termos de prestígio e reputação, viu essa equação inverter-se em seu desfavor, a partir da acusação de cumplicidade na profanação do sagrado. Diante disso, o

\footnotetext{
154 "O que é formado é, naturalmente, não só o que pode ser valorado, que está acima do que pode ser experimentado; formado é também o erótico, que mergulha nas profundezas e sonda as mais remotas frestas do calabouço. Ele compartilha com toda vida formada o destino carregado de culpa e está próximo até mesmo da atitude estética, na qualidade de sua oposição a tudo que pertence ao reino do Deus alheio às formas." (Weber, Max apud Schwentker, 1996, pág. 170)

${ }^{155}$ As experiências cênicas do Teatro Oficina, dirigido por José Celso Martinez Correa, são evidências artísticas da tentativa de romper com a racionalidade instrumental contemporânea, por meio de espetáculos que unem fortemente o estético e o erótico, defendendo uma "salvação intra-mundana".
} 
patrocinador mudou de lado, rompeu seu elo com a esfera artística, ao retirar a obra da exposição. Justificou sua decisão não como uma concordância com os argumentos da religiosidade, mas em função de sua lógica interna, de sua própria legalidade. Com sua resolução tomada, o BB reafirmou a racionalidade econômica que lhe dá plausibilidade perante os demais atores sociais, ao explicar que sua decisão deveu-se a razões corporativas e ao risco de perda de mercado. A ameaça dos religiosos de fechamento das contas bancárias foi levada a sério e evidenciou que a aliança com a esfera artística não continha caráter benevolente ou altruísta, já que, diante de inimigo externo a essa aliança, o patrocinador desconsiderou os valores reivindicados pela esfera artística, de liberdade de criação e do caráter provocativo das obras.

Os artistas, por sua vez, sentindo-se traídos por aquele que lhes garantia o substrato material e a legitimação cultural, articularam uma reação que consistiu em ocultar algumas obras, colocando panos sobre elas, e protestos públicos. Acusaram o patrocinador de autoritário e censor e questionaram publicamente em seu manifesto qual seria o real interesse do patrocínio: "será que agora a programação do CCBB será desenvolvida para agradar àqueles que possuem aplicações financeiras nesse banco?" (http://www.canalcontemporaneo.art.br/brasa/archives/000708.html, consultado em 22/10/08). Perderam a batalha, pois além de a obra não ter sido reinserida na exposição, o Banco do Brasil decidiu cancelar sua continuidade no CCBB Brasília.

Por que perderam? Talvez porque tenham rompido com a diplomacia que permite a coexistência do "politeísmo de valores" próprios da vida moderna. A independência das esferas tem como pressuposto a garantia de legislar somente na área que é delimitada pelo universo valorativo que lhe dá coerência e sustentação. $A$ obra de Márcia X é hostil e pretende interferir em pilar de sustentação do campo religioso, que é a separação entre o profano e o sagrado. Não caberia a quem é externo à esfera religiosa, e ainda mais autorizado por uma instituição cultural, tentar questionar a submissão do profano ao sagrado.

Perderam também porque o universo valorativo que dá plausibilidade à obra de arte censurada é hermético o suficiente para impedir que não iniciados vejam razões para afirmar o seu valor simbólico. A ausência de sentido imputada à ação de desenhar pênis com terços permitiu ao patrocinador aliar-se à percepção hegemônica de que "talvez aquela obra não tivesse muito significado mesmo". 
Por fim, a liberdade religiosa parece ter mais plausibilidade do que a liberdade artística. Em outras palavras, o direito de não ter os símbolos religiosos questionados (paralelo ao dever de não os afrontar) parece ser mais presente do que o direito dos artistas de se expressarem da forma que melhor Ihes convier. Isso porque, talvez, o campo religioso (ainda) tenha mais poder normativo e coercitivo do que o campo artístico. Se tanto o sagrado quanto o artístico são acompanhados de aura que lhes confere poder transcendente à materialidade dos significantes que the dão sustentação, a negação do sagrado é acompanhada de culpa que não admite tergiversação. Se a racionalização da esfera artística estimula manifestações que colocam constantemente em xeque seus valores, seus critérios de consagração e suas instituições, a esfera religiosa se ancora em dogmas que não permitem maiores questionamentos das bases sobre as quais se estrutura.

Os defensores do patrocínio público às artes podem crer que o episódio envolvendo a censura da exposição Erotica pelo CCBB seja argumento decisivo para que o patrocínio artístico empresarial seja condenado. Contudo, o fato de o patrocínio ser governamental não garante que as artes tenham maior liberdade de expressão. Cidadãos, políticos conservadores e filisteus distanciados da normatividade artística e mais familiarizados com a lógica racional econômica podem exigir das autoridades públicas restrições a obras consideradas "indecentes" segundo a moralidade dominante.

O senador protestante Jesse Helms travou batalha jurídica e política, em 1989 e 1990 contra o New Endowment of Arts (NEA), órgão responsável pelas políticas públicas federais para as artes nos Estados Unidos, em função de exposições fotográficas patrocinadas com recursos públicos, cujo teor fora considerado ofensivo à moral e aos bons costumes, em função de seu conteúdo julgado pornográfico e blasfemo. A obra ofensiva de Andres Serrano também envolvia crucifixo, dessa vez associado aos fluidos corporais, como sangue e esperma. Outras obras do fotógrafo Robert Mapplethorpe também causaram polêmica em função de seu conteúdo ter sido julgado pornográfico, além de fazer proselitismo da homossexualidade. Em função dessas acusações, o Congresso aprovou interdições ao apoio público de conteúdos artísticos julgados indecentes ou obscenos e indeferiu o repasse de recursos às exposições julgadas ofensivas (Archer, 2001: 214-215).

A comissão independente criada pelo congresso estadunidense estabeleceu novas diretrizes para o NEA, em função do episódio citado no parágrafo precedente 
(Heilbrun \& Gray, 2007: 274-275), cuja principal orientação é a restrição ao subsídio a trabalhos de arte que ofendam alguma parte da audiência, já que os recursos utilizados têm origem pública. A arte patrocinada deve estimular o mútuo respeito pela diversidade de valores e crenças. Esse episódio evidenciou igualmente 0 conflito valorativo existente entre o direito do contribuinte de determinar como quer que seu direito seja gasto e a absoluta necessidade de proteger a liberdade de expressão. O artista Hans Hacke (Bourdieu \& Hacke, 1995:18) considera que a observação de "regras de decência e do respeito à diversidade dos valores do público americano" lembra os "gesundes Volksempfinden ${ }^{156}$, que geraram a depuração nazista do que consideravam como 'arte degenerada' nos museus alemães.

O que está em disputa nessa discussão é o direito que o campo artístico reivindica de exprimir livremente sua repulsa ou crítica a símbolos considerados sagrados no campo religioso ou em qualquer outra esfera da vida social. A argumentação nesse pólo da luta simbólica tem fundamento no conceito moderno de multiculturalismo, isto é, o respeito à diversidade de valores e crenças. Ora, não parece que os atores sociais do campo artístico queiram estabelecer algum tipo de fundamentalismo artístico, pelo qual imponham sua normatividade aos demais campos. Reivindicam tão somente a liberdade de expressão e a autonomia do seu campo. Opõem-se, portanto, à posição segundo a qual, em nome do multiculturalismo, possa haver questionamento ao direito à livre expressão.

Se a dominação do campo econômico sobre o campo artístico ocorre de maneira sutil e minimizada na estruturação da programação do CCBB, no episódio da exposição Erotica ela mostrou-se da forma mais virulenta possível, por meio da censura à obra de arte.

${ }^{156}$ Gesundes Volksempfinden foi o termo cunhado por Joseph Goebbels para as atitudes de extermínio de judeus, homossexuais e ciganos, com a finalidade de "higienizar" a sociedade alemã. 


\section{Capítulo 7}

\section{AVALIANDO A EFICÁCIA DO PATROCÍNIO: MÍDIA, PÚBLICO E CRÍTICA}

A divulgação de um evento na mídia e a presença de público são os dois principais critérios utilizados para averiguar a eficácia do patrocínio pelo CCBB. Esses dados aparecem com destaque nos cadernos semestrais de avaliação das atividades, e constam do Acordo de Trabalho dos CCBBs e da Diretoria de Marketing.

Com esses dois critérios $^{157}$ de avaliação de sucesso do patrocínio, todo o processo de seleção de eventos, amplamente pautado em juízos qualitativos, se resume, como é de praxe na ciência administrativa, a dados numéricos, facilmente controláveis e com parâmetros definidos. As formas de avaliar um patrocínio bemsucedido são externas às obras favorecidas; o sucesso é dimensionado mais pelo impacto na recepção do que por qualquer caráter intrínseco da proposta artística em questão. Essa sistemática de avaliação do patrocínio às artes coaduna-se com algumas ações de marketing das empresas, em que o envolvimento com as características imanentes dos produtos vendidos é pequeno, e os profissionais se preocupam, sobretudo, com a maneira pela qual o que divulgam atingirá olhos, corações e mentes dos consumidores. A aparência, a repercussão e a preocupação com a imagem revelam o lado narcisista das empresas, ambiciosas em conquistar e manter clientes, bombardeados com estímulos de toda natureza e por trânsitos "informacionais" ao mesmo tempo redundantes e contraditórios. Na era do consumo em grande escala, os meios de comunicação são veículos privilegiados para que as intenções das corporações atinjam o maior número possível de pessoas.

Se o consumo cultural das obras patrocinadas pelo CCBB restringe-se a uma elite com elevado capital cultural, a qual dispõe das predisposições necessárias a sua fruição, as notícias constantemente veiculadas sobre a existência de um Centro Cultural subvencionado pelo BB atingem vasta gama de pessoas, ainda que não sejam suas usuárias. Ressalte-se, contudo, que os veículos de comunicação, longe de se configurarem altruisticamente como propagadores de informações, são

\footnotetext{
${ }^{157}$ Pesquisa com enfoque administrativo realizada por Leocadio e Marchetti (sem data) constata que os critérios de avaliação do patrocínio realizado pela Petrobrás, ABN Real, Pirelli e Pão de Açúcar seguem os mesmos parâmetros.
} 
empresas inseridas na lógica de reprodução do capital, e também dependem de outras, compradoras de espaços publicitários para venda de seus produtos. Nessa complexa rede de interdependências, que se forma em torno da busca incessante do lucro, insere-se a esfera artística, normalmente desguarnecida de apoio financeiro governamental direto para a sua produção. Estruturada internamente como campo com dinâmica extremamente conflituosa, nele os atores sociais disputam por prestígio, capital econômico e capital simbólico.

É interessante notar que o "espaço público" eleito como suporte da visibilidade desejada, tanto pelo campo artístico como pelo campo econômico, são os meios de comunicação de massa. As formas discursivas e simbólicas viabilizadas pelo patrocínio são tornadas públicas nesses veículos, notadamente - no caso do jornalismo cultural - pela imprensa escrita.

A centralidade que a mídia ocupa na distribuição de prestígio aos membros do campo artístico, afirmando-se também como instância de consagração, deriva de sua capacidade de amplificar, mitificar e dar reputação àqueles que se tornam pauta dos cadernos de cultura. Como, no campo artístico, o capital simbólico se afirma muitas vezes pela negação do capital econômico e como a alocação dos recursos financeiros, no patrocínio empresarial, se dirige preferencialmente a quem possui capital simbólico, este se torna uma das grandes fontes de poder dentro do campo:

\begin{abstract}
A única acumulação legítima, para o autor como para o crítico, para o comerciante de quadros como para o editor ou o diretor de teatro, consiste em fazer um nome, um nome conhecido e reconhecido, capital de consagração que implica um poder de consagrar objetos (é o efeito de griffe ou de assinatura) ou pessoas (pela publicação, a exposição etc.), portanto, de conferir valor, e de tirar os lucros dessa operação. (Bourdieu, 2005:170)
\end{abstract}

\title{
7.1 A QUANTIFICAÇÃO DO SIMBÓLICO
}

Tanto na análise documental efetuada como nas entrevistas realizadas com funcionários do CCBB, os elementos que receberam mais destaque na avaliação de um empreendimento foram a quantificação da presença de público nos eventos patrocinados e o espaço que os órgãos de imprensa dedicaram às obras artísticas subvencionadas. Não são os únicos. No entanto, para legitimar-se internamente e manter as verbas de que dispõe, o CCBB procura atender às expectativas do seu mantenedor, no tocante ao retorno dos investimentos financeiros que realiza. A 
principal forma de que dispõe para comprovar o bom destino dos recursos financeiros utilizados para patrocínio é a quantificação do público, que evidencia (em princípio) o retorno simbólico obtido com a arte exposta com a chancela e o logotipo da empresa.

Uma estratégia para atrair público poderia resultar na preferência por propostas artísticas que tivessem mais apelo popular. Essa preocupação está presente na programação do CCBB, ainda que não de modo exclusivo, nas propostas museológicas, as quais atraem não apenas o público escolar, mas também os que têm menos capital cultural e, portanto, parecem mais reticentes em relação às formas contemporâneas de arte. Também está presente nas escolhas teatrais que privilegiam a presença de atores (atrizes) consagrados (as) e de grande reputação. Contudo, como foi visto, tais escolhas não podem ser caracterizadas como comerciais ou populares, na medida em que elas não buscam atender a uma grande demanda pré-existente. Trata-se de uma espécie de consumo que requer certas predisposições ou, ao menos, o desejo de inserção na esfera da chamada "alta cultura". Além disso, a preocupação com nomes consagrados e reconhecidos denota o desejo de patrocinar obras que atendam aos cânones do campo e que não resultem em uma programação orientada de forma heterônoma:

A homologia entre o espaço dos produtores e o espaço dos
consumidores [...] funda o ajustamento não intencional entre a oferta
e a procura (no pólo temporalmente dominado e simbolicamente
dominante do campo, com os escritores que produzem para seus
pares, ou seja, para o próprio campo ou mesmo para a fração mais
autônoma desse campo, e, no outro extremo, com aqueles que
produzem para as regiões dominantes do campo do poder, por
exemplo, o "teatro burguês"). Contrariamente ao que sugere Max
Weber para o caso particular da religião, o ajustamento à demanda
nunca é completamente o produto de uma transação consciente
entre produtores e consumidores e, menos ainda, de uma busca
intencional do ajustamento, salvo, talvez, no caso dos
empreendimentos de produção cultural mais heterônomos (que, por
essa razão mesma, são chamados justamente de 'comerciais').
(Bourdieu, 2005:282)

Há a preocupação de que o CCBB se insira nos debates e na produção contemporânea das artes, o que fica evidente na sistemática de ouvir representantes de cada modalidade artística, no Painel de Tendências, para definir o eixo curatorial da programação de cada ano. Contudo, para legitimar-se internamente e manter a 
verba de que dispõe, o CCBB procura atender as expectativas do seu mantenedor quanto ao retorno dos investimentos financeiros que realiza. A principal forma disponível para comprovar a justeza dos custos envolvidos no patrocínio é, como já foi dito, a tentativa de quantificação do retorno simbólico propiciado pela arte chancelada pelo logotipo da empresa.

A audiência nas artes cênicas é medida pela ocupação da sala de teatro, sem distinção entre ingressos vendidos e convites doados. No que se refere às exposições, o controle é feito a partir de sensores eletrônicos, localizados nos andares e na entrada do edifício. Trata-se, portanto, de contagem sabidamente superestimada, que não exclui funcionários, terceirizados, pessoas que foram ao Centro Cultural exclusivamente para participar das atividades de cinema ou teatro, todos contabilizados como público de exposições.

A presença na mídia inclui a mensuração de reportagens, roteiros em guias semanais, inserções nas televisões e rádios, divulgação pelos sites na internet, críticas em jornais e revistas especializadas, colunas sociais, enfim, toda matéria que faça menção, ainda que indireta, ao evento patrocinado. Trata-se do que, na área de marketing, se convencionou chamar de mídia espontânea, ou seja, não paga.

Neste estudo, constatou-se que de espontânea a exposição na mídia tem muito pouco, na medida em que há todo um trabalho de profissionais que "assediam" as redações a fim de conseguir que sua produção seja objeto da pauta jornalística. Esse dado, contudo, é ponderado apenas indiretamente pela amplitude de leitores ou espectadores que a notícia atinge.

No caso da mídia impressa, o material divulgado é medido em centímetros e esses centímetros são transformados em reais, multiplicando-se pelo custo médio de uma publicidade paga naquele veículo. No caso da mídia televisiva, a exposição é medida em tempo de exibição, multiplicada pelo valor de anúncio pago naquele horário, naquela emissora. Os centímetros de eventuais matérias negativas (praticamente inexistentes) são deduzidos do total obtido com as matérias positivas. Essas mensurações são feitas tanto pela assessoria de imprensa, que o proponente do projeto artístico é obrigado a contratar - e que, em prazo pré-determinado, deve entregar caderno de "clipagem", com cópia das matérias e sua quantificação -, quanto pelo próprio CCBB. 
A ponderação dos centímetros de matérias se faz somente pelo custo calculado da publicidade no veículo. Os centímetros semanais de divulgação nos guias culturais dos grandes jornais acabam tendo o mesmo peso das matérias de divulgação nos cadernos culturais, apesar destas terem uma repercussão infinitamente superior. Da mesma forma, a repercussão da matéria varia de acordo com sua localização no caderno e nas páginas, bem como a existência ou não de foto e suas dimensões. Assim, a visibilidade e atratividade da reportagem interfere na definição do preço a ser atribuído ao patrocínio, que não se limita aos centímetros que ocupa na página.

A partir da transformação dos dados de magnitude (centímetros e segundos) em reais obtém-se o retorno que o patrocínio atingiu, o que pode ser comparado com o investimento realizado, isto é, com o desembolso de recursos que propiciaram a criação do produto cultural.

Os CCBBs também realizam eventualmente o que em marketing se chama de pesquisa de recall, a qual consiste em perguntar ao público, na saída do evento ou alguns dias após a sua participação, se o nome do patrocinador é lembrado.

A utilização desses dois critérios, mídia e público, para a avaliação do patrocínio, demonstra alguns vícios analíticos. Primeiramente, são variáveis dependentes. Identificamos no período e nas artes estudados nesta pesquisa que 0 índice de correlação ${ }^{158}$ entre os valores contabilizados como mídia espontânea e o público foi de 0,67 , no caso das exposições, e de 0,72 , no caso das artes cênicas, o que indica uma correlação de moderada a forte entre as variáveis. Isso aponta a influência da mídia na presença do público, nos eventos patrocinados, podendo haver relação de causalidade entre o grau de exposição na imprensa e a definição de escolha das pessoas diante das ofertas culturais. Isso é corroborado pela percepção de que o público freqüentador de exposições e peças teatrais também consome notícias da mídia impressa e televisiva, sendo por ela influenciado.

Considerados esses critérios e tomando o material analisado nesta pesquisa, as exposições com maior público foram Manobras Radicais, com 100.567 visitantes e Antes - Histórias da Pré-História, com 59.469. No que se refere ao retorno de mídia, as exposições Arte de Cuba e Manobras Radicais obtiveram os valores mais expressivos: $\mathrm{R} \$ 2.899 .582,26$ e $\mathrm{R} \$ 2.307 .537,00$, respectivamente. Ponderado o 
retorno de mídia pelo valor do patrocínio, destaca-se a exposição Henfil do Brasil, com retorno de $\mathrm{R} \$ 8,46$ por real investido. Em segundo lugar, Manobras Radicais com retorno de $\mathrm{R} \$ 5,95$ por real investido. Nenhuma das exposições teve retorno inferior ao investimento feito, ou seja, o valor do espaço na mídia, se desembolsado pelo BB em anúncios publicitários, seria superior ao pago aos artistas para realizarem as mostras. Patrocinar eventos "bons" de mídia torna-se, portanto, investimento relativamente pequeno com alta probabilidade de retorno.

No pólo oposto, as exposições individuais Alfredo de Oliveira, Polisemiose e Um Indeterminado, justamente as de artistas menos consagrados, tiveram os menores públicos e baixos indicadores de retorno de capital investido (Anexo 28).

$\mathrm{Na}$ área de artes cênicas, a peça com mais público e maior percentual de ocupação da sala de teatro foi Molly Sweeney - um rastro de luz, que também obteve maior retorno de mídia, quantificado em $\mathrm{R} \$ 3.335 .075,74$. A peça com maior retorno do capital investido foi Outono Inverno, com $\mathrm{R} \$ 15,13$ para cada real de patrocínio. Molly Sweeney obteve o segundo maior retorno em mídia absoluta e público. No pólo oposto, o projeto Dramaturgias 2006 e as peças Rita Formiga e Peça de Elevador obtiveram os piores indicadores de público e retorno sobre o capital investido (Anexo 29).

Os casos de insucesso no retorno da mídia e do público não devem necessariamente ser interpretados como falhas administrativas ou estratégicas nas escolhas efetuadas. Na maior parte dos casos, o retorno esperado de mídia, quando - CCBB propõe o desembolso do recurso, aproxima-se dos valores apurados posteriormente. Dessa forma, dentro da política cultural pautada pela diversidade das escolhas, o CCBB premeditadamente dá espaço àqueles projetos que sabidamente terão menos retorno de mídia e de público, destinando-lhe também menos recursos, como já visto.

Com esses critérios, o CCBB pretende quantificar um dado que é simbólico e se refere ao ganho obtido na sua imagem, ao patrocinar um bem artístico. Os funcionários do CCBB admitem que essa quantificação seja insuficiente e ressentem-se por não possuirem outro instrumental que propicie avaliação mais precisa. Em última instância, esses instrumentos medem visibilidade e não ganhos de imagem, já que não é apurado o quanto o público atingido passou a ter

\footnotetext{
${ }^{158} \mathrm{O}$ índice de correlação estabelece o grau de dependência de duas variáveis em um intervalo de -1 a +1 ,
} sendo que $r=-1$ indica uma correlação negativa perfeita e $r=+1$ indica uma correlação positiva perfeita e $r=0$ 
percepção melhorada da empresa patrocinadora. O pressuposto é que a mera informação do auxílio aprovado, por si só, garanta um julgamento positivo daquele que se expôs às obras beneficiadas, presencialmente, como público no evento patrocinado, ou como mero receptor da informação jornalística, o que pode não corresponder aos fatos. Evidente que, considerada a valorização do campo artístico junto aos diversos segmentos sociais, difícil seria a existência de julgamento negativo sobre o patrocínio. Entretanto, é possível que ocorra um julgamento neutro ou indiferente acerca da empresa patrocinadora, ou, de outra forma, a quantidade de informação disponível garante visibilidade, mas não necessariamente ganhos de imagem.

\subsection{EmPRESAS PATROCINADORAS E MídIA: INTERDEPENDÊCIA E CONFLITOS}

As empresas de mídia aparecem como parceiras importantes das empresas patrocinadoras, contribuindo decisivamente para a eficácia do investimento cultural, se entendido por eficaz, como fazem os profissionais de marketing, o patrocínio que garante visibilidade. Graças ao espaço que tornam disponíveis gratuitamente, para a divulgação dos eventos culturais subsidiados, o patrocinador obtém o resultado esperado de seu investimento. Ocorre que a empresa cedente do espaço gratuito de patrocínio (por intermédio das reportagens que citam espontaneamente o nome do patrocinador) também vende espaços publicitários, que são, hoje, as principais fontes de receita do setor de comunicação.

Em artigo de sua autoria, um ex-Diretor de Marketing e Comunicação do BB reclama da resistência da mídia à divulgação das marcas das empresas que patrocinam de eventos culturais. Mostra-se indignado com o fato de, por um lado, as reportagens, sempre negativas, sobre assaltos a bancos, não pouparem a exposição, em fotografias e textos, da marca do banco assaltado e, por outro, omitirem a marca e o logotipo da empresa patrocinadora quando da divulgação de fatos positivos, como o apoio à cultura e ao esporte. Por obrigação contratual, os atletas devem vestir-se com as logomarcas dos patrocinadores, mas, nas fotos que divulga, a mídia, muitas vezes, omite essa informação: 
Penso que buscar visibilidade é um esforço legítimo, por parte das empresas e de suas marcas. As parcerias financeiras e apoios empresariais ajudam a materializar fatos de interesse público e de entretenimento. Agitam o circuito diário de emoções que o público busca através da mídia. Nutrem a pauta e contribuem para aumentar o consumo da informação. Fazem parte, portanto, da cadeia produtiva e comercial da notícia. O leitor, ou espectador não ignora o funcionamento desse ciclo. Não se trata, portanto, de ludibriá-los. (Naegele, 2001:56)

O argumento acima pauta-se, portanto, no fato de o patrocínio empresarial atender a necessidades dos leitores dos jornais e colocar as empresas patrocinadoras como fornecedoras de assunto para a imprensa, alimentado-a de insumos imprescindíveis para a sua produção. A divulgação do nome do patrocinador não seria atitude manipuladora, nessa perspectiva, já que o leitor ou o espectador teriam conhecimento dos interesses que norteiam "a cadeia produtiva e comercial da notícia". O fato de criar notícia daria, portanto, o direito de ser notícia. Instaura-se o conflito porque, na legalidade própria - para usar a expressão de Bordieu - do jornalismo, o nome do patrocinador não seria uma informação relevante para o consumidor da notícia, e seria uma espécie de merchandising. 0 leitor estaria, sim, interessado em saber as características da obra artística, de seu criador, de como se insere no campo artístico, mas seria irrelevante saber quem viabilizou financeiramente sua produção.

Assim, continua o executivo do BB:

Quando os veículos de comunicação, no Brasil, se empenham em suprimir nomes e créditos de patrocinadores - a não ser, como vimos, no caso de ocorrências negativas - estão atirando no próprio pé, quebrando um elo da cadeia produtiva tão necessário para as etapas desse processo. (idem, ibidem)

A menção à quebra da "cadeia produtiva" reside na defesa da lógica de mercado, que é rompida com a decisão de omitir o nome do patrocinador na reportagem. O tom ameaçador ${ }^{159}$ da fala ("atirando no próprio pé") retira a aura romantizada do jornalismo ("a defesa intransigente da veracidade dos fatos") para lembrar que ele também se insere na dinâmica capitalista de consumo e lucratividade. Continua o autor:

\footnotetext{
${ }^{159}$ O texto reproduz conferência patrocinada pelo Banco do Brasil, destinada a jornalistas.
} 
A experiência internacional, se considerarmos alguns países europeus, revela que mesmo pautas originadas a partir de iniciativas de patrocínio, são possíveis de tratamento editorial equilibrado. Penso que há um caminho a percorrer para encontrarmos um modelo adequado para essas coberturas jornalísticas. Um modelo no qual a mídia possa se pautar dentro de sua autonomia e dar crédito às iniciativas culturais, esportivas e comunitárias das empresas. É possível noticiar eventos ou registrar imagens respeitando-se a informação correta e completa, sem exageros ou contornos mercadológicos ou propagandísticos. Democracia avançada e mídia amadurecida correspondem a um cenário no qual a regra é deixar bem claro quais são os interesses em jogo. (idem: 56-57)

Defende-se, então, a transparência dos interesses em jogo na ação de patrocínio, sem que a mídia assuma postura que a abstenha de valorizar ou depreciar esse ou aquele elemento que seja objeto da notícia. Transparência é cobrada dos outros atores sociais que fazem parte do "jogo", mas não são explicitados os interesses subjacentes ao desejo de visibilidade presente na ação de patrocínio.

Em que consistirá o interesse do patrocinador em reportagem sobre uma manifestação artística: revelar explicitamente o interesse que ele tem na melhoria de imagem, para obscurecer eventuais ações que tenham causado danos aos consumidores? Ou evidenciar seu "genuíno e descompromissado" empenho no desenvolvimento do campo artístico, visto como esfera que rompe com a racionalidade própria do campo econômico, no sentido da responsabilidade social? Em que consistirá tornar transparente o interesse do artista na reportagem: revelar seu desejo de consagração e popularidade? Ou divulgar a "genialidade" da obra simbólica criada? Em que consistirá, ainda, evidenciar os interesses da imprensa: revelar seu interesse na ampliação do público leitor, o que acarretaria textos que atendessem a uma demanda pré-existente e, com mais leitores, mais anunciantes? Ou tornar efetiva a cobertura jornalística isenta e descompromissada? É pertinente dar seqüência à reflexão propiciada pelo executivo do BB:

Afinal, como já mencionei, a produção da notícia é também um processo comercial. Às economias desenvolvidas correspondem, maior respeito, às regras do marketing legítimo, às ações de visibilidade das empresas. Quando risca o nome de patrocinadores dos acontecimentos, a mídia está despersonalizando ações. Diluindo, no caldeirão da notícia, os interesses em conflito, a batalha 
pela visibilidade que vai além do espetáculo esportivo. Será que isso é bom para a democracia e para a economia? Será que despersonalizar conflitos, mesmo que sejam os conflitos indiretos, ancorados em marcas e imagens institucionais, contribui para 0 amadurecimento crítico da sociedade? A mídia tem sido extremamente eficiente quando cobra seriedade dos empresários, ética na política e na gestão das empresas públicas. Mas peca, por outro lado, ao não reconhecer os resultados positivos de empreitadas audaciosas de responsabilidade social e sucessos de marketing cultural e esportivo. (idem, ibidem:56-57)

Recusando a divulgação do nome do patrocinador, a mídia estaria, nessa perspectiva, rompendo com as regras do jogo, prejudicando a "economia e a democracia”. A exclusão, na matéria jornalística, do nome do patrocinador é aqui vista como contrária aos interesses coletivos, porque não contribui para a divulgação dos benefícios sociais advindos das ações de "marketing cultural e esportivo". De outra parte, ao mencionar que "a produção da notícia é também um processo comercial", é ressaltado como as mídias, tanto a impressa quanto a televisiva, sobrevivem: em grande parte, por meio de valores arrecadados com a publicidade veiculada pelas empresas o que faz delas também um produto simbólico patrocinado, assim como a arte.

O patrocínio empresarial em reportagem jornalística parece ser considerado um contra-senso na lógica mercadológica da empresa de mídia, na medida em que se trata de publicidade gratuita em um veículo que sobrevive de vender publicidade paga. O empresário da mídia poderia contestar a argumentação acima, afirmando que, no caso de o patrocinador desejar espaço publicitário em seu veículo, bastará comprá-lo, pois isso também faz parte da regra do "jogo da democracia e da economia", e, outrossim, o nome do patrocinador não é informação relevante à matéria jornalística.

A omissão mencionada constituiria, nas palavras do executivo citado, "despersonalização" da ação cultural, uma vez que, além do artista, jamais omitido, a menção ao patrocinador também consistiria fato jornalístico. A reivindicação da visibilidade do nome do patrocinador é, portanto, uma afirmação da empresa como sujeito, ainda que coadjuvante, do processo de criação, cuja relevância pretende ser reconhecida pela inserção da no texto jornalístico.

O debate em torno dessa questão evidencia a relação estabelecida entre empresas patrocinadoras e órgãos de imprensa. Poder-se-ia caracterizar essa 
relação como motivada por uma "interdependência conflituosa", mediante a qual a aproximação entre os atores sociais atendesse a interesses recíprocos, ao mesmo tempo que a necessidade de afirmação da autonomia desses campos forçaria a imposição de limites à associação das partes, gerando pontos de conflitos.

Os órgãos de imprensa não consideram como informação relevante ao leitor ou espectador o nome do patrocinador da obra cultural, omitindo-o freqüentemente. Ao fazer desse modo, seguem critérios e valores próprios do campo jornalístico, afirmando a sua autonomia. É possível pensar a comunicação de massa (Girardi Jr, 2007) como um campo específico da vida social, que - tal como as artes e o campo econômico - reivindica autonomia, tem regras, valores e formas de hierarquização e distribuição de capital simbólico próprios, e estabelece com os demais campos mecanismos ao mesmo tempo conflituosos e interdependentes de relacionamento.

\subsection{JORNALISMO CULTURAL: COMO TRANSFORMAR ARTE EM NOTÍCIA}

É bastante freqüente a reclamação a propósito dos espaços reduzidos destinados ao jornalismo cultural, nos veículos diários e semanais da imprensa escrita $^{160}$. Se, em seus programas, a mídia televisiva não dá destaque maior à cobertura do que acontece no meio artístico, notadamente ao que foge da indústria do entretenimento, nos veículos impressos - mais elitizados - há uma quase tradição de reserva de espaço às notícias culturais.

O pioneiro na atribuição de mais destaque ao tema, em São Paulo, foi o jornal O Estado de São Paulo (OESP), que, em 1956, criou o seu suplemento Cultura. Com perfil bastante diferenciado dos "segundos cadernos" de hoje, o jornal alimentava-se das discussões travadas pelos profissionais do também incipiente meio acadêmico. Antônio Cândido, Décio de Almeida Prado e Sábato Magaldi, entre outros, todos professores da Universidade de São Paulo, eram os "jornalistas" responsáveis pela divulgação e análise das produções do campo artístico.

\footnotetext{
${ }^{160}$ Há quem conteste essa constatação, como Maurício Stycer, mas a sua visão parece ser posição minoritária: "Um primeiro problema do jornalismo cultural no Brasil, algo que poderia ser visto por alguns como um elemento positivo, é o excesso de espaço. Não conheço no mundo nenhuma imprensa que dê tanto espaço para o jornalismo dito cultural quanto a imprensa brasileira. Nenhum dos jornais que conheço com algum hábito de leitura, como The New York Times, Guardian, na Inglaterra, Libération ou Le Monde na França, La Repubblica ou Corriere della Serra na Itália, El País na Espanha, dedicam à cultura um caderno diário de dez, 12 páginas." (Lindoso, 2007).
} 
Na década de 70, a Folha de S. Paulo (FSP), lançou seu caderno semanal destinado à cultura, o Folhetim, muito marcado pelas presenças constantes dos poetas concretistas Haroldo e Augusto de Campos.

Esses suplementos foram sucedidos por cadernos diários destinados às artes, como Caderno 2 (OESP) e a llustrada (FSP), que, contudo, vêm tendo seus espaços cada vez mais reduzidos. Neles, o perfil acadêmico dos escritores deu lugar a jornalistas, que começaram a especializar-se na área cultural. Isso significou mudança bastante radical no perfil desses veículos. Deixaram de lado o caráter ensaístico e analítico dos primeiros textos e passaram a utilizar técnicas de redação presentes nos demais cadernos. Essa mudança de linha editorial não significa que os acadêmicos tenham sido totalmente alijados; eles continuam sempre presentes, agora, entretanto, como convidados, nos periódicos de maior circulação.

Os motivos da redução do espaço destinado às artes extrapolam os interesses desta pesquisa, mas suspeita-se que residam em dois aspectos: um mais econômico, relacionado ao custo do papel e da produção de jornais mais volumosos, e outro relacionado às demandas por informação mais imediata e concisa da parte dos leitores.

Grosso modo, o jornalismo cultural arvora-se em dois papéis: o de divulgar os fatos novos (lançamentos, estréias, por exemplo) relativos aos produtos artísticos lançados, e o de comentar e analisar esses produtos. Em inglês, os dois momentos são chamados de "preview" e "review". O primeiro assume características de reportagem, sendo que o texto informativo, muitas vezes é permeado por citações de entrevistas efetuadas com os produtores culturais. O segundo, de caráter mais opinativo, assume características de crítica, resenha ou ensaio.

A matéria de lançamento segue normalmente o formato padrão do texto jornalístico. O tradicional lead de abertura traz de forma sucinta o que é o lançamento cultural, quem o produziu, em que circunstâncias, onde pode ser visto, acrescido de mais algumas informações. A objetividade e a linguagem clara e precisa costumam caracterizar essas matérias. Segue-se, em geral, a contextualização do artista, de suas obras anteriores e de sua biografia, a relação com o meio artístico e as condições da criação. A descrição do produto cultural ganha espaço maior, no qual se evidencia o esforço do jornalista em relatar as características essenciais das obras, o que, em alguns casos, como o das artes plásticas contemporâneas, torna essa tarefa bastante complexa. O texto é finalizado 
com o que é chamado de "serviço", com informações práticas como endereço, horário e preço dos ingressos.

É necessário relativizar a objetividade do "preview". Para muitos artistas, a própria seleção da obra a ser divulgada já é uma deferência do jornal. A maior parte das peças e exposições não tem espaço nos cadernos de cultura, sendo a eles relegado apenas o "serviço" constante nos guias semanais e, em alguns casos, nem isso. O destaque dado à reportagem é outro fator que influencia na definição da notoriedade da obra. Portanto, matérias de capa de caderno são mais valorizadas, bem como as situadas no alto da página, as que apresentam chamada na primeira página do jornal - fato raro para notícias de caráter cultural - e as que são acompanhadas de foto. Em suma, um "preview" pode ser classificado de diversas formas, de acordo com o destaque dado pela edição ${ }^{161}$. Além disso, o jornalismo cultural permite-se liberdade em relação à objetividade esperada, muito embora não mantenha o caráter ensaístico e opinativo de outrora. Um tom ligeiramente opinativo não é considerado "crime" na prática jornalística dos segundos cadernos. Nessa linha de liberdade, podem ser incluídas as matérias de divulgação de Beth Néspoli, cujas manchetes "Emoções fortes servidas num jantar de família" e "A magia do mundo dos sentidos", ambas com fotos e com matérias extensas, publicadas n'O Estado de São Paulo, em 25 de novembro de 2006 e 16 de março de 2005, respectivamente, constituíam praticamente um convite persuasivo ao leitor para que assistisse aos espetáculos Outono e Inverno e Molley Sweeney. Disso é possível considerar que, embora não tenha um papel explícito de crítica, o jornalismo cultural, ao divulgar a obra, tem influência decisiva no sucesso do espetáculo junto ao público, pois hierarquiza, distingue, privilegia e exclui uns em relação a outros, levando os leitores dos jornais a utilizarem-no como norteador de suas escolhas.

Outra característica marcante dos cadernos de cultura, em São Paulo, é o lugar central das agendas culturais em suas pautas, acompanhando lançamentos e estréias do "mercado" artístico. São raras as reportagens de cunho mais investigativo e ampliado, que extrapolam o fato novo do surgimento de algum produto cultural. Dessa forma, as pautas assumem papel próximo ao da

${ }^{161}$ Nos Anexos 30 e 31, há uma compilação das matérias de divulgação das exposições e peças patrocinadas pelo CCBB nos dois principais jornais da cidade. 
publicidade ${ }^{162}$, dando visibilidade aos produtos, ainda que não explicitamente com o objetivo de vendê-los.

Tendo em vista a grande oferta de produtos culturais de uma cidade como São Paulo, os jornais diários adquirem papel decisivo nas escolhas do público, uma vez que, nas áreas analisadas, o perfil do público consumidor de arte é semelhante ao do consumidor de notícias impressas. O texto jornalístico é um "discurso competente" que auxilia esse público a separar o "joio do trigo", a definir prioridades, estimulando-o a ver determinados espetáculos e exposições, em detrimento de outros. Os cadernos de cultura constituem, dessa maneira, uma das instâncias de consagração do campo artístico.

As escolhas feitas pelos jornalistas, em conjunto com os editores, pautam-se por dois critérios básicos: o primeiro, relacionado ao interesse que o público possa ter naquela notícia; o segundo, vinculado à relevância que determinado artista ou obra tem no campo artístico, no seu julgamento, muitas vezes em uníssono com os demais especialistas desse campo.

Comparado com os segundos cadernos das décadas de 60 ou 70 , o jornalismo cultural atual é mais pragmático, no sentido de que dá maior ênfase à prestação de serviço do que à reflexão e à crítica, servindo como guia de consumo cultural para o leitor. As críticas são em geral curtas e breves. Os textos com maior profundidade de análise restringem-se a espaços autorais assinados. Conseqüentemente, o que Szantó afirma sobre o jornalismo cultural norte-americano também é válido para o brasileiro:

O resultado desse jornalismo cultural orientado para o serviço é o que se percebe atualmente na maioria dos jornais americanos. Mais da metade do espaço editorial destinado ao jornalismo cultural consiste em listas: intermináveis colunas detalhando todas as exposições, todas as apresentações musicais, todas as conferências que acontecem na cidade. O leitor tem menos resenhas críticas, porque se assume que a informação crítica, a inteligência crítica está com o leitor. O papel do jornal é o de simplesmente proporcionar esse vasto painel de informações. Isso produz uma cobertura rasa, mas útil. (Szantó, 2007).

Percebe-se também que as áreas artísticas possuem espaços diferenciados nos cadernos culturais. As artes vinculadas à indústria cultural, como cinema,

\footnotetext{
${ }^{162}$ Algumas manchetes assumem claramente o tom publicítário como o título de capa da revista Época sobre o primeiro filme da séria Harry Potter: "A magia vai começar" (Maurício Stycer. "Seis Problemas". In Lindoso (org.), 2007).
} 
música e, em menor grau, televisão, obtêm maior espaço do que as artes cênicas e as artes plásticas. Isso pode relacionar-se ao peso econômico que aquelas indústrias exercem sobre a imprensa. O jornalismo impresso torna-se alvo privilegiado de diversos ramos da indústria cultural, como o editorial, o cinematográfico e o musical, que dependem da divulgação de seus produtos para torná-los não apenas conhecidos, mas atrativos para os consumidores. Essas empresas são objeto de cobiça dos artistas, pois sabem que sua reputação depende da publicidade que os veículos de comunicação de massa fazem de maneira privilegiada. São também desejadas pelo corpo de especialistas que utilizam os espaços jornalísticos para construir vínculos, atacar adversários e se promoverem publicamente. Nesse contexto, os artistas e produtores culturais sentem-se impelidos a "brigar" com os empresários da indústria cultural para que sua produção tenha cobertura:

\begin{abstract}
A pressão sobre a mídia é ainda mais comum vinda do setor empresarial da cultura. Uma pressão intensa é feita sobre os jornais para que cubram Hollywood. Se for o caso de um jornal de porte médio que queira colocar uma foto de Julia Roberts na capa, os estúdios pedirão uma contrapartida: mais espaço, mais cobertura positiva, mais proeminência. Isso é profundamente problemático porque é com a indústria cinematográfica que os jornais ganham dinheiro por meio da cobertura cultural, de maneira que os jornais relutam em enfrentá-los. Os estúdios acham que, se gastam tanto dinheiro, devem receber cobertura positiva. [...] Não percebem que os espectadores precisam de críticos que tenham independência de julgamento. (Szantó, 2007:40)
\end{abstract}

Os veículos da imprensa, assim como as instituições culturais, são instâncias de consagração e distribuição de prestígio, contribuindo para a criação e manutenção das hierarquias e para estabelecer critérios de distribuição de capital simbólico. O texto jornalístico insere-se no campo artístico como discurso de autoridade, outorgando credibilidade, plausibilidade e confiabilidade ao objeto cultural, mesmo quando não entra no mérito da relevância artística da obra ou de sua proposta conceitual. 


\subsection{O PAPEL DO ASSESSOR DE IMPRENSA NA FABRICAÇÃO DA PAUTA CULTURAL}

O campo artístico tem criado profissionais para lidar com meios externos ao campo, os quais, não tendo o mesmo prestígio dos criadores, são, contudo, decisivos para o sucesso da empreitada cultural. O primeiro é o Produtor Cultural, ator social já objeto de análise nesta tese, responsável por vender a obra aos patrocinadores e, posteriormente, pela sua viabilidade econômica, infra-estrutura de realização e prestação de contas ao patrocinador e órgãos públicos. O segundo é responsável pela "venda" do produto cultural aos jornalistas e chefes de redação.

Contratado pelo artista ou, muitas vezes, indicado pela instituição cultural patrocinadora, o assessor de imprensa responde pela divulgação da obra e pela persuasão dos responsáveis pelas pautas dos veículos de imprensa. Isso se deve ao fato de que os artistas competem entre si pelo espaço na mídia. Mesmo os guias de semana, que possuem caráter bastante abrangente, não comportam a quantidade de exposições e espetáculos existentes na cidade.

O CCBB exige que os projetos patrocinados pelo mantenedor contem com assessor de imprensa para trabalhar na divulgação do evento, não obstante o fato de possuir seu próprio assessor. Figura conhecida no campo artístico, o assessor de imprensa atende a interesses não só dos patrocinadores, mas, sobretudo, dos artistas que querem ver seu trabalho com a máxima divulgação possível, a fim de atingir patamares elevados de público e notoriedade.

Os assessores de imprensa dos projetos artísticos patrocinados, e do próprio CCBB, assumem, na construção da notícia, o papel de fonte. Nesse caso, o relacionamento interpessoal com os jornalistas de redação dos periódicos de maior circulação é decisivo na conquista da pauta:

Entre os aspectos envolvidos nas rotinas produtivas do noticiário e na escolha das fontes, a disponibilidade da fonte é decisiva. Muitas vezes o jornalista prefere consultar fonte já tradicional - mesmo que não seja a mais indicada a opinar sobre o assunto - porque é a mais acessível no momento. $O$ jornalista especializado manifesta a tendência de consolidar grupo estável de informantes. Fontes estáveis são aquelas que conquistaram credibilidade proporcionando, ao longo do tempo, informações confiáveis e certas. Contando com esse grupo-base, o jornalista preenche com mais 
facilidade a necessidade imperiosa de concluir sua matéria nos rígidos limites de tempo da atividade jornalística. Dispondo de tais garantias, o jornalista pode até auto-criticar o uso viciado das mesmas fontes, mas acaba cedendo à lógica da produtividade, uma vez que dispõe, junto a estas fontes, de material suficiente para elaborar a notícia. (Banco do Brasil, 2001:23)

Os assessores de imprensa entrevistados para este estudo afirmaram que contribuem de maneira decisiva na redação das matérias publicadas pelos jornais. Isso foi comprovado pela constatação da grande semelhança existente entr os textos jornalísticos publicados em órgãos de imprensa os mais diversos. Vocabulário e referências idênticos estão presentes em diversas matérias de divulgação. Essa homogeneidade é explicada quando se verifica que o assessor de imprensa é a fonte do press release, incorporado de maneira inconteste pela maior parte das redações de muitos jornais. Redações enxutas, prazos exíguos e comodismo profissional podem explicar o fato de, muitas vezes, os editores admitirem que o jornalista prescinda de sua tarefa precípua, a de redigir a notícia, e assuma como verdade o texto do assessor de imprensa.

Interessante observar que alguns clippings se mostram bastante "malsucedidos", diante da evidente falta de material de divulgação da obra pela imprensa. Nesse caso, os assessores de imprensa procuram deixar registrados os seus esforços, ainda que sem resultados. No clipping da exposição de Alfredo de Oliveira, por exemplo, o assessor de imprensa detalhou as tentativas de divulgação e publicidade do trabalho:

\footnotetext{
"Sugestão de Pauta - Revista Bravo - Gisele Kato - Encaminhado e-mail para Gisele Kato dia 19/04 com release anexo como sugestão. Tentado contato com Gisele em 04/05 sem sucesso. Não atende o ramal. Tentar mais tarde. No voice-mail da Gisele tem uma mensagem dizendo que ela está morando no Rio e que o contato com ela é apenas por e-mail. Remandado (sic) e-mail em 05/05. Conseguido contato com Gisele em 10/05. Disse que recebeu o email, mas sem muito interesse. Resultado: não foi publicado." (Clipping de Imprensa da Exposição Alfredo de Oliveira)
}

A leitura do farto material dos clippings dos projetos patrocinados pelo CCBB permite diagnosticar a inserção mais incisiva do texto do jornalista no campo artístico. Ela se dá por meio das críticas. O que aparece com destaque nos textos jornalísticos de divulgação são características externas à obra, envolvendo, 
sobretudo, o perfil e a trajetória dos artistas. Os 55 anos de carreira de Walmor Chagas foram fartamente abordados em todos os veículos, deixando em segundo plano sua proposta artística de discutir o predomínio da imagem sobre a palavra na contemporaneidade, tema do espetáculo patrocinado. Da mesma forma, as fotos da atriz Bárbara Paz, conhecida do público por sua participação no programa Casa dos Artistas, veículado pelo SBT, ganharam dimensão maior do que a discussão proposta pelo texto de Mishima. O valor dos objetos (diamantes, jóias) utilizados pelo artista Vik Muniz e o fato de ser um artista brasileiro consagrado, que obteve sucesso no circuito comercial internacional, também é destaque, em detrimento de sua proposta de discutir a centralidade das celebridades no imaginário popular. Dessa forma, aspectos biográficos predominam em prejuízo da descrição mais aprofundada da própria obra.

Os assessores de imprensa trabalham, sobretudo, na divulgação do "espetáculo" e para isso contam com banco de dados (mailings) com os contatos de jornalistas, editores da área de cultura, variedades e comportamento, críticos e membros da "classe artística". Enviam para esse vasto público, que chega a atingir 3.000 nomes, convites, press releases e imagens. Trabalham de maneira enfática junto aos colunistas sociais, procurando convencê-los a participar, ou enviar sua equipe, para as estréias e vernissages.

A estréia é o pico do trabalho, quando os assessores procuram agendar 0 maior número possível de entrevistas. O seu grande desafio é manter o evento na mídia, após a estréia, quando o produto deixa de ser atrativo.

Segundo o manual de relacionamento com a imprensa do BB, são seis as características que fabricam um conteúdo jornalístico de alta relevância, com condições de conquistar espaço nobre nos veículos de comunicação de massa:

- vínculo forte com a atualidade;

- proximidade com a realidade do público destinatário;

- ênfases na notoriedade de pessoas, lugares, datas e temas;

- valorização das conseqüências [do fato] para a vida das pessoas;

- clara delimitação de eventuais conflitos existentes;

- acentuação do caráter utilitário da informação [interesse público]. (Banco do Brasil, 2001:33)

O primeiro item explica o fato de o jornalismo cultural pautar-se pelos lançamentos culturais. O terceiro tem a ver com a ênfase colocada sobre questões biográficas dos artistas. A importância que o CCBB dá à capacidade técnica dos 
proponentes dos projetos na seleção da obra a ser patrocinada, como vimos no Capítulo 4, e a programação, em que predominam nomes consagrados, como vimos no Capítulo 5, atende ao terceiro objetivo da lista acima, tendo em vista que a notoriedade do artista rende mais espaço jornalístico. O último item está relacionado à importância do "serviço" na conclusão da reportagem.

A resposta à pergunta sobre o que transforma um fato em notícia envolve, portanto, critérios e instrumentos próprios dos órgãos de imprensa os quais permitem reduzir o número de fatos em uma quantidade limitada e constante de notícias. O enquadramento que o jornalista dá a sua matéria é determinado por concepções prévias sobre os fatos que serão objeto de seu julgamento e que, certamente, envolvem os valores e os critérios de hierarquização do campo artístico, quando se trata de matérias culturais. Envolvem também constrangimentos que abarcam um amplo espectro de fatores que vão desde a relação do repórter com seu editor, passando pela linha editorial do veículo, os laços e interesses estabelecidos com as fontes, o impacto e a atratividade da notícia junto ao público e a avaliação que os pares, de empresas concorrentes, farão da matéria.

O último elemento referido acima remete a uma propriedade freqüentemente ressaltada por Bourdieu em sua teoria dos campos, a qual, por sua vez, remete à constante luta interna e às forças em conflito que geram a dinâmica cotidiana dos campos:

Jornalistas têm muito pouco conhecimento a respeito de seu público. Além disso, boa parte dos leitores de suas matérias sequer conhece seus nomes. É uma boa razão para que esses profissionais passem a escrever para seu grupo de referência: editores, colegas de redação ou concorrentes, fontes, grupos de interesse e, até mesmo, amigos com certo capital cultural, caracterizados como leitores mais atentos do que os demais. [...] A credibilidade de um jornal é sempre uma credibilidade perante concorrentes ou indiretamente perante outros campos (político, religioso, acadêmico) (Girardi Jr. 2007:151152)

A fonte, no jornalismo cultural, representada muitas vezes pelo assessor de imprensa, não tem somente um papel tradicional de deter a informação a ser transmitida aos jornalistas, mas incumbe-se, sobretudo, de transformar o bem cultural em acontecimento, em fato. Se, em geral, no jornalismo, as fontes assumem postura defensiva, receosas de ter suas opiniões distorcidas, manipuladas ou reduzidas, nos cadernos culturais, elas assumem papel pró-ativo, de intensa 
parceria e reciprocidade, com os jornalistas das redações. Os assessores de imprensa fazem constantemente o papel de demandante diante das redações, tentando seduzir o jornalista e o editor para a relevância do projeto cultural que defende, a fim de conseguir uma pequena fração do já exíguo espaço destinado aos assuntos culturais.

\subsection{A POUCA EXPRESSIVIDADE DA CRÍTICA DE ARTE NA AVALIAÇÃO DO PATROCÍNIO}

Apesar de a metodologia de quantificação prever que as matérias negativas sejam deduzidas das matérias positivas, não se verificou esse procedimento quando foram publicadas críticas negativas aos eventos patrocinados. Por outro lado, a crítica que exalta a peça ou o espetáculo tinha o mesmo peso do que as reportagens de divulgação, sem muito juízo de valor a respeito da obra. Isso diminui o poder da apreciação especializada das instâncias de julgamento próprias do campo artístico, fazendo com que a avaliação efetuada pelo patrocinador não incorpore o impacto que a obra patrocinada teve em relação à tradição artística e à sua inovação. É verdade que as críticas positivas e as premiações que os eventos angariam são incluídas em relatórios e divulgadas no site da instituição, mas elas não são hierarquizadas e utilizadas como critério de comparação entre os projetos patrocinados.

O pequeno peso da apreciação crítica na avaliação do patrocínio pode ser relacionado com certo retraimento da crítica de arte no Brasil. O que Sant'Anna aponta acerca da crítica literária poderia ser estendido às demais áreas artísticas:

Não há mais crítica literária no país (...). Há articulistas, há resenhadores, mas falta a referência crítica sistêmica dentro dos suplementos, como ocorria até os anos 70. É necessária a manutenção de críticos especializados não apenas porque isto retira a atividade do amadorismo, do compadrismo, do ocasionalismo, mas porque crítico é mais que uma pessoa, é uma instância, uma memória viva e atuante em sua área. Ele pode estabelecer melhor que os comentários eventuais, nexos entre obras anteriores dos artistas, porque tem obrigação de informar-se sobre a trajetória e a formação de cada autor dentro de uma visão de conjunto da própria cultura nacional. Além do mais, o crítico constrói também uma obra que é um sistema de idéias. $\mathrm{E}$ a leitura da cultura tem tanto na obra dos artistas quanto na obra dos críticos dois pilares referenciadores 
para mútuo entendimento. Hoje os críticos foram substituídos por repórteres e entrevistadores. É como se houvesse mais interesse no indivíduo que na obra, mais interesse na biografia que no texto, mais interesse na visualidade da paginação que na textualidade. (Sant'Anna, 2001:48)

O trabalho dos críticos é veiculado preponderantemente por meio da imprensa escrita, em jornais ou revistas ${ }^{163}$. As peças do CCBB, nos anos 2005 e 2006, tiveram número superior de críticas em relação às exposições (Anexos 32 e 33). A ausência de críticas pode revelar certa falta de expressividade do trabalho apresentado, muito embora, como a oferta de opções culturais na cidade é abundante e o espaço nos jornais e revistas reduzido, somente uma minoria dos trabalhos recebe algum comentário crítico nesses veículos.

Heinich aponta para o caráter selecionador que a crítica de arte assume, ao afirmar:

não tanto pelos ataques ou pelos elogios mas pelos comentários ou pelos silêncios, quer dizer de inclusões ou de exclusões no campo do que vale ser comentado: escapando da posição do favorável ou contrário, da admiração ou do ataque virulento, ela é somente eloqüente ou silenciosa. Os simples comentários, mesmo não glorificantes, permitem o ingresso do criador no círculo dos artistas dignos da palavra, enquanto a abstenção o mantém no limbo, nesta zona de trânsito artístico entre a esperança do reconhecimento e o ressentimento do anonimato, e mesmo o desespero de não ser um verdadeiro artista. A derrota não é mais a incapacidade de atrair os elogios do que a impotência de fazer falar de si. (Heinich, 1998a:268)

Se isso é correto, e acredita-se que seja, o CCBB São Paulo tem obtido resultados razoáveis, considerando que $70 \%$ das peças (incluindo os programas Dança em Pauta e Dramaturgias) e $40 \%$ das exposições tiveram críticas publicadas em jornais ou revistas.

Nesse contexto, o crítico tem papel chave no campo artístico, haja vista que possui autoridade para julgar, classificar e avaliar os bens produzidos. Na qualidade de especialista, torna-se o profissional responsável pela mediação da obra e do artista, junto a um público ampliado e aos produtores dos bens artísticos. Com a

\footnotetext{
${ }^{163}$ Há que se citar, contudo, algumas revistas, tomando como exemplo as artes cênicas, mais especializadas (algumas acadêmicas), contemplando artigos com maior profundidade analítica: Sala Preta, do Departamento de Artes Cênicas da Universidade de São Paulo; Folhetim, do grupo Teatro do Pequeno
} 
publicação de seus textos, o crítico "cimenta" grupos a partir de afinidades e rivalidades, teoriza sobre os conflitos, hierarquiza as produções, cria formas de nomeação e classifica os bens simbólicos.

Para efeito deste estudo, a compilação das críticas baseou-se em pesquisa realizada nos clippings de imprensa apresentados pelas produções dos espetáculos e exposições, tendo em vista exigência contratual do patrocinador e também em pesquisa realizada junto aos principais jornais e revistas da cidade.

São escassas as publicações especializadas no campo artístico, no Brasil. Em São Paulo, três revistas se destacam: a Bravo!, de circulação mensal, pela Editora Abril, dedicada a inúmeras modalidades artísticas; a Bien 'Art, lançada em 2004, produzida pela Fundação Bienal de São Paulo, com foco nas artes visuais; e a Cult, da Editora Bregantini, com foco em literatura e filosofia. Além desses periódicos, os principais jornais diários ${ }^{164}$ contam também com corpo de críticos, os quais publicam nos cadernos de cultura.

Acerca da autonomia e independência da crítica em relação aos produtores dos bens culturais, afirma Cauquelin:

Quando a existência e a consistência de um mercado independente estão devidamente estabelecidas, a partir dos anos 1890, o poder da crítica de arte é dominante sobre todos os outros planos e substitui progressivamente o poder do reconhecimento "oficial" [da Academia]. A crítica de arte não é mais um acompanhamento nem uma transposição; ela se torna - além de sua destinação comercial uma tentativa de decifrar e de teorizar as novas formas plásticas. $E$ desse modo conquista certa autonomia, acompanhada da independência recentemente adquirida pelos artistas, concorrendo para estabelecer a autonomia da forma pictórica como tal (Cauquelin, 2005: 41)

Das quinze exposições realizadas pelo CCBB, somente seis receberam críticas. As críticas de Felipe Chaimovich para as exposições de Farnese de Andrade - Objetos ${ }^{165}$ e Mary Vieira - O Tempo do Movimento ${ }^{166}$; a crítica de Marcelo

Gesto, do Rio de Janeiro e O Percevejo, do Departamento de Teoria do Teatro da Escola de Teatro da Universidade do Rio de Janeiro (UNI-RIO).

164 Os dois principais jornais contam com críticos especializados em artes cênicas (no período sob análise, Sérgio Salvia Coelho, na área de teatro, e Inês Bogéa, na área de dança da Folha de S. Paulo, e Mariângela Alves de Lima e Beth Néspoli, na área de teatro, e Ana Francisca Ponzio, na área de dança do 0 Estado de São Paulo,) e em artes plásticas (Fabio Cypriano e Felipe Chaimovich, esse mais como colaborador, da Folha de S. Paulo).

165 “(Chaimovich, Felipe. Arte construtiva é desafiada hoje, Folha de S. Paulo, São Paulo, 19/02/2005, Ilustrada, E8). Apesar de bastante positiva a avaliação que o crítico faz da exposição, reclama da impossibilidade de manuseio de algumas obras, o que, segundo ele, representa "limitação à plena fruição da mostra (...) A 
Coelho também para a exposição de Farnese de Andrade- Objetos ${ }^{167}$ e a crítica de Juliana Monachesi para a exposição Polisemiose ${ }^{168}$ foram bastante positivas. A matéria $^{169}$ de capa da Revista Bravo! sobre a exposição Erotica também foi bastante elogiosa e com vasta cobertura.

As críticas com ponderações preponderantemente negativas ficaram por conta de Fabio Cypriano, que escreveu sobre as mostras Vik Muniz e Artes de Cuba, classificando-as como regular ${ }^{170}$. No primeiro caso, a crítica dirigiu-se, sobretudo, ao artista e à maneira considerada repetitiva por meio da qual elabora suas criações. Contudo, envolveu também o curador:

Já há algum tempo, a fórmula se tornou uma máquina de reproduções e pastichização ad infinitum de si mesmo, evidenciando que ele abandonou o que possuía de melhor no início da carreira: o caráter experimental aliado à inconteste erudição acerca da matéria fotográfica. [...] Com as duas séries que apresenta no CCBB, Muniz radicaliza ainda mais essa busca pelo popular e por uma explicação simplista de sua obra. Agora são estrelas de cinema estrangeiras, com Liz Taylor ou Catherine Deneuve, e personagens de filmes de terror, como Drácula e Frankenstein. Os materiais usados para suas construções é que mudaram, pois, em vez de elementos precários, como papel, linhas e açúcar, agora são produtos de ostentação, como diamantes no caso das divas, e caviar, para os monstros. A metáfora aqui se torna gritante. Na montagem, tais elementos são também ostensivamente divulgados: um texto informa que o valor do caviar usado é de US\$17 mil, e o dos diamantes, US\$650 mil. Ora a fórmula de sucesso criada aqui se apresenta mesmo redundante, especialmente com os diamantes para as divas. Sua técnica continua a impressionar pela precisão, mas isso, convenhamos, está mais próximo do campo da publicidade do que da arte. ${ }^{171}$

A crítica publicada sobre a mostra Artes de Cuba dirigiu-se, sobretudo, à curadora:

Exposições sobre períodos abrangentes da cultura visual de um país correm sempre o risco da superficialidade. (...) $O$ conjunto

engenhosidade [da obra "Grupo rítmico de colunas: ascendente descendente"] permanece restrita à teoria sem a contraparte interativa. (...) Para torná-las [as obras] atuais, o público deveria operar sobre as peças, seja de modo a compreender intelectualmente o processo de derivação rigorosa das formas, seja pelo deslocamento das partes móveis."

${ }^{166}$ Chaimovich, Felipe. Objetos de Farnese revelam universalidade, Folha de S. Paulo, São Paulo, 28/05/05, llustrada, E7

167 Coelho, Marcelo. Ovos, bonecas e relicários, Folha de S. Paulo, São Paulo, 20/04/05, Ilustrada, E12

${ }^{168}$ Monachesi, Juliana. Onde colocar o desejo. Bien'Art, São Paulo, novembro de 2005, 13-14.

169 Oliva, Fernando. Erotismo é alegria, movimento e transformação. Bravo!, São Paulo, outubro de 2005

170 A Folha de S. Paulo classifica suas críticas em seu rodapé com estrelas que quantificam a avaliação efetuada em escala que vai de "bola preta" a quatro estrelas, sendo que "bola preta" equivale a péssimo; uma estrela, ruim; duas estrelas, regular; três estrelas, bom e quatro estrelas, ótimo. 
apresentado se configura mais como uma versão de segunda categoria da 'história oficial' das artes plásticas ocidentais do que uma pesquisa que revela características da produção cubana. (...) Desse período (pós-Revolução Cubana de 1959), impossível não notar a ausência das obras de Ana Mendieta, artista que envolveuse em atividades anti-Fidel Castro, exilou-se nos EUA e lá desenvolveu uma das mais profícuas obras vinculadas à performance. Essa omissão revela o caráter oficial da mostra, que se vale, quase que exclusivamente, do acervo do Museu Nacional de Belas Artes de Havana. Finalmente, a produção contemporânea apresenta um já renomado grupo de artistas, com Los Carpinteros, Carlos Garaicoa, Tania Bruguera e Jose Bedia, misturados a outros com tão pouca expressão, que o conjunto acaba enfraquecido. Talvez, em mostras dessa natureza, menos seja mais. ${ }^{172}$

Um outra crítica dessa exposição, em que também são apontados alguns problemas de curadoria, foi mais generosa com a mesma mostra. Ambas concordam com o problema acarretado pela multiplicidade e quantidade excessiva de obras na exposição:

É oportunidade rara e imperdível, embora se possa observar que a
curadoria - realizada com o acervo do Museo Nacional de Bellas
Artes de Cuba pela crítica de arte cubana Ania Rodriguez - caiu em
armadilha incontornável a esse modelo expositivo. Apesar do critério
de qualidade, nitidamente exercido na seleção das obras e na
acurada busca de uma amarração histórica, o conjunto resulta
caleidoscópico demais. É impossível estabelecer percurso fluido,
capaz de revelar a densidade específica de cada contribuição autoral
enfocada, quando se dispõe de uma média de apenas duas obras
por artista. Claro que a alguns mestres - como Lam, René Porto-
carrero e José Bedia, por exemplo - foi dado o respiro de obras em
maior número, que funcionam como 'câmaras de descompressão'
para nossas retinas, forçadas a percorrer terreno abrupto, com
constantes mudanças de linguagens sem que a anterior esteja
suficientemente explicitada. Algo assim como um rodízio que entope
seu prato de novas opções enquanto você nem chegou a mastigar
direito a fatia que acabou de colocar na boca. ${ }^{173}$

Ponderações negativas sobre as exposições do CCBB não alteraram a avaliação que o patrocinador fez do evento. Ambas as mostras tiveram avaliação positiva pelos critérios quantitativos utilizados, em centimetragem e presença de

${ }_{171}$ Cypriano, Fábio. Vik Muniz faz metáfora óbvia. In Folha de S. Paulo, São Paulo, 20/03/2005, Ilustrada, E5.

172 Cypriano, Fabio. Tom oficial marca "Arte de Cuba". Folha de S. Paulo, São Paulo, 27/03/2006, Ilustrado, E6

173 Moraes, Angélica. Sem perder a ternura. Bravo!, São Paulo, fevereiro de 2006, 25. 
público, o que revela o pouco peso que as opiniões dos especialistas têm na perspectiva do patrocínio empresarial.

$\mathrm{Na}$ área de artes cênicas, somente duas peças estudadas não receberam críticas (Madame de Sade e Peça de Elevador). Contabilizaram-se, na análise dos clippings de imprensa, dezoito críticas, em diversos veículos. Três delas, que tinham predominantemente apreciações negativas, eram relativas aos espetáculos Um homem indignado, Rita Formiga e Cinema Éden. Sérgio Sálvia Coelho classificou a primeira como regular (duas estrelas), afirmando:

Apesar de satirizar a primazia da imagem, portanto, o espetáculo aposta na imagem como saída da crise, e falha justamente na direção de ator desses parceiros virtuais. São bastante amadoras as participações especiais, ora por inexperiência dos jovens atores, ora por roubarem a cena sem cerimônia, como no caso de José Celso ${ }^{174 . "[A p e s a r ~ d e ~ s e r ~ u m ~ m o n o ́ l o g o, ~ o ~ a t o r ~ W a l m o r ~ C h a g a s ~}$ dialogava com outros personagens que apareciam em uma tela]

Dirceu Alves Jr. não se rende à reputação de Cleide Yáconis na peça Cinema Éden:

Entregue ao desafio, ela tenta equilibrar as fragilidades do espetáculo. Do alto do seu talento, não consegue. Ao seu lado, estão atores jovens, como o apenas boa-pinta André Fusko e a bela e talentosa Maria Manoella, encarnação de Duras em cena, além de dois coadjuvantes que comprometeriam menos se ficassem de fora. De suas bocas, sai um texto duro, frio e distanciado que não explora nem o intenso clima de incesto vividos pelos irmãos. ${ }^{175}$

Da mesma forma, Mariângela Alves de Lima escreve crítica contundente ao pontuar que a peça é confusa com problemas de dramaturgia ("Sem dúvida, a carta é o ponto alto de uma peça confusa, indecisa entre a revolta existencial gratuita e caracterização da vida dos colonos franceses na antiga Indochina"), ressaltando, contudo, o trabalho primoroso da protagonista:

É na verdade a atriz, formada e experimentada no teatro de
conjunto, que constrói minuciosamente um percurso para a sua
personagem, a partir de pequenos indícios factuais e psicológicos.
[...] Não fosse esse lastro, que é uma colaboração da intérprete à

\footnotetext{
${ }^{174}$ Coelho, Sérgio Sálvia. "Walmor Chagas exerce o verbo em monólogo". Folha de S. Paulo, São Paulo, 21/05/05, llustrada, E7.

${ }^{175}$ Alves Jr., Dirceu. "Talento de Cleide Yáconis não salva a montagem brasileira do texto de Marguerite Duras". Isto é Gente, São Paulo, 24/01/05, 34.
} 
continuidade dramática, não haveria nada muito interessante nessa encenação. ${ }^{176}$

Essas duas peças, contudo, receberam outras críticas altamente positivas. Sérgio Sálvia Coelho classifica o espetáculo como bom, tecendo crítica bastante elogiosa, apesar de admitir tratar-se de um teatro verborrágico e incoerente que "exige muito do público"177. Mariângela Alves de Lima, por sua vez, discorda do crítico do jornal concorrente, ao avaliar positivamente a peça Um homem indignado:

[A] Direção opta pela beleza, fluidez e pelo valor afirmativo da imagem. (...) Sendo o teatro um conjunto de signos verbais, visuais e espaciais onde se insinuam o indizível sob o que é dito, a glorificação da imagem sob a crítica feita ao seu utilitarismo e a sedução da proximidade física sob a frase onde se declara o desejo de solidão, este espetáculo acaba por ser, com a sua formalização sedutora e comovente, um exercício de cooperação produtiva entre a linguagem milenar do teatro e o que há de novo no espaço etéreo das representações mediadas pelo impulso elétrico. ${ }^{178}$

É possível identificar diferenças substanciais entre as críticas de Mariangela Alves de Lima (OESP) e Sérgio Salva Coelho (FSP). Primeiramente, é preciso ressaltar que o espaço disponível para a primeira é bastante superior ao do segundo, o que permite às críticas de 0 Estado maior elaboração e profundidade. Alves de Lima escreve em geral um texto mais elaborado, com grande habilidade no manejo de palavras, demonstrando erudição e dando à crítica um tom acadêmico. Coelho apresenta um texto mais conciso com características da redação jornalística.

Tomadas como exemplo as críticas feitas ao espetáculo Cinema Éden, ambos os críticos referidos enunciam um problema no espetáculo, que é a primazia do texto sobre os demais elementos teatrais, proveniente aquele de um romance adaptado para o teatro e para o cinema, pela própria Marguerite Duras. Os dois concordam que a adaptação para o teatro feita pela autora não resultou em uma nova linguagem teatral, mas consistiu na edição dos melhores trechos do romance. Coelho, apesar de usar adjetivos como "verborrágico" e "incoerente" na qualificação

\footnotetext{
${ }^{176}$ Lima, Mariângela Alves. Cleide Yáconis restaura magnetismo no palco. O Estado de São Paulo, São Paulo, 11/02/05, Caderno 2, D10.

${ }^{177}$ Coelho, Sérgio Sálvia. Cinema Éden cria espetáculos de evocações. Folha de S. Paulo, São Paulo, 03/02/05, Ilustrada, E 8.

178 Lima, Mariângela Alves. Walmor seduz com sabedoria. O Estado de São Paulo, São Paulo, 29/04/05. Caderno 2, D7.
} 
do teatro de Duras, credita eventuais problemas do espetáculo não aos elementos em cena, mas ao despreparo do público:

[O texto dramatúrgico], associando um simbolismo maneirista ao engajamento da narrativa épica, exige muito dos atores e do público. Como na música erudita contemporânea, a sofisticação técnica apaixona os iniciados e desorienta os desavisados, que podem sucumbir ao tédio, como se estivessem diante de uma língua estrangeira. ${ }^{179}$

Em contrapartida, Alves de Lima responsabiliza diretamente a adaptação do romance como um dos fatores responsáveis pelo resultado negativo do espetáculo:

Ao que parece, a economia necessária para essa transposição impôs cortes drásticos. Em primeiro plano sobrevivem a narradora e seus sentimentos, sem que saibamos bem por que o irmão sofre tanto e quem é o cavalheiro que corteja a mocinha. Uma vez que a jovem sente muito e pensa pouco, enquanto os outros personagens não têm oportunidade nem de pensar nem de sentir, não há pontos de apoio para os outros atores. ${ }^{180}$

Ambos concordam, no entanto, quanto ao grande mérito interpretativo da protagonista, a qual parece ser a grande âncora da peça. Não obstante, Alves de Lima ressalva: "há mais de um século esse apreço pelo virtuosismo do intérprete deixou de ser o foco central do teatro", em uma demonstração de que as divergências são freqüentes entre os críticos. Para citar um último exemplo, Beth Néspoli ao avaliar positivamente o espetáculo As Turca, faz ressalvas ao texto dramatúrgico, ao afirmar:

Difícil, porém, entender o motivo da mudança de tom na cena do desabafo da irmã "calada" - música melodramática de fundo, congelamento gestual - que com outra realização poderia estar inserida de forma mais orgânica na montagem, em vez de destoar, negativamente, da linguagem do espetáculo até então. A dramaturgia também resolve mal a necessária "tomada de conhecimento" das notícias vindas de Beirute, com a presença "forçada" da televisão em dois momentos estratégicos. Mas são senões que não tiram o prazer de ver esse espetáculo sem nenhuma conotação pejorativa, ideal para levar mães e tias. ${ }^{181}$

\footnotetext{
${ }^{179}$ Coelho, Sérgio Sálvia. Cinema Éden cria espetáculos de evocações. Folha de S. Paulo, São Paulo, 03/02/05, llustrada, E 8

${ }^{180}$ Lima, Mariângela Alves. Cleide Yáconis restaura magnetismo no palco. O Estado de São Paulo, São Paulo, 11/02/05, Caderno 2, D10

${ }^{181}$ Néspoli, Beth. As Turca evita caricatura de traços culturais - e acerta. O Estado de São Paulo, São Paulo, 01/12/205, Caderno 2, D9.
} 
Maria Lúcia Candeias, por sua vez, considera a primeira peça da dramaturga Andrea Bassit "muito bem construída", fazendo, contudo, um raro e breve reparo ao patrocinador: "O único senão fica por conta do Banco do Brasil que cancelou o serviço de vans, de modo que ou se vai de metrô, ou é necessário caminhar pela rua à noite." 182

O caráter pouco consensual pode ser um elemento que dificulte a consideração da crítica na avaliação da eficácia do patrocínio. Os critérios diferenciadores do "bom" produto cultural em relação aos demais e, no limite, do "mal" produto, são diversificados, o que torna a análise com base nas críticas carregada de certa dose de imprecisão, quando comparada aos dados numéricos normalmente utilizados.

Além da crítica, os veículos da imprensa escrita também dão dicas expressas aos leitores, em colunas que certamente influenciam as escolhas do público. Com textos curtos ou cotações, essas colunas têm, segundo depoimento de jornalista, elevado índice de leitores, em busca de referenciais que os auxiliem na decisão sobre qual evento visitar ou a qual espetáculo assistir, dentre a vasta gama de opções culturais oferecidas. Assim, a Revista Bravo! possui um roteiro no qual indica algumas exposições e espetáculos, com chamadas padronizadas como "Importância", "Preste Atenção", "Por que ir". A revista Veja, classifica as exposições com estrelas; e, na área teatral, além das estrelas, insere na coluna "As dez melhores peças em cartaz" as peças mais bem consideradas. O jornal O Estado de São Paulo possui duas colunas para chamar a atenção do público para aquilo que considera melhor: "Mostras/Peças Recomendadas" e "Em minha modesta opinião". A Folha de S. Paulo mantém as colunas "llustrada indica" e, no caderno dominical Mais, possui a coluna "Os dez mais", adicionada de indicadores qualificadores de suas críticas por meio de estrelas.

A avaliação mais artística do patrocínio, que ocorre de maneira informal nas discussões internas, nas ponderações das críticas e na opinião do público, carece de sistematização. Isso demonstra pouco comprometimento com os valores próprios do campo artístico, cujos critérios de avaliação deveriam passar necessariamente por apreciações acerca da inventividade, inovação e relevância cultural. Tais valores aparecem de maneira enfática, como vimos, na seleção dos projetos, mas perdem

${ }^{182}$ Candeias, Maria Lucia Status ameaçado - As Turca e Canãa, a Terra prometida discutem decadência social. Gazeta Mercantil, São Paulo, 25/11/05.. 
todo o significado na avaliação do patrocínio, feita a posteriori. As premiações parecem mais valorizadas pelo CCBB do que as críticas que os espetáculos e exposições recebem. Elas podem contribuir de forma mais explícita para a imagem da instituição, uma vez que a crítica bem elaborada não se resume ao aplauso ou à vaia.

Cabendo analisar em um sentido mais amplo o fenômeno diagnosticado de enfraquecimento da crítica artística, para além do patrocínio do CCBB, seria possível levantar algumas hipóteses para a perda de prestígio do especialista. A primeira, menos provável, é a de que os artistas se tornaram auto-suficientes, podendo, com isso, ignorar solenemente os especialistas com os quais compartilham valores caros ao campo. A segunda, mais plausível, é a de que importa muito mais se inserir em uma rede de relações de curadores, marchands, galeristas, programadores culturais e gerentes de instituições artísticas, do que ter o trabalho avalizado por qualquer especialista. A opinião de um artista, publicada em artigo polêmico, corrobora com essa hipótese:

O sucesso de um artista hoje não depende somente, nem mesmo principalmente, do valor intrínseco do que ele produz, dos méritos plásticos ou estéticos de sua obra, mas sobretudo de sua capacidade de inserção num "sistema" que funciona cada vez mais segundo as regras do mercado, do consumo e da moda - mesmo quando se veste o surrado disfarce da transgressão. [...] As duas instalações ["Ainda Viva" de Laura Vinci e "Quebra-molas" de Débora Bolsoni] pecam por serem inofensivas, fechadas em si mesmas, que não se articulam com nenhum processo exterior a elas próprias. Os artistas têm obrigação de vincular suas obras à realidade? Não. Mas, quando instalações desse tipo se tornam a tendência dominante da arte fica a impressão de esgotamento e alienação. [...] Abolidos os cânones, qualquer adolescente é capaz de transgressões parecidas, e as fronteiras entre a criação artística e a empulhação pura e simples se tornam muito tênues. A falência da crítica como fator relevante agrava esse quadro, já que quem legitima o artista hoje é o sucesso em si: se faz sucesso é bom. Nada mais capitalista. Mas talvez mesmo este o destino de todas as artes (a literatura, a música etc.), isto é, enquadrar-se numa lógica de mercado ou morrer. ${ }^{183}$

Portanto, não é que o crítico tenha perdido totalmente a sua importância, mas ele tornou-se mais um especialista em uma rede de poder que tem um número maior de instâncias de consagração e distribuição de prestígio. 


\subsection{O PATROCÍNIO MIDIÁTICO COMO PROPULSOR DA REPUTAÇÃO, IMAGEM E PRESTÍGIO DA EMPRESA}

Esse est percipi: ser é ser percebido. A máxima do filósofo irlandês Berkeley sintetiza o narcisismo que predomina tanto no mundo empresarial quanto no campo artístico. A visibilidade pública aparece como a grande chave do sucesso em ambos. A mídia, ao garantir e amplificar a imagem que os atores sociais desejam construir sobre si mesmos, aparece como elemento central no processo do patrocínio cultural.

A busca de público e de espaço na mídia não é exclusividade dos patrocinadores. Esse também é o objetivo dos artistas. Entretanto, nenhum deles externa isso de maneira muito clara. Os patrocinadores revestem seus investimentos em arte com um discurso que oscila da responsabilidade social à melhoria da imagem da empresa. Artistas costumeiramente remetem suas escolhas às motivações intrínsecas de expressão, e raramente assumem seu desejo de visibilidade midiática. Apesar de, com freqüência, criticarem as escolhas pautadas em critérios de marketing, almejam, da mesma forma, que seus trabalhos tenham repercussão na imprensa, reconhecimento da crítica e acolhida do público (relevante observar que a importância dada à visibilidade varia de acordo com a "arte" produzida, sendo que, em alguns raros casos, presença excessiva na mídia rende reputação negativa).

Talvez a busca de público e de espaço na mídia sejam o denominador comum que torne possível a universos com valores tão díspares se ligarem e criarem vínculos sociais. É necessário ressaltar que reconhecimento, status e prestígio são moedas correntes em qualquer categoria profissional e que, associados à questão material e econômica, constituem os principais fatores a impulsionar carreiras, motivar conflitos e disputas.

No meio artístico, esse fato adquire conotações ainda mais claras por tratarse de atividade profissional realizada no contato com a audiência, de maneira coletiva e pública. Dessa forma, espera-se que peças tenham teatro lotado a cada apresentação, assim como exposições tenham público em toda a sua temporada. $O$ artista recebe a alcunha contemporânea de celebridade muito em função de sua presença em meios de comunicação de massa, que cultuam e estimulam a criação

\footnotetext{
${ }^{183}$ Trigo, Luciano. É de fama e dinheiro que se trata a arte? Folha de S. Paulo, São Paulo,19/11/2007, Ilustrada,
} 
da aura mítica em torno desses profissionais, colaborando para a disseminação romantizada da atividade artística.

Esse fenômeno - alguns o denominam de mediatização da sociedade extrapola as fronteiras da arte e do mundo empresarial. Eco (1999:231) defende que vivemos processo de substituição da moral e da ética por uma espécie de corrida pela "publicização" do ser, já que os padrões de conduta são mobilizados pela pulsão de visibilidade midiática. A conclusão de Guy Debord (1997) caminha na mesma direção ao afirmar que "o que aparece é bom, o que é bom aparece".

A mídia exerce, portanto, um papel central sobre o campo artístico, influenciando as formas de produção dos bens simbólicos:

Uma parte cada vez mais importante da produção cultural - quando não provém de pessoas que, trabalhando nas mídias, estão certas de ter o apoio das mídias - é definida em sua data de publicação, seu título, seu formato, seu volume, seu conteúdo e seu estilo de maneira a satisfazer as expectativas dos jornalistas que a farão existir ao falar dela. (Bourdieu, 2005:377)

O efetivamente novo em nosso meio social é que o narcisismo tenha atingido também as empresas. Diagnosticado muitas vezes pela teoria psicológica como fator de desajuste individual, caracterizado por excessiva preocupação com a imagem, o termo narcisismo vem ocupando também os textos de cientistas sociais como instrumental para a interpretação da cultura e da vida social. A luta incessante por prestígio, glória ou dinheiro estabelece rivalidades internas em diversos campos, fazendo com que se manter permanentemente em evidência passe a ser um imperativo.

Assim define Lasch o indivíduo narcisista: "O narcisista depende de outros para validar sua auto-estima. Não consegue viver sem uma audiência que o admire." (Lasch, 1983:30) Não é de estranhar, portanto, que não se tenha encontrado no CCBB análise mais aprofundada da eficácia do patrocínio inserida em uma avaliação do impacto da obra patrocinada no campo artístico, mas sim a partir da quantificação da imagem especular refletida pela mídia, a qual, por sua vez, reflete para um público ampliado a ação "benevolente" do patrocinador. Qualquer efeito positivo da ação de patrocínio à margem do público e da cobertura da imprensa não valida a imagem que os membros da instituição tem si próprios. A própria associação da empresa com o campo artístico denota motivação narcísica na medida em que visa 
afirmar a imagem de benevolência da instituição patrocinadora. Ela tira proveito do carisma e do poder "desinteressado" do campo artístico. Isso adquire sentido mais consistente quando a associação empresa/campo artístico é ampliada e refletida na atenção das pessoas exteriores aos campos envolvidos. A mídia garante a afirmação da imagem positiva desejada por ambos, patrocinador e artista, ao possibilitar o seu encontro com a audiência, mesmo que esta não interaja efetivamente com o bem simbólico patrocinado, mas apenas consuma a notícia de sua existência.

As empresas patrocinadoras querem beneficiar-se do importante papel dos veículos de comunicação de massa no culto e na criação de celebridades:

Os meios de comunicação de massa, com seu culto da celebridade e sua tentativa de cercá-la de encantamento e excitação, fizeram dos americanos uma nação de fãs, de freqüentadores de cinema. A "mídia" dá substância e, por conseguinte, intensifica os sonhos narcisistas de fama e glória, encoraja o homem comum a identificarse com as estrelas e a odiar o "rebanho", e torna cada vez mais difícil para ele aceitar a banalidade da existência cotidiana (Lasch, 1983, pág. 43)

O desejo não manifesto dos profissionais de marketing cultural é de que a empresa se torne, ela mesma, uma celebridade, tal qual os artistas que patrocina, e que detenha também uma aura de atração nos consumidores de bens culturais por meio da illusio que ronda a "imagem" melhorada, em função do investimento artístico que realiza. No entanto, o "desinteresse interessado" dos artistas em suas criações, vistos pelos públicos como o mais genuíno desejo de expressão artística, não pode ser tão facilmente transferido aos patrocinadores. $O$ discurso da responsabilidade social entra em contradição com a explicitação dos objetivos do marketing cultural e transforma o patrocínio em ação de interesse. Tal discurso não soa nos ouvidos ou aparece aos olhos do público consumidor de cultura como algo desinteressado, senão que responde a interesses mercadológicos, de redução da carga tributária ou de conquista de clientes.

Retomando: o conflito instaurado por católicos radicais ao contestarem a exposição Erotica, discutido no capítulo anterior, ilustra, em um episódio, situação de crise reveladora daquela tensão latente entre os campos, levando a que as matérias negativas sobre o CCBB e seu patrocinador predominassem na cobertura da imprensa, fato raro em casos de patrocínios. Nesses momentos de crise, o Manual 
que orienta os profissionais de comunicação do BB estabelece alguns procedimentos a adotar:

"É na crise que os princípios éticos da corporação se sobressaem ou, pelo contrário, capitulam ante a pressão do público e da mídia. A manifestação sobre a crise deve ser, portanto, fruto de um trabalho conjunto, expressa por um discurso corporativo. (...) Não subestimar o poder da publicidade negativa, não se precipitar em declarar inocência e não querer minimizar o problema. A crise exige que a Empresa se coloque ao lado dos contribuintes/ consumidores/ clientes/ cidadãos atingidos. É lá que a mídia vai estar, de maneira a fazer valer seu estatuto de representante do interesse público. Essa atitude, por parte da empresa envolvida, não implica corroborar denúncias ou acusações, mas expressar uma solidariedade simbólica. A construção de sentido, na mídia, sempre tenderá a enquadrar as situações de crise como contendas que envolvem os muito fortes contra os mais fracos." (Banco do Brasil, 2001:29-30)

Naquela situação, contudo, analisada a cobertura da imprensa, percebe-se que o partido dos "mais fracos", assumido pela mídia, foi o dos artistas, os quais foram "censurados pelo poder autoritário" do patrocinador. Já a escolha do BB foi de estar ao lado de outro elo ainda "mais fraco", como preceitua seu Manual de Relacionamento com a Imprensa, o da imensa maioria católica, de reduzido capital cultural, e que não vê muito sentido em desenhos de pênis com terços.

A imprensa vive paradoxo semelhante ao dos patrocinadores empresariais, no que respeita à tentativa de conciliação entre o empresarial e o simbólico. Enquanto indústria, inserida na lógica capitalista do lucro, ela tem de atender às exigências numéricas de leitores e assinantes e, conseqüentemente, não pode ou deve distanciar-se do "gosto médio", da matéria televisiva, do cinema holywoodiano, da música popular. Em contrapartida, a fim de estabelecer-se perante as elites, as quais valorizam o que é considerado "alta cultura", precisa satisfazer exigências próprias do campo artístico em conflito com as imposições comerciais.

Não parece exagerado afirmar que vivemos um processo de mediatização das relações sociais, em conseqüência da qual a interação humana se pauta por lógicas próprias da mídia. Braga (2007) defende que os processos de interação mediatizados tornaram-se referenciais hegemônicos na construção simbólica da realidade social, prevalecendo sobre outras formas de interação. Chauí aponta riscos na intermediação dos produtos culturais pelos meios de comunicação de massa: 
Sob a ação dos mass media, as obras de pensamento e de arte correm vários riscos, como: 1) de expressivas, tornarem-se reprodutivas e repetitivas; 2) de trabalho da criação, tornarem-se eventos para consumo; 3) de experimentação do novo, tornarem-se consagração do consagrado pela moda e pelo consumo; 4) de duradouras, tornarem-se parte do mercado da moda, passageiro, efêmero, sem passado e sem futuro; 5) de formas de conhecimento que desvendam a realidade e instituem relações com o verdadeiro, tornarem-se dissimulação, ilusão falsificadora, publicidade e propaganda. [...] Visto que a destruição dos fatos, acontecimentos e obras segue a lógica do consumo, da futilidade, da banalização e do simulacro, não espanta que tudo se reduza, ao fim e ao cabo, a uma questão pessoal de preferência, gosto, predileção, aversão, sentimentos. É isto o mercado cultural. (Chauí, 2006:21-22)

Parece acertado imputar à mídia papel central na constituição do que se convencionou denominar de "esfera pública":

A Esfera Pública constrói-se, desta forma, pela ação mediada das estruturas de comunicação e pela luta simbólica dos movimentos sociais e seus porta-vozes, criando um ponto de encontro entre as formas de integração sócio-política e as formas de integração comunicativa. Nela, os movimentos sociais, os agentes do mundo da vida, funcionam como sensores não especializados desse mundo, capazes de detectar e apresentar problemas, tematizá-los, apresentar soluções ou dramatizá-los. (...) Os meios de comunicação de massa assumem um papel importante, ao libertar os processos comunicativos dos locais em que tenderiam a ficar restritos - tanto no espaço quanto no tempo. Sendo assim, permitem uma circulação generalizada das formas simbólicas, 'alargando o espaço discursivo' (Girardi Jr, 2007:132-133).

Apesar de os campos artístico e econômico possuírem legalidades e normatividades a princípio excludentes, seus atores disputam internamente por prestígio e reputação. Na busca desse capital simbólico bastante disputado, a necessidade de parecer dotados de poder e em situação de dominação, aos olhos dos demais, não prescinde de mecanismos públicos de divulgação de uma imagem construída a partir de avaliações dos pares e do corpo de especialistas de cada campo. Contudo, como a dimensão pública do prestígio é indispensável para assegurar a dominação no campo, ambos utilizam do mesmo espelho para refletir a imagem que desejam. A mídia aparece como a instância pretensamente isenta e neutra que dará espaço para a consolidação desse capital simbólico. Mais do que fiel da balança entre os dois mundos, as empresas da imprensa permitem a coesão 
entre os dois campos, ao viabilizar a publicidade de que ambos necessitam. Por serem empresas tanto quanto os patrocinadores, a mídia também está em busca de vender seus produtos e conquistar anunciantes. Manter alianças com os dois campos é interessante para a manutenção dos interesses empresariais dos jornais, televisões e rádios, pois ambos anunciam e ambos fornecem pautas para a imprensa.

Concluindo, poder-se-ia afirmar que, se a economia das trocas simbólicas (Bourdieu, 2004a) é pautada pela utilização de uma racionalidade antieconômica, distanciando-se dos cálculos racionais (oferta, procura, demanda, preço) das práticas econômicas modernas, a apropriação do simbólico por uma instituição financeira dá-se pela tentativa de racionalização econômica (quantificando o sucesso de seus eventos a partir da aparição na mídia e atração de público). Essa estratégia escapa, contudo, da tangibilidade instrumental que marca suas práticas cotidianas. Ao reduzir o patrocínio à exposição na mídia e à presença do público, o patrocinador, a um tempo, estabelece diálogo e comunhão de valores com o campo artístico e constrói para si um instrumental que permite vislumbrar ganhos financeiros onde estes inexistem (a lógica do ganho da publicidade espontânea) e ganhos simbólicos (melhoria da imagem) de difícil comprovação. O lucro simbólico desejado com o patrocínio, de difícil aferição, é substituído pelo lucro financeiro, de fato inexistente, este sim passível de mensuração. Tal qual o feiticeiro de Mauss (2003), a contaminação mágica proporcionada pelo patrocínio remete menos às habilidades, interesses e recursos do mágico do que à função que lhe é delegada, cuja autoridade e eficácia é outorgada pelo grupo. "Ele tem naturalmente o espírito de sua função, a gravidade de um magistrado; é sério porque é levado a sério, e é levado a sério porque se tem necessidade dele." (Mauss, 2003:131)

A crença no lucro simbólico seduz o patrocinador, que nele enxerga os valores cada vez mais caros ao mercado econômico, em especial às instituições financeiras -- honra, prestígio, distinção, entre outros -, ou, ainda, uma melhora de imagem, nas palavras dos profissionais de marketing, oferecendo plausibilidade e sustentação às ações de patrocínio.

Os profissionais de marketing ordenam uma estrutura discursiva e "teórica" que sustenta esse "conhecimento", e amparam as práticas de patrocínio das empresas. Oferecendo explicações para o sucesso do patrocínio, legitimam as práticas das empresas, e atendem também a interesses dos atores sociais do 
campo artístico dotados de maior consagração e, portanto, com mais acesso aos recursos de patrocínio. 


\section{CONSIDERAÇÕES FINAIS}

A análise dos dados e informações obtidas no curso da pesquisa permite-nos concluir que o CCBB insere-se na intersecção de dois campos sociais com lógicas, a princípio, distintas e antagônicas. Fundado por decisão do BB, gerenciado por funcionários dessa empresa e subvencionado por recursos por ela fornecidos, o CCBB é parte integrante do campo econômico. Dessa maneira ele é visto pela Diretoria do $\mathrm{BB}$, por seus funcionários e também por seu público o que implica a presença, em sua atuação, de valores caros a esse universo, nos quais o CCBB não aparece como instituição cultural com fim em si mesmo, mas está a serviço de outros interesses, os quais transcendem sua ação no interior do campo artístico.

A visão instrumental da instituição coloca-a a serviço do seu mantenedor, ao qual se subordina e deve obediência, e, em troca dos recursos que the são destinados, deve funcionar como um instrumento de comunicação do banco com seus públicos.

A principal moeda de troca do CCBB é a contribuição que pode dar para a melhoria da imagem do Banco, criando-Ihe um "crédito moral" junto aos seus públicos, já que a atividade principal do mantenedor está, por natureza, imersa em valores que o associam ao desrespeito aos usuários, principalmente pela qualidade no atendimento prestado e pela cobrança de tarifas e juros elevados. Necessitando manter e atrair clientes, em mercado em que a diferenciação dos produtos e dos produtores, por preço, é difícil, o peso da marca torna-se fator importante na decisão de compra dos consumidores. Daí a preocupação constante com a imagem. Agregando aos traços habituais de um banco atributos como inovação, criatividade, ousadia e - de forma contraditória - o desinteresse econômico, próprios do campo artístico, o CCBB fornece a seu mantenedor a recompensa devida, tornando a marca de ambos mais prestigiosa e com maior reputação. Entretanto, o que torna vulnerável aos olhos do patrocinador qualquer ato de favorecimento pelo Centro Cultural é a dificuldade de avaliar de forma categórica se ocorreu a "contaminação simbólica" desejada. Trata-se de conseguir - o que não é facilmente verificável - dar aos públicos de interesse da empresa uma representação convincente do capital que afirma possuir, a fim de obter proveitos reais com as propriedades imaginárias "emprestadas" do campo artístico. Essa dificuldade é tanto maior no caso de esse capital simbólico obtido por aproximação com outro campo contradizer as 
propriedades objetivas do patrocinador, plenas de conotações negativas. A legitimidade do CCBB é ameaçada internamente, no campo econômico, em suas relações com as instâncias de poder do mantenedor, em função das evidências muito pouco concretas (dentro da normatividade do campo econômico) de como o capital econômico se transforma em capital simbólico, para que esse lucro simbólico se converta novamente em capital econômico. Considerando que a illusio do campo econômico se afirma pela busca incessante de resultados, o patrocínio tende a ser visto preponderantemente como gasto que atende a interesses externos ao campo .

$\mathrm{A}$ arte mostra-se útil para o BB, em especial por contrabalançar o caráter utilitário, secularizado e racionalizado da vida financeira; o CCBB surge como tentativa de encantamento de uma esfera totalmente comprometida com o que há de mais material e pragmático. A arte, porque portadora de atributos muitas vezes subversivos e não-convencionais, e, de certa forma, também desejados pela lógica empresarial contemporânea, encontra aqui seu espaço de inserção, sem precisar negar radicalmente a autonomia, mas, sem deixar de comprometer-se com seu financiador.

Integrante do campo artístico, o CCBB mantém-se em competição com as demais instituições culturais da cidade, na disputa por públicos, artistas e, particularmente, espaço na mídia. Em uma cidade que oferece muitas ofertas culturais, com instituições mais conhecidas e de maior reputação, o CCBB ocupa uma fração intermediária do campo artístico. Em função de suas proporções reduzidas e do acesso dificultado para a elite consumidora de bens culturais, encontra dificuldade de projetar sua programação nos patamares que seus funcionários parecem almejar. Não obstante, consegue espaço considerável na mídia, muito em função da programação que oferece, afeita aos requisitos do que é valorizado no campo artístico. É colocada, portanto, em posição de destaque em relação a outras instituições com menos recursos e sem atrativos que as consolidem perante o público. $O$ fato de ser mantido pelo BB também rende benefícios ao Centro Cultural, por tratar-se de instituição a qual se associam valores como solidez, tradição e respeitabilidade.

A união dos dois campos, o econômico e o artístico, contraria a própria lógica de constituição do último, o qual surge em oposição ao primeiro. A normatividade do campo artístico se ancora na crença da capacidade que possui o artista de transubstanciar as obras que cria, tornando-as objetos dignos de apreciação, que 
perderiam seu potencial simbólico, caso fossem determinadas explicitamente por valores do campo econômico. A indignação dos artistas contra qualquer forma de subserviência a interesses exteriores ao seu próprio campo, sejam eles regidos pela lógica do mercado ou por interesses políticos ou religiosos, é condição necessária para a manutenção da autonomia do campo, bem como de sua estruturação, com as devidas formas e mecanismos de distribuição de poder e reputação. A independência em relação ao poder econômico é lei fundamental da constituição do campo artístico, razão pela qual o patrocínio empresarial é tão prenhe de contradições e denegações.

O patrocínio empresarial, tal qual vivenciado na sociedade brasileira, implica um duplo ocultamento. Primeiramente, é ocultado o interesse mercadológico do "investimento", muitas vezes sob a máscara da responsabilidade sócio-ambiental. Há interesse na melhora da "imagem" e em suas resultantes financeiras, quer pela retenção, ou conquista de clientes, quer pela sedimentação da marca na memória dos consumidores, ou, ainda, como conseqüência, pelo aumento da lucratividade.

Apesar de admitido explicitamente pelos profissionais de marketing, executivos e empresários, a valorização da imagem não é dado explícito no ato do patrocínio.

O mecenato é uma forma sutil de dominação que age graças ao fato de que ele não é percebido como tal. Todas as formas de dominação simbólica se exercem sobre a base do conhecimento insuficiente; isto é, com a cumplicidade daqueles que se submetem a ela. (Bourdieu \& Haacke, 1995:58)

Em segundo lugar - com peso menor no caso do CCBB, por tratar-se de instituição vinculada a empresa pública - oculta-se o desembolso de dinheiro público, travestido de investimento privado, em função da renúncia fiscal possibilitada pelas leis de incentivo.

Os ocultamentos ou, nas palavras de Bourdieu, a denegação do econômico, atendem às expectativas não só do patrocinador, mas também às do patrocinado. $A$ ascese no mundo pragmático das necessidades materiais é condição para a salvação no mundo moralmente superior das artes. Muito embora o mercado das artes plásticas aparente o oposto, não é incomum o lucro econômico imediato de uma obra reduzi-la ao "toma lá, dá cá" de uma troca comercial, desqualificando-a, e a seu artista, em termos de capital simbólico. Dessa forma, tanto o gesto do 
patrocínio quanto a própria obra artística produzida precisam aparecer como um dom (uma atitude da empresa "socialmente responsável"), um gesto despretensioso e desinteressado, do qual se espera tão somente a possibilidade de fruição e deleite.

A produção artística necessita ser vivida como algo que não exige retorno, nenhum "contra-dom", vista como fruto da necessidade mais subjetiva do artista e de expressão da sua criatividade. O reconhecimento é, para o artista, ao menos para aqueles que profetizam "a arte pela arte", uma conseqüência menor diante da sua grande necessidade de expressão (ao menos necessita ser publicamente afirmada, para obter o reconhecimento implicitamente almejado) (Bourdieu, 2005:170).

Se, no caso do patrocínio ao esporte ou às causas sociais, o vínculo com uma empresa não representa demérito maior para o beneficiário, no caso dos artistas, essa dependência necessita de camuflagem, sob pena de comprometer ambas as partes. O campo artístico constitui-se por sua independência em relação ao poder econômico. Sobretudo aqueles que ocupam as posições dominantes do campo sentem-se obrigados a explicitar sua autonomia em relação a todos os poderes mundanos, que lhe são externos.

O dom embutido na ação do patrocínio, quando vivenciado como algo desinteressado, contudo, não se legitima dentro das leis, regras e valores do campo econômico. Internamente às empresas, qualquer ação que não deixe claro o retorno financeiro almejado foge inteiramente essa lógica e sofre severas contestações. $O$ retorno simbólico esperado com o patrocínio, em termos de prestígio e reputação, ainda que de difícil quantificação e de longo prazo de maturação, torna o apoio às artes passível de inserção na lógica do campo econômico, mesmo que propicie um retorno de natureza diferente daquela normalmente esperada com os dispêndios efetuados por uma empresa. O lucro "imediato" com o patrocínio é simbólico e não monetário.

O proveito temporal que o patrocinador tira do capital simbólico de que dispõe - artista só é possível porque este, em função de sua recusa a qualquer determinação externa (principalmente qualquer interesse econômico), e sujeitandose somente às regras do campo artístico, consegue reputação e reconhecimento, acumulando o capital simbólico que é apropriado pelo patrocinador. Assim, não diagnosticamos, a não ser pelo realce dado à censura, no caso da exposição Erotica, que o ato do patrocínio implique perda de autonomia para o campo artístico, 
até porque isso não interessa a nenhuma das partes. Desse modo, ficou evidente a preocupação de que as escolhas artísticas sejam efetuadas pelo CCBB de acordo com a lógica e os cânones do campo artístico, ainda que internamente, para aprovação dos projetos, a ênfase seja posta em benefícios mais concretos, como, por exemplo, nas perspectivas negociais abertas com o "marketing de relacionamento".

O quadro das interações sociais torna-se mais complexo quando o patrocinador, estruturando seu instituto ou centro cultural, se insere de forma definitiva no campo artístico, e deixa de ser mero aproveitador das benesses simbólicas dos criadores, para tornar-se, concomitantemente, instância de consagração. Age de forma decisiva na illusio que gera o criador artístico.

A disputa pelo escasso capital econômico proporcionado pelo patrocínio propicia mais poder de consagração ao patrocinador. É bom para o currículo de qualquer artista ter exposto ou ter se apresentado no CCBB, o que denota o interesse comercial que dá sustentação ao patrocínio. Ele é suficientemente ocultado, de forma a não comprometer a instituição no seu lado "estrutura de consagração do campo artístico". Dessa forma, ao tempo que o patrocínio empresarial é visto pelos artistas com desconfiança, em função dos "interesses escusos" que o motivam, é também objeto de desejo em decorrência, não só por permitir viabilizar empreitadas artísticas consideradas impossíveis de outra forma, como por proporcionar reputação ampliada no campo artístico.

A pergunta subseqüente poderia ser: quem dá ao CCBB o poder de consagração, não obstante seus interesses extrapolarem o campo artístico? Por que ele não é renegado como impostor que, sorrateiramente, visa a se apropriar de um capital simbólico que pertence a outrem?

A resposta "à la Bourdieu" parece novamente a mais adequada: o poder de consagração não está no CCBB, mas no espaço de jogo das relações objetivas que o constitui como instituição cultural. Da mesma forma que o poder de criação da obra de arte não está no artista. O poder de transubstanciação mágica, presente nos artistas e nas instituições culturais, é

uma impostura legítima, coletivamente ignorada, portanto, reconhecida. O artista que, ao apor seu nome em um ready-made, confere-lhe um preço de mercado sem relação com seu custo de fabricação deve sua eficácia mágica a toda a lógica do campo que o reconhece e autoriza; seu ato não seria nada mais que um gesto 
insensato ou insignificante sem o universo dos celebrantes e dos crentes que estão dispostos a produzi-lo como dotado de sentido e de valor por referência a toda a tradição da qual suas categorias de percepção e de apreciação são o produto (Bourdieu, 2005:195)

Tal como na relação do público com a arte contemporânea, a qualificação do objeto simbólico como arte só é possível ao preço do encobrimento da realidade de que o bem instado à categoria mágica transcendente nada mais é do que um objeto como tantos outros. Na relação do CCBB com o campo artístico, seu poder mágico de consagração só lhe é outorgado ao preço do recalque do caráter instrumental que o patrocínio empresarial contém.

O duplo ocultamento reflete-se nas escolhas e na grade de programação do CCBB. No caso das artes cênicas, a aliança prioritária com os segmentos consagrados, haja vista a preocupação de as escolhas recaírem, sobretudo, em personalidades com carreiras e reputação consolidadas (Sérgio Brito, Cleyde Yáconis, Walmor Chagas, Marilena Ansaldi, Júlia Lemmertz, dentre outras.), sem mencionar o longo currículo dos diretores. Essa aliança denota a busca pela apropriação do capital simbólico que esses nomes podem proporcionar à empresa. No entanto, considerando que o teatro é uma arte que se sustenta economicamente apenas em raríssimos casos, esses artistas, não obstante o capital simbólico que detêm, muito provavelmente não teriam capital econômico para viabilizar, por si sós, as produções patrocinadas pelo CCBB. Tal enfoque predominante não exclui, contudo, as brechas abertas para as frações dominadas, as quais, mesmo com menos recursos envolvidos, oferecem maior risco, o que muitas empresas não ousariam patrocinar.

Em linhas gerais, a programação de artes cênicas expõe a recusa do teatro experimental ou alternativo, detentor de maior capital simbólico no interior do campo, cujo consumo é feito principalmente pelos próprios produtores culturais e atrai menos público; também contém a negação do teatro comercial, desvalorizado pelas estruturas de consagração do campo, que tem maior adesão das platéias menos cultivadas. O caminho intermediário adotado pelo CCBB permite-lhe a boa aceitação da crítica e do público, tanto o que tem mais como o que tem menos capital cultural, sem se associar ao segmento do campo artístico mais arriscado, controverso e hermético da produção experimental. 
No caso das artes plásticas, não obstante o grande espaço dado às exposições de arte contemporânea, as mostras mais valorizadas (em termos de valores individuais destinados a exposição, até por serem mais dispendiosas) são as que têm características mais museológicas, denotando postura mais conservadora diante do embate atual mais candente no campo artístico. Considerado esse aspecto, percebe-se também aqui aliança com o segmento dominante desse campo, já que, dentre os escolhidos, predominam os que têm mais capital simbólico. Contudo, como nas artes cênicas, também é reservado espaço, ainda que menor, a artistas menos consagrados, os quais, por estarem em início de carreira, se afirmam mais pela contestação do que pelo reforço da tradição. Esse hibridismo (exposições museológicas e exposições de arte contemporânea) na programação de artes plásticas atesta que a preocupação com a diversidade não é apenas elemento de retórica, refletindo-se na programação. $O$ reverso dessa escolha talvez seja o fato de - CCBB não conseguir posicionamento mais definido no interior do campo artístico, pela não consolidação de traços distintivos que the permitam construir identidade mais clara na comparação com os demais equipamentos culturais da cidade.

As trocas que o Centro Cultural faz com os componentes do campo artístico dependem das posições relativas dos artistas patrocinados na estrutura do campo. Tanto em uma arte como na outra, quem possui mais capital simbólico acumulado tem mais fácil acesso aos recursos, como é a tônica do patrocínio empresarial. Isso, obviamente reforça as estruturas de dominação no interior do campo artístico.

Preocupado com a imagem de instituição pública e democrática, o CCBB procura evitar que seu patrocínio seja oferecido somente a projetos que envolvam artistas consagrados, o que certamente the rende atributos positivos, ao envolver as representações coletivas vinculadas a essas figuras. Dessa forma, subsidia os considerados "talentos ascendentes". Entretanto, essas situações ocorrem em número menor e envolvem verbas reduzidas. O privilégio dado ao patrocínio de nomes conhecidos atende à necessidade mercadológica de buscar retorno positivo $\mathrm{e}$ aprovação de público e de mídia.

A arte não apenas propicia prestígio, mas também legitima a atuação do patrocinador. Mesmo bancos bem estabelecidos e com imagem consolidada como 0 BB necessitam dela não só para manter presença no imaginário coletivo, mas também para compensar a própria natureza menos nobre de sua atividade. Trata-se de atividade bastante propícia para gerar esse efeito legitimador, na medida em que, 
aparentemente, é desinteressada e etérea, e cuja criação decorre, em princípio, de determinação intrinsecamente motivada do artista. Se, de maneira muito enfática, a empresa carece de uma recompensa externa para legitimar-se, o "artista genuíno", ao contrário, afirma-se independente de todo e qualquer reconhecimento externo à sua criação; o dinheiro e a fama dela advindos, se existirem, precisam ser vivenciados como conseqüências acidentais de um percurso e não como mola propulsora da criação.

Bourdieu (2003) esclarece que as práticas culturais engendram elevado valor de distinção social, necessitando capital cultural para sua fruição. Em outras palavras, o fato de haver predisposições culturais que permitam o consumo de determinados bens simbólicos reforça a posse dessas qualificações e estabelece a distância necessária daqueles que não as possuem. A princípio, interessa à empresa patrocinadora manter tais distinções, pois elas reforçam os atributos positivos daqueles que possuem capital simbólico.

Alguns pesquisadores (Gomes, 2004; Fleury, 2006) têm identificado os dois extremos possíveis da relação entre capital cultural acumulado e práticas culturais (isto é, entre os "cultivados", possuidores de capital cultural e freqüentadores regulares de equipamentos culturais, e os "retraídos", sem capital e sem prática de consumo cultural), e uma crescente população intermediária (chamados de "displicentes ${ }^{184 ")}$, a qual, embora possua capital cultural, não tem hábito nem predisposição para esse consumo. Se houver efetivamente uma tendência de migração dos "retraídos" para os "displicentes", isso é sinal de que a arte vem perdendo seus atributos de distinção, já que os "retraídos", ao contrário dos "displicentes", possuem certa reverência em relação ao objeto artístico, apesar da ausência de predisposição para fruí-lo.

No caso do patrocínio empresarial, a moeda da arte é justamente o traço distintivo capaz de contaminar o patrono com carga valorativa altamente positiva. Perdendo a aura que a acompanha, certamente haverá ainda maior desinteresse por esse tipo de dispêndio. Entretanto, o aparente crescimento do mercado de artes plásticas em direção às camadas médias da população parece evidenciar o oposto: crescimento do interesse por obter o status proporcionado pela arte. Trata-se, enfim, de fenômeno a ser ainda mais bem pesquisado, mas a tendência das instituições 
culturais e órgãos públicos de ampliarem sua compreensão de obra cultural, em direção a um sentido mais antropológico do termo, corrobora a constatação do enfraquecimento da crença na superioridade da "alta cultura". Isso se associa, ainda, a um movimento dos próprios produtores da "alta cultura" para critérios mais fluidos e elásticos de legitimação dos bens simbólicos incorporados e legitimados como válidos de apreciação. Além disso, o público de "alta cultura" também parece mais maleável à fruição de elementos que não se enquadrem necessariamente nessa denominação.

Uma questão: o que permite o acoplamento desses campos com legalidades tão distintas? As homologias estruturais existentes entre o artístico e o econômico residem, dentre outros aspectos, na relevância que a questão da imagem, do prestígio e da reputação tem em ambas. A mídia aparece como o terceiro elemento que permite a concretização da coalizão entre interesses econômicos e artísticos. Reverberando, avalizando e também definindo as posições que os diversos integrantes do campo artístico devem ocupar, segundo os valores e os interesses em disputa na arena do campo, os órgãos de imprensa afirmam-se não só como instância de consagração, mas também como espelho narcísico que permite cimentar os elos do patrocínio. A valorização da arte patrocinada também valoriza seu patrocinador, já que a matéria que divulga a exposição e a peça teatral prestigia tanto os artistas quanto a instituição que viabiliza sua arte. A consangüinidade estabelecida entre artistas, mídia e instituição cultural gera uma rede de dependências as quais, não obstante os conflitos freqüentes, permitem o atendimento e a ampliação de interesses mútuos.

O que se procura demonstrar, portanto, é que as recompensas esperadas pelo $\mathrm{BB}$, com os patrocínios empenhados, não advêm diretamente do trabalho do artista. Tornam-se menos relevantes os méritos intrínsecos dos trabalhos patrocinados, do que sua capacidade de mobilizar múltiplas fontes que poderão propiciar o retorno almejado, entre as quais papel central é atribuído à mídia.

Uma contraposição faz-se presente na maneira como patrocinado e patrocinador vêem o sucesso de suas empreitadas. O artista patrocinado, principalmente o não-comercial, tem em seus pares e no corpo de especialistas do campo artístico o principal referencial de sucesso da obra, muito embora possa

${ }^{184}$ Caracterizam-se por elevadas qualificações, principalmente escolares, menos seletivos pela generalização de títulos e qualificações, além de hábitos de saída regulares, além de forte juvenilidade e rara freqüência a 
valorizar a acolhida do "grande público" e da mídia. O patrocinador, por outro lado, procura essencialmente aprovação em uma audiência mais ampliada, não se restringindo ao campo artístico. Basta ver a centralidade que uma crítica publicada no jornal tem para o artista e a inexpressividade que ela tem no sistema de apuração de resultados de patrocínio para o CCBB.

O tênue equilíbrio constitutivo do trabalho cotidiano do Centro Cultural, derivado da necessidade de agradar a dois senhores, às vezes se mostra impraticável: de um lado, os que legitimam internamente a sua existência - a Diretoria de Marketing e todo o corpo diretivo da empresa, muito pouco sensível e inteirado da lógica do campo artístico -; de outro, o campo artístico, seus produtores, mídia e público, tendo em vista que, sem ser legitimado como instituição artística, o CCBB não encontraria respaldo para suas escolhas.

A decisão de retirar a obra de Márcia $X$ da exposição Erotica, pelo fato de ela ter sido contestada por segmentos da sociedade carioca diante da associação da sexualidade a símbolos religiosos revela que, acuado pela ameaça de perdas econômicas, a escolha do mantenedor reafirma seu papel social predominante como portador da racionalidade econômica, o que contradiz tanto o discurso da responsabilidade social, quanto a defesa dos valores artísticos. Contudo, esse caso, apesar de sua relevância, não deve ser objeto da maior preocupação pelos integrantes do campo artístico, pois 0 ato sistemático de censura desqualificaria totalmente qualquer instituição cultural. O maior risco está na censura não explicitada e feita pelos próprios artistas, no anseio de viabilizar suas obras.

As produções artísticas não são somente mercadorias, nem apenas formas de propiciar prestígio para seus criadores, ou para quem as aprecia ou adquire. Revestem-se de poder simbólico que tanto pode estar a serviço de formas de dominação e exploração quanto de formas que visem à emancipação e à crítica de situações injustas ou degradantes. A maneira como essas produções são financiadas interfere diretamente no campo ideológico da fabricação e da recepção desses bens. Ainda que empresas não estabeleçam mecanismos explícitos de censura, podem induzir artistas a uma espécie de autocensura para serem admitidos no reduzido círculo dos que se beneficiam do patrocínio empresarial.

Há uma rede de dependências cruzadas que garantem a existência do patrocínio. As empresas necessitam melhorar sua imagem e as obras artísticas 
propiciam um casamento que pode provocar essa contaminação positiva. Os artistas necessitam de recursos para viabilizar seus projetos e ganham legitimidade quando são patrocinados por instituições culturais de renome, ainda que vinculadas a empresas. A exposição de suas obras nessas instituições garante prestígio e valoriza o preço de suas peças no mercado das artes. As instituições têm necessidade de reconhecimento dos corpos de especialistas para manterem sua competitividade no mercado simbólico, e continuarem atraindo artistas de renome e público.

Se, por um lado, os Estados nacionais, em função de corporativismos, nepotismos, corrupção, clientelismos, burocracias ou mesmo ineficiência, mostramse incapazes de gerir, de forma satisfatória, os escassos recursos destinados à cultura, por outro, ainda não foi inventada instância que possa atuar como freio aos poderes econômicos e aos próprios interesses políticos na adoção de políticas culturais que fujam à lógica da rentabilidade financeira ou do fácil gosto estético da maioria. Se existisse, asseguraria espaço, ainda que sem amparo das instâncias próprias de consagração, também para aquelas obras que atingem público reduzido ou que não atraem a atenção da mídia, respaldadas exclusivamente por seu caráter experimental e inventivo. Isso não significa que o patrocínio estatal tenha, necessariamente, se mostrado mais eficaz na promoção desses interesses. Como diz Bourdieu: "O mecenato de Estado se arrisca sempre a favorecer os medíocres, os mais dóceis." (Bourdieu \& Haacke, 1995:74). No entanto, como, no caso das democracias, o campo de forças presentes no Estado responde à maior possibilidade de controle público - além de os vetores que geram as escolhas provirem de múltiplas fontes e, portanto, as relações de poder estarem mais pulverizadas do que no campo empresarial, em que o interesse econômico do acionista se apresenta como a força praticamente exclusiva -- o patrocínio governamental direto abre mais possibilidades para a afirmação plena da autonomia do campo artístico.

Essa é a condição para que haja patrocínio, pois a arte que não atenda aos cânones de seu campo e se vincule a outros interesses pode não atingir o prestígio desejado em uma ação de marketing. Se, para promover-se junto aos consumidores, a empresa necessita tomar emprestados valores no mercado artístico, isso significa que não the interessa que o objeto continente desses valores perca as suas especificidades. 
É maniqueísta a visão de que arte verdadeira seja aquela recusada pelo marketing cultural e de que a atividade artística patrocinada seja "vendida" ou "comercial". O patrocinador investe em cultura fundamentalmente para atender interesses mercadológicos, mas também despende recursos para satisfazer interesses os quais, aparentemente, não são seus, mas do campo artístico. De outra parte, é claro que se trata de um investimento conservador, na medida em que não está preocupado com o desenvolvimento da esfera cultural, na maneira como entende os componentes do campo artístico.

A pesquisa realizada permitiu dar conta da complexidade da dinâmica social na qual predominam as trocas entre campos que permitem múltiplas articulações, dependências e subordinações (Anexo 34). Os detentores do poder econômico, personificados em uma instituição cultural, não almejam impor seu universo valorativo aos artistas, predominando certa condescendência com as escolhas por eles efetuadas, desde que não atinjam diretamente as fontes de receita do patrocinador. Essa sua condescendência ou permissividade é condição para que se possa apropriar do capital simbólico detido pelo campo artístico:

Tentar estabelecer uma relação direta entre os produtores e o grupo social ao qual devem seu apoio econômico (colecionadores, espectadores, mecenas etc.) é esquecer que a lógica do campo faz com que se possam utilizar os recursos oferecidos por um grupo ou uma instituição para produzir produtos mais ou menos independentes dos interesses ou dos valores desse grupo ou dessa instituição. [...] Universo paradoxal em que a liberdade com relação às instituições encontra-se inscrita nas instituições. (Bourdieu, 2005:291)

Ressalte-se a situação privilegiada do CCBB na interação com os demais agentes sociais do campo artístico, já que, no papel social de financiador das atividades a ele referidas, tem poder para conceder ou não o patrocínio, a quem deseja, nas condições que julga adequadas e no volume que considera suficiente. Coloca-se, portanto, no pólo dominante da relação com os membros do campo artístico, os quais devem submeter-se (fala-se em "submissão" dos projetos culturais) para a obtenção do apoio desejado. Esse poder, contudo, está longe de ser absoluto, já que o CCBB deve obediência a uma série de constrições colocadas pela rede de interdependências próprias do campo artístico. Um dos seus limitadores, como foi constatado, reside na esfera da criação propriamente artística, pois, após o projeto artístico ter sido aprovado, não foram detectadas interferências 
do patrocinador ou qualquer inserção no fazer ou no produto da criação, exceção feita ao caso analisado da exposição Erotica. Dessa forma, o exercício do poder discricionário faz-se notar na ação mais decisiva de todo o processo de criação artística: a eleição do projeto digno de patrocínio. Ao permitir a viabilização de alguns em detrimento de outros, o CCBB interfere diretamente no campo artístico, permitindo que posições se consolidem, avanços se perpetuem e nomes se consagrem, distribuindo recursos financeiros, mas, sobretudo, prestígio e reputação aos escolhidos dentre os inúmeros que submeteram seus projetos.

A idéia corrente de que o patrocínio empresarial representa ameaça à autonomia da expressão não considera que o artista contemporâneo, mais do que liberdade artística, procura, de certa forma, restrições ao seu fazer:

Eis porque é simplista imaginar a situação dos artistas contemporâneos em termos de 'liberdade': eles não têm mais, como no século XIX, um problema de liberdade ou de autonomia em relação às convenções e às instituições, mas têm um duplo e contraditório problema de inclusão em um mundo da arte com regras do jogo muito complexas, e de subversão desse mundo - mundo doravante excluído do senso comum e dos critérios que dariam sentido ao jogo com os critérios, liberto dos limites que permitiriam ultrapassá-los. De maneira que os artistas hoje não buscam mais a autonomia, não têm mais interesse por mais liberdade: eles buscam, sobretudo, encontrar as obrigações, desafiar as expectativas, identificar os limites. (...) A permissividade das instituições aprisiona os artistas em uma liberdade indefinida, fazendo com que eles não tenham outra escolha senão a de serem livres - livres, ao menos, dentro dos limites das regras do jogo que eles contribuem para definir, uma vez tendo conseguido ingressar nesse jogo (Heinich, 1998a:349).

A relação dos artistas contemporâneos com as instituições que os patrocinam, sejam privadas ou públicas, é um dilema para eles, pois, por um lado, são as instituições que asseguram seu reconhecimento e sua subsistência, mas, por outro, colocam em dúvida aquilo que é fundamental para sua afirmação enquanto artistas no paradigma contemporâneo - a atitude transgressiva em relação a qualquer tentativa de institucionalização.

Klein aponta movimento em sentido contrário, realizado pelas grandes corporações, o de roubar a cena cultural, tornando-se elas próprias manifestações simbólicas, levando a heteronomia às últimas conseqüências: 
A publicidade e o patrocínio sempre se voltaram para o uso da imagem para equiparar produtos e experiências culturais e sociais positivas. O que torna diferente o branding dos anos 90 é que ele cada vez mais procura retirar dessas associações do reino da representação e transformá-las em uma realidade da vida. [...] Embora nem sempre seja a intenção original, o efeito do branding avançado é empurrar a cultura que a hospeda para o fundo do palco e fazer da marca a estrela. Isso não é patrocinar cultura, é ser a cultura. E por que não devia ser assim? Se as marcas não são produtos, mas conceitos, atitudes, valores e experiências, por que também não podem ser cultura? [...] esse projeto tem sido tão bemsucedido que os limites entre os patrocinadores corporativos e a cultura patrocinada desapareceram completamente. Mas essa fusão não foi um processo de mão única, com artistas passivos permitindo que corporações multinacionais agressivas os empurrassem para 0 fundo. [...] Assim, o que no passado foi um processo de vender cultura a um patrocinador por um determinado preço foi suplantado pela lógica do "co-branding" - uma parceria fluida entre gente famosa e marcas famosas. (Klein, 2006:54-55)

Não foi identificado esse movimento no patrocínio do BB. Ao contrário, a atuação do patrocinador manifesta-se, sobretudo, pela discrição dos bastidores. Apesar de, na ação de patrocínio, ser central a preocupação com a visibilidade da marca, ela não se sobrepõe às manifestações artísticas patrocinadas. A ingerência na atividade criadora do artista pelo CCBB, se não é nula, é mínima. Essa atitude de não interferência é fundamental para manter a independência da criação artística, sob pena de ser violado o seu caráter "sagrado" e diminuído o status da arte.

A crença de que valores comerciais e empresariais corrompem a atividade artística e somente valores estéticos devem prevalecer é uma ambigüidade com a qual instituição mantida por uma empresa vivencia cotidianamente. É preciso pensar no interesse do patrocinador sem colocá-lo à frente da criação artística, que deve ser soberana.

Do lado dos artistas, talvez em função da extrema carência dos recursos, não se percebe contaminação negativa ou ameaça à integridade da obra patrocinada derivadas do contato com alguma logomarca. A visão romântica de que o patrocínio macula a arte em sua integridade e autonomia parece não coadunar com a dinâmica de interação entre os campos, na contemporaneidade. O que o patrocínio faz, em muitos casos, é reforçar os mecanismos excludentes e hierarquizados que já constam da estruturação do campo artístico. Dessa forma, os artistas não se submetem ao patrocínio empresarial exclusivamente porque dependem 
economicamente das empresas, mas também porque é graças a essa dependência que conseguem distanciar-se dos outros artistas não-patrocináveis, distância que decorre da própria afirmação como artista de prestígio.

A interpretação de Bourdieu (2005:247) para as formas heterônomas de organização social do campo artístico refere-se essencialmente a dois tipos de dominação: a demanda específica de um patrão ou mecenas; ou as expectativas e a sanção anônima de um mercado consumidor. Considerando que seus estudos têm por base a sociedade francesa, onde o patrocínio empresarial só teve início no final da década de 90, essa interpretação pareceu, em um primeiro momento, suficiente. Contudo, a análise das escolhas do CCBB permitiu perceber que a heteronomia se afirma de maneira muito sutil, não sendo possível a interpretação pelo esquema acima. Ela está presente nos critérios efetivos de inclusão e exclusão, mas não nos critérios explicitados como os norteadores das escolhas. Pelo fato de ser também uma instituição cultural, a obtenção do patrocínio não é vista como submissão à demanda externa, mesmo porque o projeto foi inscrito e concebido pelo próprio artista.

Acertadamente, para sua afirmação como instituição cultural, o CCBB procura estabelecer suas escolhas baseando-se em critérios do próprio campo artístico, mesmo reconhecendo que o estabelecimento desses critérios seja cada vez mais difícil, em função dos consensos serem cada vez mais fluidos.

Os parâmetros para a escolha das obras a serem patrocinadas pelo CCBB seguem prioritariamente as incertas regras do campo artístico. A baixa regulação ocupacional, evidenciada pelo pequeno peso dado aos diplomas e à formação acadêmica, associada à necessidade de manutenção da "mística" que envolve o talento e o dom nato, a abertura e ausência de controles que caracterizam o aspecto libertário do campo, exigem, em contrapartida, muitas barreiras informais que permitam a hierarquização do campo. Somente número limitado de artistas é aceito nos reduzidos círculos de consagração.

O CCBB procura romper com essas barreiras informais e tácitas, formalizando critérios públicos para a seleção de projetos artísticos. No entanto, como vimos, esses critérios, publicamente divulgados, no intuito de dar mais transparência à seleção, não rompem com as barreiras que beneficiam posições privilegiadas do campo. O peso dado à "competência técnica", impossibilitada de ser traduzida como 
saber acumulado, ou certificada por instituições isentas, é interpretado a partir da reputação propiciada por trabalhos anteriores.

A complexidade da produção artística repousa no fato de que ela não é totalmente determinada, mas também jamais é plenamente autônoma. A complexidade do campo econômico reside na sua profunda dependência do universo valorativo que pauta as escolhas dos consumidores. A articulação entre esses campos por intermédio do patrocínio revela como interesses tão diversos podem coexistir e resultar em manifestações simbólicas as quais, apesar de portadoras de tais interesses, não se reduzem a eles. 


\section{REFERÊNCIAS BIBLIOGRÁFICAS}

Abbing, Hans. Why are Artists Poor? The Exceptional Economy of the Arts. Amsterdam: Amsterdam Universtiy Press, 2002.

Agra, Lucio. História da Arte do Século XX: idéias e movimentos. São Paulo: Editora Anhembi Morumbi, 2004.

Ajzenberg, Tatiana. Marketing cultural \& Construção da Marca. São Paulo: Dissertação de Mestrado, ECA, 2005

Alonso, Artele de Lourdes. Marketing Cultural - um estudo sobre a produção cultural a partir das leis de incentivo em uma sociedade de mercado. São Paulo, Dissertação de Mestrado. USP/ECA, 1992.

Altamiro, Carlos (director). Términos Críticos de Sociologia de la Cultura. Buenos Aires, Paidós, 2002.

Arantes, Otília Beatriz Fiori. "A 'virada cultural do sistema de artes". Margem Esquerda - ensaios marxistas. São Paulo: Boitempo, n. 6, setembro de 2005.

Archer, Michael. Arte Contemporânea - uma história concisa. São Paulo: Martins Fontes, 2001.

Arruda, Maria Arminda do Nascimento. A Embalagem do Sistema - A Publicidade no Capitalismo Brasileiro. São Paulo: Livraria Duas Cidades, 1985.

Arruda, Maria Arminda do Nascimento. "A política cultural: regulação estatal e mecenato privado." Tempo Social: Revista de Sociologia da USP. São Paulo, v. 15, n.2, nov. 2003.

Arruda, Maria Armida do Nascimento. Metrópole e Cultura - São Paulo no meio século XX. Bauru, SP: Edusc, 2001.

Assis, Maria Elisabete Arruda de. Cultura como Marketing, Marketing como Troca: a Reciprocidade e o Centro Cultural Banco do Brasil Río de Janeiro. Recife: Tese de Doutorado - Departamento de Ciências Sociais - Universidade Federal de Pernambuco, 2007.

Bagla, Lusin. Sociologie des organisations. Paris: La Découverte, 2003.

Balfe, Judith Huggins (org.) Paying the piper: causes and consequences of art patronage. Chicago: University of Illinois Press, 1993. 
Banco do Brasil. Relatório Anual 2007. Brasília: Banco do Brasil, 2008.

Banco do Brasil. A mídia e a construção da imagem empresarial. Brasília: Banco do Brasil, 2001.

Banco do Brasil. Manual de Relacionamento com a Imprensa. Brasília: Banco do Brasil, 2001.

Baracho, Maria A. P. e Félix, Luiz F. F. Responsabilidade Social e Marketing Cultural. Cadernos do CEHC no. 8, novembro de 2002, Centro de Estudos Históricos e Culturais, Fundação João Pinheiro, Belo Horizonte.

Baracho, Maria A. P. e Félix, Luiz F. F. Renúncias Fiscais: o segmento cultural numa abordagem comparativa. Cadernos do CEHC no. 6, setembro de 2002, Centro de Estudos Históricos e Culturais, Fundação João Pinheiro, Belo Horizonte.

Basbaum, Ricardo. "' $X$ ': Percursos de alguém além de equações." Concinnitas. Revista do Instituto de Artes da UERJ, Rio de Janeiro, nำ4, março 2003.

Baudrillard, Jean. Simulacros e Simulações. Lisboa: Editora Relógio D’Água, 1991.

Baudrillard, Jean. "De la marchandise absolue". In Melo, Alexandre (org.). Arte e Dinheiro. Lisboa: Assírio \& Alvim, 1994.

Baxandall, Michael. O olhar renascente- pintura e experiência social na Itália da Renasença. São Paulo: Editora Paz e Terra, 1991.

Becker, Howard. Arts Worlds. Berkeley: University of Califórnia Press, 1982.

Benhamou, Françoise. L'économie de la culture. Paris: La Decouverte, 2004.

Berbel, J.V. Banco do Brasil - Comunicação e Marketing. Dissertação de mestrado, Rio de Janeiro, UFRJ, ECO, 1992.

Bernoux, Philippe. La sociologie des entreprises. Paris: Éditions du Seuil, 1999.

Bonnewitz, Patrice. Primeiras lições sobre a sociologia de P. Bourdieu. São Paulo, Vozes, 2003.

Borges, Vera. "A arte como profissão e trabalho: Pierre-Michel Menger e a sociologia das artes." In Revista Crítica de Ciências Sociais, 67, Dezembro de 2003, 129-134.

Botelho, Isaura. As leis de incentivo fiscais à Cultura. In Marketing Cultural: um investimento com qualidade. São Paulo: Informações Culturais, 1998. 
Botelho, Isaura. "Os equipamentos culturais na cidade de São Paulo: um desafio para a gestão pública." In Espaço e Debates - Revista de Estudos Regionais e Urbanos. São Paulo: NERU, jan./dez. 2003, no 43/44.

Bourdieu, Pierre, A Economia das Trocas Simbólicas. 5ª ed. Coleção Estudos - 20 , São Paulo: Perspectiva, 2004a.

Bourdieu, Pierre. A produção da crença - contribuição para uma economia dos bens simbólicos. São Paulo: Zouk, 2004b.

Bourdieu, Pierre. As Regras da arte. São Paulo: Companhia das Letras, 2005.

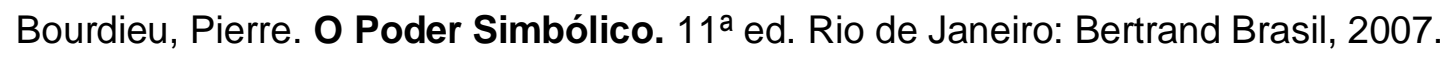

Bourdieu, Pierre. A distinção: crítica social do jultagamento. São Paulo: Edusp; Porto Alegre: Zouk, 2008.

Bourdieu, Pierre e Darbel, Alain. O amor pela arte. São Paulo: Edusp, 2003.

Bourdieu, Pierre \& Haacke, Hans. Livre-troca: diálogos entre ciência e arte. Rio de Janeiro: Bertrand Brasil, 1995.

Bourdieu, Pierre (ed.) e Miceli, Sérgio (org.) Liber 1. São Paulo: Edusp, 1997.

Bourdieu, Pierre \& Wacquant, L.J.D. Réponses...Pour une anthropologie réflexive. Paris: Le Seuil, 1992.

Braga, José Luiz. "Mediatização como processo interacional de referência". In Médola, A. S. L. D. ; Araujo, Denize C. e Bruno, F. (orgs.). Imagem, visibilidade e cultura midiática. Porto Alegre: Sulina, 2007.

Braga, José Luiz. A sociedade enfrenta sua mídia - dispositivos sociais de crítica midiática. São Paulo: Paulus, 2006.

Brant, Leonardo. Mercado Cultural: panorama crítico e guia prático para gestão e captação de recuros. São Paulo: Escrituras, Instituto Pensarte, 2004.

Brant, Leonardo (org.) Políticas Culturais. Barueri: Manole, 2003.

Brunner, José Joaquin. América Latina: Cultura y Modernidad. Santiago: Mx. Grigalbo, 1992.

Canclini, Nestor Garcia. Culturas Híbridas: Estratégias para Entrar e Sair da Modernidade. São Paulo: Editora EDUSP, 2000.

Canclini, Néstor García. A produção simbólica: teoria e metodologia em sociologia da arte. Rio de Janeiro: Civilização Brasileira, 1979. 
Cardoso, Fernando Henrique. O presidente e o sociólogo - entrevista de Fernando Henrique Cardoso a Roberto Pompeu de Toledo. São Paulo: Companhia das Letras, 1998.

Carvalho, Mario César. "Censura corrompe finalidade de museus". In Folha de S. Paulo, 21/04/2006.

Castello, R. "Cultura”. In Lamounier. A era FHC: um balanço. São Paulo: Cultura Editora, 2002.

Cauquelin, Anne. Arte Contemporânea - Uma Introdução. São Paulo: Martins Fontes, 2005.

Cenni, Roberto Três centros culturais da cidade de São Paulo São Paulo, 1991 Dissertação (Mestrado)

Champey, Inês. "Hans Haacke: jogo da arte e apostas de poder." Bourdieu, P. (ed.) Miceli, Sérgio (sel. e org.). Líber 1. São Paulo: Universidade de São Paulo, 1997.

Chauí, Marilena. Uma opção radical e moderna: Democracia Cultural. in: Revista Pólis, no. 12, 1993.

Chauí, Marilena. "Cultura política e política cultural". In. Estudos Avançados. São Paulo, v. 9, n. 23, p. 71-84, jan/abr. 1995.

Chauí, Marilena. Simulacro e poder - uma análise da mídia. São Paulo: Editora Fundação Perseu Abramo, 2006.

Chiarelli, Tadeu. "Para Beatrice". Chiarelli, Tadeu (org.) Erotica. Os sentidos da arte. São Paulo: Associação de amigos do CCBB, 2005.

Cocchiarale, Fernando. “Uma Obra Iconoclasta”. In Jornal do Brasil, fevereiro de 2005.

Coelho, Teixeira. Usos da cultura: políticas de ação cultural. Rio de Janeiro: Paz e terra, 1986.

Coelho, Teixeira. O que é Ação Cultural. São Paulo: Brasiliense, 1989.

Coelho, Teixeira. Moderno Pós Moderno. São Paulo, lluminuras, 2001.

Coelho, Teixeira. Dicionário Crítico de Política Cultural. São Paulo: lluminuras, 2004.

Conde, Idalina. "Obra e Valor. A questão da Relevância. In Melo, Alexandre. Arte e Dinheiro. Lisboa: Assírio \& Alvim, 1994.

Cordeiro, Márcia Perígolo Cordeiro. O olhar do gestor de comunicação: as atividades do Centro Cultural Banco do Brasil, como contribuição para a revitalização do centro da cidade de São Paulo. São Paulo, ECA, 2002 
Correa, Marcos Barreto. Do Marketing ao desenvolvimento cultural: relacionamento entre empresa e cultura: reflexões e experiências. Belo Horizonte: Rona, 2004.

Correia, Inês Fernandes De Mecenas ao marketing de cultura: um histórico do patrimônio como motor da cultura e do jornalismo São Paulo, Dissertação ECA, 2002.

Corvin, Michel. Dictionnaire Encyclopédique du Théâtre. Paris: Bordas, 1995.

Cosac, Charles. Farnese - Objetos. São Paulo: Cosac Naify, 2005.

Couty, Daniel \& Ryngaert, Jean-Pierre. "Représentation théâtrale et espace social." Couty, Daniel e Rey, Alain (org.). Le Théâtre. Paris: Larrousse, 2001.

Crescitelli, Edson \& Mattar, Michel Fauze \& Silva, Aurio Lucio Leocadio. "O Efeito de ações de Patrocínio sobre o Top of Mind - um estudo exploratório do mercado brasileiro." In eGesta Revista de Comunicação Eletrônica, v.1, n.2, jul-set, 2005, p. 34-53.

Debord, Guy. Sociedade do Espetáculo. São Paulo: Contraponto Editora, 1997

Djian, Jean-Michel. Politique Culturelle: la fin d'un mythe. Paris: Éditions Gallimard, 2005.

Domino, Christophe. L'Art Contemporain au Musée National d'Art Moderne Centre Georges Pompidou. Paris: Editions Scala, 2005.

Dória, Carlos Alberto. Os Federais da Cultura. São Paulo: Editora Biruta, 2003.

Drucker, P. F. A prática da administração de empresas. São Paulo: Pioneira, 1981

Dubuffet, Jean. Asphyxiante Culture. Paris: Les éditions de minuit, 1986.

Ducret, André. L'art pour objet - travaux de sociologie. Bruxelles: Lettre volée, 2006.

Dumazedier, Jofre. Sociologia Empírica do Lazer. São Paulo: Perspectiva, 2004.

Durand, José Carlos G. et alli. "Patrocínio empresarial e incentivos fiscais à cultura no Brasil: análise de uma experiência recente." In Revista de Administração de Empresas da EAESP/FGV. Vol. 37, n.4, SP, 1997.

Durand, José Carlos. "Cultura como objeto de política pública." São Paulo em Perspectiva, n.8, p. 66-72, 2001.

Durand, J. C. Empresas e Culturas no Brasil. São Paulo: Fundação Getúlio Vargas, 1995.

Durand, J.C. Políticas e Gestão Cultural nos EUA e Europa. EAESP/FGV/NPP. Núcleo de Pesquisas e Comunicações; Relatório de Pesquisas, 2000. 
Durand, J. C. Arte, Privilegio e Distinção- artes plásticas, arquitetura e classe dirigente no Brasil. São Paulo: Perspectiva, 1989.

Durkheim, Emile. "Representações individuais e coletivas" In: Sociologia e Filosofia (E. Durkheim), Rio de Janeiro: Forense Universitária, 1970 pp. 15-49.

Duvignaud, Jean. Sociologie du théatre. Paris: Presses Universitaires de France, 1999.

Duvignaud, Jean. Sociologia do comediante. Rio de Janeiro: Zahar Editores, 1972.

Eagleton, Terry. A Idéia de Cultura. São Paulo: Editora da Unesp, 2005.

Eagleton, Terry . As llusões do Pós-Modernismo. São Paulo: Zahar, 1998

Eco, Umberto. Como se faz uma tese. São Paulo: Perspectiva, 1989.

Eco, Umberto e Delumeau, Jean. Entrevistas sobre o fim dos tempos. Rio de Janeiro: Rocco, 1999.

Elias, Norbert. Mozart - Sociologia de um Gênio. Rio de Janeiro: Jorge Zahar Ed., 1995.

Elias, Noberto. A Sociedade de Corte. Rio de Janeiro: Jorge Zahar Editora, 2001.

Encrevé, Pierre e Lagrave, Rose-Marie (org.) Trabalhar com Bourdieu. Rio de Janeiro: Bertrand Brasil, 2005.

Fabbrini, Ricardo Nascimento. A arte depois das vanguardas. Campinas: Editora da Unicamp, 2002.

Farias, Agnaldo. Arte Brasileira Hoje. São Paulo: Publifolha, 2002.

Fé, Ana Lúcia Damasceno Moura. Contribuição para o estudo de imagem - casos de empresas bancárias. São Paulo, Dissertação de Mestrado, 1997.

Featherstone, Mike. O Desmanche da Cultura - Globalização, Pós-Modernismo e Identidade. São Paulo: Studio Nobel: SESC, 1997.

Feijó, M.C. O que é política cultural? São Paulo: Brasiliense, 1983.

Ferreira, Reinaldo Benjamin. Centro Cultural Banco do Brasil: uma experiência que deu certo - memórias. Rio de Janeiro: Engenho \& Arte,1997 
Fischer, Fernando Marketing cultural : uso e prática em empresas brasileiras Rio de Janeiro, Dissertação (Mestrado) -- Instituto de Pós-Graduação e Pesquisa em Administração COPPEAD/UFRJ, 1998.

Fleury, Laurent. Sociologie de La Culture et des Pratiques Culturelles. Paris: Armand Coulin, 2006.

Francblin, Catherine; Sausset, Damien; Leydier, Richard. L'ABCdaire de I'Art contemporain. Paris: Flammarion, 2003.

Franceschi, Antonio et al. Marketing Cultural: um investimento de qualidade. São Paulo: Informações Culturais, 1988.

Freitas, Verlaine. Adorno \& a arte contemporânea. Rio de Janeiro: Jorge Zahar Editora, 2003.

Freud, Sigmund. Totem e tabu. Rio de Janeiro: Imago, 1999.

Fundação João Pinheiro. Centro de Estudos Históricos e Culturais. Diagnóstico dos investimentos em cultura no Brasil. Belo Horizonte, 1999,

Fundação João Pinheiro. O Produto Interno Bruto das atividades culturais. Antonio Braz de Oliveira e Silva (coord.). Belo Horizonte: FJP/Governo de Minas Gerais, 1998

Garcia, Silvana (org.). Odisséia do Teatro Brasileiro. São Paulo: Editora SENAC, 2002.

Garonzik, Elan e Wood, Susan. Cultural Funding in Europe: a directory of foundation and corporate funders in arts and culture in Europe. Brussels: European Foundation Centre, 1995.

Girardi Jr., Liráucio. Pierre Bourdieu: questões de Sociologia e Comunicação. São Paulo: Annablume; Fapesp, 2007.

Gomes, Rui Telmo. «A distinção banalizada? Perfis sociais dos públicos de cultura». In Gomes, R.T. (org.) Públicos da Cultura. Lisboa: Observatório das Actividades Culturais, 2004.

Grenfell, Michael \& Hardy, Cheryl. Art Rules: Pierre Bourdieu and visual arts. New York: Berg Publishers, 2007.

Guinsburg, Jacó; Faria, João Roberto e Lima, Mariângela (orgs.). Dicionário do Teatro Brasileiro. São Paulo: SESC / Ed. Perspectiva, 2006.

Harrington, Austin. Art and Social Theory: sociological arguments in aesthetics. Cambridge: Polity Press, 2004.

Harvey, David. A Condição Pós-Moderna. São Paulo: Loyola, 1992. 
Haskell, Francis. Mecenas e pintores - arte e sociedade na Itália barroca. São Paulo: Edusp, 1997.

Hauser, Arnold. História Social da Arte e da Literatura. São Paulo: Martins Fontes, 2003.

Heilbrun, James \& Gray, Charles M. The Economics of Art and Culture. New York: Cambridge University Press, 2007.

Heinich, Nathalie. Le Triple Jeu de L'Art Contemporain. Paris: Les Éditions de Minuit, 1998a.

Heinich, Nathalie Ce que l'art fait à la sociologie. Paris: Editions de Minuit, 1998b.

Heinich, Nathalie. La sociologie de l'art. Paris: Éd. La Découverte, coll. Repères, 2001.

Herranz, Pedro Embid; Dávila, Miguel Martin \& Fernándes, Victor. Marketing Financeiro. McGraw-Hill,1998.

Holanda, Heloisa Buarque e Herkenhof, Paulo. "Sobre mulheres e manobras radicais". In Banco do Brasil, Manobras Radicais. São Paulo: Associações Amigos do Centro Cultural Banco do Brasil, 2006.

Itaú Cultural, Perfil da Coleção Itaú - Curadoria e texto de Stella Teixeira de Barros; prefácio de Olavo Egydio Setubal. São Paulo: Itaú Cultural, 1998.

Itaú Cultural. Enciclopédia Itaú Cultural de Teatro. In www.itaucultural.org.br/teatro/.

Jameson, Fredric. Pós-Modernismo - A lógica cultural do capitalismo tardio. São Paulo: Ática, 1996.

Jameson, Fredric. "Pós-Modernidade e Sociedade de Consumo". In Novos Estudos CEBRAP. São Paulo, no. 12, pp., 16-26, jun. 85

Klein, Naomi. Sem Logo - A tirania das marcas em um planeta vendido. Rio de Janeiro: Editora Record, 2006.

Kotler, Philip, Armstrong, Gary. Princípios de Marketing. Prentice Hall do Brasil, 1994.

Kotler, Philip \& Bloom, Paul. Marketing de Serviços Profissionais. São Paulo: Editora Manole, 2002

Lagnado, Lisette. “Mercado de arte contempoânea” In Revista D'Art, no. 12.

Lago, Pedro Corrêa do. Caricaturistas brasileiros: 1836-1999. Rio de Janeiro: Sextante Artes, 1999 
Las Casas, Alexandre Luzzi. Marketing de Serviços. São Paulo: Atlas, 2007.

Lasch, Christopher. Cultura do Narcisismo. Rio de Janeiro: Imago, 1983.

Leão, Doralice Soares. O papel da mídia impressa no embate marketing cultural $\mathbf{x}$ marketing social. São Paulo, Dissertação de Mestrado. Comunicação e Semiótica, 2004

Lehmann, Hans-Thies. Teatro Pós-Dramático. São Paulo: Cosac Naify, 2007.

Lemos, A. H. da C. O processo decisório de criação do Centro Cultural do Banco do Brasil. Dissertação de Mestrado, Rio de Janeiro, FGV, EBAM, 1994.

Leocadio, Aurio Lucio e Marchetti, Renato. "Marketing Cultural: critérios de avaliação utilizados pelas empresas patrocinadoras". Mimeo. Apresentado no VI SemeAD.

Leveratto, Jean-Marc. La mesure de I'art. Sociologie de la qualité artistique. Paris: La Dispute, 2000.

Lindoso, Felipe (org.). Rumos [do] Jornalismo Cultural. São Paulo: Summmus: Itaú Cultural, 2007.

Lisbonne, Karine e Zürcher, Bernard. L'Art avec pertes ou profit? Paris: Flammarion, 2007.

Machado Neto, Manoel Marcondes. Marketing Cultural: das práticas à teoria. Rio de Janeiro: Editora Ciência Moderna, 2005.

Madeira, Angélica. "A itinerância dos artistas: a construção do campo das artes visuais em Brasília (1958-1967)". In Tempo Social. São Paulo, Volume 14, número 2, outubro de 2002.

Madeira, Cláudia. Novos Notáveis - Os Programadores Culturais. Oeiras: Celta Editora, 2002.

Magaldi, Sábato. Panorama do Teatro Brasileiro. São Paulo: Global, 1997.

Mandaji, Mônica dos Santos. Me dá um dinheiro aí (uma análise sobre os caminhos a serem percorridos pelos produtores culturais na busca por patrocínio e a contribuição da Seção Cultura e patrocínio, do jornal $O$ Estado de São Paulo, neste trajeto). Dissertação, ECA, 2003.

Martorella, R. (ed.). Art and Business: an international perspective on sponsorship. USA: Proeger Publishers, 1996.

Marx, Karl e Engels, Friederich. Sobre Literatura e Arte. São Paulo: Global, 1979.

Mauss, Marcel. Sociologia e Antropologia. São Paulo: Cosac \& Naify, 2003. 
Menger, Pierre-Michel. Portrait de I'artiste em travailleur - métamorphoses du capitalisme. Paris: Éditions du Seuil et La Republique des Idées, 2002.

Miceli, Sergio Nacional estrangeiro, história social e cultural do modernismo artístico em São Paulo. São Paulo : Cia. das Letras, 2003, v.1. p.211.

Miceli, Sergio Imagens negociadas - Retratos da elite brasileira (1920-1940). São Paulo: Cia. das Letras, 1996 p.174.

Miceli, Sérgio. Intelectuais e Classes dirigentes no Brasil. São Paulo: DIFEL, 1979.

Miceli, Sérgio. Estado e Cultura no Brasil. São Paulo: DIFEL, 1984.

Miceli, Sérgio. "Capital Cultural”. In Altamiro, Carlos (director). Términos Críticos de Sociologia de la Cultura. Buenos Aires, Paidós, 2002.

Michaud, Yves. El juicio estético. Barcelona: Idea Books, 2002

Michaud, Yves. L’Artiste e les Comissaires. Paris: Éditions Jacqueline Chambon, 1989.

Milanesi, Luiz Augusto. Centros de Cultura: forma e função. Hucitec: São Paulo, 1990.

Moraes, Dênis de. O Rebelde do traço: a vida de Henfil. 2.ed. Rio de Janeiro: J. Olympio, 1997

Moulin, Raymonde. L'Artiste, I'institution et le marché. Paris: Flammarion, 1997

Moulin, Raymonde. O mercado de Arte - mundialização e novas tecnologias. Porto Alegre: Zouk, 2007.

Moureau, Nathalie. «Aprroche organisationnelle des monde de la peinture contemporaine : de la 'bureaucratie professionnelle' à 'I'adhocratie'»In Approches Comparatives en Economie de la Culture. Paris: ADDEC (Association pour le développement et la diffusion de l'économie de la culture) e GREC - Intergroupe de recherches en économie de la culture, 1995.

Naegele, Renato. “A Objetividade Jornalística e o Viés Negativo”. In Espaços na Mídia: história, cultura e esporte. Brasília: Banco do Brasil, 2001.

Nussbaumer, Gisele Marchiori. O Mercado da Cultura em Tempos (Pós) Modernos. Santa Maria: Editora da UFSM, 2000.

Oliva, Fernando. “Arte erótica - O lugar do desejo”. In Bravo!. Outubro de 2005. 
Oliveira, Berenice Albuquerque Raulino. Uma experiência de ação cultural em teatro: Divisão de Artes Cênicas e Música do Centro Cultural São Paulo. São Paulo, Dissertação apresentada ao Departamento de Artes Cênicas da ECA - USP, 1995.

Oliveira, Francisco. "O capital contra a democracia". Conferência no Seminário "Os Sentidos da Democracia e da Participação", Instituto Pólis, São Paulo, $1^{\circ}$ de julho de 2004, mimeo.

Olivieri, Cristiane. O Incentivo fiscal federal à cultura e o Fundo Nacional de Cultura como política cultural do Estado: usos da lei Rouanet (1996-2000). Dissertação, ECA, 2002.

Pavis, Patrice. Dicionário de Teatro. São Paulo: Perspectiva, 1999.

Peixoto, Maria Inês Hamann. Arte e Grande Público - a distância a ser extinta. Campinas: Autores Associados, 2003.

Peixoto, Nelson Brissac. "Isto aqui é um negócio” In Revista D’Art, n. 12, 2005.

Pierucci, Antônio Flavio. O desencantamento do Mundo. São Paulo: Editora 34, 2003.

Pomaro, José Carlos. Marca: o real valor de uma imagem. São Paulo, Dissertação de Mestrado, ECA, 2004.

Pradel, Jean-Louis. A arte contemporânea. Lisboa: Edições 70, 2002.

Prazeres, Luciana Martins Prazeres. Iniciativas Culturais, Espaços de Desenvolvimento - Os casos do Centro Cultural Banco do Brasil e do Ecomuseu do Quarteirão Cultural do Matadouro, Rio de Janeiro. Dissertação de Mestrado. Instituto de Psicologia, Universidade Federal do Rio de Janeiro, 1996.

Puglisese Jr., Felipe. "Quanto vale a sua marca?". In Época Negócios. Rio de Janeiro: Editora Globo, agosto 2007.

Pugnaloni, Clara Maria. Do uso da ação cultural como fator de difusão da imagem corporativa: o caso Gerdau. Dissertação Mestrado, ECA, 2004.

Rego, Norma Pereira. Pasquim: gargalhantes pelejas. Rio de Janeiro: Relume Dumará, 1996

Reis, Ana Carla Fonseca. Marketing cultural e financiamento da cultura. São Paulo: Pioneira Thomson Learning, 2003.

Ribeiro, Renato Janine. "Cultura e Sociedade no Brasil". In Franceschi, Antônio de et al. Marketing Cultural: um investimento com qualidade. São Paulo: Informações Culturais, 1998.

Robert, Paul. Le Nouveau Petit Robert. Paris: Dictionnaires Le Robert, 2000. 
Rochlitz, Rainer. Subversion et subvention - Art contemporain et argumentation esthétique. Paris: Gallimard, 1994.

Rossanvalon, Pierre. Liberalismo Econômico: História da Idéia de Mercado. Florianópolis: Edusc, 1992.

Rouge, Isabelle de Maison. L’Art Contemporain. Paris: Le Cavalier Bleu, 2006.

Sant'Anna, Affonso Romano. "Artes e Artimanhas do mercado". In Revista D'Art, n. 12, 2005.

Sant'Anna, Afonso Romano. "Paradigmas do Jornalismo Cultural". In Espaços na Mídia: história, cultura e esporte. Brasília: Banco do Brasil, 2001.

Santos, Maria de Lourdes Lima. "Cultura, Aura e Mercado". In Melo, Alexandre (org.) Arte e Dinheiro. Lisboa: Assírio e Alvim, 1994.

Sarkovas, Yacoff. In Franceschi, A. et all. Marketing Cultural - Um Investimento com Qualidade. São Paulo: Informações Culturais, 1998.

Sarkovas, Yacoff. "O incentivo fiscal à cultura no Brasil". In Revista D'Art, n. 12, 2005.

Sarkovas, Yacoff. "Entretenimento, Cultura e Comunicação do Negócio". In Espaços na Mídia: história, cultura e esporte. Brasília: Banco do Brasil, 2001.

Sarlo, Beatriz. "O lugar da arte". Cenas da Vida Pós-Moderna: intelectuais, arte e vídeo-cultura na Argentina. Rio de Janeiro: Editora UFRJ, 1997.

Schuster, J. Mark D. Supporting the Arts: na international comparative study. Washington, D.C.: U.S. Government 'Printing Office, 1985.

Schwentker, Wolfgang. "A paixão como um modo de vida - Max Weber, o círculo de Otto Gross e o erotismo". In Revista Brasileira de Ciências Sociais. Anpocs, número 32, ano 11, outubro de 1996.

Sennett, Richard. A Corrosão do Caráter. São Paulo: Record, 1999.

SESC São Paulo. Uma Idéia Original - SESC São Paulo 50 anos. São Paulo: SESC, 1997.

SESC. Diretrizes Gerais de Ação dos SESC. Rio de Janeiro, mimeo, 2004.

Silva, Antônio Carlos de Araújo. A encenação no coletivo: re-territorializações da função do diretor no processo colaborativo. São Paulo, Tese de Doutorado - ECA, 2008.

Silva, Liliana Sousa e. O Público e o Privado: a política cultural brasileira no caso dos institutos Moreira Salles e Itaú Cultural. Dissertação de Mestrado - ECA. São Paulo, 2000. 
Silva, Frederico. Os Gastos Culturais dos Três Níveis de Governo e a Descentralização. IPEA, Texto para discussão n. 876. Brasília, abril de 2002

Silva, Frederico Barbosa da. "Notas sobre o Sistema Nacional de Cultura - Instituto de Pesquisa Econômica Aplicada (IPEA), 2005.

Silva, Frederico A. Barbosa. Política Cultural no Brasil, 2002-2006: acompanhamento e análise. Brasília, Ministério da Cultura/ IPEA - Instituto de Pesquisa Econômica Aplicada, 2007.

Silva, Maria Celina de Mello e. Centro Cultural - Construção e Reconstrução de conceitos. Dissertação de mestrado, Rio de Janeiro, Uni-Rio, CCH, 1995.

Sodré, Muniz. "O ethos mediático". In Antropológica do espelho. Petrópolis: Vozes, 2002.

Szantó, András. "Um quadro ambíguo". In Lindoso, Felipe (org.). Rumos [do] Jornalismo Cultural. São Paulo: Summmus: Itaú Cultural, 2007.

Tavares, Cristiane Cordeiro Nascimento. Marketing Cultural: contribuições para o fortalecimento da imagem de organizações modernas. São Paulo, Tese, ECCA, 2003.

Toffler, Alvin. A Terceira Onda. 5ª Ed. Rio de Janeiro: Record, 1982.

Tönnies, Ferdiand. Community and Society. Nova York: Dover Publications, 2002.

Urfalino, Philippe. L'invention de la politique culturelle. Paris: Hachette Littératures, 2004.

Vaz, Gil Nuno. Marketing Institucional: o mercado de idéias e imagens. São Paulo: Pioneira, 1995.

Velho, Gilberto. “Entrevista com Gilberto Velho”. In Estudos Históricos, Rio de Janeiro, número 28, 2001.

Vieira, Marco Estevão de Mesquita. Distinção, Cultura de Consumo e Gentrificação: o Centro Cultural Banco do Brasil e o Mercado de Bens Simbólicos. Brasília: Tese de Doutorado - Departamento de Sociologia - Universidade de Brasília, 2006.

Vieira, Vania Feichas. Os donos do centro - discursos e estratégias de intervenção no centro de São Paulo. São Paulo: Dissertação (mestrado), Antropologia Social, USP, 2004.

Villafañe, Justo. Imagem Positiva - Gestão estratégica da imagem das empresas. Lisboa: Edições Sílabo, 1998.

Weber, Max. A Ética Protestante e o Espírito do Capitalismo. 6ª Edição. São Paulo: Livraria Pioneira Editora, 1989. 
Weber, Max. Os fundamentos racionais e sociológicos da música. Coleção: Clássicos. São Paulo: Editora EDUSP, 1995

Weber, Max. "Rejeições religiosas do mundo e suas direções." In Max Weber. Textos Selecionados. São Paulo, Abril Cultural, Coleção Os Pensadores, 1988, pp. 237-268.

Weber, Max. Hindouisme et Bouddhisme. Paris: Éditions Flammarion, 2003.

Weffort, Francisco \& Souza, Márcio (orgs.). Um olhar sobre a cultura brasileira. Brasília, Ministério da Cultura, 1998. também editado por Rio de Janeiro: Associação d’Amigos da FUNARTE, 1998.

Weil, P. Communication Oblige! Communication institutionnelle et de Martekting. Les Éditions d'Organisation, 1990.

Wu, Chin-Tao. Privatização da cultura - a intervenção corporativa nas artes desde os anos 80. São Paulo: Boitempo, 2006.

Zolberg, Vera L. Para uma sociologia das artes. São Paulo: Editora Senac, 2006. 


\section{REFERÊNCIAS DE LEGISLAÇÃo}

Brasil. Constituição da República Federativa do Brasil. Organização dos textos, notas remissivas e índices por Juarez de Oliveira. 3.ed. São Paulo: Saraiva, 1989.

DECRETO №. 1.494, DE 17 DE MAIO DE 1995. - Regulamenta a Lei no. 8.313, de 23 de dezembro de 1991, estabelece a sistemática de execução do Programa Nacional de Apoio à Cultura (Pronac), e dá outras providências. Disponível em: http://www.apade.com.br/decreto1494.htm. Acesso em 25/10/2008

DECRETO-LEI №. 9.853 DE 13 DE SETEMBRO DE 1946. Atribui à Confederação Nacional do Comércio o encargo de criar e organizar o Serviço Social do Comércio e dá outras providências. Disponível em: http://www6.senado.gov.br/legislacao/ListaTextolntegral.action?id=78724. Acesso em 25/10/2008.

LEI №. 7.505, DE 2 DE JULHO DE 1986. Dispõe sobre benefícios fiscais na área do imposto de renda concedidos a operações de caráter cultural ou artístico. Disponível em: http://www.planalto.gov.br/ccivil_03/leis/L7505.htm. Acesso em 25/10/2008.

LEI № 8.313, DE 23 DE DEZEMBRO DE 1991. Restabelece princípios da Lei $n^{\circ} 7.505$, de 2 de julho de 1986, institui o Programa Nacional de Apoio à Cultura (Pronac) e dá outras providências. Disponível em: http://www.planalto.gov.br/ccivil_03/leis/L8313cons.htm. Acesso em 25/10/2008.

LEI № 8.666, DE 21 DE JUNHO DE 1993. Regulamenta o art. 37, inciso XXI, da Constituição Federal, institui normas para licitações e contratos da Administração Pública e dá outras providências. Disponível em: http://www.planalto.gov.br/ccivil_03/LEIS/L8666cons.htm. Acesso em 25/10/2008.

LEI № 9.874, DE 23 DE NOVEMBRO DE 1999. Altera dispositivos da Lei no 8.313, de 23 de dezembro de 1991, e dá outras providências. Acesso em 25/10/2008. 


\section{ReferênCIAS de Periódicos}

Abreu, Silvio de. Ilustrada Escolhe. Folha de S. Paulo, São Paulo, 08/01/06, llustrada, E7.

Alves Jr., Dirceu. "Talento de Cleide Yáconis não salva a montagem brasileira do texto de Marguerite Duras". Isto é Gente, São Paulo, 24/01/05, 34

Arantes, Paulo. Paulo Arantes: um pensador na cena paulistana [Entrevista a Beth Néspoli]. 0 Estado de São Paulo, São Paulo, 16/07/07, Caderno 2, D3

Arantes, Silvana. Bem na Fita. Folha de S. Paulo, São Paulo, 08/06/08, llustrada, E1-E4.

Arantes, Silvana. Minc revida artilharia de São Paulo. In Folha de S. Paulo, São Paulo,16/06/08, llustrada, E4

Arantes, Silvana. O circo do incentivo. Folha de S. Paulo, São Paulo, 26/04/2006, llustrada, E1.

Barros, Guilherme. Basiléia 2 aumenta concentração. Folha de S. Paulo, São Paulo, 12/08/2007, Dinheiro, B2

Brasil, Ubiratan. A mãe coragem de Cleyde Yáconis, O Estado de S. Paulo, São Paulo, 12/01/05, Caderno 2, D1.

Brasil, Ubiratan. O aniversário do indignado Walmor Chagas. O Estado de S. Paulo, São Paulo, 18/03/05, Caderno 2, D6.

Candeias, Maria Lucia Status ameaçado - As Turca e Canãa, a Terra prometida discutem decadência social. Gazeta Mercantil, São Paulo, 25/11/05.

Carvalho, Mário Cesar. BB cancela a exposição "Erotica" em Brasília. Folha de S. Paulo, São Paulo, 03/05/06, Cotidiano, C6

Carvalho, Mario Cesar. Censura a arte viola a Constituição, afirma Gil. In Folha de S. Paulo, São Paulo, 26/04/2006. Cidades, C8

Carvalho, Sérgio de e Rodrigues, Marco Antônio. O negócio da cultura. Folha de S. Paulo, São Paulo, 16/04/08, Opinião, A3

Chaimovich, Felipe . Objetos de Farnese revelam universalidade, Folha de S. Paulo, São Paulo, 28/05/05, llustrada, E7

Chaimovich, Felipe. Arte construtiva é desafiada hoje, Folha de S. Paulo, São Paulo, 19/02/2005, llustrada, E8 
Chaimovich, Felipe. Ilustrada Escolhe - Sexo e desejo através dos tempos, Folha de S. Paulo, São Paulo, 4/12/2005, llustrada, E7

Cocchiarale, Fernando. Uma Obra Iconoclasta, Jornal do Brasil, Rio de Janeiro, 10/02/05, Caderno B, 5.

Coelho, Marcelo. Ovos, bonecas e relicários, Folha de S. Paulo, São Paulo, 20/04/05, llustrada, E12

Coelho, Sérgio Sálvia. Cinema Éden cria espetáculos de evocações. Folha de S. Paulo, São Paulo, 03/02/05, llustrada, E 8

Coelho, Sérgio Sálvia. "Walmor Chagas exerce o verbo em monólogo". Folha de S. Paulo, São Paulo, 21/05/05, llustrada, E7.

Cruz, Ney Hayashi. "Bancos Federais ganham R\$ 24,4 bi sob Lula", Folha de S. Paulo, 28/02/2007, Economia, B1.

Cypriano, Fábio. Ilustrada Escolhe - Último fim de semana da mostra que traça um panorama da relação entre arte e erotismo. Folha de S. Paulo, São Paulo, 7/1/2006, llustrada, E6.

Cypriano, Fabio. Tom oficial marca "Arte de Cuba". Folha de S. Paulo, São Paulo, 27/03/2006, llustrado, E6

Cypriano, Fábio. Vik Muniz faz metáfora óbvia. In Folha de S. Paulo, São Paulo, 20/03/2005, llustrada, E5.

Dubra, Pedro Ivo. Entre Novas Paredes - Nem tão cubos, nem tão brancos. Folha de S. Paulo, São Paulo, 02 a 08/03/2007, Guia da Folha, 70-76.

Dubra, Pedro Ivo. Guta Stresser estrela peça de Domingos de Oliveira. Folha de S. Paulo, São Paulo, 15/09/06, Guia da Folha, 32.

Folha de S. Paulo, São Paulo, 29/04/06. Opinião, A2. grifo nosso

Folha de S. Paulo. Reportagem Local. Bancos ganham bem mais que empresas. Folha de S. Paulo, São Paulo, 01/04/2007, Dinheiro, B4

Folha de S. Paulo. Sucursal Brasília. Concentração avança no setor bancário. Folha de S. Paulo, São Paulo, 26/05/2007, Dinheiro, B3.

Folha de S. Paulo. Aperfeiçoar a Lei Rouanet [Editorial]. Folha de S. Paulo, São Paulo, 06/04/08, Opinião, A2

Frateschi, C. e Ferreira, Juca. Incentivo ao Teatro?. Folha de S. Paulo, São Paulo, 27/03/08, Opinião, A3) 
Fundação Getúlio Vargas. “Conglomerados Financeiros”. Conjuntura Econômica, junho de 2007.

Garçon, Juliana. Território de Gigantes. Folha de S. Paulo, São Paulo, 24/10/2006. Folha Top of Mind, 78-86.

Helena Katz em São Paulo ganha sua companhia oficial de dança. O Estado de São Paulo, São Paulo, 28/01/08, Caderno 2, D5

Lima, Mariângela Alves. Cleide Yáconis restaura magnetismo no palco. O Estado de São Paulo, São Paulo, 11/02/05, Caderno 2, D10

Lima, Mariângela Alves. Walmor seduz com sabedoria. O Estado de São Paulo, São Paulo, 29/04/05. Caderno 2, D7

Margarido, Orlando. Com que quadro eu vou? Veja SP, São Paulo, 16/05/2007. Arte. 22-40. Marti, Silas. Galerias de arte miram o mercado internacional. Folha de S. Paulo, São Paulo, 19/08/2007, Negócios, 2-3.

Maria, Cleusa. Mary Vieira: a artista que o Brasil desconhece. Jornal do Brasil, Rio de Janeiro, 26/04/05, Caderno B.

Monachesi, Juliana. Onde colocar o desejo. Bien 'Art, São Paulo, novembro de 2005, 13-14.

Monachesi, Juliana. Packer amplia discussão sobre corpo, Folha de S. Paulo, São Paulo, 23/12/06, llustrada, E4

Moraes, Angélica. Sem perder a ternura. Bravo!, São Paulo, fevereiro de 2006, 25.

Néspoli, Beth. As Turca evita caricatura de traços culturais - e acerta. O Estado de São Paulo, São Paulo, 01/12/205, Caderno 2, D9.

Neves, Julio. Folha de São Paulo, São Paulo, 05/07/06, Opinião, A3

Neves, Lucas. Portenhos em cena. Folha de S. Paulo, São Paulo, 22/09/08, Ilustrada, E1

O Estado de São Paulo. Mostras Recomendadas. O Estado de São Paulo, São Paulo, 11/11/2005, D4.

Oliva, Fernando. "Arte erótica - O lugar do desejo”. Bravo!. São Paulo, Outubro de 2005, 20-28.

Oliva, Fernando. Erotismo é alegria, movimento e transformação. Bravo!, São Paulo, outubro de 2005.

Salomon, Marta. Governo eleva renúncia fiscal em 44\%. Folha de São Paulo, São Paulo, 07/07/08, Dinheiro, B1 
Santos, Valmir. Walmor Chagas critica poder da imagem. Folha de S. Paulo, São Paulo, 16/03 /05, llustrada, E10.

Souza, Leonardo. Lucros dos Bancos sobem mais. Folha de S. Paulo, São Paulo, 21/06/2004, Dinheiro, B4

Stivalleti, Thiago. A memória de Marguerite Duras encontra a força de Cleyde Yáconis, Folha de S. Paulo, São Paulo, 23/01/05, llustrada, E6.

Stivalleti, Thiago. Cleyde Yáconis investiga a memória de Duras. Folha de S. Paulo, São Paulo, 12/01/05, llustrada, E5.

Trigo, Luciano. É de fama e dinheiro que se trata a arte? Folha de S. Paulo, São Paulo,19/11/2007, llustrada, E4

Varella Dráuzio. Tributo ao SESC. Folha de S. Paulo, São Paulo, 29/09/2007, llustrada, E15

Veja São Paulo, São Paulo, 16/11/2005, Roteiro, 32. 


\section{RefERÊNCIAS DE Web Sites}

American Marketing Association. www.marketingpower.com, consultado em 25/10/08.

Arte Plural - Assessoria de Comunicação (Jornalista Fernanda Teixeira) http://www.artepluralweb.com.br/atualizacao/releases/06/janeiro/capobianco_expos_henfil_b rasil.htm, consultado em 16/02/08.

Associação Viva $\quad 0 \quad$ Centro. Disponível em: http://www.vivaocentro.org.br/bancodados/centrosp/estatisticas.htm. Acessado em 25/10/08

Banco do Brasil. Disponível em: www.bb.com.br. Acesso em 25/10/08.

Bravo! Disponível em http://bravonline.abril.com.br. Acesso em 25/10/08.

Canal Contemporâneo. Disponível em: http://www.canalcontemporaneo.art.br/brasa/archives/000713.html. Acesso em 25/10/2008.

Centro Cultural São Paulo. Disponível em: http://www.centrocultural.sp.gov.br/ccsp_oquee.asp. Acessado em 25/10/08.

CIE Brasil. CIE - Corporación Interamericana de Entretenimiento. Disponível em http://207.36.181.42/show_subcat.cfm?SubCatID=9. Acesso em 25/10/08.

Departamento de Expansão Cultural da Secretaria de Cultura do Município de São Paulo. Disponível em www.decsp.org. Acesso em 25/10/08.

Febraban - Federação Brasileira de Bancos. Disponível em: http://www.febraban.org.br/Arquivo/Servicos/Imprensa/Conc0404.pdf. Consultado em $25 / 10 / 08$

http://money.cnn.com/magazines/fortune/global500/2007/index.html

Instituto Tomie Othake. Disponível em http://www.institutotomieohtake.org.br/instituto/parcerias/teparcerias.htm. Acesso em 25/10/08.

Itaú Cultural. Disponível em www.itaucultural.org.br. Acesso em 25/10/08

MAM - Museu de Arte Moderna. Disponível em www.mam.org.br. Acesso em 25/10/08.

Navas, Adolfo Montejo. "Desenhando com Terços" Disponível em: http://marciax.uol.com.br/mxText.asp?sMenu=4\&sText=15. Acesso em 25/10/08

MASP - Museu de Arte Moderna. Disponível em: www.masp.uol.br 
Ministério da Cultura. Disponível em: www.minc.gov.br

Observatório Social. Disponível em www.observatoriosocial.org.br. Acesso em 25/10/08.

Prefeitura Municipal de São Paulo. Disponível em www.prefeitura.sp.gov.br. Acesso em 25/10/08.

Revista Marketing Cultural Online. Disponível em: www.marketingcultural.com.br. Consultado em $25 / 10 / 08$

Rezende, Marcelo. "Artista da llusão". Disponível em: http://bravonline.abril.com.br/indices/artesplasticas/artesplasticasmateria_249259.shtml

SEADE - Fundação Sistema de Análise de Dados. Disponível em www.seade.gov.br.

Secretaria Municipal de Planejamento do Município de São Paulo. Disponível em http://sempla.prefeitura.sp.gov.br/orc_orc_2007.php. Acessado em 25/10/08.

SESC - Serviço Social do Comércio. Disponível em http://www.sescsp.org.br/sesc/sos/index.cfm? forget=14\&inslog=16. Acessado em 25/10/08.

Troster, Roberto Luis. "Concentração Bancária". Site da Febraban, consultado em 02 de agosto de 2007 : http://www.febraban.org.br/Arquivo/Servicos/Imprensa/Conc0404.pdf

The Barbican Centre. Disponível em: http://www.barbican.org.uk/about-barbican. Acesso em 25/10/08

UNESCO - Organização das Nações Unidas para a Educação, a Ciência e a Cultura. Disponível em: www.unesco.org.br/publicacoes/copy_of_pdf/decunivdiversidadecultural.doc. Acesso em 25/10/08.

Vitruvius - Portal de Arquitetura http://www.vitruvius.com.br/noticia/noticia_detalhe.asp?id=146, consultado em 17/02/08.

You Tube. Matéria veiculado no "Jornal Nacional”, da Rede Globo de Televisão, em 12/10/1995, disponível no site www.youtube.com, consultado em 22/10/2008 


\section{ANEXOS}




\section{ANeXo 1 - Público e V ALORES INVESTIDOS POR ÁREA ARTística}

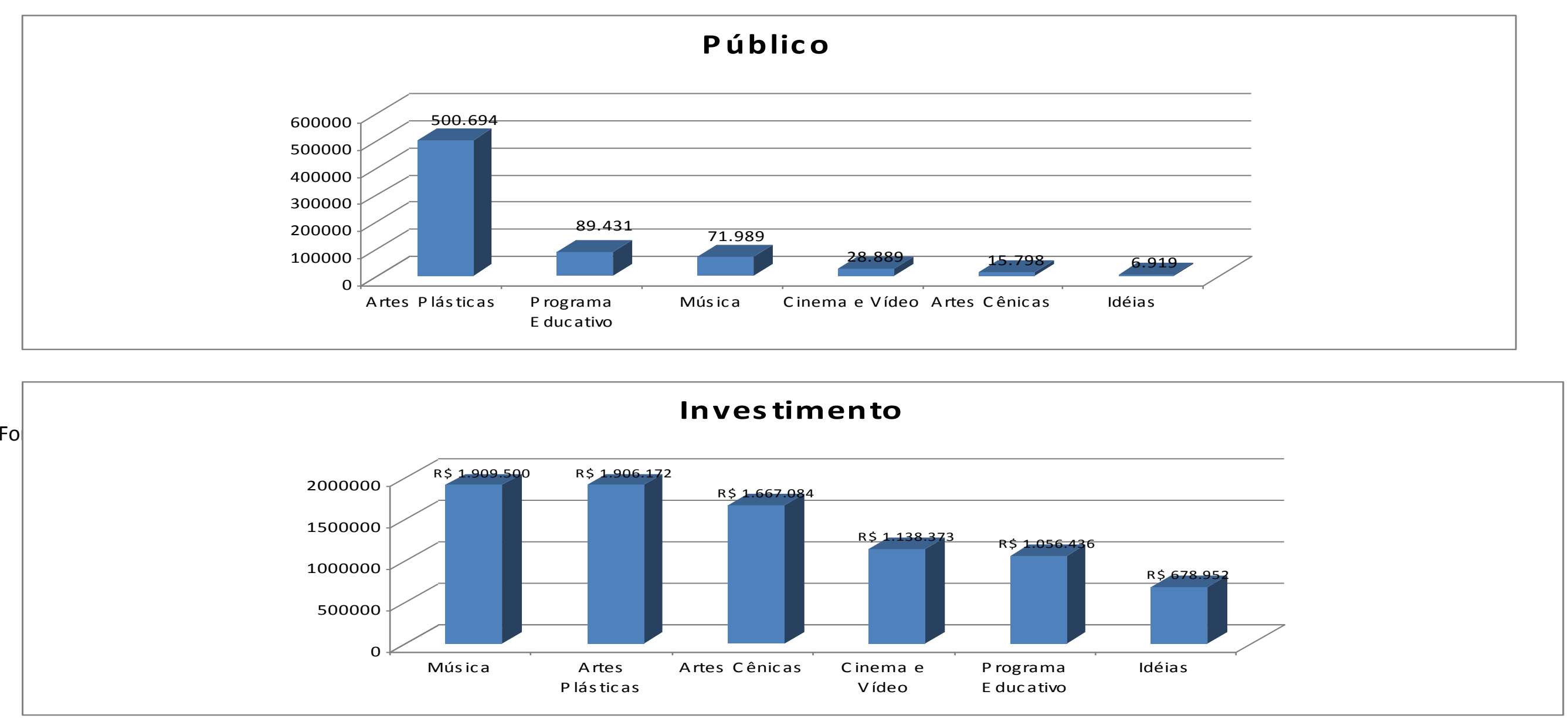




\section{ANEXo 2 - Número de Visitantes dos CCBBS}

\begin{tabular}{|l|c|c|c|c|}
\hline \multicolumn{3}{|c|}{ Visitantes dos Centros Culturais em 2005 } & \multicolumn{2}{c}{ Visitantes dos Centros Culturais em 2006 } \\
\hline CCBB & Público Total & Média diária & Público Total & 8.553 \\
\hline Rio de Janeiro & 2.540 .365 & 8.302 & 2.641 .739 & 3.285 \\
\hline São Paulo & 842.321 & 2.980 & 852.635 & 1.356 \\
\hline Brasília & 310.386 & 958 & 420.655 & 13.194 \\
\hline Total & 3.693 .072 & 12.240 & 3.915 .029 & \\
\hline
\end{tabular}


ANEXo 3 - Organograma Banco do Brasil

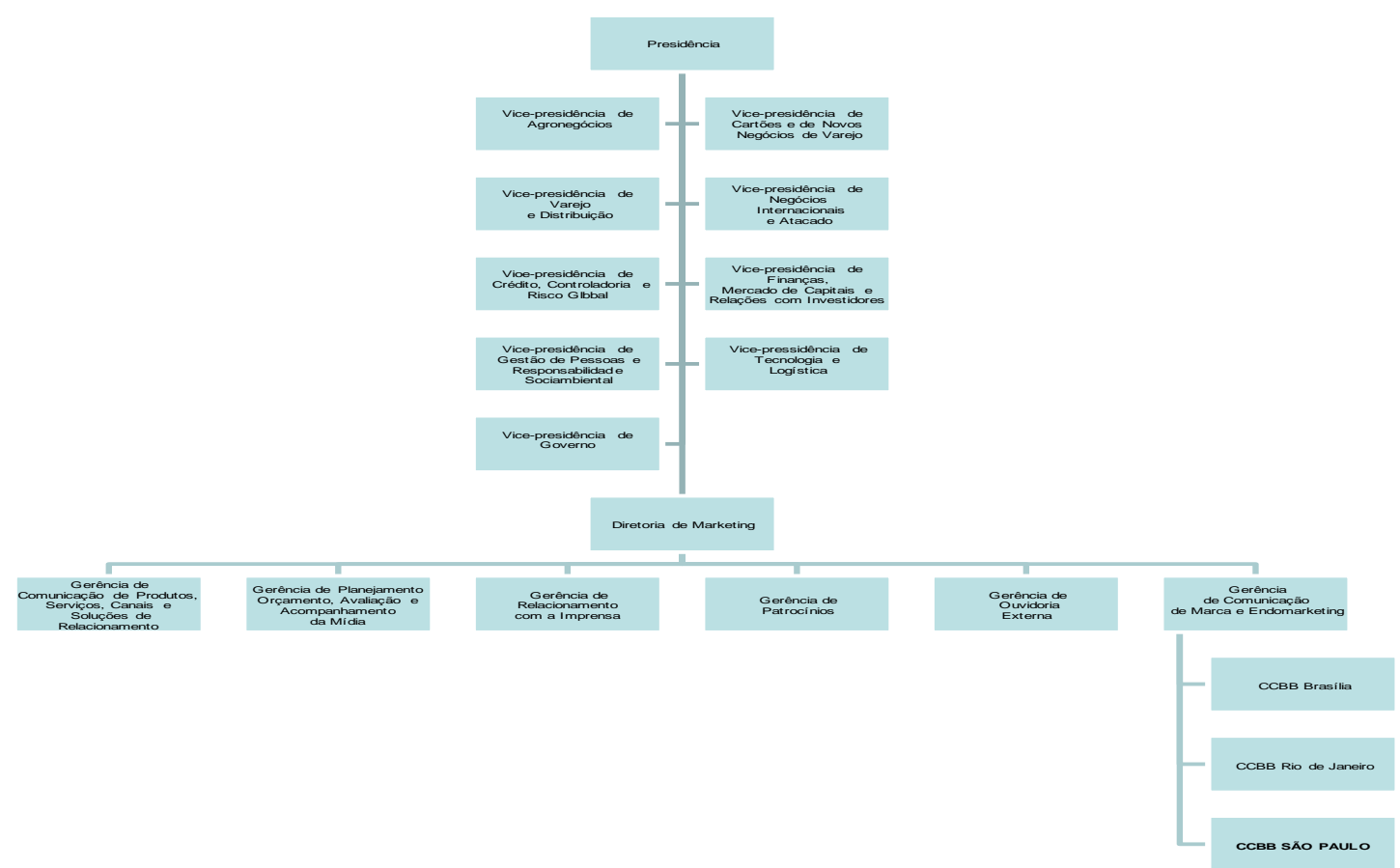




\section{ANEXo 4 - MAGNITUDE DO MANTENEDOR}

\begin{tabular}{|c|c|c|c|c|c|c|}
\hline BB em Números & & & & & & \\
\hline Itens Patrimoniais ( $\mathbf{R} \$$ milhões) & 2003 & 2004 & 2005 & 2006 & 2007 & $\Delta 2006(\%)$ \\
\hline Ativos Totais & 230.144 & 239.014 & 252.977 & 296.356 & 357.750 & 20,7 \\
\hline Operações de Crédito & 65.591 & 74.825 & 85.942 & 113.858 & 138.817 & 21,9 \\
\hline Depósitos & 110.014 & 115.532 & 137.658 & 158.841 & 188.282 & 18,5 \\
\hline Patrimônio Líquido & 12.172 & 14.106 & 16.850 & 20.758 & 24.262 & 16,9 \\
\hline Administração de Recursos de Terceiros & 102.658 & 124.021 & 153.508 & 182.683 & 220.136 & 20,5 \\
\hline Resultado (R\$ milhões) & 2003 & 2004 & 2005 & 2006 & 2007 & $\Delta 2006(\%)$ \\
\hline Res. Bruto da Inter. Financeira & 10.006 & 10.208 & 10.809 & 10.808 & 15.155 & 40,2 \\
\hline Receitas de Prestação de Serviços & 5.491 & 6.607 & 7.648 & 8.887 & 9.902 & 11,4 \\
\hline Despesas de Pessoal & -6.812 & -7.096 & -7.473 & -7.871 & -9.161 & 16,4 \\
\hline Lucro Líquido & 2.381 & 3.024 & 4.154 & 6.044 & 5.058 & $-16,3$ \\
\hline Índices (\%) & 2003 & 2004 & 2005 & 2006 & 2007 & \\
\hline $\begin{array}{l}\mathrm{RSPL}{ }^{1} \text { - Lucro Líquido/Patrimônio Líquido } \\
\text { Médio }\end{array}$ & 22,3 & 23 & 26,8 & 32,1 & 22,5 & \\
\hline $\begin{array}{l}\text { Eficiência }^{2} \text { - Desp. Administrativas/Rec. } \\
\text { Operacionais }\end{array}$ & 56,3 & 54,2 & 48,1 & 47,5 & 51,4 & \\
\hline Cobertura - RPS/Despesas de Pessoal & 80,6 & 93,1 & 102,3 & 112,9 & 108,1 & \\
\hline Dados estruturais & 2003 & 2004 & 2005 & 2006 & 2007 & $\Delta 2006$ (\%) \\
\hline Pontos de Atendimento & 13.220 & 14.450 & 14.804 & 15.113 & 15.297 & 1,2 \\
\hline Terminais de Auto-Atendimento & 37.018 & 39.015 & 40.191 & 39.661 & 39.045 & $-1,6$ \\
\hline Funcionários & 80.640 & 79.725 & 83.751 & 82.672 & 81.855 & -1 \\
\hline Clientes (mil) & 18.750 & 21.088 & 22.907 & 24.374 & 26.003 & 6,7 \\
\hline Clientes Pessoa Física (mil) & 17.533 & 19.719 & 21.474 & 22.815 & 24.336 & 6,7 \\
\hline Clientes Pessoa Jurídica (mil) & 1.217 & 1.368 & 1.432 & 1.559 & 1.667 & 6,9 \\
\hline \multicolumn{7}{|c|}{1 - Retorno sobre o Patrimônio Líquido. Exprime o ganho percentual auferido pelos proprietários. } \\
\hline \multicolumn{7}{|l|}{2 - Quanto menor, melhor. } \\
\hline Fonte: Banco do Brasil, 2008. & & & & & & \\
\hline
\end{tabular}




\section{Anexo 5 - InVestiment do Banco do Brasil em Cultura}

\section{Valores Investidos em Cultura}

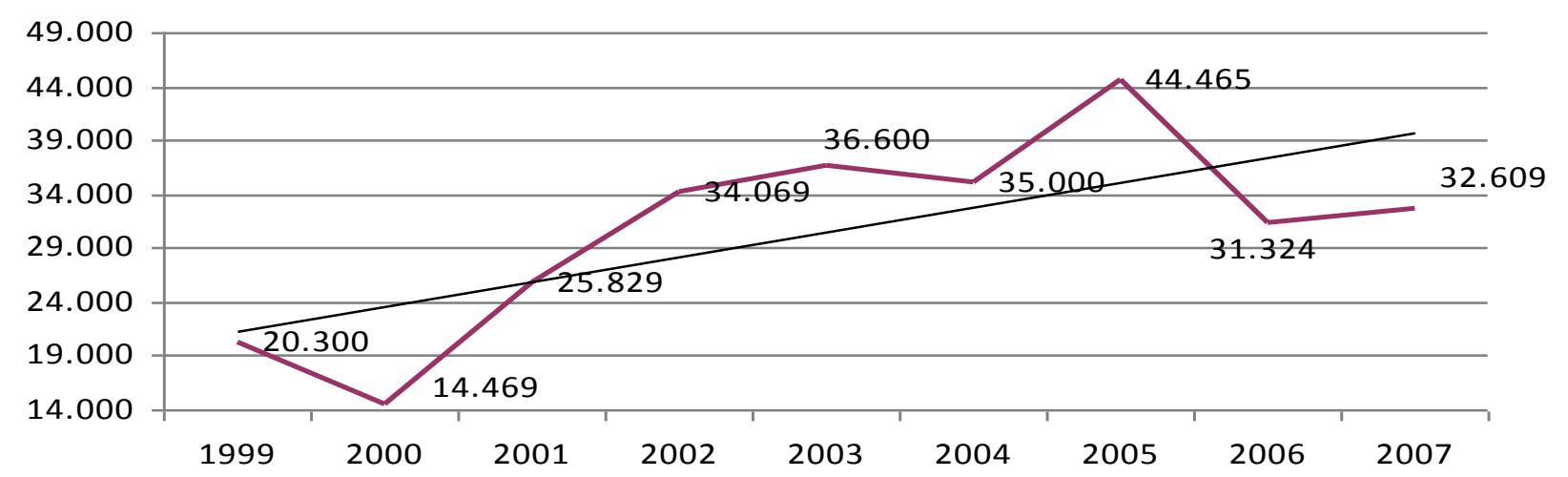

\section{Patrocínio Artístico do C C B B em Relação à} Receita Líquida

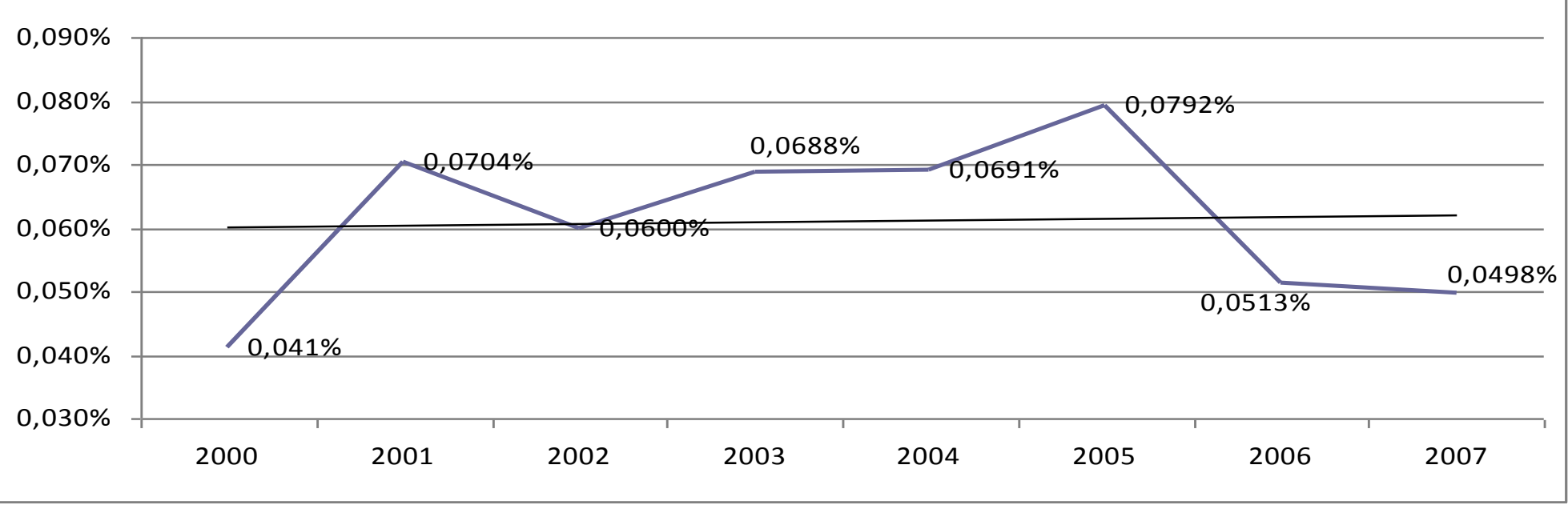




\section{Patrocínio Artís tico do C CB B em Relação ao Resultado Operacional}

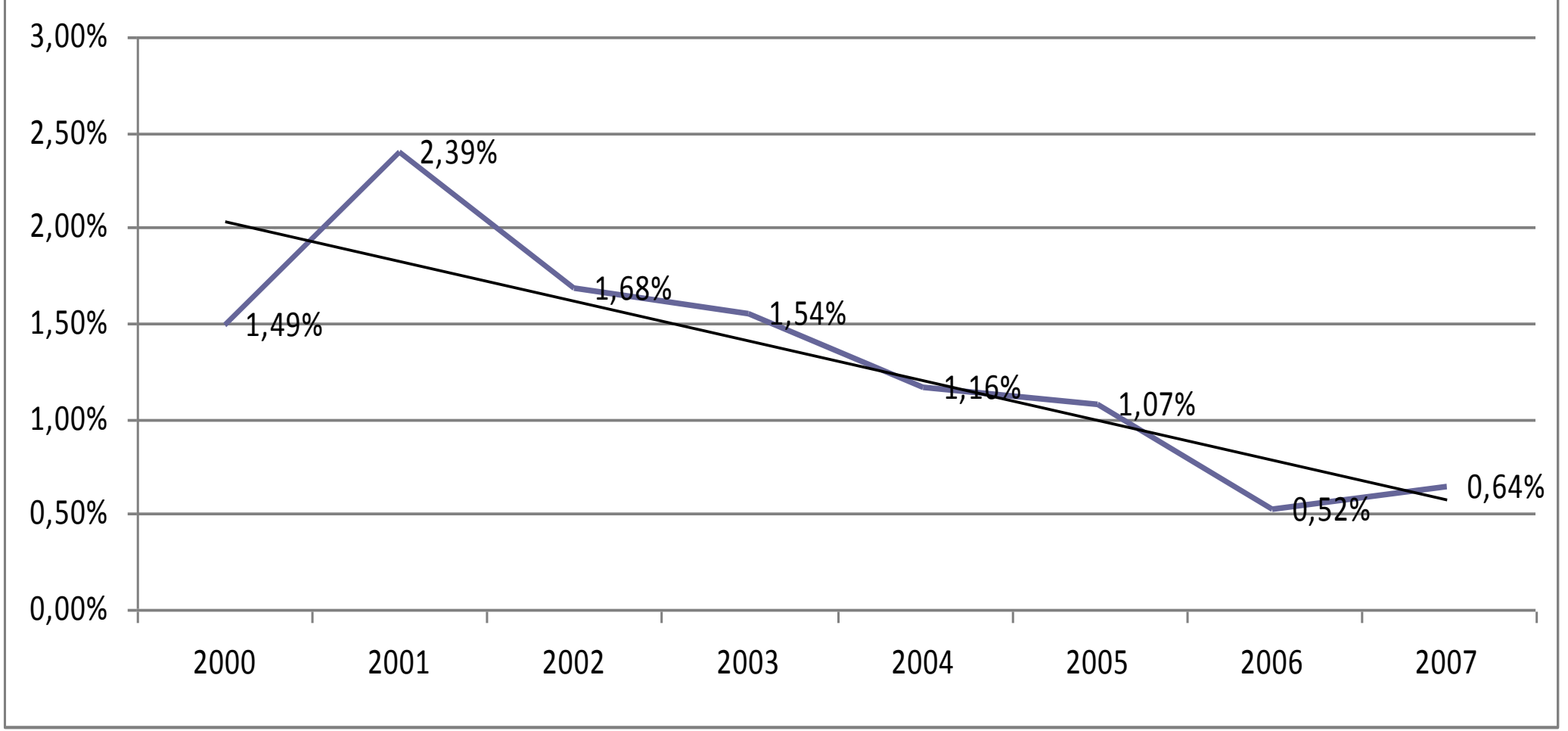

Fonte: Balanços Sociais Banco do Brasil 


\section{ANEXo 6 - Comparativo dos INVESTIMENTOS CULTURAIS dAS EMPRESAS}
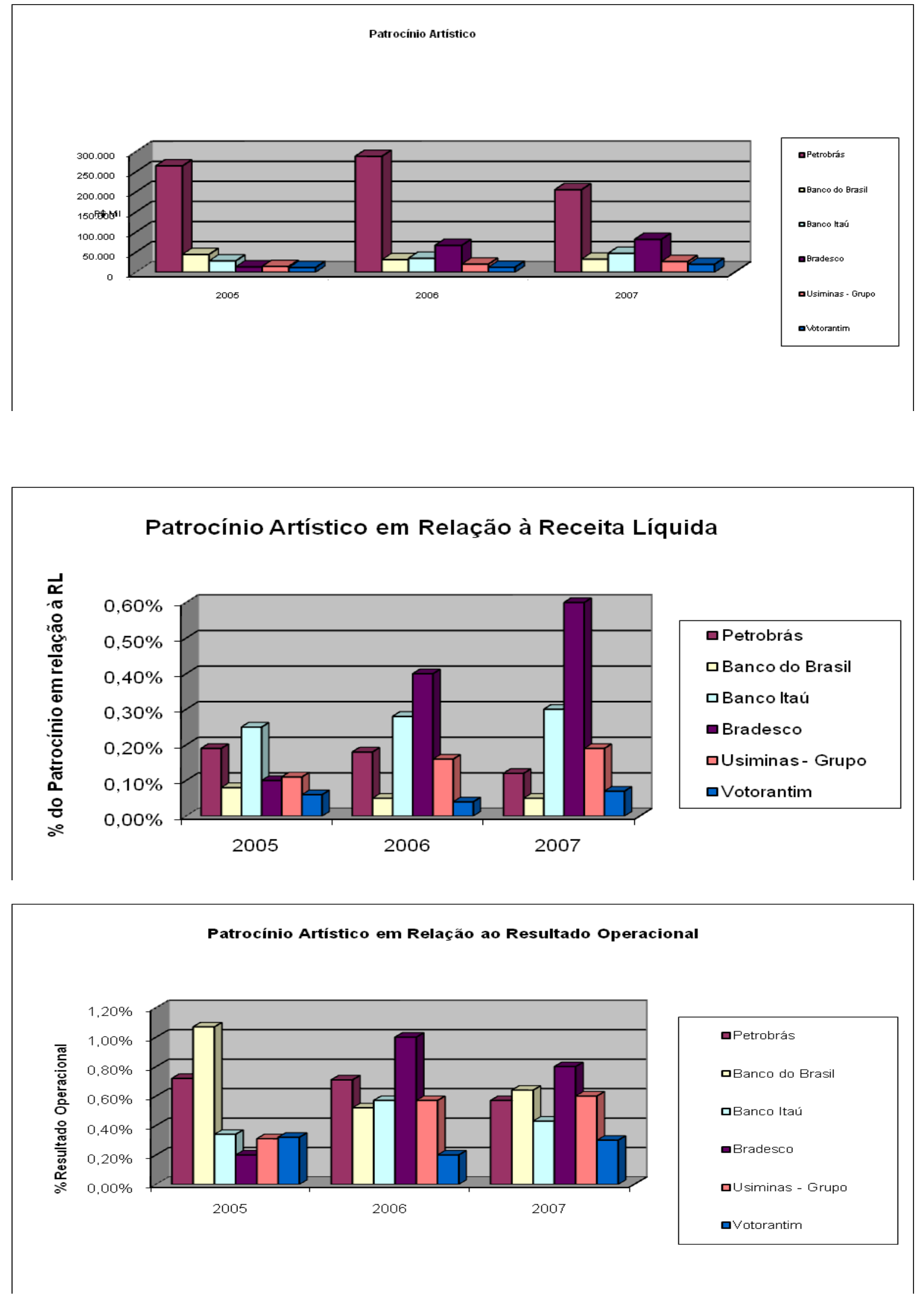

Fonte: Balanço Social das Empresas 


\section{ANEXO 7 - INSTITUTOS E FUndAÇõES CULTURAIS VINCULAdOS A INSTITUIÇõES} FINANCEIRAS185

\begin{tabular}{|c|c|c|c|}
\hline País & Cidades & Banco & Instituição Cultural \\
\hline Alemanha & Berlim & Deutche Bank & Deutsche Guggenheim Berlin \\
\hline Alemanha & Munique & Allianz Group & Allianz Cultural Foundation \\
\hline Bélgica & Bruxelas & ING Bank Belgium & ING Belgium Cultural Space \\
\hline Brasil & $\begin{array}{l}\text { Brasília, Rio de } \\
\text { Janeiro e São Paulo }\end{array}$ & Banco do Brasil & Centro Cultural Banco do Brasil \\
\hline Brasil & $\begin{array}{l}\text { Brasília, Curitiba, } \\
\text { Rio de Janeiro, } \\
\text { Salvador e São } \\
\text { Paulo }\end{array}$ & $\begin{array}{l}\text { Caixa Econômica } \\
\text { Federal }\end{array}$ & Caixa Cultural \\
\hline Brasil & São Paulo & HSBC & HSBC Belas Artes (cinema) \\
\hline Brasil & São Paulo & Itaú & Instituto Itaú Cultural \\
\hline Brasil & $\begin{array}{l}\text { Belo Horizonte, } \\
\text { Poços de Caldas, } \\
\text { Rio de Janeiro e São } \\
\text { Paulo }\end{array}$ & Unibanco & $\begin{array}{l}\text { Instituto Moreira Salles e Espaços } \\
\text { Unibanco de Cinema (em diversas } \\
\text { cidades) }\end{array}$ \\
\hline Brasil & Porto Alegre & Santander & Santander Cultural \\
\hline Brasil & $\begin{array}{l}\text { Fortaleza, Cariri e } \\
\text { Sousa }\end{array}$ & $\begin{array}{l}\text { Banco do Nordeste do } \\
\text { Brasil (BNB) }\end{array}$ & Centros Culturais BNB \\
\hline Espanha & Barcelona & Caixa Catalunya & Fondació Caixa Catalunya (La Pedrera) \\
\hline Espanha & Barcelona e Madrid & Caja Madrid & $\begin{array}{l}\text { Fondacion Caja Madrid / La Casa } \\
\text { Encendida }\end{array}$ \\
\hline Espanha & Barcelona & La Caixa & Caixaforum \\
\hline França & Paris & BNP Paribas & Fondation BNP Paribas \\
\hline Portugal & Lisboa e Porto & $\begin{array}{l}\text { Caixa Geral de } \\
\text { Depósitos }\end{array}$ & Culturgest \\
\hline
\end{tabular}

\footnotetext{
${ }^{185}$ Levantamento não exaustivo
} 
ANEXo 8 - INVESTIMENTOS EM CULTURA POR SEgmENTO DA ECONOMIA - 101 MAIORES GRUPOS CAPTADORES VIA LEI DE INCENTIVO -AGRUPADOS POR ÁREA DE ATUAÇÃo

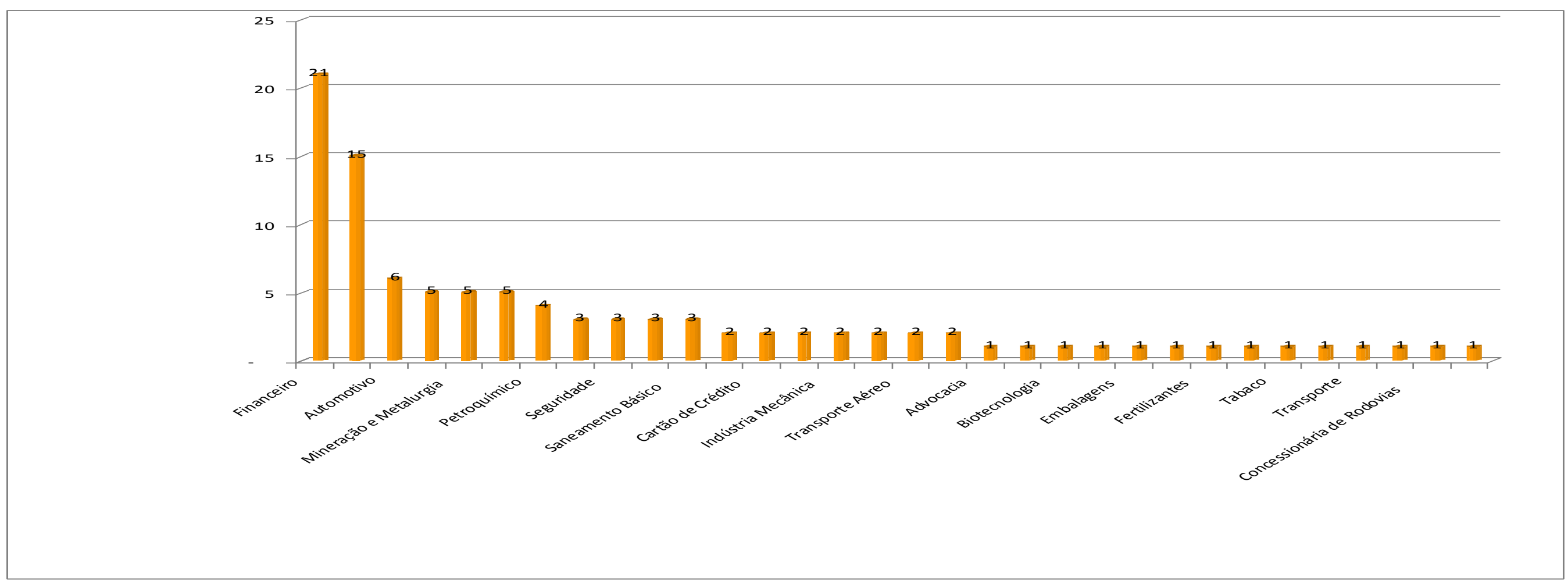

Fonte: Ministério da Cultura e Revista Marketing Cultural On-line. Dados de 2007. Nos grupos com atividades em mais de um segmento da economia, a classificação se deu pela empresa predominante no grupo. 


\section{Anexo 9 - Recursos Captados via Lei de InCentivo por Segmento da Economia}

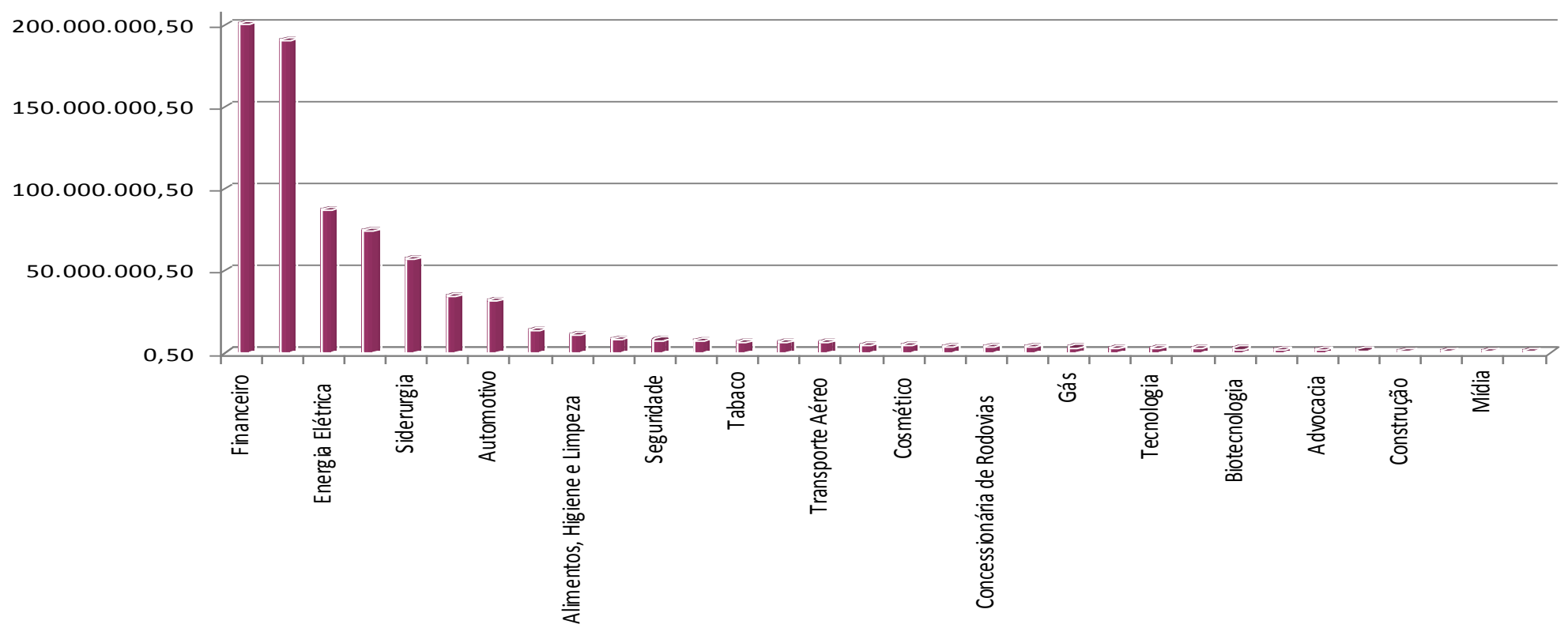

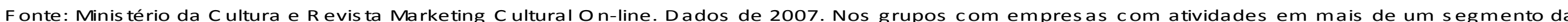
classificação se deu pela empresa predominante no grupo. 


\section{ANEXO 10 - COMERCIAL PUBLICITÁRIO dO UNIBANCO}

\section{"Nem parece Banco"}

O cliente, graficamente representado por um ponto de interrogação vermelho, dirige-se à agência bancária. Em "off" ouve-se uma voz cantarolando:

-- Feche sua conta, feche sua conta...

O funcionário do banco, obeso, parado ao lado de um caminhão, na entrada da agência, lê uma folha de papel, enquanto entregadores retiram caixas do caminhão. Dirige-se ao seu chefe dizendo:

-- Oh, Gilson, complicação põe onde?

[Ao fundo, ouvem-se ruídos]

A agência é colocada em cena, com enquadramento em uma série de arquivos antigos e papéis saindo pelas gavetas. Clientes aguardam em uma fila. Na parede, a inscrição:

"Banco S.A."

Gilson responde com voz estridente, agachado na frente de um arquivo:

-- Ah, vai espalhando em qualquer lugar.

O funcionário pergunta novamente:

-- Oh, Gilson, burocracia põe onde?

Gilson responde, irritado:

-- Na minha mesa e na tua, né? Pô!

Vêem-se carregadores com caixas em que se lê: "Fila", "Impaciência” "Mau humor". O funcionário pergunta mais uma vez:

-- Fila, impaciência, mau humor?

Gilson responde:

-- Ah, joga logo em cima dos clientes.

As caixas são despejadas em cima do ponto de interrogação, que reage, assustado e indefeso. 
[corte]

Outra agência é apresentada em cena. Moderna, limpa e com uma recepcionista na entrada. Lê-se na parede: "Unibanco". Ao fundo, ouve-se uma voz repetir:

-- Abra sua conta e acabam os ruídos.

Segue-se uma voz em off: "Abra sua conta. Abra sua conta".

Acabam os ruídos e entra trilha sonora com harmonia melodiosa de saxofone.

Um funcionário magro pergunta a seu chefe que, ao contrário de caixas grandes, tem nas mãos pequenos sacos:

-- Leo, Burocracia põe onde, hein?

O chefe responde:

-- Lixo.

O funcionário, segurando o pequeno saco diz:

-- Complicação?

0 chefe responde:

-- No lixo.

E os funcionários fazem novas perguntas:

-- Fila, impaciência, mau humor?

O chefe responde:

-- Deixa eu ver: Lixo, lixo e lixo.

O funcionário diz:

-- Tá legal, cuidado com o cliente.

Aparece o mesmo ponto de interrogação do "cenário" anterior. Ao ver a cena, transforma-se de ponto de interrogação vermelho para um ponto de exclamação verde . Voz em "off" diz:

-- Unibanco, nem parece banco!

O comercial termina com a imagem que reforça o que o locutor diz:

-- Unibanco. Nem parece banco. Abra sua conta. www.unibanco.com.br. 


\section{Anexo 11 - Teatros na Cidade de SÂo Paulo (localização, CaPACIDAde E PREÇO)}

\begin{tabular}{|c|c|c|c|c|}
\hline Nome & Bairro & Região & Lugares & Ingresso \\
\hline Abril & Bela Vista & Central & 1533 & 132,50 \\
\hline Ágora & Bela Vista & Central & 90 & 10,00 \\
\hline Alfa & Santo Amaro & Sul & & 112,50 \\
\hline Alfredo Mesquita & Santana & Norte & 219 & \\
\hline Aliança Francesa & Vila Buarque & Central & 230 & 20,00 \\
\hline Artes (Teatro das Artes) & Pinheiros & Oeste & 796 & 70,00 \\
\hline Arthur Azevedo & Mooca & Leste & 480 & 10,00 \\
\hline Arthur Azevedo & Mooca & Leste & 480 & \\
\hline Ator (Teatro do Ator) & Consolação & Central & & 20,00 \\
\hline Augusta - Sala Experimental & Consolação & Central & 60 & 30,00 \\
\hline Augusta - Sala Nobre & Consolação & Central & 302 & 40,00 \\
\hline Avenida Club & Pinheiros & Oeste & 500 & 45,00 \\
\hline Bela Vista & Consolação & Central & & 30,00 \\
\hline Bibi Ferreira & Bela Vista & Central & 395 & 45,00 \\
\hline Brigadeiro & Bela Vista & Central & 676 & 30,00 \\
\hline Cacilda Becker & Vila Romana & Oeste & 212 & 15,00 \\
\hline Café Concerto Uranus & Campos Elíseos & Central & 150 & 20,00 \\
\hline $\begin{array}{l}\text { Cambridge Hotel - Espaço } \\
\text { Portinari }\end{array}$ & Centro & Central & 70 & 10,00 \\
\hline $\begin{array}{l}\text { Casarão da Escola Paulista } \\
\text { de Restauro }\end{array}$ & Bela Vista & Central & 40 & 15,00 \\
\hline Casarão do Belvedere & Bela Vista & Central & 30 & 20,00 \\
\hline $\begin{array}{l}\text { Centro Brasileiro Britânico - } \\
\text { Sala Cultura Inglesa }\end{array}$ & Pinheiros & Oeste & 157 & 20,00 \\
\hline Centro Cultural da Juventude & \begin{tabular}{|l} 
Vila Nova \\
Cachoeirinha
\end{tabular} & Norte & 220 & \\
\hline Centro Cultural FIESP - & Bela Vista & Central & 456 & 1,50 \\
\hline
\end{tabular}




\begin{tabular}{|c|c|c|c|c|}
\hline Teatro Popular do SESI & & & & \\
\hline $\begin{array}{l}\text { Centro Cultural São Paulo - } \\
\text { Espaço Cênico Ademar } \\
\text { Guerra }\end{array}$ & Liberdade & Central & 70 & 12,50 \\
\hline $\begin{array}{l}\text { Centro Cultural São Paulo - } \\
\text { Sala Jardel Filho }\end{array}$ & Liberdade & Central & 324 & 15,00 \\
\hline $\begin{array}{l}\text { Centro da Terra (Teatro do } \\
\text { Centro da Terra) }\end{array}$ & Vila Pompéia & Oeste & 100 & 20,00 \\
\hline $\begin{array}{l}\text { Colégio Santa Cruz (Teatro do } \\
\text { Colégio...) }\end{array}$ & Alto de Pinheiros & Oeste & 460 & 40,00 \\
\hline Crowne Plaza & Consolação & Central & 153 & 27,50 \\
\hline $\begin{array}{l}\text { Cultura Artística - Sala Esther } \\
\text { Mesquita (incendiado) }\end{array}$ & Consolação & Central & 1156 & 55,00 \\
\hline $\begin{array}{l}\text { Cultura Artística - Sala } \\
\text { Rubens Sverner (incendiado) }\end{array}$ & Consolação & Central & 338 & 65,00 \\
\hline Cultura Inglesa Pinheiros & Pinheiros & Oeste & 195 & 30,00 \\
\hline Dança (Teatro de Dança) & Ipiranga & Sul & & \\
\hline Décio de Almeida Prado & Itaim Bibi & Oeste & 200 & \\
\hline Dell'Arte & Santo Amaro & Sul & 150 & 15,00 \\
\hline Denoy de Oliveira & Bela Vista & Central & 100 & 20,00 \\
\hline Dias Gomes & Vila Mariana & Sul & 520 & 30,00 \\
\hline Escola Brincante & Sumarezinho & Oeste & 130 & 20,00 \\
\hline Espaço Cênico Teatrix & Jardim Paulista & Oeste & 60 & 20,00 \\
\hline Espaço Cultural Arte Design & Jardim Paulista & Oeste & 40 & 30,00 \\
\hline $\begin{array}{l}\text { Espaço Cultural Juca Chaves } \\
\text { (Teatro Extra Itaim) }\end{array}$ & Itaim Bibi & Oeste & & 25,00 \\
\hline Espaço das Artes & Vila Mariana & Sul & 90 & 12,00 \\
\hline Espaço dos Satyros 1 & República & Central & 80 & 20,00 \\
\hline Espaço dos Satyros 2 & República & Central & 70 & 25,00 \\
\hline Espaço Incenna & Vila Mariana & Sul & 50 & 30,00 \\
\hline Espaço Magma & Vila Madalena & Oeste & 26 & 30,00 \\
\hline Espaço Maquinaria & Bela Vista & Central & 99 & 15,00 \\
\hline
\end{tabular}




\begin{tabular}{|c|c|c|c|c|}
\hline Espaço Parlapatões & República & Central & 96 & 21,67 \\
\hline Estudio do Latão & Vila Madaleno & Oeste & & \\
\hline Fábrica São Paulo -sala 1 & Consolação & Central & 134 & 10,00 \\
\hline Fábrica São Paulo -sala 2 & Consolação & Central & 80 & 30,00 \\
\hline Flávio Império & Cangaíba & Leste & 212 & \\
\hline Folha & Consolação & Central & 305 & 17,00 \\
\hline Galpão do Folias & Santa Cecília & Central & 97 & 20,00 \\
\hline Gazeta & Cerqueira César & Central & & 45,00 \\
\hline Imprensa & Bela Vista & Central & 478 & 30,00 \\
\hline Imprensa - Espaço Vitrine & Bela Vista & Central & 45 & 25,00 \\
\hline $\begin{array}{l}\text { Instituto Cultural Capobianco - } \\
\text { sala Teatro da Memória }\end{array}$ & Centro & Central & 90 & 20,00 \\
\hline Italia & Centro & Central & & 10,00 \\
\hline Jaraguá & Centro & Central & 280 & 35,00 \\
\hline João Caetano & Vila Clementino & Sul & 436 & \\
\hline Lugar & Consolação & Central & & 15,00 \\
\hline Maksoud Plaza & Bela Vista & Central & 420 & 60,00 \\
\hline Maria Della Costa & Bela Vista & Central & 370 & 40,00 \\
\hline Martins Pena & Penha & Leste & 249 & \\
\hline Municipal & Sé & Central & & \\
\hline N.Ex.T & República & Central & 70 & 20,00 \\
\hline Nair Bello & Consolação & Central & 200 & 80,00 \\
\hline Nill de Pádua & Saúde & Sul & & 10,00 \\
\hline Oficina & Bela Vista & Central & 350 & 20,00 \\
\hline Paulo Eiró & Santo Amaro & Sul & 600 & 15,00 \\
\hline Paulo Eiró & Santo Amaro & Sul & 600 & \\
\hline Plínio Marcos & Água Branca & Oeste & 100 & 20,00 \\
\hline Procópio Ferreira & Cerqueira César & Oeste & 670 & 50,00 \\
\hline
\end{tabular}




\begin{tabular}{|c|c|c|c|c|}
\hline Puri & Cerqueira César & Central & 120 & 10,00 \\
\hline $\begin{array}{l}\text { Raul Cortez (ex-Teatro } \\
\text { Fecomércio) }\end{array}$ & Bela Vista & Central & 522 & 80,00 \\
\hline Renaissance & Cerqueira César & Oeste & 462 & 60,00 \\
\hline Ruth Escobar - Sala Dina Sfat & Morro dos Ingleses & Central & 390 & 35,00 \\
\hline $\begin{array}{l}\text { Ruth Escobar - Sala Miriam } \\
\text { Muniz }\end{array}$ & Morro dos Ingleses & Central & 59 & 10,00 \\
\hline Sala Crisantempo & Pinheiros & Oeste & 95 & 20,00 \\
\hline $\begin{array}{l}\text { Sérgio Cardoso - sala } \\
\text { Paschoal Carlos Magno }\end{array}$ & Bela Vista & Central & 144 & 20,00 \\
\hline $\begin{array}{l}\text { Sérgio Cardoso - sala Sérgio } \\
\text { Cardoso }\end{array}$ & Bela Vista & Central & 856 & 10,00 \\
\hline SESC 24 de Maio & Centro & Central & 80 & \\
\hline $\begin{array}{l}\text { SESC Av. Paulista - espaço } \\
10 \text { andar }\end{array}$ & Bela Vista & Central & 50 & 15,00 \\
\hline $\begin{array}{l}\text { SESC Av. Paulista - espaço } \\
12 \text { andar }\end{array}$ & Bela Vista & Central & 80 & 11,25 \\
\hline $\begin{array}{l}\text { Sesc Av. Paulista - espaço } 5 \\
\text { andar }\end{array}$ & Bela Vista & Central & 60 & 8,25 \\
\hline $\begin{array}{l}\text { Sesc Av. Paulista - teatro } \\
\text { auditório }\end{array}$ & Bela Vista & Central & 230 & 6,00 \\
\hline $\begin{array}{l}\text { SESC Av. Paulista - teatro de } \\
\text { câmara }\end{array}$ & Bela Vista & Central & 54 & 11,25 \\
\hline $\begin{array}{l}\text { Sesc Consolação - Teatro } \\
\text { Anchieta }\end{array}$ & Vila Buarque & Central & 320 & 16,67 \\
\hline Sesc Ipiranga & Ipiranga & Sul & 80 & 8,00 \\
\hline Sesc Pinheiros & Pinheiros & Oeste & & \\
\hline Sesc Santana & Santana & Norte & 349 & 14,00 \\
\hline SESI Vila Leopoldina & Vila Leopoldina & Oeste & 80 & \\
\hline Shopping Frei Caneca & Consolação & Central & 592 & 50,00 \\
\hline Spaço dos Insights & Vila Uberabinha & Sul & 70 & 22,50 \\
\hline Studio 184 & República & Central & 30 & 20,00 \\
\hline TBC - Sala Arena & Bela Vista & Central & 180 & 20,00 \\
\hline
\end{tabular}




\begin{tabular}{|l|l|l|r|r|}
\hline TBC - Sala TBC & Bela Vista & Central & 400 & 20,00 \\
\hline Tendal da Lapa & Lapa & Oeste & & \\
\hline Theatro São Pedro & Barra Funda & Oeste & & \\
\hline Tucarena & Perdizes & Oeste & 180 & 20,00 \\
\hline Tusp & Vila Buarque & Central & 195 & 20,00 \\
\hline Vento Forte - Sala das Maos & Itaim Bibi & Oeste & 150 & 15,00 \\
\hline Viga Espaço Cênico & Itaim Bibi & Oeste & 60 & 20,00 \\
\hline Vila (Teatro da Vila) & Pinheiros & Oeste & 74 & 20,00 \\
\hline Vivo & Vila Madalena & Oeste & 99 & 50,00 \\
\hline X (Teatro X) & Morumbi & Sul & 280 & 20,00 \\
\hline
\end{tabular}

Fonte: Guia da Folha, 17 a 23/08/2007, 21 a 27/09/07; Folha de S. Paulo, 26/08/07; Guia $O$ Estado de S. Paulo de 24 a 30/08; site http://www6.prefeitura.sp.gov.br/secretarias/cultura/servicos/0003 consultado em 26/08/07 


\section{Anexo 12 - Artes Plásticas - Galerias, Escritórios de ARTe, Instituições Culturais e Museus em SÃo Paulo}

\begin{tabular}{|c|c|}
\hline Nome & Bairro \\
\hline Aloísio Cravo Arte \& Leilões & Jardim Europa \\
\hline Amoa Konoya Arte Indígena & Jardim América \\
\hline Ana Cláudia Roso Escritório De Arte & Jardim Paulista \\
\hline Arte 57 Escritório De Arte & Jardins \\
\hline Arte aplicada & Cerqueira César \\
\hline Arte Infinita Galeria & Pinheiros \\
\hline Brazil gallery & Moema \\
\hline Britto Central & Jardins \\
\hline Caixa Cultural & Sé \\
\hline Calligraphia Galeria E Loja De Arte & Centro \\
\hline Casa da xiclet galeria & Pinheiros \\
\hline Casa Das Artes Galeria & Higienópolis \\
\hline Casa das Rosas & Cerqueira César \\
\hline Casa de Dona Yaya & Bela Vista \\
\hline Casa triângulo & Itaim Bibi \\
\hline CCBB & Centro \\
\hline Centro Cultural da Juventude & Vila Nova Cachoeirinha \\
\hline Centro Cultural Sao Paulo & Liberdade \\
\hline Centro da Cultura Jurdaica & Pinheiros \\
\hline Centro Universitario Maria Antonia & Vila Buarque \\
\hline Clube A Hebraica & Jardim Paulistano \\
\hline Collectors Arte Século Xx & Jardins \\
\hline Dan galeria & Jardim América \\
\hline
\end{tabular}




\begin{tabular}{|c|c|}
\hline D-Concept Escritório De Arte & Jardins \\
\hline Escritório De Arte Almavera & Pinheiros \\
\hline Escritório De Arte Oswaldo Kathalian & Jardins \\
\hline Espaço arte m. Mizrahi & Higienópolis \\
\hline Espaço Cultural BM\&F & Centro \\
\hline Espaço Cultural Citi & Bela Vista \\
\hline Espaço Cultural do Banco Central & Cerqueira César \\
\hline Espaço Cultural Instituto Cervantes & Bela Vista \\
\hline Espaço Vivo & Santana \\
\hline Estação Pinacoteca & Luz \\
\hline Estúdio Buck & Vila Olímpia \\
\hline Faap Centro & Sé \\
\hline Fundacao Cultural Ema Gordon Klabin & Jardim Europa \\
\hline Fundacao Maria Luisa e Oscar Americano & Morumbi \\
\hline Gabinete De Arte Raquel Arnaud & Pinheiros \\
\hline Galeria 8 rosas & Jardins \\
\hline Galeria Antonio Meneghetti & Jardim América \\
\hline Galeria baró cruz & Vila Nova Conceição \\
\hline Galeria Berenice Arvani & Cerqueira César \\
\hline Galeria bergamin & Jardim Paulista \\
\hline Galeria Brasiliana & Pinheiros \\
\hline Galeria Brito Cimino & Vila Olímpia \\
\hline Galeria central & Santa Cecília \\
\hline Galeria Choque Cultural & Pinheiros \\
\hline Galeria De Arte Almeida \& Dale & Jardim Paulista \\
\hline Galeria de Arte do SESI & Bela Vista \\
\hline Galeria deco & Bela Vista \\
\hline Galeria Eduardo H Fernandes & Vila Madalena \\
\hline Galeria Emma Thomas & Cerqueira César \\
\hline
\end{tabular}




\begin{tabular}{|c|c|}
\hline Galeria Estação & Pinheiros \\
\hline Galeria Fortes Vilaça & Pinheiros \\
\hline Galeria Horizonte & Vila Nova Conceição \\
\hline Galeria Jacques Ardies & Vila Mariana \\
\hline Galeria Leme & Butantã \\
\hline Galeria Luisa Strina & Jardins \\
\hline Galeria Mali Villas-Bôas & Jardim Paulista \\
\hline Galeria Millan & Pinheiros \\
\hline Galeria Nara Roesler & Jardim Europa \\
\hline Galeria Oeste & Pinheiros \\
\hline Galeria Olido & Centro \\
\hline Galeria Polinesia & Consolação \\
\hline Galeria POP & Pinheiros \\
\hline Galeria Projeto Obra & Moema \\
\hline Galeria Sergio Caribé & Vila Nova Conceição \\
\hline Galeria Thomas Cohn & Jardim Europa \\
\hline Galeria Vermelho & Consolação \\
\hline Galeria Virgilio & Pinheiros \\
\hline Grafiteria & Pinheiros \\
\hline Graphias - Casa Da Gravura & Vila Mariana \\
\hline Gravura Brasileira & Pinheiros \\
\hline Instituto de Arte Contemporanea & Vila Buarque \\
\hline Instituto de Estudos Brasileiros & Butantã \\
\hline Instituto Lina Bo e P. M. Bardi & Morumbi \\
\hline Instituto Tomie Ohtake & Pinheiros \\
\hline$\overline{\mathrm{IQ}}$ & Cerqueira César \\
\hline Itaú Cultural & Bela Vista \\
\hline James Lisboa Escritório De Arte & Cerqueira César \\
\hline Jo Slaviero \& Guedes Galeria De Arte & Jardim Paulistano \\
\hline
\end{tabular}




\begin{tabular}{|c|c|}
\hline Laura Marsiaj Arte Contemporânea & Pinheiros \\
\hline Léica Gallery & Itaim Bibi \\
\hline Lordello \& Gobbi Escritório De Arte & Jardim Paulistano \\
\hline Luiz Caribé Escritório De Arte & Itaim Bibi \\
\hline MAC Ibirapuera & Ibirapuera \\
\hline MAC USP & Butantã \\
\hline MAM Ibirapuera & Ibirapuera \\
\hline Marília Razuk Galeria De Arte & Jardim Paulista \\
\hline MASP & Bela Vista \\
\hline Memorial da America Latina & Barra Funda \\
\hline Mônica Filgueiras Galeria De Arte & Jardim Paulista \\
\hline MuBe - Museu Brasileiro Escultura & Jardim Europa \\
\hline Multipla De Arte & Santo Amaro \\
\hline Museu Afro Brasil & Ibirapuera \\
\hline Museu Anchieta & Centro \\
\hline Museu da Casa Brasileira & Pinheiros \\
\hline Museu da Imagem e do Som & Jardim Europa \\
\hline Museu da Imigracao & Mooca \\
\hline Museu de Arte Sacra & Luz \\
\hline Museu de Arte Brasileira (FAAP) & Higienópolis \\
\hline Museu do Theatro Municipal & Centro \\
\hline Museu Lasar Segall & Vila Mariana \\
\hline Museu Paulista (do Ipiranga) & Ipiranga \\
\hline Nóbrega Antiquário \& Galeria De Arte & Jardins \\
\hline Nova André Galeria De Arte & Jardim Paulistano \\
\hline Oficina Cultural Oswald de Andrade & Bom Retiro \\
\hline Oficina Da Luz & Pinheiros \\
\hline Paço das Artes & Butantã \\
\hline Palacio do Governo de Sao Paulo (Palácio dos Bandeirantes - Acervo) & Morumbi \\
\hline
\end{tabular}




\begin{tabular}{|l|l|}
\hline Paulo Kuczynski Escritório De Arte & Jardins \\
\hline Pavilhão Ascensão & Vale do Anhangabaú \\
\hline Pinacoteca do Estado & Bom Retiro \\
\hline Pinakotheke São Paulo & Morumbi \\
\hline Pop - Livraria e Galeria de Arte & Pinheiros \\
\hline Portal Galeria & Jardim América \\
\hline Quatiara Escritório De Arte & Jardins \\
\hline Ricardo Camargo Galeria & Jardim Paulistano \\
\hline SESC Av. Paulista - 3 andar & Bela Vista \\
\hline SESC Pinheiros & Pinheiros \\
\hline Solar da Marquesa & Centro \\
\hline Spazio Surreale & Jardim Paulista \\
\hline Tableau Leilão De Arte & Jardins \\
\hline Valu Oria Galeria De Arte & Jardim Paulista \\
\hline $\begin{array}{l}\text { Fonte: Guia da Folha, 17 a 23/08/2007; Folha de S. Paulo, 26/08/07; Guia O Estado de S. Paulo de } \\
\text { 24:/www.saopaulo.sp.gov.br/saopaulo/cultura/museus_imigr.htm consultado em }\end{array}$ \\
\hline
\end{tabular}




\section{Anexo 13 - Perfil do Frequentador}
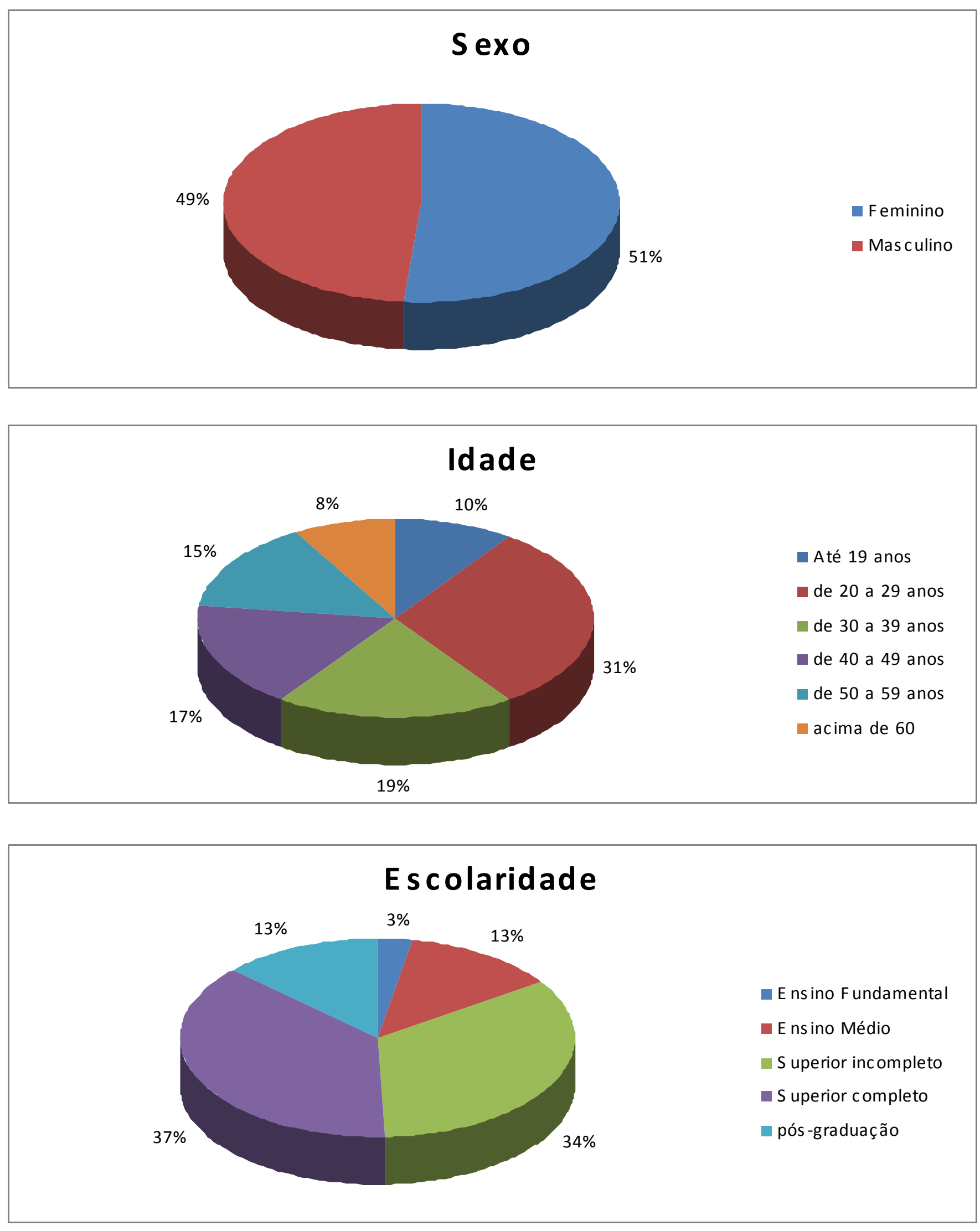


\section{Ocupação}

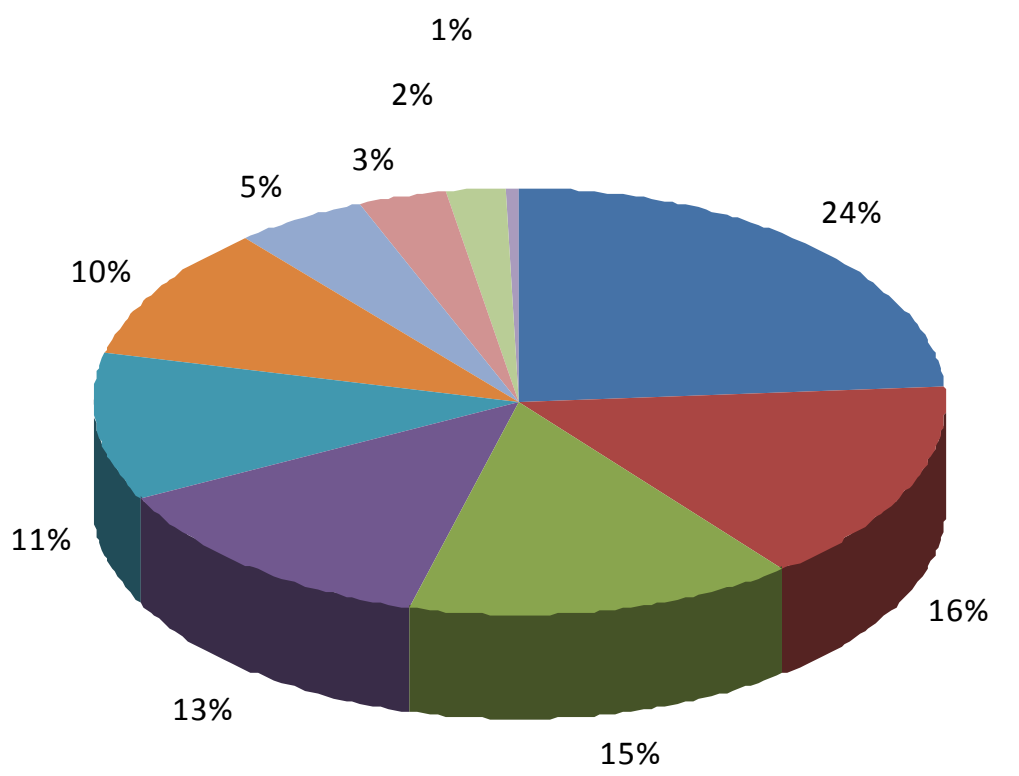

- E mpregado setor privado

- Es studante

- Empregados setor

público

- Autônomo

- A pos entado

- P rofis sional Liberal

- Des empregado

E mpresário

Dona de casa

\section{Renda}

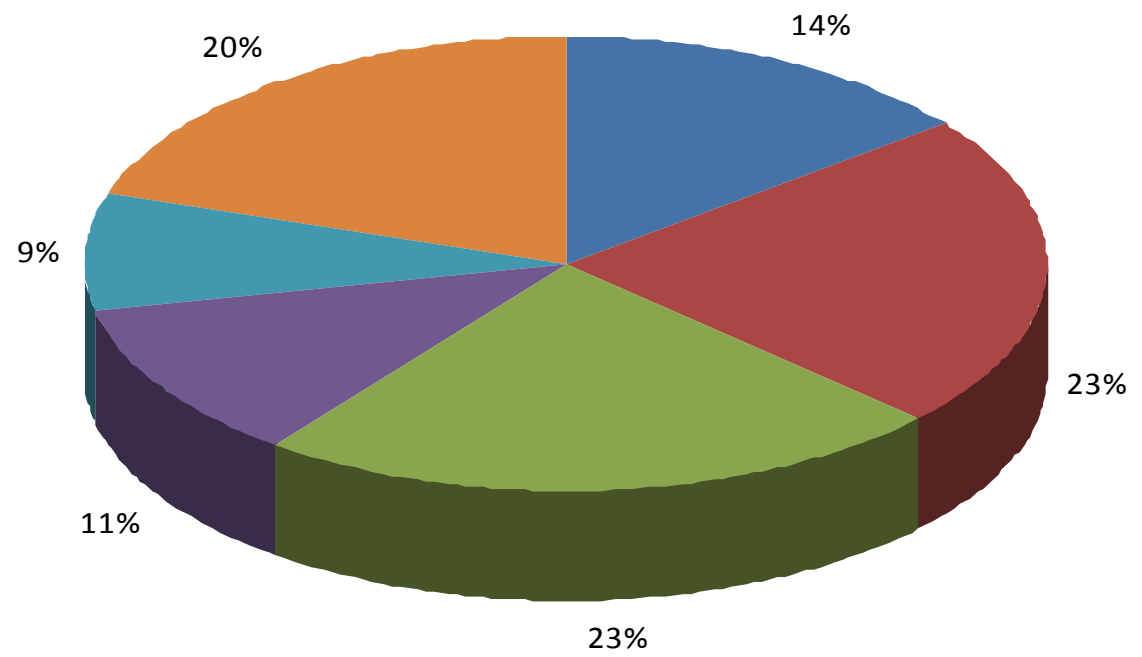

- Não tem renda

- A té R\$ 1000

a de 1.001 a 2.000

a De 2.001 a 3.000

a de 3.001 a 4.000

Acima de 4.001

$23 \%$ 


\section{Anexo 14 - Grau de Transparência na Seleção dos Projetos Culturais}

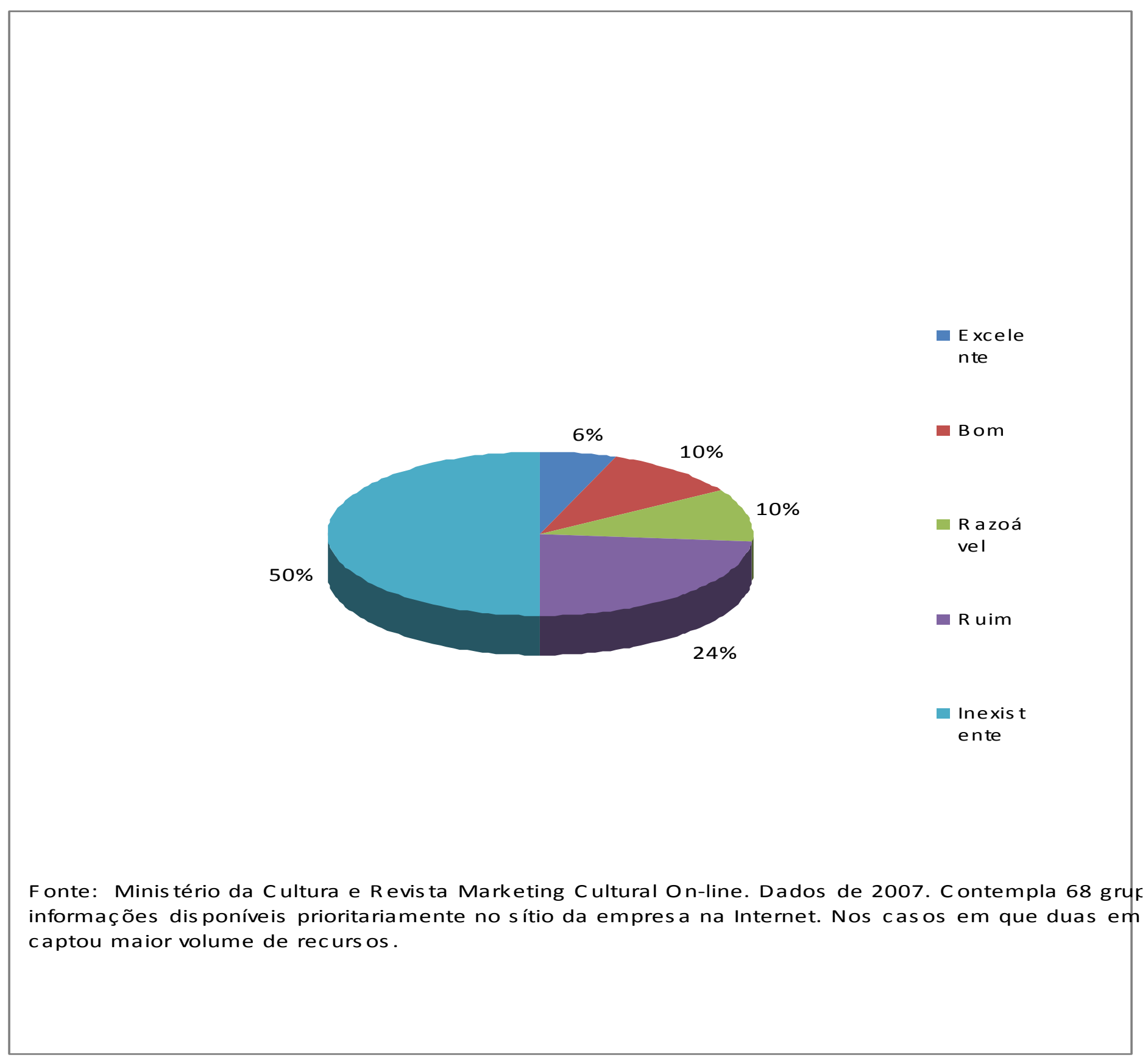


Anexo 15 - Perfil do Funcionário do CCBB São Paulo

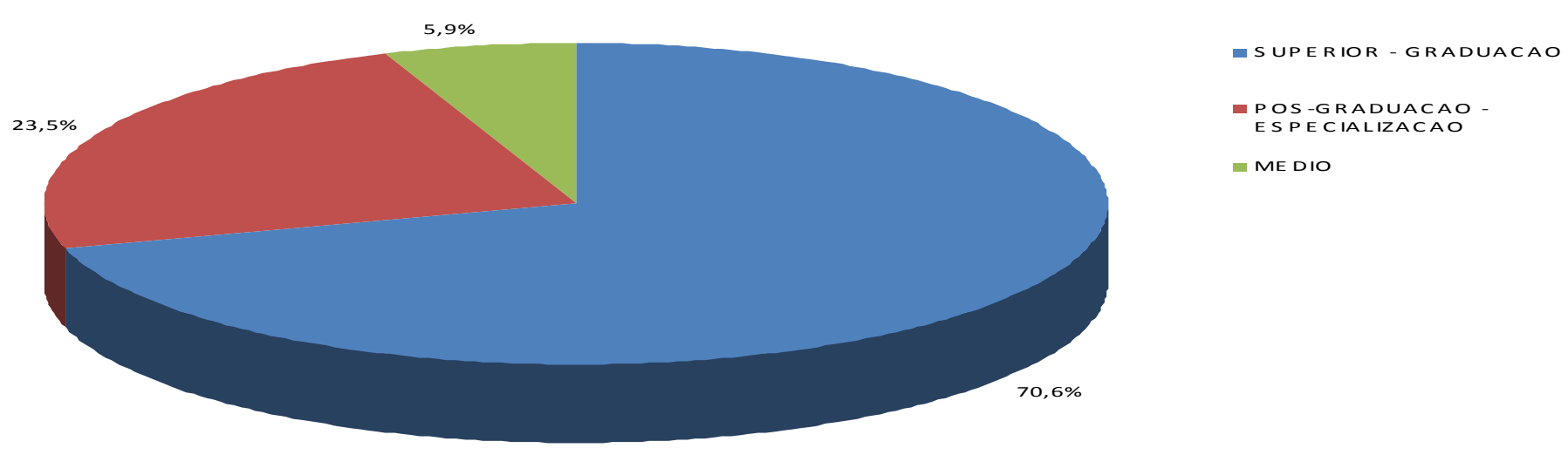




\section{Anexo 16 - Critérios de SeleÇÃo - Comparação entre Empresas}

\begin{tabular}{|c|c|c|}
\hline Petrobrás & Caixa Econômica Federal & Banco do Brasil \\
\hline \begin{tabular}{|l} 
Relevância (Diferencial do \\
projeto - exemplaridade, \\
caráter emergencial, \\
ineditismo, pioneirismo, \\
resgate histórico, potencial \\
transformador, alcance \\
regional, alcance público)
\end{tabular} & $\begin{array}{l}\text { Projetos de maior relevância } \\
\text { cultural, sendo prioritário o } \\
\text { critério de qualidade para } \\
\text { seleção. Relevância cultural - a } \\
\text { temática do projeto deve ser de } \\
\text { amplo interesse público e } \\
\text { contribuir para o enriquecimento } \\
\text { sociocultural da comunidade. }\end{array}$ & $\begin{array}{l}\text { Relevância Conceitual e } \\
\text { Temática = Concepção e } \\
\text { argumentação que evidenciem } \\
\text { importância histórica, cultural e } \\
\text { artística. }\end{array}$ \\
\hline $\begin{array}{l}\text { Mérito Qualitativo (mérito } \\
\text { intrínseco do projeto - análise } \\
\text { da relevância do conteúdo } \\
\text { proposto) }\end{array}$ & \multicolumn{2}{|c|}{$\begin{array}{l}\text { Qualidade do projeto ( concepção geral do espetáculo, currículo } \\
\text { dos integrantes, texto dramático ou roteiro) }\end{array}$} \\
\hline \multicolumn{3}{|l|}{ Exemplaridade } \\
\hline Ineditismo & & \multirow[t]{2}{*}{$\begin{array}{l}\square \text { Inovação = Originalidade e } \\
\text { ineditismo da proposta. }\end{array}$} \\
\hline Pionerismo & & \\
\hline \multicolumn{3}{|l|}{ Potencial Transformador } \\
\hline \multicolumn{3}{|l|}{ Alcance Regional } \\
\hline Alcance Público & $\begin{array}{l}\text { Expectativa de interesse do } \\
\text { público - O projeto deve ser de } \\
\text { interesse do público local ou ter } \\
\text { a capacidade de formar público } \\
\text { para aquele artista, grupo ou } \\
\text { tema específico. }\end{array}$ & $\begin{array}{l}\text { Potencial de Atratividade de } \\
\text { Público }\end{array}$ \\
\hline $\begin{array}{l}\text { Viabilidade técnica (viabilidade } \\
\text { de execução - clareza dos } \\
\text { objetivos propostos; } \\
\text { capacidade gerencial da } \\
\text { proponente; competência } \\
\text { técnica da equipe envolvida) }\end{array}$ & $\begin{array}{l}\text { Adequação aos espaços físicos } \\
\text { disponíveis - o espaço pleiteado } \\
\text { pelo projeto deve ser coerente } \\
\text { com sua concepção temática, } \\
\text { relevância e necessidade em } \\
\text { termos de dimensões espaciais. }\end{array}$ & $\begin{array}{l}\square \text { Adequação física = } \\
\text { Adaptabilidade aos espaços. }\end{array}$ \\
\hline $\begin{array}{l}\text { Viabilidade físico-financeira } \\
\text { (orçamento - adequação aos } \\
\text { objetivos propostos para o } \\
\text { projeto) }\end{array}$ & Adequação orçamentária & $\begin{array}{l}\square \text { Adequação financeira }= \\
\text { Compatibilidade com a } \\
\text { disponibilidade orçamentária e } \\
\text { preços praticados no mercado. }\end{array}$ \\
\hline Capacidade técnica & $\begin{array}{l}\text { Currículo do proponente - a } \\
\text { empresa ou instituição } \\
\text { proponente deve ser apta a } \\
\text { realizar o projeto pretendido, } \\
\text { tendo em seu histórico trabalhos } \\
\text { similares que comprovem sua }\end{array}$ & $\begin{array}{l}\text { Viabilidade Técnica = } \\
\text { Demonstração de capacidade } \\
\text { de realização ou envolvimento } \\
\text { de profissionais com notória } \\
\text { especialização. }\end{array}$ \\
\hline
\end{tabular}




\begin{tabular}{|c|c|c|}
\hline & capacidade realizadora & $\square$ \\
\hline \multicolumn{3}{|c|}{ Atividades continuadas de pesquisa } \\
\hline $\begin{array}{l}\text { Formas de interação com a } \\
\text { comunidade }\end{array}$ & \multicolumn{2}{|c|}{ Contribuição ao enriquecimento cultural da comunidade } \\
\hline Garantias de acesso público & & \\
\hline \multicolumn{3}{|c|}{ Intercâmbios com outras companhias } \\
\hline & \multicolumn{2}{|c|}{$\begin{array}{l}\text { Racionalização para ocupação dos espaços em função de } \\
\text { períodos previstos para montagens e as demais programações }\end{array}$} \\
\hline & & $\begin{array}{l}\square \text { Identidade Institucional = } \\
\text { Afinidade com princípios e } \\
\text { valores éticos, de transparência, } \\
\text { respeito e compromisso com a } \\
\text { comunidade e o País." }\end{array}$ \\
\hline $\begin{array}{l}\square \text { Faixa 1: até } \mathrm{R} \$ 200.000,00 \\
\text { (duzentos mil reais) por ano; } \\
\square \text { Faixa 2: até } \mathrm{R} \$ 350.000,00 \\
\text { (trezentos e cinqüenta mil } \\
\text { reais) por ano; e } \\
\square \text { Faixa 3: até } \mathrm{R} \$ 500.000,00 \\
\text { (quinhentos mil reais) por ano. }\end{array}$ & $\begin{array}{l}\text { Valor do projeto - O valor } \\
\text { solicitado pelo projeto deve ser } \\
\text { coerente com sua relevância, } \\
\text { com suas necessidades } \\
\text { estruturais e de recursos } \\
\text { humanos e com os valores } \\
\text { praticados pelo mercado. }\end{array}$ & Até $\mathrm{R} \$ 300.000,00$ por projeto \\
\hline
\end{tabular}


Anexo 17 - Artes Cênicas - Qtde. de Semestre em Cartaz, Período e Dias da Semana

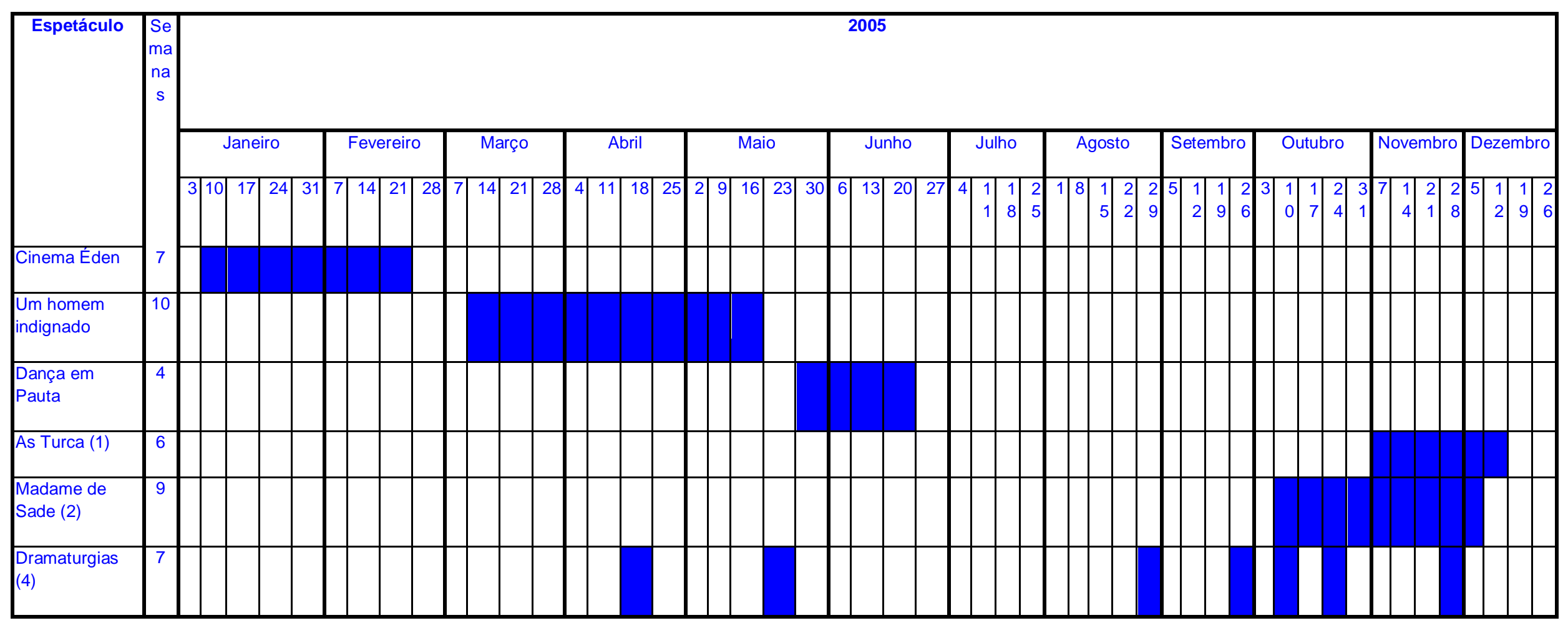




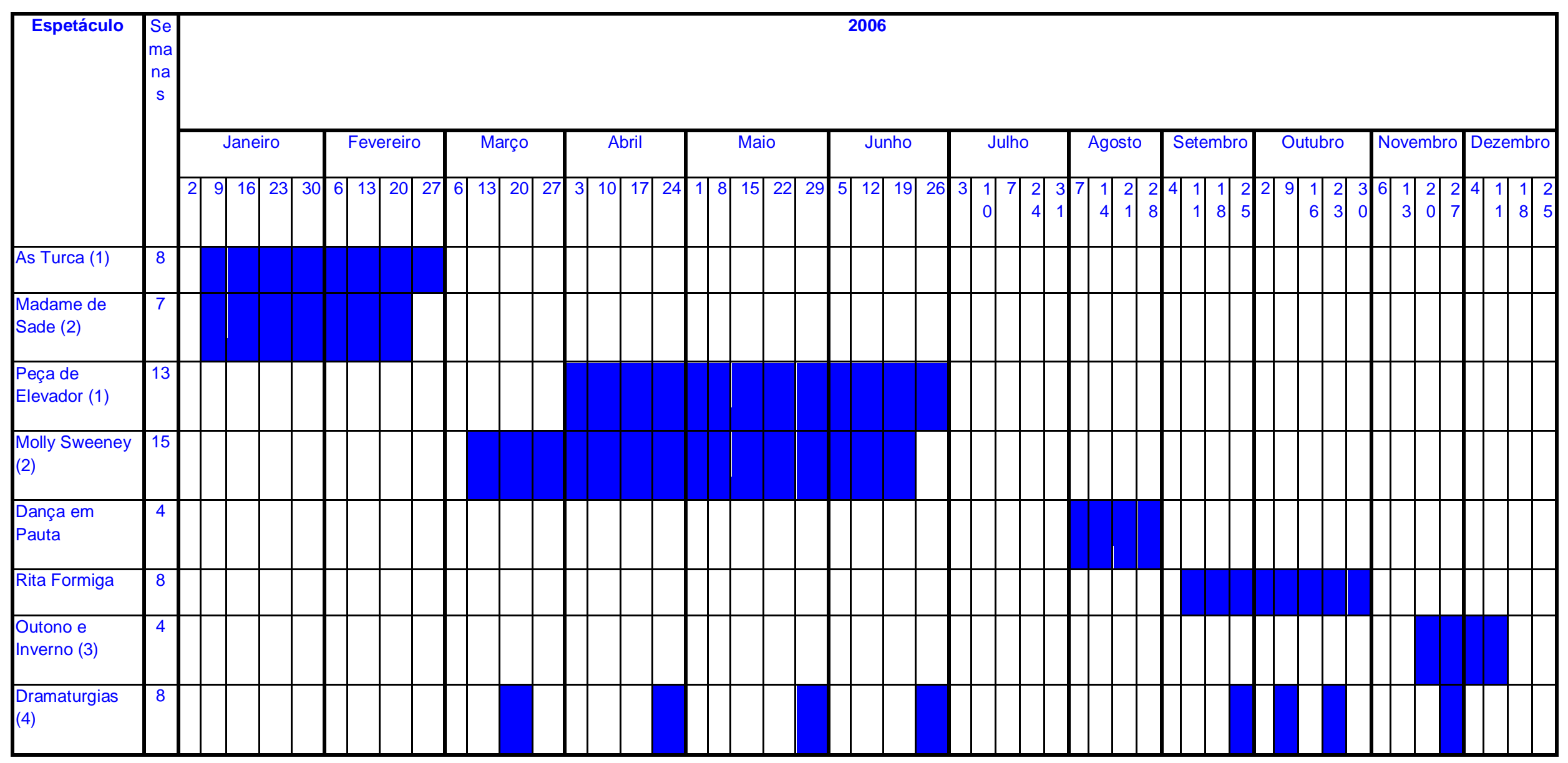


Anexo 18 - Artes Plásticas - Distribuição Espacial no CCBb e Período dos Exposições

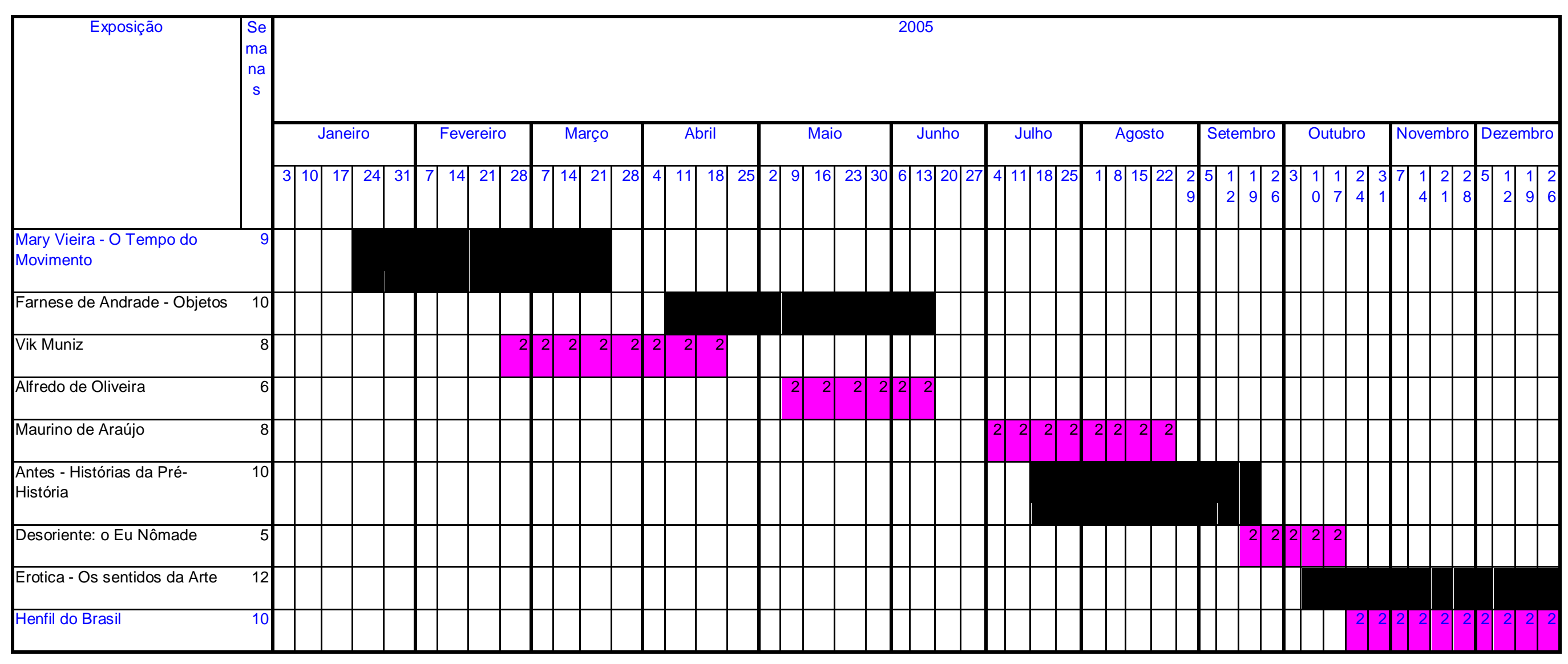




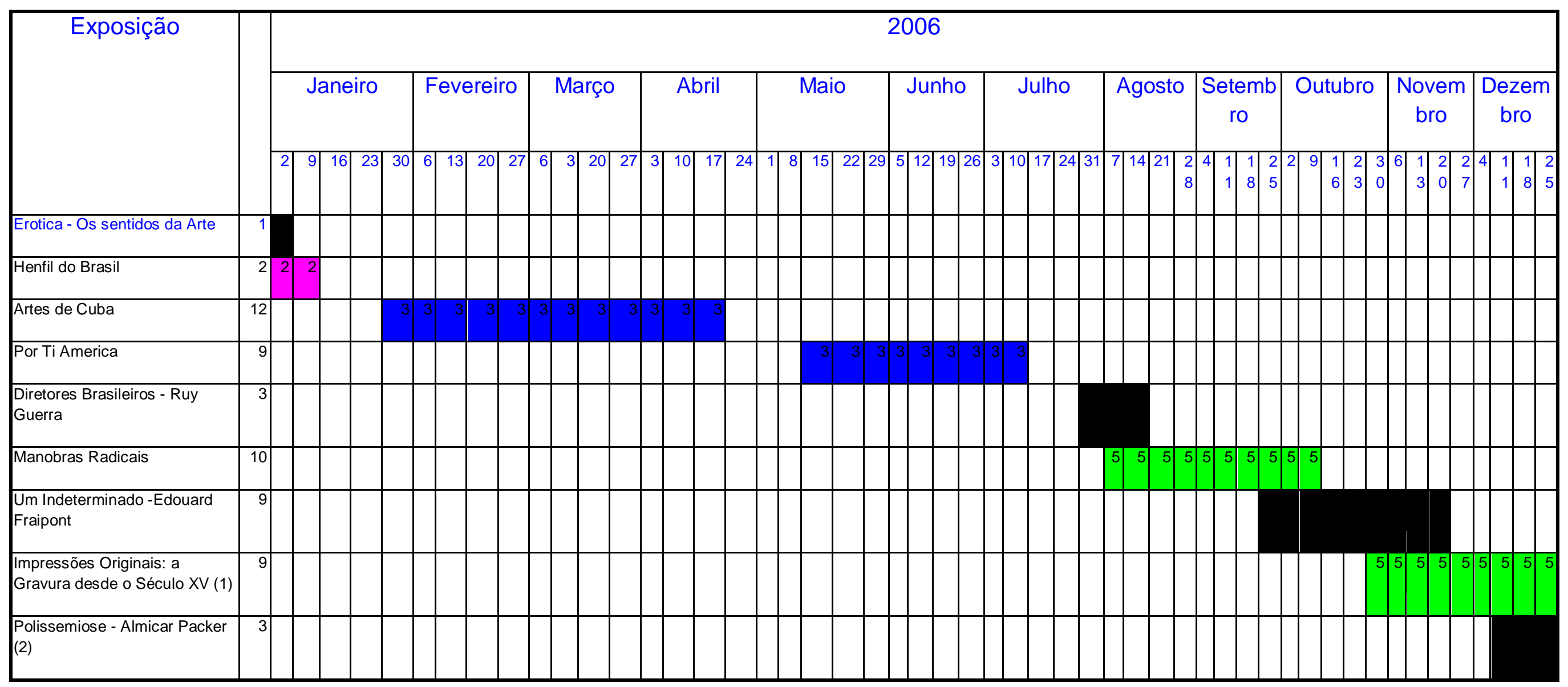




\section{AneXo 19 - SinOPSE dAs PeÇAS}

\begin{tabular}{|c|c|}
\hline As Turca & $\begin{array}{l}\text { As Turca é uma comédia dramática cuja ação se passa na cozinha de uma casa no } \\
\text { interior de São Paulo, onde três descendentes de libaneses - as irmãs Nura, Dulce e } \\
\text { Vitória, com respectivamente, } 40,50 \text { e } 60 \text { anos - preparam um típico almoço de família, } \\
\text { na expectativa do retorno de um sobrinho que foi estudar na Universidade Americana de } \\
\text { Beirute. Com um humor que conduz à reflexão, a peça da atriz Andrea Bassit retrata as } \\
\text { características da cultura árabe e sua influência na sociedade brasileira, o choque de } \\
\text { gerações, a decadência financeira de uma família e suas relações afetivas. Direção: } \\
\text { Regina Galdino. Com Cláudia Mello, Juçara Moraes e Andréa Bassit }\end{array}$ \\
\hline $\begin{array}{l}\text { Cinema } \\
\text { Éden }\end{array}$ & $\begin{array}{l}\text { Um casal de irmãos inicia um ritual de carícias sobre o corpo imóvel da mãe, na } \\
\text { tentativa de fazê-la voltar à sua vida de sonho. Exorcizam-na de suas dores e derrotas e } \\
\text { também de suas próprias culpas. Filha e filho estabelecem, então, uma narrativa } \\
\text { dolorosa, mas de imenso amor uns pelos outros e deixam-se embalar pelas lembranças } \\
\text { da história dessa mãe obstinada em busca de seu sonho. Cinema Éden é, sem dúvida, } \\
\text { a peça teatral mais representativa da obra de Marguerite Duras, um dos grandes } \\
\text { expoentes da literatura francesa. Adaptada de seu livro Un Barrage contre le Pacifique, } \\
\text { ela contém dados biográficos referentes à sua juventude na Indochina, às suas relações } \\
\text { amorosas e à forte presença de sua mãe e seus irmãos. Esses desenhos biográficos, } \\
\text { inseridos em situações ficcionais, revelaram-se a marca de toda sua obra. Trata-se de } \\
\text { um espetáculo dirigido principalmente a todos que possuem um sonho secreto, por mais } \\
\text { delirante que seja, e para aqueles que vêem na literatura e na poesia um caminho para } \\
\text { o conhecimento. T }\end{array}$ \\
\hline \begin{tabular}{|l|} 
Dança em \\
Pauta 2005
\end{tabular} & $\begin{array}{l}\text { O Dança em Pauta versão } 2005 \text { comemora um marco histórico da dança brasileira: os } \\
30 \text { anos de estréia do espetáculo Isso ou Aquilo (1975), que representou um rito de } \\
\text { passagem na carreira da bailarina e atriz Marilena Ansaldi, projetando-a como uma das } \\
\text { mais marcantes personalidades das artes cênicas do Brasil. Para resgatar a memória de } \\
\text { um período emblemático da dança brasileira, o Dança em Pauta traz Ansaldi de volta } \\
\text { aos palcos com o espetáculo Dessassossego, que recupera as interpretações solo que } \\
\text { aprofundaram a relação da bailarina-atriz com o teatro e certamente contribuirá para que } \\
\text { se ilumine o percurso de modernização da dança no País. O programa continua } \\
\text { reforçando suas premissas ao estimular talentos brasileiros, intercâmbios regionais e } \\
\text { internacionais, incluindo a América Latina. Confira também a Mostra de Audiovisual } \\
\text { Dança em Pauta. }\end{array}$ \\
\hline \begin{tabular}{|l|} 
Dança em \\
Pauta 2006
\end{tabular} & $\begin{array}{l}\text { A quarta edição da mostra Dança em Pauta do CCBB reafirma seu compromisso com a } \\
\text { dança brasileira por meio de criações que revelam a diversidade de propostas da } \\
\text { produção nacional, representada por autores que vivem no Brasil e no exterior. A } \\
\text { abertura do evento conta com Sonia Mota, artista que mudou-se para a Alemanha } \\
\text { depois de integrar movimentos de renovação da dança brasileira. Ainda na abertura, } \\
\text { uma nova geração de intérpretes apresenta uma coreografia da mineira Morena } \\
\text { Nascimento. Além de manter em foco a produção paulista, o Dança em Pauta de } 2006 \\
\text { traz espetáculos do Rio de Janeiro, Belo Horizonte e Brasília. Da França, vem a } \\
\text { companhia KassenK, dirigida pelo brasileiro Osman Khelili. Duas criações de São Paulo, } \\
\text { uma delas concebida pela dupla Mariana Muniz e Cláudia Palma, a outra por José Maria } \\
\text { Carvalho, sob direção de Hélio Cícero, terão como tema a obra de João Guimarães } \\
\text { Rosa, cuja obra máxima - Grande Sertão: Veredas - comemora } 50 \text { anos em } 2006 \text {. }\end{array}$ \\
\hline \begin{tabular}{|l|} 
Dramaturgi \\
as - 2005 - \\
Primeiro
\end{tabular} & $\begin{array}{l}\text { Dramaturgias é um programa regular do CCBB São Paulo voltado para a leitura de } \\
\text { textos dramatúrgicos seguida de debates. No primeiro semestre de } 2005 \text {, o ciclo O Olhar } \\
\text { Feminino na Dramaturgia Contemporânea aborda temas como a violência, a ética, a }\end{array}$ \\
\hline
\end{tabular}




\begin{tabular}{|c|c|}
\hline Semestre & $\begin{array}{l}\text { justiça, o trabalho e o amor, sob a ótica de diversas autoras contemporâneas. Em abril o } \\
\text { tema é Ética e Trabalho. Em maio, Desenraizamento. }\end{array}$ \\
\hline $\begin{array}{l}\text { Dramaturgi } \\
\text { as - } 2005 \text { - } \\
\text { Segundo } \\
\text { Semestre }\end{array}$ & $\begin{array}{l}\text { Dramaturgias é um programa regular do CCBB São Paulo voltado para a leitura de } \\
\text { textos dramatúrgicos seguida de debates. No segundo semestre de } 2005 \text {, o ciclo será } \\
\text { inspirado no universo da cultura popular. Coordenação geral de Neusa Andrade. Para } \\
\text { conferir a programação consulte o folder específico do evento. }\end{array}$ \\
\hline $\begin{array}{l}\text { Dramaturgi } \\
\text { as - } 2006 \text { - } \\
\text { Novos } \\
\text { Talentos }\end{array}$ & $\begin{array}{l}\text { Dramaturgias é um programa regular do CCBB São Paulo voltado para a leitura de } \\
\text { textos da literatura dramática contemporânea, seguida de debate com mediador, autor, } \\
\text { diretores e atores. Na sua quinta edição, enfoca a produção de artistas novos, que estão } \\
\text { no início de sua trajetória, mas que já apresentam trabalhos consistentes, intenso e } \\
\text { provocadores. Consultoria de Alberto Guzik (primeiro semestre) e Silvana Garcia } \\
\text { (segundo semestre) e direção geral de Neusa Andrade. }\end{array}$ \\
\hline $\begin{array}{l}\text { Madame } \\
\text { de Sade }\end{array}$ & $\begin{array}{l}\text { Madame de Sade, de Yukio Mishima, investiga, por intermédio do universo feminino, } \\
\text { acontecimentos históricos da vida do aristocrata francês Marquês de Sade, célebre no } \\
\text { século XVIII por seus textos pornográficos, sua vida sexual e posições políticas amorais. } \\
\text { Contrariando todas as expectativas, Renée, a Madame de Sade, parecia apaixonada } \\
\text { pelo marido e com ele chegou ao limite de sua moralidade e imaginação. Para muitos } \\
\text { biógrafos, e especialmente para Mishima, Renée, uma mulher absolutamente fiel, agiu } \\
\text { de forma inesperada e incompreensível quando o Maruês foi posto em liberdade após } \\
\text { anos de prisão. Convencido de que algo incompreensível, mas absolutamente } \\
\text { verdadeiro, sobre a natureza humana se escondia atrás do contraditório comportamento } \\
\text { da mulher, Mishima escreveu esta obra na tentativa de desvendar este enigma. Texto: } \\
\text { Yukio Mishima. Direção: Roberto Lage. }\end{array}$ \\
\hline $\begin{array}{l}\text { Molly } \\
\text { Sweeney - } \\
\text { Um rastro } \\
\text { de luz }\end{array}$ & $\begin{array}{l}\text { História inspirada em um caso narrado pelo neurologista Oliver Sacks, em que a } \\
\text { personagem Molly Seeney, portadora de um tipo de visão parcial, enxerga apenas } \\
\text { vultos. Seu marido, Frank, é um irlandês sonhador e desastrado sempre às voltas com } \\
\text { esquemas para enriquecer, que sempre se frustram. Ele traz um oculista que já fora } \\
\text { célebre nos EUA, mas agora é um alcóolatra tentando esquecer a mulher que o traiu, } \\
\text { para restituir a visão de Molly por meio de uma cirurgia. O marido vê na cura de Molly } \\
\text { uma causa de sucesso e o cirurgião acredita que recobraria a fama e, quem sabe, sua } \\
\text { mulher. Mesmo satisfeita com seu mundo e sabendo que os dois a usam, ela faz a } \\
\text { operação. Molly começa a ver, mas se amedronta com o novo mundo. Texto de Brian } \\
\text { Firel, adaptado por João Bethencourt. Direção de Celso Nunes, com Julia Lemmertz, } \\
\text { Ednei Giovenazzi e Orã Figueiredo. }\end{array}$ \\
\hline \begin{tabular}{|l} 
Outono e \\
Inverno
\end{tabular} & $\begin{array}{l}\text { A peça do sueco Lars Norén é uma pequena obra-prima que mergulha na alma humana. } \\
\text { A ação se passa num almoço em que a roupa suja é lavada entre as duas filhas } \\
\text { quarentonas e os pais, num contraponto entre duas fases da via (daí o título). Um } \\
\text { diálogo contundente e impactante. No elenco, Suely Franco, Sérgio Brito e duas } \\
\text { premiadas atrizes da nova geração que fizeram carreira no Grupo Tapa: Emília Rei e } \\
\text { Denise Weinberg. Direção de Eduardo Tolentino. Duração: } 120 \text { minutos }\end{array}$ \\
\hline $\begin{array}{l}\text { Peça de } \\
\text { Elevador }\end{array}$ & $\begin{array}{l}\text { A Cia. Elevador de Teatro Panorâmico, dirigida por Marcelo Lazaratto, comemora cinco } \\
\text { anos de existência com novo espetáculo. A peça tem coo cenário dois elevadores, } \\
\text { escolhidos por se encaixarem na pesquisa dramatúrgica em torno de temas do cotidiano } \\
\text { de uma grande metrópole, onde os indivíduos estão sempre em trânsito. O texto, } \\
\text { assinado por Cássio Pires, surgiu desse longo processo criativo e conta diferentes } \\
\text { histórias, de forma fragmentada, de acordo com os tempos de subida e descida dos } \\
\text { elevadores, que conduzem e espionam os personagens e suas questões. Além das }\end{array}$ \\
\hline
\end{tabular}




\begin{tabular}{|l|l|}
\hline & $\begin{array}{l}\text { características cotidianas de um edifício comercial, nesse prédio os elevadores podem } \\
\text { conduzir até andares fantásticos, que nem suspeitamos existir. O elevador é retratado } \\
\text { como um espaço de passagem, de espera, coo um espaço que não é, ao menos a } \\
\text { priori, o início nem o fim de nada, mas o meio, o 'entre' uma coisa e outra. Texto: Cássio } \\
\text { Pires. Direção: Marcelo Lazzaratto. Com Ademir Emboava, Carolina Fabri, Gabriel } \\
\text { Mizziara, Heloisa Cintra, Juliana Pi }\end{array}$ \\
\hline Formiga & $\begin{array}{l}\text { Rita Formiga é o encontro inédito do consagrado dramaturgo e diretor Domingos de } \\
\text { Oliveira com a jovem e talentosa atriz Guta Stresser, que contracena com Cláudio Tizo } \\
\text { nesta comédia com pitadas de drama e que trata da estranha relação de Rita, uma } \\
\text { jovem atriz, frustrada e sonhadora, com seu vizinho escritor. Ao longo da peça, ela conta } \\
\text { suas peripécias amorosas, frustrações, expectativas com relação à vida e ao mundo. A } \\
\text { estória se passa no final da década de } 60 \text { e retrata seu universo de jovens sonhadores e } \\
\text { aspirantes a artistas. Rita Formiga traz ao público os problemas vividos pelos jovens de } \\
\text { qualquer época: amores frustrados, amizade, trabalho, frustrações, e a eterna busca } \\
\text { pela felicidade. Texto de Domingos de Oliveira e Maria Gladis. Direção de Domingos de } \\
\text { Oliveira. Com Guta Stresser e Cláudio Tizo. }\end{array}$ \\
\hline $\begin{array}{l}\text { Um homem } \\
\text { indignado }\end{array}$ & $\begin{array}{l}\text { Escrito e interpretado pelo ator Walmor Chagas - que completa } 55 \text { anos de carreira em } \\
\text { 2005 - o espetáculo traça um panorama psicológico de um ator sexagenário, angustiado } \\
\text { com a cada vez mais gritante realidade política, artística e profissional do País e do } \\
\text { mundo. O embate entre o outrora mundo regido pelas palavras e o mundo criado após o } \\
\text { advento da televisão, onde as imagens soberanas, está no centro do conflito que } \\
\text { envolve ainda a questão da terceira idade e do teatro contemporâneo. O homem aluga } \\
\text { um estúdio para realizar seu próprio 'reality show': um suicídio diante da câmera. } \\
\text { Direção do também cineasta Djalma Limongi Batista. }\end{array}$ \\
\hline
\end{tabular}




\section{Anexo 20 - Artes Cênicas: Ficha Técnica, Qtde de Apresentações e Valores Patrocinados}

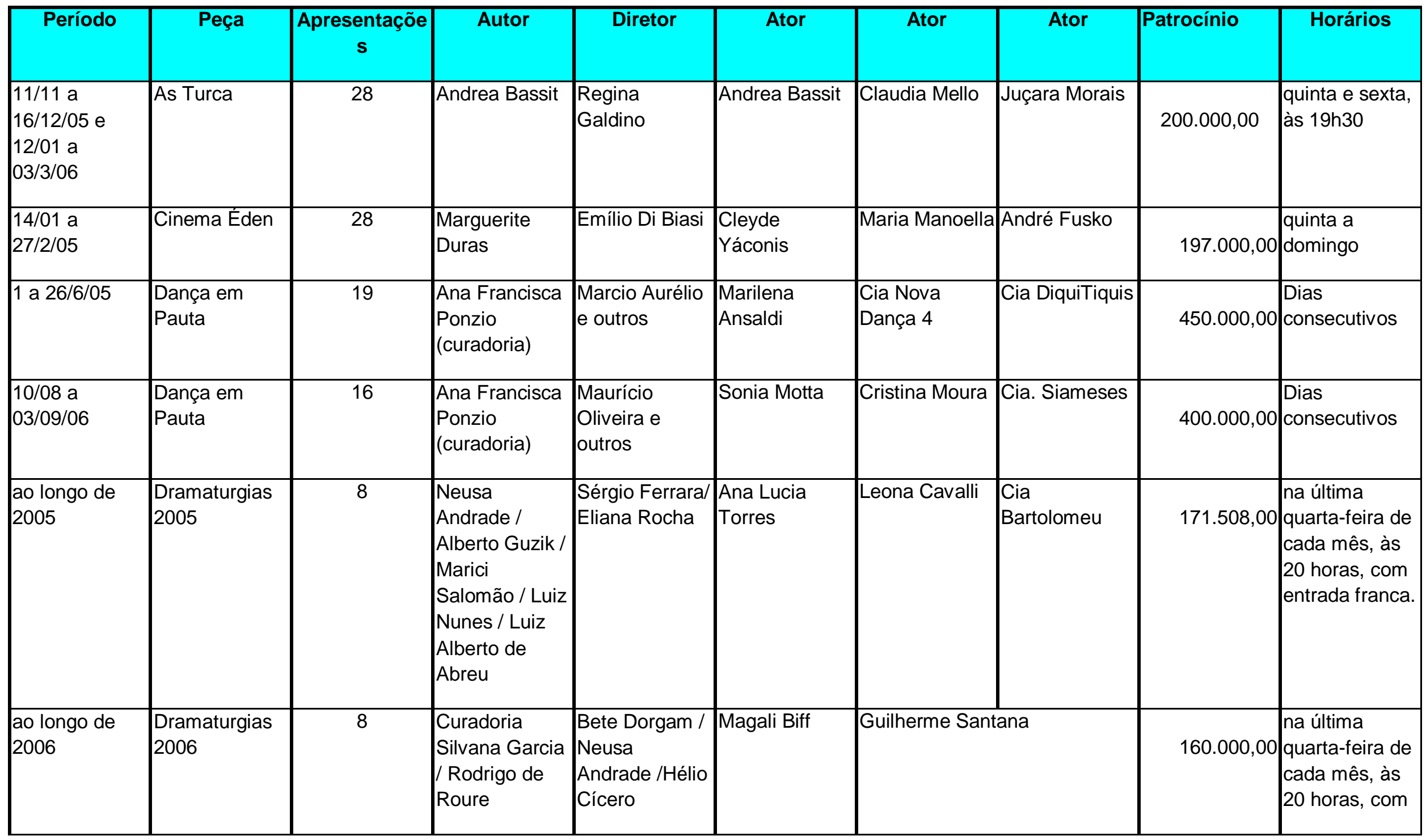




\begin{tabular}{|c|c|c|c|c|c|c|c|c|c|}
\hline & & & & & & & & & entrada franca. \\
\hline $\begin{array}{l}15 / 10 a \\
11 / 12 / 05 \text { e de } \\
14 / 01 a \\
26 / 2 / 06\end{array}$ & $\begin{array}{l}\text { Madame de } \\
\text { Sade }\end{array}$ & 33 & Yukio Mishima & Roberto Lage & Barbara Paz & Imara Reis & Jerusa Franco & $300.000,00$ & \begin{tabular}{|l} 
Sábados e \\
Domingos, às \\
$19 \mathrm{~h} 30$
\end{tabular} \\
\hline \begin{tabular}{|l|}
$18 / 03 a$ \\
$25 / 6 / 06$
\end{tabular} & $\begin{array}{l}\text { Molly Sweeney } \\
\text { - Um rastro de } \\
\text { luz }\end{array}$ & 33 & Brian Friel & Celso Nunes & Julia Lemmertz & $\begin{array}{l}\text { Ednei } \\
\text { Giovenazzzi }\end{array}$ & Orã Figueiredo & $260.000,00$ & $\begin{array}{l}\text { sábados e } \\
\text { domingos }\end{array}$ \\
\hline \begin{tabular}{|l}
$06 / 04 a$ \\
$30 / 6 / 06$
\end{tabular} & $\begin{array}{l}\text { Peça de } \\
\text { Elevador }\end{array}$ & 26 & Cassio Pires & \begin{tabular}{|l|} 
Marcelo \\
Lazaratto
\end{tabular} & $\begin{array}{l}\text { Ademir } \\
\text { Emboava }\end{array}$ & Carolina Fabri & $\begin{array}{l}\text { Gabriel } \\
\text { Mizziara }\end{array}$ & $200.000,00$ & $\begin{array}{l}\text { quintas e } \\
\text { sextas }\end{array}$ \\
\hline $17 / 3$ a $22 / 5 / 05$ & $\begin{array}{l}\text { Um homem } \\
\text { indignado }\end{array}$ & 40 & $\begin{array}{l}\text { Walmor } \\
\text { Chagas }\end{array}$ & \begin{tabular}{|l} 
Djalma \\
Limongi Batista
\end{tabular} & $\begin{array}{l}\text { Walmor } \\
\text { Chagas }\end{array}$ & Camila Amado & & $307.481,17$ & $\begin{array}{l}\text { quinta a } \\
\text { sábado, ás } 20 \\
\text { horas e } \\
\text { domingo às } 19 \\
\text { horas }\end{array}$ \\
\hline
\end{tabular}




\section{Anexo 21 - Prêmio Shell de Teatro de São Paulo- Principais CATEGORIAS}

\begin{tabular}{|l|l|l|l|l|}
\hline Ano & Diretor & Autor & Ator & Atriz \\
\hline 2007 & Cibele Forjaz & Dib Carneiro & Rodolfo Vaz & Lúcia Romano \\
\hline 2006 & Antônio Araújo & Sérgio Roveri & Marat Descartes & Georgette Fadel \\
\hline 2005 & $\begin{array}{l}\text { Rodolfo Garcia } \\
\text { Vasquez }\end{array}$ & Grace Passô & Norival Rizzo & Denise Weinberg \\
\hline 2004 & Cristiane Paoli-Quito & Newton Moreno & Luís Damasceno & Marília Pêra \\
\hline 2003 & $\begin{array}{l}\text { Marco Antônio } \\
\text { Rodrigues }\end{array}$ & $\begin{array}{l}\text { Luís Alberto de } \\
\text { Abreu }\end{array}$ & Cacá Carvalho & Fernanda Torres \\
Corrêa & Bosco Brasil & Dan Stuhlbach & Juliana Galdhino \\
\hline
\end{tabular}

Fonte: www.shell.com, consultado em 22/09/08 


\section{Anexo 22 - Jurados do Prêmio Shell de SÃo Paulo}

\begin{tabular}{|l|c|}
\hline \multicolumn{1}{|c|}{ NISTÓRICO DOS JURADOS DO PRÉMIO SHELL DE } \\
TEATRO
\end{tabular}




\section{Anexo 23 - Sinopse das Exposições de ArTes Plásticas}

\begin{tabular}{|c|c|}
\hline Alfredo de Oliveira & $\begin{array}{l}\text { Alfredo de Oliveira (Campinas/SP, 1953) é autodidata e trabalhou por } \\
\text { cerca de } 20 \text { anos como economista. Na década de } 80 \text {, depois de assumir } \\
\text { sua carreira artística, que alimentava como hobby desde os seus } 13 \text { anos } \\
\text { de idade, Alfredo fez viagens a vários países, vivenciando suas culturas e } \\
\text { artes. O resultado dessa pesquisa revela uma produção madura e centrada } \\
\text { sobremaneira no concretismo, fonte de inspiração e referência ao artista, } \\
\text { que atualmente vive e trabalha na capital paulista. Nesta exposição, } \\
\text { composta de } 50 \text { obras em guache sobre papel, Alfredo apresenta suas } \\
\text { geometrias, novos planos e sensações em cores criadas a partir de várias } \\
\text { combinações e nuances, com exceção do branco, em um trabalho } \\
\text { intimista, realizado em pequenos formatos. }\end{array}$ \\
\hline $\begin{array}{l}\text { Antes - Histórias da } \\
\text { Pré-História }\end{array}$ & $\begin{array}{l}\text { Esta exposição, que chega a São Paulo depois de grande sucesso nos } \\
\text { CCBBs do Rio de Janeiro e Brasília, reúne artefatos, objetos de arte e } \\
\text { achados arqueológicos. As histórias da pré-história do Brasil, pouco } \\
\text { conhecidas do grande público, são contadas por meio de documentação } \\
\text { em mídia, filmes, esqueletos, evidências históricas e da paisagem nacional } \\
\text { que antecede aos índios. Com a curadoria de Niéde Guidon e Anne-Marie } \\
\text { Pessis, a reunião de desenhos, gravuras, pinturas, esculturas, cerâmicas } \\
\text { de dois, } 10,20 \text { ou } 30 \text { mil atrás diz respeito à emocionante aventura do } \\
\text { homem de se expressar, de deixar a sua marca, imemorial, anônima, } \\
\text { porém eterna e singular. }\end{array}$ \\
\hline Artes de Cuba & $\begin{array}{l}\text { A exposição Arte de Cuba apresenta o mais significativo conjunto de peças } \\
\text { cubanas já vistas fora da llha, abrangendo desde o surgimento das } \\
\text { vanguardas, quando a produção artística cubana ganhou de fato uma } \\
\text { identidade própria, até as manifestações contemporâneas. Na mostra } \\
\text { destacam-se vários momentos: o surgimento e a consolidação da arte } \\
\text { moderna nas primeiras décadas do século passado, os movimentos } \\
\text { abstratos, a pluralidade estética, que acompanha as mudanças da } \\
\text { revolução nos anos } 60 \text { e } 70 \text {, e a renovação e experimentação } \\
\text { características dos anos } 80 \text { até hoje. A mostra oferece um extenso } \\
\text { panorama da arte cubana desde o século XX, composta por } 61 \text { artistas, } \\
\text { entre eles: Wilfredo Lam, Marcelo Pogolotti, Luis Martinez Pedro, Raúl } \\
\text { Martínez, Flavio Garciandia, Lázaro Saavedra e Carlos Garaicoa. } \\
\text { Curadoria de Ania Rodríguez. }\end{array}$ \\
\hline $\begin{array}{l}\text { Desoriente: o Eu } \\
\text { Nômade }\end{array}$ & $\begin{array}{l}\text { A exposição de fotografias de Leonardo Kossoy leva o espectador a uma } \\
\text { volta ao mundo, do oriente ao ocidente europeu, do hemisfério sul ao } \\
\text { hemisfério norte, de um deslocamento a outro. Começa e termina em } \\
\text { movimento: pernas andando por um mercado do mundo, uma revoada de } \\
\text { pássaros em algum outro canto da Terra. No meio tempo, nos leva de } \\
\text { paraíso tropical para paraíso europeu, de cidade para o campo e de volta, } \\
\text { uma fragmentada relação social para outra, (des) construindo no seu } \\
\text { caminho a relação entre o olhar em movimento da câmera e o alvo móvel } \\
\text { do Eu psicológico. A curadoria é de Carol Armstrong, tutora do Programa } \\
\text { de Estudos Independentes do Whtiney Museum de Nova York e professora } \\
\text { pela Universidade de Princetown, EUA. }\end{array}$ \\
\hline
\end{tabular}




\begin{tabular}{|c|c|}
\hline $\begin{array}{l}\text { Erotica - Os } \\
\text { sentidos da Arte }\end{array}$ & $\begin{array}{l}\text { A exposição com curadoria do Prof. Dr. Tadeu Chiarelli revela como as } \\
\text { questões relativas ao erotismo foram e vêm sendo abordadas por artistas e } \\
\text { artesãos das mais diversas épocas e momentos históricos. A exposição, } \\
\text { que conta com mais de } 100 \text { obras, explora esses temas, estritamente no } \\
\text { campo da arte e da estética, demonstrando que as questões da } \\
\text { sexualidade e do erotismo podem guardar uma dimensão que transcende } \\
\text { a atual banalização. Para tanto, apresenta obras de importantes artistas } \\
\text { brasileiros e estrangeiros como Pablo Picasso, Tunga, Auguste Rodin, } \\
\text { Ismael Nery, Eric Fischl, Eliseu Visconti, Edgard de Souza, Nan Goldin, } \\
\text { entre outros, do passado mais remoto até a atualidade mais premente, } \\
\text { formando um panorama expressivo da questão do erotismo na arte. } \\
\text { Recomendável para maiores de } 12 \text { anos. }\end{array}$ \\
\hline \begin{tabular}{|l|} 
Farnese de \\
Andrade - Objetos
\end{tabular} & $\begin{array}{l}\text { Esta exposição apresenta um dos mais singulares representantes das } \\
\text { artes plásticas brasileiras, o mineiro Farnese de Andrade (Araguari/MG, } \\
1926 \text { - Rio de Janeiro/RJ, 1996). Sua obra, adormecida há mais de duas } \\
\text { décadas, revela parte do revés do movimento da arte concreta no Brasil, } \\
\text { que tem sua supremacia desde os meados dos anos } 50 \text {. Farnese, laureado } \\
\text { com vários prêmios coo desenhista e gravador, iniciou suas 'construções' } \\
\text { em 1964, atividade essa que exerceria até o final de sua vida. As } \\
\text { 'construções', tema único desta exposição, são apresentadas através do } \\
\text { conjunto de } 1390 \text { objetos, o que permite registrar a amplitude do universo } \\
\text { particular do artista. }\end{array}$ \\
\hline Henfil do Brasil & $\begin{array}{l}\text { Mostra inédita que reúne acervo com mais de } 400 \text { desenhos originais do } \\
\text { artista Henrique de Souza Filho, o Henfil (1944-1988), cartunista, } \\
\text { quadrinhista e colaborador do histórico jornal O Pasquim, além de fotos, } \\
\text { imagens, frases, publicações e depoimentos. Por meio de seu traço } \\
\text { econômico e de elevada expressividade, criou personagens tipicamente } \\
\text { brasileiros em favor das críticas ao autoritarismo e às mazelas sociais, } \\
\text { contribuindo, assim, para a recriação do desenho de humor politicamente } \\
\text { engajado. Curadoria de Paulo Sérgio Duarte e Júlia Peregrino. }\end{array}$ \\
\hline $\begin{array}{l}\text { Impressões } \\
\text { Originais: a } \\
\text { Gravura desde o } \\
\text { Século XV }\end{array}$ & $\begin{array}{l}\text { A exposição apresenta obras-primas da gravura universal, criadas por } \\
\text { vários artistas. Gênios da arte como Holbein, Jacques Calot e Albrecht } \\
\text { Dürer, entre outros representam os séculos XV e XVI. Também estão } \\
\text { presentes obras de Rembrandt e Goltzius, como expoentes do realismo do } \\
\text { Século de Outro nos Países Baixos. Hogarth e Piranesi representam a } \\
\text { elegância do século XVIII. O Romanticismo e a Revolução do } \\
\text { Impressionismo são achados nas obras de Goya, Daumier, Toulouse } \\
\text { Lautrec. O despertar da arte moderna é evidenciado nas obras de James } \\
\text { Ensor e, por fim, a arte moderna mostra seu vigor nas gravuras do século } \\
\text { XX com Beckmann, Kandisky, Morandi e Picasso. Em seu conjunto, as } \\
\text { gravuras desses e de outros mestres permitem um entendimento da } \\
\text { evolução da história da arte em papel, do século XV ao XX. Curadoria de } \\
\text { Carlos Martins, Valeria Piccoli e Pieter Tjabbes. }\end{array}$ \\
\hline Manobras Radicais & $\begin{array}{l}\text { Com curadoria do crítico de arte Paulo Herkenhoff e da professora Heloisa } \\
\text { Buarque de Hollanda, a exposição Manobras Radicais apresenta o } \\
\text { resultado de uma reflexão sobre um movimento e um desvio na arte } \\
\text { brasileira: as singularidades e diferenças de gêneros estabelecidos por } \\
\text { artistas mulheres. A mostra reúne obras de mais de } 40 \text { artistas, entre elas } \\
\text { Nair de Teffé, Anita Malfatti, Tarsila do Amaral, Maria Martins, Lygia Clark, }\end{array}$ \\
\hline
\end{tabular}




\begin{tabular}{|c|c|}
\hline & $\begin{array}{l}\text { Anna Maria Maiolino, Lygia Pape, Mira Schendel, Iole de Freitas, Jac } \\
\text { Leirner, Leda Catunda, Lenora de Barros, Brígida Baltar, Rosana Palazyan } \\
\text { e Adriana Varejão. }\end{array}$ \\
\hline $\begin{array}{l}\text { Mary Vieira - O } \\
\text { Tempo do } \\
\text { Movimento }\end{array}$ & $\begin{array}{l}\text { Mary Vieira (1927-2001) é considerada internacionalmente uma das } \\
\text { pioneiras da arte cinética, que propõe uma interação do público com as } \\
\text { obras de arte que se movem e se transformam. Estudou na Escola de Ulm } \\
\text { - Alemanha e, embora nascida em São Paulo, viveu a maior parte de sua } \\
\text { vida entre Itália e Suiça, onde foi professora de Estruturação do Espaço, na } \\
\text { Kunstgewerbeschülle, na Basiléia. Mary Vieira também recebeu vários } \\
\text { prêmios internacionais como designer gráfica e realizou obras } \\
\text { monumentais em Zurique e Basiléia, na Suiça, e em Brasília e São Paulo, } \\
\text { no Brasil. A exposição reúne um conjunto de obras inédito para o público } \\
\text { brasileiro, vindo da Itália e da Suiça, e obras das principais instituições } \\
\text { brasileiras, como Museu de Arte Moderna de São Paulo (MAM-SP), Museu } \\
\text { de Arte Moderna do Rio de Janeiro (MAM-RJ) e Museu de Arte Brasileira } \\
\text { da Fundação Armando Álvares Penteado (MAB-FAAP). São apresentas } \\
\text { também peças gráficas, fotos de obras públicas e dois filmes sobre a } \\
\text { artista. A exposição cria a possibilidade para o }\end{array}$ \\
\hline Maurino de Araújo & $\begin{array}{l}\text { Em sua primeira exposição individual na cidade de São Paulo, o escultor } \\
\text { mineiro Maurino de Araújo (Rio Casca / MG, 1943) apresenta cerca de } 40 \\
\text { esculturas. A rigor, Maurino é o que se chama um "toreuta", um daqueles } \\
\text { artistas-artesãos que, ao longo da história, escavam imagens } \\
\text { tridimensionais em blocos de madeira, geralmente destinadas ao culto } \\
\text { religioso. Maurino mostra peças pequenas e coloridas, em tons intensos, } \\
\text { predominando o azul-marinho e bordô, talhadas com gestos vigorosos e } \\
\text { acentuadas deformações expressivas. O resultado de mais de } 30 \text { anos de } \\
\text { carreira do artista pode ser conferido com exclusividade nesta exposição, } \\
\text { com curadoria de Olívio Tavares de Araújo. }\end{array}$ \\
\hline Polissemiose & $\begin{array}{l}\text { Para essa exposição, o artista que vive e produz em São Paulo, conjugou } \\
\text { fotografias, vídeos, registros de performances e uma instalação criada para } \\
\text { o cofre do edifício do CCBB. Os trabalhos apresentados são inéditos e } \\
\text { geram uma discussão sobre o corpo e o espaço como experiência e } \\
\text { linguagem. O título da exposição deriva da composição das palavras } \\
\text { polissemia (a propriedade que uma mesma palavra tem de apresentar } \\
\text { vários significados) e semiose (termo que o semiótico inglês Charles Pierce } \\
\text { introduziu para designar o processo de significação das palavras, a } \\
\text { produção de significados). }\end{array}$ \\
\hline Por Ti America & $\begin{array}{l}\text { A arqueologia revelou evidências de uma ocupação do território americano } \\
\text { que nos convidam a viajar por mais de } 15 \text { mil anos no passado. Nesse } \\
\text { percurso, história, arqueologia, matemática, astronomia, linguística e } \\
\text { sociologia unem-se na busca de uma compreensão de nossos } \\
\text { antepassados, cuja história representa o tema dessa exposição. Objetos } \\
\text { de valor artístico dos principais museus de arqueologia e instituições da } \\
\text { Argentina, Brasil, Chile, Colômbia, Guatemala, México e Peru evidenciam a } \\
\text { sofisticação intelectual, cultural e tecnológica das sociedade pré- } \\
\text { colombianas e trazem os testemunhos da magnitude do passado indígena } \\
\text { da América. Depois de realizada no CCBB Rio de Janeiro e no CCBB } \\
\text { Brasília, a exposição chega a São Paulo, com duas obras inéditas, as }\end{array}$ \\
\hline
\end{tabular}




\begin{tabular}{|l|l|}
\hline Edouard Fraipont & Estelas que são grandes blocos de pedra. Curadoria: Marcia Arcuri. \\
\hline $\begin{array}{l}\text { Um Indeterminado - } \\
\text { o fotógrafo paulistano apresenta seres improváveis, transfigurados, com } \\
\text { seus corpos redesenhados ou velados a partir de uma escrita de luz na } \\
\text { captação fotográfica, em áreas internas, fechadas e urbanas. No exterior } \\
\text { do cofre, são exibidas figuras que se encontram em amplas paisagens } \\
\text { noturnas à beira mar, agindo nesse espaço cósmico com a forte presença } \\
\text { luminosa da lua e de estrelas. }\end{array}$ \\
\hline $\begin{array}{ll}\text { Vik Muniz -Divas e } \\
\text { Monstros }\end{array}$ & $\begin{array}{l}\text { Vik Muniz apresenta, nesta exposição que inaugura o espaço do 10 andar } \\
\text { do CCBB, uma série de 12 fotografias intitulada Divas e Monstros. Os } \\
\text { retratos de divas cinematográficas realizados em diamantes e os monstros } \\
\text { de Hollywood em caviar representam o trabalho mais recente desse artista } \\
\text { brasileiro nascido em São Paulo, em 1961, e um dos nomes mais } \\
\text { aclamados da arte contemporânea internacional. Vik Muniz é um mestre da } \\
\text { representação ilusória, do desenho, do trompe-I'oeil. Já utilizou materiais } \\
\text { dos mais efêmeros (chocolate, açúcar, poeira, entre outros) para criar suas } \\
\text { imagens. Em Divas e Monstros, é a textura densa e negra do caviar que } \\
\text { pontua a feiúra de Frankenstein, de Drácula, da Múmia e do Fantasma da } \\
\text { Ópera e a resplandecência dos diamantes brancos que iluminam o rosto } \\
\text { de Maria Callas, Grace Kelly, Sophia Loren, Brigitte Bardot, Liz Taylor, } \\
\text { Catherine Deneuve, Romy Schneider e Monica Vitti. }\end{array}$ \\
\hline
\end{tabular}


Anexo 24 - Artes Plásticas: Ficha Técnica, localização no Prédio, Valores Patrocinados, Duração

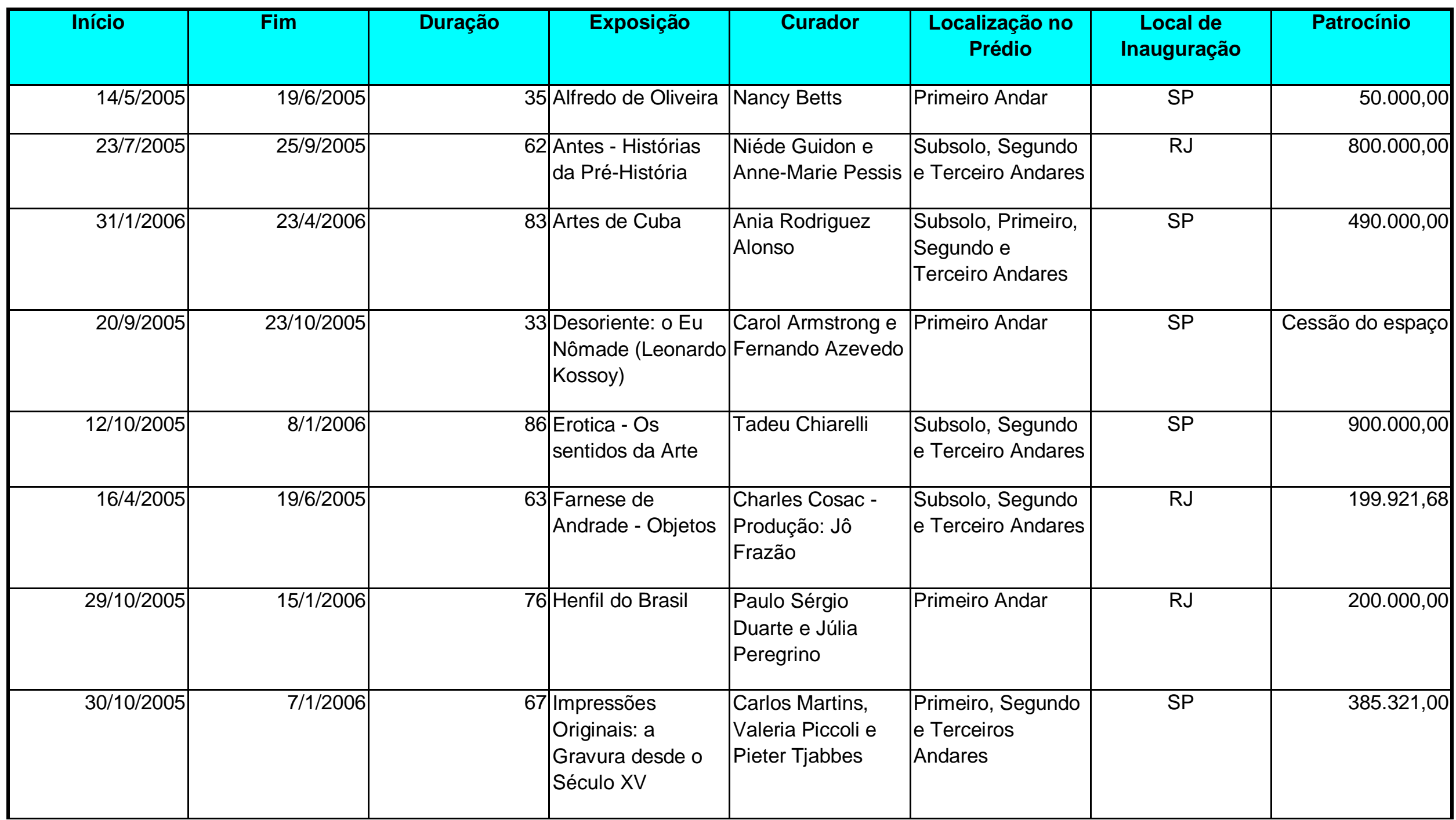




\begin{tabular}{|c|c|c|c|c|c|c|c|}
\hline Início & Fim & Duração & Exposição & Curador & $\begin{array}{l}\text { Localização no } \\
\text { Prédio }\end{array}$ & $\begin{array}{c}\text { Local de } \\
\text { Inauguração }\end{array}$ & Patrocínio \\
\hline $8 / 8 / 2006$ & $15 / 10 / 2006$ & 67 & Manobras Radicais & $\begin{array}{l}\text { Paulo Herkenhoff e } \\
\text { Heloisa Buarque } \\
\text { de Hollanda }\end{array}$ & $\begin{array}{l}\text { Primeiro, Segundo } \\
\text { e Terceiros } \\
\text { Andares }\end{array}$ & SP & $388.000,00$ \\
\hline $29 / 1 / 2005$ & $27 / 3 / 2005$ & 58 & $\begin{array}{l}\text { Mary Vieira - O } \\
\text { Tempo do } \\
\text { Movimento }\end{array}$ & Denise Mattar & \begin{tabular}{|l|} 
Subsolo, Segundo \\
e Terceiro Andares
\end{tabular} & SP & $299.939,75$ \\
\hline 12/12/2006 & $18 / 2 / 2007$ & 66 & $\begin{array}{l}\text { Polissemiose } \\
\text { (Amilcar Packer) }\end{array}$ & $\begin{array}{l}\text { Fabio Cypriano / } \\
\text { Regina Melin / } \\
\text { Santiago G. } \\
\text { Navarro }\end{array}$ & Subsolo & $\mathrm{SP}$ & $100.000,00$ \\
\hline $25 / 9 / 2006$ & $26 / 11 / 2006$ & 61 & $\begin{array}{l}\text { Um Indeterminado } \\
\text { (Edouard Fraipont) }\end{array}$ & Felipe Chaimovitch & Subsolo & SP & $101.550,00$ \\
\hline $5 / 3 / 2005$ & $24 / 4 / 2005$ & 49 & Vik Muniz & Nessia Leonzini & Primeiro Andar & SP & $167.738,00$ \\
\hline
\end{tabular}


Anexo 25 - Artes Plásticas - Agrupamento por Modaliddade de Exposição (R\$)

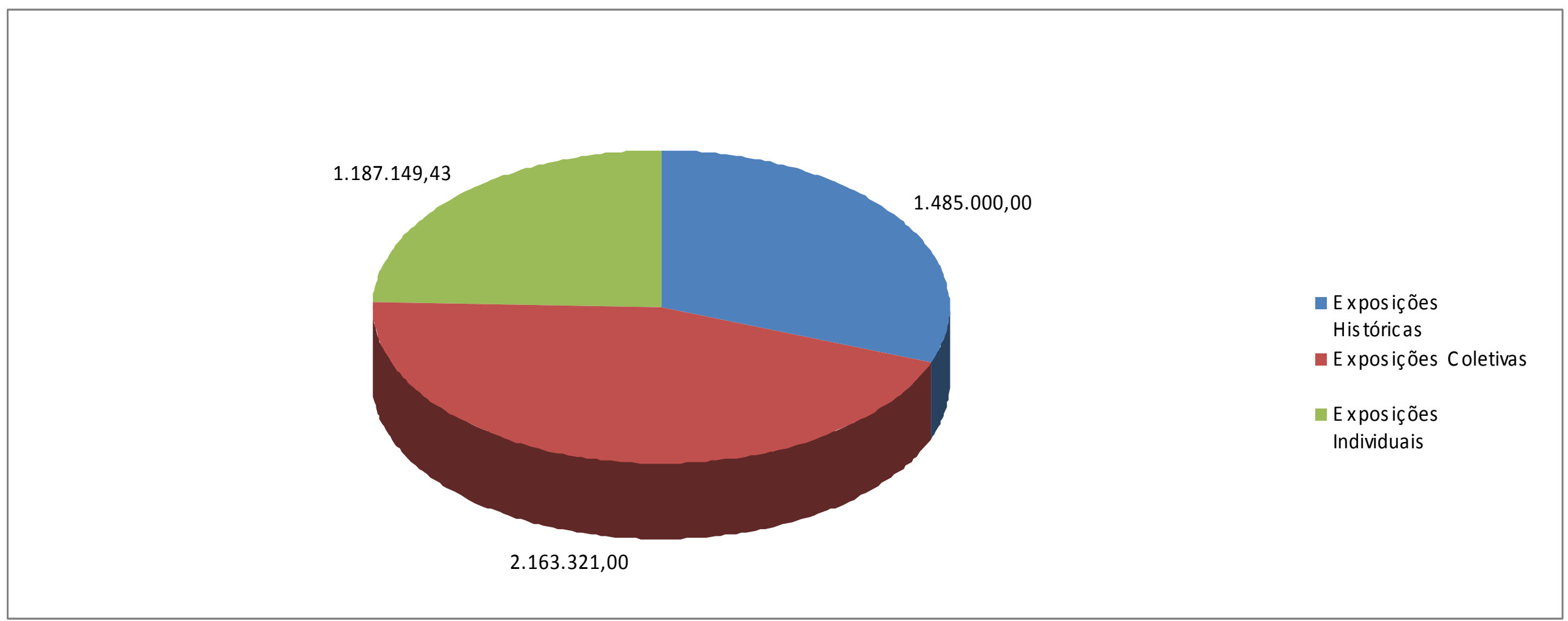

Fonte: CCBB São Paulo 


\section{ANEXo 26 - REZANDo com Terços - MÁrcia X}

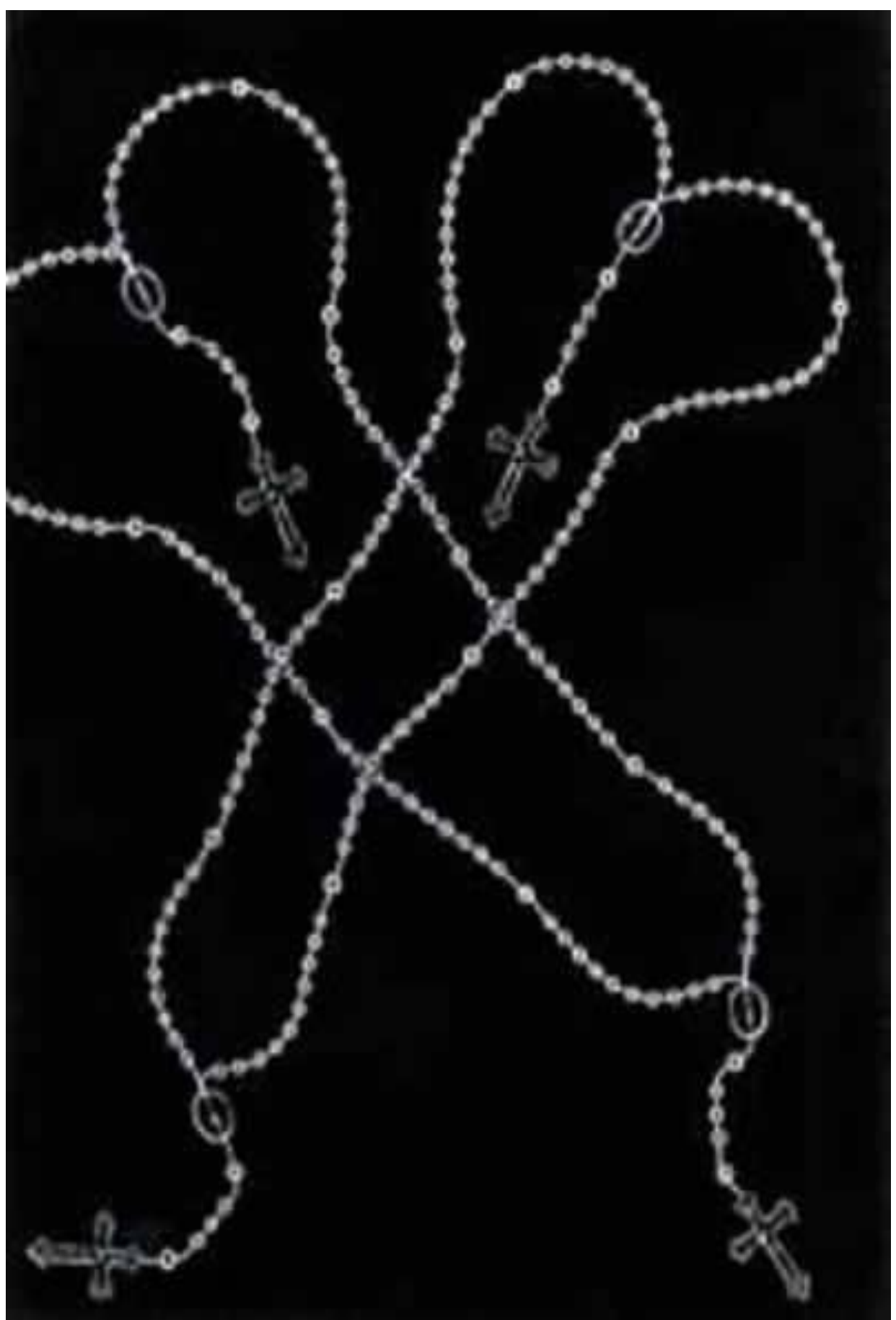



ANEXO 27 - EROTICA: ASSOCIAÇÃO E CONFLITOS ENTRE CAMPOS

Anexo 27 - Erotica: associação e conflitos entre campos

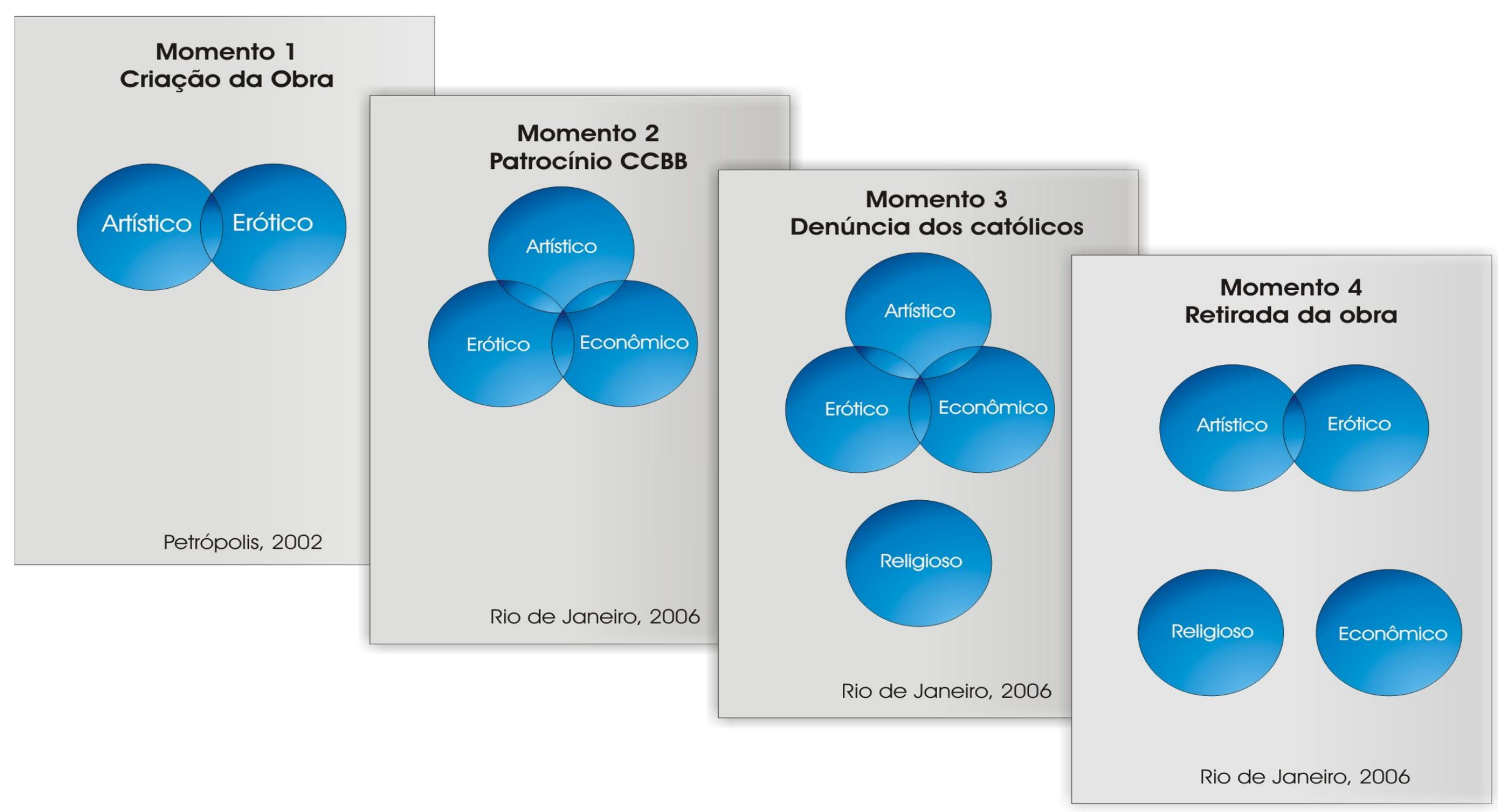


Anexo 28 - Artes Plásticas - Retorno de Midia e Público

\begin{tabular}{|c|c|c|c|c|c|}
\hline & Público & Patrocínio $(\mathbf{R} \$)$ & Retorno de Mídia (R\$) & $\begin{array}{c}\text { Reais Investidos/ } \\
\text { Visitante }\end{array}$ & $\begin{array}{c}\text { Retorno de Mídia/ Real } \\
\text { Investido }\end{array}$ \\
\hline Henfil do Brasil & 39.686 & $200.000,00$ & $1.692 .977,00$ & 5,04 & 8,46 \\
\hline Manobras Radicais & 100.567 & $388.000,00$ & $2.307 .537,00$ & 3,86 & 5,95 \\
\hline Arte de Cuba & 51.584 & $490.000,00$ & $2.899 .582,26$ & 9,50 & 5,92 \\
\hline Farnese de Andrade & 34.586 & $199.921,68$ & $1.120 .916,00$ & 5,78 & 5,61 \\
\hline Vik Muniz & 36.650 & $167.738,00$ & $826.015,00$ & 4,58 & 4,92 \\
\hline Média & 43.529 & $337.776,90$ & $1.010 .970,09$ & 7,29 & 3,29 \\
\hline Polisemiosse & 21.153 & $100.000,00$ & $311.406,00$ & 4,73 & 3,11 \\
\hline Mary Vieira & 39.493 & $299.939,75$ & $886.707,00$ & 7,59 & 2,96 \\
\hline Um Indeterminado & 17.010 & $101.550,00$ & $193.140,14$ & 5,97 & 1,90 \\
\hline Erotica - Os sentidos da Arte & 55.939 & $900.000,00$ & $1.584 .036,00$ & 16,09 & $\overline{1,76}$ \\
\hline Impressões Originais & 34.236 & $385.321,00$ & $608.072,00$ & 11,25 & 1,58 \\
\hline Por Ti America & 55.159 & $685.000,00$ & $1.077 .693,00$ & 12,42 & 1,57 \\
\hline Maurino de Araújo & 30.332 & $68.000,00$ & $105.831,00$ & 2,24 & 1,56 \\
\hline Antes - Histórias da Pré-História & 59.469 & $781.183,00$ & $1.172 .880,00$ & 13,14 & 1,50 \\
\hline Alfredo de Oliveira & 17.070 & $50.000,00$ & $69.392,00$ & 2,93 & 1,39 \\
\hline Cubo (Evento Externo) & 60.000 & $250.000,00$ & $308.367,00$ & 4,17 & 1,23 \\
\hline
\end{tabular}


Anexo 29 - Artes Cênicas - Retorno de Mídia e de Público

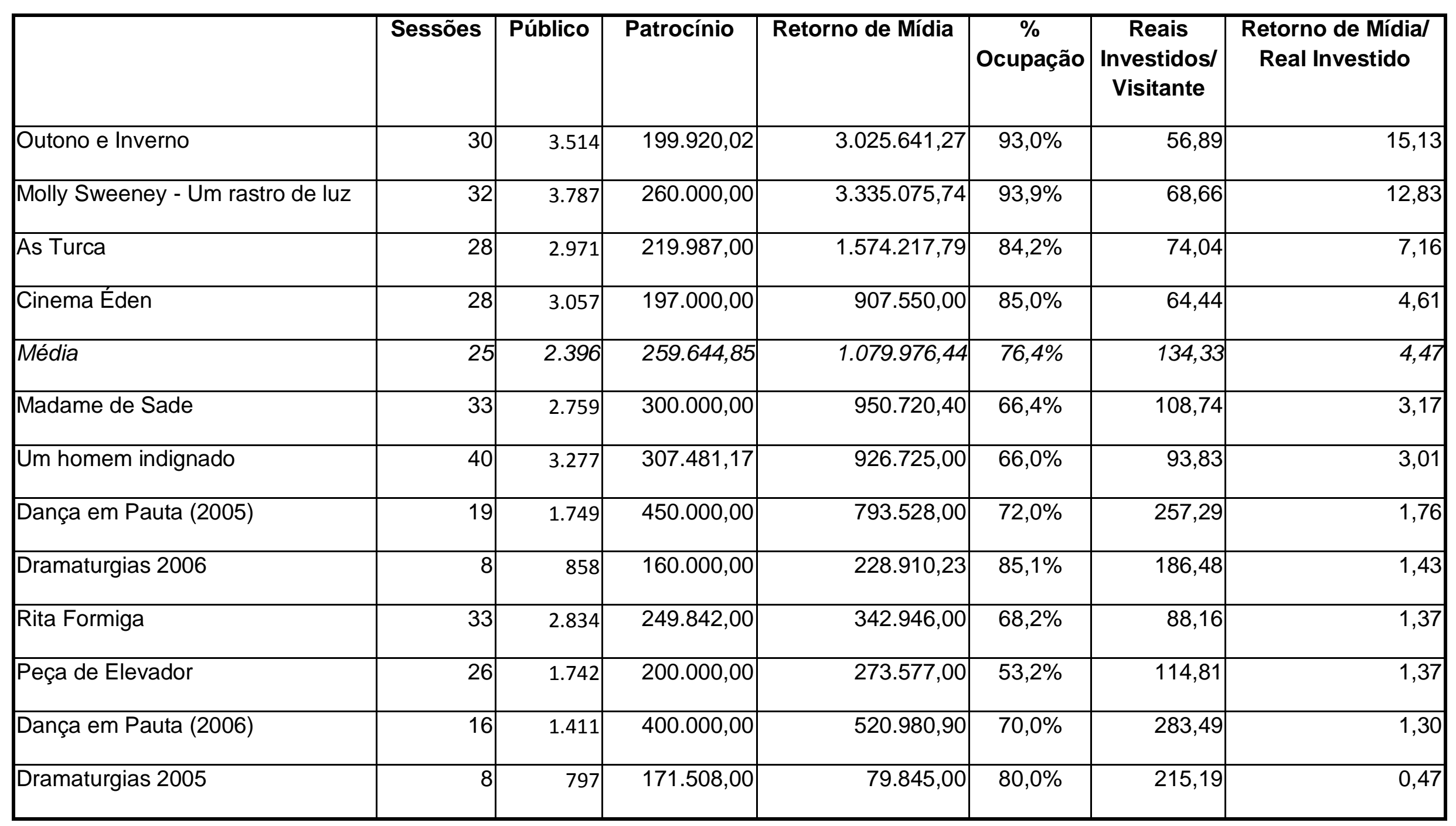


AneXo 30 - Artes Plásticas - Matérias de Divulgação em Jornais

\begin{tabular}{|c|c|c|c|c|c|c|c|c|c|c|}
\hline & \multicolumn{5}{|c|}{ Folha de S. Paulo } & \multicolumn{5}{|c|}{ O Estado de São Paulo } \\
\hline Exposição & Data & Autor & $\begin{array}{c}\text { Localizaçã } \\
0\end{array}$ & Manchete & Chamada & Data & Autor & $\begin{array}{c}\text { Localizaç } \\
\text { ão }\end{array}$ & Manchete & Chamada \\
\hline Alfredo de Oliveira & nihil & & & & & & & & & \\
\hline $\begin{array}{l}\text { Antes - Histórias } \\
\text { da Pré-História }\end{array}$ & $23 / 7 / 2005$ & $\begin{array}{l}\text { Reinaldo } \\
\text { José Lopes }\end{array}$ & $\begin{array}{l}\text { pág. E5 - } \\
1 / 2 \\
\text { superior } \\
\text { com foto }\end{array}$ & $\begin{array}{l}\text { CCBB exibe arte } \\
\text { rupestre em } \\
\text { movimento }\end{array}$ & \begin{tabular}{|l|} 
Antes-Hstórias da \\
Pré-História reúne \\
objetos pré- \\
históricos e edição \\
de pinturas, com \\
curadoria de \\
Niède Guidon
\end{tabular} & $23 / 7 / 2005$ & $\begin{array}{l}\text { Camila } \\
\text { Molina }\end{array}$ & $\begin{array}{l}\text { D5, 1/2 } \\
\text { pág, com } \\
\text { fotos }\end{array}$ & $\begin{array}{l}\text { Uma visita à } \\
\text { singular pré- } \\
\text { história } \\
\text { brasileira }\end{array}$ & \begin{tabular}{|l|} 
Mostra com \\
cerca de 150 \\
peças atesta a \\
riqueza do \\
passado \\
nacional
\end{tabular} \\
\hline Artes de Cuba & $30 / 1 / 2006$ & $\begin{array}{l}\text { Gabriela } \\
\text { Longman }\end{array}$ & $\begin{array}{l}\text { E3 } \\
\text { Superior } \\
\text { com fotos } \\
3 / 4\end{array}$ & \begin{tabular}{|l} 
Mostra reúne \\
produção \\
cubana do \\
século 20
\end{tabular} & \begin{tabular}{|l|} 
Com abertura \\
hoje, exposição \\
percorre as \\
manifestações \\
nacionais da ilha; \\
identidade é tema \\
recorrente.
\end{tabular} & $30 / 1 / 2006$ & $\begin{array}{l}\text { Camila } \\
\text { Molina }\end{array}$ & $\begin{array}{l}\text { D1 Página } \\
\text { Inteira com } \\
\text { fotos } \\
\text { grandes }\end{array}$ & $\begin{array}{l}\text { Visão } \\
\text { Inesperada } \\
\text { de Cuba }\end{array}$ & $\begin{array}{l}\text { Primeira grande } \\
\text { exposição de } \\
\text { arte cubana que } \\
\text { é montada no } \\
\text { Brasil exibe a } \\
\text { pluralidade } \\
\text { estética do país, } \\
\text { com obras de } 61 \\
\text { artistas desde o } \\
\text { início do século } \\
20\end{array}$ \\
\hline $\begin{array}{l}\text { Desoriente: o Eu } \\
\text { Nômade }\end{array}$ & $20 / 9 / 2005$ & & $\begin{array}{l}\text { texto } \\
\text { reduzido } \\
\text { com fotos }\end{array}$ & $\begin{array}{l}\text { Leonardo } \\
\text { Kossoy abre } \\
\text { exposição no } \\
\text { CCBB }\end{array}$ & \begin{tabular}{|l} 
Imagens feitas por \\
Leonardo Kossoy \\
em Xangai que \\
estão em cartaz \\
na mostra \\
"Desoriente: o Eu \\
nômade", com 22
\end{tabular} & nihil & nihil & nihil & nihil & nihil \\
\hline
\end{tabular}




\begin{tabular}{|c|c|c|c|c|c|c|c|c|c|c|}
\hline & & & & & fotografias... & & & & & \\
\hline $\begin{array}{l}\text { Erotica - Os } \\
\text { sentidos da Arte }\end{array}$ & $10 / 10 / 2005$ & & $\begin{array}{l}\text { Manchete } \\
\text { na pág. E1 } \\
\text { e pág E3 - } \\
\text { superior } \\
\text { com fotos } \\
\text { grandes }\end{array}$ & $\begin{array}{l}\text { Império dos } \\
\text { sentidos // } \\
\text { Exposição } \\
\text { examina } \\
\text { camadas do } \\
\text { erotismo }\end{array}$ & $\begin{array}{l}\text { Exposição em } \\
\text { São Paulo e livros } \\
\text { sobre histórias em } \\
\text { quadrinhos } \\
\text { compõem um } \\
\text { painel de obras } \\
\text { inspiradas pelo } \\
\text { erotismo // CCBB } \\
\text {-SP abre na } \\
\text { quarta "Erotica" } \\
\text { que reúne desde } \\
\text { obras de artistas } \\
\text { do século } 19 \text { até } \\
\text { contemporâneso }\end{array}$ & $11 / 10 / 2005$ & $\begin{array}{l}\text { Maria } \\
\text { Hirszman }\end{array}$ & $\begin{array}{l}\text { D3 - com } \\
\text { foto }-1 / 4\end{array}$ & $\begin{array}{l}\text { O desejo } \\
\text { segue sua } \\
\text { sina e vira } \\
\text { arte em } \\
\text { 'Erotica' }\end{array}$ & $\begin{array}{l}\text { Mostra que tem } \\
\text { inicio amanhã no } \\
\text { CCBB garimpa } \\
\text { obras que vão } \\
\text { além da mera } \\
\text { alusão ao sexo }\end{array}$ \\
\hline $\begin{array}{l}\text { Farnese de } \\
\text { Andrade - Objetos }\end{array}$ & nihil & $\begin{array}{l}\text { Gustavo } \\
\text { Fioratti }\end{array}$ & $\begin{array}{l}3 / 4 \text { com } \\
\text { fotos }\end{array}$ & $\begin{array}{l}\text { Farnese de } \\
\text { Andrade expõe } \\
\text { seus fantasmas }\end{array}$ & $\begin{array}{l}\text { CCBB inaugura } \\
\text { hoje mostra com } \\
121 \text { peças criadas } \\
\text { pelo artista, } \\
\text { inspiradas em sua } \\
\text { família e infância } \\
\text { em Minas Gerais }\end{array}$ & $17 / 4 / 2006$ & $\begin{array}{l}\text { Olívio } \\
\text { Tavares de } \\
\text { Araújo e } \\
\text { Camila } \\
\text { Molina }\end{array}$ & $\begin{array}{l}\text { D2 - } \\
\text { Página } \\
\text { inteira com } \\
\text { foto }\end{array}$ & $\begin{array}{l}\text { A sedução } \\
\text { misteriosa } \\
\text { de Farnese } \\
\text { (OTA) ; A } \\
\text { maior } \\
\text { exposição } \\
\text { do artista } \\
\text { em São } \\
\text { Paulo (CM) }\end{array}$ & $\begin{array}{l}\text { Mostra repara } \\
\text { avaliação } \\
\text { histórica e crítica } \\
\text { que relegou } \\
\text { artista mineiro a } \\
\text { segundo plano } \\
\text { (OTA) - Em } 130 \\
\text { obras, no CCBB, } \\
\text { uma } \\
\text { oportunidade de } \\
\text { entrar no seu } \\
\text { universo } \\
\text { enigmático (CM) }\end{array}$ \\
\hline Henfil do Brasil & $29 / 10 / 2005$ & $\begin{array}{l}\text { Janaina } \\
\text { Fidalgo }\end{array}$ & $\begin{array}{l}\text { E11, com } \\
\text { foto }\end{array}$ & $\begin{array}{l}\text { CCBB abre hoje } \\
\text { em São Paulo } \\
\text { mostra com mais } \\
\text { de } 400 \text { peças do }\end{array}$ & \multicolumn{3}{|c|}{ "Henfil do Brasil (ainda) toca mazelas do país } & & & \\
\hline
\end{tabular}




\begin{tabular}{|c|c|c|c|c|c|c|c|c|c|}
\hline & & & & $\begin{array}{l}\text { cartunista; } \\
\text { catálogo } \\
\text { reproduz partes } \\
\text { dos orginais }\end{array}$ & & & & & \\
\hline $\begin{array}{l}\text { Impressões } \\
\text { Originais: a } \\
\text { Gravura desde o } \\
\text { Século XV }\end{array}$ & $31 / 10 / 2006$ & Mario Gioia & $\begin{array}{l}\text { E6 - } 1 / 4 \\
\text { com foto }\end{array}$ & \multicolumn{2}{|c|}{$\begin{array}{l}\text { CCBB abriga painel histórico da arte } \\
\text { da gravura }\end{array}$} & \begin{tabular}{l|l}
$31 / 10 / 2006$ & $\begin{array}{l}\text { Camila } \\
\text { Molina }\end{array}$
\end{tabular} & $\begin{array}{l}\text { d12 - 1/2 } \\
\text { pág. Com } \\
\text { fotos }\end{array}$ & $\begin{array}{l}\text { A gravura } \\
\text { desde o } \\
\text { século } 15\end{array}$ & $\begin{array}{l}\text { Ampla mostra no } \\
\text { CCBB faz o } \\
\text { percurso da } \\
\text { produção gráfica } \\
\text { por meio de } \\
\text { obras de nomes } \\
\text { de peso da } \\
\text { história da arte }\end{array}$ \\
\hline Manobras Radicais & $7 / 8 / 2006$ & & & \multicolumn{4}{|c|}{ Mostras vêem múltiplos discursos femininos e distintos modos de pintar } & & \\
\hline $\begin{array}{l}\text { Mary Vieira - O } \\
\text { Tempo do } \\
\text { Movimento }\end{array}$ & $24 / 1 / 2005$ & \begin{tabular}{|l} 
Luiz \\
Fernando \\
Vianna
\end{tabular} & $\begin{array}{l}\text { E6, com } \\
\text { foto }\end{array}$ & \begin{tabular}{|l|} 
SP e Rio \\
recebem mestres \\
da arte cinética
\end{tabular} & \begin{tabular}{|l|} 
CCBB carioca \\
abre mostra de \\
Jesús Soto, morto \\
na quarta \\
passada; o \\
paulistano abriga \\
obras de Mary \\
Vieira
\end{tabular} & \begin{tabular}{l|l}
$23 / 3 / 2005$ & $\begin{array}{l}\text { Camila } \\
\text { Molina }\end{array}$
\end{tabular} & $\begin{array}{l}3 / 4 \text { de } \\
\text { página } \\
\text { com foto }\end{array}$ & $\begin{array}{l}\text { Obra de } \\
\text { mary Vieira } \\
\text { é reunida } \\
\text { em catálogo }\end{array}$ & $\begin{array}{l}\text { Por ocasião da } \\
\text { ampla exposição } \\
\text { em cartaz até } \\
\text { domingo no } \\
\text { CCBB, a } \\
\text { publicação será } \\
\text { lançada hoje } \\
\text { com debate }\end{array}$ \\
\hline Maurino de Araújo & \multicolumn{9}{|l|}{ nihil } \\
\hline Polissemiose & 9/12/2006 & $\begin{array}{l}\text { Gustavo } \\
\text { Fioratti }\end{array}$ & $\begin{array}{l}\mathrm{E}-572 \mathrm{~cm} \\
\text { com foto }\end{array}$ & $\begin{array}{l}\text { Amilcar Parker } \\
\text { subverte os } \\
\text { significados do } \\
\text { cotidiano }\end{array}$ & \begin{tabular}{|l|} 
Questionar o \\
funcionamento e a \\
ordenação do \\
mundo são \\
propostas do \\
artista, que \\
inaugura mostra \\
de vídeos hoje, no
\end{tabular} & nihil & & & \\
\hline
\end{tabular}




\begin{tabular}{|c|c|c|c|c|c|c|c|c|c|}
\hline & & & & & CCBB & & & & \\
\hline Por Ti America & $16 / 5 / 2006$ & $\begin{array}{l}\text { Renaldo } \\
\text { José Lopes }\end{array}$ & \begin{tabular}{|l|} 
E5 \\
Superior, \\
com fotos e \\
quadro
\end{tabular} & $\begin{array}{l}\text { Mostra busca } \\
\text { visão comum da } \\
\text { América antes } \\
\text { de Colombo }\end{array}$ & $\begin{array}{l}\text { Artefatos de cerca } \\
\text { de } 50 \text { culturas da } \\
\text { região mostram a } \\
\text { imersão do mito e } \\
\text { do ritual no } \\
\text { cotidiano indígena }\end{array}$ & \begin{tabular}{l|l}
$16 / 5 / 2006$ & $\begin{array}{l}\text { Karla } \\
\text { Dunder }\end{array}$
\end{tabular} & $\begin{array}{l}\text { d12 - 1/2 } \\
\text { pág. Com } \\
\text { fotos }\end{array}$ & \begin{tabular}{|l|} 
A \\
sofisticação \\
da cultura \\
indígena
\end{tabular} & $\begin{array}{l}\text { Exposição Por ti } \\
\text { America, no } \\
\text { CCBB, reúne } \\
\text { peças e objetos } \\
\text { arqueológicos de } \\
\text { civilizações pré- } \\
\text { colombianas }\end{array}$ \\
\hline $\begin{array}{l}\text { Um Indeterminado } \\
\text {-Edouard Fraipont }\end{array}$ & \multicolumn{9}{|l|}{ nihil } \\
\hline Vik Muniz & $5 / 3 / 2005$ & $\begin{array}{l}\text { Gustavo } \\
\text { Fioratti }\end{array}$ & $\begin{array}{l}\text { 1/4 pág. } \\
\text { Baixo }\end{array}$ & $\begin{array}{l}\text { SP vê riqueza de } \\
\text { Vik Muniz e se } \\
\text { abre para } \\
\text { italiano inédito e } \\
\text { gravurista }\end{array}$ & sem chamada & \begin{tabular}{l|l}
$3 / 3 / 2005$ & $\begin{array}{l}\text { Camila } \\
\text { Molina }\end{array}$
\end{tabular} & $\begin{array}{l}\text { D3 - com } \\
\text { foto }-1 / 4\end{array}$ & \begin{tabular}{|l|} 
Vik Muniz \\
exibe a nova \\
série "Divas \\
e Monstros"
\end{tabular} & $\begin{array}{l}\text { Além da } \\
\text { curadoria de } \\
\text { Mapplethorpe, } \\
\text { ele expõe no } \\
\text { CCBB }\end{array}$ \\
\hline
\end{tabular}




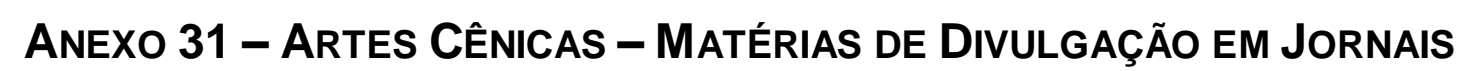

\begin{tabular}{|c|c|c|c|c|c|c|c|c|c|c|}
\hline \multirow[b]{2}{*}{ Peça } & \multicolumn{5}{|c|}{ Folha de S. Paulo } & \multicolumn{5}{|c|}{ O Estado de São Paulo } \\
\hline & Data & Pág. & Autor & Manchete & Chamada & Data & Autor & Pág. & Manchete & Chamada \\
\hline As Turca & $10 / 11 / 2005$ & $\begin{array}{l}\text { E5, com } \\
\text { foto }\end{array}$ & $\begin{array}{l}\text { Valmir } \\
\text { Santos }\end{array}$ & $\begin{array}{l}\text { Peça aborda } \\
\text { conflitos da } \\
\text { tradição árabe }\end{array}$ & $\begin{array}{l}\text { "As Turca", de Andréa } \\
\text { Bassit, mostra três } \\
\text { irmãs que brigam e } \\
\text { demonstram afeto em } \\
\text { meio às dificuldades } \\
\text { financeiras }\end{array}$ & $10 / 11 / 2005$ & Beth Néspoli & $\begin{array}{l}\text { D12, com } \\
\text { foto }\end{array}$ & $\begin{array}{l}\text { As Turca' } \\
\text { confonta } \\
\text { Oriente e } \\
\text { Ocidente }\end{array}$ & $\begin{array}{l}\text { Espetáculo enfoca três irmãs de } \\
\text { ascendência árabe vivendo no } \\
\text { interior de São Paulo, mas } \\
\text { acompanhando o que acontece } \\
\text { no mundo }\end{array}$ \\
\hline Cinema Éden & $12 / 1 / 2005$ & $\begin{array}{l}\text { não } \\
\text { consta, } 3 / 4 \\
\text { da página, } \\
\text { com foto }\end{array}$ & $\begin{array}{l}\text { Thiago } \\
\text { Stivaletti }\end{array}$ & $\begin{array}{l}\text { Cleyde Yáconis } \\
\text { investiga a } \\
\text { memória de } \\
\text { Duras }\end{array}$ & $\begin{array}{l}\text { Atriz, que interpreta a } \\
\text { mãe da autora } \\
\text { francesa em "Cinema } \\
\text { Éden"; defende a } \\
\text { formação de } \\
\text { companhias estatais } \\
\text { no páis }\end{array}$ & 12/1/2005 & $\begin{array}{l}\text { Ubiratan } \\
\text { Brasil }\end{array}$ & $\begin{array}{l}\text { Capa } \\
\text { Caderno } \\
2, \text { com } \\
\text { três fotos, } \\
\text { uma delas } \\
\text { bem } \\
\text { grande }\end{array}$ & $\begin{array}{l}\text { A mãe } \\
\text { coragem de } \\
\text { Cleyde } \\
\text { Yáconis }\end{array}$ & $\begin{array}{l}\text { Depois de uma ausência de dois } \\
\text { anos, atriz encontra o texto certo, } \\
\text { retoma a disposição de atuar e } \\
\text { volta ao teatro em Cinema } \\
\text { Éden,inspirada em um texto } \\
\text { autobiográfico da escritora } \\
\text { francesa Marguerite Duras. A } \\
\text { peça narra a vida de uma víuva } \\
\text { francesa e de seus filhos, presos } \\
\text { a um sistema corrupto que } \\
\text { impede o cultivo de uma terra, } \\
\text { mas que a transforma em uma } \\
\text { líder camponesa. }\end{array}$ \\
\hline \begin{tabular}{|l} 
Dança em \\
Pauta (2005)
\end{tabular} & $30 / 5 / 2005$ & $\begin{array}{l}\text { E1, COM } \\
\text { FOTO, } \\
\text { GRANDE }\end{array}$ & \begin{tabular}{|l|} 
Inês \\
Bogéa
\end{tabular} & $\begin{array}{l}\text { Pescadora de } \\
\text { Emoções }\end{array}$ & $\begin{array}{l}\text { Após } 12 \text { anos longe } \\
\text { dos palcos, Marilena } \\
\text { Ansaldi, uma das mais } \\
\text { importantes } \\
\text { dançarinas brasileiras, } \\
\text { volta à cena aos } 70 \\
\text { anos. }\end{array}$ & $1 / 6 / 2005$ & Karla Dunder & $\begin{array}{l}\text { D10 com } \\
\text { foto }\end{array}$ & $\begin{array}{l}\text { Marilena } \\
\text { Ansaldi } \\
\text { retorna ao } \\
\text { palco após } 12 \\
\text { anos }\end{array}$ & $\begin{array}{l}\text { Com Desassossego, inspirado na } \\
\text { obra de Fernando Pessoa, ela } \\
\text { abre o festival Dança em Pauta, } \\
\text { no CCBB }\end{array}$ \\
\hline \begin{tabular}{|l} 
Dança em \\
Pauta (2006)
\end{tabular} & $10 / 8 / 2006$ & \begin{tabular}{|l} 
E12 1/2 \\
PÁG, com
\end{tabular} & $\begin{array}{l}\text { Raquel } \\
\text { Cozer }\end{array}$ & $\begin{array}{l}\text { CCBB repatria } \\
\text { bailarinos do }\end{array}$ & $\begin{array}{l}\text { Dança em Pauta } \\
\text { celebra Sonia Mota, } \\
\text { longe do Brasil há } 17\end{array}$ & $10 / 8 / 2006$ & Karla Dunder & $\begin{array}{l}\mathrm{D} 14,1 / 2, \\
\text { com fotos }\end{array}$ & \begin{tabular}{|l|} 
Dança em \\
Pauta promete
\end{tabular} & $\begin{array}{l}\text { Projeta chega à sua quarta edição } \\
\text { reunindo bailarinos experintes e } \\
\text { jovens talentos em } 13\end{array}$ \\
\hline
\end{tabular}


361

\begin{tabular}{|c|c|c|c|c|c|c|c|c|c|c|}
\hline & & foto & & exterior & anos & & & & surpresas & espetáculos de 9 coreógrafos \\
\hline $\begin{array}{l}\text { Dramaturgias } \\
2005\end{array}$ & $2 / 3 / 2005$ & $\begin{array}{l}\text { E3, } \\
\text { pequeno, } \\
\text { sem foto }\end{array}$ & $\begin{array}{l}\text { Reportage } \\
\text { m Local }\end{array}$ & $\begin{array}{l}\text { Projeto observa } \\
\text { a dramaturgia } \\
\text { atual com 'olhos } \\
\text { femininos' }\end{array}$ & $\begin{array}{l}\text { Leituras gratuitas têm } \\
\text { início hoje no CCBB } \\
\text { paulistano }\end{array}$ & $2 / 3 / 2005$ & $\begin{array}{l}\text { Ubiratan } \\
\text { Brasil }\end{array}$ & $\begin{array}{l}\text { D3, } \\
\text { pequeno, } \\
\text { com foto }\end{array}$ & $\begin{array}{l}\text { Olhar } \\
\text { Feminino em } \\
\text { cena }\end{array}$ & $\begin{array}{l}\text { Tema atrai, no CCBB, textos } \\
\text { inéditos de diversos países }\end{array}$ \\
\hline $\begin{array}{l}\text { Dramaturgias } \\
2006\end{array}$ & $22 / 9 / 2006$ & $\begin{array}{l}\text { Guia da } \\
\text { Folha pág. } \\
39\end{array}$ & $\begin{array}{l}\text { Pedro Ivo } \\
\text { Dubra }\end{array}$ & $\begin{array}{l}\text { Projeto traz } \\
\text { produção não- } \\
\text { paulista }\end{array}$ & \multicolumn{3}{|c|}{$\begin{array}{l}\text { Com consultoria da professora e pesquisadora } \\
\text { Silvana Garcia, o projeto Dramaturgias, inicia uma } \\
\text { nova etapa... }\end{array}$} & & & \\
\hline $\begin{array}{l}\text { Madame de } \\
\text { Sade }\end{array}$ & $13 / 10 / 2005$ & $\begin{array}{l}\text { não } \\
\text { consta } \\
\text { com foto }\end{array}$ & $\begin{array}{l}\text { Valmir } \\
\text { Santos }\end{array}$ & \begin{tabular}{|l|} 
Peça de \\
Mishima lança \\
olhar feminino \\
sobre Sade
\end{tabular} & \begin{tabular}{|l|} 
Roberto Lage dirige \\
drama do escritor \\
japonês protagonizado \\
por Bárbara Paz e \\
inspirado na mulher do \\
marquês
\end{tabular} & $14 / 10 / 2005$ & Beth Néspoli & $\begin{array}{l}\text { Não } \\
\text { consta, } \\
\text { com foto }\end{array}$ & \begin{tabular}{|l|} 
Sade sob a \\
interpretação \\
e o olhar das \\
mulheres
\end{tabular} & $\begin{array}{l}\text { Peça do japonês Yukio Mishima } \\
\text { dirigida por Roberto Lage faz } \\
\text { mais do que lançar luz sobre o } \\
\text { polêmico marquês e tenta chegar } \\
\text { à alma de sua mulher }\end{array}$ \\
\hline $\begin{array}{l}\text { Molly } \\
\text { Sweeney }\end{array}$ & $18 / 3 / 2006$ & $\begin{array}{l}\text { E9 } 1 / 2 \\
\text { com foto }\end{array}$ & $\begin{array}{l}\text { Valmir } \\
\text { Santos }\end{array}$ & $\begin{array}{l}\text { "Molly" constrói } \\
\text { reflexão sobre } \\
\text { cegueira }\end{array}$ & $\begin{array}{l}\text { Na peça do irlandês } \\
\text { Brian Friel, Julia } \\
\text { Lemmertz vive mulher } \\
\text { que é submetida a } \\
\text { operação para } \\
\text { enxergar e sofre } \\
\text { impacto da realidade }\end{array}$ & $16 / 3 / 2005$ & Beth Néspoli & \begin{tabular}{|l|} 
D14- \\
página \\
inteira \\
com fotos
\end{tabular} & $\begin{array}{l}\text { A magia do } \\
\text { mundo dos } \\
\text { sentidos }\end{array}$ & $\begin{array}{l}\text { Em Molly Sweeney, Julia } \\
\text { Lemmertz é uma deficiente visual } \\
\text { independente e feliz }\end{array}$ \\
\hline $\begin{array}{l}\text { Outono e } \\
\text { Inverno }\end{array}$ & $25 / 11 / 2006$ & $\begin{array}{l}\text { E9 } 1 / 2 \\
\text { com foto }\end{array}$ & $\begin{array}{l}\text { Valmir } \\
\text { Santos }\end{array}$ & $\begin{array}{l}\text { Tolentino monta } \\
\text { drama familiar } \\
\text { sueco }\end{array}$ & $\begin{array}{l}\text { Diretor e fundador do } \\
\text { grupo Tapa conduz o } \\
\text { espetáculo "Outono e } \\
\text { Inverno", texto } \\
\text { assinado pelo } \\
\text { dramaturgo Lars } \\
\text { Norén }\end{array}$ & $25 / 11 / 2006$ & Beth Néspoli & $\begin{array}{l}\text { D8 }-1 / 4 \\
\text { página } \\
\text { com foto }\end{array}$ & \begin{tabular}{|l|} 
Emoções \\
fortes servidas \\
num jantar de \\
família
\end{tabular} & $\begin{array}{l}\text { Outono e Inverno, do sueco } \\
\text { Norén, tem direção de Tolentino }\end{array}$ \\
\hline $\begin{array}{l}\text { Peça de } \\
\text { Elevador }\end{array}$ & $6 / 4 / 2006$ & $\begin{array}{l}\text { E8 } \\
\text { superior } \\
\text { com foto }\end{array}$ & $\begin{array}{l}\text { Valmir } \\
\text { Santos }\end{array}$ & $\begin{array}{l}\text { Montagem } \\
\text { costura o sobe- } \\
\text { e-desce dos } \\
\text { elevadores }\end{array}$ & $\begin{array}{l}\text { Formada há cinco } \\
\text { anos, companhia } \\
\text { estréia hoje "Peça de } \\
\text { Elevador", no CCBB, } \\
\text { com dez histórias }\end{array}$ & $\begin{array}{c}\text { sem } \\
\text { divulgação }\end{array}$ & & & & \\
\hline
\end{tabular}




\begin{tabular}{|c|c|c|c|c|c|c|c|c|c|c|}
\hline & & & & & $\begin{array}{l}\text { curtas. Em cinco anos, } \\
\text { esta é a sétima } \\
\text { montagem da Cia } \\
\text { Eleador de Teatro } \\
\text { Panorâmico. Ela é } \\
\text { integrada por dez } \\
\text { atores, a maioria vinda } \\
\text { do Tearo Escola Célia } \\
\text { Helena }\end{array}$ & & & & & \\
\hline Rita Formiga & 14/9/2006 & & $\begin{array}{l}\text { Valmir } \\
\text { Santos }\end{array}$ & $\begin{array}{l}\text { Oliveira encena } \\
\text { em SP crônica } \\
\text { da boemia }\end{array}$ & nihil & $\begin{array}{c}\text { sem } \\
\text { divulgação }\end{array}$ & & & & \\
\hline $\begin{array}{l}\text { Um homem } \\
\text { indignado }\end{array}$ & $16 / 3 / 2005$ & $\begin{array}{l}\text { E10, com } \\
\text { foto }\end{array}$ & $\begin{array}{l}\text { Valmir } \\
\text { Santos }\end{array}$ & $\begin{array}{l}\text { Walmor Chagas } \\
\text { critica poder da } \\
\text { imagem }\end{array}$ & $\begin{array}{l}\text { Ator volta pela } \\
\text { segunda vez à } \\
\text { dramaturgia em "Um } \\
\text { homem indignado", } \\
\text { monólogo em que } \\
\text { critica a invasão dos } \\
\text { 'reality shows'. }\end{array}$ & $18 / 3 / 2005$ & $\begin{array}{l}\text { Ubiratan } \\
\text { Brasil }\end{array}$ & $\begin{array}{l}\text { Página } \\
\text { D6, com } \\
\text { foto }\end{array}$ & $\begin{array}{l}\text { O aniversário } \\
\text { do indignado } \\
\text { Walmor } \\
\text { Chagas }\end{array}$ & $\begin{array}{l}\text { Ator, que completa } 55 \text { anos de } \\
\text { carreira, escreve e interpreta } \\
\text { monólogo em que valoriza a } \\
\text { palavra }\end{array}$ \\
\hline
\end{tabular}


Anexo 32 - Críticas - Artes CÊNICAS

\begin{tabular}{|c|c|c|c|c|c|c|c|c|}
\hline \multicolumn{5}{|c|}{ Folha de S. Paulo } & \multicolumn{4}{|c|}{ O Estado de São Paulo } \\
\hline Data & Autor & Cotação & Título da Crítica & Chamada & Data & Autor & Título da Crítica & Chamada \\
\hline $3 / 2 / 2005$ & $\begin{array}{l}\text { Sérgio S. } \\
\text { Coelho }\end{array}$ & 3 estrelas & $\begin{array}{l}\text { Cinema Éden' cria } \\
\text { espetáculos de } \\
\text { evocações }\end{array}$ & $\begin{array}{l}\text { Montagem de Emílio di } \\
\text { Biasi, em cartaz no } \\
\text { CCBB, absorve } \\
\text { inegralmente o texto } \\
\text { verborrágico de } \\
\text { Marguerite Duras }\end{array}$ & $11 / 2 / 2005$ & $\begin{array}{l}\text { Mariangela } \\
\text { Alves de } \\
\text { Lima }\end{array}$ & $\begin{array}{l}\text { Cleide Yáconis restaura } \\
\text { magnetismo no palco }\end{array}$ & $\begin{array}{l}\text { Numa peça confusa, } \\
\text { interpretação primorosa traz de } \\
\text { volta os aplausos em cena } \\
\text { aberta }\end{array}$ \\
\hline $21 / 5 / 2005$ & $\begin{array}{l}\text { Sérgio S. } \\
\text { Coelho }\end{array}$ & 2 estrelas & $\begin{array}{l}\text { Walmor Chagas exerce o } \\
\text { verbo em monólogo }\end{array}$ & $\begin{array}{l}\text { Em 'Um homem } \\
\text { indignado', ator satiriza } \\
\text { a primazia a imagem, } \\
\text { abre feridas e se torna } \\
\text { porta-voz da revolta } \\
\text { geral }\end{array}$ & $29 / 4 / 2005$ & $\begin{array}{l}\text { Mariangela } \\
\text { Alves de } \\
\text { Lima }\end{array}$ & Walmor seduz com sabedoria & $\begin{array}{l}\text { Em Um homem indignado,um } \\
\text { espetáculo-depoimento, o grande } \\
\text { ator desfila refinamento e todo o } \\
\text { seu saber acumulado. }\end{array}$ \\
\hline \multicolumn{5}{|l|}{ sem crítica } & 1/12/2005 & \begin{tabular}{|l|} 
Beth \\
Néspoli
\end{tabular} & $\begin{array}{l}\text { As Turca evita caricatura de } \\
\text { traços culturais - e acerta }\end{array}$ & $\begin{array}{l}\text { Direção opta por valorização do } \\
\text { bom trio de intérpretes }\end{array}$ \\
\hline $11 / 12 / 2006$ & $\begin{array}{l}\text { Sergio Salvia } \\
\text { Coelho }\end{array}$ & 4 estrelas & $\begin{array}{l}\text { Atores brilham em } \\
\text { montagem sutil }\end{array}$ & sem chamada & 15/12/2006 & $\begin{array}{l}\text { Mariangela } \\
\text { Alves de } \\
\text { Lima }\end{array}$ & $\begin{array}{l}\text { Embates verbais por excelentes } \\
\text { intérpretes }\end{array}$ & $\begin{array}{l}\text { Outono e Inverno permite aos } \\
\text { atores o exercício do discrso } \\
\text { revelado no corpo }\end{array}$ \\
\hline $4 / 6 / 2005$ & Inês Bogéa & 4 estrelas & $\begin{array}{l}\text { Marilena Ansaldi encena } \\
\text { multidão de si mesma }\end{array}$ & $\begin{array}{l}\text { No espetáculo } \\
\text { "Desassossego", de } \\
\text { Marcio Aurelio, a } \\
\text { bailarina volta aos } \\
\text { palcos } 12 \text { anos, mais } \\
\text { atriz do que nunca. }\end{array}$ & $4 / 6 / 2005$ & \begin{tabular}{|l} 
Beth \\
Néspoli
\end{tabular} & \begin{tabular}{|l|} 
Crítica "Solo de Marilena \\
Ansaldi equilibra intensidade e \\
delicadeza
\end{tabular} & $\begin{array}{l}\text { Em Desassossego, só até } \\
\text { amanhã, a grande intérprete } \\
\text { desfia suas angústias e } \\
\text { contradições aliando técnica e } \\
\text { sensibilidade" }\end{array}$ \\
\hline \multicolumn{4}{|l|}{ Bravo! } & \multicolumn{5}{|c|}{ Outros veículos da imprensa } \\
\hline
\end{tabular}




\begin{tabular}{|c|c|c|c|c|c|c|c|c|}
\hline Data & Autor & $\begin{array}{c}\text { Título da } \\
\text { Crítica }\end{array}$ & Chamada & Meio de comunicação & Data & Autor & Título da Crítica & Chamada \\
\hline & & & & ISTO É GENTE & $24 / 1 / 2005$ & $\begin{array}{l}\text { Dirceu } \\
\text { Alves Jr. }\end{array}$ & $\begin{array}{l}\text { Talento de Cleide Yáconis não } \\
\text { salva a montagem brasileira do } \\
\text { texto de Marguerite Duras }\end{array}$ & $\begin{array}{l}\text { Entregue ao desafio, ela tenta } \\
\text { equilibrar as fragilidades do } \\
\text { espetáculo. }\end{array}$ \\
\hline \multirow[t]{2}{*}{ abril de 2005} & $\begin{array}{l}\text { Jefferson del } \\
\text { Rios }\end{array}$ & $\begin{array}{l}\text { O Palco } \\
\text { contra a } \\
\text { Tela }\end{array}$ & \multicolumn{6}{|c|}{$\begin{array}{l}\text { Aos } 55 \text { anos de carreira, Walmor Chagas defende em Um Homem Indignado a cultura do ator contra o predomínio da imagem do cinema e da } \\
\text { TV. }\end{array}$} \\
\hline & & & & Gazeta Mercantil & 25.11 .05 & $\begin{array}{l}\text { Maria } \\
\text { Lucia } \\
\text { Candeias }\end{array}$ & "Status ameaçado & $\begin{array}{l}\text { "As Turca" e "Canaã, a Terra } \\
\text { Prometida" discutem decadência } \\
\text { social }\end{array}$ \\
\hline \multirow[t]{2}{*}{ abril de 2006} & $\begin{array}{l}\text { Alberto } \\
\text { Guzik }\end{array}$ & $\begin{array}{l}\text { A } \\
\text { delicadeza } \\
\text { das } \\
\text { sombras }\end{array}$ & $\begin{array}{l}\text { Com simplicidade e } \\
\text { precisão, o diretor Celso } \\
\text { Nunes retrata o lirismo } \\
\text { trágico de Molly } \\
\text { Sweeney, peça em que a } \\
\text { protagonista tem de } \\
\text { escolher se deseja ou } \\
\text { não exergar }\end{array}$ & Gazeta Mercantil & 24 a $26 / 03 / 06$ & $\begin{array}{l}\text { Maria } \\
\text { Lucia } \\
\text { Candeias }\end{array}$ & A luz na escuridão & $\begin{array}{l}\text { Molly Sweeney faz enxergar os } \\
\text { sonhos alheios }\end{array}$ \\
\hline & & & & Isto é Gente & $25 / 9 / 2006$ & D.A.J. & \multicolumn{2}{|c|}{$\begin{array}{l}\text { Rita Formiga -Guta Stresser estrela texto de Domingos Oliveira } \\
\text { que poderia ser um monólogo }\end{array}$} \\
\hline $\begin{array}{l}\text { dezembro de } \\
2006\end{array}$ & $\begin{array}{l}\text { Sérgio } \\
\text { Roveri }\end{array}$ & $\begin{array}{l}\text { Campo } \\
\text { Minado }\end{array}$ & $\begin{array}{l}\text { Com estilo impiedoso e } \\
\text { mordaz, o dramaturgo } \\
\text { Sueco Lars Norén revela } \\
\text { o potencial destrutivo de } \\
\text { um prosaico jantar que } \\
\text { reúne pais e filhas } \\
\text { maduras }\end{array}$ & O Globo RJ & & $\begin{array}{l}\text { Bárabar } \\
\text { Heliodora }\end{array}$ & $\begin{array}{l}\text { Longo conto sobre a civilidade } \\
\text { sueca }\end{array}$ & $\begin{array}{l}\text { Texto de Lars Norén fica muito } \\
\text { aquém de outros que já trataram } \\
\text { do mesmo tema }\end{array}$ \\
\hline
\end{tabular}


Anexo 33 - Críticas - Artes Plásticas

\begin{tabular}{|c|c|c|c|c|c|c|c|c|c|c|}
\hline & \multicolumn{5}{|c|}{ Folha de S. Paulo } & \multicolumn{5}{|c|}{ Outros Veículos da Imprensa } \\
\hline Exposição & Data & Autor & Cotação & $\begin{array}{l}\text { Título da } \\
\text { Crítica }\end{array}$ & Chamada & $\begin{array}{l}\text { Meio de } \\
\text { Comunicação }\end{array}$ & Data & Autor & Título da Crítica & Chamada \\
\hline $\begin{array}{l}\text { Mary Vieira - O Tempo } \\
\text { do Movimento }\end{array}$ & $19 / 2 / 2005$ & \begin{tabular}{|l} 
Felipe \\
Chaimovich
\end{tabular} & 3 & \begin{tabular}{|l} 
Arte \\
construtiv \\
a é \\
desafiada \\
hoje
\end{tabular} & sem chamada & Estado de Minas & $30 / 1 / 2005$ & $\begin{array}{l}\text { Walter } \\
\text { Sebastião }\end{array}$ & $\begin{array}{l}\text { A revolucionária e o } \\
\text { iconoclasta (mais divulgação } \\
\text { do que crítica) }\end{array}$ & $\begin{array}{l}\text { Mostras com } \\
\text { trabalhos de Mary } \\
\text { Vieira, em São Paulo } \\
\text { e de Farnese de } \\
\text { Andrade, no Rio de } \\
\text { Janeiro, reúnem } \\
\text { trabalhos dos } \\
\text { artistas que } \\
\text { estudaram com } \\
\text { Guignard, nos anos } \\
\text { 40, em BH }\end{array}$ \\
\hline $\begin{array}{l}\text { Farnese de Andrade - } \\
\text { Objetos }\end{array}$ & 28/5/2005 & \begin{tabular}{|l} 
Felipe \\
Chaimovich
\end{tabular} & 4 & $\begin{array}{l}\text { Objetos } \\
\text { de } \\
\text { Farnese } \\
\text { de } \\
\text { Andrade } \\
\text { revelam } \\
\text { universali } \\
\text { dade }\end{array}$ & sem chamada & Folha de S. Paulo & 20/4/2005 & $\begin{array}{l}\text { Marcelo } \\
\text { Coelho }\end{array}$ & Ovos, bonecas e relicários & \\
\hline Vik Muniz & $20 / 3 / 2005$ & \begin{tabular}{|l|} 
Fabio \\
Cypriano
\end{tabular} & 2 & $\begin{array}{l}\text { Vik Muniz } \\
\text { faz } \\
\text { apologia } \\
\text { da } \\
\text { metáfora } \\
\text { óbvia }\end{array}$ & $\begin{array}{l}\text { Exposição em cartaz } \\
\text { no CCBB até } 24 \text { de } \\
\text { abril retrata divas e } \\
\text { monstros feitos com } \\
\text { diamantes e caviar }\end{array}$ & nihil & & & & \\
\hline $\begin{array}{l}\text { Erotica - Os sentidos da } \\
\text { Arte }\end{array}$ & nihil & & & & & Bravo! & \begin{tabular}{|l} 
outubro de \\
2005
\end{tabular} & Fernando Oliva & \begin{tabular}{|l|} 
Arte Erótica (CAPA) - \\
Projeto itinerante reúne \\
longas-metragens, série de \\
conferências e uma \\
exposição com mais de 100 \\
obras para discutir sexo e \\
desejo (CAPA) - O lugar do
\end{tabular} & $\begin{array}{l}\text { O projeto Erotica } \\
\text { abriga, no CCBB-SP, } \\
\text { uma grande } \\
\text { exposição, um ciclo } \\
\text { de cinema e uma } \\
\text { série de } \\
\text { conferências que }\end{array}$ \\
\hline
\end{tabular}




\begin{tabular}{|c|c|c|c|c|c|c|c|c|c|c|}
\hline & & & & & & & & & Desejo & $\begin{array}{l}\text { revelam como o } \\
\text { homem simboliza } \\
\text { suas pulsões } \\
\text { sexuais. }\end{array}$ \\
\hline Artes de Cuba & $27 / 3 / 2006$ & \begin{tabular}{|l|} 
Fabio \\
Cypriano
\end{tabular} & 2 & $\begin{array}{l}\text { Tom } \\
\text { oficial } \\
\text { marca } \\
\text { "Arte de } \\
\text { Cuba" }\end{array}$ & sem chamada & Bravo! & \begin{tabular}{|l|} 
Fev06 - \\
matéria pág. \\
100 a 106 -
\end{tabular} & \begin{tabular}{|l} 
Angélica \\
Moraes
\end{tabular} & Sem perder a ternura - & $\begin{array}{l}\text { O CCBB apresenta } \\
\text { extensa exposição } \\
\text { de arte cubana, do } \\
\text { Modernismo até a } \\
\text { atualidade, e } \\
\text { sublinha a vigorosa } \\
\text { produção } \\
\text { contemporânea da } \\
\text { llha }\end{array}$ \\
\hline $\begin{array}{l}\text { Impressões Originais: a } \\
\text { Gravura desde o Século } \\
\text { XV }\end{array}$ & nihil & & & & & Bravo! & $\begin{array}{l}\text { novembro } \\
\text { de } 2006\end{array}$ & Fernando Oliva & A Evolução da Gravura & $\begin{array}{l}\text { Mostra no ccbb de } \\
\text { são paulo reúne } \\
\text { obras de Durer, } \\
\text { Goya, Picasso, Andy } \\
\text { Warhol e outros } \\
\text { mestres em trabalhar } \\
\text { com impressão } \\
\text { sobre papel. A } \\
\text { exposição é prova } \\
\text { de que a técnica não } \\
\text { pára de se } \\
\text { reinventar. }\end{array}$ \\
\hline Polissemiose & $23 / 12 / 2006$ & \begin{tabular}{|l|} 
Juliana \\
Monachesi
\end{tabular} & 4 & \begin{tabular}{|l} 
Packer \\
amplia \\
discussão \\
sobre \\
corpo
\end{tabular} & sem chamada & & & & & \\
\hline
\end{tabular}




\section{AneXo 34 - DinÂmica dos Campos no PatrocínIo do CCBB}

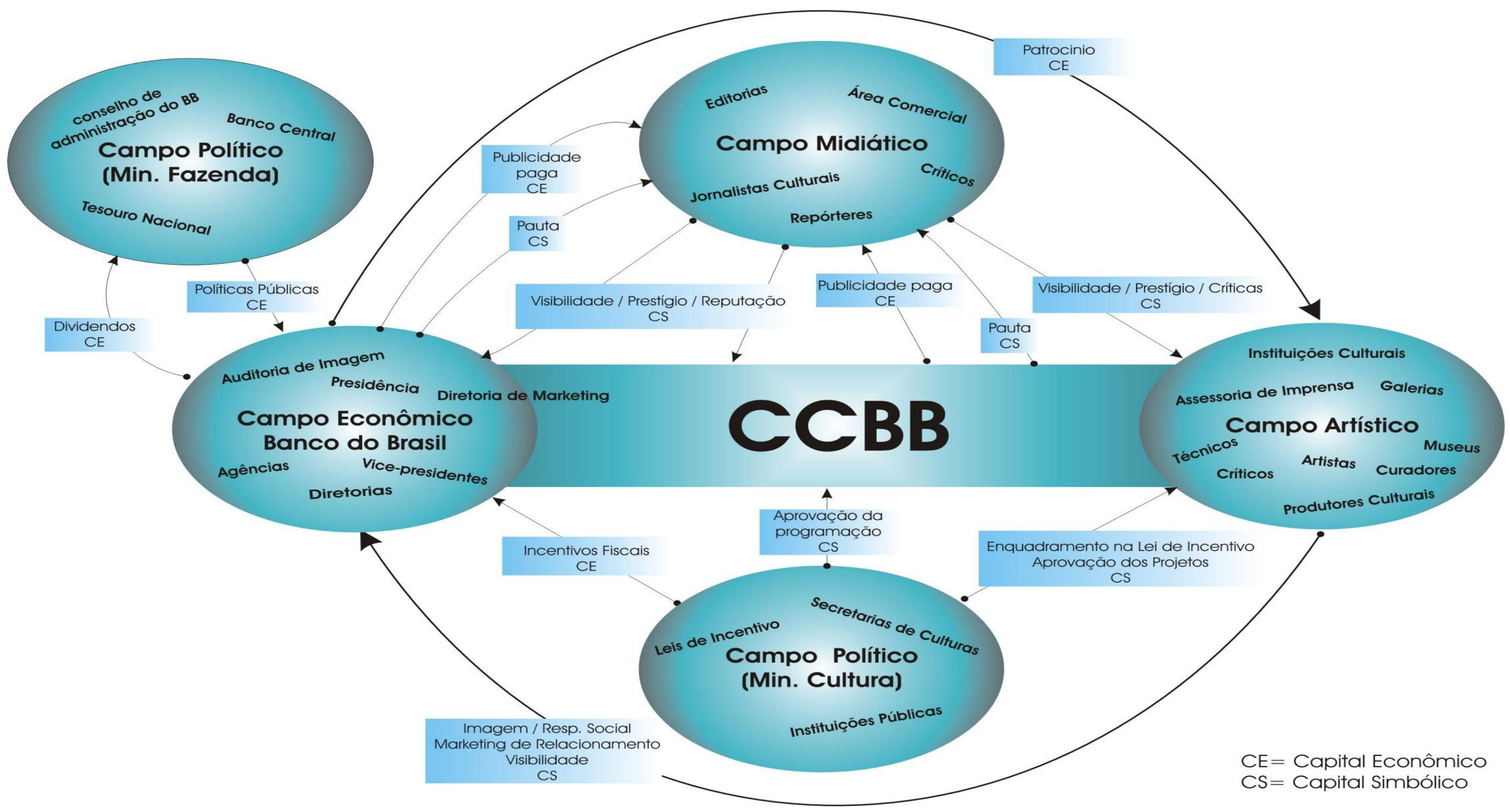

